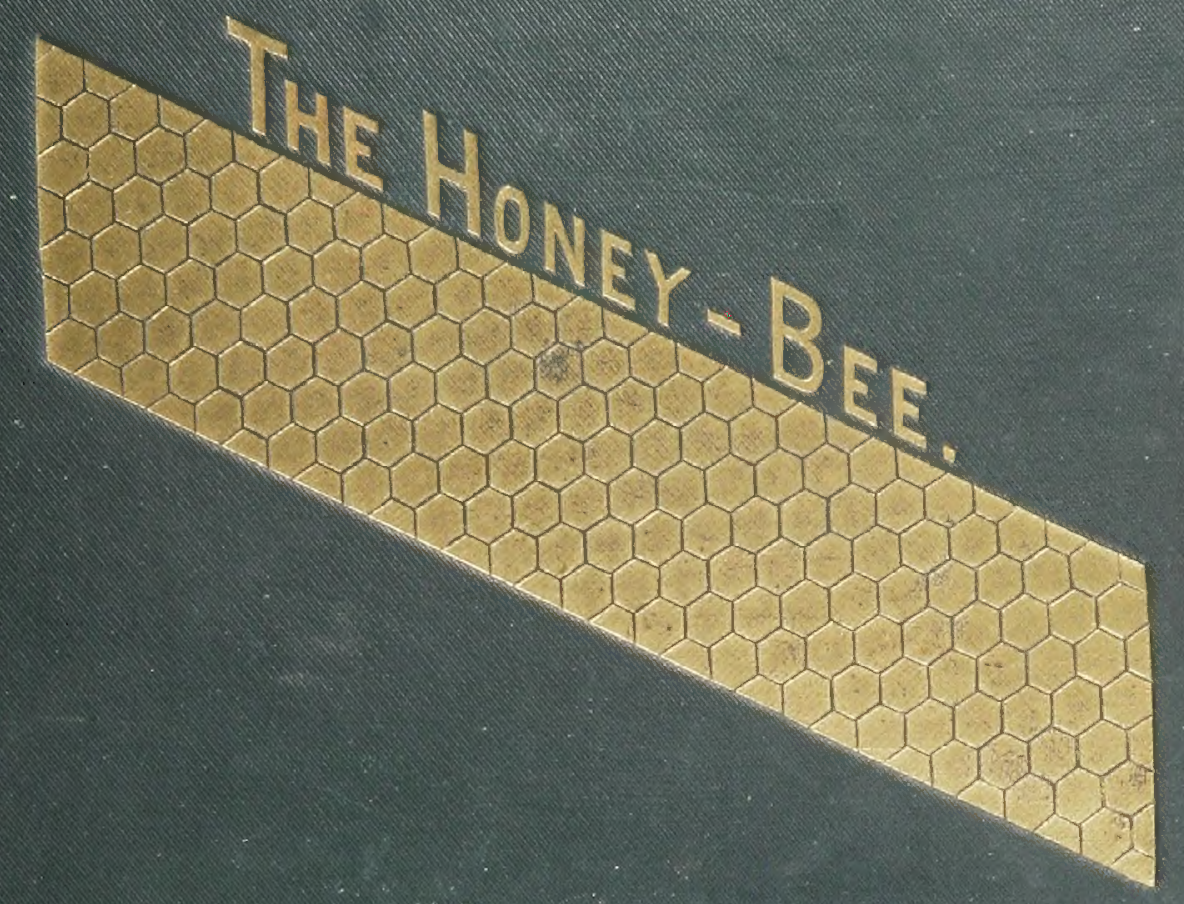




\section{Cornell University Library}

The original of this book is in the Cornell University Library.

There are no known copyright restrictions in the United States on the use of the text.

http://www.archive.org/details/cu31924003227646 


\section{Cornell University LIbrary \\ J 3.L286 1919}

Langthothon the hive \& honey-bee.

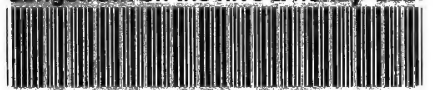

31924003227646 


Plate 1.

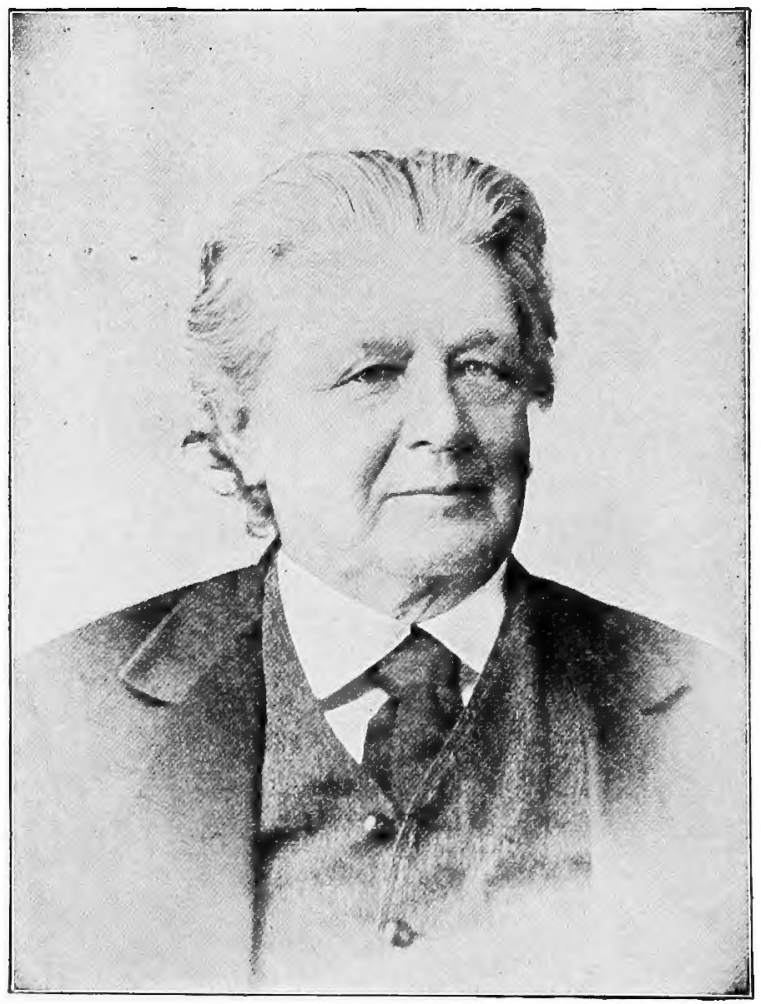

L. L. LANGSTROTH at 70. 


\section{LANGSTROTH c}

ON THE

\section{HIVE $\&$ HONEY BEE}

REVISED BY DADANT

Twentieth Edition
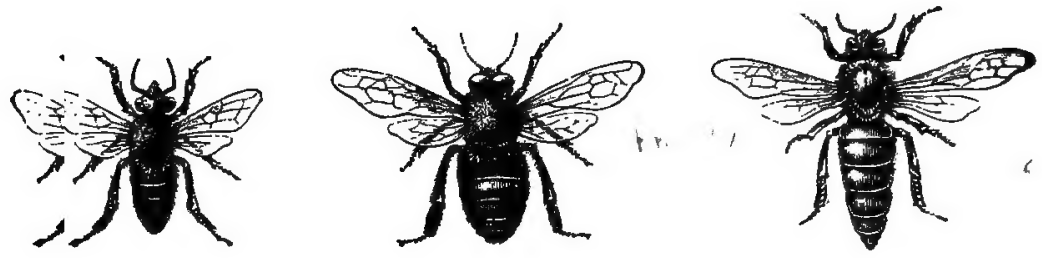

PUBLISHED BY

DADANT E SONS

Hamilton, Hancock County,"Illinols, U. S. A.

1919

$\mathrm{r}$ 


$$
\begin{gathered}
\text { C } 3936 \% \\
\text { COPYRIGHTED } 1888 \text { BY } \\
\text { CHAS. DADANT \& SON } \\
\text { ALI RIGHTS RESERVED } \\
\text { COPYRIGHTED } 1919 \text { BY } \\
\text { C. P. DADANT }
\end{gathered}
$$



Plate 2.

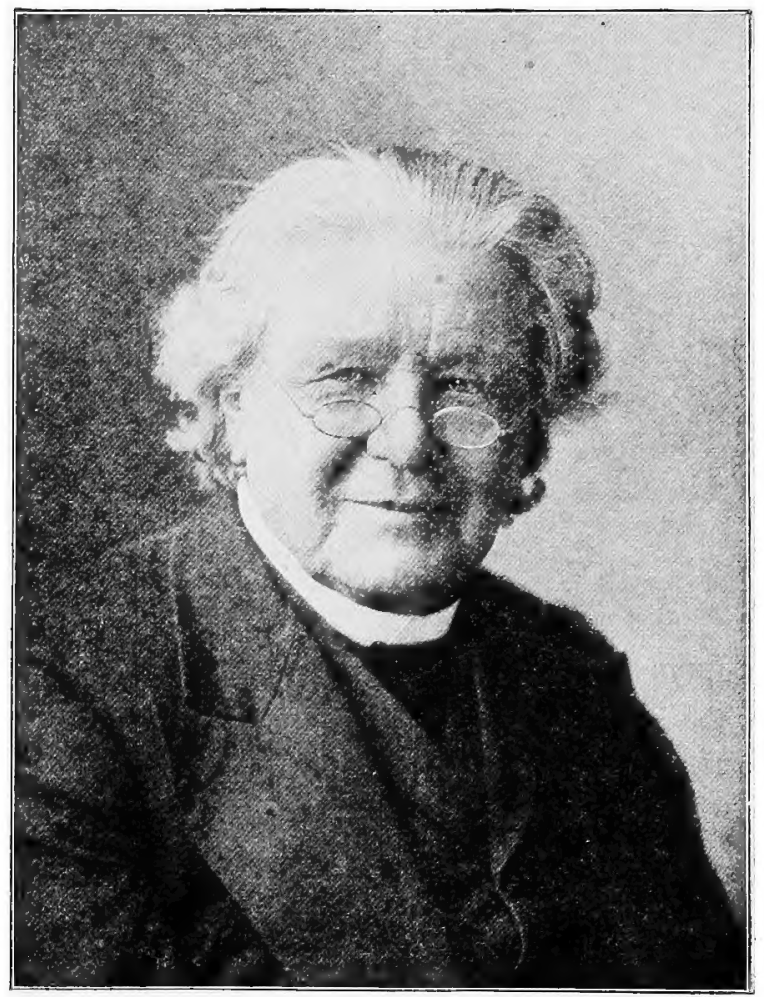

L. L. LANGSTROTH at 80. 


\section{BIOGRAPHY OF L. L. LANGSTROTH}

LORENZO LORRAIN LANGSTROTH, the "father of American Apiculture," was born in the city of Philadelphia, December 25,1810 . He early showed unusual interest in insect life. His parents were intelligent and in comfortable circunstances, but they were not pleased to see him "waste so much time" in digging holes in the gravel walks, filling them with crumbs of bread and dead flies, to wateh the curious habits of the ants. No books of any kind on natural history were put into his hands, but, on the contrary, much was said to discourage his "strange notions." Still he persisted in his observations, and gave to them much of the time that his playmates spent in sport.

In 1827, he entered Yale College, graduating in 1831. His father's means having failed, he supported himself by teaching, while pursuing his theological studies. After serving as mathematical tutor in Yale College for nearly two years, he was ordained Pastor of a Congregational chureh in Andover, Massachusetts, in May, 1836, and was married in August of that year to Miss A. M. Tucker of New Haven.

Strange to say, notwithstanding his passion in early life for studying the habits of insects, he took no interest in such pursuits during his college life. In 1837, the sight of a glass vessel filled with beautiful comb honey, on the table of a friend, led him to visit the attic where the bees were kept. This revived all his enthusiasm, and before he went home he purchased two colonies of bees in old box hives. The only lit- 
erary knowledge which he then had of bee-culture was gleaned from the Latin writings of Virgil, and from a modern writer, "who was somewhat skeptical as to the existence of a queenbee."

In 1839, Mr. Langstroth removed to Greenfield, Massachusetts. His health was much impaired, and he had resigned his pastorate. Increasing very gradually the number of his colonies, he sought information on all sides. The "Letters of Huber" and the work of Dr. Bevan on the honey bee (London, 1838), fell into his hands and gave him an introduction to the vast literature of bee-keeping.

In 1819, having removed to Philadelphia, Mr. Langstroth, with the help of his wife, began to experiment with hives of different forms, but made no special improvements in them until 1851, when he devised the novable frame hive, used at the present day in preference to all others. This is recorded in his journal, under the date of October 30, 1851, with the following remarks: "The use of these frames will, I am persuaded, give a new impetus to the easy and profitable management of bees."

This invention, which gave him perfect control over all the combs of the hive, enabled him afterwards to make many remarks and incidental discoveries, the most of which he recorded in his book, on the habits and the natural history of the honey-bee. The first edition of the work was published in 1852, and in its preparation he was greatly assisted by his accomplished wife. A revised edition was published in 1857, another in 1859, and large editions, without further revisions, were published until 1889, when the Dadants undertook the first re-writing of the book.

In January, 1852, Mr. Langstroth applied for a patent on 
Plate 3.

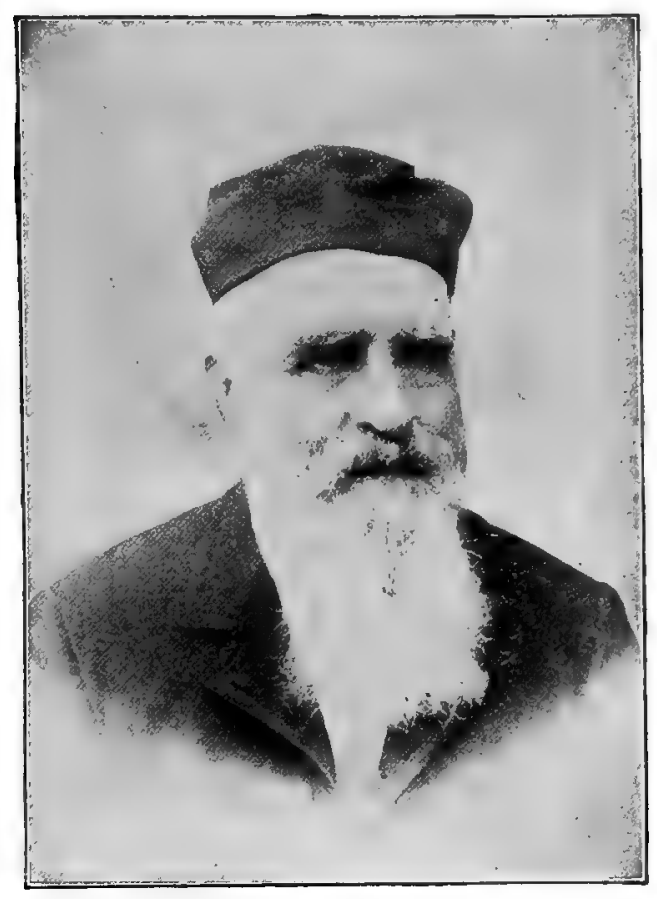

CHARLES DADANT at 70. 

his invention. This was granted him; but he was deprived of all the profits of this valuable discovery, by infringements and subsequent law-suits, which impoverished him and gave him trouble for years; though no doubt remains now in the mind of any one, as to the originality and priority of his discoveries.

From the very beginning, his hive was adopted by such men as Quinby, Grimm and others, while the inventions of Munu and Debeauvoys are now buried in oblivion.

Removing to Oxford, Ohio, in 1858, Mr. Langstroth, with the help of his son, engaged in the propagation of the Italian bee. From his large apiary he sold in one season $\$ 2,000$ worth of Italian queens. This amount looks small at the present stage of bee-keeping, but it was enormous at a time when so few people were interested in it.

The death of his only son, and repeated attacks of a serious head trouble, together with physical infirmities caused by a railroad accident, compelled Mr. Langstroth to abandon extensive bee-culture in 1874. But when his health permitted, his ideas were always turned toward improvements in beeculture. On the 19th of August, 1895, he wrote us, asking us to try the feeding of bees with malted milk, to induce the rearing of brood. He had also written to others on the same subject. On the 19th of September he wrote in the American Bee Journal, that, after comparative experinents he had found that a thirteen comb Langstroth hive gave more honey than the ordinary ten frame hive, thus showing that his mind was at all times occupied with bees.

Mr. Langstroth died Oetober 6th, 1895, at Dayton, Ohio, while delivering a sermon. He was nearly eighty-five years old. His name is now "venerated" by American bee-keepers, 
vi

who are aware of the great debt due him by the fraternity. $\mathrm{He}$ is to them what Dzierzon* is to German Apiarists, a master whose teachings will be retained for ages.

Mr. Langstroth was an eminent scholar. His bee library was one of the most extensive in the world. He learned French without a teacher, simply through his knowledge of Latin, for the sole purpose of reading the many valuable works on bees in the French language. He was a pleasant and eloquent speaker. His writings are praised by all, and we can not close his biography better than by quoting an able writer, who called him the "Huber of America."

* Pronounce Tseertsone. 
Plate 4.

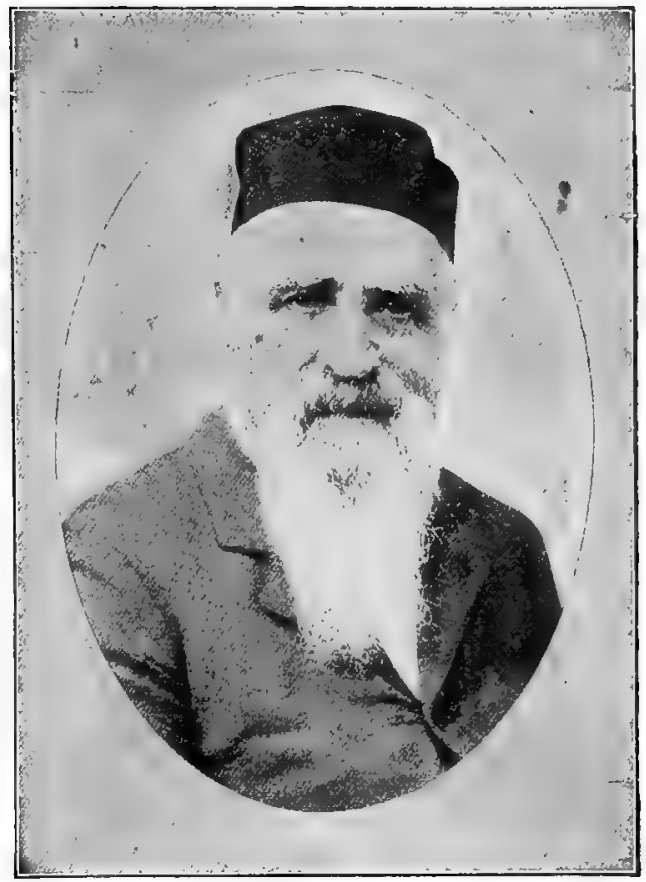

CHARLES DADANT at 80. 



\section{BIOGRAPHY OF CHARLES DADANT}

Mr. Charles Dadant was born May 22, 1817, at Vaux-SousAubigny, in the golden hills of Burgundy, France. After his education in the College of Langres, he went into the mercantile business in that city, but ill-success induced him to remove to America. He settled in Hamilton, Illinois, in 1863, and found a profitable occupation in bee-culture, which in his hands yielded marvelous results. He soon became noted as one of the leading apiarists of the world.

After a few years of trial he made a trip to Italy, in 1872, to import the bees of that country to America. Though at first unsuccessful, he persisted in his efforts and finally achieved great success. He was the first to lay down rules for the safe transportation of queen bees across the sea, which is now a matter of daily occurrence.

Later on, in partnership with his son, C. P. Dadant, he undertook the manufacture of comb foundation which has been eontinued by the firm, together with the management of several large apiaries, run almost exclusively for the production of extracted boney.

Although well versed in the English language, which he mastered at the age of forty-six, with the help of a pocket dictionary, Mr. Dadant was never able to speak it fluently and many of the readers of his numerous writings were astonished when meeting him to find that he could converse with difficulty. His writings were not confined to American publications, for in 1870 he began writing for European bee-journals and con- 
tinued to do so until his methods were adopted, especially in Switzerland, France, Italy and Russia, where the hive which he recommended is now known under his name. For twenty years he was a regular contributor to the Revue Internationale D'Apiculture, and, as a result, there is probably not another bee-writer whose name is so thoroughly known the world over.

Mr. Dadant was made an honorary member of more than twenty bee-keepers' associations throughout the world and his death, which occurred July 16, 1902, was lamented by every bee publication on both continents.

Mr. Dadant was a congenial man and a plilosopher. $\mathrm{He}$ retained his cheerfulness of spirit to his last day.

In addition to his supervision of the revision of this book, he was the author of a small treatise on bees, "Petit Cours d'Apiculture Pratique." He also published, in connection witl his son, a pamphlet on "Extracted Honey," 1881, now out of print. 


\section{PREFACE}

The first editions of the work of Langstroth were honored with the title of "The Classic in Bee-Culture." The first rewritten revision was published in 1889 , and this was so well received in the bee-keeping world that Mr. Charles Dadant translated it into the French language. With the help of Edouard Bertrand, it was published at Geneva. A little later a Russian edition was published-by Kandratieff, of St. Petersburg-which has caused a revolution in bee-culture in Russia. A Spanish edition is published in Barcelona by Pons Fabregues.

Mr. Charles Dadant died in 1902. Meantime progress has continued and we again have to bring this classic work forward by additions and a few"corrections.

In this edition we have aimed to preserve the first experiments and quotations made, whenever they have proven correct. We believe in giving credit to the first man who has ascertained a fact in natural history or has made a discovery. We have discarded all the cuts from Girard, because it was evident that most of his anatomical studies were copied from Barbò and Clerici, without giving them credit, and we have preferred to secure permission to copy the latter, whose work has not yet been excelled. It was published in Milan, under the title of "Atlante Di Apicoltura," by A. De Rauschenfels, former editor of L'Apicoltore.

Experienced bee-keepers will notice that we do not describe many new implements. It is because we believe in teaching beginners to use only that which has been thoroughly tested and is unquestionably good. Many new things will not stand the test of long years of practice. It is sufficient, among other things, to quote the metal corners for frames and the reversible hives. Metal corners were recommended at the time of our first revision, and we gave them a mention; they are now dis- 
carded even by their inventor. Reversible hives were the craze, and were praised in every way. We gave two of them a mention in our pages, with a warning against their use. Reversible hives are now almost entirely abandoned.

We recommend the large hives, yet we know they are not popular, because buyers want inexpensive hives. We have bowed before public wishes and give descriptions of several popular hives which are certainly successful. But we use large hives ourselves, for we consider them the best.

In our preface of the first revision we extended our thanks to Mr. C. F. Muth, now deceased, and to Miss Favard, for their help in our work. The writer has undertaken this last revision alone, but owes gratitude for sound advice on many points to a man who has to do with both practice and theory and whose long experience entitles him to the consideration of all bee-keepers, Doctor C. C. Miller, author of "A Year Among the Bees" and "Fifty Years Among the Bees." Dr. Miller, with small hives, enlarged at the proper time and again reduced in the brood chamber for the honey crop, has shown what could be done with intelligent and energetic management. He is not only a successful writer but a most extensive producer of comb honey, and is justly entitled to the name given him of the "Nestor of American Bee-Keeping."

The work of Father Langstroth, sustained in Europe by the pen of the Senior Dadant, has entirely changed European methods of bee-culture. The improved hive, based upon the Langstroth system, has been adopted all over the world, and testimonials come to us from the most remote countries showing that the methods taught have proven successful.

The principal changes in this edition are upon the question of "Diseases," as much progress has lately been made in the knowledge concerning foul-brood.

Hamilton, Illinois, January, 1919.

$$
\text { C. P. DADANT. }
$$




\title{
THE HIVE AND HONEY BEE
}

\author{
CHAPTER I. \\ PHYSIOLOGY OF THE HONEY-BEE.
}

1. ALL the leading facts in the natural history, and the breeding of bees, ought to be as familiar to the Apiarist, as the same class of facts in the rearing of his domestic animals. A few crude and half-digested notions, however satisfactory to the old-fashioned bee-keeper, will no longer meet the wants of those who desire to conduct bee-culture on an extended and profitable system. Hence we have found it advisable to give a short description of the principal organs of this interesting insect and abridged passages taken from various scientific writers whose works have thrown an entirely new light on many points in the physiology of the bee. If the reader will bear with us in this arduous task he will find that we have tried to make the descriptions plain and simple, avoiding, as much as possible, scientific words unintelligible to many of us.

2. Honey-bees are insects belonging to the order $H y$ menoptera; thus named from their four membranous, gauzy wings. They can flourish only when associated in large numbers, as in a colony. Alone, a single bee is almost as helpless as a new-born child, being numbed by the chill of a cool summer night.

3. The habitation provided for bees is called a hive. The inside of a bee-hive shows a number of combs about half-aninch apart and suspended from its upper side. These combs 
are formed of hexagonal cells of various sizes, in which the bees raise their young and deposit their stores.

4. In a family, or colony of bees, are found (Plate 5) 1st, One bee of peculiar shape, commonly called the Queen, or mother-bee. She is the only perfect female in the hive, and all the eggs are laid by her;

2nd, Many thousands of worker-bees, or incomplete females, whose office is, while young, to take care of the brood and do the inside work of the hive; and when older, to go to the fields and gather honey, pollen, water, and propolis or beeglue, for the needs of the colony; and

$3 d$, At certain seasons of the year, some hundreds and even thousands of large bees, called Drones, or male-bees, whose sole function is to fertilize the young queens, or virgin females.

Before describing the differences that characterize each of these three kinds, we will study the organs which, to a greater or less extent, they possess in common, and which are most prominently found in the main type, the worker-bee.

\section{General Characteristics.}

5. In bees, as in all insects, the frame-work or skeleton that supports the body is not internal, as in mammals, but mostly external. It is formed of a horny substance, scientifically called chitine, and well described in the following quotation :

6. "Chitine is capable of being moulded into almost every conceivable shape and appearance. It forms the hard hack of the repulsive cockroach, the beantiful scale-like feathers of the gaudy butterfly, the delicate membrane which supports the lacewing in mid air, the transparent cornea covering the eyes of all insects, the almost impalpable films cast by the moulting larvæ, and the black and yellow rings of our native and imported bees, besides internal braces, tendons, membranes, and ducts innumerable. The external skeleton, hard for the most part, and varied in thickness in beautiful adaptation to the strain to which it may be exposed, gives persistency of form to the little wearer; but it needs, wherever movement is necessary, to have 
Plate 5.
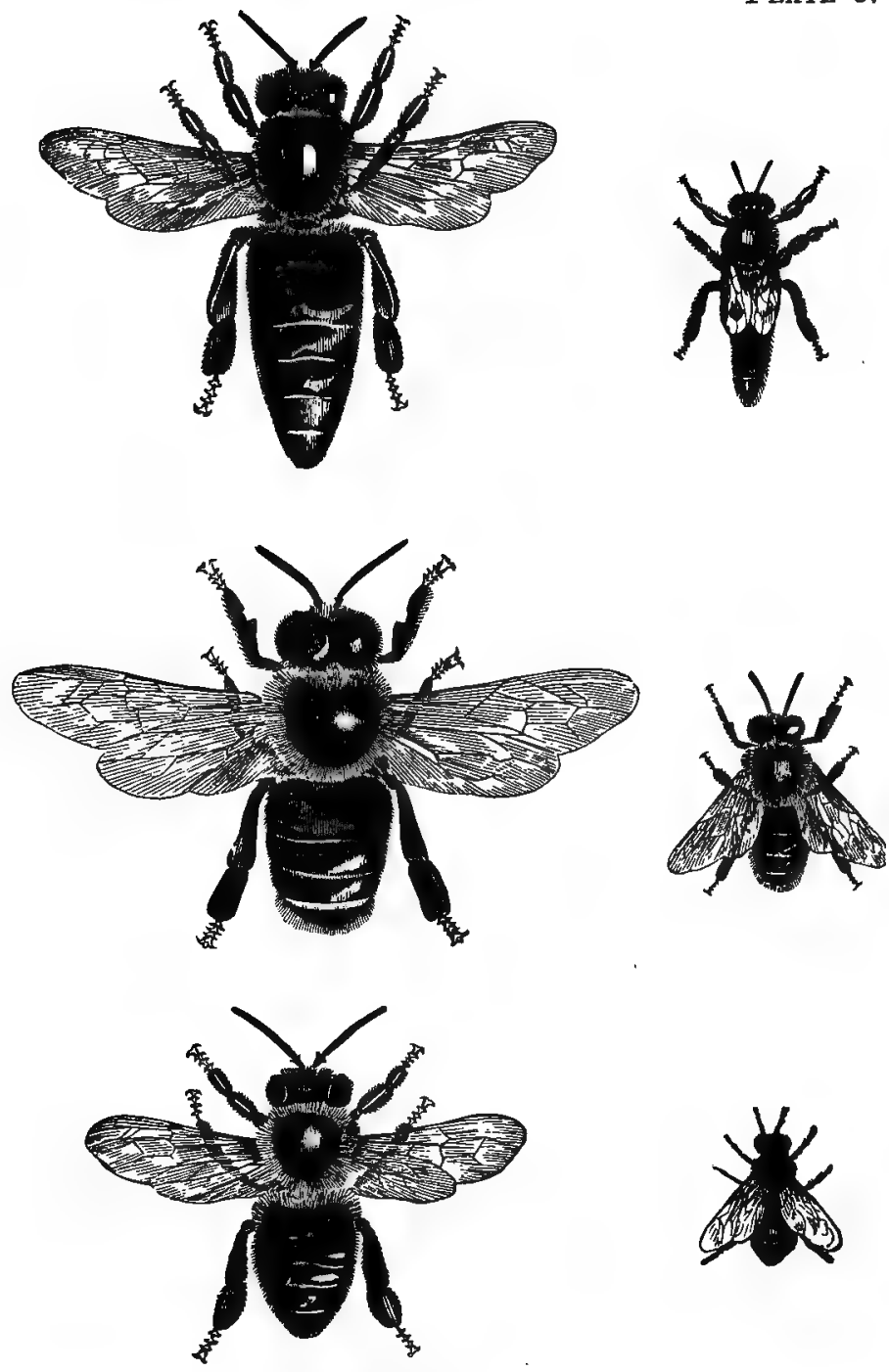

QUEEN, DRONE AND WORKER. Magnified and natural size. 

delicate extensions joining the edges of its unyielding plates. This we may understand by examining the legs of a lobster or crab, furnished like those of the bee, with a shelly case, but so large that no magnifying glass is required. Here we see that the thick coat is reduced to a thin and easily creased membrane, where, by flexion, one part is made to pass over the other.',......

"Again, almost every part of the body is covered by hairs, the form, structure, direction, and position of which, to the very smallest, have a meaning." (Cheshire, "Bees and Beekeeping," p. 30. London, 1887.)

7. Mr. Cheshire explains that, as the skeleton or framework of the bee is not sensitive, these hairs act as organs of touch, each one containing a nerve. They also act as clothing and aid in retaining heat-

"and give protection, as the stiff, straight hairs of the eyes, whilst some act as brushes for cleaning, others are thin and webbed for holding pollen grains; whilst by varied modifications, others again act as graspers, sieves, piercers, or mechanical stops to limit excessive movement."

8. The three sections of the body of the honey-bee are perfectly distinct: the head; the thorax, or centre of locomotion, bearing the wings and legs; and the abdomen, containing the honey-sack, stomach, bowels, and the main breathing organs.

The principal exterior organs of the head are the antennæ, the eyes, and the parts composing the mouth.

9. The eyes are five in number, two composite eyes, one on each side of the head, which are but clusters of small eyes or facets, and three convex eyes, or ocelli, arranged in a triangle at the top of the head.

10. The facets of the composite eyes, thousands in number, are six-sided, like the cells of the honey-comb, and being directed towards nearly every point, they permit the insect to see in a great number of directions at the same time.

11. In comparing the eyes of worker, queen and drone, Mr. Cheshire says: 
"The worker spends much of her time in the open air. Accurate and powerful vision are essentials to the proper prosecution of her labors, and here I found the compound eye possessing about 6,300 facets. In the mother of this worker I expected to find a less number, for queens know little of daylight. After wedding they are out of doors but once, or at most twice, in a year.* This example verified my forceast, by showing 4,920 facets on each side of the head. A son of this mother, much a stay-at-home also, was next taken. His facets were irregular

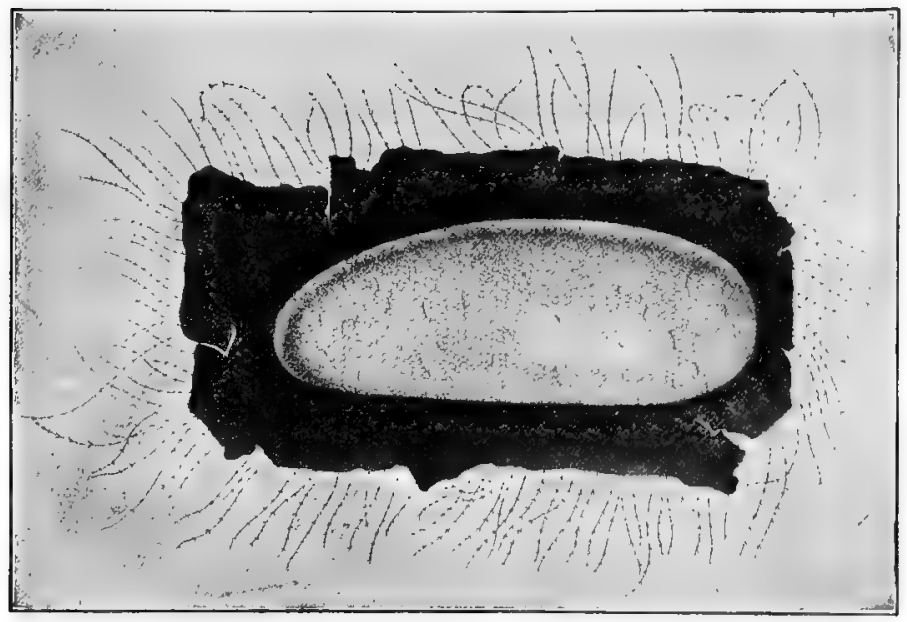

Fig. 1.

THE COMPOSITE EYE OF A WORKER-BEE MAGNIFIED.

(Copied from the Atlante di Apicoltura, microscopic studies of Count Gaetano Barbò, of Milan.)

in size, those at the lower part of the eye being much less than those near the top; but they reached the immense number of 13,090 on each side of the head. Why should the visual apparatus of the drone be so extraordinarily developed beyond that of the worker, whose need of the eye seems at first to be much more pressing than his?",

- When going out with a swarm. 
This question Mr. Cheshire answers, as will be seen further, in considering the antennæ. (26)*

12. The three small eyes, ocelli, are thought by Maurice Girard ("Les Abeilles," Paris, 1878), and others, to have a microseopic function, for sight at short distances. In the bive, the work is performed in the dark, and possibly (?) these eyes are fitted for this purpose.

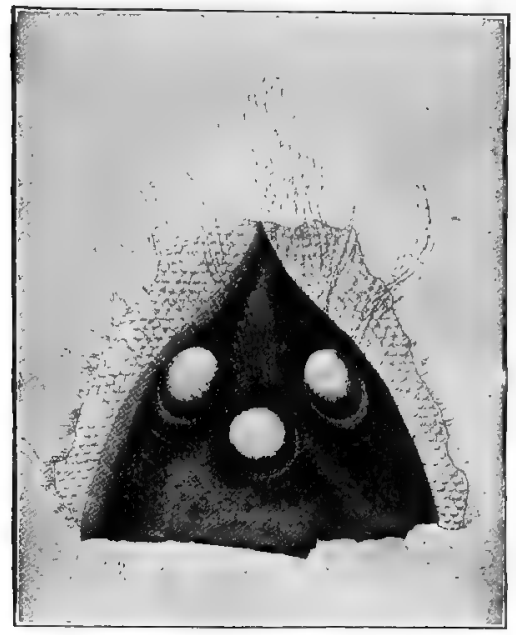

Fig. 2.

SMALI EYES, OR OCELLI OF THE DRONE.

Magnified. (Copied from Barbỏ.) The facets on each side belong to the large eyes.

13. Their return from long distances, either to their hive or to the place where they have found food, proves that bees can see very far. Yet, when the entrance to their hive has been changed, even only a few inches, they cannot readily find it.

Their many eyes looking in different directions, enable them

* The reader will readily understand that the numbers between parentheses refer to the paragraphs bearing those numbers. This is for the convenience of the student. 
to guide themselves by the relative position of objects, hence they always return to the identical spot they left.

14. If we place a colony in a forest where the rays of the sun can scarcely penetrate, the bees, at their exit from the hive, will fly several times around their new abode, then, selecting a small aperture through the dense foliage, they will rise above the forest, in quest of the flowers scattered in the fields. And like children in a nutting party, they will gather the $e_{\llcorner.}$crop here and there, a mile or more away, without fear of being lost or unable to return.

As soon as their honey-sack is full, or, if a threatening cloud passes before the sun, they start for home, without any hesitation, and, among so many trees, even while the wind mingles the leafy twigs, they find their way; so perfect is the organization of their composite eyes.

15. Bees can notice and remember colors. While experimenting on this faculty, we placed some honey on small pieces of differently colored paper. A bee alighted on a yellow paper, sucked her load and returned to her hive. While she was absent, we moved the paper. Returning, she came directly to the spot, but, noticing that the yellow paper was not there, she made several inquiring circles in the air, and then alighted upon it. According to Mr. A. J. Cook a similar experiment with the same results, was made by Lubbock. ("Bee-keepers' Guide," Lansing, 1884.)

16. We usually give our bees flour, in shallow boxes, at the opening of Spring, before the pollen appears in the flowers. These boxes are brought in at night. Every morning they are put out again, after the bees have commenced flying and hover around the spot. 'If by chance, some bits of white paper are scattered about the place, the bees visit those papers, mistaking them for flour, on account of the color.

17. But "the celebrated Darwin was mistaken in saying that the colorless blossoms, which he names obscure blossoms, are scarcely visited by insects, while the most highly colored blossoms are very fondly visited by bees." (Gaston Bonnier, "Les Nectaires," Paris, 1879.) 
18. For, although color attracts bees, it is only one of the means used by nature to bring them in contact with the flowers. The smell of honey is, certainly, the main attraction, and this attraction is so powerful, that frequently, at daybreak in the summer, the bees will be found in full flight, gathering the honey which has been secreted in the night, when nothing, on the preceding evening, could have predicted such a crop. This happens especially when there is a production of honey-dew, after a storm. We have even known bees to gather

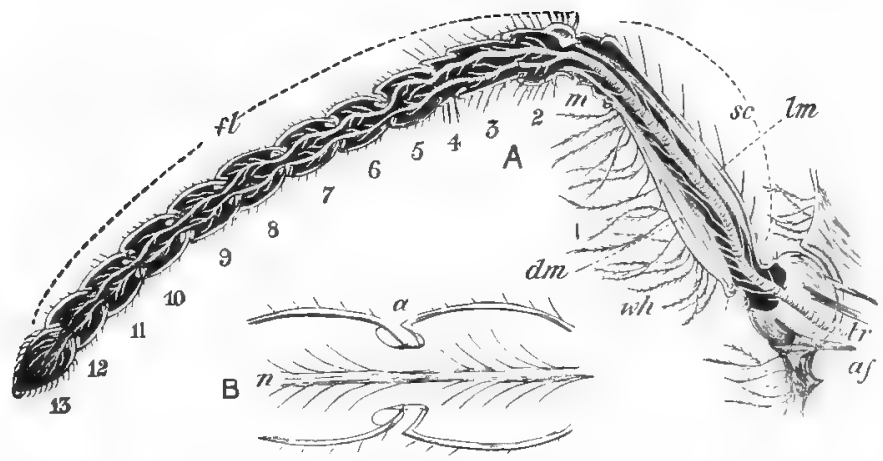

Fig. 3.

LONGITUDINAL SECTION OF DRONE ANTENNA, NGRVE STRUCTURTS REMOVED.

(Magnified 20 times. From Cheshire.)

A. $s c$, scape ; $h$, flagellum; 1,2 , \&c., number of joints ; af, antennary fossa, or hollow; $t r$, trachea; $m$, soft membrane; $w h$, webbed hairs; $l m$, levator muscle; $d m$, depressor muscle.

B, small portion of flagellum (magnified 60 times); $n$, nerve; $c$, articulation of joint.

honey from the tulip trees, (Liriodendron tulipifera) on very clear moonlight nights.

19. The antennæ (fig. 3, A, B), two flexible horns which adorn the head of the bee, are black, and composed of twelve joints, in the queen and the worker, and thirteen in the drone. The first of these joints, the scape, next to the head, is longer than the others, and can move in every direction. The antenna is covered with hairs. 
"These hairs, standing above the general surface, constitute the antennæ marvelous touch organs; and as they are distributed all round each joint, the worker-bee in a blossom eup, or with its head thrust into a cell in the darkness of the hive, is, by their means, as able accurately to determine as though she saw; while the queen, whose antenna is made after the same model, can perfectly distinguish the condition of every part of the eell into which her head may be thrust. The last joint, which is flattened on one side, near the end, is more thickly studded, and here the hairs are uniformly bent towards the axis of the whole organ. No one could have watched bees without discovering that, by the antennæ, intercommunication is accomplished; but for this purpose front and side hairs alone are required; and the drone, unlike the queen and worker, very suggestively, has no others, since the condition of the cells is no part of his care, if only the larder be well furnished." (Cheshire.)

20. The celebrated Francois Huber, of Geneva, made a number of experiments on the antennæ, and ascertained that they are organs of smell'and feeling.

Before citing his discoveries, we must pay our tribute of admiration to this wonderful man. (Plate 6.)

Huber, in early manhood, lost the use of his eyes. His opponents imagined that to state this fact would materially discredit his observations. And to make their case still stronger, they asserted that his servant, Francis Burnens, by whose aid he conducted his experiments, was only an ignorant peasant. Now this so-called "ignorant peasant" was a man of strong native intellect, possessing the indefatigable energy and enthusiasm indispensable to a good observer. He was a noble specimen of a self-made man, and rose to be the chief magistrate in the village where he resided. Huber has paid a worthy tribute to his intelligence, fidelity, patience, energy and skill. A single fact will show the character of the man. It became necessary, in a certain experiment, to examine separately all the bees in two hives. "Burnens spent eleven days in performing this work, and during the whole time he scarcely 



\section{Plate 6.}

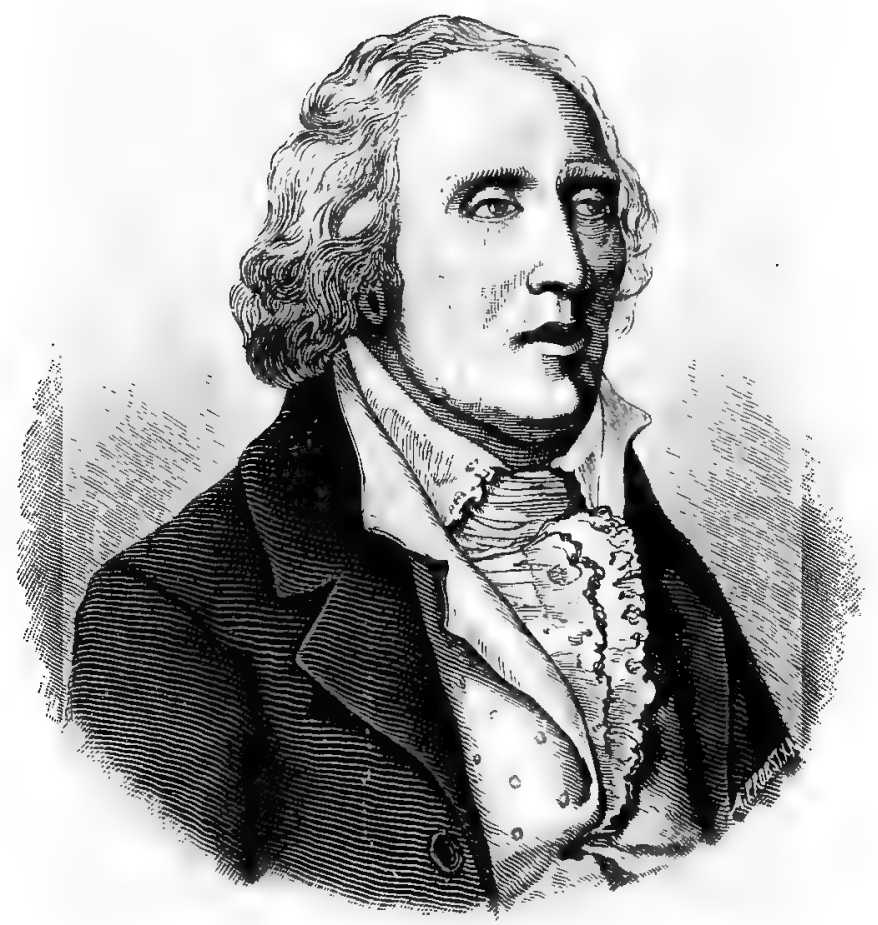

FRANCOIS HUBER,

Author of the "Nouvelles Observations sur les Abeilles," published in Geneva, Switzerland, 1792-1814.

This writer is mentioned pages $8,9,10,14,47,50,51,54,55,57,59$, $77,84,99,104,105,110,123,124,141,180,206$, $209,244,282,300,301,394,491$. 
allowed himself any relaxation, but what the relief of his eyes required."

Huber's work on bees is such an admirable specimen of the inductive system of reasoning, that it might well be studied as a model of the only way of investigating nature, so as to arrive at reliable results.

21. Huber was assisted in his researches, not only by Burnens, but by his own wife, to whom he was betrothed before. the loss of his sight, and who nobly persisted in marrying him, notwithstanding his misfortune and the strenuous dissuasions of her friends. They lived longer than the ordinary term of human life in the enjoyment of great domestic happiness, and the amiable naturalist, through her assiduous attentions, scarcely felt the loss of his sight.

22. Milton is believed by many to have been a better poet in consequence of his blindness; and it is highly probable that Huber was a better Apiarist from the same cause. His active, yet reflective mind, demanded constant employment; and he found, in the study of the habits of the honey-bee, full scope for his powers. All the observations and experiments of his faithful assistants being daily reported, many inquiries and suggestions were made by him, which might not have occurred to him, had he possessed the use of his eyes.

Few, like him, have such command of both time and money, as to be able to prosecute on so grand a scale, for a series of years, the most costly experiments. Having repeatedly verified his most important observations, we take great delight in holding him up to our countrymen as the PRINCE of APIARISTS.

23. Huber, having imprisoned a queen in a wire cage, saw the bees pass their antennæ through the meshes of the cage, and turn them in every direction. The queen answered these tokens of love by clinging to the cage and erossing her antennæ with theirs. Some bees were trying to draw the queen out, and several extended their tongues to feed her through the meshes. Wonderful as the experiment seemed at that time, 
the fact is verified now by daily occurrences in queen-rearing. Huber adds:

"How can we doubt now that the communication between the workers and the queen was maintained by the touch of the antennæ?"

24. That bees can hear, either by their antennæ or some other organ, few will now deny, even although the sound of a gun near the hive is entirely unnoticed by them.

"Should some alien being watch humanity during a thunder-storm, he might quite similarly decide that thunder was to us inaudible. Clap might follow clap withont securing any external sign of recognition; yet let a little child with tiny voice but shriek for help, and all would at once be awakened to activity. So with the bee: sounds appealing to its instincts meet with immediate response, while others evoke no wasted emotion.', (Cheshire.) '

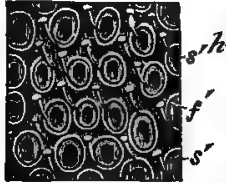

A

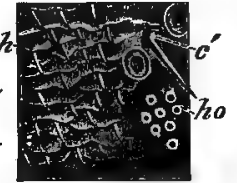

B

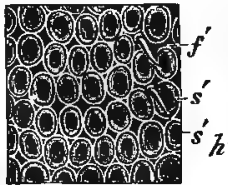

C

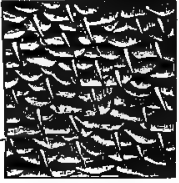

D

Fig. 4.

PARTS OF SURFACE OF ANTENNAE.

(Magnified 360 times. From Cheshire.)

A, portion of front surface of one of the lower members of the flagellum (worker or queen), $s^{\prime}$, smelling organ; $f^{\prime}$, feeling hair.

$B$, portion of the side and back of same (worker), $h$, ordinary hair; $c^{\prime}$, conoid hair; ho (auditory?) hollows.

C, portion of one of the lower members of flagellum (drone).

D, portion of lower member of flagellum (back, worker or queen).

"The sound that bees produce by the vibrating of their wings is often the means of calling one another. If you place a bee-hive in a very dark room, their humming will draw the scattered bees together. In vain do you cover the hive, or change its place, the bees will invariably go towards the spot whence the sound comes." (Collin, "Guide du Propriétaire d'Abeilles," Paris, 1875.)

25. To prove that bees can hear is easy, but to determine 
the location of the organ is more difficult. The small holes which were discovered on the surface of the antennæ, have been considered as organs of hearing by Lefébure (1838), and by others later. Cheshire has noticed these small holes in the six or seven last articulations of the antennæ: holes which become more numerous towards the end of the antenna, so that the last joint carries perhaps twenty. He, also, considers these as the organs of hearing, especially because they are larger in the drones, who may need to distinguish the sounds of the queen's wings." On this question, Prof. Cook, in his "Bee-keepers' Guide," says:

"No Apiarist has failed to notice the effect of various sounds made by the bees upon their comrades of the hive, and how contagious are the sharp note of anger, the low hum of fear, and the pleasant tone of a swarm as they commence to enter their new home. Now, whether insects take note of these vibrations as we recognize pitch, or whether they just distinguish the tremor, I think no one knows."

26. It is well proven that bees can smell with their antennæ, and Cheshire carefully describes the "smell hollows," not to be mistaken for the "ear holes," which are smaller, but also located on the antennæ.

"In the case of the worker, the eight active joints of the antenna have an average of fifteen rows, of twenty smell-hollows each, or 2,400 on each antenna. The queen has a less number, giving about 1,600 on each antenna. If these organs are olfactory, we see the reason. The worker's necessity to smell nectar explains all. We, perhaps, exclaim-Can it be that these little threads we call antennæ can thus carry thousands of organs each requiring its own nerve end? But greater surprises await us, and I must admit that the examinations astonished me greatly. In the drone antenna we have thirteen joints in all, of which nine are barrel-shaped and special, and these are covered completely by smell-hollows. An average of thirty rows of these, seventy in a row, on the nine joints of the two antennæ, give the astounding number of 37,800 distinct or-

* The queens and the drones, in flight, each have a peculiar and eas. ily diștinguishạble sound. 
gans. When I couple this development with the greater size of the eye of the drone, and ask what is his function, why needs he such a magnificent equipment? and remember that he has not to scent the nectar from afar, nor spy out the coy blossoms as they peep between the leaves, I feel forced to the conclusion that the pursuit of the queen renders them necessary." (Cheshire.)

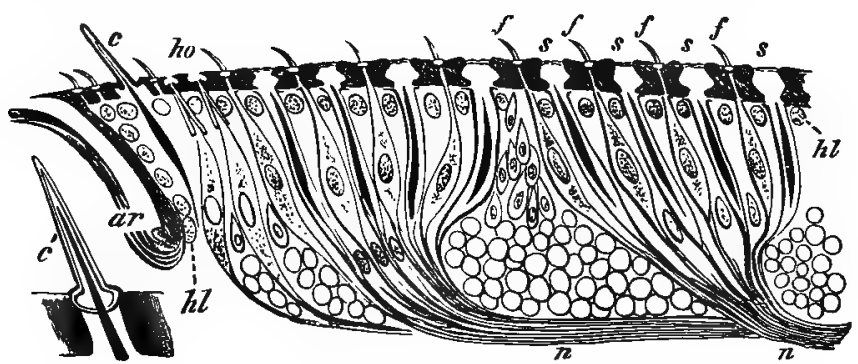

Fig. 5.

LONGITUDINAL SECTION THROUGH PORTION OF FLAGELLUM OF ANTENNA OF WORKER.

(Magnifled 300 times. From Cheshire.)

$f$, feeling hair; st, smelling organ; ho, hollow; $c$, conoid or coneshaped hair; $h l$, hypodermal or under-skin layer; $n, n$, nervds in bundles; $a r$, articulation; $c^{\prime}$, conoid hair, magnified 800 times.

27. While giving these short quotations and beautiful engravings from Cheshire's anatomy of the bee, we earnestly advise the scientific bee-student to procure and read his work. Mr. Cheshire shows us those minute organs so beautifully and extensively magnified, that in reading his book we feel as though we were transported by some Genius inside of the body of a giant insect, every detail of whose organism was laid open before us. However wonderful the statement made above, of the existence of nearly 20,000 organs in such a small thing as the antenna of a bee, this fact will not be disputed. Those of our bee-friends, who have had the good luck to meet the editor of the British Bee-Journal, Mr. Cowan, during his trip to America, in 1887, will long remember the wonderful microscopical studies, and the microscope which he brought 
with him. This instrument, the most powerful by far that we ever had seen, gave us a practical peep into the domain of the infinitesimal.

28. Better than any other description of the smallness of atoms is that given by Flammarion, in his "Astronomie Populaire":

"It is proven," he says, "that an atom cannot be larger than one ten-millionth of a millimeter. It results from this, that the number of atoms contained in the head of a pin, of an ordinary diameter, would not be less than

$$
8,000,000,000,000,000,000,000 \text {. }
$$

And if it was possible to count these atoms, and to separate them, at the rate of one billion per second, it would take 250,000 years to number them."

29. Girard reports, as follows, an experiment on the olfactory organs of our little insects :

"While a bee was intently oceupied sucking honey, we brought near her head a pin dipped in ether. She at once showed symptoms of a great anxiety; but an inodorous pin remained entirely unnoticed."

30. Whatever be the location of their olfactory organs, they are unquestionably endowed with a marvelous power of detecting the odor of honey in flowers or elsewhere.

One day we discovered that some bees had entered our honeyroom, through the key-hole. We turned them out, and stopped it up. Some time after, more bees had entered, and we vainly searched for the crevice that admitted them. Finally a feeble hum caused us to notice that they were coming down the chimney to the fire-place, which was closed by a screen. The wedge which held this screen having become somewhat loose, the motion of the screen in windy weather opened a hole just large enough for a bee to crawl through. A few bees were waiting behind the screen, and as soon as its motion allowed one to pass, she manifested her joy by the humming which led to the discovery. These bees, escaping with a load, when 
the door was opened, had become customary and interested visitors.

31. Every bee-keeper has noticed that their flight is guided by the scent of flowers, though they be a mile or more away. In the city of Keokuk, situated on a hill in a curve of the Mississippi, the bees cross the river, a mile wide, to find the flowers on the opposite bank.

32. "Not only do bees have a very acute sense of smell, but they add to this faculty the remembrance of sensations. Here is an example: We had placed some honey on a window. Bees soon crowded upon it. Then the honey was taken away, and the outside shutters were closed and remained so the whole winter. When, in Spring, the shutters were opened again, the bees came back, although there was no honey on the window. No doubt, they remembered that they got boney there before. So, an interval of several months was not suffieient to efface the impression they had received.-(Huber, "Nouvelles Observations sur les Abeilles,' Genève, 1814.)

33. It is well known, also, that bees wintered in cellars (646) remember their previous location when taken out in the Spring.

If food is given to a colony, at the same hour, and in the same spot, for two days in suocession, they will expect it the third day, at the same time and place.

34. "When one of her antennæ is eut off, no change takes place in the behavior of the queen. If you cut both antenriæ near the head, this mother, formerly held in such high consideration by her people, loses all her influence, and even the maternal instinct disappears. Instead of laying her eggs in the cells, she drops them here and there." -(Huber.)

The experiments made by Huber on workers and drones, in regard to the loss of the antennœ, are equally conclusive. The workers, deprived of their antennæ, returned to the hive, where they remained inactive and soon deserted it forever, light being the only thing which seemed to have any attraction for them.

In the same way, drones, deprived of their antennæ, de- 
serted the observatory hive, as soon as the light was excluded from it, although it was late in the afternoon, and no drones were flying out. Their exit was attributed to the loss of this organ, which helps to direct them in darkness.

35. The inference is obvious, that a bee deprived of her antennæ loses the use of her intellect.

"If you deprive a bird, a pigeon, for instance, of its cerebral lobe, it will be deprived of its instinct, yet it will live if you stuff it with food. Furthermore, its brain will eventually be renewed, thus bringing back all the uses of its senses." (Claude Bernard, "Science Expérimentale.")

Bees, however, cannot live without their antennæ, and these organs would not grow again, like the brains of birds, the legs of crawfishes, or the tails of lizards.

36. Let us notice, in reference to the sensorial organs, that the brain of workers is very much larger than that of either the queen or the drone, who need but a very common instinct to perform their functions; while the various occupations of the workers, who act as nurses, purveyors, sweepers, watchful wardens, and directors of the economy of the bee-hive, necessitate an enlargement of faculties very extraordinary in so small an insect.

37. We cannot leave this subject without quoting the celebrated Hollander, Swammerdam, as Cheshire does:

"I cannot refrain from confessing, to the glory of the immense, incomprehensible Architect, that $I$ have but imperfectly described and represented this small organ; for to represent it to the life in its full perfection, far exceeds the utmost efforts of human knowledge."

38. We have now come to the most difficult organ to describe-the mouth of the bee. But we will first visit the interior of the head and of the thorax, to find the nursing and salivary glands, and explain their uses.

39. The workers have three pairs of glands: two pairs, different in form, placed in the head (fig. 6), and one larger pair located in the thorax or corselet. The upper pair, which 
resembles a string of onions, is absent in the drones and queens. According to Girard, these upper glands were discovered by Meckel in 1846. They are very large and dilated in the young worker bees, while they act as nurses, but are slim in the bees of a broodless colony. In the old bees, that

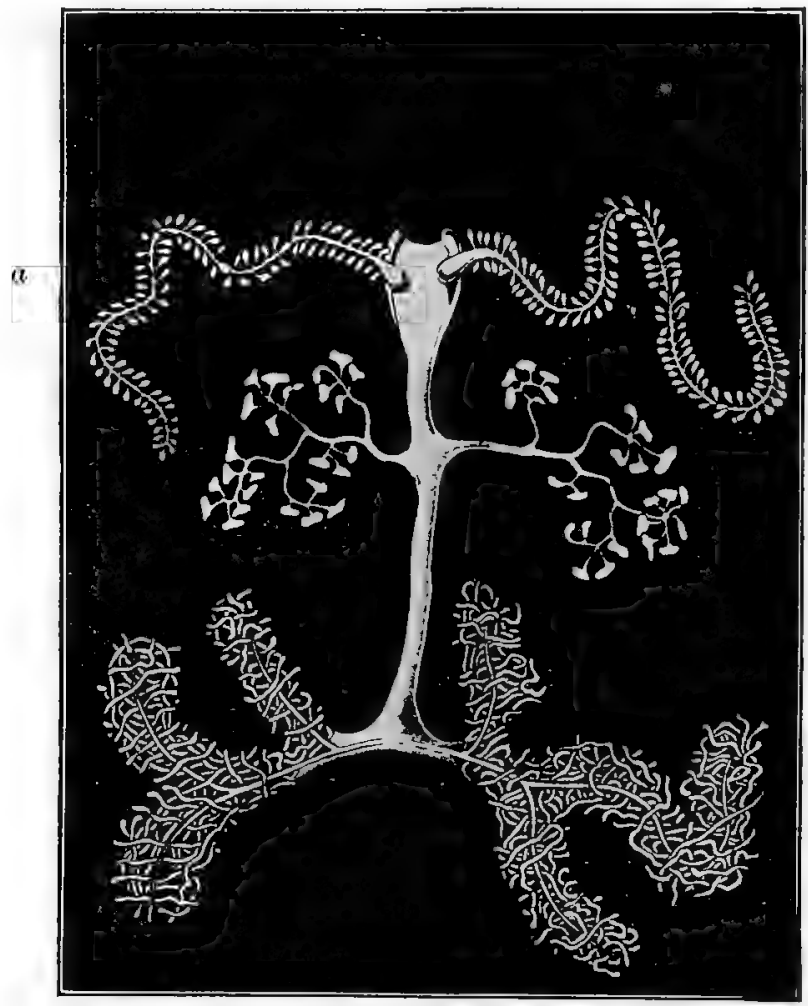

Fig. 6.

SALIVARY GLANDS OF THE WORKER-BEE,

(Magnified. After Barbò.) $a, a$, glands of the head; $b$, glands of the thorax. The two upper pairs are glands of the head, the lower are glands of the thorax. 
no longer nurse the brood, they wither more and more, till they become shrunken and seemingly dried. Hence Maurice Girard, and others before him, have concluded very rationally that these upper glands produce the milky food given to the larvæ, during the first days of their development. Mr. Cheshire has confirmed the very reasonable theory that the queen, during the time of egg-laying, is fed by the workers from the secretions of this gland.

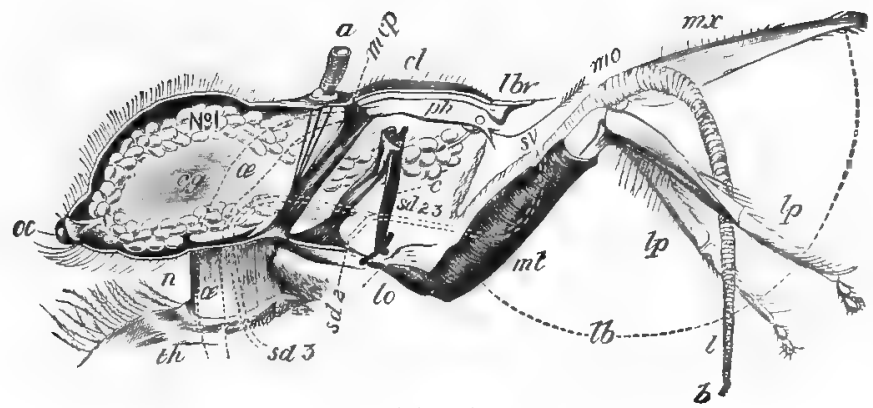

Fig. 7.

LONGITUDINAL SECTION THROUGH HEAD OF WORKER.

(Magnified 14 times. From Cheshire.)

$u$, antenna, with three muscles attached to mcp, meso-cephalic pillar; $c l$ clypeus; $l b r$, labrum or upper lip; No. 1, upper salivary or ehyle gland (this gland really runs in front of the meso-cephalic pillars, but here the latter are kept in view); o, opening of same in the mouth; oc, ccellus or simple eye; $c g$, cephalic ganglion, or brain system; $n$, neck; th, thorax; oe, oesophagus or gullet; $s d, 2,3$, salivary ducts of glands two and three; $s v$, salivary valve; $p h$ pharynx; $l b$, labium or lower lip, with its parts separated for display; $m t$, mentum or chin; mo, mouth; $m x$, maxilla; $l p$, labial palpi; $l$, ligula or tongue; $b$, bouton.

40. "The queen at certain periods has the power of produeing between 2,000 and 3,000 eggs daily (98). A careful calculation shows that 90,000 of these would occupy a cubic inch and weigh 270 grains. So that a good queen, for days or even weeks* in succession, would deposit, every twenty-four

* These facts have been demonstrated so repeatedly, that they are as well established as the most common laws in the breeding of our domestic animals, 
hours, between six and nine grains of highly-developed and extremely rich tissue-forming matter. Taking the lowest estimate, she then yields the incredible quantity of twice her own weight daily, or more accurately four times, since at this period more than half her weight consists of eggs. Is not the reader ready to exclaim: What enormous powers of digestion she must possess! and sinee pollen is the only tissue-forming food of bees, what pellets of this must she constantly keep swallowing and how large must be the amount of her dejections! But what are the facts? Dissection reveals that her chyle stomach is smaller than that of the worker, and that at the time of her highest efforts, often scarcely a pollen grain is discoverable within it, its contents consisting of a transparent mass, microscopically indistinguishable from the so-called "royal jelly"; while the most practical bee-men say that they never saw the queen pass any dejections at all. These contradictions are utterly inexplicable, except upon the theory I propound and advocate. She does pass dejections, for I have witnessed the fact; but these are very watery." ....-(Cheshire.)

Thus, according to Cheshire, the food eaten by the queen, during egg-laying, is already digested and assimilated by the bees, for her use. Her dejections, which are scanty and liquid, are licked up by the workers, as are also the dejections of the drones, if not too abundant.

41. The other two pairs of glands, which are common to workers, queens, and drones, evidently produce the saliva. The functions of both must be the same, for they unite in the same canal ( $s d, 2,3$, fig. 7 ), terminated by a valvule, which, passing though the mentum or chin $(m t)$, opens at the base of the tongue. The saliva produced by them is used for different purposes. It helps the digestion; it changes the chemical condition of the nectar ( $2 \mathbf{1 6})$ harvested from the flowers; it helps to knead the scales of wax (201) of which the combs are built, and perhaps the propolis (236) with which the hives are varnished. It is used also to dilute the honey when too thick, to moisten the $(\mathbf{2 6 3})$ pollen grains, to wash the hairs when daubed with honey, etc.

These glands yield their saliva while the tongue of the bees 
is stretched out; but the upper glands (No. 1, fig. 7), which open on both sides of the pharynx or mouth $(p h)$, can yield their product only when the tongue is bent backwards, to help feed the larva (64) lying at the bottom of the cell.

4.2. The mouth of the bee has mandibles or outer jaws, which move sidewise, like those of ants and other insects, instead of up and down as in higher animals. These jaws are short, thick, without teeth, and beveled inside so as to form a hollow when joined together, as two spoons would do. With them, they manipulate the wax to build their comb, open the anthers of flowers to get the honey, and seize and hold, to drag them out, robbers or intruders, cr débris of any kind.

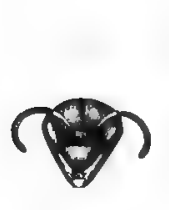

Fig. 8.

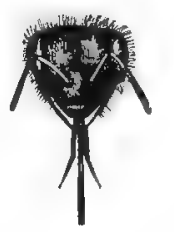

Fig. 9.

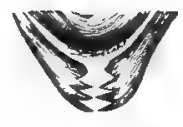

Fig. 10.

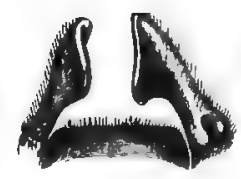

Fig. 11.

Head of honey- Head of honey- Mandibie of honey- Mandible of honeyhornet. bee. (Magnified.)

bee.

(Magnified.)

(Magnified.)

43. Fig. 10 shows the jaws of the Mexican hornet highly magnified. Fig. 11 shows the jaws of the honey-bee, highly magnified. Notice the difference in the shape of the two, the saw-like appearance of the one, and the spatula shape of the other. A glance at these figures is enough to convince any intelligent horticulturist of the truth of Aristotle's remarkmade more than two thousand years ago-that "bees hurt no kinds of sound fruit, but wasps and hornets are very destruetive to them."

We shall give further evidence concerming the correctness of this statement. (871)

44. Below the antennæ, the clypeus or shield ( $c l$, fig. 7) projects, which is prolongated by an elastic rim called labrum or upper lip $(l b r)$. The pharynx is the mouth $(p h)$, and the 
cosophagus (œ) the gullet, through which the food goes into the stomach.

As we have already seen, the canals of the upper glands open on each side of the mouth, and discharge their product into it at will.

45. The chin or mentum $(m t)$ is not literally a part of the mouth. It can move forward and backward, and supports several pieces, among which is the tongue, or proboseis, or ligula $(l)$. The tongue is not an extension of the chin, but has its root in it, and can only be partly drawn back into it, its extremity, when at rest, being folded back under the chin.

46. There are, on each side of the tongue, the labial palpi or feelers* (b, fig. 12 , and $l p$, fig. 7 ), which are fastened to the chin by linged joints. They are composed of four pieces each, the first two of which are broad, and the other two small and thin, and provided $\pi$ ith sensitive hairs of a very fine fabric. Outside of the palpi are the maxillæ ( $c$, fig. 12 , and $m x$, fig. 7 ) which in some insects have the function of jaws, but which, in the bee, only serve, with the palpi, to enfold the tongue in a sort of tube, formed and opened at the will of the insect, and which, by a certain muserlar motion, as also by the ability of the tongue to move up and down in this tube, force the food up into the mouth.

17. The tongue is covered with hairs, which are of graded sizes, so that those nearest the tip or bouton are thin and flexible. It-the tongue-is grooved like a trough, the edges of which can also unite to form a tube, with perfect joints. It is easily understood that if the tongue were a tube, the pollen grains when conveyed through it would obstruct it, especially when daubed with very thick honey.

48. "A most beautiful adaptation here becomes evident. Nectar gathered from blossoms needs conversion into honey. Its cane sugar must be changed into grape sugar, and this is accomplished by the admixture of the salivary secretions of Systems Nos. 2 and 3 (sd, 2, 3, fig. 7), either one or both. The tongue is drawn into the mentum by the shortening of the re-

Organs of taste according to Leydig and Jobert. 
Plate 7.

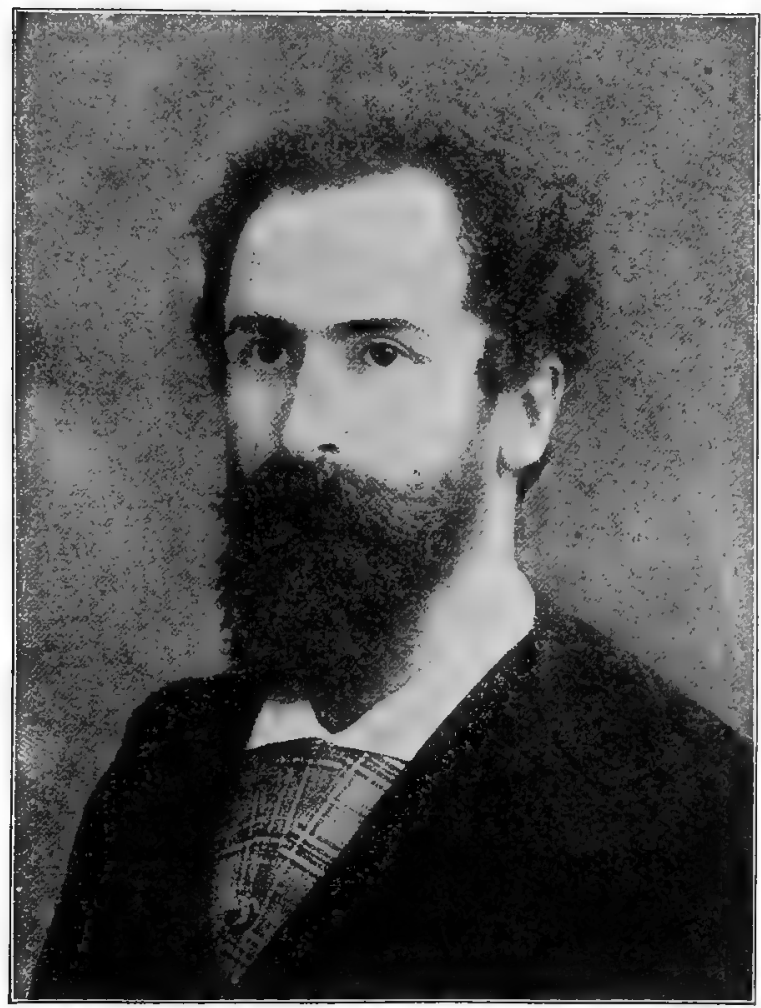

COUNT GAETANO BARBO,

Author of the Microscopic Studies, shown in figs. 1, 2, 6, 12, 15, 16, 17, $18,20,23,26,28,33,37,38,39,44$. 


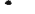


tractor linguæ muscle, which, as it contracts, diminishes the space above the salivary valve, and so pumps out the saliva, which mixes with the nectar as it rises, by methods we now

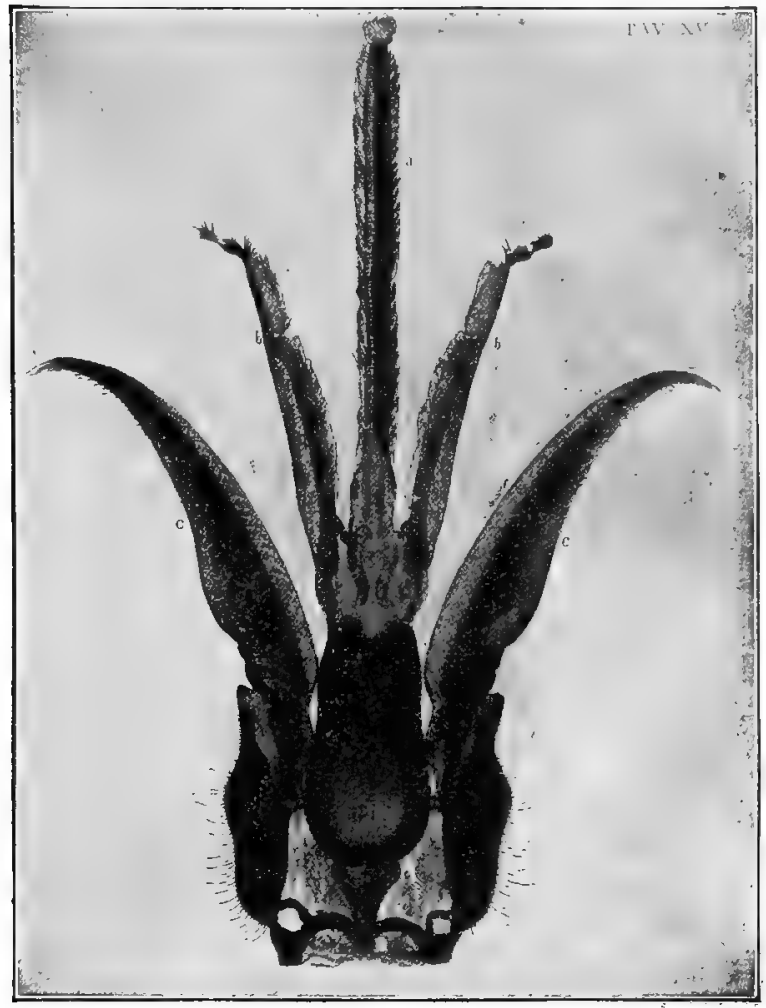

Fig. 12.

TONGUE AND APPENDAGES.

(Magnified. After Barbo.)

$a$, tongue; $b$, labial palpi; $c$, maxilla.

understand. Bees, it has often been observed, feed on thick syrup slowly; the reason is simple. The thick syrup will not pass readily through minute passages without thinning by, a 
fluid. This fluid is saliva, which is demanded in larger quantities than the poor bees can supply. They are able, however, to yield it in surprising volume, which also explains how it is that these little marvels can so well elean themselves from the sticky body honey. The saliva is to them both soap and water, and the tongue and surrounding parts, after any amount of daubing, will soon shine with the lustre of a mirror." -(Cheshire.)

49. The length of the tongue of the honey-bee is of great importance to bee-keepers. Some flowers, such as red clover, have a corolla so deep, that few bees are able to gather the honey produced in them. Therefore, one of the chief aims of progressive bee-keepers, should be to raise bees with longer tongues. This can undoubtedly be done sooner or later, by careful selection, in the same way that all our domestic plants and animals have been improved in the past. For this, patience and time are required.

50. The thorax is the intermediate part of the body. It is also called "corselet." It is formed of three rings soldered into one. Each of the three rings bears one pair of legs, on its under side; and each of the last two rings bears a pair of wings, on its upper side; making four wings and six legs, all fastened on the thorax.

51. Each leg is composed of nine joints (B, Plate 8 ), the two nearest the body $(c, t r)$ being short. The next three are the femur $(f)$, tibia $(t i)$, and planta $(p)$ also called metatarsus. The last four joints form the tarsus $(t)$ or foot.

52. The last joint of the tarsus, or tip of the foot, is provided with two claws (an, fig. 13), that eling to objects or to the surfaces on which the bee climbs. These claws can be folded, somewhat like those of a cat (A, fig. 13), or ean be turned upwards ( $B$, fig. 13) when the bees are hanging in clusters. When they walk on a polished surface, like the pane of a window, which the claws cannot grasp, the latter are folded down; but there is between them a small rubber-like pocket, pulvillus ( $p v, \mathrm{~A}, \mathrm{~B}$ ) which secretes a sticky, "clammy" substance, that enables the bee to cling to the smoothest surfaces. House-flies and other insects cling to walls and win- 
dows by the same process. It was formerly asserted that insects cling to the smooth surfaces by air suction, but the above explanation is correct, and you can actually see "the footprints of a fly" on a pane of glass, with the help of a microscope, remnants of the "clammy" substance being quite discernible. By this ingenious arrangement, bees can walk indifferently upon almost anything, since wherever the claws fail, the pulvilli take their place.

53. "But another contrivance, equally beautiful, remains to be noticed. The pulvillus is carried folded in the middle (as at C, fig. 13), but opens out when applied to a surface, for it has at its upper part an elastic and curved rod (cr) which straightens as the pulvillus is pressed down, C and D, fig. 13, making this clear. The flattened-out pulvillus thus holds strongly while pulled, by the weight of the bee, along the surface, to which it adheres, but comes up at once if lifted and rolled off from its opposite sides, just as we should peel a wet postage stamp from its envelope. The bee, then, is held securely till it attempts to lift the leg, when it is freed at once; and, by this exquisite yet simple plan, it can fix and release each foot at least twenty times per second."-(Cheshire.)

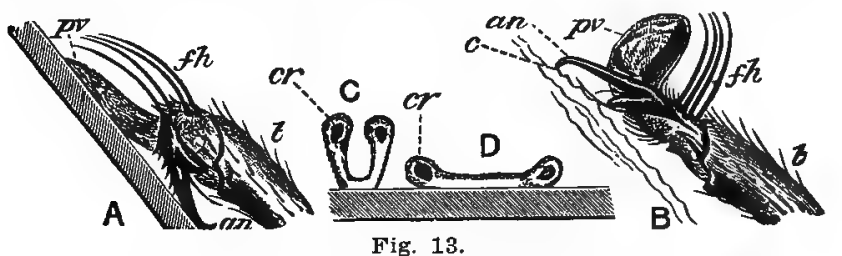

BEE'S FOOT IN CLIMBING, SHOWING ACTION OF PULVILLUS.

(Magnified 30 times. From Cheshire.)

A, position of the foot in climbing slippery surface or glass; $p v$, pulvillus; $f$, feeling hairs; $a n$, anguiculus, or claw; $t$, tarsal joint.

$B$, position of the foot in climbing rough surface.

C, section of pulvillus just touching flat surface; $c r$, curved rod.

D, pulvillus applied to surface.

54. The legs of bees, like all other parts of their body, are covered with hairs of varied shapes and sizes, the deseription of which is beyond the limits of this work. We will con- 
fine ourselves to a short explanation of the uses which have a direct bearing upon the work of the bee.

The hairs of the front, or first, pair of legs (C, Plate 8), are especially useful in cleaning the eyes and the tongue, and gathering the pollen grains.

55. On the metatarsus, the lower of the two largest joints of these front legs, is a rounded notch ( $\mathrm{E}, a$, Plate 8), closed when the leg is folded, by a sort of spur or velum, $(v, \mathrm{C}, \mathrm{E}$, $\mathrm{H})$ fastened to the tibia, or upper large joint. The learned Dr. Dubini, of Milan (L'Ape, Milan, 1881), speaks of it as being used to cleanse the antennæ and the tongue of the pollen that sticks to them. Mr. Cheshire thinks it is used only to cleanse the antennæ, from the fact that this notch, which has teeth like a comb (F, Plate 3), is found as well in the queen and the drone as in the worker, and that its aperture corresponds exactly to the different sizes of the antennæ of each sex. (H, Plate 8.)

56. The second pair of legs have no notch, but the lower extremity of the tibia bears a spur (D, s, Plate 8) or spine, which is used in loosening the pellets of pollen, brought to the hive on the tibias of the posterior legs (Plate 8). This spur also helps in cleaning the wings.

5\%. The posterior or hind legs are very remarkable, in several respects. Between the tibia and the metatarsus (B, $w p$, Plate 8) they have an articulation, whose parts close like pincers, and which serves to loosen from the abdomen the scales of wax to be mentioned further on (201). As neither the queen nor the drone produces wax, they are destitute of this implement.

58. "But the chicf interest centers on the two joints last mentioned (ti, P, A, B, Plate 8), as a device for carrying the pollen of the blossom home to the hive. The metatarsus is enlarged into a sub-quadrangular form, constituting a flattish plate, slightly convex on both surfaces. The outer face (p, A, Plate 8 ) is not remarkable, but the one next the body ( $p, B)$ is furnished with stiff combs, the teeth of which are horny, straight spines, set closely, and arranged in transverse rows 
Plate 8.

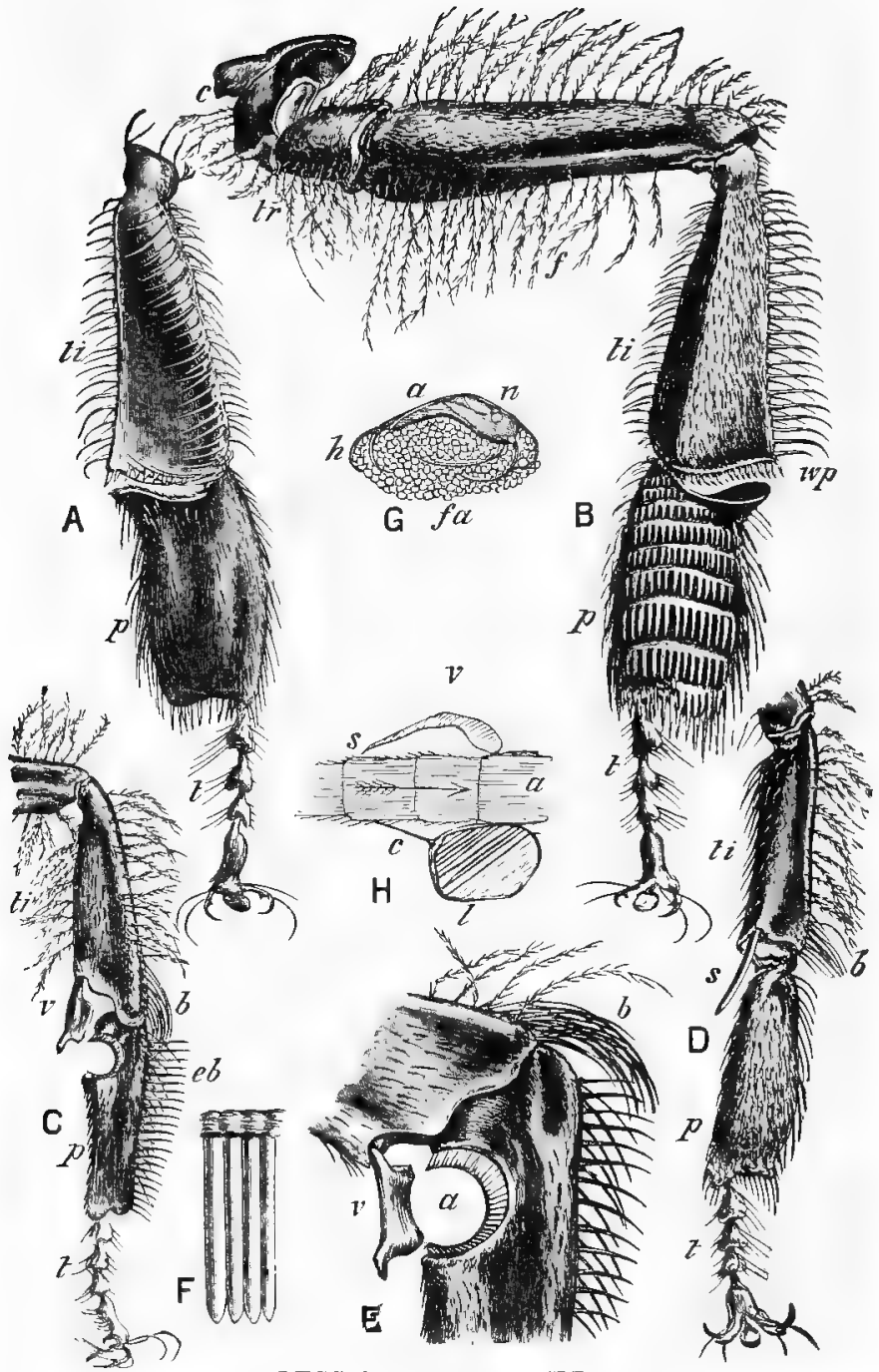

LEGS OF WORKER-BEE.

(Magnified 10 times. From Cheshire.)

A, third right leg, side from the body. $t i$, tibia, showing pollen basket; $p$, planta or metatarsus; $t$, tarsus. $B$, third right leg, side next the body. $c$, coxa; $t r$, trochanter; $w p$, pincers. $C$, front right leg. $v$, velum; $b$, brush; $e b$, eye-brush. D, second right leg. $b$, brush. E, joint of first leg, more enlarged. $v$, velum; $a$, antenna comb ; $b$, brush. F, teeth of antenna comb, magnified 200 times. G, cross-section of tibia through pollen-basket. $n$, nerve; $h$, holding hairs: $f a$, farina or pollen. H, antenna in process of cleaning. $v$, velum; $s$, scraplng edge; $a$, antenna; $l$, section of leg; $c$, antenna comb. 
across the joint, a little projecting above its plane, and the tips of one comb slightly overlapping the basis of the next. Their colour is reddish-brown; and entangled in the combs, we almost invariably discover pollen granules, which have been at first picked up by the thoracic hairs, but combed out by the constant play of the legs over the breast-in which work, the second pair, bearing a strong resemblance to the third, performs an important part.",

59. "So soon as the bees have loaded these combs, they do not return to the hive, but transfer the pollen to the hollow sides of the tibia, seen at $\mathrm{ti}$ A. This concavity, corbicula, or pollen basket, is smooth and hairless, except at the edges, whence spring long, slender, eurved spines, two sets following the line of the bottom and sides of the basket, while a third bends over its front. The concavity fits it to contain pollen, while the marginal hairs greatly increase its possible load, like the sloping stakes which the farmer places round the sides of his waggon when he desires to earry loose hay, the set bent over (see G, Plate 8) accomplishing the purpose of the cords by which he saves his property from being lost on the road. But a difficulty arises: How ean the pollen be transferred from the metatarsal comb to the basket above? Easily; for it is the left metatarsus that charges the right basket, and vice versa. The legs are crossed, and the metatarsus naturally scrapes its comb-face on the upper edge of the opposite tibia, in the direction from the base of the combs towards their tips. These upper hairs standing over $w p, B$, or close to ti, A (which are opposite sides of the same joint), are nearly straight, and pass between the comb teeth. The pollen, as removed, is caught by the bent-over hairs, and secured. Each scrap adds to the mass, until the face of the joint is more than covered, and the hairs just embrace the pellet as we see it in the cross-section at G. The worker now hies homewards, and the spine, as a crow-bar, does its work.' '-(Cheshire.)

60. The four wings, in two pairs, are supported by hollow nervures or ribs, and have a great power of resistance. In flight, the small wings are fastened to the large ones by small hooks (fig. 14), located on the edge of their outer nervure, that catch in a fold of the inner edge of the large 
wings. Thus united, they present to the air a stronger surface and give the bees a greater power of flight. No doubt, a single pair of wings of the same surface would have better attained the desired aim, but their width would have annoyed the bees in going inside of the cells, either to feed the larvæ or to deposit supplies. Imagine a blue fly trying, with its wide wings, to go inside of a cell!

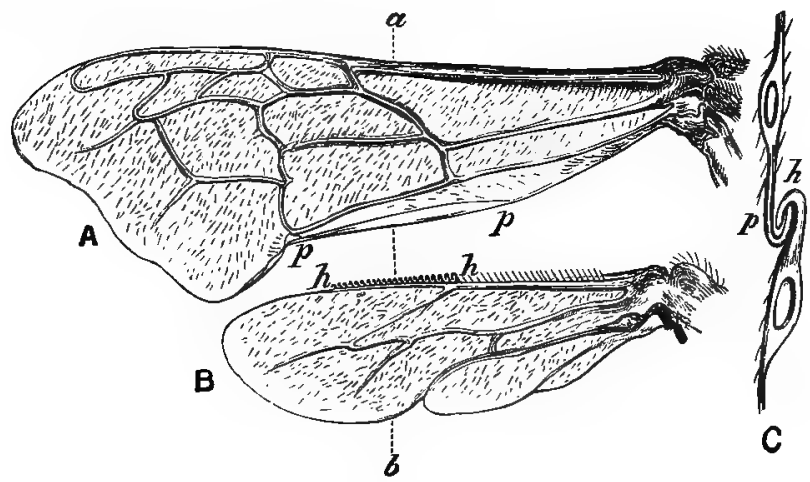

Fig. 14.

WINGS OF THE HONEY BEE.

(Argnified. From Cbeshire.)

A, anterior wing, under side; $p, p$, plait.

B, posterior wing, under side; $h, h$, hooklets.

C, cross-section of wings through line, $a, b$, showing hooklets in plait.

61. "Mr. Gaurichon has noticed that when the bees fan, or ventilate the entrance of the hive, their wings are not hooked together as they are in flight, but act independently of one another." (Dubini, 18s1.) A German entomologist, Landois, states that, according to the pitch of their hum, the bees' flight must at times be equal to 440 vibrations in a second, but he noticed that this speed could not be kept up without fatigue. It is well known that the more rapid the vibrations, the higher the pitch.

62. Digesting Apparatus. - The honey obtained from the blossoms, after mixing with the saliva (11), and passing 
through the mouth and the osophagus, is conveyed into the honey-sack.

63. This organ, located in the abdomen, is not larger than a very small pea, and so perfectly transparent as to appear, when filled, of the same color as its contents; it is properly

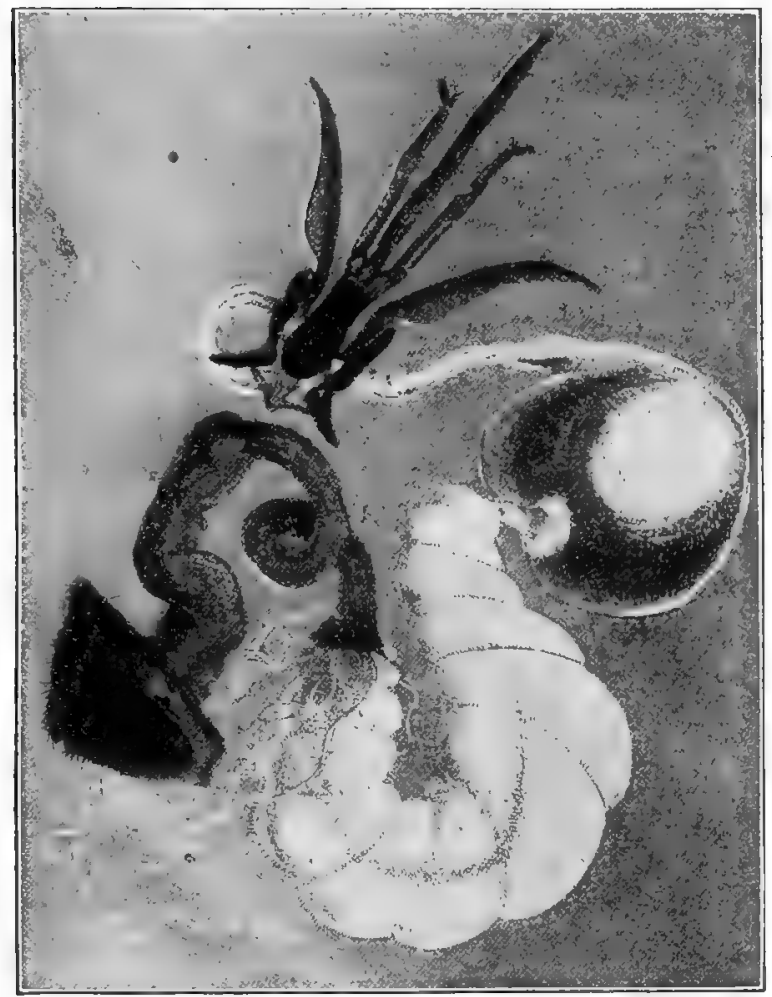

Fig. 15.

DIGESTING APPARATUS.

(Magnified. After Barbò.)

$a$, tongue; $b$, œsophagus; $c$, honey-sack; $d$, stomach; $e$, malpighian tubes; $f$, small intestine; $g$, large intestine. 
the first stomach, and is surrounded by muscles which enable the bee to compress it, and empty its contents through her proboscis into the cells. She can also, at will, keep a supply, to be digested, at leisure, when leaving with a swarm (418), or while in the cluster during the cold of winter (620), and use it only as fast as necessary. For this purpose, the honeysack is supplied at its lower extremity, inside, with a round ball, which Burmeister has called the stomach-mouth, and which has been beautifully described by Schiemenz (1883). It opens by a complex valve and connects the honey-sack with the digesting-stomach, through a tube or canal, projecting inside the latter. This canal is lined with hairs pointing downward, which prevent the solid food, such as pollen grains, from returning to the honey-sack. Cheshire affirms that this stomach-mouth, which protrudes into the honey-sack, acts as a sort of sieve, and strains the honey from the grains of pollen floating in it, appropriating them for digestion, and allowing the honey to flow back into the sack. The bee could thus, at will, "eat or drink from the mixed diet she carries."

64. According to Schonfeld, (Illustrierte Bienenzeitung) the chyle, or milky food which is used to feed the young larvæ,-and which we have shown to be, most probably, the product of the upper pair of glands (39-40),-would be produced from the digesting-stomach, which he and others call chyle-stomach. Although we are not competent in the matter, we would remark that the so-called chyle-stomach produces chyme, or digested food, from which the chyle, or nourishing constituent, is absorbed by the cell-lining of the stomach and of the intestines, and finally converted into blood. We do not see how this chyle could be thickened and regurgitated by the stomach to be returned to the mouth.

65. In mammals, the chyliferous vessels do not exist in the stomach, but in the intestine, the function of the stomach being only to digest the food by changing it into chyme, from which the chyle is afterwards separated, for the use of the body.

66. Again, in the mammals, the glands which produce 
milk are composed of small clusters of acini, which take their secretions from the blood and empty them into vessels terminating at the surface of the breast. The action of the upper gland (39-40), in the bee, is exactly similar to the action of those lacteal glands, and the fact that this gland is absent in the queen and in the drone is, to us, positive evidence that the chylous or lacteal food (given the larvæ) is produced by these glands alone, and not by the direct action of the digesting-stomach.

67. The food arriving in the stomach is mixed with the gastric juice, which helps its transformation, and the undulating motion of the stomach sends it to its lower extremity, toward the intestines. But, before entering into them, the chyme receives the product of several glands which have been named Malpighian tubes ( $e$, fig. 15) from the scientist Malpighi, who was the first to notice them. A grinding motion of the muscles placed at the junction of the stomach with the intestines, acting on the grains of pollen not yet sufficiently dissolved, prepares them to yield their assimilable particles to the absorbing cells in the walls of the small intestine. Thence they go into the large intestine, from which the refuse matter is discharged by the worker-bee, while on the wing. We italicize the words, because this fact has considerable bearing on the health of the bees, when confined by cold or other causes, as will be seen further on. (689.)

68. "The nervous system (fig. 16) of the honey-bee, the seat of sensation and of the understanding, is very interesting. The honey-bee, more perfect in organization than the butterfly, begins as a larva deficient in legs, very much inferior to the caterpillar from which the butterfly proceeds. The drones, although larger than the workers, especially in the head, have a smaller brain. This state of things coincides with the fact that the drones are not intelligent, while no one can refuse gleams of intelligence to the worker-bees, as nurses and builders." (Girard.)

69. The heart, or organ of the circulation of the blood, formed of five elongated rooms, in the abdomen, is terminated 
in the thorax, and in the head, by the aorta, which is not contractible. Each room of the heart presents, on either side, an opening for the returning blood. The blood, "soaking through

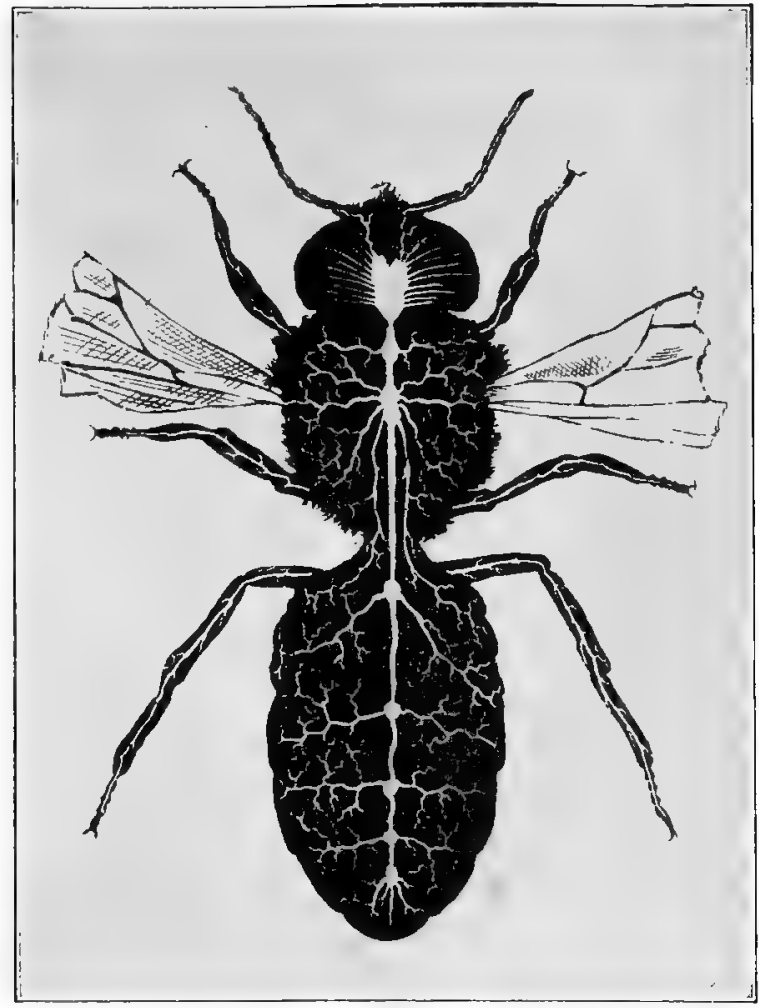

Fig. 16.

NERVOUS SYSTEM OF THE HONEY BEE.

(Magnified. After Barbò.)

the body" (Cheshire), comes in contact with the air contained in the tracheal ramifications, where it is arterialized, or in plainer words, renovated, before coming back to the heart. 
The bee is not provided with any discernible blood or lymphatic vessels save the aorta, and its blood is colorless.

70. The breathing organ of the bee is spread through its

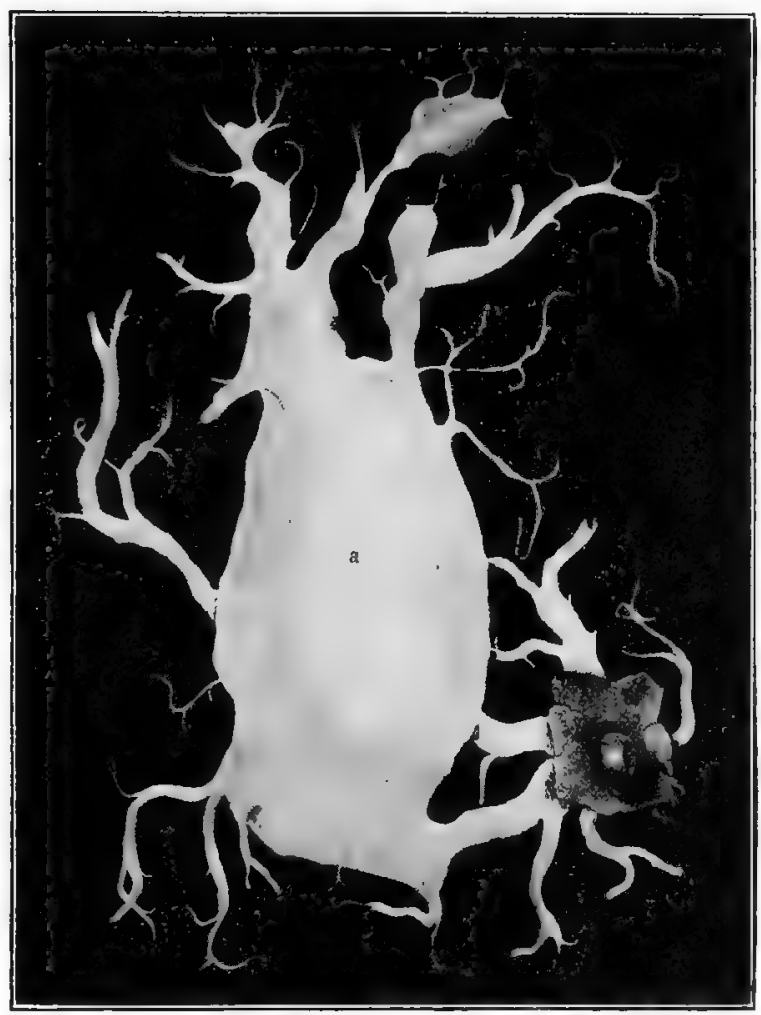

Fig. 17.

TRACHEAL BAG.

(Magniffeđ. After Barbò.)

whole body. It is formed of membranous vessels, or tracheæ, whose ramifications spread and penetrate into the organs, as the rootlets of a plant sink down into the soil. Connected 
with these, there is, on each side of the abdominal cavity, a large tracheal bag, (fig. 17), variable in form and dimensions, according to the quantity of air that it contains. Bees breathe through holes, or spiracles, which are placed on each side of the body, and open into the tracheal bags and tracheæ.

71. "The act of respiration consists in the alternate dilatation and contraction of the abdominal segments. By filling, or emptying the air-bags, the bee can change her specific gravity. When a bee is preparing herself for flight, the act of respiration resembles that of birds, under similar circumstances. At the moment of expanding her wings, which is indeed an act of respiration, the spiracles or breathing holes are expanded, and the air, rushing into them, is extended into the whole body, which by the expansion of the air-bags, is enlarged in bulk, and rendered of less specific gravity; so that when the spiracles are closed, at the instant the insect endeavors to make the first stroke with, and raise itself upon, its wings, it is enabled to rise in the air, and sustain a long and powerful flight, with but little muscular exertion." **** "Newport has shown that the development of heat in insects, just as in vertebrates, depends on the quantity and activity of respiration and the volume of circulation." -(Packard, Salem, 1869.)

72. Mr. Cheshire notices that bees, even in full, vigorous youth and strength, are not at all times able to take flight. The reader may have noticed that if they are frightened, or even touched with the finger, they will occasionally move only by slight jumps. This temporary inability to fly, is due to the small quantity of air that their tracheal saes contain. They were at rest, their blood circulated slowly, their body was comparatively heavy; but when their wings were expanded, the tracheal bags, that were as flat as ribbons, were soon filled with air, and they were ready to take wing.

Practical Apiarists well know that bees may be shaken off the comb, and gathered up, with a shovel, with a spoon, or even with the hands, to be weighed or measured in open vessels, like seeds. The foregoing remarks give the explanation of this fact, 
73. When the tracheal bags are filled with air, bees, owing to their peculiar structure, can best discharge the residue contained in their intestines.

The queen is differently formed, her ovaries occupying part of the space belonging to the air-sacks in the worker, hence her discharges, like those of the drones (190), take place in the hive. (40.) The queen's air-sacks are much smaller than those of the worker, hence comes a difficulty to take wing.

74. "The tracheous bags of the abdomen, which we would be tempted to name abdominal lungs, hold in reserve the air needed to arterialize the blood and to produce muscular strength and heat, in connection with the powerful flight of the insect. Heat is indispensable, to keep up the high temperature of the hive, for the building of comb and rearing of brood. The aerial vesicles increase, by their resonance, the intensity of the humming, and are used also like the valve of a balloon, to slacken or increase the speed of the flight, by the variation of density, according to the quantity or weight, of the air that they contain. This accumulated air is also the means of preventing asphyxy, which the insects resist a long time. Lastly, these air-bags help in the mating of the sexes, which takes place in the air; the swelling of the vesicles being indispensable to the bursting forth of the male organs." -(Girard.)

75. The hum that is produced by the vibration of the wings is different in each of the three kinds of inhabitants of the hive, and easily recognizable to a practiced ear. The hum of the drone is the most sonorous. But worker-bees, when angry or frightened, or when they call each other, emit different and sharper sounds. On the production of these sounds, bee-keepers and entomologists are far from being agreed.

"Inside of every opening of the aerial tubes is a valvular muscle, which helps to control the mechanism of respiration. This can be opened or closed at will, by the bee, to prevent the ingress, or egress, of air. It is by this means that the air is kept in the large tracheous bags and decreases the specific gravity of the insect. The main resonant organ of the bee is placed in front of this stopping musele, at the entrance of the trachea. 
"The humming is not produced solely by the vibrating of the wings, as is generally admitted. Chabrier, Burmeister, Landois, have discovered in the humming, three different sounds: the first, caused by the vibration of the wings; the second, sharper, by the vibration of the rings of the abdomen; the third, the most intense and acute, prodnced by a true vocal mechanism, placed at the orifices of the aerial tubes." (Girard.)

\%6. The bee-keeper who understands the language of bees, can turn it to his advantage. Here are some examples:

"When something seems to irritate the bees, who are in front of a hive, on the alighting-board, they emit a short sound, z-z-z-, jumping at the same time towards the hive. This is a warning. Then they fly and examine the object of their fears, remaining sustained by their wings, near the suspected object, and emitting at the same time, a distinet and prolonged sound. This is a sign of great suspicion. If the object moves quickly, or otherwise shows hostile intent, the song is changed into a piercing cry for help, in a volce whistling with anger. They dash forward violently and blindly, and try to sting.

"When they are quiet and satisfied, their voice is the humming of a grave tune; or, if they do not move their wings, an allegro murmur. If they are suddenly caught or compressed, the sound is one of distress. If a hive is jarred at a time when all the bees are quiet, the mass speedily raise a hum, which ceases as suddenly. In a queenless hive, the sound is doleful, lasts longer, and at times increases in force. When bees swarm, the tune is clear and gay, showing manifest happiness." (Ettl-Klauss, 1836.)

ซซ. The German pastor Stahala has published a very complete study on the language of bees, which has appeared in some of the bee-papers of Italy, France and America. We do not consider it as altogether accurate; but there are some sounds described that all bee-keepers ought to study, especially the doleful wail of colonies which have lost their queen, and have no means of rearing another.

78. The Strisg.-The sting of a bee, a terror to so many, is indispensable to her preservation. Without it, the attrac- 
tion, which honey presents to man and animals, must have caused the complete destruction of this precious insect, years ago.

79. This organ is composed, 1st, of a whitish vesicle, or poison sack, about the size of a small mustard seed, located in the abdomen, in which the venomous liquid is stored. This liquid is elaborated in two long canals, similar in appearance to the Malpighian tubes, each of which is terminated at its upper extremity, by a small round bag or enlargement. It is similar to formic acid, although perhaps more poisonous.

80. 2nd, In the last ring of the abdomen, and connected with the poison sack, is a firm and sharp sheath, open in its whole length, which supports the sting proper, and acts independently of it. The bee can force this sheath out of the abdomen, or draw it in, at will.

81. $3 d$, The sting is composed of two spears of a polished, chestnut-colored, horny substance, which, supported by the sheath, make a very sharp weapon. In the act of stinging, the spears emerge from the sheath, about two-thirds of their length. Between them and on each of them, is a small groove, through which the liquid, coming from the poison-sack, is ejected into the wound.

82. Each spear of the sting has about nine barbs, which are turned back like those of a fish hook, and prevent the sting from being easily withdrawn. When the insect is prepared to sting, one of these spears, having a little longer point than the other, first darts into the flesh, and being fixed by its foremost barb, the other strikes in also, and they alternately penetrate deeper and deeper, till they acquire a firm hold of the flesh with their barbed hooks.

"Meanwhile, the poison is forced to the end of the spears, by much the same process which carries the venom from the tooth of a viper when it bites." -(Girard.)

83. The muscles, though invisible to the eye, are yet strong enough to force the sting, to the depth of one-twelfth of an inch, through the thick skin of a man's hand. 
"The action of the sting," says Paley, "affords an example of the union of chemistry and mechanism; of chemistry, in respect to the venom which can produce such powerful effects; of mechanism, as the sting is a compound instrument. The machinery would have been comparatively useless, had it not been for the chemical process by which, in the insect's body, honey

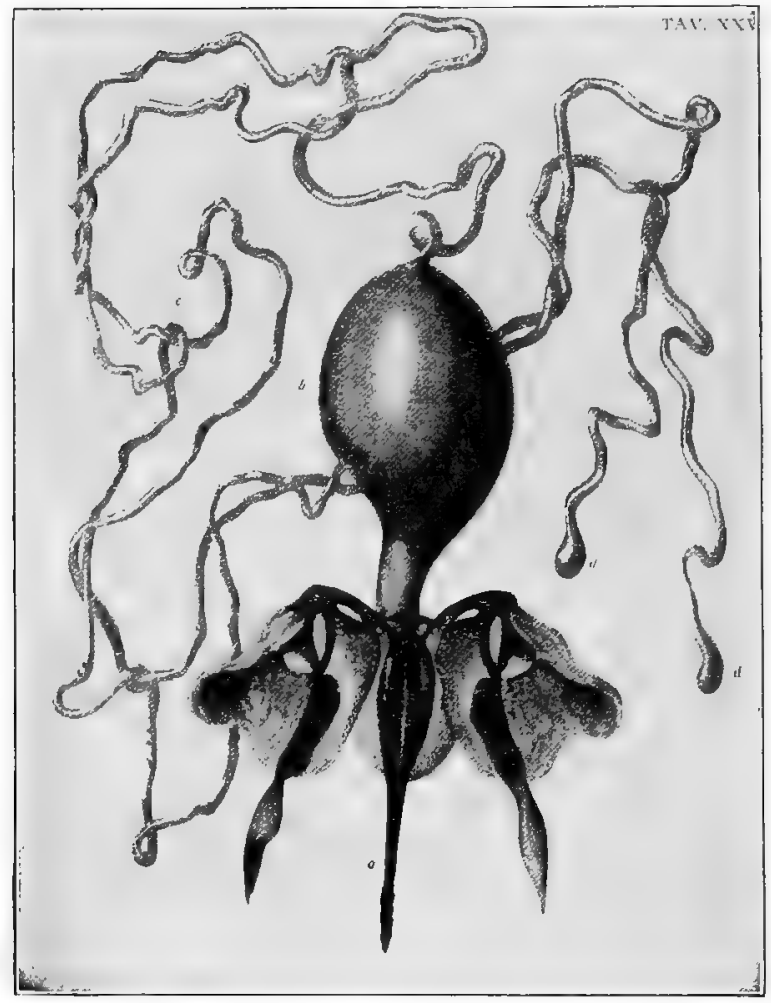

Fig. 18.

THE STING OF THE WORKER BEE, AND ITS APPENDAGES.

(Magnified. After Barbò.)

$a$, sting: $b$, poison-sack; $c, c$, poison glands; $a, d$, secreting bags. 
is converted into poison; and on the other hand, the poison would have been ineffectual, without an instrument to wound, and a syringe to inject it.

"Upon examining the edge of a very keen razor by the microscope, it appears as broad as the back of a pretty thick knife, rough, uneven, and full of notches and furrows, and so far from anything like sharpness, that an instrument as blunt as this seemed to be, would not serve even to cleave wood. An exceedingly small needle being also examined, it resembled a rough iron bar out of a smith's forge. The sting of a bee viewed through the same instrument, showed everywhere a polish amazingly beautiful, without the least flaw, blemish, or inequality, and ended in a point too fine to be discerned."'

84. As the extremity of the sting is barbed like an arrow, the bee can seldom withdraw it, if the substance into which she darts it is at all tenacious. A strange peculiarity of the sting and the muscles pertaining to it, is their spasmodic aetion, which continues quite a while, even after the bee has torn herself away, and has left them attached to the wound. In losing her sting, she often parts with a portion of her intestines, and of necessity soon perishes. Wasps and hornets are different from bees in this respect, for they can sting repeatedly without endangering their lives.

Although bees pay so dearly for the exercise of their patriotic instincts, still, in defense of home and its sacred treasures, they

"Deem life itself to vengeance well resign'd, Die in the wound and leave their sting behind."

85. The sting is not, however, always lost. When a bee prepares to sting, she usually eurves her abdomen so that she can drive in her sting perpendicularly. To withdraw it, she turns around the wound. This probably rolls up its barbs, so that it comes out more readily. If it had been driven obliquely instead of perpendicularly, as sometimes happens, she could never have extracted it by turning around the wound.

86. Sometimes, only the poison-bag and sting are torn 
off, then she may live quite a while without them, and strange to say, seems to be more angry than ever, and persists in making useless attempts to sting.

8\%. If a hive is opened during a Winter day, when the weather does not permit the bees to fly, a great number of them raise their abdomens, and thrust out their stings, in a threatening manner. A minute drop of poison can be seen on their points, some of which is ocoasionally flirted into eyes of the Apiarist, and causes severe irritation. The odor of this poison is so strong and peculiar, that it is easily recognized. In warm weather it excites the bees, and so provokes their anger, that when one has used its sting in one spot on skin or elothes, others are inclined to thrust theirs in the same place.

88. The sting, when accompanied by the poison-sack, may inflict wounds hours, and even days, after it has been removed, or torn, from the body of the bee. But when buried in honey, its poison is best preserved, for it is very volatile, and when exposed to the air, evaporates in a moment. The stings of bees, which, perchance, may be found in broken combs of honey, often retain their power, and we have known of a person's being stung in the mouth, by carelessly eating honey in which bees had been buried by the fall of the combs.

Mr. J. R. Bledsoe, in the American Bee Journal, for 1870 , writes:

89. "It may often happen that one or both of the chief parts of the sting are left in the wound, when the sheath is withdrawn, but are rarely perceived, on account of their minuteness; the person stung congratulating himself, at the same time, that the sting has been extracted. I have had occasion to prove this fact repeatedly in my own person and in others. * * The substance of the sting, on account of its nature, is readily dissolved by the fluids of the body, consequently giving irritation as a foreign body for only a short time comparatively. The sting when boiled in water becomes tender and easily crushed."

For further particulars concerning the sting, we will refer our readers to the chapter entitled "Handling Bees." - (378.) 
Plate 9.
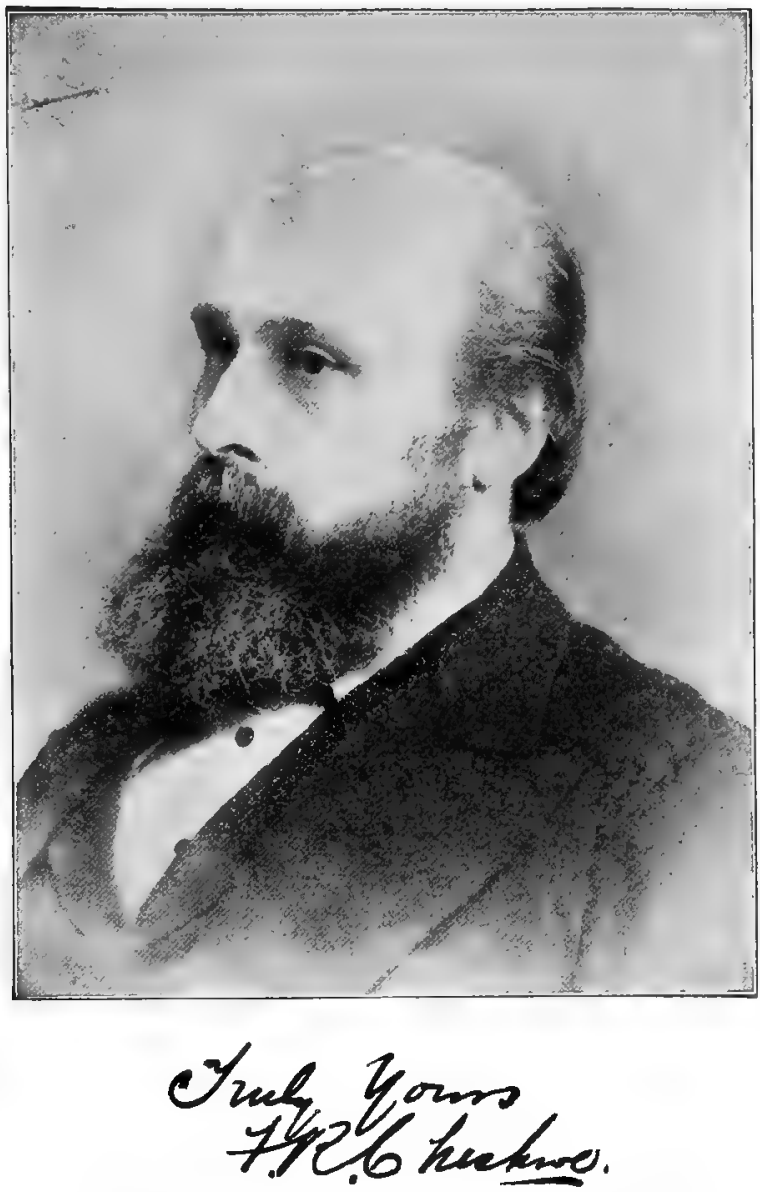

F. R. CHESHIRE, F. L. S., F. R. M. S.

\section{Author of "Bees and Bee-Keeping."}

The writer is mentioned pages $2,3,4,5,7,8,10,11,12,16.17,18,20$, 21. 22, 23, 24, 25, 26, 28, 30, 32, 39, 61, 73, 84, 94, 104, 122, $127,145,352,358,394,395,472,474,481,483$. 


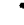


90. Before terminating this comparatively short, but perhaps, to many of our readers, tedious study of the organs of the bee, we desire to commend Messrs. Girard, Packard, Cook, Schiemenz, Dubini, and especially Mr. F. Cheshire, who, by their writings, have helped us in this part of our undertaking. We must add also that the more we study bees, the more persuaded we are that Mr. Packard was right when he wrote:

91. "Besides these structural characters as animals, endowed with instinct, and a kind of reason, differing, perhaps, only in degree, from that of man, these insects outrank all the articulates. In the unusual differentiation of the individual into males, females, and sterile workers, and a consequent subdivision of lapor between them; in dwelling in large colonies; in their habits and in their relation to man as domestic animals, subservient to his wants, the bees possess a combination of characters which are not found in any other sub-order of insects, and which rank them first and highest in the insect series." ("Guide to the Study of-Insects.' )

92. One of the especial peculiarities of the hymenopters is the care most of them give to their progeny. We will show how bees nurse their young. Other insects of the same suborder construct their nests of clay or paper, or burrow in the wood, or in the earth. All prepare for their young a sufficient supply of food; some of pollen and honey, others of animal substance. Several kinds of wasps provide their nests with living insects, spiders, caterpillars, ete., that they have previously paralyzed, but without killing them, by piercing them with their stings.

Ants seem to possess even a greater solicitude. When their nests are overthrown, they carry their larvæ to some hidden place out of danger.

We have exhibited the use of the organs of bees as a race. We will now examine the character of each of the three kinds of inhabitants of the bee-hive. 


\section{The Queen.}

93. Although honey-bees have attracted the attention of

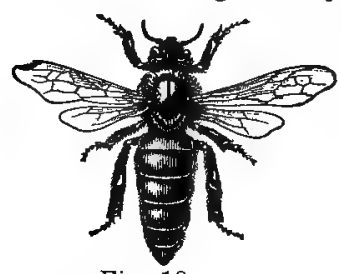

Fig. 19 . naturalists for ages, the sex of the inmates of the bee-hive was, for a long time, a mystery. The ancient authors, having noticed in the hive, a bee, larger than the others, and differently shaped, had called it the "King Bee."

91. To our knowledge, it was un English bee-keeper, Butler; who, first among bee-writers, affirmed in 1609, that the King Bee was really a queen, and that he had seen her deposit eggs. ("Feminine Monarchy.")

95. This discovery seems to have passed unnoticed, for Swammerdam, who ascertained the sex of bees by dissection, is held as having been the first to proclaim the sex of the queen-bee. (Leyde, 1737.) A brief extract from the celebrated Dr. Boerhaare's Memoir of Swammerdam, showing the ardor of this naturalist, in his study of bees, should puit to blush the arrogance of those superficial observers, who are too wise to avail themselves of the knowledge of others:

"This treatise on Bees proved so fatiguing a performance, that Swammerdam never afterwards recovered even the appearance of his former health and vigor. He was most continually engagel by day in making observations, and as constantly by night in recording them by drawings and suitable explanations.

"Fis daily labor began at six in the morning, when the sun afforded him light enough to survey such minute objects; and from that hour till twelve, he continued without interruption, all the while exposed in the open air to the scorehing heat of the sun, bareheaded, for fear of intercepting his sight, and his head in a manner dissolving into sweat under the irresistible ardors of that powerful luminary. And if he lesisted at noon, it was only because the strength of his eyes was too much weakened by the extraordinary afflux of light, and the use of microscopes, to continue any longer upon such small objects. 
"He often wished, the better to accomplish his vast, unlimited views, for a year of perpetual heat and light to perfect his inquiries; with a polar night, to reap all the advantages of them by proper drawings and descriptions."

96. The name of queen was then given to the mother bee, although she in no way governs, but seems to reign like a beloved mother in her family.

97. She is the only perfect female in the hive, the laying of eggs being her sole function; and so well does she accomplish this duty, that it is not uncommon to find queens who lay more than 3,500 eggs per day, for several weeks in succession during the height of the breeding season. In our observing kives we have seen them lay at the rate of six eggs in a minute. The fecundity of the female of the white ant is, however, much greater than this, being at the rate of sixty eggs a minute; but her eggs are simply extruded from her body, and carried by the workers into suitable nurseries, while the queen-bee herself deposits her eggs in their appropriate cells.

98. This number of 3,500 , that a good queen can lay per day, will seem exaggerated to many bee-keepers, owners of small hives. They will perhaps ask how such laying can be ascertained. Nothing is easier. Let us suppose that we have found a hive, with 1,200 square inches of comb occupied by brood. As there are about 55 worker-cells to the square inch of comb (217), 27 to 28 on each side, we multiply 1,200 by 55 , and we have 66,000 as the total number of cells occupied at one time. Now, it takes about 21 days for the brood to develop from the egg to the perfect insect, and we have 3,145 as the average number of eggs laid daily by that queen, in 21 days. Of course, this amount is not absolutely accurate, as the combs are not always entirely filled, but it will suffice to show, within perhaps a few hundred, the actual fecundity of the queen.

Such numbers can be found every year, in most of the good colonies, provided that the limited capacity of the hive will not prevent the queen from laying to the utmost of her ability. 
99. The laying of the queen is not equal at all seasons. She lays most during the spring and summer months, previous to the honey crop and during its flow. In late autumn and winter months, she lays but little.

100. Her shape is widely different from that of the other bees. While she is not near so bulky as a drone, her body is longer; and as it is considerably more tapering, or sugarloaf in form, than that of a worker, she has a somewhat wasplike appearance. Her wings are much shorter in proportion than those of the drone or worker; * the under part of her body is of a golden color, and the upper part usually darker than that of the other bees. $t$ Her motions are generally slow and matronly, although she can, when she pleases, move with astonishing quickness. No colony can long exist without the presence of this all-important insect; but must as surely perish, as the body without the spirit must hasten to inevitable decay.

101. The queen is treated with the greatest respect and affection by the bees. A circle of her loving offspring often surround her, testifying in various ways their regard; some gently embracing her with their antennæ, others offering her food from time to time, and all of them politely backing out of her way, to give her a clear path when she moves over the combs. If she is taken from them, the whole colony is thrown into a state of the most intense agitation as soon as they ascertain their loss; all the labors of the hive are abandoned; the bees run wildly over the combs, and frequently rush from the hive in anxious search for their beloved mother. If they cannot find her, they return to their desolate home, and by their sorrowful tones reveal their deep sense of so deplorable a calamity. Their note at such times, more especially when they first realize their loss, is of a peculiarly mournful character; it sounds somewhat like a succession of wailings on the minor key, and can no more be mistaken by an experienced bee-keeper, for their ordinary happy hum ( $\mathbf{7 6})$, than the

* The wings of the queen are in reality longer than those of the worker.

$\dagger$ This applies only to queens of the black or common race. 
piteous moanings of a sick child could be confounded by the anxious mother with its joyous crowings when overflowing with health and happiness. We shall give in this connection, a description of an interesting experiment.

102. A populous stock was removed, in the morning, to a new place, and an empty hive put upon its stand. Thou-

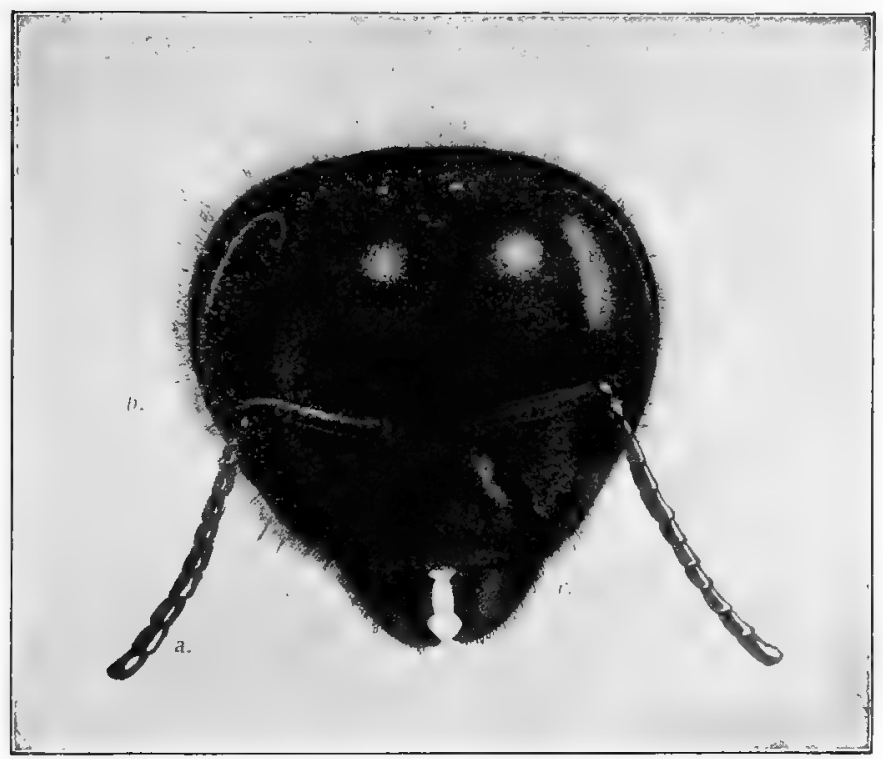

Fig. 20.

HEAD OF QUEEN.

(Magnified. After Barbò.)

sands of workers which were ranging the fields, or which left the old hive after its removal, returned to the familiar spot. It was truly affecting to witness their grief and despair; they flew in restless circles about the place where once stood their happy home, entering the empty hive continually, and expressing in various ways, their lamentations over so cruel a bereavement. Towards evening, ceasing to take wing, they roamed in restless platoons, in and out of the hive, and over its surface, as if in search of some lost treasure. A small 
piece of brood-comb was then given to them, containing worker-eggs and worins. The effect produced by its introduction took place much quicker than can be described. Those which first touched it raised a peculiar note, and in a moment, the comb was covered with a dense mass of bees; as they recognized, in this small piece of comb, the means of deliverance, despair gave place to hope, their restless motions and mournful voices ceased, and a cheerful hum proclaimed their delight. If some one should enter a building filled with thousands of persons tearing their hair, beating their breasts, and by piteous cries, as well as frantic gestures, giving vent to their despair, and could by a single word cause all these demonstrations of agony to give place to smiles and congratulations, the change would not be more instantaneous than that produced when the bees received the brood-comb!

The Orientals called the honey-bee "Deborah; She thist. speaketh." Would that this little insect might speak, in words more eloquent than those of man's device, to those who reject any of the doctrines of revealed religion, with the assertion that they are so improbable, as to labor under a fatal a priori objection. Do not all the steps in the development of a queen from the worker-egg, labor under the very same objection? and have they not, for this reason been formerly regarded, by many bee-keepers, as unworthy of belief? If the favorite argument of infidels will not stand the test, when applied to the wonders of the bee-hive, is it entitled to serious weight, when, by objecting to religious truths, they arrogantly take to task the Infinite Jehovah for what $\mathrm{He}$ has been pleased to do or to teach? With no more latitude than is claimed by such objectors, it were easy to prove that a man is under no obligation to beliere any of the wonders of the bee-hive, even although be is himself an intelligent eye-witness to their substantial truth.*

103. The process of rearing queen-bees will now be par-

* The passages referring to religious subjects have been nearly all retained in the revision, at $M r$. Langstroth's request, even when not In accordance with our views. As intelligent men are always tolerant, we know our readers will not object to them. Mr. Langstroth was is clergyman. 
ticularly described. Early in the season, if a hive becomes very populous, and if the bees make preparations for swarm-

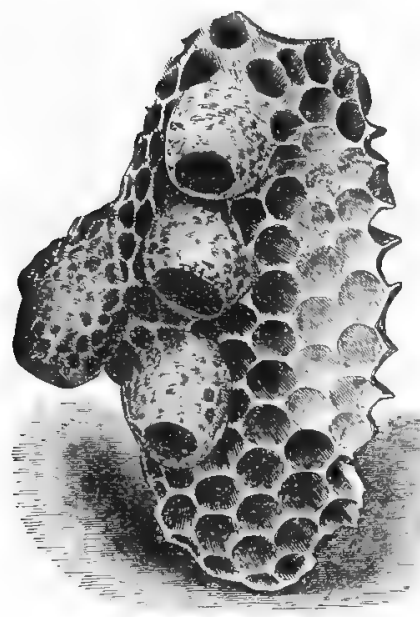

Fig. 21.

QUEEN-CELLS IN PROGRESS. ing, a number of royal cells are begun, being commonly constructed upon those edges of the combs. which are not attached to the sides of the hive. These cells somewhat resemble a small pea-nut, and are about an inch deep, and one-third of an inch in diameter: being very thick, they require much wax for their construction. They are seldom seen in a perfect state after the hatching of the queen, as the bees cut them down to the shape of a small acorn-cup (fig. 21.) These queen-cells, while in progress, receive a very unusual amount of attention from the workers. There is scarcely a second in which a bee is not peeping into them; and as fast as one is satisfied, another pops in her head to report progress, or increase the supply of food. Their importance to the community might easily be inferred from their being the center of so much attraction.

104. While the other cells open sideways, the queen-cells always hang with their mouth downwards. Some Apiarists think that this peculiar position affects, in some way, the development of the royal larvæ; while others, having ascertained that they are uninjured if placed in any other position, consider this deviation as among the. inscrutable mysteries of the bee-hive. So it seemed to us until convinced, by a more careful observation, that they open downwards simply to save room. The distance between the parallel ranges of comb in the hive is usually too small for the royal cells to open sideways, without interfering with the opposite cells, To economize space, 
the bees put them on the unoccupied edges of the comb, where there is plenty of room for such very large cells.

105. The number of royal cells in a hive varies greatly; sometimes there are only two or three, ordinarily not less than five; and occasionally, more than a dozen.

Some races of bees have a disposition to raise a greater number of queen-cells than others. At the Toronto meeting of the North American Bee-keepers' Association, in September, 1883, Mr. D. A. Jones, the noted Canadian importer of Syrian and Cyprian bees, and at that time publisher of the Canadian Bee Journal, exhibited a comb containing about eighty queen-cells, built by a colony of Syrian bees (560). In 1905, Dr. C. C. Miller succeeded in raising one hundred and nineteen queen cells on two combs of brood in a colony of Cyprian bees. (Fig. 22.) Such cases are rare in the hive of any other race.

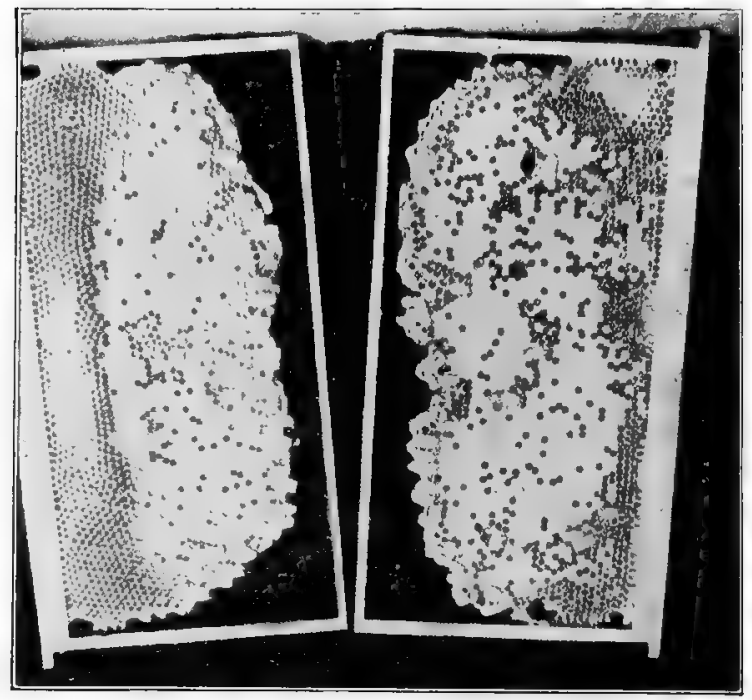

Fig. 22.

QUEEN CELLS BUILT BY CYPRIAN BEES.

(American Bee Journal.) 
106. As it is not intended that the young queens should all be of the same age, the royal-cells are not all begun at the same time. It is not fully settled how the eggs are deposited in these cells. In some few instances, we have known the bees to transfer the eggs from common to queencells; and this may be their general method of procedure. Mr. Wagner put some queenless bees, brought from a distance, into empty combs that had lain for two years in his garret. When supplied with brood, they raised their queen in this old comb! Mr. Richard Colvin, of Baltimore, and other apiarian friends, have communicated to us instances almost as striking. Yet, Huber has proved that bees do not ordinarily transport the eggs of the queen from one cell to another. We shall hazard the conjecture, that, in a crowded state of the hive, the queen deposits her eggs in cells on the edges of the comb, some of which are afterwards changed by the workers into royal cells. Such is a queen's instinctive hatred of her own kind, that it seems improbable that she should be intrusted with even the initiatory steps for securing a race of successors.

(For further particulars concerning the raising of large numbers of queen-cells, see 515-530.)

107. The egg which is destined to produce a queen-bee does not differ from the egg intended to become a worker; but the young queen-larvæ are much more largely supplied with food than the other larvæ; so that they seem to lie in a thick bed of jelly, a portion of which may usually be found at the base of their cells, soon after they have hatched, while the food given to the worker-larvæ after three days, and for the last days of their development, is coarser and more sparingly given, as will be seen farther on.

108. The effects produced on the royal larvæ by their peculiar treatment are so wonderful, that they were at first rejected as idle whims, by those who had neither been eyewitnesses to them, nor acquainted with the opportunities enjoyed by others for accurate observation. They are not only contrary to all common analogies, but seem marvelously 
strange and improbable. The most important of these effects we shall briefly enumerate.

1st. The peculiar mode in which the worm designed for a queen is treated causes it to arrive at maturity almost onethird earlier than if it had been reared a worker. And yet, as it is to be much more fully developed, according to ordinary analogy, it should have had a slower growth.

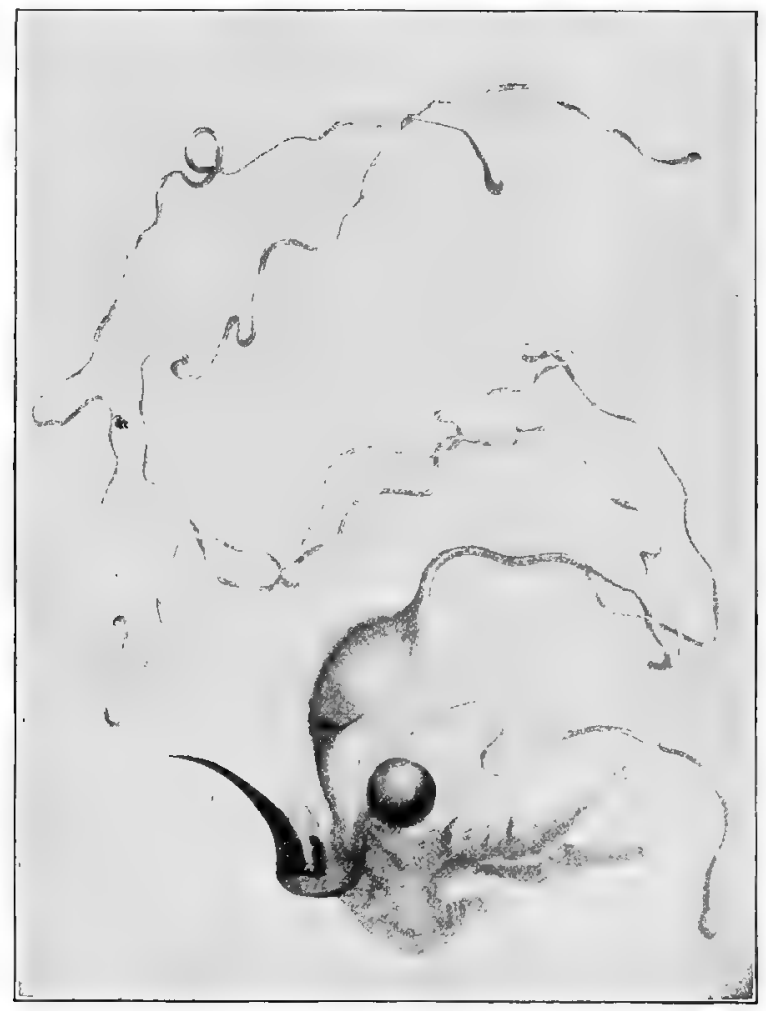

Fig. '23.

THE STING OF THE QUEEN.

(Magnified. After Barbò.) 
2d. Its organs of reproduction are completely developed, so that it can fulfill the office of a mother.

3d. Its size, shape, and color are greatly changed; its lower jaws are shorter, its head rounder, and its abdomen without the receptacles for secreting wax; its hind legs have neither brushes nor baskets, and its sting is curved (fig. 23) and one-third longer than that of a worker.

4th. Its instincts are entirely changed. Reared as a worker, it would have thrust out its sting at the least provocation; whereas now, it may be pulled limb from. limb without attempting to sting. As a worker, it would have treated a queen with the greatest consideration; but now, if brought in contact with another queen, it seeks to destroy her as a rival. As a worker, it would frequently have left the hive, either for labor or exercise; as a queen, it never leaves it after impregnation, except to accompany a new swarm.

5th. The term of its life is remarkably lengthened. As a worker, it would not have lived more than six or seven months; as a queen, it may live seven or eight times as long. All these wonders rest on the impregnable basis of demonstration, and instead of being witnessed only by a select few, are now, by the use of the movable-comb hive', familiar sights to any bee-keeper.

109. The process of rearing queens, to meet some special emergency, is even more wonderful than the one already described. If the bees have worker-eggs, or worms not more than three days old, they make one large cell out of three, by nibbling away the partitions of two cells adjoining a third. Destroying the eggs or worms in two of these cells, they place before the occupant of-the other, the usual food of the young queens; and by enlarging its cell, give it ample space for development. As a security against failure, they usually start a number of queen-cells, for several days in succession.

It was a German bee-keeper, Schirach, who discovered that a queen can be raised from a worker-egg. ("The New Natural and Artificial Multiplication of Bees," Bautzen, 1761.) 
110. Duration of Development.-The eggs hatch in three days after they are laid. The small worm which is intended to produce a queen, is six days in its larval state, and seven in its transformation into a chrysalis and winged insect. These periods are not alssolutely fixed; being of shorter or longer duration, according to the warmth of the hive and the care given by the bees. In from ten to sixteen days, in ten days, if the larva selected is about three days old; in sixteen, if newly laid eggs are selected, they are in possession of a new queen, in all respects resembling one reared in the natural way; while the exss in the adjoining cells. which have been developed as workers, are nearly a week longer in coming to maturity.

111. The Viritix Qtens. - Feeble and pale, in the first moments after her birth, the young queen, as soon as she has acrpuired some strength, travels wer the combs, looking for a rival, either hatched or unhatched.

112. "Harkly had ten minutes elapsed after the young queen emerged from her cell, when she began to look for sealed queen-cells. She rushed furiously upon the first that she met, and, by dint of hard work, made a small opening in the end. We saw her cirawing, with her mandibles, the silk of the cocoon, which covered the inside. But, probally, she did not suceeed arcurcling to her wishes, for she left the lower end of the eell, and wont to work on the uph'r end, where she finally mirle a wider opening. As soon as this was suffieiently large, she turned about, to push ler abdomen into it. She made several motions, in different dircetions, till she succeerled in striking her rival with the deadly sting. Then she left the eell; and the bees, which harl remainerl, so far, perfectly passive, began to enlarge the gap which she had made, and drew ont the corpse of a queon just out of her uymphal sheil. During this time, the victorious young queen rushed to another queen-cell, and again made a large opening, but she did not introduce her abdomen into it: this second cell containing only a royal-pupa not yet formel. There is some probability that, at this stage of de. velopment, the nymphs of queens inspire less anger to their rivals; but they do not escape their doom; for, whenever a queen-cell has been prematurely opened, the bees throw out its 
occupant, whether worm, nymph, or queen. Therefore, as soon as the victorious queen had left this second cell, the workers enlarged the opening and drew out the nymph that it contained. The young queen rushed to a third cell; but she was unable to open it. She worked languidly and seemed tired of her first efforts." -(Huber.)

113. Huber did not allow this experiment to go on any further, as he wished to use the remainder of the queen-cells. Had he left these cells untouched, the bees would have finished the work of destruction.

111. We have noticed repeatedly, that the queen-cells are always destroyed a few hours after the birth of the queen, unless the colony has determined to swarm. In the latter case, the workers prevent the newly-hatched queen from approaching the queen-cells, till she is old enough and strong enough to leave with the swarm. (113.)

115. Like some human beings who cannot have their own way, she is highly offended when thus repulsed, and utters, in a quick succession of notes, a shrill, angry sound, not unlike the rapid utterance of the words, "peep, peep." If held in the elosed hand, she will make a similar noise. To this angry note, one or more of the unhatched queens, imprisoned and nursed in their cells by the bees, answer by the sound "kooa, kooa"; the difference in their voices being due to the confinement of the latter in the cell.

These sounds, so entirely mlike the usual steady hum of the bees, are almost infallible indications that a swarm will soon issue. They are occasionally so lond as to be heard at some distance from the hive.

The reader will understand that all these facts relate to a hive of bees, from which the old queen has been previously and suddenly removed, either by the Apiarist for some purpose, or by swarming, or arcident.

116. Sometimes two queens batel at the same time. We give below a translation of Huber's account in such event:

"On the 15th of May, 1790, two queens emerged from their cells, at about the same time, in one of our observing hives. 
They rushed quickly upon one another, apparently in great anger, and grasped one another's antennx, so that the head, corselet and abdomen of the one, were touching the head, corselet and abdomen of the other. Had they curved the posterior extremity of their bodies, they could have stung each other, and both would have perished. But it seems that Nature has not wished that their duels should result in the death of both combatants, and that it is prescribed to queens, while in this position, to flee instantly with the greatest haste. As soon as both rivals understood that they were in danger from one another, they disentangled themselves and fled apart......A few minutes after, their fears ceased and they attacked one another again, with the same result. The worker bees were much disturbed, all this time, and more so while the combatants were separated. Each time, the bees stopped the queess in their flight, keeping them prisoners for a minute. At last, in a third attack, the stronger, or more savage, of the queens, ran to her unsuspecting rival, seized her across the wings, and, climbing upon her, pierced her with her sting. The vanquished queen, crawled languidly about, and soon after died.' - ("Nouvelles Observations."')

11\%. Although it is generally admitted that two queens sannot inhabit the same hive, it happens, sometimes, that mother and daughter are found living peaceably together, and even laying egg's at the same time. This is when the bees, having noticed the decrease in fecundity of the old queen, have raised a young queen to replace her. But this abnormal state lasts only a few weeks, or a few months at most.

118. Our junior partner was, one day, hunting for a queen with his sister. "What a large and bright-colored queen!" exclaimed he, on finding her. "Why, no! she is dark and small," said his sister. Both were right, for there were two queens, wother and daughter, on the same comb, and not six inches apart. At another time we were looking for an old queen, whose prolifieness.had decreased, intending to supersede her. To our wonder, the hive was full of brood. We found the old queen. Evidently a queen so small, so 
ragged and worn, could not be the mother of such a quantity of brood. We continued our search and found another queen, daughter of the first, large and plump. Had we introduced a strange queen into this hive, after having destroyed the old one, thinking that we had made the colony queenless, she would have been killed.

119. We could relate a number of such instances. The most interesting case was the simultaneous laying of two queens of different breeds in the same hive, one black, the other Italian. The colony had two queens, when we introduced our Italian queen. We found the younger one and killed her, and the old one was so little considered by her bees, that they accepted our imported queen and allowed both to remain together. To our astonishment there were some black bees hatching among the pure Italians, and it was not till we accidentally discovered the old black queen that we understood the matter.

There are more such cases than most bee-keepers would imagine, and when these happen to buyers of improved races of bees, if they are not very close observers, they are apt to accuse venders of having cheated them. Such instances make the business of queen selling quite disagreeable.

120. Impregnation.-The fecundation of the queen bee has occupied the minds of Apiarists and savants for ages. A number of theories were advanced. If a number of drones are confined in a small box, they give forth a strong odor: Swammerdam supposed that the queen was impregnated by this scent (aura seminalis) of the drones. Réaumur, a renowned entomologist, in 1744, thought that the mating of

- the queen was effected inside of the hive. Others advanced that the eggs were impregnated by the drones in the cells.

After making a number of experiments to verify these theories, and finding all false, Huber finally ascertained that, like many other insects, the queen was fecundated in the open air and on the wing; and that the influence of this connection lasts for several years, and probably for life.

121. Five days or more after her birth, the virgin queen 
goes out to have intercourse with a drone. Several bee-keepers of note, such as Neighbour of England ("Cook's Manual, 1884), and Dzierzon of Germany, wrote that a queen may go out on her marriage-flight when only three days old. The shortest time we have ever noticed between the birth of a queen and her first bridal-flight was five days, and on this we are in accordance with Mr. Alley of Massachusetts, one of the most extensive queen breeders in the world. The average time is six or seven days. Earlier bridal-trips are probably due to the disturbing of the colony by the Apiarist, for we have noticed that this disturbing hastens the maturity of the workers. The bridal-flight takes place about noon, at which time, the drones are flying most numerously.

122. On leaving her hive, the queen flies with her head turned towards it, often entering and departing several times before she finally soars into the air. Such precautions on the part of a young queen are highly necessiry, that she may not, on her return, lose her life, by attempting, through mistake, to enter a strange hive. Many queens are lost in this way.

123. As the mating of the queen and the drone takes place in the air, very few persons have witnessed it. The following narration will please our readers:

"A short time ago, during one of those pleasant days of May, I was roaming in the fields, not far from Courbevoie. Surrenly I heard a loud humming and the wind of a rapid flight brushed my rheek. Fearing the attack of a hornet, I made an instinctive motion with my hand to drive it away. There were two insects, one of which pursued the other with eagerness, coming from high in the air. Frightened no doubt, by my movements, they arose again, flying rertirally to a great height, still in pursuit of cacle other. I imagined that it was a battle, and desiring to know the result, "I followed, at my best, their motious in the air, and got ready to lay hold of them, as soon as they would be within reach.

"T did not wait long. The pursuing insect rose above the other, and suddenly fell on it. The shock was ccrtainly violent, for both united, dropped with the swiftness of an arrow and 
passed by me, so near that I struck them down with my handkerchief. I then discovered that this bitter battle was but a love-suit. The two insects, stunned and motionless, were coupled. The copulation had taken place in the air, at the instant when I had seen one of them falling on the other, twenty or twenty-five feet above the ground.

"It was a queen-bee and a drone. Persuaded that I had killed them, I made no scruple of piercing them both with the same pin. But the pain recalled them to life again, and they promptly separated. This separation was violent, and resulted in the tearing off of the drone's organ (188) which remained attached to the queen. The queen was yet alive on the following morning. For some time after her separation from the drone, she brushed the last ring of her abdomen, as though trying to extract the organ of the drone. She endeavored to bend herself, probably in order to bring this part within reach of her jaws, which were constantly moving, but the pin prevented her from attaining her aim. Her activity soon decreased, and she ceased to move." -(Alex. Lovi, Journal Des Fermes, Paris, 1869.)

Messrs. Cary and Otis had witnessed a similar occurrence in July, 1861. (1merican Bee Journal, Vol. I, page 66.)

121. It is now well demonstrated that in a single mating, a queen is fertilized for life, although in a few rare instances they have been said to mate two days in suceession, perhaps because the first mating was insufficient.

125. After the queen has re-entered the hive, she gets rid of the organ of the drone by drawing it with her claws, and she is sometimes helped in this work by the worker-bees. The drone dies in the act of fertilization. (188.)

126. Although fertilization of the queen in confinement has been tried by many, it has never been successful. Those who, from time to time, claimed to have succeded were evidently deceiving themselves through ill-made experiments. (18\%.)

12\%. Having ascertained that the queen-bee is fecundated in the open air and on the wing, Huber still could not form any satisfactory conjecture how eggs were fertilized 
which were not yet developed in her ovaries. Years ago, the celebrated Dr. John Hunter (1792), and others, supposed that there must be a permanent receptacle for the male sperm, opening into the oviduct. Dzierzon, who must be regarded as one of the ablest contributors of modern times to apiarian science, maintained this opinion, and stated that he had found such a receptacle filled with a fluid resembling the semen of the drones. He does not seem to have then demonstrated his discoveries by any miscroscopic examinations.

128. In the Winter of 1851-2, the writer subuitted for scientific examination several queen-bees to Dr. Joseph Leidy, of Philadelphia, who had the highest reputation both at home and abroad, as a naturalist and miscroscopic anatomist. $\mathrm{He}$ found, in making his dissections, a small globular sae, about 1-38 of an inch in diameter, communicating with the oviduct, and filled with a whitish fluid; this fluid, when examined under the miscroscope, abounded in the spermatozoids, the living germs which characterize the seminal fluid. A comparison of this substance, later in the season, with the semen of a drone, proved them to be exactly alike. Prof. Siebold, in 1843, examined the spermatheca of the queen-bee, and found it after copulation, filled with the seminal fluid of the drone. At that time, Apiarists paid no attention to his views, but considered them, as he says, to be only "theoretical stuff." It seems, then, that Prof. Leidy's dissection was not, as we had hitherto supposed, the first, of an impregnated spermatheca.

129. These examinations have settled, on the impregnable basis of demoustration, the mode in which the eggs of the queen are fecundated. In descending the oviduct to be deposited in the cells, they pass by the mouth of this seminal sac, or "spermatheca," and receive a portion of its fertilizing contents. Small as it is, it contains sufficient to impregnate nillions of eggs. In precisely the same way, the motherwasps and hornets are fecundated. The females only of these insects survive the Winter, and often a single one begins the construction of a nest, in which at first only a few eggs are deposited. How could these eggs hatch, if the females 
- 
Plate 10.

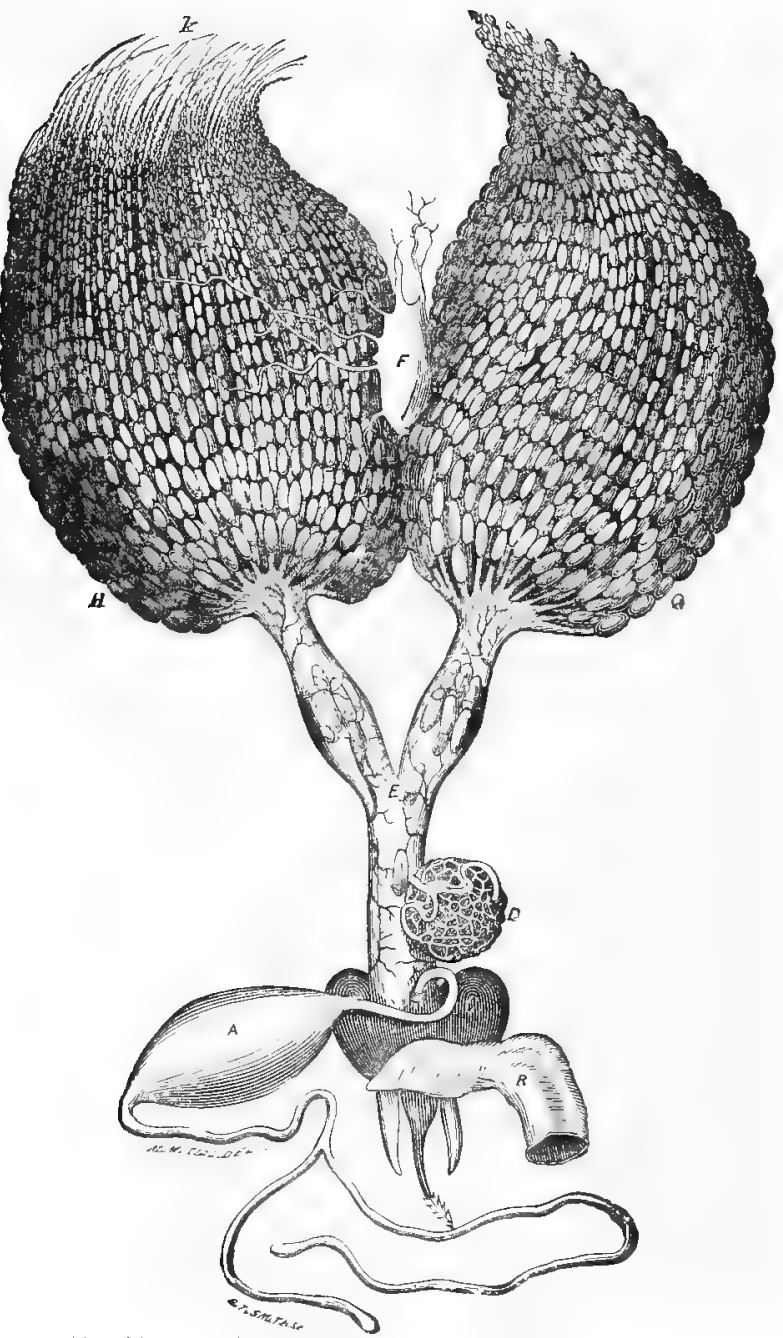

THE OVARIES OF THE QUEEN, IN COMBINATION WITH THE STING.

(Magnified.)

$H$ and $G$, ovaries uniting in a common oviduct $E ; D$, spermatheca; $A$, poison-sack; $R$, rectum; $C$, muscles; $H^{\prime}$, air bag. 
had not been impregnated the previous season? Dissection proves that they have a spermatheca similar to that of the queen-bee. It never seems to have occurred to the opponents of Huber, that the existence of a permanently-impregnated mother-wasp is quite as diffeult to be accounted for, as the existence of a similarly impregnated queen-bee.

130. The celebrated Swammerdam, in his observations upon insects, made in the latter part of the serenteenth century, las given a highly magnified drawing of the ovaries of the queen-bee, a reduced copy of which we present (Plate 10) to our readers. The small globular sac $(D)$, communicating with the oviduct $(E)$, which he thought secreted a fluid for sticking the eggs to the base of the cells, is the seminal reservoir, or spermatheca. Any one who will carefully dissect a queen-bee, may see this sac, even with the naked eye.

It will be seen that the ovaries ( $G$ and $H$ ) are double, each consisting of an amazing number of duets filled with eggs, which gradually increase in size. Since the first edition of this work was issued, we have ascertained that Posel (page 54) describes the oviduct of the queen, the spermatheca and its contents, and the use of the latter in impregnating the passing egg. His work was published at Munich, in 1784. It seems also from his work ("A Complete Treatise of Forest and Horticultural Bee-Culture," page 36), that befor'e the investigations of Huber, Jansha, the bee-keeper royal of Maria Theresa, had discovered the fact that the young queens leave their hive in search of the drones.

131. Huber, while experimenting to ascertain how the queen was fecundated, confined some young ones to their hives by contracting the entrances, so that they were more than three weeks old before they could go in search of the drones. To his amazement, the queens whose impregnation was thus retarded never laid any eggs but such as produced drones!

He tried this experiment repeatedly, but always with the same result. Bee-keepers, even from the time of Aristotle, had observed that all the brood in a hive were occasionally drones. 
132. Dzierzon appears to have been the first to ascertain the truth on this subject; and his discovery must certainly be ranked among the most astonishing facts in all the range of animated nature.

Dzierzon asserted that all impregnated eggs produce females, either workers or queens; and all unimpregnated ones, males, or drones! He stated that in several of his hives he found drone-laying queens, whose wings were so imperfect that they could not fly, and which, on examination, proved to be unfecundated. Hence, he concluded that the eggs laid by an unimpregnated queen-bee had sufficient vitality to produce drones.

133. Parthenogenesis, meaning "generation of a virgin," is the nane given to this faculty of a female, to produce offspring without having been fecundated, and is not at all rare among insects.

131. In the Autumn of 1852, our assistant found a young queen whose progeny consisted entirely of drones. The colony had been formed by removing a few combs containing bees, brood, and eggs, from another hive, and had raised a new queen. Some eggs were found in one of the combs, and young bees were already emerging from the cells, all of which were drones. As there were none but worker-cells in the live, they were reared in them, and not having space for full development, they were dwarfed in size, although the bees had pieced the cells to give more room to their occupants.

We were not only surprised to find drones reared in workercells, but equally so that a young queen, who at first lays only the eggs of workers, should be laying drone-eggs; and at once conjectured that this was a case of an unimpregnated drone-laying queen, sufficient time not having elapsed for her impregnation to be unnaturally retarded. All necessary precautions were taken to determine this point. The queen was removed from the hive, and althongh her wings appeared to be perfect, she could not fly. It seemed probable, therefore, that she luad nerer been able to leave the hive for impregnati $x$ 
135. To settle the question beyond the possibility of doubt, we submitted this queen to Professor Leidy for microseopie examination. The following is an extract from his report: "The ovaries were filled with eggs, the poisonsac full of fluid; and the spermatheca,distended with a perfectly colorless, transparent, viscid liquid, without a trace of spermatozoids."

136. On examining this same colony a few days later, we found satisfactory evidence that these drone-eggs were laid by the queen which had been removed. No fresh eggs had been deposited in the cells, and the bees on missing her had begun to build royal cells, to rear, if possible, another queen. Two of the royal cells were in a short time discontinued; while a third was sealed over in the usual way, to undergo its changes to a perfect queen. As the bees had only a dronelaying queen, whence came the female egg from which they were rearing a queen?

At first we imagined that they might have stolen it from another hive; but on opening this cell it contained only $a$ dead drone! Huber had deseribed a similar mistake made by some of his bees. At the base of this cell was an unusual quantity of the peculiar jelly fed to develop young queens. One might almost imagine that the bees had dosed the unfortunate drone to death; as though they had hoped by such liberal feeding to produce a change in his sexual organization.

13\%. In the Summer of 1854, we found another dronelaying queen in our Apiary, with wings so shrivelled that she could not fly. We gave her successively to several queenless colonies, in all of which she deposited only drone-eggs.

138. In Italy there is a variety of the honey-bee differing in size and color from the common kind. If a queen of this variety is crossed with the common drones, her drone-progeny will be Italian (551), and her worker-brood a cross between the two; thus showing that the kind of drones she will produce has no dependence on the male by which she is feecundated. 
"The following interesting experiment was made by Ber. lepseh, in order to confirm the drone-productiveness of a virgin queen. He contrived the confinement of queens at the end of September, 1854, and, therefore, at a time when there was no longer any males; he was lucky enough to keep one of them through the Winter, and this produced drone-ofispring on the $2 d$ of March, in the following year, furnishing fifteen hundred cells with brood. That this drone-lscaring queen remained a virgin, was proved by the dissection which Leuckart undertook, at the request of Berlepsch. The found the state and contents of the seminal pouch of this queen to be exactly of the same nature as those found in virgin queens. The seminal receptacle in such females never contains semen-masses, with their characteristic spermatozoids, but only a limpid fluid, destitute of cells and granules which is produced from the two appendicular glands of the seminal eapsule; and, as I suppose, serves the purpose of keeping the semen transferred into the seminal capsule in a fresh state, and the spermatozoids active, and, consequently, capable of impregnation." -(Siebold, "Partbenogen. esis.' ')

139. Agrin, to prove that Dzierzon was right, Professon" Von Siebold, in 1855, dissected several eggs at the Apiary "f Baron Von Berlepsch, and he found spermatozoids in every female eys, or ew laid in worker-cell, but although he examined thirty-two male eggs, or exws laid in drone(ells, be could not discover a single spermatozoid either in or around them. In the act of copulation, the sperm of the drone is received into the spermatheea (Plate $10, D$ ), which is placed near and can empty itself into the oviduct. When an exw passes by the spermatheca, if the circumstances are such that a few spermatozoids empty out of the bag on the eres, the sex of it is changed from male to female.

It alprears that there is in each $\cos$ a small opening called niveryle, through which the living spermatozoids enter, when the circumstanres are such that a few of them can slip out of the seminal bas and slide into the oviduct. Such is the procesis of inlpregnation.

110. A ristotle noticel, more than 2,000 years ago, that 
Plate 11.

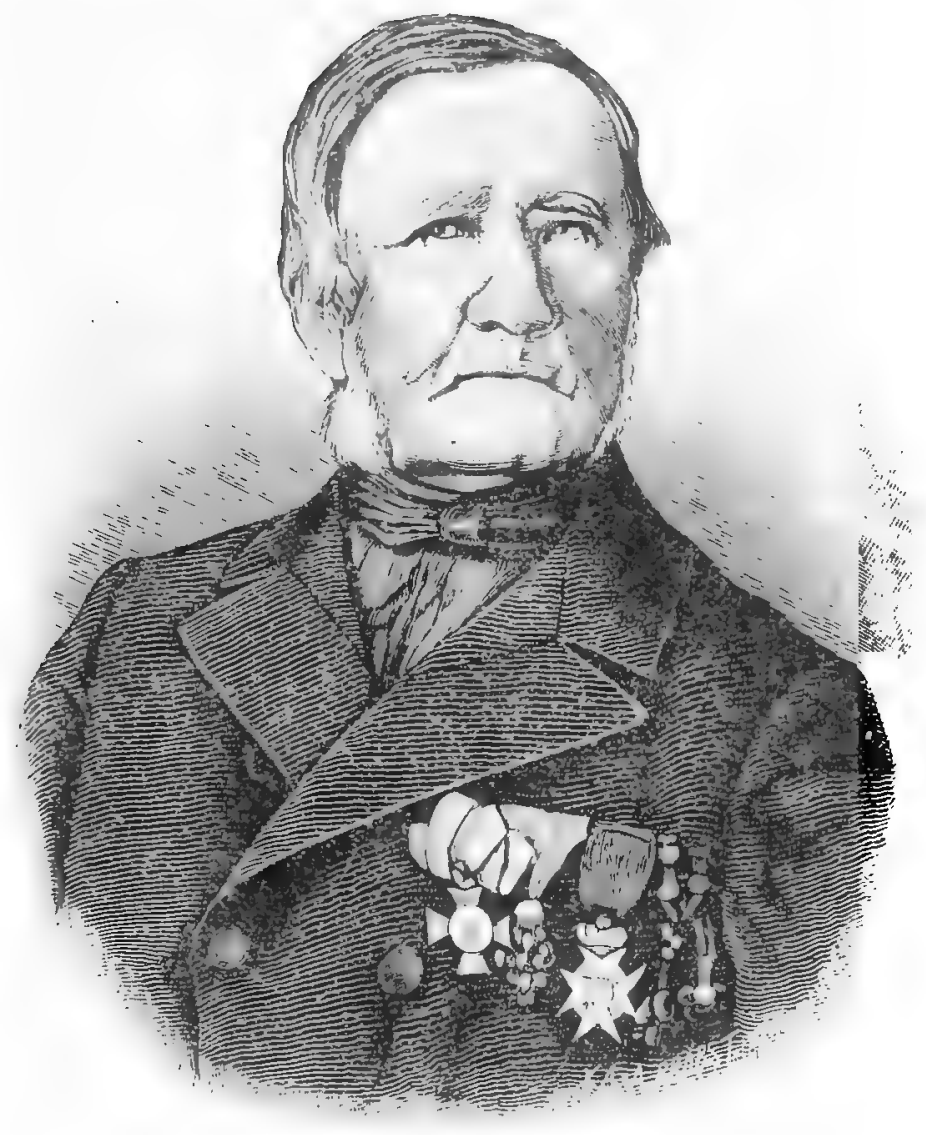

DZIERZON,

Discoverer of Parthenogenesis in Queen-bees.

This writer is mentioned pages $54,56,58,60,62,64,66,68,69,75$, $84,124,125,140,145,244,294,296,297,208$, $360,361,366,375,397,549$. 

the eggs which produce drones are like the worker-eggs." With the aid of powerful microseopes we are still unable to detect any difference in the size or outside appearance of the eggs of the queen.

141. These facts, taken in connection, constitute a perfect demonstration that unfecundated queens are not only able to lay eggs, but that their eggs have sufficient vitality to produce drones.

It seems to us probable, that after feeundation has been delayed for about three weeks, the organs of the queen-bee are in such a condition that it can no longer be effected; just as the parts of a flower, after a certain time, wither and shut up, and the plant becomes incapable of fructification. Perhaps, after a certain time, the queen loses all desire to go in search of the male.

There is something analogous to these wonders in the "aphides" or green lice, which infest plants. We have undoubted evidence that a fecundated female gives birth to other females, and they in turn to others, all of which without impregnation are able to bring forth young; until, after a number of generations, perfect uales and females are produced, and the series starts anew!

However improbable it may appear that an unimpregnated egg can give birth to a living being, or that sex can depend on impregnation, we are not at liberty to reject facts because we cannot comprehend the reasons of them. He who allows himself to be guilty of such folly, if he aims to be consistent, must eventually be plunged into the dreary gulf of atheism. Common sense, philosophy, and religion alike teach us to receive, with becoming reverence, all undoubted facts, whether in the natural or spiritual world; assured that however mysterious they may appear to us, they are beautifully consistent in the sight of Him whose "understanding is infinite."

\footnotetext{
*Cheshire says that "worker-egg" is a misnomer, since all workereggs are impregnated, and hence female-eggs. But the term is too intelligible and popular, for us to change it; since Cheshire himself bows before custom, and uses it.
} 
142. It had long been known that the queen deposits drone-eggs in the large or drone-cells, and worker-eggs in the small or worker-cells (fig 47), and that she usually makes no mistakes. Dzierzon inferred, therefore, that there was some way in which she was able to decide the sex of the egg before it was laid, and that she must have such control over the mouth of the seminal sac as to be able to extrude her eggs, allowing them at will to receive or not a portion of its fertilizing contents. In this way he thought she determined their sex, according to the size of the cells in which she laid them.

143. Mr. Samuel Wagner had advanced a highly ingenious theory, which accounted for all the facts, without admitting that the queen had any special knowledge or will on the subject. He supposed that, when she deposited her eggs in the worker-cells, her body was slightly compressed by their size, thus causing the eggs as they passed the spermatheca to receive its vivifying influence.

144. But this theory was orerthrown by the fact that the queen sometimes lays eggs in cells that are built only to a third of their length, whether worker-cells or drone-cells, and in which no compression can take place. Yet, it is very difficult to admit that the queen is endowed with a faculty that no other animal possesses, that of knowing and deciding the sex of her progeny beforehand. It seems to us that she must be guided by her instinct like all other beings, for she always begins, in the Spring, by laying in small cells, using large cells only when no others are in reach in the warm part of the hive. Sometimes, however, when she is very heavy with eggs, she lays in drone-cells as she comes to them, and will sometimes seek them. Usually it is only when the hive is warm throughout, and worker-cells all oceupied, that she fills the unoccupied drone-cells. This has given rise to the popular theory that the bees raise drones whenever they intend to swarm. It is possible that the width of the cells and the position of her legs when laying in drone-cells (224) prevents the action of the museles of her spermatheca. 
145. The preference of the queen for worker-cells can not be disputed. If all the drone-combs are removed from a hive and replaced with worker-combs, she will not show any displeasure. She will live in that hive for years, without laying any drone-eggs, except, perhaps, here and there, in odd-shaped junction-cells. Mr. A. I. Root makes the same remark:

"By having a hive furnished entirely with worker-comb, we can so nearly prevent the produetion of drones, that it is safe enough to call it a complete remedy."-(" A B C of Bee Culture," 1883.)

146. If, on the other hand, we furnish a swarm with nothing but drone-eomb, already built, they would soon leave the hive. But, if a few worker-cells are among the dronecells, the queen will find them and will lay in them. On this subject, Mr. Root says :

147. "Bees sometimes rear worker-brood in drone-comb when compelled to from want of room, and they always do it by contracting the mouth of the cells, and leaving the young bee a rather large berth in which to grow and develop." "If you give a young laying queen a hive supplied only with dronecombs, she will rear worker-brood in these drone-cells. The mouth of the cells will be contraeted with wax as mentioned before."

148. An experiment, made in Bordeaux, under the supervision of Mr. Drory, editor of the "Rucher," has proven that the queen may lay worker-eggs in drone-cells. A pieee of drone-comb containing worker-brood, was sent us by him. The eggs were laid irregularly and the mouth of the cells had been contracted, as mentioned by Mr. Root. This contraction of the cell mouth seems indispensable to enable the queen to put in motion the muscles of her spermatheca.

149. We will add, with Mr. Root, that in the Spring, or late in the Fall, when the erop is not abundant, the queen will travel over drone-combs without depositing a single egg in them Even by feeding the colony, when in these con- 
ditions, the queen cannot be readily induced to lay in dronecells. Our conclusions on this point differ from those of Mr. Root. We think that the queen prefers worker-cells to drone-cells, because the fecundation of the eggs by the action of the muscles of the spermatheca probably gives her a pleasant sensation, which she does not experience in laying droneeggs.

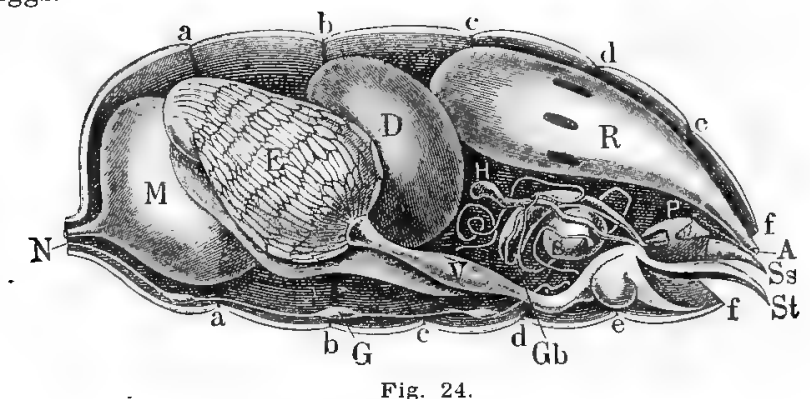

ABDOMEN OF THE QUEEN-BEE.

(Magnified. From the "Illustrierte Bienenzeitung.")

$a, b, c, d, e$, rings of the abdomen; $N$, nerve-chain; $M$, honey-sack; $E$, ovaries; $D$, stomach; $R$, rectum; $G$, ganglions; $A$, anus; $S s$, ovipositor; $S t$, sting; $P$, muscles; $H$, gland; $S$, poison-sack.

150. Some very prolific queens occasionally lay droneeggs in worker-cells. It may be due to fatigue. This will readily be admitted when we consider the number of eggs laid in one day. (98.)

151. Dzierzon found that a queen which had been refrigerated for a long time, after being brought to life by warmth, laid only male eggs, whilst previously she had also laid female eggs. Berlepsch refrigerated three queens by placing them thirty-six hours in an ice-house. Two of tirem never revived, and the third laid, as before, thousands of eggs, but from all of them only males were evolved. In two instances, Mr. Mahan has, at our suggestion, tried similar experiments, and with like results. A short exposure of a queen, to pounded ice and salt, answers every purpose. The 
spermatozoids are in some way rendered inoperative by severe cold.

152. The queen begins laying about two days after impregnation. She is seldom treated with much attention by the bees until after she has begun to replenish the cells with eggs; although if previously deprived of her, they show, by their despair, that they fully appreciated her importance to their welfare.

The extraordinary fertility of the queen-bee has already been noticed. The process of laying has been well described by the Rev. W. Dunbar, a Seotch Apiarist:

153. "When the queen is about to lay, she puts her hearl into a cell, and remains in that position for a second or two, to ascertain its fitness for the deposit she is about to make. She then withdraws her head, and curving her body downwards, inserts the lower part of it into the cell; in a few seconds she turns half round upon herself and withdraws, leaving an egg behind her."

In the Winter, or early Spring, she lays first in the middle of the cluster, and continues in a circle, around the first eggs laid, till she has filled most of the warmed space. She then crosses over to the next comb and does the same thing; as the bees always eluster on different combs in groups exactly opposite, to produce the utmost possible concentration and economy of heat for developing the various changes of the brood.

154. Queens lay more or less according to, 1st, The season; $2 n d$, The number of bees that keep up the heat of the brood-nest, and $3 d$, The quantity of food which they eat. When bees harvest honey or pollen, or when these necessaries are provided artificially by the Apiarist, they feed the queen as they pass by her, oftener than they would otherwise; hence her laying increases in Spring, and decreases in Summer or Fall. It is certain that when the weather is uncongenial, or the colony too feeble to maintain sufficient heat, fewer eggs are matured, just as unfavorable eircumstances diminish the 
number of eggs laid by the hen; and when the weather is very cold, the queen stops laying, in weak colonies.

In the latitude of Northern Massachusetts, we have found that the queen ordinarily ceases to lay some time in October; and begins again, in strong stocks, in the latter part of December. On the 14th of January, 1857 (the previous month having been very cold, the thermometer sometimes sinking to $17^{\circ}$ below zero), we examined three hives, and found that the central combs in two contained eggs and unsealed brood; there were a few cells with sealed brood in the third. Strong stocks, even in the coldest climates, usually contain some brood ten months in the year.

155. "Queens differ much as to the degree of their fertility. Those are best which deposit their eggs with uniform regularity, leaving no cells unsupplied-as the brood hatches at the same time on the same range of comb, which.can be again supplied; the queen thus losing no time in searching for empty cells." -(Dzierzon.)

In bee-life, as well as in human affairs, those who are systematic, ordinarily accomplish the most.

To test the difference of fecundity between queens, $\mathrm{Mr}$. De Layens, while transferring bees (5\%4), in middle April, counted the eggs dropped on a black cloth (578), in forty minutes, by the queens of four different colonies. The poorest queen dropped but one egg, the second twelve, the third eighteen, and the fourth twenty. On the fifteenth of July the colony of the first queen was very poor, the second was of average strength, and both the others were very strong.

156. It is amusing to see how the supernumerary eggs of the queen are disposed of. If the workers are too few to take charge of all her eggs, if there is a deficiency of beebread to nourish the young; or if, for any reason, she does not think best to deposit them in the cells, she stands upon a comb, and simply extrudes them from her oviduct, the workers devouring them as fast as they are laid.

One who carefully watches the habits of bees will often feel inclined to speak of his little favorites as having an 
intelligence almost if not quite akin to reason; and we have sometimes queried, whether the workers who are so fond of a tit-bit in the shape of a newly-laid egg ever experienced a struggle between appetite and duty; so that they must practice self-denial to refrain from breakfasting on the eggs so temptingly deposited in the cells.

157. It is well known to breeders of poultry, that the fertility of a hen decreases with age, until at length she may become entirely barren. By the same law, the fecundity of the queen-bee ordinarily diminishes after she has entered her third year. An old queen sometimes ceases to lay workereggs; the contents of her spermatheca becoming exhausted, the eggs are no longer impregnated, and produce only drones.

The queen-bee usually dies of old age in her fourth year, although she has been known to live longer. There is great advantage, therefore, in hives which allow her, when she has passed the period of her greatest fertility, to be easily removed.

\section{THE WORKER-BEE.}

158. The workers are the smallest inhabitants of a beehive, and compose the bulk of the population. A good swarm ought to contain at least 20,000; and in large hives, strong colonies, which are not reduced by swarming, frequently number three or four times as many during the height of the breeding season.

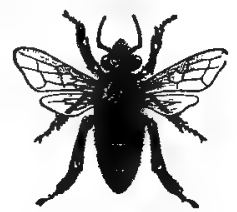

Fig. 25.

159. Their functions are varied. The young bees work inside of the hive, prepare and distribute the food to the larvæ, take eare of the queen, by brushing her with their tongues, nurse her, maintain the heat of the hive, or renew the air and evaporate the newly-gathered honey (249), by ventilating (261, 366). They elean the hive of dirt or 
débris, close up all the cracks, and secrete the greater part of the wax which is produced in the hive.

The old bees may, if necessary, do a part of the same work; but, as we have seen, $(\mathbf{3 9})$, old age renders some unfit to prepare the food of the larvæ. More alert than the young bees, they do the outside work, gather honey (216), pollen (263), and water (271), for the use of the family, and propolis (236) to cement the cracks.

160. "Dzierzon states it as a fact, that worker-bees attend more exclusively to the domestic concerns of the colony in the early period of life; assuming the discharge of the more active out-door duties only during the later periods of their existence. The Italian bees (551) furnished me with suitable means to test the correctness of this opinion.

"On the 18th of April, 1855, I introduccd (533) an Italian queen into a colony of common bees; and on the 10 th of May following, the first Italian workers emerged from the cells. On the ensuing day, they emerged in great numbers, as the colony had been kept in good condition by regular and plentiful feeding. I will arrange my observations under the following heads:

161. "1. On the 10th of May, the first Italian workers emerged; and on the 17th they made their first appearance outside of the hive. On the next day, and then daily till the 29 th, they came forth about noon, disporting in front of the hive, in the rays of the sun. They, however, manifestly, did not issue for the purpose of gathering honey or pollen, for during that time none were noticed returning with pellets; none were seen alighting on any of the flowers in my garden; and $I$ found no honey in the stomachs of such as I caught and killed for examination. The gathering was done exclusively by the old bees of the original stock, until the 29th of May, when the Italian bees began to labor in that vocation also-being then 19 days old.

162. "2. On the feeding troughs placed in my garden, and which were constantly crowded with common bees, I saw no Italian bees till the 27th of May, seventeen days after the first bad emerged from the cells.

"From the 10th of May on, I daily presented to Italian bees, in the hive, a stick dipped in honey. The younger ones never 
attempted to lick any of it; the older occasionally seemed to sip a little, but immediately left it and moved away. The common bees always eagerly licked it up, never leaving it till they had filled their honey-bags. Not till the 25 th of May did I see any Italian bee lick up honey eagerly, as the common bees did from the beginning.

"These repeated observations force me to conclude that, during the first two weeks of the worker-bees's life, the impulse for gathering honey'and pollen does not exist, or at least is not developed; and that the development of this impulse proceeds slowly and gradually. At first the young bee will not even touch the honey presented to her; some days later she will simply taste it, and only after a further lapse of time will she consume it eagerly. Two weeks elapse before she readily eats honey, and nearly three weeks pass, before the gathering impulse is sufficiently developed to impel her to fly abroad, and seek for honey and pollen among the flowers.

163. "I made, further, the following observations respect" ing the domestic employments of the young Italian bees:

" 1 . On the 20th of May, I took out of the hive all the combs it contained, and replaced them after examination. On inspect. ing them half an hour later, I was surprised to see that the edges of the combs, which had been eut on removal,* were covered by Italian bees exclusively. On closer examination, I found that they were busily engaged in re-attaching the combs to the sides of the hive. When I brushed them away, they instantly returned, in eager haste, to resume their labors.

“2. After making the foregoing observations, I inserted in the hive a bar from which a comb had been cut, to ascertain whether the rebuilding of comb would be undertaken by the Italian bees. I took it out a few hours subsequently, and found it covered almost exclusively by Italian workers, though the colony, at that time, still contained a large majority of common bees. I saw that they were sedulously engaged in building comb; and they prosecuted the work unremittingly, whilst I held the bar in my hand. I repeated this experiment several

* Mr. Donhoff, the writer of this quotation, used the Dzierzon hive, the combs of which are suspended in the bive by an upper bar only, and cannot be taken out unless their edges, that are built against the sides of the-hive, are cut. 
days in succession, and satisfied myself that the bees engaged in this work were always almost exclusively of the Italia. r race. Many of them had scales of wax visibly protruding between their abdominal rings (201). These observations show that,

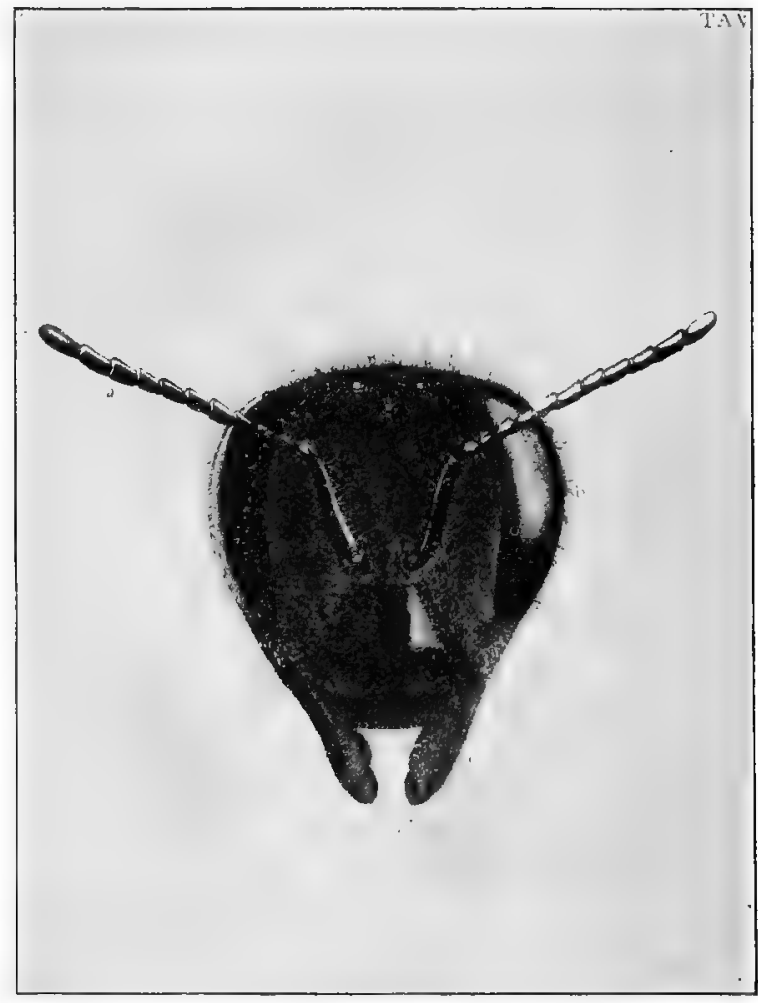

Fig. 20 .

HFAD OF WORKER-BEE.

(Magnified. After Barbo.)

in the early stage of their existence, the impulse for combbuilding is stronger than later in life.

164. "3. Whenever I examined the colony during the first 
three weeks after the Italian bees emerged, I found the broodcombs covered principally by bees of that race: and it is, hence, probable that the brood is chiefly attended to and nursed by the younger bees. The evidence, however, is not so conclusive as in the casc of comb-building, inasmuch as they may have congregated on the brood-combs because these are warmer than the others.

"I may add another interesting observation. The fæces in the intestines of the young Italian bces was viscid and yellow; that of the common or old bees was thin and limpid, like that of the queen-bee. This is confirmatory of the opinion, that, for the production of wax and jelly, the bees require pollen; but do not need any for their own sustenance." - (B. Z., 185b, p. 163. Dr. Donhoff, translated by the late S. Wagner.)

165. There are none but gentlemen of leisure in the commonwealth of bees, but assuredly- there are no such ladies, whether of high or low degree. The queen herself has her full share of duties, the royal office being no sinecure, when the mother who fills it must daily deposit thousands of eggs.

"The eggs of bees are of a lengthened, oval shape with a slight curvature, and oi a bluish white color: being besmeared, at the time of laying, with a glutinous sub-

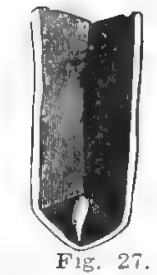

THE EGG IN THE CELL.

(Magnified.) stance, they adhere to the bases of the cells, and remain unchanged in figure or situation for three or four days; they are then hatched, the bottom of each cell presenting to view a small white worm.' -(Bevan.)

166. For the first three days after their hatching, these worms are fed with a jelly, thought to be prepared or secreted by the upper pair of glands of the worker-bees (39), which are very large in the nurses. This milky food is a whitish, transparent fluid, and is distributed to the larvæ, as it is needed. After four or perhaps five days, the larva is too large for the bottom of the cell, where it was coiled up, to use the language of Swammerdam, like a dog when going 
to sleep; and stretches itself till it occupies the whole length of the cell, lying on its back. Its food at this time, is changed for a semi-digested mixture of honey and pollen.

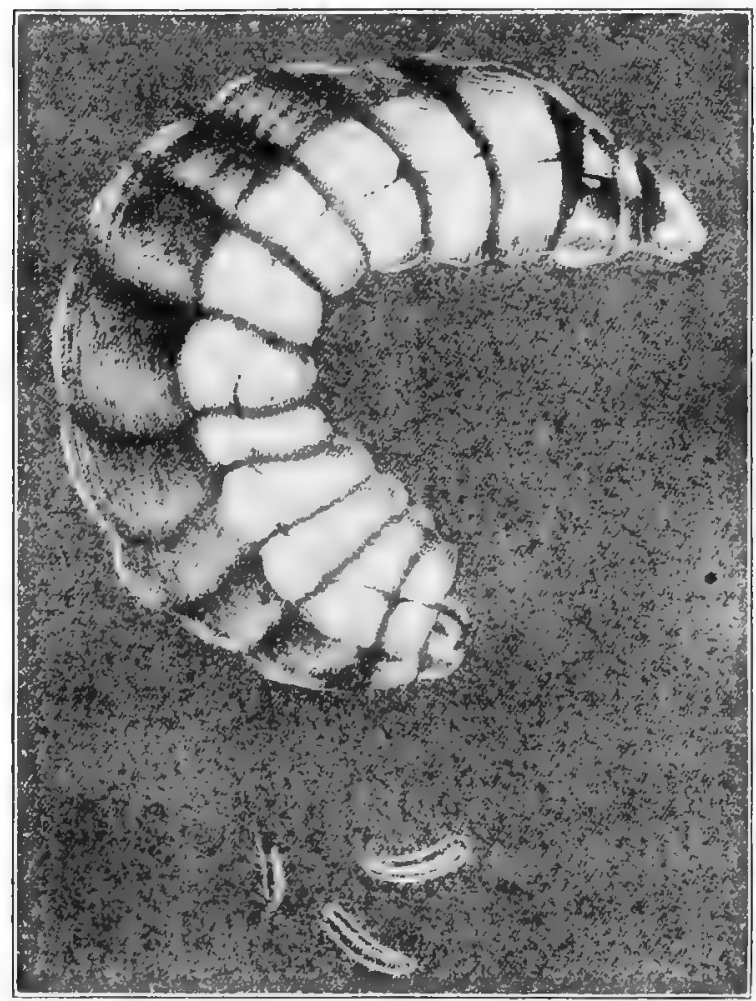

Fig. 28.

EGGS AND IARVA,

(Magnified. After Barbo.)

"The mixture of honey and pollen given at the end of the nursing, is easily detected by its color, which is yellower, on ac- 
count of the pollen, and can be seen through the skin of the larva." (Dubini.)

167. The larva, or grub, grows apace, but not without experienc ing a difficulty to which the human family is, in some sort, subject in the period of youth. Its

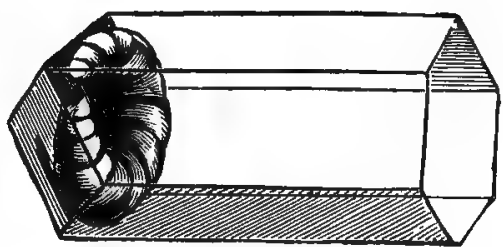

Fig. 29.

COILED IN THE CELL.

(Magnified. From Sartori and Rauschenfels.)

coat is inclastic and does not grow with the wearer, so that it soon, fitting badly, has to be thrown off; but, happily in the case of the larva, a new and larger one has already been formed beneath it, and the discarded garment, more delicate than gossamer, is pushed to the bottom of the cell." -(Cheshire.)

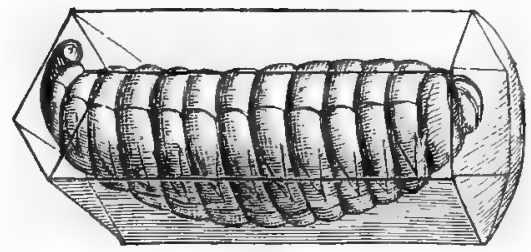

Fig. 30 .

STRETCHED IN THE CELL.

(Magnified.)

168. "The nursingbecs now seal over the cell with a light brown cover, externally more or less convex (the cap of a drone-cell being more convex than that of a worker), and thus differing from that of a honey-cell, which is paler and somewhat concave." ( ("Bevan on the Honey-Bee.")

The cap of the brood-cell is made not of pure wax, but of a mixture of bee-bread and wax; and appears under the mieroscope to be full of fine holes, to give air to the inclosed insect. From its texture and shape it is easily thrust off by the bee when mature, whereas if it consisted wholly of wax, the insect would either perish for lack of air, or be unable to force its way into the world. Both the material and shape of the lids which close the honey-cells are different: they are of pure wax, and are slightly concave, the better to resist the pressure of their contents. The bees sometimes neglect to cap the cells of some of the brood, and some persons have thought that this brood was diseased, but it hatehes 
all the same. The larva is no sooner perfeetly inclosed, than it begins to spin a cocoon after the manner of the silk-worm, and ('heshire teaches us that it does not encase the insect, but is only at the mouth of the cell, "and in no case extends far down the sicles."

To return to Beran:

169. "When it has undergone this change, it has usually borne the name of nymph, or pupa. It has now attained its full growth, and the large amount of nutriment which it has taken serves as a store for developing the perfect insect.

"The working-bee nymph spins its cocoon in thirty-six hours. After passing about three days in this state of preparation for a new existence, it gradually undergoes so great a change as not to wear a vestige of its previous form."

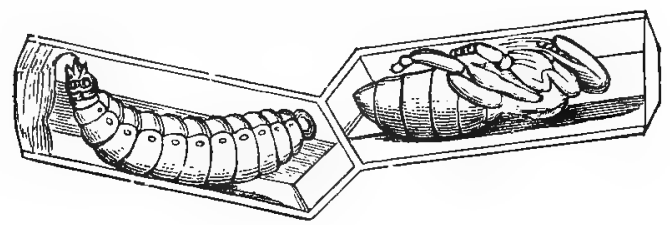

Fig. 31.

SPINNING OF THE COCOON AND TRANSFORMATION INTO NYMPH.

(Magnified. From Sartori and Rauschenfels.)

170. The last east-off skin of the larva, "which, by the creature's movements within the cell, becomes plastered to the walls and joins the cocoon near the mouth end" (Cheshire), is left behind, and forms a closely-attached and exact lining to the cell; lyy this means the breeding-cells become smaller, and their partitions stronger, the oftener they change their tenants.

So thin is this lining, that brood combs more than twenty years old have been found to raise bees apparently as large as any other in the Apiary.

171. About twenty-one days are usually required for the transformations from the worker-egg to the perfect insect. But the time may be shortener or lengthened by the tem. 
perature, or the conditions of the colony. Dzierzon and others wrote that a worker-bee can hatch in nineteen to twenty-one days. Collin says nineteen to twenty-three. That the brood can remain even longer before hatching, is confirmed by the

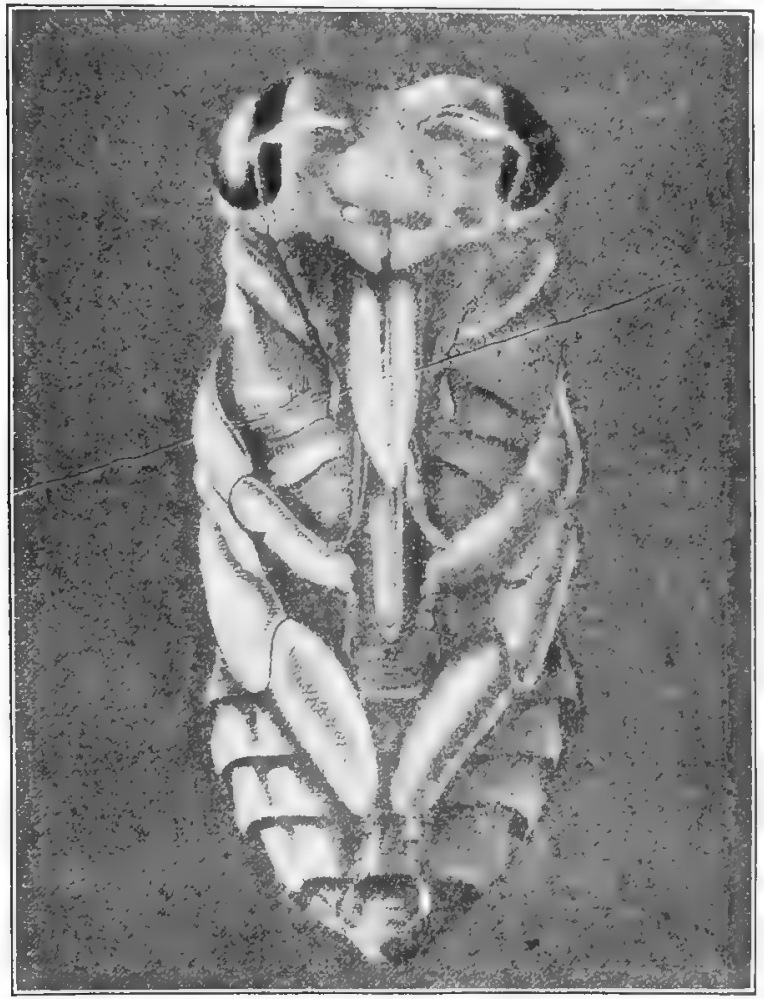

Fig. 32.

NYMPH,

(Magnificđ. After Barbõ.)

report of A. Saunier, in the South of France. Having deprived a hive of all its inhabitants, he found bees, hatching twenty-three days afterwards, that had not even been sealed 
in their cells, since there had been no nurses there to do this work. ("L'Apiculteur." Paris, 1870.) As these were already full-grown larvæ, when the hive was deprived of its bees, they must have been twenty-seven days old when hatching. In this experiment, the heat produced by the larvæ, coupled with that of the atmosphere, had been sufficient to keep them alive and help their slow development.

We have often noticed the brood of swarms, that had deserted their hives, still alive after a cold night, but in each case its development was delayed.

172. A newly hatched worker, like a newly hatched queen, is easily recognized by her small size, her pale gray color, and ther weak appearance. After a few days, she has grown considerably larger. She is then in the bloom of health; her color is bright, she has not yet lost a single hair of the down which covers her body. These hairs fall gradually from age and work, and sometimes disappear almost entirely.

173. The first excursion of the young bee out of the hive takes place when she is about eight days old (160.) The disturbing of the colony, or the lack of old bees may cause them to go out earlier.

The first flight of young worker-bees is easily remembered when once seen. It usually takes place in the afternoon of a sunny day. They first walk about on the platform in a hesitating manner and then take flight. Their humming, and joyous and peaceable circles to reconnoitre the location of their home, recalls to memory the gay playing of children in front of the school-house door. Their second trip is made about a week after the first; it is then that they bring in their first load. A young bee coming home is readily recognized by the small size of the pollen pellets she carries, when compared with those of older bees, and by the turns she makes before alighting.

174. The Apiarist should become acquainted with the behavior of young bees, so as not to mistake their pleasant flight for the restless motions of robber-bees. (664.)

175. Although the workers are females, they are incapable 
of fecundation (108). Yet the rudimental ovaries of some of them contain a few undeveloped eggs (fig. 33).

176. Occasionally some of them are sufficiently developed to be capable of laying eggs; but these eggs always produce drones. Laying workers appear only when a colony has been queenless for some time. Huber thought that fertile workers were reared in the neighborhood of the young queens, and that they received some of the peculiar food, or jelly on which these queens are fed.* But it is more probable that it is the increase of the milky food, given lavishly to the larvæ in the first stage of their development, during a good honey flow, which enlarged their ovaries (108), and that the young bees, thus raised, having no more larvæ to nurse when the hive has suddenly become queenless, feed each other with their milky food, which excites their laying, as it does for the queens (39). The number of drone-laying workers is sometimes very large in a hopelessly queenless hive; we have seen at least a dozen laying on the same comb. $\mathbf{M r}_{\mathrm{r}}$. Viallon, a noted bee-keeper of Louisiana, once had so many in one queenless colony, that he was able to send several dozen for dissection to bee-keepers in this country and Europe.

17\%. Some persons may question the wisdom of Nature in endowing the workers with the means of laying droneegg's, when there is no queen in the colony to be fecundated by them. But Nature does nothing without purpose. The main cause of the loss of the queen, when there is no brood

* An extract from Huber's preface will be interesting in this connection. After speaking of his blindness, and praising the extraordinary taste for Natural History, of his assistant, Burnens, "who was born with the talents of an observer," he says: "Every one of the facts I now publish, we have seen, over and over again, during the period of eight years, which we have employed in making our observations on bees. It is impossible to form a just idea of the patience and skill with which Burnens has carried out the experiments which I am about to describe; he has often watched some of the working-bees of our hives, which we had reason to think fertile, for the space of twentyfour hours, without distraction **** and he counted fatigue and pain as nothing, compared with the great desire he felt to know the results." 
fit to raise others (10\%), and therefore, no hopes of survival for the colony, is usually the death of the young queen in her bridal flight (122). At some seasons, the drones are

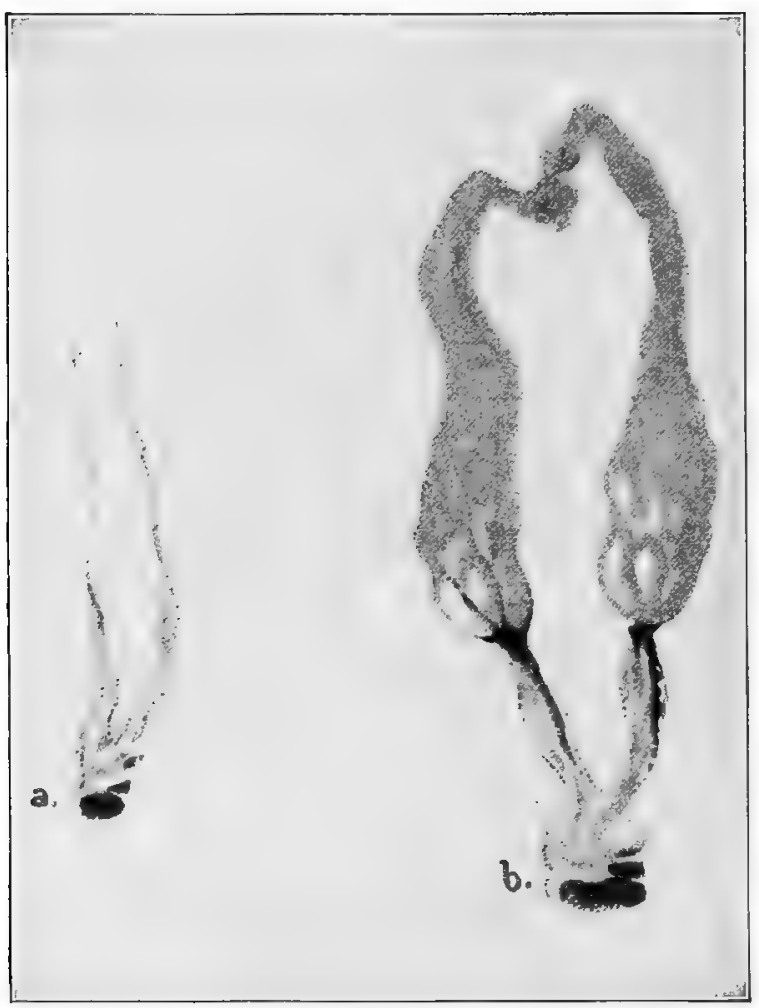

Fig. 33.

COMPARATIVE SIZE OF TILE OVARIES OF STERILE AND DRONE-LAYING
WORKERS. (Magnified. After Barbò.)

scarce, and a young queen may be compelled to make several trips before she finds one. If she gets lost, the hive having remained queenless for at least eight or ten days (109), the 
brood is too old to be used to raise another, and the colony is doomed. That other colonies may not be victims of similar accidents, owing to the scarcity of drones, Nature endows this worthless colony with the faculty of drone-raising.

It is by the same provision of Nature that unhealthy trees, on the eve of death, are seen covered with blossoms and fruits. They make the strongest efforts to save their race from extinction, and perish afterwards.

178. The drone-laying of worker-bees is easily discovered by the Apiarist. Their eggs are laid without order, some cells containing grown larvæ, or sealed pupæ, by the side of cells containing eggs; while the eggs of a queen are very regularly

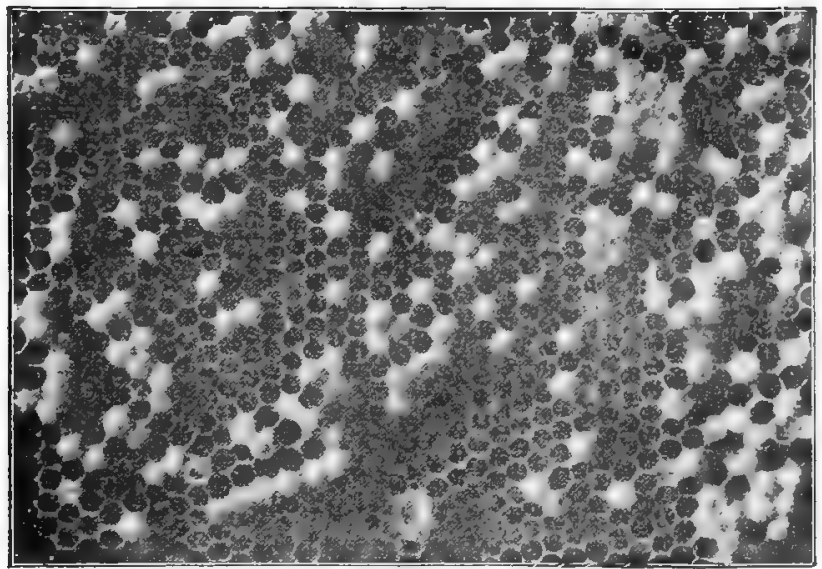

Fig. 34.

BROOD FROM DRONE-LAYING WORKER.

(Forty Years Among the Bees.)

By C. C. Miller.

laid. Huber states that the fertile workers prefer large cells in which to deposit their drone eggs, resorting to small ones only when unable to find those of greater diameter. A hive in our Apiary having much worker-comb, but only a small piece of drone size, a fertile worker filled the latter so entiress with eggs that some of the cells contained three or four each. 
179. Sometimes the bees do not seem to know that these eggs are drone-eggs, and in their eagerness to raise a queen, they treat some of them as such, by enlarging their cells and feeding them on special food (109). The poor overfed drones, thus raised, usually perish in the cell (136). The workers soon dwindle away, and the colony perishes.

180. They often even fail to raise any queen from brood, which may be given them by the Apiarist, unless some hatching bees are given at the same time. The latter, when informed of the needs of the colony, usually succeed in raising a queen. The introduction of a laying-queen in a laying-worker colony, is the best remedy. (533.)

181. The bees of the same colony understand each othex very well for all their necessities, and they work with an entrain which is truly admirable. They know each other, probably by smell, for it is very rare to see a bee of the hive treated as a robber $(\mathbf{6 6 - 1})$. They never use their sting except to defend themselres, when hurt, or their home, when they think it is threatened.

182. Their life is short, but their age depends rery much upon their greater or less exposure to injurious influences, and severe labors. Those reared in the Spring and early part of Summer, upon whom the heaviest labors of the hive devolve, appear to live not more than thirty-five days, on an average; while those bred at the close of Summer, and early in Autum, being able to spend a large pare of their time in repuse, attain a much greater age. It is very evident that "the bee" (to use the words of a quaint old writer) "is a Summer bird"; and that, with the exception of the queen, none live to be a year old.

If an Italian queen be given, in the working season, 'to a hive of eommon bees, in about three months none of the latter will be found in the colony, and as the black queen rcmored has left eggs in the eells, which take twenty-one days to hatch, it is eviclent that the bees all die from fatigue or accident in the remaining seventy days, making their average life thirty-five days in the working season. 
The age which individual members of the community may attain, must not be confounded with that of the colony. Bees have been known to occupy the same domicile for a great number of years. We have seen flourishing colonies more than twenty years old; the Abbé Della Rocea speaks of some over forty years old; and Stoche says that he saw a colony, which

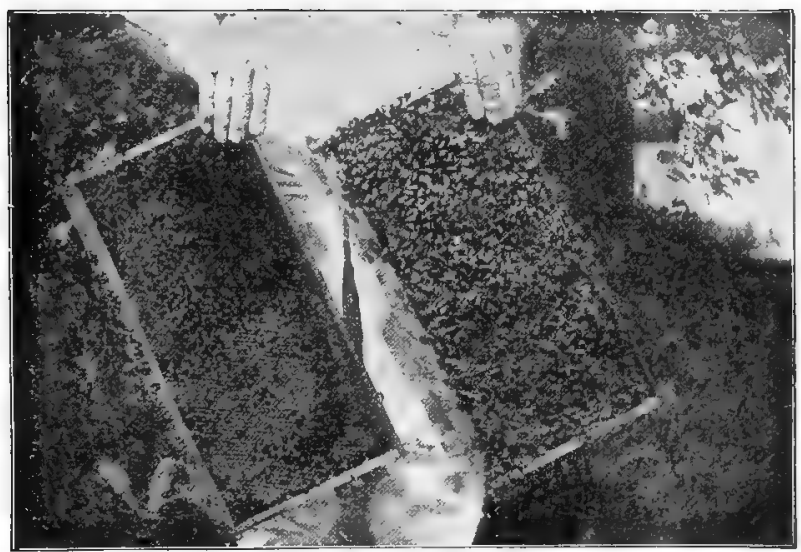

Fig. 35.

COMBS OF BROOD.

(Forty Years Among the Bees.)

he was assured had swarmed aunually for forty-six years! Such cases have led to the erroneous opinion, that bees are a long-lived race. But this, as Dr. Evans* has observed, is just as wise as if a stranger, contemplating a populous city, and personally unacquainted with its inhabitants, should, on paying it a second visit, many years after, and finding it equally populous, imagine that it was peopled by the same individuals, not one of whom might then be living.

* Dr. Evans was an Englísh physician, and the author of a beautiful poem on bees. 
'Like leaves on trees, the race of bees is found, Now green in youth, now withering on the ground, Another race the Spring or Fall supplies, They droop successive, and successive rise." '-Evans.

Apiarists, unaware of the brevily of the bee's life, have often constructed huge "bee-palaces" and large closets, vainly imagining that the bees would fill them, being unable to see any reason why a colony should not increase until it numbers its inhabitants by millions or billions. But as the bees can never at one time equal, still less exceed, the number which the queen is eapable of producing in a season, these spacious dwellings have always an abundance of spare room. It seems strange that men can be thus deceived, when often in their own apiary they have healthy stocks, which, though they have not swarmed for a year or more, are no more populous in the Spring; than those which have regularly parted with vigorous colonies.

183. There is something cruel in the habits of the bee. Whenever one of them becomes unable to work from some cause or other, if she does not perish in her efforts to go to the fields, the other bees drag her out pitilessly; their love being concentrated on the whole family, not on a single individual. Y'et, when one is hurt, and complains, hundreds of others resent the injury and are ready to arenge her.

181. Notched and ragged wings and shiny bolies, instead of gray liain's and winkled faces, are the signs of old age in the bee, indicating that its season of toil will soon be over. They appear to die rather suddenly; and often spend their last days, and even their last hours, in useful labors.

Place yourself before a hive, and see the indefatigable energy of these industrious veterans, toiling along with their heary burdens, side by side with their more youthful compeers, and then judge if, while qualified for useful labor, you ought ever to surrender yourself to slothful indulgence.

Let the eheerful hum of their busy old age inspire you with better resolutions, and teach you how much nobler it is to die with harness on, in the active discharge of the duties of life. 


\section{The Drones.}

185. The drones are the male bees. They are much larger and stouter than either the queen or workers; although their bodies are not quite so long as that of the queen. They have no sting (78) with which to defend themselves, and no suitable proboscis (48) for gathering honey from the flowers, no baskets on their thighs (59) for holding bee-bread, and no pouclies (201)

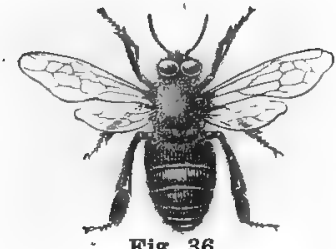

Eig. 36.

on their abdomens for secreting wax. They are, therefore, physically disqualified for the ordinary work of the hive. Their proper office is to impregnate the young queens.

"Their short proboscis sips

No luscinus nectar from the wild thyme's lips,

From the lime's leaf no amber drops they steal,

Nor bear their grooveless thighs the foodful meal:

On other's toils in pamper'd leisure thrive

The lazy fathers of the industrious hive."

-Evans.

186. The drones begin to make their appearance in April or May; earlier or later, according to the forwardness of the season, and the strength of the colony. Like the other inhabitants of the hive they cannot perform the work for which they are intended, till at least one week old. They go out of the hives only when the weather is warm, and at mid-day.

187. As we have seen (122), the mating of the queen with a drone always takes place in the air. Physiologists say that it cannot be otherwise, because the sexual organs of the drone cannot be extruded unless his abdomen is swelled by the filling of all the tracher with air. This happens only in swift flight (\%). 
Dzierzon supposes that the sound of the queen's wings, when she is in the air, excites the drones. Evidently their eyes (11) and ears (25) which are highly developed, as proven by Cheshire, help them also in the search of the queen, which is their sole occupation, when in the field. In the interior of the hive, they are never seen to notice her; so that she is not molested, even if thousands are members of the same colony with herself. But outside of the hive, they readily follow her, led, according to Dzierzon, by the peculiar hum of her flight, and certainly also, by the senses of suell and of sight, which are more perfect than those of the worker, most likely for this single purpose.

"When the queen flies abroad, the fleetest drone is more likely to succecd in his addresses than another, and thus he impresses upon posterity some part of his own superior activity and energy. The slow and weak in the race die without heirs, so that the survival of the fittest is not an accident, but a predetermination. In previous chapters we have considered his highly-developed eyes, meeting at the rertex of his head, his multitudinous smell-hollows, and his strong large wings, the advantage of which now appcars in a clearer light; his quickness in diseovering a mate, whose neighborhood is to him filled with irresistible odours, and his ability in keeping her in view during pursuit, are no less helpful to his purpose than fleetness on the wing...."'-(Cheshire.)

188. The drone perishes in the act of impregnating the queen. Although, when cut into two pieces, each piece will retain its vitality for a long time, we accidentally ascertained, in the Summer of 1852, that if his abdomen is gently pressed, and sometimes if several are closely held in the warm hand, the male organ will often be permanently extruded, with a motion very like the popping of roasted pop-corn; and the insect, with a shiver, will curl up and die, as quickly as if blasted with the lightning's stroke. This singular provision is unquestionably intended to give additional security to the queen when she leaves her hive to have intercourse with the drone. Huber first discovered that she returned with the male 
organ torn from the drone, and still adhering to her body. If it were not for this arrangement, her spermatheca could not be filled, unless she remained so long in the air with the drone, as to incur a very great risk of being devoured by birds. In one instance, some days after the impregnation of a queen, we found the male organ, in a dried state, adhering so firmly to her body, that it could not be removed without tearing her to pieces.

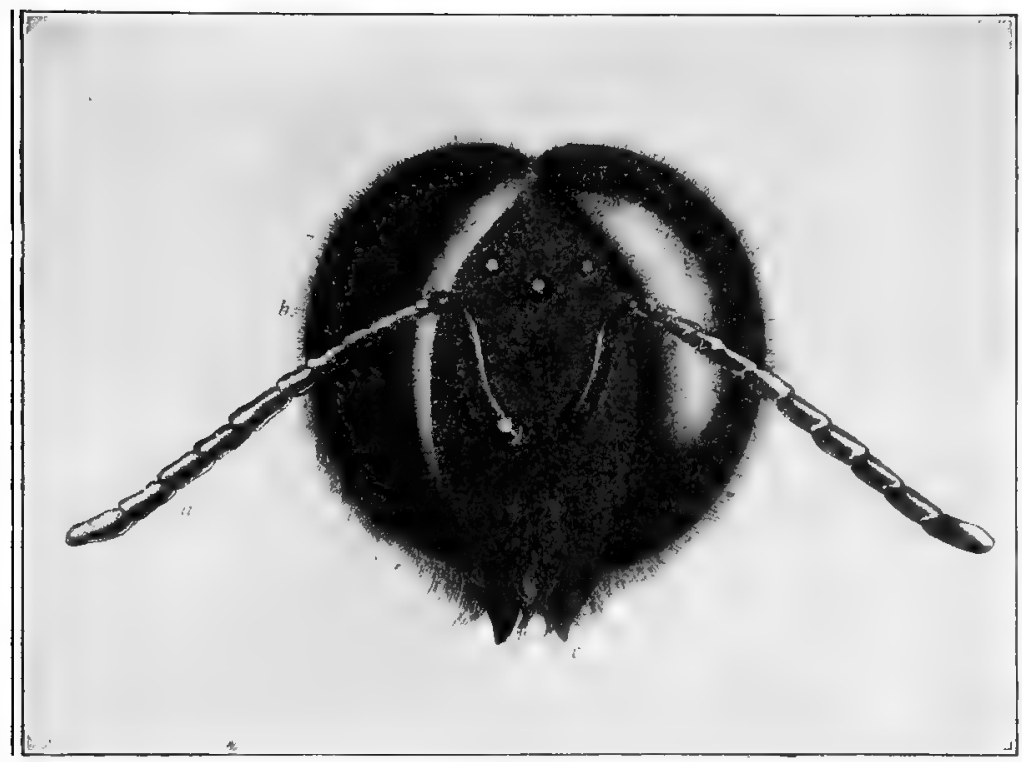

Fig. 37.

HEAD OF DRONE.

(Maguified. After Barbò.)

189. The number of drones in a hive is often very great, amounting not merely to hundreds, but sometimes to thousands. As a single one will impregnate a queen for life, it would seem that only a few should be reared. But as sexual intercourse always takes place high up in the air, the young queens 
must necessarily leave the hive; and it is very important to their safety that they should be sure to find a drone without being compelled to make frequent excursions; for being larger than workers, and less active on the wing, queens are more

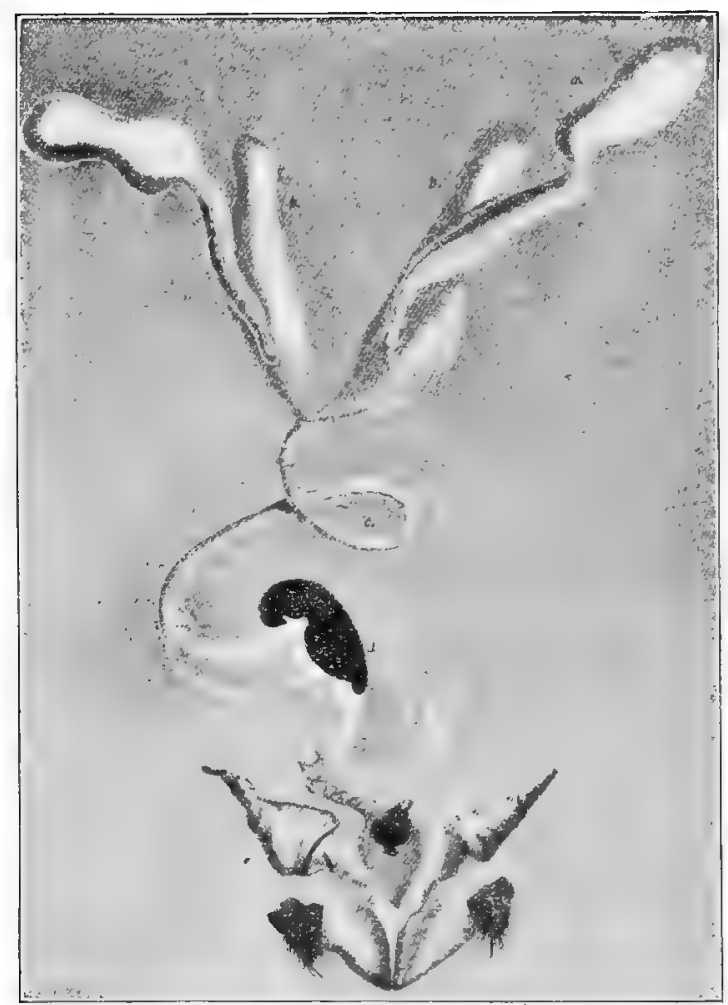

Fig. 38 .

SEXUAL ORGANS OF DRONE.

(Magnified. After Barbò.)

$a, a$, testicles; $b, b$, mucous glands; $c$, seminal duct; $d$, part in which the spermatophore is formed; $e$, bollow horns and penis. 
exposed to be caught by birds, or destroyed by sudden gusts of wind.

In a large Apiary, a few drones in each hive, or the number usually found in one, would suffice. Under such circumstances bees are not in a state of nature, like a colony living in a forest, which often has no neighbors for miles.

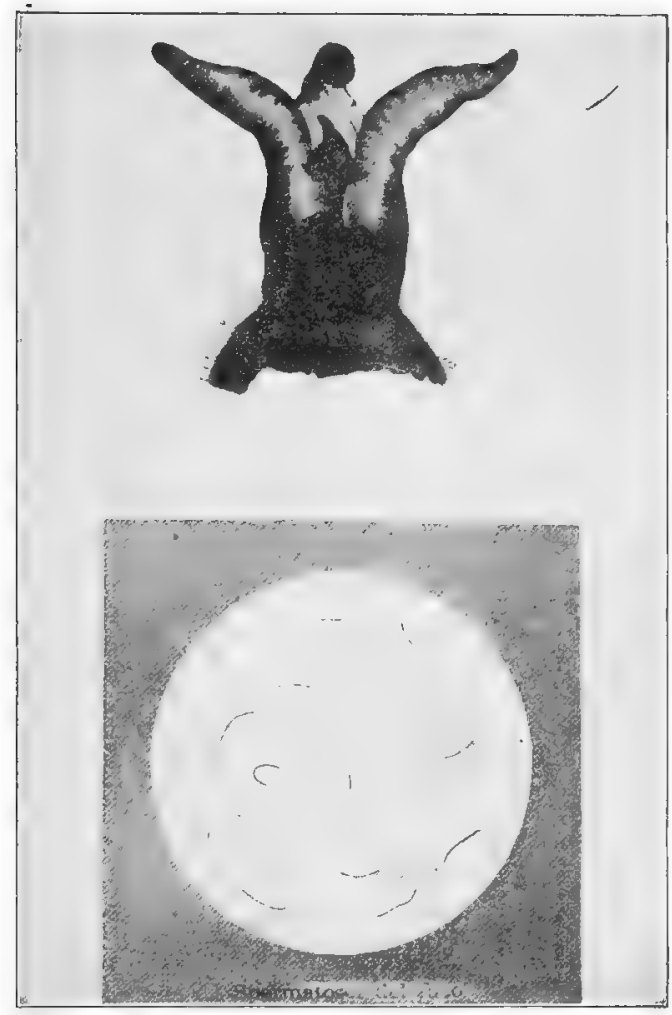

Fig 39.

PENIS AND SPERMATOZOIDS.

(Much magnified. After Barbò.) 
A good colony, even in our climate, sometimes sends out three or more swarms, and in the tropical climates, of which the bee is probably a native, they increase with astonishing rapidity. Every new swarm, except the first, is led off by a young queen; and as she is never impregnated until she has been established as the head of a separate family, it is important that each should be accompanied by a goodly number of drones; this requires the production of a large number in the parent-hive.

190. This necessity no longer exists when the bee is domesticated, since several colonies are kept in the same place, and the breeding of so many drones should be discouraged. Their brood takes useful space that might as well be occupied with worker-brood. One thousand good-for-nothing drones take up as much breeding-space as fifteen hundred workers (221), and require as much food, with negative results. Some hives, in a state of nature, produce so many drones that a great part of the surplus crop is disposed of by these voracious loafers. Besides, the comparatively large volume of the male organs, in connection with the gluttony of the drones, explains why they usually void their dejections in the hive, while workers retain them till they are on the wing $(\mathbf{7 3})$, and why the cells of the combs of hives which have a large quantity of these gormands, become dark and thick sooner than the others.

The importance of preventing the over-production of drones has been corroborated by the discovery of Mr. P. J. Mahan, that those leaving the hive have quite a large drop of honey in their stomachs-while those returning from their pleasure excursions, having digested their dimners, are prepared for a new supply $(\mathbf{6 0 0})$.

Aristotle ("History of Animals," Book IX, Chap. XI) speaks of the irregular and thick combs built by some colonies, and the superabundance of drones issuing from them. He describes their excursions as follows:

"The drones, when they go abroad, rise into the air with a circular flight, as though to take violent exercise, and when they 
have taken enough, return home, and gorge themselves with honey."

"The drone," says quaint old Butler (1609) "is a gross, stingless bee, that spendeth his time in gluttony and idleness. For howsoever he brave it with his round velvet cap, his side gown, his full paunch, and his loud voice, yet is he but an idle companion, living by the sweat of others' brows. He worketh not at all; either at home or abroad, and yet spendeth as much as two laborers: you shall never find his maw without a drop of the purest nectar. In the heat of the day he flieth abroad, aloft and about, and that with no small noise, as though he would do some great act; but it is only for his pleasure, and to get him a stomach, and then returns he presently to his cheer."

191. The bee-keepers in Aristotle's time were in the habit

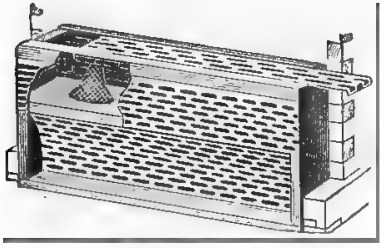

Fig. 40 .

ALLEY'S DRONE-TRAP. of destroying the exces: of drones. They excluded them from the hive-when taking their accustomed airing -by contracting the entrances with a kind of basket work. Butler recommends a similar trap, which he calls a "drone-pot."

One of the modern inventions to destroy them is Alley's drone-trap* improved by J. A. Batchelder; but it is much better to save the bees the labor and expense of rearing such a host of useless consumers. This can readily be done, when we have the control of the combs; for, by removing the dronecomb, and supplying its place with worker-cells, the overproduction of drones may be easily prevented. Those who object to this, as interfering with nature, should remember that the bee is not in a state of nature; and that the same objection might, with equal force, be urged against killing off

* The perforated zinc, used in drone-traps, which we think was inyented by Collin, ("Guide," p. 3, Paris, 1865), is so cut, that neither queen nor drone but only the worker bee can pass through its opening. 
or castrating the supernumerary males of our domestic animals.

192. Soon after the harvest is over, or if there is a lull in the yield of honey, the drones are expelled from the hive. The worker-bees sting them, or gnaw the roots of their wings, so that when driven from the hive, they cannot return. If not ejected in either of these summary ways, they are so persecuted and starved, that they soon perish. At such times they often retreat from the comb, and keep by themselves upon the sides or bottom-board of the hive. The hatred of the bees extends even to the unhatched young, which are mercilessly pulled from the cells and destroyed with the rest.

Healthy colonies almost always destroy the drones, as soon as forage becomes scarce. In the vicinity of Philadelphia, there were only a few days in June, 1858, when it did not rain, and in that month the drones were destroyed in most of the hives. When the weather became more propitious, others were bred to take their place. In seasons when the honey-harvest has been abundant and long protracted, we have known the drones to be retained, in Northern Massachusetts, until the 1st of November. If bees could gather honey and could swarm the whole year, the drones would probably die a natural death.

How wonderful that instinct which, when there is no longer any occasion for their services, impels the bees to destrcy - those members of the colony reared with such devoted attention!

193. It is interesting to notice the actions of the drones when they are excluded from the hive. For a while they eagerly search for a wider entrance, or strive to force their bulky bodies through the narrow gateway. Finding this to be in vain, they solicit honey from the workers, and when refreshed, renew their efforts for admission, expressing, all the while, with plaintive notes, their deep sense of such a cruel exclusion. The bee-keeper, howerer, is deaf to their entreaties; it is better for hin that they should stay without, and better for them-if they only knew it-to perish by his 
hands, than to be starved or butchered by the unfeeling workers. Towards dark, or early in the morning-when clustered, for warmth, in the portico-they may be brushed into a vessel of water, and given to chickens, which will soon learn to devour them.

194. Drones are sometimes raised in worker-cells (150). They are smaller in size, but apparently as perfect as the full-size drones, all their organs being well developed.

For the stages of development of drones, see the comparative table at the end of this chapter (197).

195. We have repeatedly queried, why inpregnation might not have taken place in the hive, instead of in the open air. A few dozen drones would then have sufficed for the wants of any colony, even if it swarmed, as in warm climates, half a dozen times, or oftener, in the same season; and the young queens would have incurred no risks by leaving the hive for fecundation.

196. If a farmer persists in what is called "breeding in and in," that is, without ehanging the blood, the ultimate degeneracy of his stock is the consequence." This law extends, as far as we know, to all animal life, man himself not being exempt from its influence. Have we any reason to suppose that the bee is an exception? or that degeneracy would not ensue, unless some provision were made to counteract the tendency to "in-and-in breeding?" If fecundation had taken place in the hive, the queen would have been impregnated by: drones from a common parent; and the same result must have taken place in each suceessive generation, until the whole species would eventually have "run out." By the present arrangement, the young queens, when they leave the hive, often find the air swarming with drones, many of which belong to other colonies, and thus, by crossing the breed, provision is constantly made to prevent deterioration.

* In the above, Mr. Langstroth refers to indiscriminate breeding. In-and-in breeding, by selection, intensifies certain qualities, such as the development of fat, or of muscle, but it also intensifies the defects, generally causing a decrease of vitality or of health in the race. 
Experience has proved that impregnation may be effected not only when there are no drones in the colony of the young queen, but even when there are none in her immediate neighborhood. Intercourse takes place very high in the air (perhaps that less risk may be incurred from birds), and this favors the crossing of stocks.

19\%. Comparative Table of tree Tormal Duration of tire Bee's Transformatons frodi Eggs to Winged Insects.

Queen. Worker. Drone.

Eggs $\ldots \ldots \ldots \ldots \ldots \ldots$. days 333

Growth of larva.......... " $51 / 2 \quad 6 \quad 61 / 2$

Spinning of cocoon......... " $\quad 1 \quad 2 \quad 11 / 2$

Period of rest............ " $42 \quad 2 \quad 3$

Metamorphosis into pupa.... " " 111

Duration of this stage...... " $\quad 31 / 2 \quad 7 \quad 9$

Av. time from egg to winged insect. $\begin{array}{lll}-16 & -21 & -24\end{array}$ 


\section{CHAPTER II.}

THE BUILDING OF BEES, - COMB.

198. When a swarm (406) has found a suitable habitation, some of the bees clean it of its rubbish, if necessary, while others, at once, prepare to build the furniture, which is intended as cradles for the young bees, and as a store-room for the provisions, and is ealled comb.

According to Webster, this word is probably talsen from

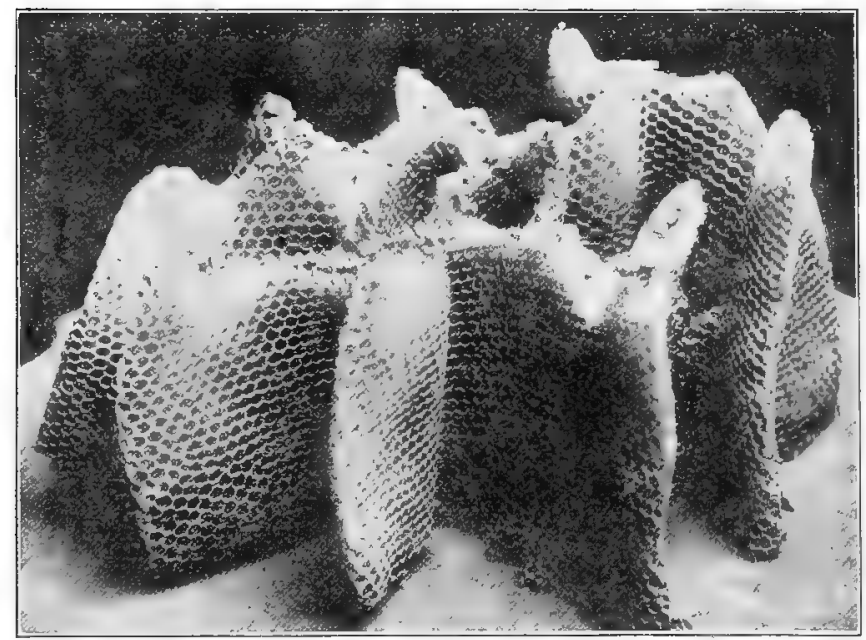

Fig. 41.

COMBS BUILT UPWARDS.

the Anglo-Saxon "comb," which means a hollow; the combs being hollow struetures, with exceedingly light walls.

199. The combs are usually begun at the highest point of the hive and built downwards, yet, when some breaking hap- 
pens, or when the harvest is short and the weather is cool, the bees sometimes build them upwards; but they are far from haring the usual regularity. Combs are made of wax, a natural secretion which is produced by bees somewhat as cattle produce fat, ly eating.

200. "Wax is not chemically a fat or glyceride, yct it is nearly allied to the fats in

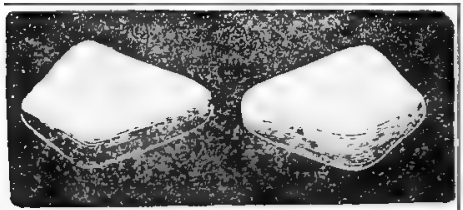

Fig. 42. WAX SCAIES. (Magnified.) atomic constitution, and the physiological conditions fan voring the formation of one are curiously similar to those aiding in the production of the other. We put our poultry up to fat in confinement, with partial light, to sccure bodily inactivity, we keep warm and fecil highly. Our bees, under Nature's teaching, put themselves up to yiels wax under conditions so parallel, that the suitability of the fatting $\operatorname{coops}_{1}$ is vindicated."'-(Cheshire.)

Yet let it not be thought that beeswax in the fat of the bee, but itis prirluction is on similar lines.

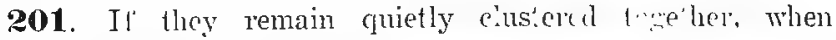
gorged with honcy, or ary liquid sweet, the wax is secreted in the shape of de.inate seales in four small pouches, on each sicke of the abdomen, of worker-bees.

"These seales, of an irregular pentagonal shape, are so thin and light, that one hundred of them hardly weigh as much as a kernel of wheat." -(Dubini, "L'Ape.").

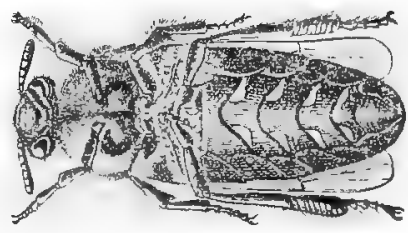

Fig. 43.

SECRETION OF WAX DCALES.

(Magnified.)

(Frcm the "Intustricrte Bienenichany.")

202. In the young bees, which are endowed with a great appetite, they form, probably, without their knowledge, dur- 
ing the honey season; and if there is no place to use them, they are gathered in small knots here and there. This only happens when the combs are entirely filled and sealed. It has been noticed, most especially, in hives in which a comb had been broken down by heat. (333.) In such cases, many of the bees gorge themselves with the wasting honey, and

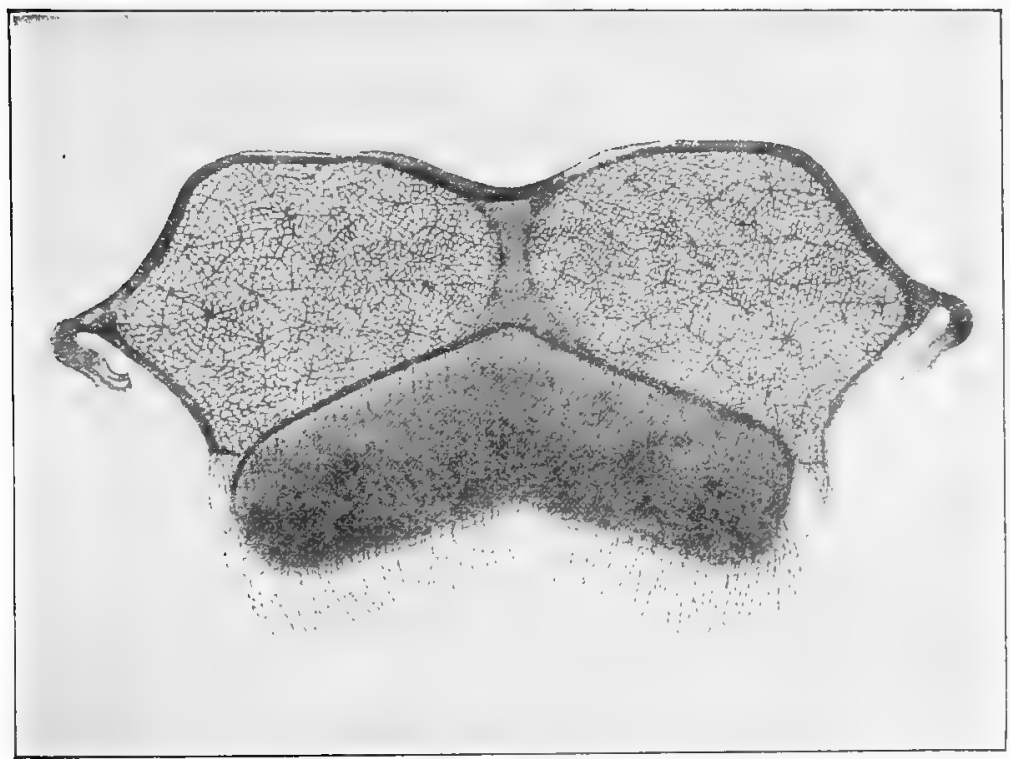

Fig. 44.

THE WAX-PRODUCING ORGAN OF THE WORIER.

(Magnified. After Barbò.)

cluster on the outside, until the heat has subsided, and the running honey has been gathered up. Scales of wax, in lumps, can then be found where they have clustered.

203. Although the faculty of producing wax is diminished in old bees, who are subject to the natural law which nakes it more difficult to fatten an old animal, it is proved that they may also produce small scales of wax. 
"During the active storing of the past season, especially when comb building was in rapid progress, I found that nearly every bee taken from the flowers contained wax scales of varying sizes in the wax-pockets."'-(A. J. Cook.)

201. The first condition indispensable for bees to produce wax, is to have the stomach well filled.

It is an interesting fact that honey-gathering and combbuilding go on simultaneously; so that when one stops, the other ceases also. As soon as the honey harvest begins to fail, so that consumption is in advance of production, the bees cease to build new comb, even though large portions of their hive are unfilled. When honey no longer abounds in the fields, it is wisely ordered that they should not consume, in comb-building, the treasures which may be needed for Winter use. What safer rule could have been given them?

It takes about twenty-four hours for a bee's food to become transformed into wax.

205. "Having filled themselves with honey, they gather in chains; not in a single group, but in a number of groups, hanging in a parallel curtain, in the direction of the comb to be constructed. Thus a bee clings to the ceiling with her claws, or the sticky rubber of her feet, her posterior limbs hanging ciown; another bee grapples the claws of these posterior feet, with the claws of her anterior limbs, letting her hind limbs hang also, to be grappled by a third, and so on, till the first chain meets another, and both united form an arch, top downward. This single chain becomes compound when several are in the same line, and grouped near one another." -(Sartori anci Rauschenfels, "L'Apicoltura in Ttalia," Milan, 18iS.)

206.1"If we examine the bees closely during the season of comb-building and honey-gathering, we shall find many of them with the wax scales protruling between the rings that form the body, and these scales are either pieked from their bodies, or from the bottom of the hive or honey boxes in which they are building. If a bee is obliged to carry one of these wax scales but a short distance, he takes it in his mandibles, and looks as business-like with it thus, as a carpenter with a board on his shoulder. If he has to carry it from the bottom of the honey-

(1) In this witty quotation, the worker should bave been In the feminine and not in the masculine, 



\section{Plate 12.}

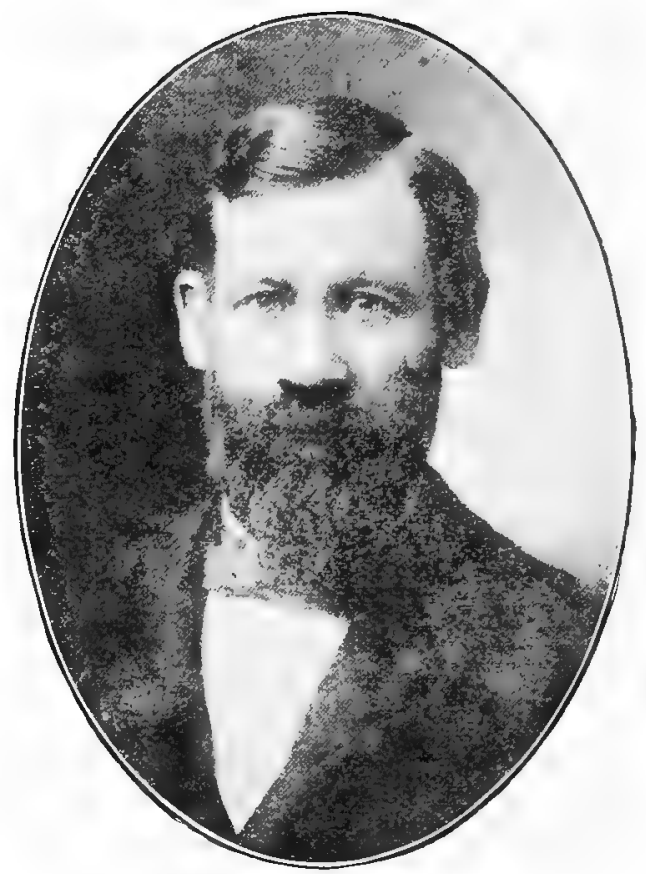

PROF. A. J. COOK,

Author of "The Bec-Kceper"s Guide"

This writer is mentioned pages $6,11,39,54,96,142,260,490,507$. 
box, he takes it in a way that I cannot explain any better than to say he slips it under his chin, in the mandibles or jaws. When thus equipped, you would never know he was encumbered with anything, unless it chanced to slip out, when he will very dexterously tuck it back with one of his forefeet. The little

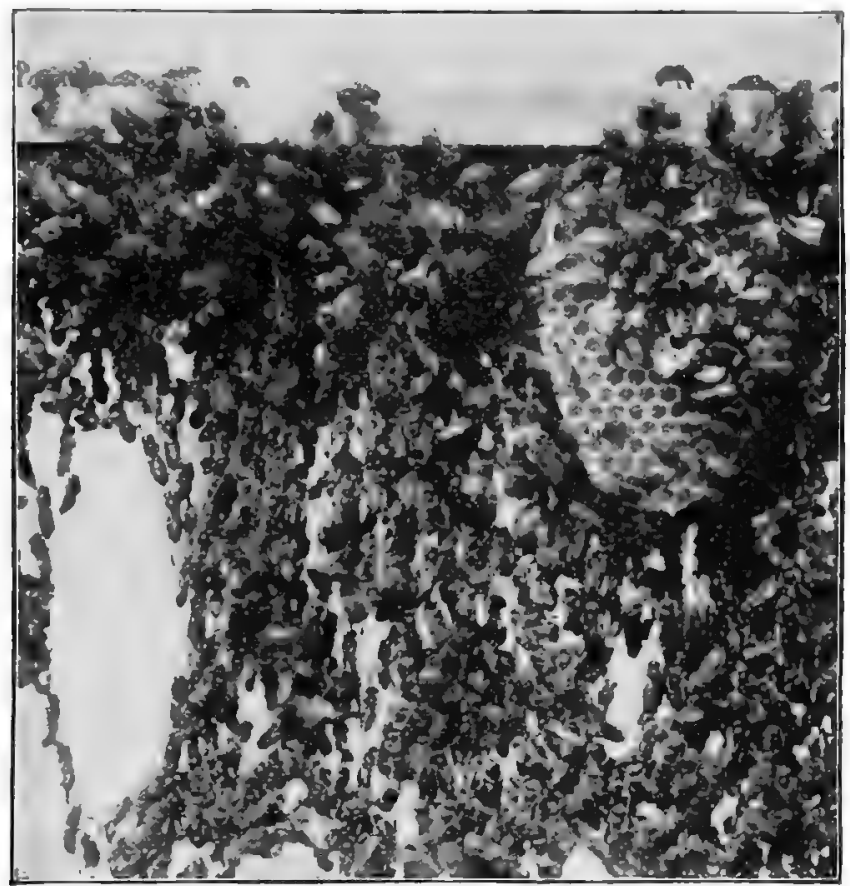

Fig. 45.

COMB BUILDIIRS.

(From Advanced Bee Culture. By W. Z. Hutchinson.)

plate of wax is so warm, from being lept under his chin, as to be quite soft when it gets back; and as he takes it out, and gives it a pinch against the comb where the building is going on, one would think he might stop a while and put it into place; but not he; for off he scampers and twists around so many different ways, you might think he was not one of the working 
kind at all. Another follows after him sooner or later, and gives the wax a pinch, or a little scraping or burnishing with his polished mandibles, then anotber, and so on, and the sum total of all these manoeuvres is that the comb seems almost to grow out of nothing; yet no bee ever makes a cell himself, and no comb building is ever done by any bee while standing in a cell; neither do the bees ever stand in rows and 'excavate,' or any thing of the kind.

"The finished comb is the result of the united efforts of the moving, restless mass, and the great mystery is, that anything so wonderful can ever result at all, from such a mixed-up, skipping-about way of working, as they seem to have.

"When the cells are built out only part way, they are filled with honey or eggs, and the length is increased when they feel disposerl, or 'get around to it,' perhaps; as a thick rim is left around the upper edge of the cell, they have the material at hand, to lengthen it at any time. This thick rim is also very necessary to give the bees a secure foothold, for the sides of the cells are so thin, they would be very apt to break down with even the light weight of a bee. When honey is coming in rapidly, and the bees are crowled for room to store it, their eagerness is so plainly apparent, as they push the work along, that they fairly seem to quiver with excitement; but, for all that, they skip about from one cell to another in the same way, no one bee working in the same spot to exceed a minute or two, at the very outside. Very frequently, after one has bent a piece of wax a certain way, the next tips it in the opposite dircetion, and so on until completion; but after all have given it a twist or a pull, it is found in pretty nearly the right spot. As near as I can discover, they moisten the thin ribbons of wax, with some sort of fluid or saliva (41). As the bee always preserves the thick rib* or rim of the comb he is working, the looker-on wonld suppose he was making the walls of a considerable thickness, but if we drive him away, and break this rim, we will find that his mandibles have come so nearly to-

* The constant preserving of this rib or heavy edge of the comb while the work progresses, explains why old comb lengthened and sealed with new wax, sometimes retains a part of its dark color throughout. Some of the old wax is undoubtedly mixed with the new, in the constant remodeling of this heavier edge, till the comb is sealed. 
gether, that the wax between them, beyond the rim, is almost as thin as a tissue paper."-("A B C of Bee Culture.").

207. It is very difficult to ascertain who first discovered these scales of wax. According to Mr. S. Wagner, J. A. Overbeck, in his Glossarium Melliturgium, p. 89, Bremen, 1765, claims that a Hanoverian pastor, named Herman C. Hornbostel, described them in the Hamburg Library, about 1745. Mr. L. Stachelhausen informed us that they were mentioned by Martin John in Ein Neu Bienenbuchel, 1691.

They were also discovered, in Germany, by a farmer. This discovery was communicated to the naturalist Bonnet by Willelmi, under the date of August 22, 1765. (Huber.)

In 1779, Thos. Wildman had noticed the scales of wax on the abdomen of the workers; and he was so thoroughly convinced that wax was secreted from honey, that he recommended feeding new swarms, when the weather is stormy, that they may sooner build comb for the eggs of the queen.

From the books written in the French language, it seems that it was Duchet, who, in his "Culture des Abeilles," printed in Freiburg in 1771, wrote first that beeswax is produced from honey, of which they eat a large quantity, "which is cooked in their bodies, as in a stove," inereasing thereby the warmth of the hive, and that beeswax "exudes out of this stove" through the rings of their body which are near the corselet. This idea of Duchet led Beaunier to examine bees, and he discovered that they produce, at one time, not two scales of wax only, but nine, the last ring having seemed to produce one. $\mathrm{He}$ adds:

208. "To employ this material, bees use their jaws, their tongues, and their antennæ. In favorable years you can see a great quantity of these pieces of wax which have fallen on the bottom of the hives." -("Traité sur l'Education des Abeilles," Vendôme, 1808.)

209. When bees are building combs, some scales of wax are often found on the bottom board, the bees having been unable to use them before they became too tough. Sometimes they pick them up afterwards and use them; some races of 
bees, the Italian (551), for instance, often use also pieces of old combs, which may be within their reach.

The comb, thus built, is easily detected on account of its darker color. Queen-cells (104) seem to be always built of particles, taken from the comb on which they hang, and are nerel of pure wax.

"Thus, filtered through yon flutterer's folded mail, ('lings the cooled wax, and hardens to a scale. Swift, at the well-known call, the ready train (For not a buz boon Nature breathes in vain) Spring to each falling flake, and bear along

Their glossy burdens to the builder throng. These with sharp sickle, or with sharper tooth, Pare each excreseence, and each angle smoothe, Till now, in finish'd pride, two radiant rows Of snow white cells one mutual base disclose. Six shining panels gird each polish'd round; The door's fine rim, with mixen fillet bound; While walls so thin, with sistur walls combined, Weak in themselves, a sure dependener fincl."

Evans.

210. The cells of bees are found to fulfill perfectly the most subtle conditions of an intricate mathematical problem.

Let it be required to find what shape a given quantity of matter must take, in order to have the greatest capacity and strongth, occupying, at the same time, the least space and consuming the least labor in its construction. When this problem is solved by the most refined mathematical processes, the answer is the hexagonal or six-sided cell of the honey-bee, with its three four-sided figures at the base!

The shape of these figures cannot be altered ever so little, except for the worse.

211. The bottom of each cell is formed of three lozenges, the latter forming one-third of the base of three opposite cells.

"If the little lozenge plates were square, we should have the same arrangement, but the bottom would be sharp pointed 
as it were, to use wax with the best economy, or to best accommodate the body of the infantile bee. Should we, on the contrary, make the lozenge a little longer, we should have the bottom of the cell too nearly flat to use wax with most economy, or for the comfort of the young bee."-("A B C of Bee Culture.")

212. "There are only three possible figures of the cells," says Dr. Reid, "which can make them all equal and similar, without any useless spaces between them. These are the equilateral triangle, the square, and the regular hexagon. It is well known to mathematicians, that there is not a fourth way possible in which a plane may be cut into little spaces that shall be equal, similar, and regular, without leaving any interstices."

An equilateral triangle would have been impossible for an insect with a round body to build. A circle seems to be the best shape for the development of the larvæ; but such a figure would have caused a needless sacrifice of space, materials, and strength. The body of the immature insect, as it undergoes its changes, is charged with a superabundance of moisture, which passes off through the reticulated cover of its cell; may not a hexagon, therefore, while approaching so nearly to the shape of a circle, as not to incommode the young bee, furnish, in its six corners, the necessary vacancies for a more thorough ventilation?

Is it credible that these little insects can unite so many requisites in the construction of their cells?

213. The fact is that the hexagonal shape of the cells is naturally produced, and without any calculation, by the bee. She wants to build each cell round; but as every cell touches the next ones, and as she does not wish to leave any space between, each one of the cells flattens at the contact, as would soap bubbles if all of the same diameter. It is the same for the lozenges of the bottom. The bee, wanting the bottom of the cell concave inside, makes it, naturally, convex outside. As this convexity projects on the opposite side of the median line, the bee who builds the opposite cells begins, naturally, on the tip of the convexity, the walls of cells just begun, since 
she wants also to make their bottom concave. The final result is that one-third of the bottom of each of three cells makes the bottom of the one cell opposite, and each one of the lozenges is flattened, so as not to encroach on the opposite cells.

211. The cells are not horizontal, but inclined from the orifice to the bottom (fig. 46), so as to be filled with honey

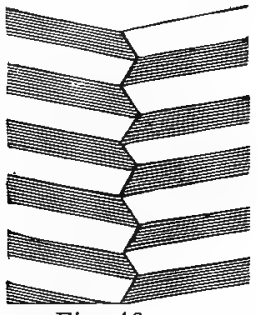

Fig. 46.

SHOWING THE SLOPE OF THE CILLS AND SHAPE OF THE BASE.

(From Sartori and Rauschenfels.) more easily. The thickness of worker-brood comb is about one inch, with cells opening on each side. The distance between combs is about 7-16 of an inch. This space is not always exact, but is never under 5-16, that being necessary for the bees to travel between the combs without interfering with one another. These distances ean be a little increased without troubling the bees, and we place the combs in our hives one and a half inches from center to center, for easier manipulation.

215. When the combs are newly built, they are white, but they get color shortly afterwards, especially during the harvest of yellow honey. When used for breeding, the cast skins and residues from the larvæ (16\%) give them a dark color, which becomes nearly black with age, especially if bees have suffered with diarrhœa (784), or raised a great many drones. (190.)

As wax is a bad conductor, the combs aid in keeping the bees warm, and there is less risk of the honey candying in the cells.

216. Is the size of the cells mathematically exact? When the first Republic of France inaugurated the decimal system of weights and measures, Réaumur proposed to take the cells of the bees as a standard to establish the basis of the system, but it was ascertained that cells are not uniform in size. 
218. The cells in which workers are reared are the smallest. Those in which the drones are reared are larger. It is generally admitted that five worker-cells measure about a linear inch, or twenty-five cells to the square inch, but this is incorrect. If five worker-cells measured exactly an inch, the number contained in a square inch would be about twentynine. As they are usually somewhat larger, the average number in a square inch is a trifle over twenty-seven. Drone-cells number about eighteen, in the same area.

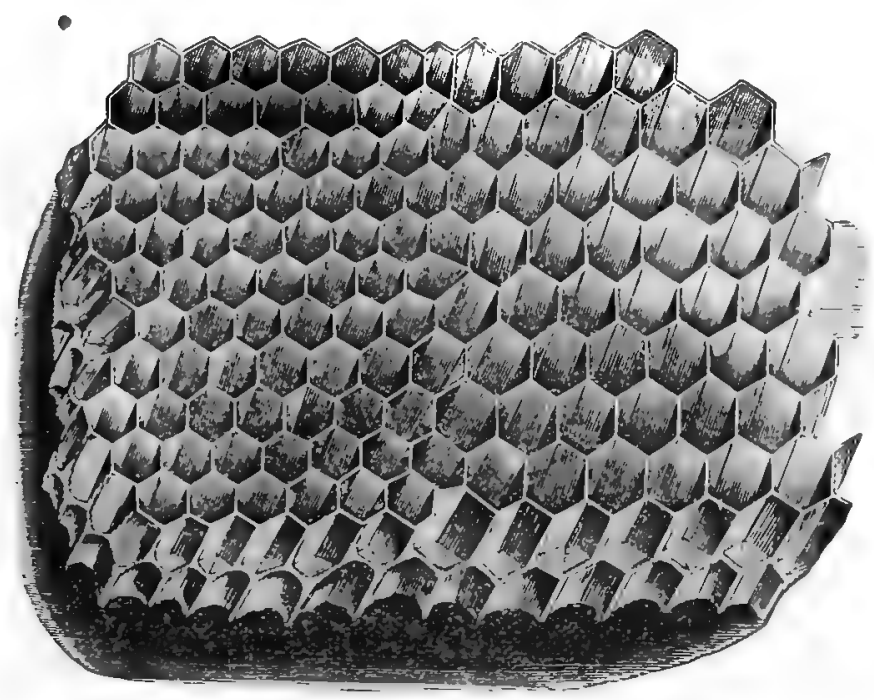

Fig, 47 .

WORKER COMB AND DRONE COMB WITH CELLS OF ACCOMMODATION.

L'Abbé Collin measured the average dimensions of the cells very carefully, and the measurements given in his work (Paris, 1865 ) are about the same as those given above.

218. The queen-cells have already been described. (104.)

As bees, in building their cells, cannot pass immediately from one size to another, they display an admirable sagacity in making the transition by a set of irregular intermediate 
cells. Fig. 47 exhilsits an accurate and beautiful representation of comb, drawn for this work from nature, by M. M. Tidd, and engraved by D. T. Smith, both of Boston, Mass. The cells are of the size of nature. The large ones are dronecells, and the small ones, worker-cells. The irregular, fivesided cells between them, show how bees pass from one size to another.

$\mathrm{Mr}$. Chesline, in his book, has criticized this engraving, on account of the acuteness of the cells of transition, or as he terms them, of accommodation. He writes: "The head of a bee could not reach the bottom of the acute angles as they are represented." Our first impression, on reading the criticism, was that Mr. Cheshire was right. Then the thought that Mr. Langstroth had his engravings made from nature led us to inspect some combs, when we found several cells of accommodation with angles at least as acute as in the cut. But we noticed also that this acuity exists only on the rims of the cells and not inside; the bees, inside the cells, having pushed out the walls, to be enabled to reach the bottom of the angles which were thus rounded inside. Mr. Langstroth wrote to us, in regard to this criticism of $\mathrm{Mr}$. Cheshire: "This piece of comb was actually copied from nature by a man of extraordinary accuracy."

219. The combs are built with such economy, that the entire construction of a hive of a capacity of nine gallons does not yield more than two pounds of beeswax when melted.

According to Dr. Donloff, the thickness of the sides of a cell in a new comb is only the one hundred and eightieth part of an inch! Cheshire states that he found some that measured only the four hundredth of an inch.

220. Mrist Apiarists before Huber's time supposed that wax was made from pollen, either in a crude or digested state. Confining a new swarm of bees to a hive in a dark and cool room, at the end of five days lie found several beautiful white combs in their tenement; these being taken from them, and the bees supplied with honey and water, new conbs were again constructed. Seven times in succession their combs were removed, and were in each instance replaced, the bees being all 
the time prevented from ranging the fields to supply themselves'with -pollen. By subsequent experiments, he proved that sugar-syrup answered the same end with honey. Giving an imprisoned swarm an abundance of fruit and pollen, he found that they subsisted on the fruit, but refused to touch the pollen; and that no combs were constructed, nor any waxscales formed in their pouches.

Notwithstanding Huber's extreme caution and unwearied patience in conducting these experiments, he did not discover the whole truth on this important subject. Though he demonstrated that bees can construct comb when fed honey or sugar, without pollen, and that they camnot make it if fed pollen without honey or sugar, he did not prove that when permanently deprived of it they can continue to work in wax, or if they can, that the pollen does not aid in its elaboration.

Some polien is always found in the stomach of wax-producing workers, and thcy never build comb so rapidiy as when they have free aceess to this article. It must, therefore, in some way, assist the bee in producing it.

221. The experiments made by Berlepsch show that bees, which are deprived of pollen when they construct combs, consume from sixteen to nineteen pounds of honey to produce a pound of comb, while, if provided with it, the amount of honey is reduced to ten or twelve pounds. If the experiment is continned without pollen for some time, the bees become exhausted and begin to perish. It is therefore demonstrated that although nitrogen, which is one of the elements of pollen, does not enter into the composition of beeswax, yet it is indispensable as food to sustain the strength of bees during their work in somb making.

222. Honey and sugar contain by weight about eight pounds of oxygen to one of carbon and hydrogen. When converted into wax, these proportions are remarkably changed, the wax containing only one pound of oxygen to more than sixteen of hydrogen and carbon. Now as oxygen is the grand supporter of animal heat, the large quantity consumed in secreting wax aids in generating that extraordinary heat which always aceompanies comb-building, and which enables the bees 
to mould the softened wax into such exquisitely delicate and beautiful forms. This interesting instance of adaptation, so clearly pointing to the Divine Wisdom, seems to have escaped the notice of previous writers.

223. Careful experiments prove that from seven to fifteen pounds of honey are usually required to make a single pound of wax. As wax is an animal oil, secreted chiefly from honey, this fact will not appear incredible to those who are aware how many pounds of corn or hay must be fed to eattle to have them gain a single pound of fat. From experiments made by Mr. P. Viallon here, and by Mrr. De Layens in France, it seems that in good circumstances bees use only about seven pounds of honey to produce a pound of wax. But the actual cost of comb to the bees is not to be reckoned only by the amount of honey digested by them to produce this wax. It must also be borne in mind that there is nearly always a loss of time, in comb-building, since the bees must digest the honey before the wax cells are formed. As stated before, comb building and honey gathering go on simultaneously, but when a swarm is hived, it takes quite a little time before any amount of comb is built, and in the meantime the harvest is on and the bees that have to build comb are unable to take full advantage of it.

Many bee-keepers are unaware of the value of empty comb. Suppose honey to be worth only ten cents per pound, and comb, when rendered into wax, to be worth thirty cents, the Apiarist who melts a pound of comb loses largely by the operation, even without estimating the time his bees have consumed in building it. It is, therefore, considered a first prineiple in bee-culture never to melt good worker-combs. A strong colony of bees, in the height of the honey-harrest, will fill them with very great rapidity.

With the box hives ( 275$)$, but little use can be made of empty comb, but by the use of movable frames, every good piece of worker-comb may be given to the bees (57).

221. As we have seen before, while the small cells are designated as worker-cells, the large ones, which vary greatly in depth and are more especially prepared to store honey, and 
in which the drones are raised, are known as store or dronecells.

225. Generally, bees build a larger number of worker than of store-cells; yet they do not follow any regulation as to the relative proportion in the quantity of each kind. Not two colonies, in the same Apiary, will show the same number of large cells, even when the hives are of equal capacity, and even if the building was done in circumstances seemingly identical. You will find a colony whose comb will consist of two-thirds worker and one-third store-cells, the adjacent colony will have but one-sixth of the latter, another a few square inches only. In a hive all the large cells are together, in ariother they are seattered. Some of these drone-combs are built from top to bottom of the hive, others are at the top only, others at the side, or at the bottom, or scattered, ete.

226. These facts, not explainable by themselves, when added to the wonderful habits of bees, have led to the theory that it was with foresight, with perfect knowledge and for a special purpose, that bees construct such a varied proportion of the two kinds of cells. Bees are represented as knowing the sex of the eggs which each kind of cells will receive; and foreseeing that their queen may not live long and that the young queens have to be fecundated (120), they build large cells in which drones could be raised.

227. We have demonstrated (213) that bees construct their cells without any geometrical calculation. We had previously (142) established that the queen does not know the sex of the eggs she is laying, and although regretting to decrease the charm with which bees were surrounded by the imagination of bee-keepers, we will try to demonstrate that, in the building of cells, they simply follow their inclination; as do all other beings, in the acts that they perform. But we have first to put forward a few facts, which are generally accepted, on which we will ground our reasoning.

228. 1st, A swarm (406), hived on empty frames, always begins its constructions by worker or small cells :

$2 d$, If the queen of a swarm is very prolific, very little of large, or store-comb, will generally be built by her bees: 
$3 d$, If, on the contrary, from old age, or from some other cause, the fecundity of a queen is deficient, her bees will fill the hive with a large quantity of store-combs:

$4 t h$, If the queen of a swarm is removed, or dies while the bees are building, all the combs, made during her absence, will consist of store-cells:

$5 t h$, If all or part of the store-combs of a hive are removed, the bees will rebuild large cells, at least three times out of four.

229. Besides these five propositions, we will remember that queens generally prefer to lay in small cells (145), and that they seem to know how to ask the workers to narrow the orifices of the store-cells, when there are no others in the hive to receive their impregnated eggs (146 to 148).

We have to remark also that, while the queen prefers the narrow cells, the workers prefer to build the wide ones, since they cease to construct worker-cells when the queen is gone, or when she is not on the spot, to remind them, by her presence, that she needs narrow cells for her impregnated eggs (116), and we will find out the cause of such differenees, in the number and in the position of each kind of combs, by following the work of the bees, in some of the circumstances in which they may have to build.

230. (a) The queen of a swarm is very prolific, the crop is abundant, and the building goes on very fast. The queen lays in all the cells, as soon as begun, disputing for tinem with the workers, who want to fill them with honey. As she follows the builders, waiting for cells, no large cells are made. After about three weeks, the bees of the first laid eggs begin to leave their cells (1/1); the queen goes back to fill these empty cells, and the workers, henceforth free from restraint, follow their preferences by building store-combs. Result: A few large cells, placed on the side or at the back of the hive.

231. (b) This other swarm has a queen as prolific as the one above. For two weeks she follows the builders as the first did, laying in the cells as soon as built. But, the erop stopping suddenly, both the building and the laying slacken, when only two-thirds of the constructions are made. After 
three weeks of scarcity, abundance comes again, and the building is resumed. But the queen is no longer among the workers, waiting for cells; she is at the other end of the hive, where she lays in the cells which were left empty when the larve that they harbored were born. Result: About one-third of store-combs.

232. (c) This third swarm has a queen whose prolificness is deficient, yet she has been able to follow the builders for a few days. She is at last left behind, and the workers begin combs with large cells. On reaching these cells, one or two days later, she passes over them without laying (149), and rejoins the builders, who hasten to comply with her desire to have worker-cells. But she is soon left behind for the second time, and the workers, unrestrained again, build large cells till she again rejoins them, to be again left behind, and so on. Result: Parts of store-combs mixed, here and there, with worker-combs.

233. (d) We have removed from a hive all its dronecombs; but as the queen is occupied in filling empty workercells in another part of the hive, the builders, following their preference, reconstruct large cells, thus annulling our work of removal.

234. (e) We have given one or two combs to a swarm as soon as it was hived, and we wonder why its bees have built so much drone-comb. The cause is obvious: the queen, finding empty cells to fill, remained a long time far from the builders, who, following their inclination, constructed dronecells.

235. We have to utilize the facts just enunciated. If we desire to prevent a swarm from building too many store-combs, we should watch the builders, and remove the large cells as soon as built; these combs, if worth saving, may be used in the surplus sections. We must remember that, to succeed, it is indispensable that no other cells but the ones to be rebuilt be left at the disposal of the queen. The same rule applies also to the removal of drone-combs at any time; and as the fulfilling of this condition is not always possible, it is better to replace the removed combs with worker comb or comb foundation (674). 
The above rules are not without exception, for unnoticed circumstances may have some influence on the building of combs; but we think that we have stated the main causes of variation.

\section{Propolis.}

236. This substance, which is used by the bees to coat the inside of the bee-live, and make it water and air tight, is obtained from the resinous buds and limbs of trees; the different varieties of poplar yield a rich supply. When first gathered, it is usually of a bright golden color, and so sticky that the bees never store it in cells, but apnly it at once to the purposes for which they procured it. If a bee is caught while bringing in a load, it will be found to adhere very firmly to her legs.

Huber planted in Spring some branches of the wild poplar, before the leaves were developed, and placed them in pots near his Apiary; the bees alighted on them, separated the folds of the large buds with their forceps, extracted the varnish in threads, and loaded with it first one thigh and then the other; for they convey it like pollen, from one leg to the other. We have seen them thus remove the warm propolis from old bottom-boards standing in the sun.

Propolis is frequently gathered from the alder, horsechestnut, birch, and willow; and as some think, from pines and other trees of the fir kind. Bees will often enter varnishing shops, attracted evidently by their smell; and in the vicinity of Matamoras, Mexico, where propolis seems to be scarce, we saw them using green paint from window-blinds, and pitch from the rigging of a vessel. Bevan mentions the fact of their carrying off a composition of wax and turpentine from the trees to which it had been applied. Dr. Evans says he has seen them collect the balsamic varnish which coats the young blossom-buds of the hollyhock, and has known them to rest at least ten minutes on the same bud, moulding the balsam with their fore-feet, and transferring it to the hinder legs, as described by Huber. 
"With merry hum the Willow's copse they scale, The Fir's Dark pyramid, or Poplar pale; Scoop from the Alder's leaf its oozy flood, Or strip the Chestnut's resin-coated bud;

Skim the light tear that tips Narcissus' ray, Or round the Hollyhock's hoar fragrance play; Then waft their nut-brown loads exulting home, That form a fret-work for the future' comb; Caulk every chink where rushing winds may roar, And seal their circling ramparts to the floor."

Evans.

23r. A mixture of wax and propolis being much more adhesive than wax alone, serves admirably to strengthen the attachments of the combs to the top and sides of the hive. If the combs are not filled with honey or brood soon after they are built, they are varnished with a delicate coating of propolis, which adds greatly to their strength; but as this natural varnish impairs their snowy whiteness, the bees ought not to be allowed access to the surplus honey-receptacles, except when about ready to store them with honey. (731.)

238. Bees make a very liberal use of propolis to fill any crevices about their premises; and as the natural summerheat of the hive keeps it soft, the bee-moth (802) selects it as a place of deposit for her eggs. Hives ought, therefore, to be made of lumber entirely free from cracks. The corners, which the bees usually fill with propolis, may have a melted mixture run into them, consisting of three parts of resin and one of beeswax; this remaining hard during the hottest weather, will bid defiance to the moth.

239. Bees gather propolis, especially when they can find neither honey nor pollen in the fields. Thus, during the honey-crop, very little of it is taken. In some countries, they use it much more plentifully, owing to its being found more readily.

240. Propolis is hard and brittle in the Winter, and its use by the bees, to glue up all parts of the hive, has created the greatest objection to drawers, close-fitting frames, hinged doors, ete., with which some patent hives are provided, and 
which become entirely immovable, when once coated with it. It is, at all times, the greatest hindrance to the neat handling of the combs, and in warm weather daubs the hands of the A piarist. It can only be cleaned from the fingers by the use, in place of soap, of a few drops of turpentine, alcohol, spirits of hartshorn, or ether.

To clean it from metal surfaces, use steam or boiling water strengthened with lye. Scraping is necessary to remove it from smooth wooden surfaces.

211. Propolis is sometimes put to a rery curious use by the bees.

"'A snail, having crept into one of M. Réaumur's hives early in the morning, after crawling about for some time, allhered, by means of its own slime, to one of the glass panes. The bees having discovered the snail, surrounded it, and formed a border of propolis round the verge of its shell, and fastened it so securely to the glass that it became immovable." -(Bevan.)

"Forever elosed the impenetrable door;

It naught avails that in its torpid veins

Year after year, life's loitering spark remains."

Evans.

"Maraldi, another eminent Apiarist, states that a snail without a shell having entered one of his hives, the bees, as soon as they observed it, stung it to death; after which, being unable to dislodge it, they covered it all over with an impervious coat of propolis." '-(Bevan.)

"For soon in fearless ire, their wonder lost, Spring fiercely from the comb the indignant host, Lay the pierced monster breathless on the ground, And clap in joy their vietor pinions round: While all in vain concurrent numbers striveTo heave the slime-girt giant from the hiveSure not alone by force instinctive swayed, But blest with reason's soul-directing aid, Alike in man or bee, they haste to pour, Thick, hard'ning as it falls, the flaky shower; Embalmed in shroud of glue the munmy lies, No worms invade, no foul miasmas rise."

Evans. 
242. In these instances, who can withhold his admiration of the ingenuity and judgment of the bees? In the first case, a troublesome ereature gained admission to the hive, which, from its unwieldiness, they could not remove, and which, from the impenetrability of its shell, they could not destroy; here, then, their only source was to deprive it of locomotion, and to obviate putrefaction; both which objects they accomplished most skillfully and securely, and, as is usual with these sagacious creatures, at the least possible expense of labor and materials. They applied their cement where alone it was required-round the verge of the shell. In the latter case, to obviate the evil of decay, by the total exclusion of air, they were obliged to be more lavish in the use of their embalming: material, and to case over the "slime-girt giant," so as to guard themselves from his noisome smell. What means more effectual could buman wisdom have devised, under similar circumstances?

243. In bygone days, it was a prevalent belief, that when any member of a family died, the bees knew what had happened; and some were superstitious enough to put the hives in mourning, to pacify their sorrowing occupants; imagining that, unless this was done, the bees would never afterwards prosper! It was frequently asserted that they sometimes took their loss so much to heart, as to alight upon the coffin whenever it was exposed. A clergyman told the writer that he attended a funeral, where, as soon as the coffin was brought from the house, the bees gathered upon it so as to excite much alarm. Some years after this oceurrence, being engaged in varnishing a table, the bees alighted upon it in such numbers, as to convince him, that love of varnish, rather than sorrow or respect for the dead, was the occasion of their conduct at the funeral. How many superstitions, believed even by intelligent persons, might be as easily explained, if it were possible to ascertain as fully all the facts connected with them!

Whittier has written a little poem, "Telling the Bees," a propos of their knowing of some one's death. 
The following is the first stanza of another poem by one of our later writers:

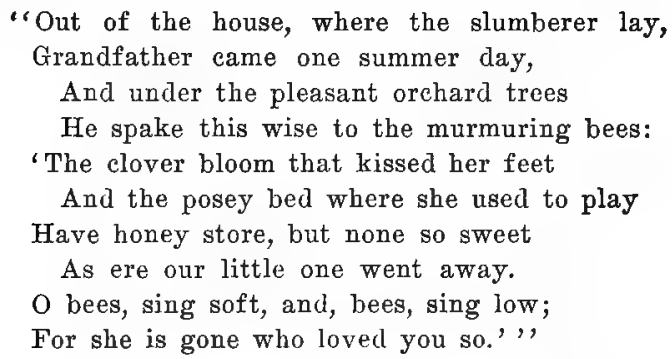

(Eugene Field.)

244. Commerciar Uses of Propolis. - "Dissolved in alcohol and filtered, it is used as a varnish, and gives a polish to wood, and a golden color to tin. A preparation made with finelyground propolis, gum arabic, incense, storax, benzoin, sugar, nitre, and charcoal, in quantities varied at will, is moulded into fumigating cones, for perfuming rooms or halls." - (Dubini, Milan, 1881.)

215. The following letter from a noted Russian Apiarist, to $\mathrm{Mr}$. E. Bertrand, then editor of the Revue Internationale d'A piculture, will be found of interest:

"During my pleasant stay at your pretty villa, I spoke to you of the utilization of propolis in the varnish of our wooden ware, which resists the dissolving power of hot water so well. I have just found a description of the process, and will communicate it to you.

"Propolis is purchased by hucksters, who pay five copecks-a little over two cents-and sometimes even less, for permission to scrape or plane the propolis from the walls of a hive that has lost its bees. The shavings, covered with propolis, are heated, put into a wax-press, and subjected to the treatment nsed in the extraction of beeswax; the propolis is then purified in hot water, to which sulphuric acid is added. About fifty ver cent. of propolis is thus obtained, which sells at forty eents per pound. 
"This propolis is poured into hot linseed-oil and beeswax, in the following proportions: Propolis 1 , beeswax 1/2, oil 2. Previously, the oil should 'linger,' as we say, on the stove, for fifteen or twenty days, that is, remain hot without boiling, to give it the property of drying. The wooden ware is dipped into the above mentioned preparation, and must remain in it ten or fifteen minutes, after which it is cooled, and rubbed and polished with woolen rags." -(A. Zoubareff, St. Petersburg, Sept. 26, 1882.) 


\section{CHAPTER III.}

\section{FOOD OF BEES. - HONEY.}

246. The main food of bees is the honey or neetar, produced by plants and flowers. That honey is a vegetable product was known to the ancient Jews, one of whose Rabbins asks: "Since we may not eat bees, which are unclean, why are we allowed to eat honey" and replies: "Because bees do not make honey, but only gather it from plants and flowers."

247. Yet during its sojourn in the honey-sack, the neetar undergoes a chemical change. Most of its cane-sugar, or saccharose, is changed into grape-sugar, or glucose.* This change is due to its mixture with the saliva of the glands, while in the honey-sack (63). "But the cane-sugar yet remains in large proportion in honey gathered on the mountains" (Girard), - or when it is gathered very fast.

218. The ncetar is produced by the plants in nectariferous tissues. in which accumulations of sugar can be found, and exudes most frequently through small apertures, named stomata.

249. It contains more or less water, according to the kind of flowers, and the conditions in which it is produced. Some flowers give nectar which is almost completely deprived of water. Such is the fuschia. When the nectar of this flower is produced in very dry weather, it sometimes crystallizes in the blossom, as it comes in contact with the air.

In some other flowers, as in the Fritillaria imperialis, the nectar contains as much as ninety-five per cent of water. But in many cases, in dry weather and especially in late honey crops, the nectar contains but little water. Although the honey of the summer crop may be said to contain from sixty

* What is chemically known as glucose should not be confounded with the impure glucose of commerce. 
to eighty per cent of water, there are many late plants that give honey which needs little evaporation. The honey from heather is said to be difficult to extract from the combs $(\mathbf{8 4 6})$, owing to its density.

250. The quantity of nectar produced by the flowers decreases during drought, and increases on the first or second day after a rain. But it is then more watery. In some seasons the saccharine juices abound, while in others they are so deficient that bees can obtain scarcely any food from fields all

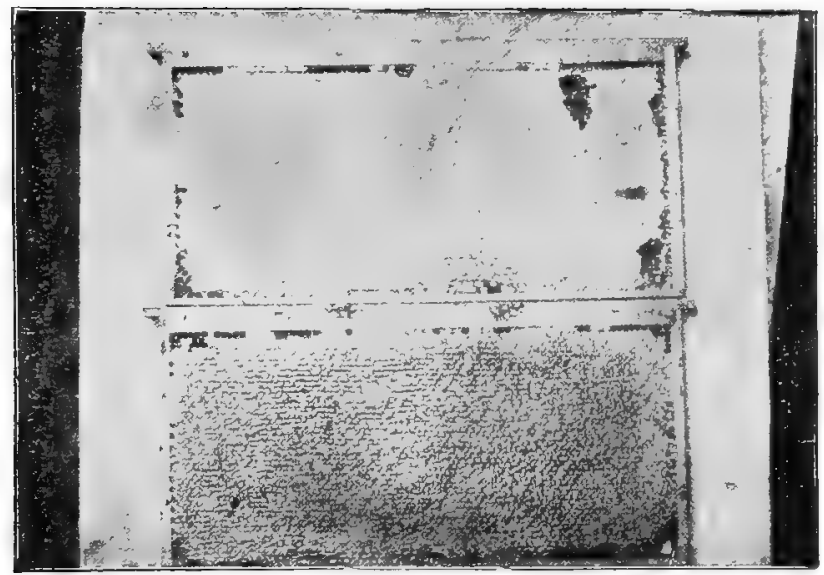

Fig. 48.

COMES CONTAINING SEALED HONEY.

(Forty Years Among the Bees.)

white with elover. A change in the secretion of honey will often take place so suddenly, that the bees will, in a few hours, pass from idleness to great activity.

As a rule, the quantity of nectar, exuded by the plants, raries according to the time of day and atmospheric conditions. Usually, it is most abundant in the morning. Its quantity decreases as the sun rises higher. At three o'clock in the afternoon, the flowers give the least nectar. Then the yield again increases till dark. In Algeria, Africa, in the 
neighborhood of Blidah, bees cannot find honey later than eight in the morning.

251. It is when the blossom is ready for fertilization, that the nectar is most abundant in it; if it is not gathered by insects, it is re-absorbed by the plant and serves, together with the sugar accumulated in the ovaries, to nourish the seeds.

252. The accumulations of sugar in the tissues, may exist, not only in the flower, but in different parts of plants, in the cotyledons, in the leaves, in the stipules, in the bracts, and between the leaves and twigs. They help the development of the tissues.

Sometimes the nectariferous tissues are destitute of stomata or openings. Then the accumulated nectar may force itself through the cuticle or skin of the plant.

The water of the sap, which runs incessantly in the plants, goes out through the different tissues in unequal quantities; as some tissues are more porous than others. Generally, water escapes in the form of steam; but, in some circumstances, when the air is moist, the water is emitted in liquid form, and may carry with it, to the outside, a part of the accumulations of sugar through which it has passed, thus producing honeydew. The more sugar this water contains, the slower its evaporation will be.

253. The dampness of the soil and of the air, and a temperature producing a profuse transpiration in plants, then a sudden stop of transpiration, are the best conditions to produce the maximum of nectar in the nectariferous tissues and of liquid exudations on the outside.

251. Most of the above statements are taken, or rather abridged, from "Les Nectaires," of Gaston Bonnier, a professor at the Ecole Normale Supérieure of Paris (1879). This work was awarded a medal by the Academy of Science of Paris. Bonnier backs his statements with one hundred and thirty engravings made from microscopic researches.

255. He explains, not only how the nectar is formed in the blossoms, but also how the extra floral nectar, the so-called honey-dew, is produced on different parts of plants, or trees. 
ite has noticed and deseribed the production of nectar (honey-dew without aphides), on many herbaceous plants, and on the following trees or shrubs: Two kinds of oak, the ash, two kinds of linden, the sorb, the barberry, two kinds of raspberry, the poplar, the birch, two kinds of maple, and the hazel brush. In some parts of Europe, this honey-dew is so plentiful, that some Apiarists transport their bees to the districts in which it is produced, during its yield.

The Abbé Boissier de Sauvages, in 1763, described two species of honey-dew. The first kind, he says, has the same origin with the manna on the ash and maple trees of Calabria and Brianson, where it flows plentifully from their leaves and trunks, and thickens in the form in which it is usually seen.("Observations sur l'Origine du Miel.") We have received specimens of a honey-dew from California, which is said to fall from the oak trees in stalactites of considerable size.

256. Bees also harvest, in some seasons, a sweet substance of poorer quality, which is a discharge from the bodies of small aphides or "plant lice."

Messrs. Kirby and Spence, in their interesting work on Entomology, have given a description of the honey-dew furnished by the aphides:

"The loves of the ants and the aphides have long been celebrated; you will always find the former very busy on those troes and plants on which the latter abound; and, if you examine somewhat more closely, you will discover that the object of the ants in thus attending upon aphides, is to obtain the saccharine fluid secreted by them, which may well be denominated their milk. This fluid, which is scarcely inferior to honey in its sweetness, issues in liquid drops from the abdomen of these insects, not only by the ordinary passage, but also, by two setiform tubes, placed one on each side, just above it. Their sucker being inserted in the tender bark is, without intermission, employed in absorbing the sap, which, after it has passed through these organs, they keep continually discharging. When no ants attend them, by a certain jerk of the body, which takes place at regular intervals, they ejaculate it to a distance. 
257. "Mr. Knight once observed a shower of honey-dew descending in innumerable small globules, near one of his oak trees. He cut off one of the branches, took it into the house, and, holding it in a stream of light admitted through a small opening, distinctly saw the aphides ejecting the fluid from their bodies with considerable force, and this accounts for its being frequently found in situations where it could not have arrived by the mere influence of gravitation. The drops that are thus spurted out, unless interrupted by the surrounding foliage, or some other interposing body, fall upon the ground; and the spots may often be observed, for some time, beneath and around the trees, affected with honey-dew, till washed away by the rain. The power which these insects possess of ejecting the fluid from their bodies, "seems to have been wisely instituted to preserve cleanliness in each individual $\mathrm{fly}$, and, indeed, for the preservation of the family; for, pressing as they do upon one another, they would otherwise soon be glued together, and rendered incapable of stirring. On looking steadfastly at a group of these insects (Aphides salicis) while feeding on the bark of the willow, their superior size enabled us to perceive some of them elevating their bodies and emitting a transparent substance in the form of a small shower:

" Nor scorn ye now, fond elves, the foliage sear, When the light aphids, arm'd with puny spear, Probe each emulgent vein, till bright below, Like falling stars, clear drops of nectar glow."

Evans.

258. "Honey-dew usually appears upon the leaves as a viscid transparent substance, as sweet as honey itself, sometimes in the form of globules, at others resembling a syrup. It is generally most abundant from the middle of June to the middle of July-sometimes as late as September.

' It is found chiefly upon the oak, the elm, the maple, the plane, the sycamore, the lime, the hazel, and the blackberry; occasionally also the cherry, currant, and other fruit trees. Sometimes only one species of trees is affected at a time. The oak generally affords the largest quantity. At the season of its greatest abundance, the happy, humming noise of the bees may be heard at a considerahle ilistance, sometimes nearly equalling in loudness the unitch bum of swarming." -(Bevan.) 
Plate 13.

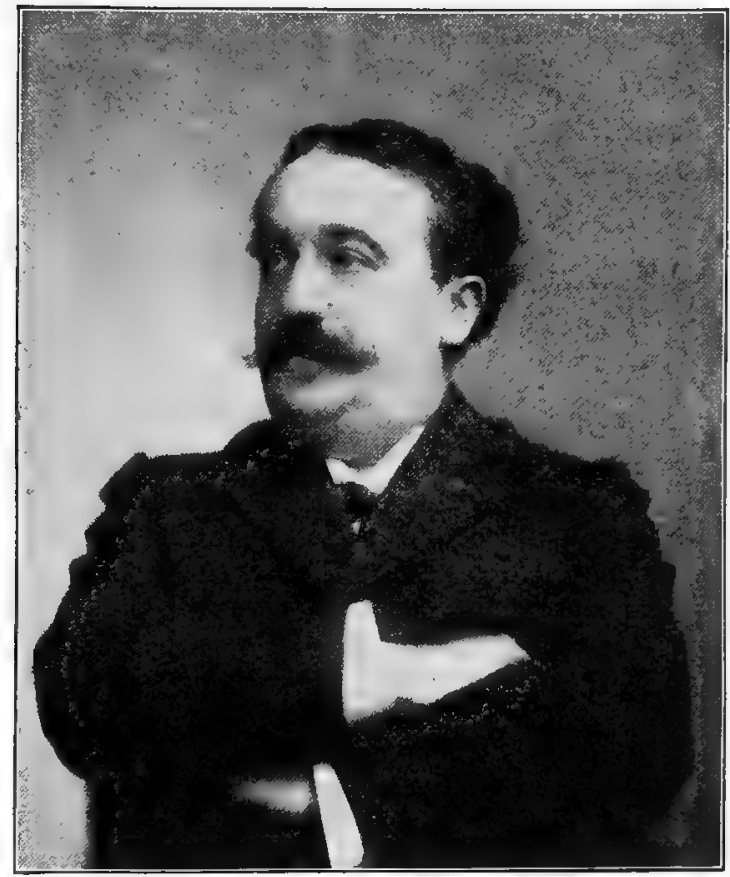

PROF. GASTON BONNIER,

Author of "Cours Complet d"A puulture" and of "Les Nectaires." This writer is mentioned pqges 6, 118, 121, 122. 

In some seasons, bees gather large supplies from these honey-dews, but it is abundant only once in three or four years. The honey obtained from this source is usually of a dark color, and never of a good quality.

259. It is very difficult to ascertain, at all times, the special source of honey-dew, whether from the trees or from the aphides. In order to give all sides a hearing, we will cite a letter from Mr. Bonnier on this subject, and leave the reader to draw his own conclusions:

"Plant lice are seen even on trees that have no extra floral nectaries. They do not produce exudations (properly speaking), but bore the tissues to eat the contents. Their presence on the plant has no connection with that of the nectar. The excremental liquid of aphides is not equally sweet in all the species, and the bees harvest only that which is very sweet. They generally prefer the true honey-dew (miellée), which exudes from the leaves at, certain times, and contains mannite and saceharine matter.

"I have seen bees, however, harvesting the sweet liquid of the aphides and the true miellée at the same time, on the aspen, maple, and syeamore.

"I have rarely seen the extra floral nectar of the special nectaries overflow and run in drops, but the true miellee of trees may fall in small drops, and some observers conclude, from this fact, that it is produced by aphides. I have often seen some trees, and even all the trees, of a timber, covered with an abundant miellee, falling in small drops, although there was not a single louse on the higher limbs.

"To sum up, we must not confound the three kinds of sweet liquid, which may be produced outside the flowers: 1st, The extra-floral nectar proper, produced, like the nectar of flowers, from special sugar tissues; $2 \mathrm{~d}$, The true miellée, produced on the surface of the leaves of trees or shrubs, without the action of aphides; 3rd, the excretion, more or less sweet, sometimes containing very little sugar, abundantly produced by a great number of aphides."

260. In some blossoms, as in the red clover, the corolla is so deep and narrow, that the nectar is out of reach of the 
honey-bee. Larger insects, such as the bumble-bee, or smaller ones, as some wasps, enjoy it to the exclusion of our favorites. Yet in some seasons, we have seen bees working on red-clover bloom, and have attributed this to the corollas being shorter, owing to drouth, or scant growth. Mr. Bonnier has discovered that, in some such flowers, the nectar is sometimes so abundant that the bees can reach it. It is true that insects, and even bees, can tear the tender corollas of some blossoms, opposite the honey receptacle, to reach the nectar, but this is of such rare instance, in the honey-bee, that it cannot be considered of any practical ralue.

261. The honey, when harvested, is stored in the rear of the hive, above the brood, and as near it as possible.

When just gathered, it is too watery to be preserved for the use of the bees. To evaporate this water, they force a strong current of air through the hive, and the bee-keeper can ascertain the days of large honey-yield, by the greater roar of the bees in front of their hive during the night following. If a strong colony is put on a platform scale, it will be found, during the height of the honey-harvest, to gain a number of pounds on a pleasant day. Much of this weight will be lost in the night, from the evaporation of the newlygathered honey. A thorough upward ventilation, in hot weather, will therefore contribute to increase the ripening of honey (763).

When the cell is about full, the bees seal it with a flat cover or capping made of wax. This capping is begun at the lower edge of the cell, and is raised gradually, as the honey is deposited within, till the cell is entirely sealed. These cappings being flat, depressed, or uneven, are easily distinguished from the caps of the brood, which are convex and of a darker color.

262. Are the caps of the honey-cells air-tight?

The caps of the brood-cells, made of pollen and wax, are undoubtedly porous enough to allow the air to reach the larva; and some Apiarists question the imperviousness of the sealing of honey-comb. Mr. Cheshire himself, while of opinion that "the bee aims at compact coverings for her honey," says that "not more than ten per cent of these are absolutely im- 
pervious to air." Yet his own description of the cause of the well-known whiteness of the cappings, owing to the air which is left behind and "cannot escape," would prove that these cappings are originally. made as air-tight as a thin coat of wax can make them. But it is possible that the thin coat of wax, though evidently air-tight, be, in some circumstances, porous enough to allow moisture to soak through it slowly, like water through leather.

\section{Pollen.}

263. The pollen, or fertilizing dust of flowers, is gathered by the bees from blossoms, and is indispensable to the nourishment of their young-repeated experiments having proved that brood cannot be raised without it. It is very rich in the nitrogenous substances which are not contained in honey, and without which ample nourishment could not be furnished for the development of the growing bee. Dr. Hunter, on dissecting some immature bees, found that their stomachs contained pollen, but not a particle of honey.

We are indebted to Huber for the discovery that pollen is the principal food of the young bees. As large supplies were often found in hives whose inmates had starved, it was evident that, without honey, it could not support the mature bees; and this led former observers to conclude that it served for the building of comb: Huber, after demonstrating that wax can be secreted from an entirely different substance, soon ascertained that pollen was used for the nourishment of the embryo bees. Confining some bees to their hive without any pollen, he supplied them with honey, eggs, and larvæ. In a short time, the young all perished. A fresh supply of brood being given to them, with an ample allowance of pollen, the development of the larvæ proceeded in the natural way.

264. We had an excellent opportunity of testing the value of this substance, in the backward. Spring of 1852 . On the 5th of February, we opened a hive containing an artificial swarm of the previous year, and found many of the cells filled with brood. The combs, being examined on the $23 \mathrm{~d}$, contained 
neither eggs, brood nor bee-bread; and the colony was supplied with pollen from another hive; the next day, a large number of eggs were found in the cells. When this supply was exhausted, laying again ceased, and was only resumed when more was furnished. During the time of these experiments, the weather was so unpromising, that the bees were unable to leave the hive.

Dzierzon is of opinion that bees can furnish food for their young, without pollen; although he admits that they can do it only for a short time, and at a great expense of vital energy; just as the strength of an animal nursing its young is rapidly reduced, if, for want of proper food, the very substance of the mother's body must be converted into milk. The experiment just described does not corroborate this theory, but confirms Huber's view, that pollen is indispensable to the development of brood.

Gundelach, an able German Apiarist, says that if a colony with a fertile queen be confined to an empty hive, and supplied with honey, comb will be rapidly built, and the cells filled with eggs, which in due time will be hatehed; but the worms will all die within twenty-four hours.

Sometimes bees, unable to feed their brood for lack of pollen, desert their hives $(\mathbf{1 0 7}, \mathbf{6 6 3})$.

265. In Seltember, 1856, we put a very large colony of bees into a new hive, to determine some points on which we were then experimenting. The weather was fine, and they gathered pollen, and built comb very rapidly; still for ten days, the queen-bee deposited no eggs in the cells. During all that time, these bees stored very little pollen in the combs. One of the days being so stormy that they could not go abroad, they were supplied with rye flour ( $\mathbf{2 6}$ ), none of which, although very greedily appropriated, could be found in the cells. During all this time, as there was no brood to be fed, the pollen must have been used by the bees either for nourishment, or to assist them in secreting wax; or, as we believe, for both these purposes.

266. Bees prefer to gather fresh pollen, even when there are large accumulations of old stores in the cells. With hives 
giving the control of the combs, the surplus of old colonies may be made to supply the deficiency of young ones; the latter, in Spring, being often destitute of this important article. Although the bees of queenless colonies do not usually go in quest of pollen, some occasionally harvest it, and as it is not used, it accumulates in the hive. Sometimes it deteriorates during the Winter and becomes worthless, from mould.

If honey and pollen can both be obtained from the same blossom, the industrious insect usually gathers a load of each. To prove this, let a few pollen-gatherers be dissected when honey is plenty; and their honey-sacks will ordinarily be full.

When the bee brings home a load of pollen, she stores it away, by inserting her body in a cell, and brushing it from her legs; it is then carefully packed down, being often covered with honey, and sealed over with wax. Pollen is seldom deposited in any except worker-cells.

Aristotle observed, that a bee, in gathering pollen, confines herself to the kind of blossom on which she begins, even if it is not so abundant as some others; thus a ball of this substance taken from her thigh, is found to be of a uniform color throughout; the load of one insect being yellow, of another, red, and of a third, brown; the color varying with that of the plant from which the supply was obtained. They may prefer to gather a load from a single species of plant, because the pollen of different kinds does not pack so well together. Réaumur has estimated, that a good colony may gather and use as much as one liundred pounds of it in a year.

26r. When bees cannot find pollen, in early Spring, they will gather flour, or meal, or even fine sawdust, as a substitute. This was noticed by Hartlib, as early as 1655 .

Dzierzon, early in the Spring, observed his bees bringing rye-meal to their hives from a neighboring mill, before they could procure any pollen from natural supplies. The hint was not lost; and it is now a common practice, wherever beekeeping is extensively earried on, to supply the bees early 
in the season with this article. Shallow troughs or boxes are set not far from the apiaries, filled about two inches deep with finely-ground, dry, unbolted rye-meal, oatmeal or even with flour. Where bolted flour, or meal, is given, it should be tightly pressed with the hands, to prevent the bees from drowning in it. To attract them to it, we bait them with a few old combs, or a little honey.

The boxes must be placed in a warm spot sheltered from the wind. Thousands of bees, when the weather is favorable, resort eagerly to them, and return heavily laden to their hives.

This artificial pollen or bee-bread, is kneaded by them with saliva, or honey brought from the hive. This is easily ascertained by tasting the little pellets, which in the hurry are loosened from their baskets, and fall to the bottom of the flour box. In fine, mild weather, they labor at this work with great industry; preferring the meal to the old pollen stored in their combs. They thus breed early, and rapidly recruit their numbers. The feeding is continued till, the blossoms furnishing a preferable article, they cease to carry off the meal.

We will here add that, as a rule, colonies that do not carry in meal or pollen, at the opening of Spring, are without brood, either because they are queenless, or from want of honey, or from some other cause.

The discovery of flour, as a substitute for pollen, removes a very serious obstacle to the culture of bees. In many districts, there is for a short time such an abundant supply of honey, that almost any number of strong colonies will, in a good season, lay up enough for themselves, and a large surplus for their owners. In many of these districts, however, the supply of pollen is often quite insufficient, and in Spring, the swarms of the previous year are so destitute, that unless the season is early, the production of brood is seriously checked, and the colony cannot avail itself properly of the the superabundant harvest of honey.

268. As bees carry on their bodies the pollen, or fertilizing substance, they aid most powerfully in the impregna- 
tion of plants (8\%8), while prying into the blossoms in search of honey or bee-bread. In genial seasons, fruit will often set abundantly, even if no bees are kept in its vicinity; but many Springs are so unpropitious, that often during the critical period of blossoming, the sun shines for only a few hours, so that those only can reasonably expect a remunerating crop whose trees are all murmuring with the pleasant hum of bees.

269. One of the laws of Nature is that the crossing of the races produces offspring with greater vigor, endurance,
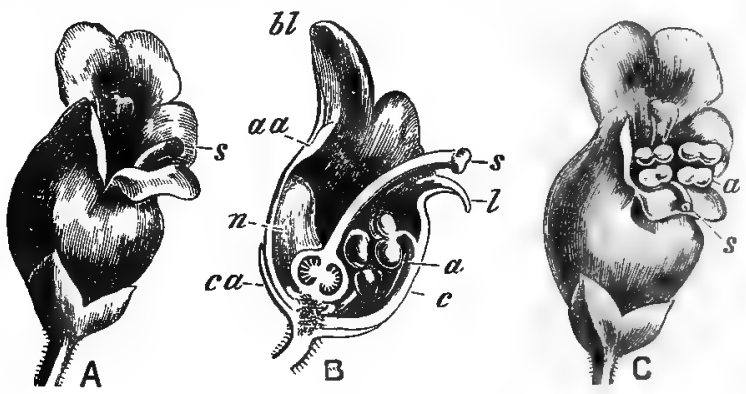

rig. 49.

SCROPHULARIA NODOSA.

(Magnified. From Cheshire.)

\section{A, young blossom. \&, stignia.}

B, section of blossom. $c a$, calyx; $c$, corolla; $a a$, aborted anthers; $s$, stigma; $l$, lip; $a$, anthers; $n$, nectar; $b l$, black lip.

C, older blossom. $s$, dropping stigma; $u$, anthers.

and faculty of reproduction. Fruits succeed better, when the pollen, which fertilizes the pistil, comes from some other blossom; and the insects are intrusted with the mission of transporting this pollen from one blossom to another, while gathering it for their own use. In some plants, fertilization would have been impossible, without the help of insects. For instance, some plants, such as the willows, are diecious, having their male organs on one tree, and their female organs on another. The bees after visiting the one for pollen, go to the other for honey, and the fecundation is effected. In some 
other plants, such as the Scrophularia Nodosa (Simpson honey plant-Fig. 49), the female organs are ready for fecundation earlier than the male. But as the flower secretes a large quantity of honey, which is replaced in its nectaries as fast as the bees gather it, the bees, in traveling from one blossom to another, carry the pollen of an old blossom to the pistil of a younger one, and fertilization is accomplished. Some plants, corn, for instance, produce such quantities of pollen, that the agency of insects is less indispensable to the fertilization of their blossoms.

2\%0. To determine the advantages which flowers derive from insect fertilization, any one can wrap a few flowers in gauze, just before the opening of the bud, and compare the number of fertile seeds, from flowers thus treated, with those of other blossoms.

We have heard farmers mention the fact that the first crop of red clover furnishes but little seed, compared with the second crop. This is because the bumble-bees, which help its fertilization, are very scarce in Spring, while they are much more plentiful in Summer. "In Australia it was found impossible to obtain seed from red clover until the bumble-bees were imported into that country" (Darwin).

A large fruit-grower told us that his cherries were a very uncertain erop, a cold northeast storm frequently prevailing when they were in blossom. He had noticed that, if the sun shone only for a couple of hours, the bees secured him a crop.

If those horticulturists, who regard the bee as an enemy (871), could exterminate the race, they would act with as little wisdom as those who attempt to banish from their inhospitable premises every insectivorous bird, which helps itself to a small part of the abundance it has aided in producing. By making judicious efforts early in the Spring, to entrap the mother-wasps and hornets, which alone survive the Winter, an effectual blow may be struck at some of the worst pests of the orchard and garden. In Europe, those engaged extensively in the cultivation of fruit, often pay a small sum in the Spring for all wasps and hornets destroyed in their vicinity. 


\section{WATER.}

2r1. Water is necessary to bees to dissolve the honey, which sometimes granulates in the cells, to digest the pollen and to prepare the food with which they feed the larvæ. They can raise a certain amount of brood without water, but they always seem to suffer more or less in consequence $(\mathbf{6 6 2})$. In the Winter, they breed but little, and the moisture which condenses on the walls of the hive is generally sufficient. Yet we have noticed that as soon as bees are brought out of the cellar $(\mathbf{6 5 3})$, if the temperature is sufficiently warm, a great many will be seen sucking water. This fact shows that Berlepsch was right when he advised bee-keepers to give water to bees during Winter, to avoid what he called disease of the thirst. Besides, every one may notice that bees take advantage of any warm Winter day to bring it to their hives; and, in early Spring, may be seen busily drinking around pumps, drains, and other moist places. Later in the season, they sip the dew from the grass and leaves.

272. Every careful bee-keeper will see that his bees are well supplied with water. If he has not some sunny spot, close at hand, where they can safely obtain it, he will furnish them with shallow wooden troughs, or vessels filled with floats or straw, from which - sheltered from cold winds, and warmed by the genial rays of the sun-they can drink without risk of drowning.

A barrel half filled with earth and then filled with water, in which some water-

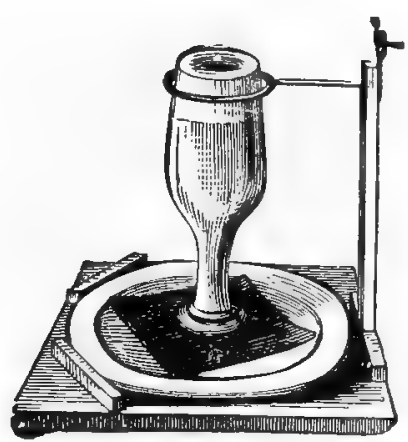

Fig. 50 .

WATER SUPPLY BOTTLE.

(From Sartori and Rauschenfels.) eress or other aquatic plants are kept, to preserve it from putrefaction, and to prevent the bees from drowning, will do very well. For a small apiary, a jug or bottle (fig. 50), 
filled with water, and inverted on a plate covered with a small piece of carpet, will be sufficient. It can also be given in the combs. Mr. Vogel, editor of the Bienenzeitung, on the 19th of March gave to a colony a comb containing crystallized honey, and another containing about three-fourths of a pound of water. Within sixteen hours, both combs were altogether emptied by the bees.

273. A learned French bee-keeper, Mr. De Layens, made many experiments in regard to this matter.

"In the month of May, 1878, I put a lump of sugar near a spot where a great many bees eame for water; they paid no attention to it. The sugar was then moistened and covered with honey. The bees, attracted by the honey, came in great numbers, and sucked up most of the moist sugar. After they became accustomed to this, I decreased the moistening, till I gave them nothing but dry sugar, when they brought water to dissolve the sugar, and removed all except the parts which were too hard to be dissolved easily. '-(Bulletin de la Suisse, Nov., 1880.)

The same writer has noticed that, in Spring, if the bees are compelled to go very far for water, many of them perish. He found a loss of three hundred and fifty grammes of beesfour-fifths of a pound-from a hive, during a sudden spring storm $(606)$.

From the 10th of April to the 31st of July, forty colonies consumed 187 litres of water, about fifty gallons; the greatest quantity used in a day being seven litres, or about fifteen pints.

That ibees do not need water, in circumstances other than. those named above, is evidenced from the fact that, in importing bees from Italy, we did not succeed in receiving them alive, until our shippers reluctantly consented to send them without water $(\mathbf{5 9 5})$.

Salt.

274. Bees seem to be so fond of salt, that they will often alight upon our hands to lick up the saline perspiration. 
"During the early part of the breeding season," said Dr. Bevan, "till the beginning of May, I keep a constant supply of salt and water near my apiary, and find it thronged with bees from early morn till late in the evening. About this period the quantity they consume is considerable, but afterwards they seem indifferent to it. The eagerness they evince for it at one period of the season, and their indifference at another, may account for the opposite opinions entertained respecting it." 


\section{CHAPTER IV.}

THE BEE-HIVES. - HIVES WITH IMMOVABLE COMBS.

275. The first hives that were provided for bees were as rude as their natural abodes. We do not need to look back very far to remember the "bee-gum," so called, probably, because it had often been made out of the gum tree, with two sticks crossing in the middle, and a rough board nailed on top, while a notch in the lower end formed the entrance. In the old World, they manufactured straw or willow "skeps" and pottery hives, which are still used in Asia and Africa. The earthen hive was simply a tube, laid on its side, and closed at each end with a movable wooden disk. This disk

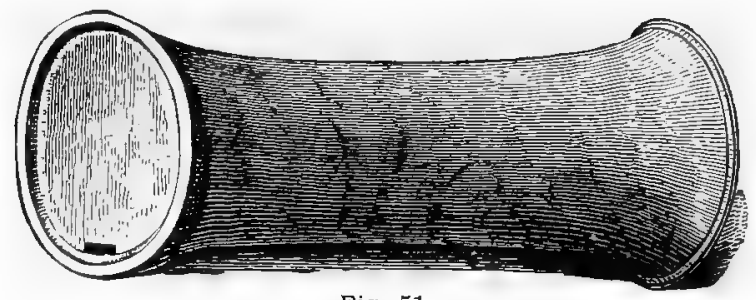

Fig. 51 .

EARTIIEN HIVE OF AFRICA AND CYPRUS.

(From “L'Apicoltore," Milan.)

was removed to take the honey, which is always located at the back part of the hives.

These earthen hives were, unquestionably, the most sensible of those old kinds. In the Islands of Greece they were set in thick stone walls, built on purpose with the entrance on one side of the wall. Sometimes they were located in the walls of the houses, and the honey was removed from the inside of the house, or, if in walls, from behind, out of the flight of bees. 
276. To get the honey from the gums, or boxes, the beekeepers used at first to drive the bees to another hive (574) and take all the contents. But most of the thus impoverished colonies perisued. This led to the thought that killing bees would be more facile, and the brimstone-pit was invented. This killing of bees was so customary that in the XVIIIth century, Joseph II, Emperor of Austria, decreed that every bee-keeper who would cut the combs in Spring, instead of brimstoning the bees, would receive one florin (about forty cents) per colony.

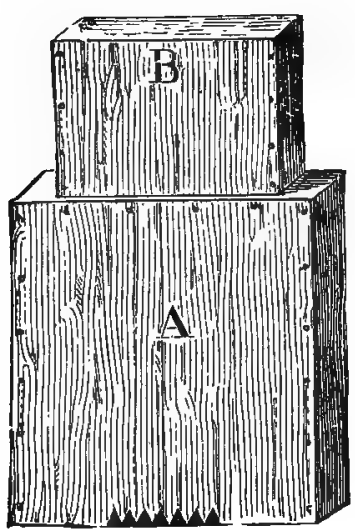

Fig. 52.

BOX HİVE, WITH CAP.

(From Hamet.)

278. About the year 1830, our senior, then a boy, sar this harvesting of combs for the first time. Clothed with il heavy linen frock, equipped with a mask of wire strong' enough to be sword-proof, and sweating under a scorching sun in this heavy garment, he helped (?) the old priest of his village to prune about twenty colonies, removing the back combs with a curved knife, from the upturned hives. It was in April; and, while the crop thus harvested was light, the 
damage inflicted to the bees was immense, for they had to rebuild their combs at a time when queens begin their greatest laying. But the bee-keepers of old were persuaded that this crop of beeswax was beneficial to bees, since it compelled them

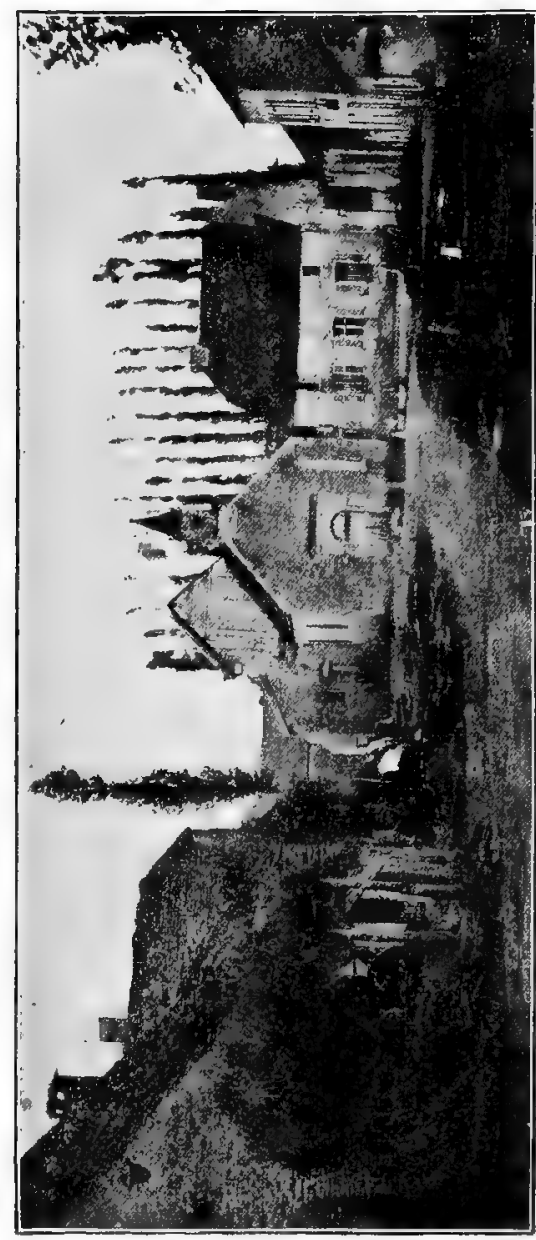

要 
to make new combs, which were considered better than older ones $(676)$.

278. Some bee-keepers, having noticed that bees place their honey at the highest part of the hive, added a cap orupper story, which communicated with the hive through a hole in the top of the latter. Still later, Apiarists found out that when the hive was very deep and the connecting hole small, the bees refused to store their honey in the eap, and

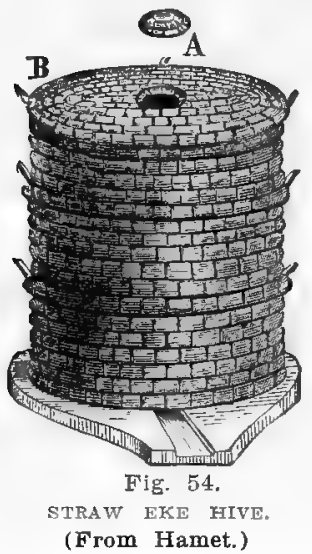

$B$, body ; $A$, hole to connect the stories with the surplus cap.

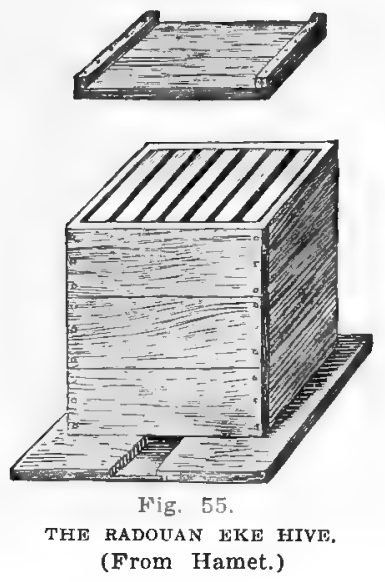

(From Hamet.)

they made their hives with open ceilings, replacing the top board of the breeding-story with slats or bars. The hives. were afterwards divided into several horizontal sections, called "ekes" (figs. 54 and 55). Instead of using a cap, some Apiarists removed the upper story, when full of honey, and placed a new story under the others. The bees then continued their constructions downwards. To separate the sections from one another, they used a wire that cut the combs. Butler, in his "Feminine Monarchy," 1634, showed hives composed of four sections, piled upon one another. Palteau, in 1750, advised bee-keepers to use a perforated ceiling at the top of each 
section. Radouan, in 1821, instead of a perforated ceiling, used triangular bars, to which the bees attached their combs. Chas. Soria, in 1845, used these bars at the bottom of each story as well as at the top, with bee space between, so that they could be removed, exchanged, or reversed, without crushing any bees, or damaging a single cell (fig. 56).

279. Other Apiarists divided their hives vertically, conformably with the shape of the combs of the bees, which hang vertically. If we are correctly informed, it was Jonas de Gelieu who inaugurated this style (fig. 57). He made his

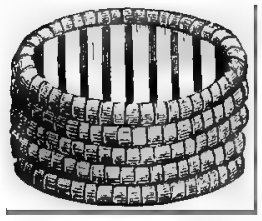

Fig. 56.

FKE OF CHAS. SORIA.

(From Hamet.)

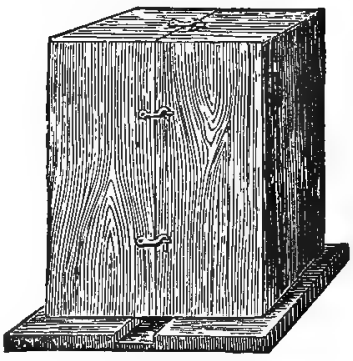

Fig. 57.

DIVIDING HTVE OF JONAS DE GELIFU.

(From Hamet.)

hive divisible into only two parts. Oettl, towards the middle of the nineteenth century, made a straw hive divided into three vertical parts- The main advantage of these hives resides in the facility of dividing them for artificial swarming. But as this method of making artificial swarms is defective, as will be shown further (4\%0), and as all these contrivances did not allow a close study of the habits of the bee, or permit the needed manipulations, it became necessary to invent a hive whose every comb, and every part, the Apiarist could promptly and easily control; a hive which, to employ the forcible expression of Mr. Hamet, could "se demonter comme un jcu de marionettes"; (be taken to pieces like a puppet-show). 
Requisites of a Complete Hive.

280. 1. A complete hive should give the Apiarist such perfect control of all the combs, that they may be easily taken out without cutting them, or exciting the anger of the bees.

2. It should permit all necessary operations to be performed without hurting or killing a single bee.

Some hives are so constructed, that they cannot be used, without injuring or destroying some of the bees; and the destruction of even a few materially increases the difficulty of managing them (399).

3. It should afford suitable protection against extremes of heat and cold, sudden changes of temperature, and the injurious effects of dampness.

The interior of a hive should be dry in Winter, and free in Summer from a pent and suffocating heat.

4. Not one unnecessary motion should be required of a single bee.

As the honey-harvest, in most locations, is of short continuance, all the arrangements of the hive should facilitate, to the utmost, the work of the busy gatherers. Hives which compel them to travel with their heavy burdens throngh densely crowded combs, are very objectionable. Bees instead of forcing their way through thick clusters, must easily pass into the top surplus honey-boxes of the hives, from any comb in the hive, and into every part, without traveling much over the combs.

5. It should be capable of being readily adjusted to the wants of either large or small colonies.

6. It should allow every good piece of worker-comb to be given to the bees, instead of melting. it into wax, and should permit of the use of comb-foundation (6r4).

r. It should prevent the over-production of drones, by permitting the removal of drone-comb from the hive.

A hive containing too much comb suitable only for storing honey, or raising drones, cannot be expected to prosper. 
8. It should allow the bottom board to be loosened or fastened at will, for ventilation, or to clear out the dead bees in Winter. If suffered to remain, they often become mouldy, and injure the health of the colony. In dragging them out, when the weather moderates, the bees often fall with them on the snow, and are so chilled, that they never rise again; for a bee, in flying away with the dead, frequently retains its hold until both fall to the ground.

9. No part of the interior of the hive should be below the level of the place of exit.

If this principle is violated, the bees must, at great disadvantage, drag, up hill, their dead, and all the refuse of the hive.

10. It should afford facilities for feeding bees, both in warm and cool weather, in case of need.

11. It should furnish facilities for enlarging, contracting, and closing the entrance, to protect the bees against robbers; and when the entrance is altered, the bees ought not, as in some hives, to lose valuable time in searching for it.

12. It should furnish facilities for admitting at once a large body of air, that the bees may be tempted to fly out and discharge their fæces, on warm days in Winter, or early Spring.

If such a free admission of air cannot be given, the bees, by losing a favorable opportunity of emptying themselves, unay suffer from diseases resulting from too long confinemont.

13. It should allow the bees, together with the heat and odor of the main hive, to pass in the freest manner, to the surplus honey receptacles.

14. Each of the parts of every hive in an apiary should be so made, as to be interchangeable from one hive to another. In this way, the Apiarist can readily make the exchanges of brood, honey, or pollen, which circumstances demand.

15. The hive should permit the surplus honey to be taken away in the most convenient, beautiful and salable forms. 
16. Il should be equally well adapted to be used as a swarmer, or non-swarmer.

17. It should enable the Apiarist to multiply his colonies with a certainty and rapidity which are impossible if he depends on natural swarming.

18. It should enable the Apiarist to supply destitute colonies with the means of obtaining a new queen.

19. It should enable him to eatch the queen, for any purpose; especially . to remove an old one whose fertility is impaired by age.

20. It should enable a single bee-keeper to superintend several hundred colonies for different individuals.

Many persons would keep bees, if an apiary, like a garden, could be superintended by a competent individual. If the bees are allowed to swarm, he may be called in a dozen different directions at once, and if any aceident, such as the loss of a queen, happens to the colonies of his customers, he can usually apply no remedy.

21. All the joints of the hive should be water-tight, and there should be no doors or shutters or drawers liable to shrink, swell, or get out of order.

22. A complete hive should be protected against the destructive ravages of mice in Winter.

23. It should permit the honey, after the gathering season is over, to be concentrated where the bees will most'need it.

24. It should permit the space for spare honey receptacles to be enlarged or contracted at will, without any alteration or destruction of existing parts of the hive.

Without the power to do this, the productive force of a eolony is in some seasons greatly diminished.

25. Its surplus honey receptacle should be as close to the brood as possible.

26. A complete hive, while possessing all these requisites, should, if possible, combine them in a cheap and simple form, adapted to the wants of all who are competent to cultivate bees. 
281. There are a few desirables to which a hive, even if it were perfect, could make no pretensions!

It could not promise splendid results to those who are too ignorant or too careless to be entrusted with the management of bees. In bee-keeping, as in all other pursuits, man must first understand his business, and then proceed upon the good old maxim, that "the hand of the diligent maketh rich." "In a word, to succeed it is indispensable to know what to do, and to do it just in time."-(S. Wagner).

It could not have the talismanic influence to convert a bad situation for honey into a good one; or give the Apiarist an abundant harvest, whether the season was productive or otherwise. As well might the farmer seek for some kind of wheat which will yield an enormous crop, in any soil, and in every season.

It could not enable the cultivator, while rapidly multiplying his colonies, to secure the largest yield of honey from his bees. As well might the breeder of poultry pretend, that in the same year, and from the same stock, he can both raise the greatest number of chickens, and sell the largest number of eggs.

\section{Movable-Comb Hrves.}

282. The bee-keepers of Greece and of C'andia seem to have been the first to provide their hives with movable bars, under which bees suspended their combs. Della Rocea mentions these and gives engraving's of them in his work, published in 1790. In 1838, Dzierzon revived this hive and improved it. In spite of the difficulty of its management, since the combs not being attached to movable-frames, but to top bars, cannot be removed without cutting them loose from the sides of the hive, Dzierzon succeeded in making discoveries, in bee physiology, which rank among the most important (132). His success was marvelous for the epoch.

283. But in the Dzierzon hive, it is often necessary to cut and remove many combs to get access to a particular one; thus if the tenth from the end is to be removed, nine must be 

Plate 14.

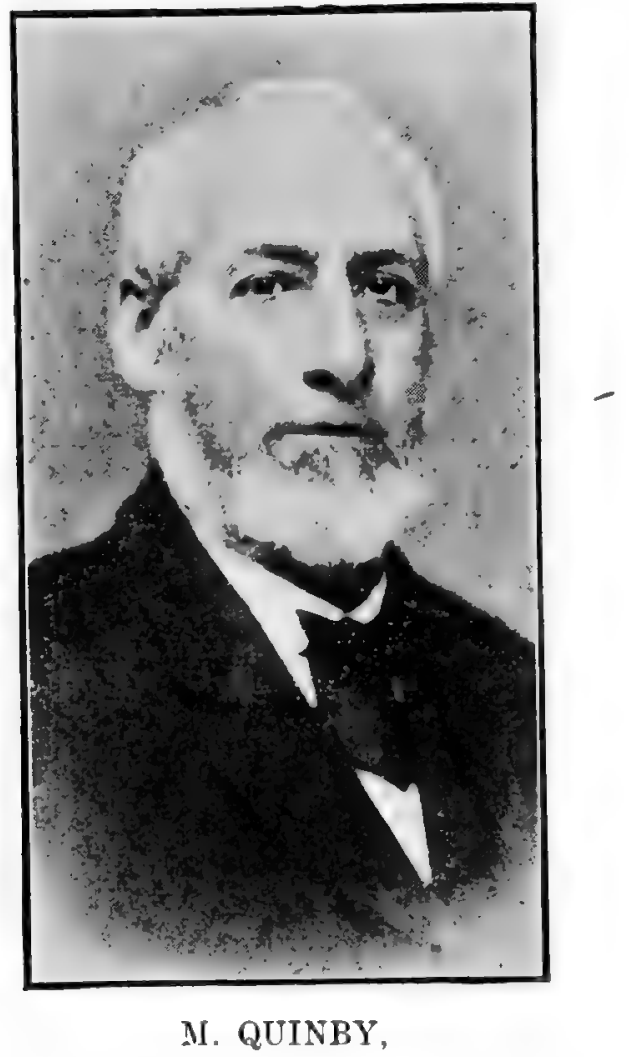

Author of "Thi Mysteries of Bee-Keeping."

This writer is mentioned pages $141,151,154,155,157,158,164,170$. 103, 378. 
taken out. This hive cannot furnish the surplus honey in a form the most salable in our markets, or admitting of safe transportation in the comb. Notwithstanding these disadvantages, it has achieved a great triumph in Germany, and given a new impulse to the cultivation of bees.

\section{Movable-Frame Hives.}

284. About one hundred years ago, Huber invented the leaf-hive, which enabled him to make his discoveries. It consisted of twelve frames; each an inch and a quarter in width,

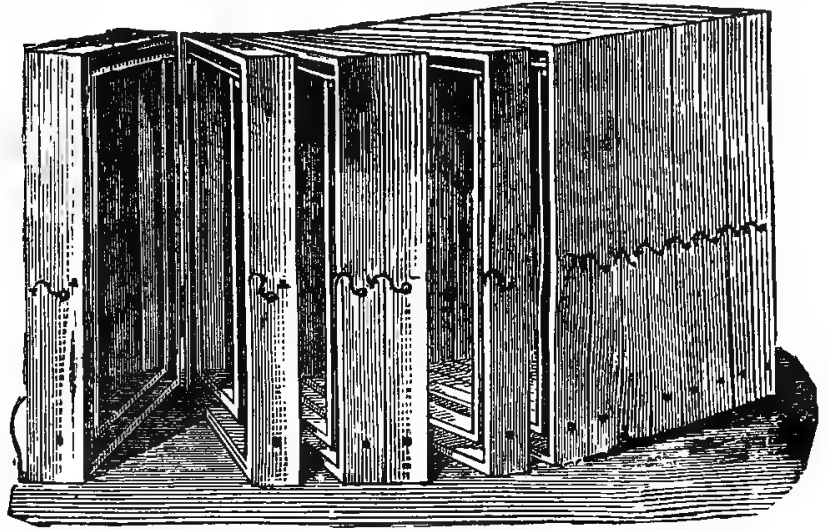

Fig. 58.

THE FUBER LEAF HIVE.

which were connected together by hinges, so that they could be opened or shut at pleasure, like the leaves of a book.

285. This hive was improved upon by several bee-keepers in Europe and America, the most noted of whom were Quinby, and his son-in-law, L. C. Root, author and publisher of "Quinby's New Bee-keeping." This style of hive is generally known as the elosed-end standing-frame hive. The reader will understand that, in these hives, the combs hang separately in frames, which, when joined together, make a body, enclosed in an onter covering. Their being used by a number of 
Apiarists, shows that these hives have some advantages, the greatest objection to then being the difficulty of fitting the frames together, after inspection, without crushing some bees, unless they have been previously shaken out.

286. Several attempts were made, in the first half of the nineteenth century, to invent a practical hanging-frame hive; that is, a hive in which each comb, hanging in a separate frame, could be readily taken out and replaced without jarring the hive, or removing the other frames. Propokovitsch, in Russia, Munn, in England, Debeauvoys, in France, tried and failed. At last, in October, 1851, Mr. Langstroth invented the trop-opening movable-frame hive, now used the world over with slight variations, in which the combs are attached to movable frames so suspended in the hives as to touch neither the top, bottom, nor sides; leaving, between the frames and the hive walls, a space of from one-fourth to three-eighths of an inch, called bee-space.

(Fig. 59.)

287. By this derice the combs ean be removed at pleasure, without any cutting, and speedily transferred to another hive. Our congenial friend, Prof. A. J. Cook, author of "The Bee-keeper's Guide," says of it: "It is this hive, the greatest apiarian invention ever made, that has placed American Apiculture in advance of that of all other countries." And no one knows, better than the revisers of this work, that such is the plain truth, as they have watehed the progress of bee-keeping in Europe, through its French, Italian, Swiss, and German bee-papers, for forty years past.

288. Mr. Langstroth, however, modestly disclaimed the idea of having attained perfection in his hive. He wrote:

"Having carefully studied the nature of the honey-bee, for many years, and compared my observations with those of writers and cultivators who have spent their lives in extending the sphere of apiarian knowledge, I have endeavored to remedy the many difficulties with which bee-culture is beset, by adapting my invention to the actual habits and wants of the insect. I have also tested the merits of this hive by long and continned experiments, made on a large scale, so that I might not, by de- 
ceiving both myself and others, add another to the useless contrivances which have deluded and disgusted a too credulous public. I would, however, utterly repudiate all claims to hav-
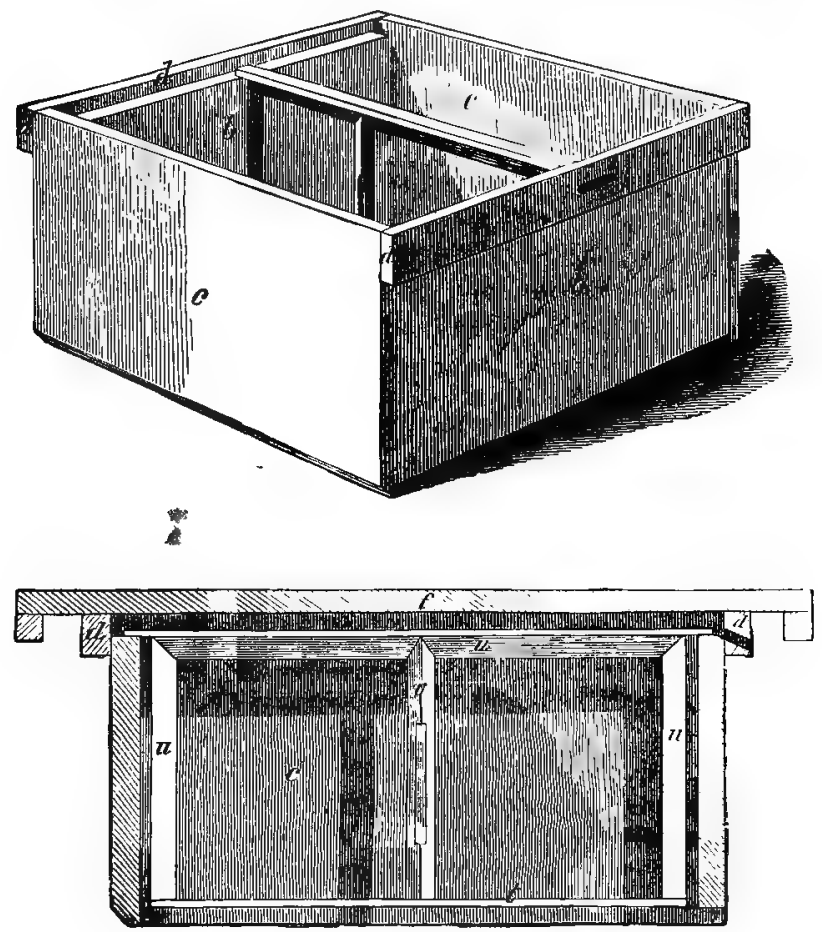

Fig. 59.

ORIGINAL LANGSTROTH HIVE.

$b, b$, front and rear of hive; $d, d$, pieces forming the rabbets for the frames to rest upon; $c, c$, sides of hive; $f$, movable cover; $u, u, t$, movable frame.

ing devised even a perfect bee-hive. Perfection belongs only to the works of Him, to whose omniscient eye were present all causes and effects, with all their relations, when He spake, and from nothing formed the Universe. For man to stamp the label of perfection upon any work of his own, is to show both his folly and presumption." 
289. A short time after the issuing of the Langstroth patent, the Baron Von Berlepsch, of Seebach, Thuringia, invented frames of a somewhat simliar character. Carl T. E. Von Siebold, Professor of Zoölogy and Comparative Anatomy, in the University of Munich, thus speaks of these frames:

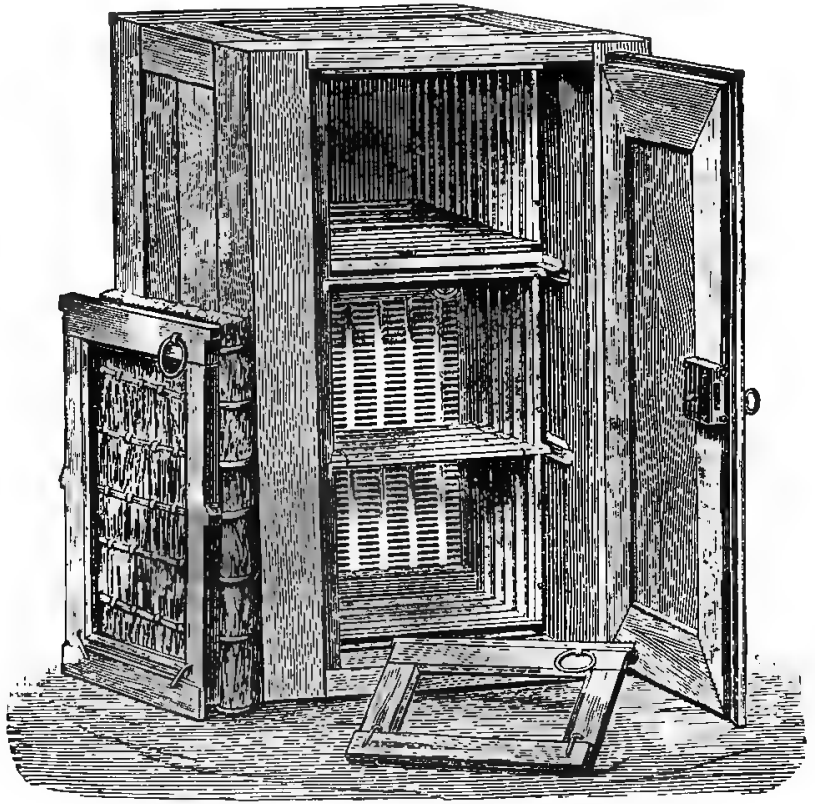

Fig. 60.

BERLEPSCH HIVE WITH BACK COSHION.

(From the "Illustrierte Bienenzeitung.")

"As the lateral adhesion of the combs built down" from the Jars frequently rendered their removal difficult, Berlepsch tried to avoid this inconvenience, in a very ingenious way, by suspending in his hives, instead of the bars, small quadrangular frames, the vacuity of which the bees fill up with their comb, by which the removal and suspension of the combs are greatly facilitated, and altogether such a convenient arrangement is 
given to the Dzierzon-hive, that nothing more remains to be desired." (PIP)

Mr. Cheshire (Bees and Bee-keeping, 2d vol. page 46) was mistaken in attributing to Dzierzon the invention of the frame-hive, for Dzierzon has not even invented, but only perfected the movable-comb hive (282-283), having always, to this day, been opposed to frames. So the German hive is known as the Berlepsch hive.

290. For years, both of these inventions shared equally the attention of bee-keepers in Europe. Berlepsch's hive is

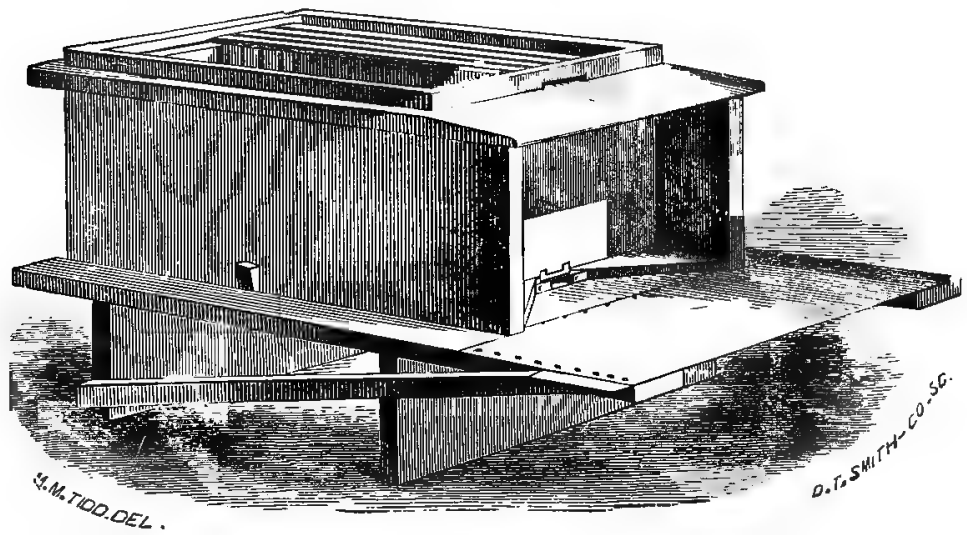

Fig. 61.

SHOWING SOME OF THE EARLY IMPROVEMENTS OF THE LANGSTROTH HIVE, STILL IN USE IN SOME SECTIONS.

used principally in Germany, Italy, and part of Switzerland; Langstroth's in England, France, and the French-speaking part of Switzerland; but it is to be noted that hives made on the principle of the Langstroth invention, are steadily gaining ground wherever both styles are used.

291. And this is not to be wondered at. The Berlepsch hive opens from the rear, like a cupboard. Two stories are used for the brood, and the third for surplus honey. This is sometimes separated from the main apartment by perforated 
zine (468), to exclude the queen, or by a board with a square hole in the center. The frames are suspended, in grooves, by the ends of their upper bars, and have to be taken out with pincers.

292. The worst feature of this hive is that, if it is necessary to reach the last frame, every one of the others has to be taken out. There are twenty combs in the brood-chamber. It is safe to say, that a hive built on the Langstroth principle, can be visited five times more rapidly, than a hive built on the Berlepsch idea. These inconveniences, coupled with the fact that the brood apartment of the Berlepsch hive is divided into two stories, and that the surplus apartment cannot be enlarged, ad infinitum, make the Berlepsch hive inferior; and we can safely predict that hives with movable ceiling will some day be exclusively used throughout the world.

293. The superiority of the Langstroth hive is so evident that we were not surprised to read in the Revue Internationale d'A piculture, Sept., 1885 :

"The question of the mobility of the ceiling was discussed at length at the Bee-keepers' Meeting held in Milan, Italy, in September, 1885. Mr. Cowan and I were unable to conceal from the Italian bee-keepers our wonder that it was not solved for them, as it has been, for a long time, in the countries of large production.

"We can predict, and without any fear of mistake, that the principles on which the Langstroth hive is based will be admitted sooner or later by the most progressive bee-keepers of the world." -(Ed. Bertrand.)

291. In 1905, an Italian writer, speaking of the Langstroth-Dadant hive, as described by the elder Dadant, calls it, "the preferred, the international, the classic, the queen of hives." (Romagna Agricola, June, 1905.)

295. The success of American bee-culture, in the last fifty ycars, was first attributed, by European bee-keepers, to the honey-producing power of the country; but the most intelligent Apiarists, who have tried the American methods, 
with the Langstroth hive, now recognize that success is principally due to the manipulations that it permits.

296. Nay, if the student will but refer to a former edition

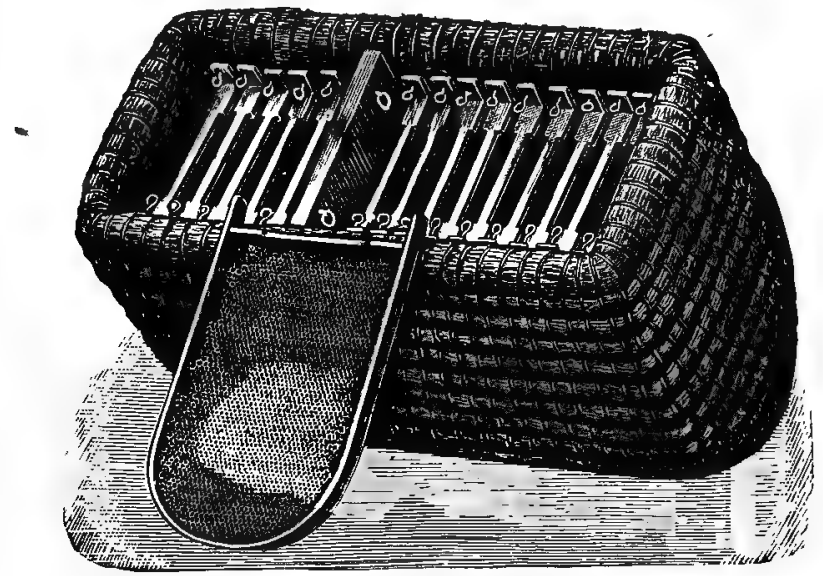

Fig. 62 .

THE GRAVENHORST HIVE.

(From the "Illustrierte Bienenzeitung.")

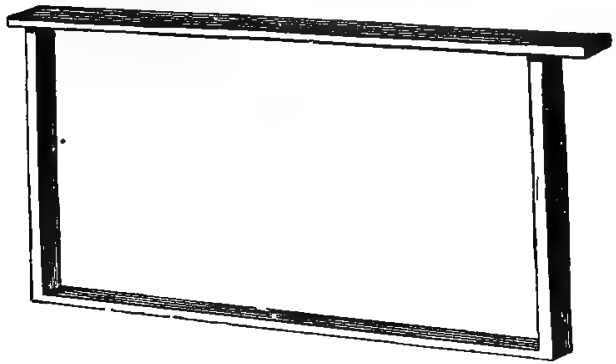

Fig. 63.

OLD STANDARD LANGSTROTH FRAME.

of this very book (1859), the first words of it will show him the progress accomplished since then:

" Practical bee-keeping in this country is in a very depressed condition, being entirely neglected by the mass of those most 


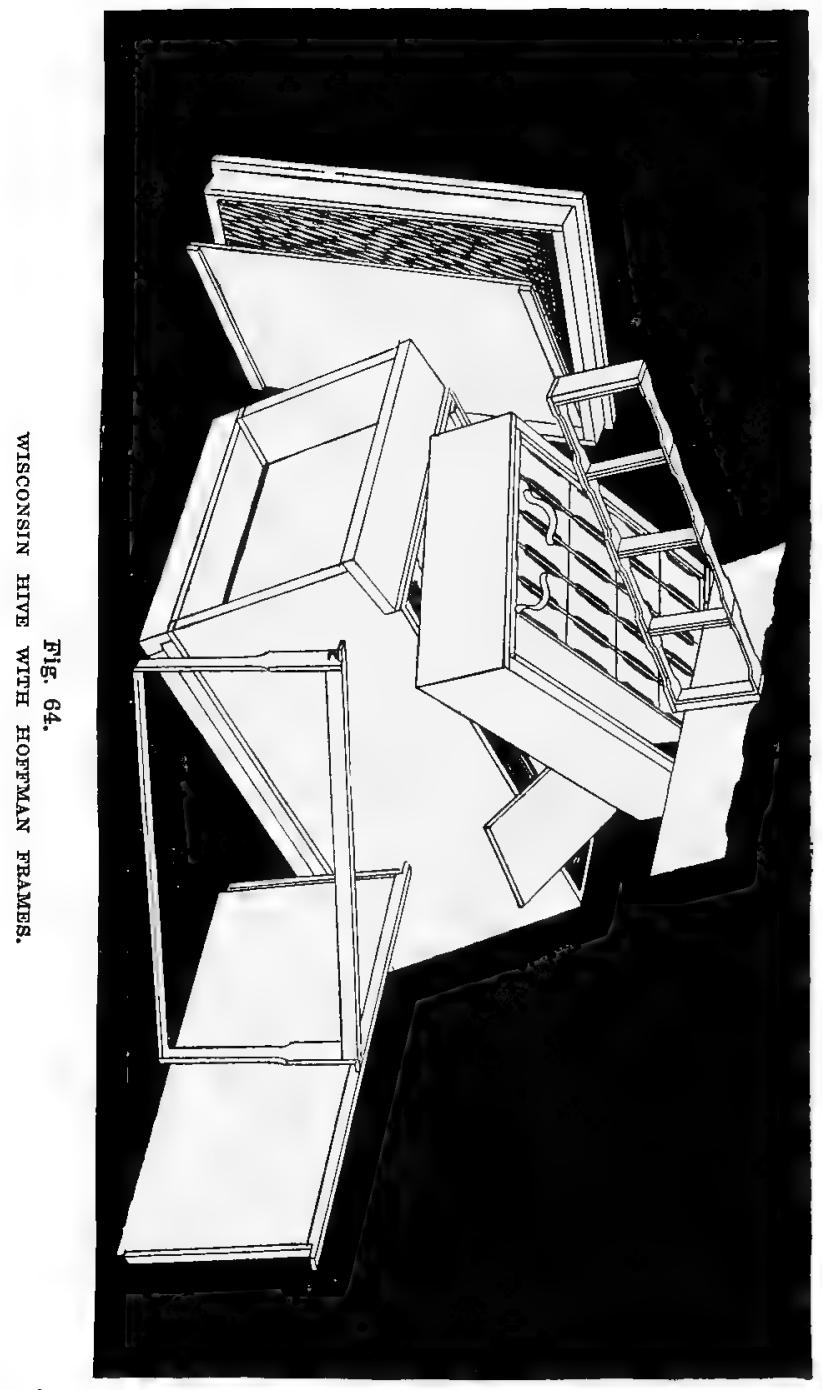


favorably situated for its pursuit. Notwithstanding the numerous hives which have been introduced, the ravages of the beemoth have increased, and success is becoming more and more precarious. While multitudes have abandoned the pursuit in disgust, many even of the most experienced are beginning to suspect that all the so-ealled 'Improved Hives' are delusions or impostures; and that they must return to the simple box or hollow log, and 'take up' their bees with sulphur in the old-fashioned way."

297. Mr. Gravenhorst, also a German, invented a movable-frame hive made of straw. We give a eut of his hive, not that it has any practitcal importance for us, but because his system is peculiar. The frames are removed from the bottom so that in order to examine the hive, one must invert it. There is no separate apartment for surplus honey.

298. Although the movable frame, hanging in the hive, by projections of the top bar (figs. 59, 63), as invented by Mr. Langstroth, is the style now almost universally adopted, there is a great diversity of opinions as to the proper size and shape of the frames, and the number, which a hive should contain. Hundreds of different sizes are used with success, from Maine to California, and from Canada to Texas.

Frames as short as $11 \frac{1}{2}$ inches are used, but the standard size is still the Langstroth, the standard frame of America.

A frame which is now very highly recommended by a number of bee-keepers and sold by most manufacturers in America is the "Hoffman frame" (fig. 65). The frames touch one another in the upper third of their side bars and are thus spaced. The advantage claimed for these is that any beginner can use them without ruming the risk of putting too many or too few in a hive, a mistake sometimes made by novices, and also that they can be handled in twos or threes without difficulty. These advantages seem to us much overbalaneed by the fact that it is difficult to put the frames together in a populous hive without crushing some bees. When a hive is opened to ascertain its condition, it is usually neces- 
sary to look over every part of it. The help gained by being able to handle two or three frames at a time is therefore more imaginary than real.

Mr. E. R. Root, the well-known editor of Gleanings in Bee Culture, who has been the most active supporter of this frame, in reply to a correspondent who complained of the frame, in Gleanings for November 1st, 1905, page 1127, acknowledges that the Hoffman frame is unsuited to localities where much propolis is used by the bees, owing to the difficulty of separating the frames when glued together.

Another very strong objection which has been raised against

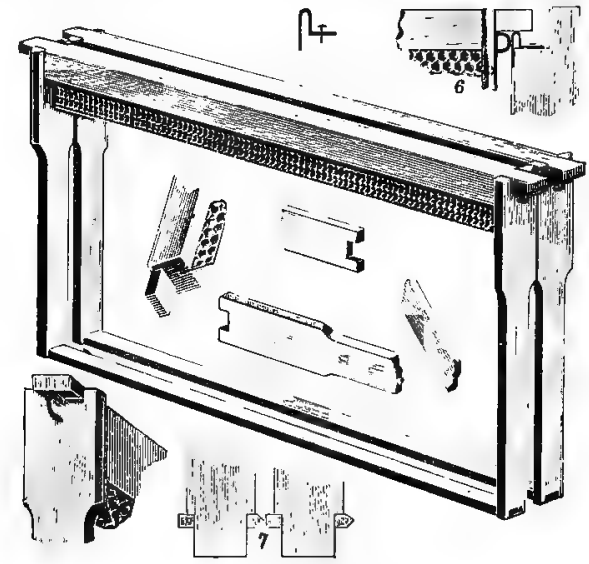

Fig. 65.

HOFFMAN FRAMES.

("The A B C of Bee Culture.")

the Hoffman frame is that it cannot be manufactured in a small shop, as it requires special tools to manufacture it. This may not have much weight with the up-to-date Apiarist, but it has been our aim to recommend the simplest and most practical implements, if effective, and we consider this objection as a weighty one, when added to other objections. The main desideratum attained by the use of the Hoffman frame, namely the spacing of the combs in a practical and stable 

Plate 16.

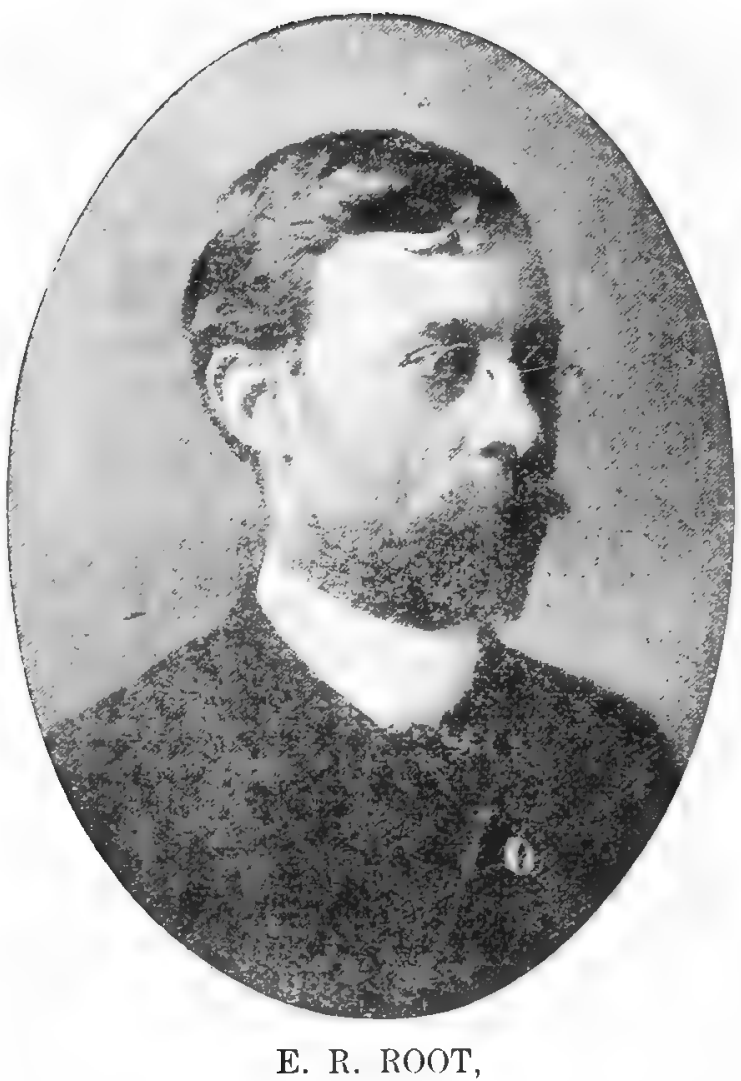

Son of A. I. Root, Reviser of "The $A B C$ and $X Y Z$ of BeeCulture," Editor of "Gleanings in Bee-Culture."

This writer is mentioned pages $150,151,326,481,482$. 
way, can be attained by other methois which will be described farther.

299. The "Hanging Quinby" (fig. 68) is the frame preferred by the writers. The "Gallup" frame is used with success by such practical Apiarists as G. M. Doolittle. The closed-end-Quinby and the Danzenbaker frames are not hanging frames, but the former is much used by New York State Apiarists and the latter is the frame preferred by E. R. Root. It is a very shallow frame.

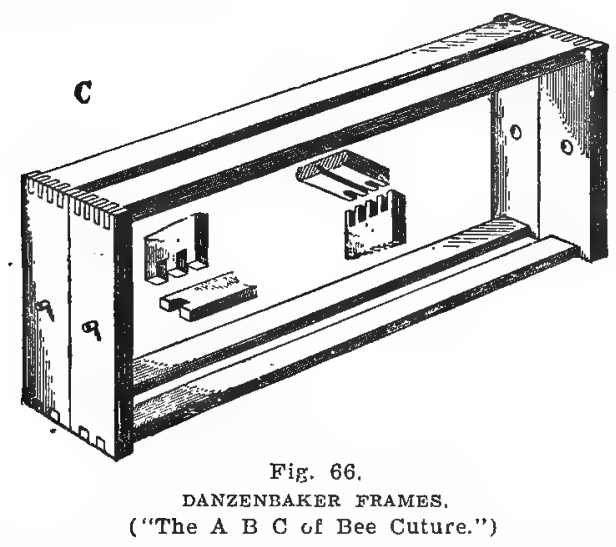

300. It is evident that profit can be derived from beeculture with almost any style of frame; but it is certain also, that, in every pursuit, some conditions produce better effects than others, under the same eireumstances.

In apiculture, as in everything else, we should try to obtain the best results with the least labor and expense, and these ean only be attained by studying the habits of the bee, and complying with them, as far as is practicable.

The combs of the brood-chamber, or main apartment of the hive, are used by the bees to raise their young, and to store their food for Winter. The size of frames must be considered, with reference to this.

301. We have seen (153) that the queen lays her eggs 
in a circle. In fact, it is necessary that she should do so, in order to lose no time in hunting for cells; else how cuuld she lay three thousand eggs, or more, per day? A very shallow frame will break the circle, and compel her to lose time. In a comb five inches deep, for instance, and fifteen or sixteen inches long, the largest circular area contains less than twenty square inches, or five hundred and fifty workercells on each side. When these are occupied with eggs, the queen, while hunting for empty cells, will find wood above and below, instead of comb, at every half turn, and will lose not only time, but eggs; for, in the busy season, her eggs have to drop, like mature fruit, if not laid in the cells. Loss of eggs is loss of bees; loss of bees at the proper time is loss of honey.

302. A two-story shallow brood-chamber is objectionable
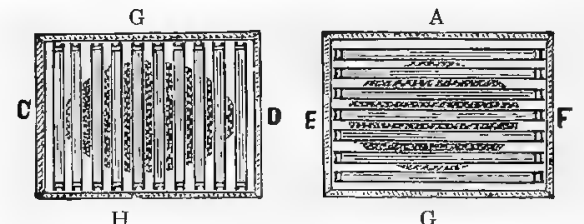

Fig. 67.

G

DIAGRAMS OF GALLUP AND LANGSTROTH HIVES.

(From the "A B C of Bee-Culture.")

for the same reason. Besides, the bees which cover the brood and keep it warm, must also keep warn the lower bar of the top frame, the upper bar of the lower frame, and the space between the two, without deriving any beneft from such an arrangement. This division of the brood-combs, into two shallow stories, is one of the causes which prevent the beekeepers of Germany from raising as many bees, in their hives, as we do here in the ordinary Langstroth hives. This disadvantage was so evident that the bee-keepers of Switzerland, who had adopted, as a standard, the Berlepsch hive (fig. 60), decided to replace the double story by a single one of the same dimension, as the Italian bee-keepers had done before, but for half the hive only. 
A short frame like the Gallup (fig. 67), presents another objection, the eluster being divided among a greater number of frames.

"For Winter, it is evident that the sides, of the clusters A. B. and C. D. (fig. 67) are better protected than the ends G. H. and E. F, and also that the long frames protect the center of the brood-nest much better than the short ones." ("A B C.")

Even a cross-bar through a frame (fig. 59) will hinder the laying of the queen, so that brood will often be raised only on one side of it. Any one can easily try this.

303. From the-foregoing, it appears that a square frame is the best for breeding. But square frames are objectionable. If they are small, they do not have enough space in each frame for Winter supplies, above or behind the brood. If they are large, they are unhandy, and their depth makes them difficult to take out without crushing bees. We have used some sixty hives, American frames, $125 / 8 \times 125 / 8$, for many years, and this is our greatest objection to them.

304. A disper frame is still more objectionable for the same reason, and because the surplus cases on top are too remote from the brood. (278.) In early Spring, the bees have more difficulty in keeping the lower end of such frames warm, as the heat always rises, and a part of it is wasted, warming up the stores, which in this hive are all above the brood. In hot weather, the combs are also more apt to break down from heat and weight combined. Such a hive is defieient in topsurface for the storing of honey in boxes.

305. It is thus evident that Mr. Langstroth and Mr. Quinby were right in using frames of greater length than depth, especially as these frames allow of more surplus room above the brood, a matter of some importance.

306. But we must beware of excess in anything. A shallow frame has too little honey above the eluster in Winter, and in long cold Winters, like that of 1884-5, a great many bees die for want of food above them, in hives con- 
taining plenty of honey, the combs, back of the cluster, being too cold.

The Langstroth-Simplicity frame is long enough, but hardly deep enough. The Quinby frame is deep enough, but would be better if a little shorter.

307. We have used on a large scale Quinby, American and Standard Langstroth-sized frames for years, and have obtained better results from the Quinby, both for wintering out of doors, and for honey producing. Yet, the Langstroth-Simplicity being the standard frame of America, we would hesitate to advise any Apiarist to change-from this size; knowing, by practical experience, how annoying it is, not to have all frames and all hires in one apiary uniform in size.

But we would counsel beginners to use the Quinby sizeespecially if they intend to winter out-of-doors-or at least to use a frame as long as the standard Langstroth and as deep as the Quinby.

The recommendation whieh we make of the Quinby size of frame is not a hasty one. This frame has been tested by us for years, side by side with numerous others, for Mr. Charles Dadant was never content until he had made a trial of all things that were given as improvements. He tested triangular frames as well as frames that approached as near to the circular shape as was possible with pine lumber as a material of manufacture. He tried deep and shallow frames, small and large frames, ranging in size from $6 \times 6$ inches to $18 \times 18$ inches. So the reader may rest assured that a very thorough practical experience caused our decision.

308. The number of frames to be used in a hive depends on their size; for we should manage our bees, as we do our other domestic animals, and give them as much space as is necessary to obtain the best results. What would we think of a farmer who would build a barn without first considering the number of animals and the amount of feed which he intended to shelter in it?

309. Many hives cannot hold one-quarter of the bees, 
comb, and honey which, in a good season, may be found in large ones; while their owners wonder that they obtain so little profit from their bees. A good swarm of bees, put, in a good season, into a diminutive hive, may be compared to a powerful team of horses harnessed to a baby wagon, or a noble fall of water wasted in turning a petty water-wheel. As the harvest of honey is always in proportion to the number of bees in the hive, and as a large colony requires no more labor from the Apiarist than a small one, the hive should afford the queen sufficient space to deposit all the eggs, which she is able to lay during twenty-one days, the average time for an egg to be transformed into a worker. Besides, it should contain a certain amount of food, honey and pollen. It is unquestionable that the quality of a queen depends on the quantity of eggs that she is able to lay. Then why limit her, by using hives so narrow that she cannot develop her fertility?

310. We have seen before $(\mathbf{9})$ that a good queen can lay 3,500 eggs per day in the good season, so that 73,500 cells may be occupied with brood at one time. If we add to this number about 20,000 cells for the provisions needed in the breeding season, we have about 94,000 cells as the number required for a strong colony. As every square inch of comb contains about 55 cells ( 218 ), 27 to 28 on each side, the combs of a hive should measure over 1,700 square inches. This space must, of course, allow of contraction, according to the needs of the colony by what is called movable division boards. (349.)

311. As a Quinby frame measures 189 square inches in. side, a hive should contain at least 9 of these frames.

As the Standard Langstroth-Simplicity frame measures about 149 square inches, the hive must contain 12 frames. The American frames must number 12, and the Gallup 14.

312. We know that many Apiarists object to these figures, because they succeed, and harvest good crops, with smaller hives. But figures, based on facts, cannot lie. Smaller hives will do only in localities, where late Springs and short 
honey crops make it impossible for the queen to lay to the utmost of her capacity, before the time when her bees would be useful.

It is perhaps necessary to say here, that we have found more opposition on this subject than on any other, especially in the bee-papers. But we take this opportunity of again energetically asserting that our preference for large hives is based on a successful practice of more than forty years, with several hundred colonies in different sized hives.

Men of great experience and success, like Doctor C. C. Miller, who use eight-frame Langstroth hives, manage "to secure the fullest breeding of prolific queens, before the opening of the honey harvest, by adding another brood chamber when the queen has fillecl the first. This additional brood chamber is removed at the time of putting on the supers and the combs of brood are divided among weaker colonies, if there are too many of them to fill one brood chamber.

This is the 'nly way in which full results may be achieved with small hives.

313. It is only by testing different sizes of hives and frames side by side, for years, on a large scale, and with the same management, as we have done, that the comparison can be made serviceable. Our experiments prove also that small frames impede the laying of the queen. The brood-chamber of a large hive can easily be reduced in size, if need be; but a small hive camot be enlarged at will, except by the addition of upper stories, which should properly be devoted to the storing of honey.

311. In addition to the disadvantages of small frames and small hives already enumerated, another-and the greatest of all-is the excess of natural swarming which they cause. The leading advocates of small hives, some of whom are large honey producers, invariably acknowledge that they have too much natural swarming; nor is it to be wondered at, since swarming is mainly caused by the lack of breeding room for the queen. (406.)

315. The main eriterion of a good farmer is the care 
that he takes to improve his stock, by selecting the best animals as reproducers. If we use hives so narrow that we cannot discern which are our most prolifie queens, and that they incite natural swarming, we are unable to improve our bees by selection. (452, 511.)

316. The distance between frames from center to center can be varied from $13 / 8$ inches to $1 \frac{1}{2}$ in the breeding apartment, of which we are now treating. In the surplus cases, it may be made much greater.

31\%. The distance of $1 \frac{1}{2}$ inches, advised by Mr. Quinby, is preferable for two reasons:

1st, It facilitates the taking out of the combs, giving a little more room to handle them, and thus aids in interchanging combs, which may have slight irregularities; when such changes are necessary to help weak colonies with brood or honey from stronger ones.

$2 n d$, It gives more room between brood-combs for the bees to cluster in Winter, and a greater thickness of honey above them, thereby placing the bees in better condition for Winter.

318. The frames must be properly distanced in the hive, and the combs must be built straight in them; for a movableframe hive, with crooked combs, is worse than a hive without any frames.

319. The building of straight combs in the frames was formerly tolerably secured by the use of a triangular wooden guide fastened to the under side of the top bar of the frame, and which the bees follow in most instances. Something of this kind was mentioned by Della Rocca as early as 1790 . ("Traité Complet sur les Abeilles.")

320. A metallic stamp was invented by $\mathrm{Mr}$. Mehring, of Bavaria, Germany, for printing or stamping the shape of the combs upon the under side of the top bar of the frames. After the outlines were made he rubbed melted wax over them, and scraped off all that did not sink into the depressions. Mr. Mehring represented this device as enabling him to dispense with guide combs, the bees appearing to be 
delighted to have their work thus accurately sketched out for them.* In practice it was found to be inferior to the triangular comb guides.

321. Pieces of worker-comb, glued to the under side of the top bar with melted wax, were used successfully. But the introduction of comb-foundation (674) has finally given us the means of securing straight combs at all times, and it may be used, for this purpose, in such narrow strips, that its cost cannot be an objection.

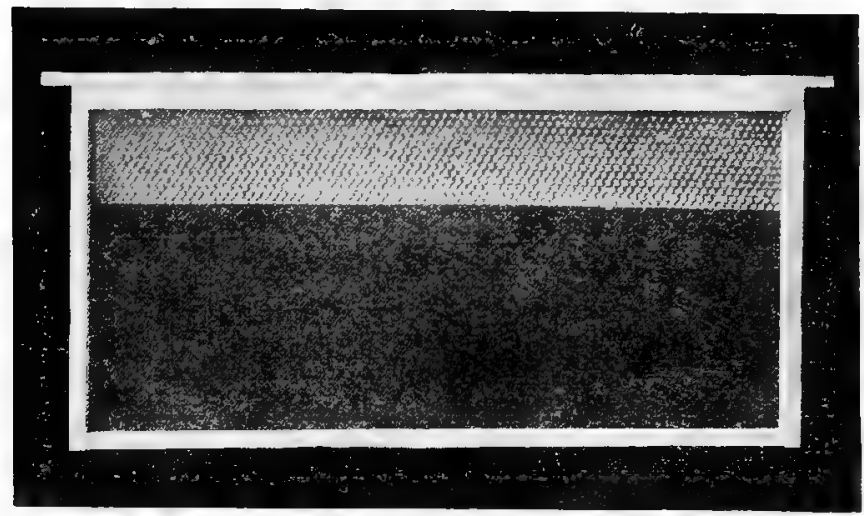

Fig. 68.

MOVABLE FRAME With FOUNDATION GUIDE.

322. As stated before ( $\mathbf{2 9 9}$ ), the frame that we use is similar in size and shape to the Quinby hanging frame, a little longer and a little deeper than the regular Langstroth frame, fig. 68. The exact size of these frames is given in diagram, fig. 72 .

323. All the parts of the movable frames should be cut out by eircular saws, and the measurement should be exact, so that the frames when nailed together may be square. If

\footnotetext{
*This invention should not be confused with that of comb-foundation, made a few years later by the same distinguished Apiarist.

(677)
} 
they are not strong and perfectly square, the proper working of the hive will be greatly interfered with.

324. The underside of the top-bar may be cut to a triangular edge, which bees usually follow readily in building combs. But comb foundation strips are now used almost altogether, and. a groove, with wedge as in fig. 69, will be found very much more serviceable. Above all, the outside measurements of the frames must be carefully preserved, no matter what style of hive and frame we use.
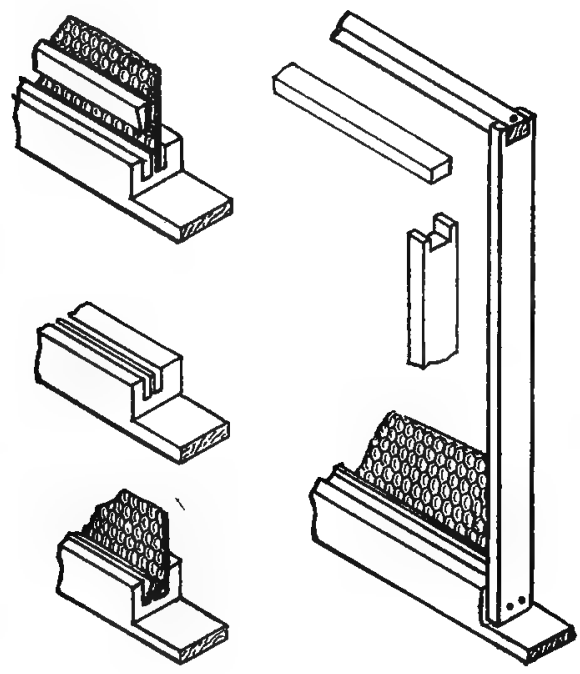

Fig. 69.

FRAME WITH GROOVE TOR FOUNDATION.

325. The width of the top bar has something to do with the amount of bridges and brace combs (397), built by the bees, between the brood-chamber and the upper stories. A wide top bar, leaving but a narrow space for passage above, will almost altogether prevent the building of bridges. For that reason, we make our top bars $1 \frac{1}{8}$ inches in width. Yet 
in producing extracted honey $(\mathbf{4 9})$ these bridges and brace combs do not annoy much.

326. It is necessary that the hive should always slant forward, toward the entrance, when occupied by bees, to facilitate the carrying out of dead bees and other useless substances, to aid the colony in protecting itself against robbers, to carry off moisture, and prevent rain from beating into the hive.

327. For this, and other reasons, the combs should run from front to rear,-so as to hang perpendicularly,-and not from side to side as they do in the Berlepseh hive.

328. The Langstroth hive, from the simple form given in fig. 59, was improved upon in many different ways. The Standard Langstroth hive has been for a long time a hive

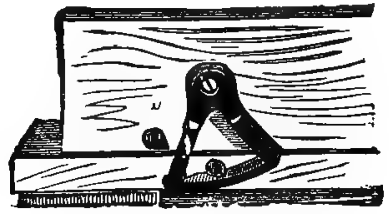

Fig 70 .

VAN DEUSEN CLAMP.

with portico, honey-board, permanent bottom-board, and ten liames.

329. The movable honey-boarl, between the broodchamber and the upper stories, has been discarded of late years. the great objection to honey-boards being that the bees glue them, and build small pieces of comb or bridges, in the space between them and the frames; the jar of their breaking, when the honey-board is removed, angering the bees.

330. The permanent bottom-board has lost favor with the great majority of bee-keepers, and is now replaced by movable bottom-boards adjustable at will. The Van Deusen hiveclamp (fig. 70), is used by many Apiarists for fastening movable bottoms or additional stories. Te have discarded the permanent bottom-board, owing to the difficulty of 
promplly cleaung it of dead bees and rubbish, when remov. ing bees from the rellar in spring, of after a liard winter passed out of doors.

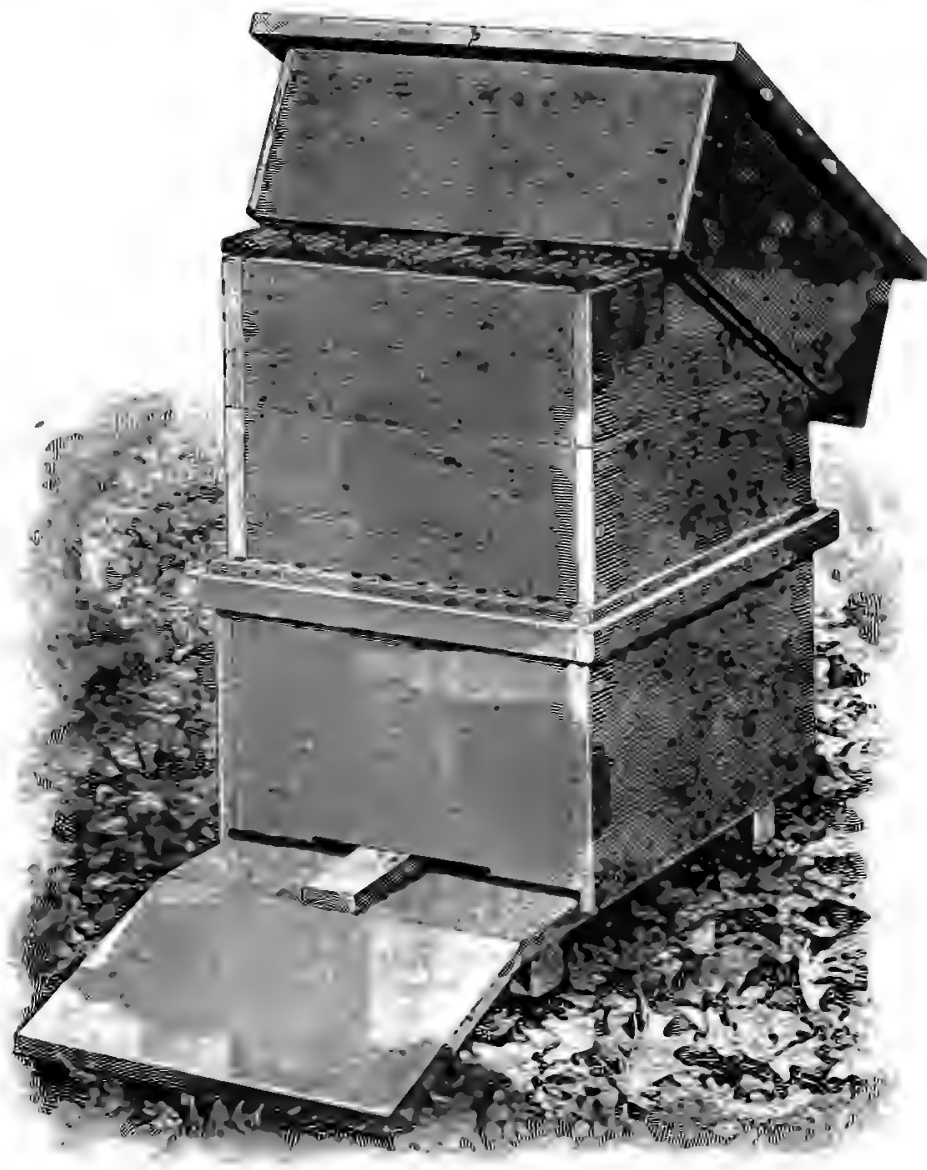

Fig. 71.

IFVT, WTTH EXTRACTING SUPERS SET BACK FOR VENTILATION IN VERY HOT WEATHER.

The cap is thrown Dack to show the straw mat. 
331. In the ventilation of the hive, we should endeavor, as far as possible, to meet the necessities of the bees, under all the varying eircumastances to which they are exposed in our uncertain climate, whose severe extremes of temperature forcibly impress upon the bee-keeper, the maxim of Virgil,

"Utraque vis pariter apibus metuenda."

"Extremes of heat or cold alike are hurtful to the bees."

332. To be useful to the majority of bee-keepers, artificial ventilation must be simple, and not as in Nutt's hive, and other labored contrivances, so complicated as to require almost as close supervision as a hot-bed or green-house.

333. With an independent bottom-board, ventilation can be given to any amount by raising the hive, as in fig. 71 , or even more. By furnishing ventilation independent of the entrance, above the brood-chamber, or between the different surplus apartments, if necessary, we improve upon the method which bees, in a state of nature, are compelled to adopt, when the openings in their hollow trees are so small, that they must employ, in hot weather, a larger force in ventilation, than would otherwise be necessary.

It has been held that an upper entrance to the broodchamber (fig. 71), with a sufficient amount of super room, is an infallible preventive of swarming. It is, at least, a very great help towards this result.

335. The bees, finding their home more pleasant, will cease to cluster on the outside, as Iong as there will be honey to gather, and room to store it in.

336. On the other hand, by the use of movable blocks, the entrance may be kept so small, in cool weather, that only a single bee can go in at once, or it may be entirely closed.

While sufficient airing must be given, the supply should be controlled, so as not to injure the brood by admitting too strong a current of chilly air. In the chapter on wintering bees, directions are given for placing absorb- 
ents in the upper story, in the winter, so as to carry off all superfluous moisture (636), without injurious ventilation.

337. For the benefit of beginners, it may be necessary to add, that the bees will glue up with propolis (236), and sooner or later entirely close any ventilating holes through which they cannot pass. Hence air holes, covered with wire cloth, miss their purpose altogether. In the same manner, and with a great deal of labor, bees will try to close any upper entrances, such as that of fig. 71 , if these remain open, when not needed for the welfare of the colony.

338. The portico (fig. 64) of the Langstroth hive has advantages, and disadvantages, which about balance one another. Its advantages are, that it shelters the bees from rain in Summer, and from cold and snow in Winter. Its disadrantages are, that it sometimes harbors enemies of bees, moths, spiders, etc., etc., and sometimes helps to hide the queen from the Apiarist's diligent search. It hinders the bee-keeper when he wants to watch closely the sport of bees before the entrance.

339. An entrance block, e, fig. 73 , is used to reduce the entrance of weak colonies in Spring or at any time when robbing is feared (668), or when warmth is desired.

The Hive We Prefer.

340. The diagram we give (fig. 72), of the hive we prefer to all others, can be taken as a pattern for any other size, by changing the size of the pieces and retaining only the exact distances between the frames and the body, and the height of the entrance. Its details can be varied ad " infinitum. It can hold eleven frames, but generally we use only nine frames and two contracting, or division-boards, or ten frames and one division-board. (349.)

This hive, in the dimensions given, is not a new, untried pattern. We have used several hundreds of them for years, 


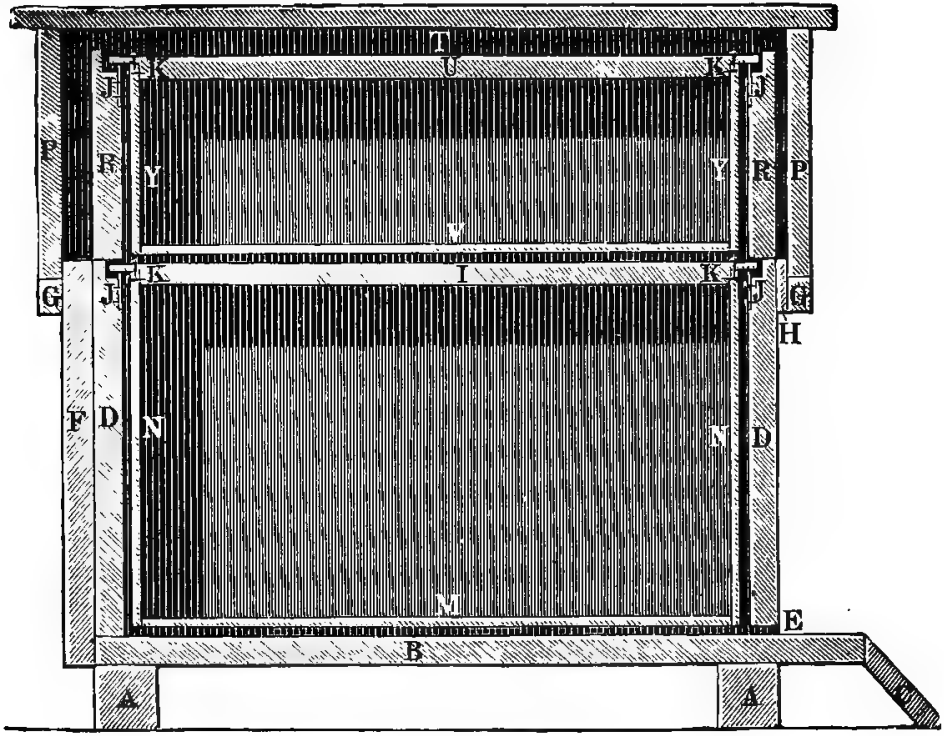

Fig. 72.

DTAGRAM OF OUR HIVE.

$A A$, cross-pieces to support the bottom, $18 \times 2 \times 2$. $B$, bottom, $25 \times 171 / 2 \times$ $\pi / 8$. $C$, apron, $10 \times 17 \frac{1 / 2}{2} 7 / 8 . D D$, front and rear of the hive, $16 \frac{1 / 2}{2} \times 121 / 4 \times$ $7 / 8$. $E$, entrance, $8 \times \frac{3}{8}$. $F$, double board nailed at the rear, $181 / 4 \times 13 \times$ $7 / 8$. GG, square slats to support the cover. $H$, lath, $1 / 2 \times 1 \% / 4$, to widen the top edge of the front board. $I$, top bar of frame, $201 / 4 \times 11 / 8$ wide $\mathrm{x}$ $7 / 5$ thick. JJJJ, rabbets $1 / 2$ wide $\mathrm{x} 5 / 8 \mathrm{high}$, dug in front and rear boards, and furnished with sheets of iron $\% / 4$ inches wide, or metal spacers projecting $1 / 4$ of an inch, on which the frame-shoulders are supported. If the grooves are not provided with these, their size should be $1 / 2 \times \% / 8$.

$K K K K$ shows how the uprights $N N$ of the frames are nailed to the top bar. $M$, bottom bar of the frame, $17 \tau ; 51 / 2 \times 7 \%$. NN, sides of the frame, $11 \frac{1}{4} \times 5-16 \times 7 / 8$. $P P$, front and rear of the cap, $181 / 2 \times 9 \times 7 / 8 . R R$, front and rear of the surplus-box, $16 \frac{1}{2} \times 6 \% / 4 \times 7 . \quad T$, empty space on top of the surplus-box, $1 \frac{1}{4}$ for the cloth and mat. $U$, top bar of the surplus-frame, same as top-bar $T . V$, bottom bar of the surplus frame, same as $M . Y Y$, sides of the surplus frames, $6 \times 1 / 4 \times 7 / 8$.

The space between $M$ and $B$ is about $1 / 2$ inch; between $D N, N D, V I$, $R Y, Y R$, should be $1 / 4$ to $\%$ of an inch. Hives of every size can be constructed on this diagram, with the only caution to preserve the spaces of the width indicated. Both top bars are grooved on the under side for foundation and wedge as per Fig. 69. 
with the best of success. It is used extensively by many large producers.

311. As a result of the publication of this book in the French and Russian languages, this hive has been adopted by

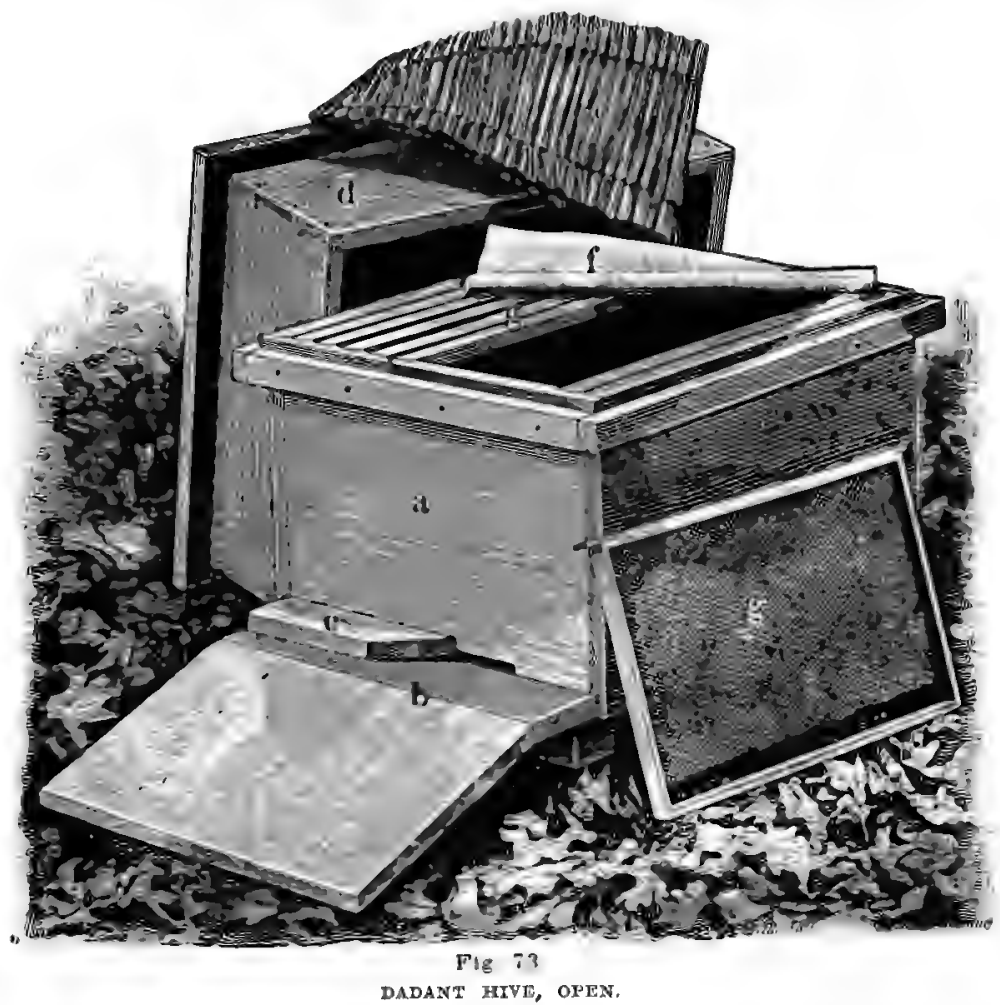

$a$, front of the hive; $b$, slanting board; $c$, movable block; $d$, cap; $e$, straw mat; $f$, enamel cloth; $g$, frame with foundation.

progressive bee-keepers in Furne, in Algeria, and esen in Asiatic countries, under the name of Dadant hive.

312. The morable bottom-board (fig. 73 ) is adjusted or encased in the body of the main hive, on all sides but the 
front, to shed the rain and better protect the colony against ants and moths. It projects forward three inches, at least, to support an adjustable entrance-block. Some Apiarists use a tin slide, instead of an entrance-block. We object to it, because, if glued by bees it may be bent in handling, and if it is nislaid, it cannot always be promptly replaced; while

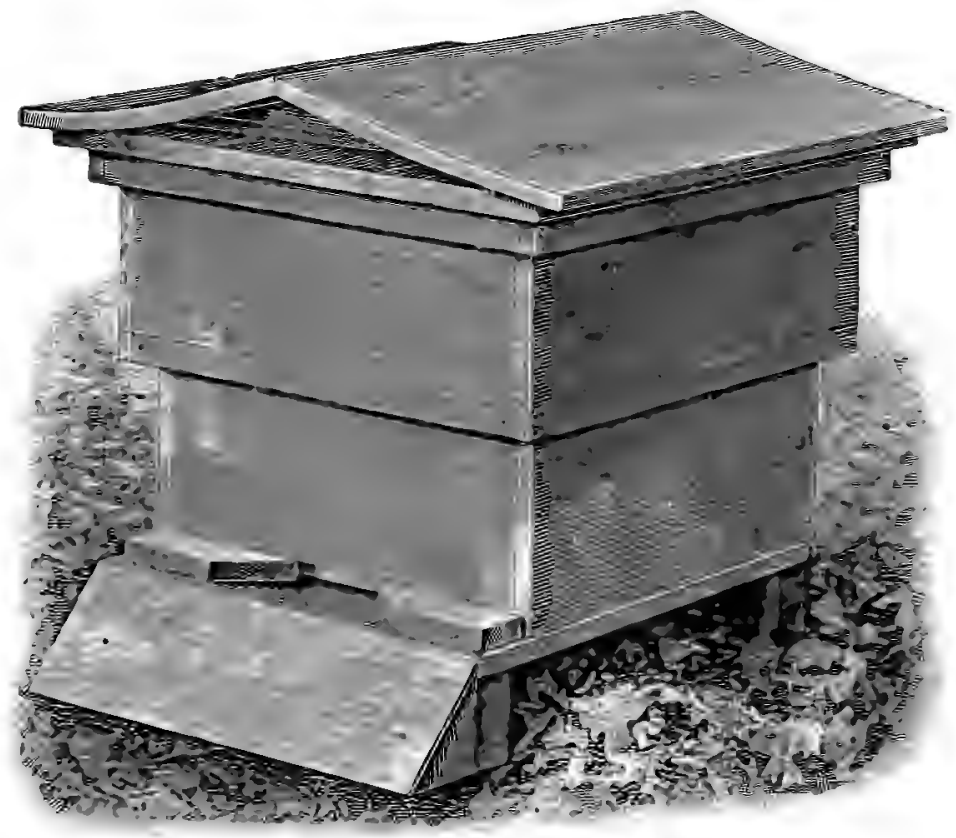

Fig. 74 .

DADANT FIVI, SETHMG FLAT ON THE BOTTOM.

any square wooden-block ean take the place of the entranceblock, if necessary.

343. The apron, or slanting-board, helps overladen workcrs areach the entrance, when they lave fallen to the ground. The blocks that support the bollon, may he made of wiequal height, so as to give the hive the proper forward slant, on 
level ground. If the grain of the lumber in the bottom-board runs from front to rear, it will shed water more readily, and rot less. If the bottom is nailed on the cross-blocks, it will not be in danger of warping.

Our Swiss friends make the bottom-board with the grain running from side to side. They say that in this way they can make it fit exactly in the lower rabbet of the hive, without swelling or shrinking. They also make the apron, with hinges fastened on the bottom-board, and in snowy or cold weather, they raise it and lean it against the hive, to protect the entrance.

311. The adjustable botlom-board is convenient in many instances. If in taking the bees from a winter repository,

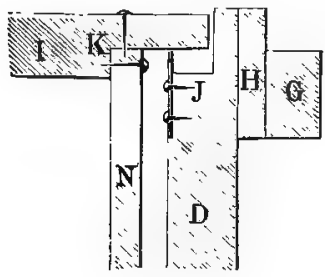

Fig 75 .

it is found wet and mouldy, you can at once exchange it for a dry one, and wipe the wet board at leisure. Or, if a comb breaks down in Summer, by weight and heat, the hive can be lifted off its bottom, and placed on a clean stand, so that the leaking honey and broken combs can be instantly removed, and robbing or daubing of bees avoided. Moreover, the bottom-board is the first part of the hive to decay, and a hive-body and cover will usually outlast two bottomboards. As many bee-keepers use the hive-bodies of small Langstroth hives in two or more stories, they do not cut an entrance in the front board, but make the bottom-board with slats on three sides so as to leave an entrance in front, fig. 84 . Doctor C. C. Miller makes his bottom-boards with a twoinch space under the frames. 
345. The body of the hive is made double on the back, which should always be the North side of the hive. (567.) This, with the division-board inside, on the West, shelters the colony more effieiently than a single board against the

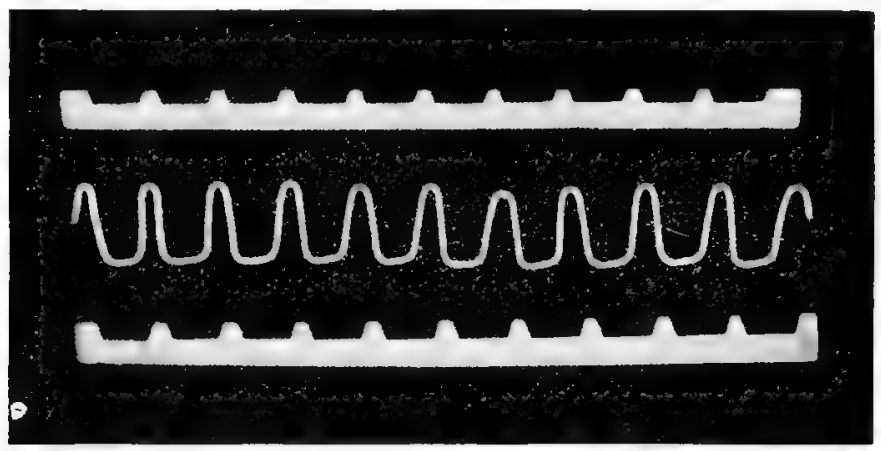

Fig. 76.

METAL RABBETS AND BOTTOM GUIDE FOR FRAMES.

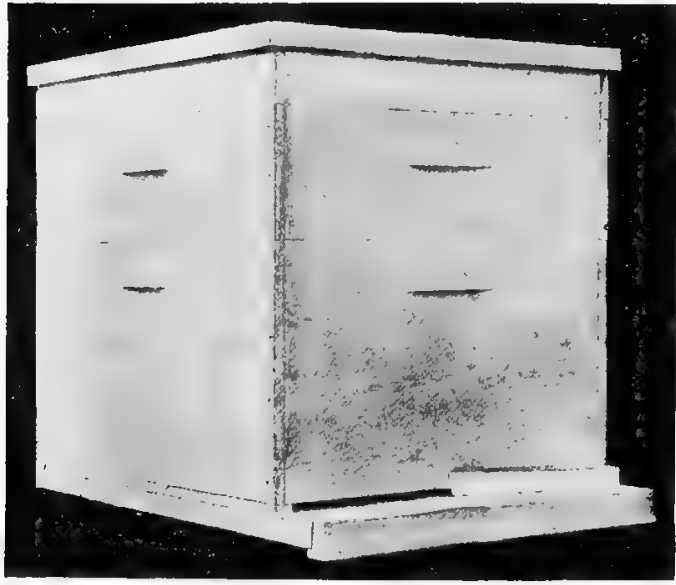

Fig. 77.

ONE AND A HALF STORY TRI-STATE LANGSTROTH HIVE. 
cold North-West winds of Winter. If the bees are to be wintered indoors, the double back may be dispensed with. A more simple form of body, setting flat on the bottom, as in fig. 74 , can also be made.

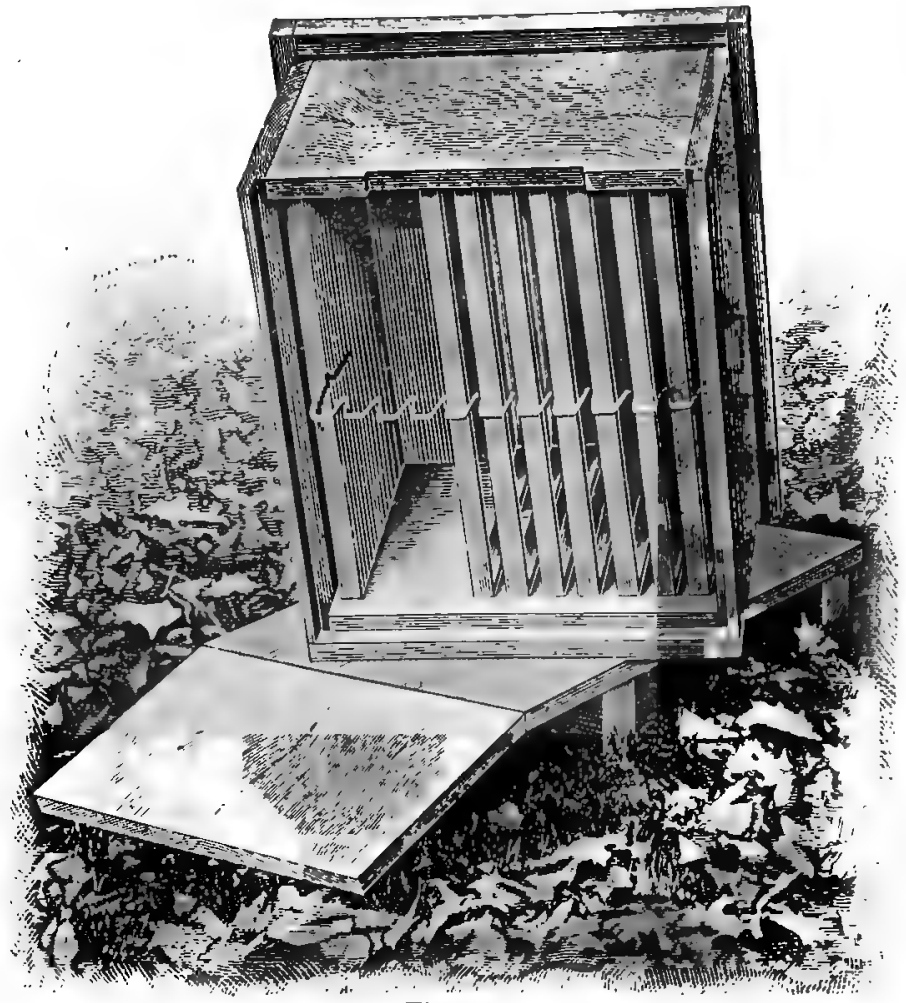

Fig. 78.

BHOWING HOW THE SPACING WIRE IS MTXED.

Objections are raised to this double back, by Apiarists .who move their bees often. In such cases the hive must be as light as possible. But we aim to leave our hives on the spot where the bees are located and weight is not an objection for us. 
316. The rabbet in which the frames hang is made with a sheet-iron shoulder (fig. 75), supporting the frame. This can be dispensed with altogether, but in such cases, the rabbet , should be only deep enough for the frame to hang as represented in fig. 59. The plain wooden rabbet is objectionable, because the bees glue the frame shoulders with propolis.

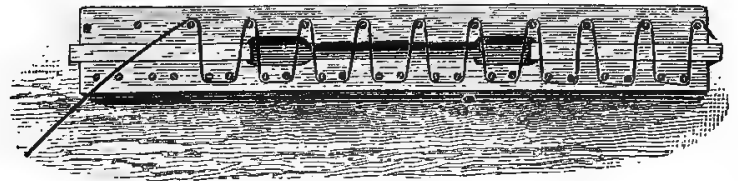

Fig. 79.

SHOWING THE TOOL USTD TO BEND THE WIRE BRACES.

A hive has been devised by E. T. Abbott of Missouri, which has a metal rabbet notehed for the frames to hang at proper distances, fig. 76. This rabbet which we now use in some of our hives is made by us quite shallow, so the frames may be slipped along with but little difficulty in case of need. A Langstroth hive made with these improvements as also with

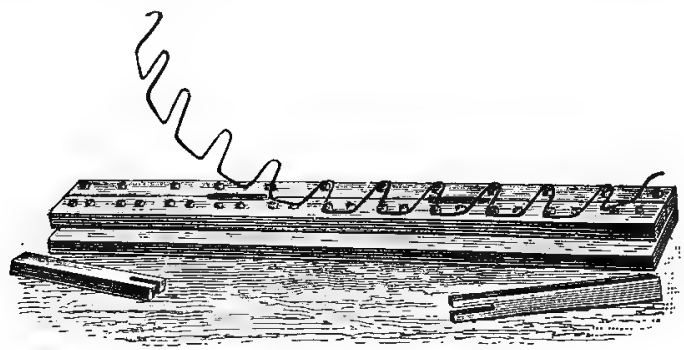

Fig. 80.

SHOWING HOW THE WIRE IS REMOVED.

a bottom guide as in fig. 78 , is now sold extensively for comb honey production (fig. 77).

348. The Spacing-wire, an improvement on Quinby's wire brace, to space the frames at the bottom, is found very convenient in hives as deep as this. It is also useful in indicat- 
ing to novices the number of frames to be placed in the hive. Even a practical bee-keeper will sometimes make the mistake of putting eleven or thirteen frames, in a hive that should hold twelve. With this wire, mistakes are impossible, as they will at once be detected. Besides, if the hive has to be transported some distance, it keeps the frames from jarring. Its cost is insignificant. Some Swiss Apiarists use two of these, one in each end.

318. The entrance should not be less than five-sixteenths, or more than three-eighths of an inch in depth, in order to give easy passage to the bees, and at the same time, keep out mice. Round holes are objectionable. Each hive is

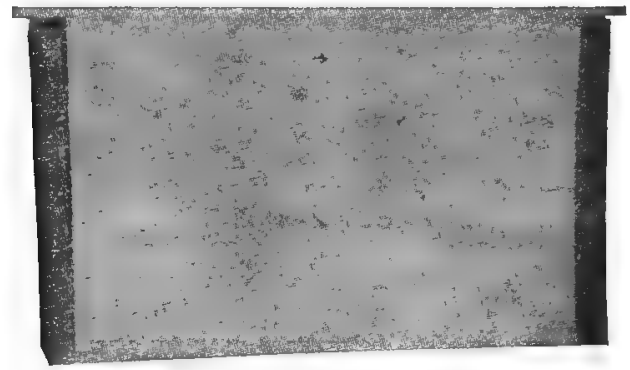

Fig, 81:

DTVISIUAY BOARD.

furnished with an entrance-block, somewhat heavy, and eut as in fig. 73 , to reduce, or close the entrance according to the emergencies.

349. The division board, also called contractor or dummy, is an indispensable feature of all good kives. With its help, the hive may be adjusted to the size of the weakest swarm, and in Winter, the space behind it can be filled with warm and absorbing material (636). The constant use of a division board, even in the strongest colonies, renders the handling of combs much easier. All Apiarists know that the first comb is the hardest to remove. By removing the board first, the combs are at once free and can be easily taken out. 
350. This board is made of the same depth as the frames, with a similar top-bar. Some Apiarists use a division-board the full depth of the hive, but in moving it, bees are crushed under it, and if any bees happen to be on the outside of it, they cannot escape, and die there. On the other hand, this bee-passage is not objectionable, since heat, having a tendency to rise, does not escape through it. The board is made one-fourth inch shorter than the inside of the hive, and a strip of oil-cloth or enamel-eloth, one and a half inches wicle, is tacked on, to fill the spaces at each end. In this way, the board fits well against the ends, and is never glued so as to make it difficult to remove. A small half-round pine-strip, laid against the end of the board, while tacking on the cloth, and pulled out afterwards, helps to tack the cloth properly. To prevent the bees from tearing or gnawing the edge of the cloth, some Apiarists nail a small strip of tin over it.

The make our division board $7 / 8$ of an inch in thickness and put it in the place of a frame. This gives $5 / 8$ of room behind it, which allows more freedom to move it.

351. In the diagram (fig. 72 ) the reader will notice the strip $H$ used to widen the upper surface of the rabbeted end of the hive. This wide surface is rery convenient, to make the cloth and straw-mat fit closely, as they can thus be cut a little longer.

352. The oil-cloth or enamel-cloth, first applied to hive purposes by $\mathrm{R}$. Bickforl, is used over the brood-frames in Spring. It fits closely, concentrates the heat, and can be removed without jar or effort. Then the surplus arrangement, or upper story, is put on, this cloth is removed and placed at the top. ( 559$)$. All Apiarists, or nearly all, who have tried the oil-cloth and honey-board simultaneously, have discarded the latter forever, except in some cases of combhoney production, when a perforated zine ( $\mathbf{2} \mathbf{2}$ ) honey-board is used between the stories. The oil-cloth is sometimes gnawed, or rather pulled to pieces by the bees in a few years, 
but its cost is so small, and its use so great, that it is worth while to replace it as often as necessary.

353. The straw-mat is one of the most useful and necessary implements of the bee-hive. It is far superior to the wooden-mat described by one or two writers. It is flexible and porous, warm in Winter, cool in Summer. It may be made of rye straw, or of what is called slough-grass, a tough and coarse grass growing in marshy places, and abounding on the bottoms of the Mississippi Valley. The mat shown in fig. 73 is only about one inch thick.

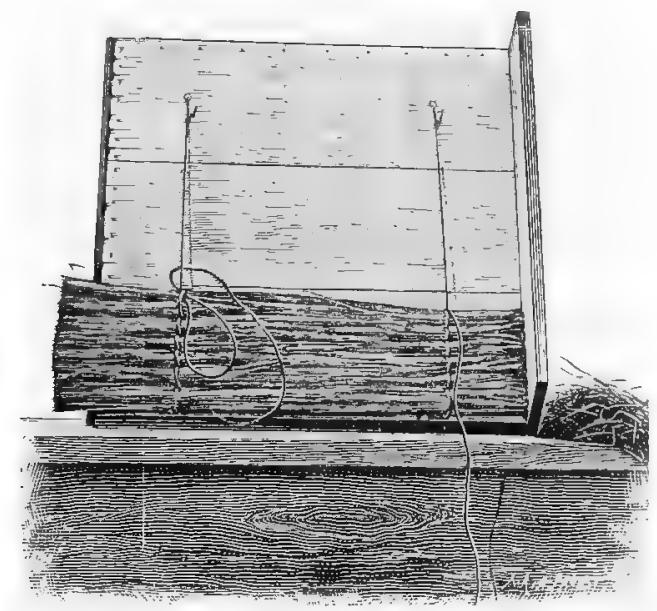

Fig. 82.

FRAME TO MAKE STRAW MATS.

But it is quite sufficient. We are sure that there is nothing' that will equal this implement, except a piece of heavy felt of proper size.

In fig. 82 we present to our readers an engxaving of a frame, for making these mats. They are very simple in construction. It is well, in making them, to use strong twine, soaked in linseed-oil; for the moisture, which escapes from the bees in Winter, would soon rot the string. 
The enamel-cloth is removed before Winter (635), and the mat placed immediately over the frames. A good mat will last as long as the hive.

We have used these mats for forty years and would not think of getting along without them.

354. The upper story or cover may be a half-story cap, in one piece (fig. 72), or in two pieces (fig. 74), or, if only full stories are used for surplus, it may be a shallow cover,

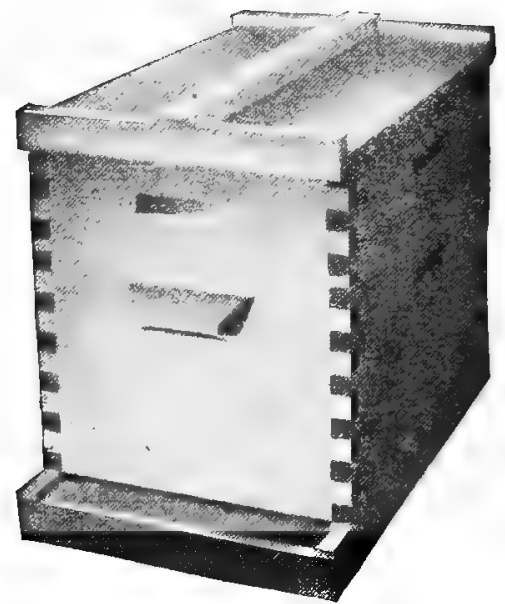

Fig. 83 .

DOVETALED OR LOCK CORNER HIVE.

which will fit over either the first or the second story. We prefer the half-story cap, which can be readily filled with absorbents for Winter, and is adapted to any style of supers.*

355. The caps must fit freely so as to be easily removed. They may be made of lighter lumber than the body of the hive, to save fatigue to the Apiarist in handling them. The top of the hive must be water-tight. Cracks, knots and seams should be avoided, or should be thoroughly painted

* This term is used by Apiarists to designate any upper box placed over the main lower hive. 
with roof-cement. Before putting together the boards which form the top of the cap of our hives, we make, along both sides of the joints, a rounded groove, three-eighths of an inch wide and one-fourth of an inch deep, in which the rainwater runs, instead of leaking inside. Mr. MeCord of $\mathrm{Ox}$ ford, 0 ., made the covers of his hives water-tight, by covering them with strong muslin; tacked on with a strip nailed

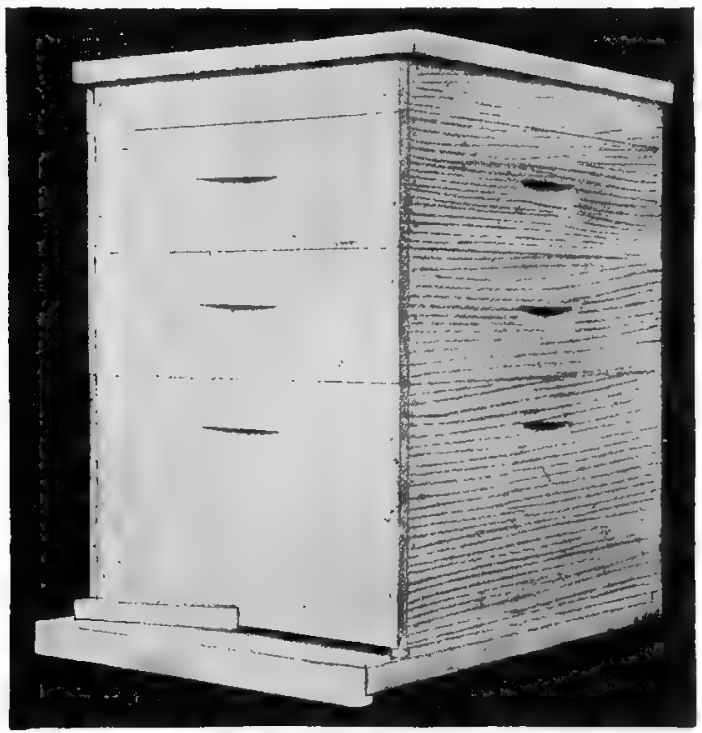

Fig. 84.

TRI-STATE HIVE, WITH FLAT COVER AND TWO SUPERS.

to the edges and thoroughly painted. Mr. G. M. Doolittle and Dr. C. C. Miller use tin, painted white, on the tops of their hives. The Swiss and French bee-keepers do the same.

A hive is made by some manufacturers which contains about as much brood-chamber space as our large hive, while more cheaply constructed. This is called the Jumbo hive (fig. 85), and is made with lock corners similar to what is termed the 
"dovetailed hive." It is an economical hive, but we prefer our hive with telescope cap as described.

356. The hives should always be painted, not only to make them last, but to give them a neat appearance. No dark colors should be used, as they absorb the sun's heat, nor should all the hives be of the same tint (503). If the joints are painted when they are put together, they will last much longer. Every old Apiarist well knows that the joints are the first to decay.

35\%. Each hive, in an apiary, should bear a number, on

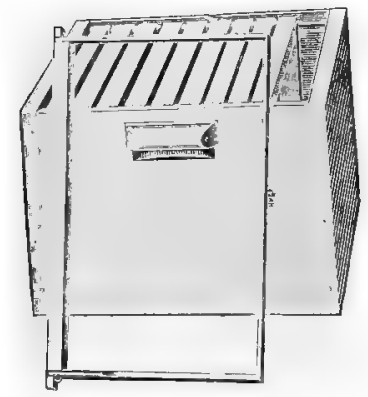

Fig. 85.

THE JUMBO HIVE.

("The A B C of Bee Culture.")

the back of the brood apartment; and this should be printed in black characters, large enough to be seen at a distance. In small apiaries bee-keepers use a slate, on each hive; but in large ones, where many operations are performed, it is better to keep a record of the condition of the colonies, and of all the operations, in a special book.

We will add, that a hive which does not furnish a thorough control orer every comb cannot allow of the manipulations which the bee-keeper's necessities demand. Of such hives, the best are those which best unite cheapness and simplicity, with protection in ITinter, and ready access to the spare honey-ioxes, or supers. 
358. In elosing this chapter on hives, we cannot refrain from advising the beginners in bee-culture to be very cautious in buying patent hives. More than eight hundred patents on bee-hives and implements have been issued in the United States from 1873 to 1890 . Not ten of these have proved to be of any use to bee-keepers. The mention of this fact will suffice to show the small value of these 790 patents, and the loss incurred by those who have bought them, before they were able to judge of their merits.

\section{Materials for Bee-Hives.}

359. The variety of opinions respecting the best materials for hives, has been almost as great as on the subject of their proper size and shape. Columella* and Virgil recommend the hollowed trunk of the cork tree, than which no material would be more admirable if it could only be cheaply procured. Straw hives have been used for ages, and are warm in Winter and cool in Summer. The difficulty of making them take and retain the proper shape for improved bee-keeping, is an objection to their use. Hives made of wood are, at the present time, fast superseding all others. The lighter and more spongy the wood, the poorer will be its power of conducting heat, and the warmer the hive in Winter and the cooler in Summer. Cedar, poplar, tulip-tree, and especially soft pine, afford excellent materials for beehives. The Apiarist must be governed, in his choice of lumber, by the cheapness with which any suitable kind can be obtained in his own immediate vicinity, and by its lasting qualities.

Scholz, a German Apiarist, recommends hives made of adobe-in which frames or slats may be used-as cheaply constructed, and admirable for Summer and Winter. Such structures, however, cannot be moved. But in many parts

* Columelia, about the middle of the first century of the Christian Era, wrote twelve books on husbandry-"De re rustica." 
of our country, where both lumber and saw-mills are scarce, and where people are accustomed to build adobe houses, they might prove desirable. The material is plastic elay, mixed with cut straw, waste tow, etc.

360. To make the movable-frame hives to the best advantage, the lumber should be cut out by a circular saw, driven by steam, water, or horse-power, or even by footpower. In buildings where such saws are used, the frames may be made from the small pieces of lumber, seldom of any use, except for fuel, and may be packed almost solid in a box, or in a hive which will afterwards serve for a pattern. One frame in such a box, properly nailed together, will serve as a guide for the rest. The parts of the hive can easily and cheaply be made by any one who can handle tools. Much has been said of late, concerning the great cost of factory-made hives. Lumber is constantly growing more scarce and higher in price, and the only way to have cheap hives is to make them of lumber selected out of odds and ends and short pieces. The dovetailed or lock corner hive (figs. 83, 85), sold by most dealers cannot be manufactured in a small shop or factory; but the lock joints are not indispensable. When the lumber is haived at the joints and nailed both ways the corners are just as likely to hold and will rot less.

361. Mr. A. I. Root, in a former edition of the A B C of Bee-Culture gave very good instructions about hive making on a small scale. We here eite, with illustrations, his explanation of "why boards warp":

"Before going further, you are to sort the bcards so as to have the heart side of the lumber come on the outside of the hive. If you look at the end of each board, you can see by the circles of growth, which is the heart side, as is shown in the cuts. At B, you see a board cnt off just at one side of the heart of the tree; at $C$, near the bark; at $A$, the heart is in th center of the board. You all know, almost without being toin that boards always warp like $\mathrm{C}$; that is, the heart side becomes convex. The reason is connected with the shrinkage of boards 
Plate 15.

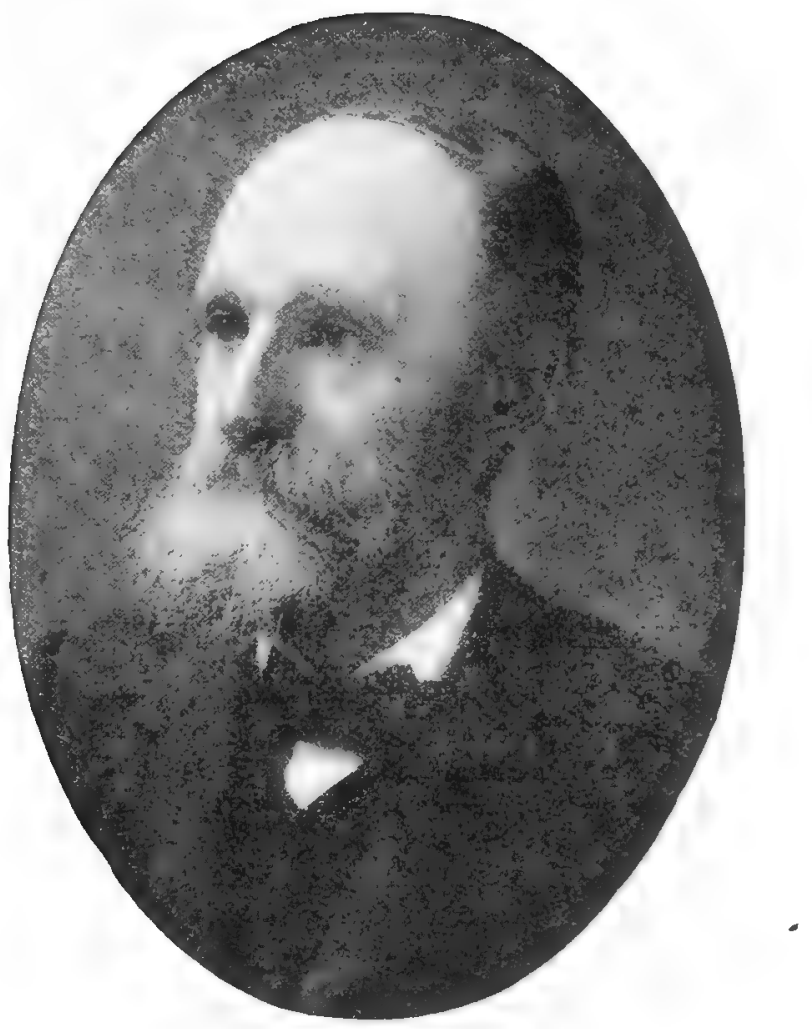

A. I. ROOT (Novice)

Author of "The $A$ B $C$ of Bee-Culture."

Formerly editor of "Gleanings in Bee-Culture."

This writer is mentioned pages $63,64,96,97,98,99,152,153,178$, $179,295,298,325,333,334,357,383,384,385,454,519$. 
in seasoning. When a log lies until it is perfectly seasoned, it often checks as in fig. 2. You will observe that the wood shortens in the direction of the circles, and but very little, if any, along the lines that run from the bark to the center. To allow this shrinkage in one direction, the log splits or checks in the direction shown. Now to go back to our boards, you will see that $B$ shrinks more than $A$, because $A$ has the heart of the tree in its eenter; that $\mathrm{C}$ will shrink, in seasoning, much more on the bark side, than on the heart side; that this cannot fail to bring the board out of a level; and that the heart side will always be convex. You have all seen bee-hives, probably, with the corners separated and gaping open, while the middle of the board was tight up in place. The reason was that the mechanic
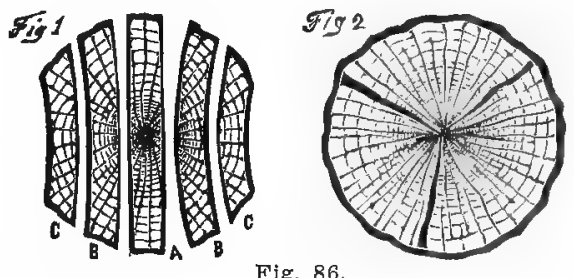

Fig. 86.

had put the boards on, wrong side out. If the heart side had been outward, the corners of the hive would have curled inwardly, and if the middle had been nailed securely, the whole hive would have been likely to have close, tight joints, even if exposed to the sun, wind, and rain."

362. Double-walled hives, chaff hives, and Winter covers, will be described in the chapter on "Wintering" $(\mathbf{6 1 9})$. The upper stories, half stories, wide frames, sections, etc., for comb, or extracted honey, will be discussed in the chapter on honey producing (/16).

\section{Ventilation of the Bee-Hive.}

363. If a populous colony is examined on a warm day, a number of bees may be seen standing upon the alightingboard, with their heads turned towards the entrance of the hive, their abdomens slightly elevated, and their wings in 
such rapid motion, that they are almost as indistinct as the spokes of a wheel, in swift rotation on its axis. A brisk current of air may be felt proceeding from the bive; and if a small piece of down be suspended at its entrance, by a thread, it will be drawn out from one part, and drawn in at another. Why are these bees so deeply absorbed in their fanning occupation, that they pay no attention to the busy numbers constantly crowding in and out of the hive? and what is the meaning of this double current of air? To Huber, we owe the satisfactory explanation of these curious phenomena. The bees, thus singularly plying their rapid wings, are ventilating the hive; and this double current is caused by pure air rushing in, to supply the place of the foul air which is forced out. By a series of beautiful experiments, Huber ascertained that the air of a crowded hive is almost as pure as the surrounding atmosphere. Now, as the entrance to such a hive is often very small, the air within cannot be renewed, without resort to artificial means. If a lamp is put into a close vessel, with only one small orifice, it will soon exhaust the oxygen, and cease to burn. If another small orifice is made, the same result will follow; but if a current of air is by some device drawn out from one opening, an equal current will force its way into the other, and the lamp will burn until the oil is exhausted.

361. It is on this principle of maintaining a double current by artificial means, that bees ventilate their crowded habitations. A file of rentilating bees stands inside and outside of the hive, each with head turned to its entrance, and while, by the rapid faming of their "many twinkling" wings, a brisk current of air is blown out of the hive, an equal current is drawn in. As this important office demands unusual physical exertion, the exhausted laborers are, from time to time, relieved by fresh detachments. If the interior of the hive permits inspection, many ventilators will be found scattered through it, in very hot weather, all busily engaged in their laborious employment. If its entrance is 
contracted, speedy accessions will be made to their numbers, both inside and outside of the hive; and if it is closed entirely, the heat and impurity quickly increasing, the whole colony will attempt to renew the air by rapidly vibrating their wings, and in a short time, if unrelieved, will die of suffocation.

365. Careful experiments show that pure air is necessary not only for the respiration of the mature bees, but for hatching the eggs, and developing the larvæ; a fine netting of air-vessels enveloping the eggs, and the cells of the larvæ being elosed with a covering filled with air-holes (168).

366. Ventilation is also necessary to ripen the nectar harvested in the fields and evaporate the water that it contains.

In Winter, if bees are kept -in a dark place, which is neither too warm nor too cold, they are almost dormant, and require very little air; but even under such circumstances, they cannot live entirely without it; and if they are excited by atmospheric changes, or in any way disturbed, a loud humming may be heard in the interior of their hives, and they need almost as much air as in warm weather. (621).

367. If bees are greatly disturbed, it will be unsafe, especially in warm weather, to confine them, unless they have a very free admission of air; and even then, unless it is admitted above, as well as below the mass of bees, the ventilators may become clogged with dead bees, and the colony perish. Bees under close confinement become excessively heated, and their combs are often melted; if dampness is added to the injurious influence of bad air, they become diseased; and large numbers, if not the whole colony, may perish from diarrhœa. Is it not under precisely such circumstances that cholera and dysentery prove most fatal to human beings? the filthy, damp, and unventilated abodes of the abject poor, becoming perfect lazar-houses to their wretched inmates.

368. We have several times examined the bees of new 
swarms which were brought to our apiary, so closely confined, that they had died of suffocation. In each instance, their bodies were distended with a yellow and noisome substance, as though they had perished from diarrhœa. A few were still alive, and although the colony had been shut up only a few hours, the bodies of both the living and the dead were filled with this same disgusting fluid, instead of the honey they had when they swarmed.

In a medical point of riew, these facts are highly interesting; showing as they do, under what circumstances, and how speedily, diseases may be produced resembling dysentery or cholera.

369. In very hot weather, if thin hives are exposed to the sun's direct rays, the bees are excessively annoyed by the intense heat, and have recourse to the most powerful ventilation, not merely to keen the air of the hive pure, but to lower its temperature.

Bees, in such weather, often leare, almost in a body, the interior of the hive, and cluster on the outside, not merely to escape the close heat within, but to guard their combs against the danger of being melted.

370. Few novices have an adequate idea of the danger to heavily laden combs from heat, especially if the cluster of bees, outside, happens to obstruct the entrance, by hanging in front of it. In the Summer of 187,7 , we have seen whole rows of hives, which were exposed to the sun's rays, in a large apiary, "melt down" almost simultaneously,causing a loss of hundreds of dollars,-for lack of sufficient ventilation, owing to the clustering of the bees in front of the entrance.

371. After one amb breaks down, the leaking honey spreads orer the bottom-board, runs out of the entrance, daubs the bees, and prevents further ventilation; then the rest of the combs fall pell-mell on one another, crushing the brood, the queen, and the remaining bees. It is utter destruction. 
372. In very hot weather, the bees are specially careful not to cluster on new combs containing sealed honey, which, from not being lined with cocoons, and from the extra amount of wax used for their covers, melt more readily than the breeding-cells.

373. Apiarists have noticed that bees often leave their honey-cells almost bare, as soon as they are sealed; but it seems to have escaped their observation, that this is absolutely necessary in very hot weather. In cool weather, they may frequently be found clustered among the sealed honeycombs, because there is then no danger of their melting.

Few things are so well fitted to impress the mind with their admirable sagacity, as the truly scientifie device by which they rentilate their dwellings. In this important matter, the bee is immensely in advance of the great mass of those who are called rational beings. It has, to be sure, no ability to decide, from an elaborate analysis of the chemical constituents of the atmosphere, how large a proportion of oxygen is essential to the support of life, and how rapidly the process of breathing converts it into a deadly poison. It cannot, like Liebig, demonstrate that God, by setting the animal and the vegetable world, the one over against the other, has provided that the atmosphere shall, through all ages, be as pure as when it first came from His ereating hand. But shame upon us! that with all our boasted intelligence, most of us live as though pure air was of little or no importance; while the bee ventilates with a philosophical precision that should put to the blush our criminal neglect.

It is said that ventilation cannot, in our case, be had without cost. Can it then be had for nothing, by the industrious bees? Those ranks of bees, so indefatigably plying their busy wings, are not engaged in idle amusement; nor might they, as some shallow utilitarian may imagine, be better employed in gathering honey, or superintending some other department in the economy of the hive. At great expense of time and labor, they are supplying the rest of the 
colony with the pure air so conducive to their health and prosperity. What a difference between them and some human beings, who, "if they lived in a glass bottle, would insist on keeping the cork in !"

Impure air, one would think, is bad enough; but all its inherent vileness is stimulated to still greater activity by airtight, or rather lung-tight stoves, which can economize fuel only by squandering health and endangering life. Not only our private houses, but our places of public assemblage are often either unimproved with any means of ventilation, or to a great extent, supplied with those so deficient, that they only

\section{"Keep the word of promise to our ear,} To break it to our hope."

Men may, to a certain extent, resist the injurious influences of foul air; as their employments usually compel them to live more out of doors: but alas, alas! for the poor women! In the very land where they are treated with such merited deference and respect, often no provision is made to furnish them with that first element of health, cheerfulness, and beauty, heaven's pure, fresh air.

\section{Observixg Hives.}

3\%4. For nearly a century, hives have been in use containing only one comb, inclosed on both sides by glass. These hives are darkened by shutters, and, when opened, the queen is as much exposed to observation as the other bees. Mr. Langstroth discovered that, with proper precautions, colonies can be made to work in observing-hives, even when exposed continually to the full light of day; so that observations may be made at all times, without interrupting by any sudden admission of light, the ordinary operations of the bees. In such hives, many intelligent persons from various States in the Union have seen the queen-bee depositing her eggs in the cells, while surrounded by an affectionate circle 
of her devoted children. They have also witnessed, with astonishment and delight, all the mysterious steps in the process of raising queens from eggs, which with the ordinary development would have produced only the common bees. Often for more than three months, there has not been a day in our apiary, in which some colonies were not engaged in rearing new queens to supply the place of those taken fron them; and we have had the pleasure of exhibiting these facts to bee-keepers, who never before felt willing to credit them.

375. An Apiarist may use the box hives a whole lifetime, and, unless he gains his information from other sources, may yet remain ignorant of some of the most important principles in the physiology of the honey-bee; while any intelligent cultivator may, with an observing-hive and the use of movable-frames, in a single season, verify for himself the discoveries which have been made only by the accumulated toil of many observers, for more than two thousand years.

"An opportunity of beholding the proceedings of the queen, in hives of the old form, is so very rarely afforded, that many Apiarists have passed their lives without enjoying it; and Réaumur himself, even with the assistance of a glass-hive, acknowledges that it was many years before he had that pleasure."'-(Bevan.)

Swammerdam, who wrote his wonderful treatise on bees, before the invention of observing-hives, was obliged to tear hives to pieces in making his investigations! When we see what important results these great geniuses obtained, with means so imperfect, if compared with the facilities which the veriest tyro now possesses, it ought to teach us a becoming lesson of humility.

The sentiments of the following extract from Swammerdam, ought to be engraven upion the hearts of all engaged in investigating the works of God:

"I would not have any one think that I say this from a love of fault-finding.' - ho had boen eriticising some incorrect draw- 
ings and descriptions-"my sole design is to have the true face and disposition of Nature exposed to sight. I wish that others may pass the like censure, when due, on my works; for I doubt not that I have made many mistakes, although I can, from the heart, say, that I have not, in this treatise designed to mislead."

376. This hive is a simplified form, but Mr. D. F. Savage suggested a still more simple one, by making the top so narrow as not to conceal any of the bees, and leaving off

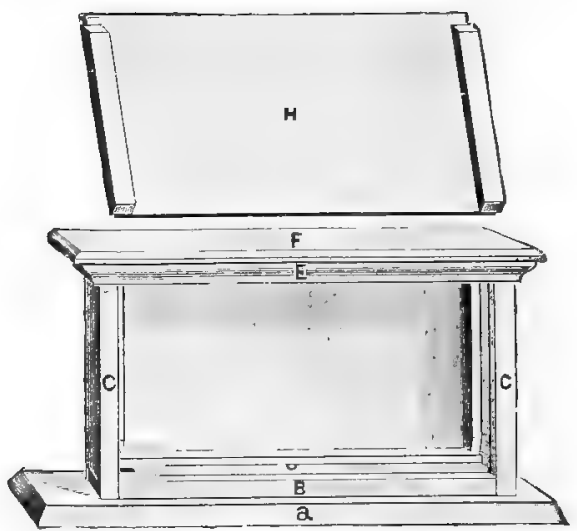

Fig. 87.

OBSERVING HIVE.

(From Alley's "Handy-Book.")

$a$, stand ; $B, C C$, movable glass frame; $E$, moulding under which the top of the shutter $H$ slips, to darken the hive, if needed; $F$, movable top, held in place by hooks. The comb of brood and bees, is put in, . by removing the top and one side.

the shutters entirely, to replace them with a dark cloth thrown over the hive. But this cloth can be used only when the hive is established inside the house. Its main advantages are to do away with the noise and jar of opening the shutters.

378. A parlor observing-hive of this form may be conveniently placed in any room in the house; the alighting- 
board being outside, and the whole arrangement such that the bees may be inspected at all hours, day, or night, without the slightest risk of their stinging. Two such hives may be placed before one window, and put up or taken down in a few minutes, without cutting or defacing the woodwork of the house.

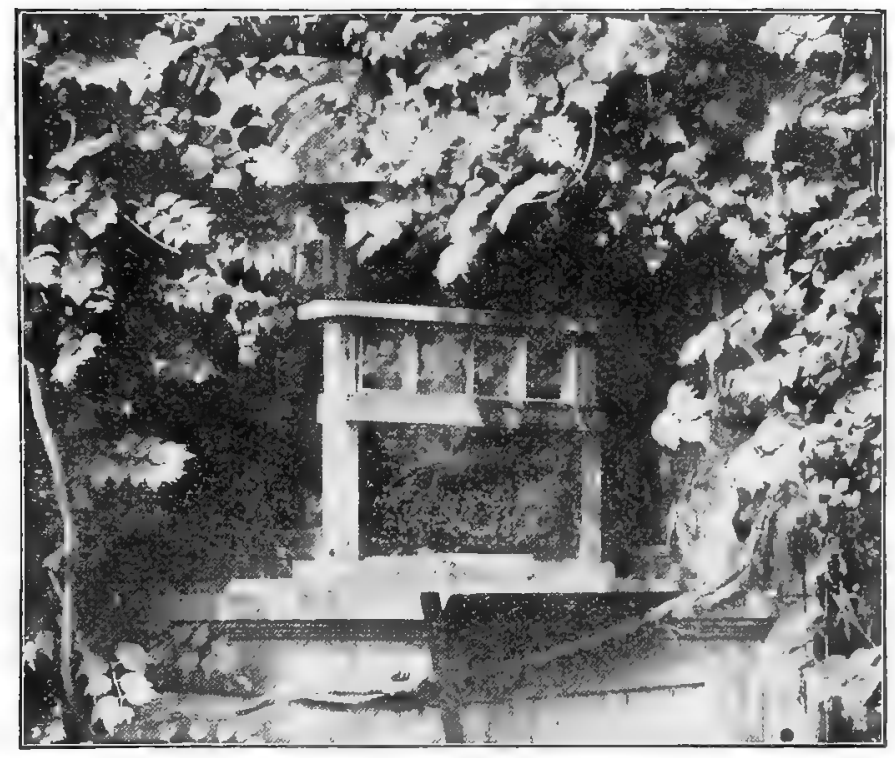

Fig. 88.

OBSERVING HIVE IN A WINDOW.

("American Bee Journal.")

An observing-hive will prove an unfailing source of pleasure and instruction; and those who live in crowded cities, may enjoy it to the full, even if condemned to the penance of what the poet has so feelingly described as an "endless meal of brick." The nimble wings of the agile gatherers will quickly waft them above and beyond "the smoky chimney-pots"; and they will bear back to their eity homes 
the balmy spoils of many a rustic flower, "blushing unseen," in simple loveliness. Might not their pleasant murmurings awaken in some the memory of long-forgotten joys, when the happy country child listened to their soothing music, while intently watching them in the old homestead-garden, or roved with them amid pastures and hill-sides, to gather the flowers still rejoicing in their "meadow-sweet breath," or whispering of the precious perfumes of their forest home?

"To me more dear, congenial to my heart, One native charm than all the gloss of art; Spontaneous joys, where nature has its play, The soul adopts and owns their first-born sway;

Lightly they frolic o'er the vacant mind, Unenvied, unmolested, unconfined, But the long pomp, the midnight masquerade, With all the freaks of wanton wealth array'd, In these, ere triflers half their wish obtain, The toilsome pleasure sickens into pain; And e'en while fashion's brightest arts decoy, The heart distrusting asks, if this be joy."

Goldsmith。 


\title{
CHAPTER V.
}

\author{
HLANDLING BEES.
}

The Honey-Bee Capable of Being Tamed.

378. IF the bee had not such a formidable weapon (78) both of offense and defense, many who now fear it might easily be induced to enter upon its cultivation. As the present system of management takes the greatest possible liberties with this insect, it is important to show how all necessary operations may be performed without serious risk of exciting its anger.

Many persons are unable to suppress their astonishment. when they see an Apiarist, with the help of a little smoke, opening hive after hive, removing the combs covered with bees, and shaking them off in front of the hives; forming new swarms, exhibiting the queen, transferring the bees with all their stores to another hive; and in short, dealing with them as if they were as harmless as flies. We have sometimes been asked, whether the hives we were opening had not been subjected to a long course of training; when they contained swarms which had been brought only the day before to our apiary.

We shall, in this chapter, show that any one favorably situated may enjoy the pleasure and profit of a pursuit which has been appropriately styled, "the poetry of rural economy," without being made too familiar with a sharp little weapon, which speedily converts all the poetry into sorry prose.

It must be manifest to every reflecting mind, that the Creator intended the bee, as truly as the horse or the cow, for the comfort of man. In the early ages of the world, and indeed until quite modern times, honey was almost the 
only natural sweet; and the promise of "a land flowing with milk and honey" had once a significance which it is difficult for us fully to realize. The honey-bee, therefore, was created not merely to store up its delicious nectar for its own use, but with certain propensities, without which man could

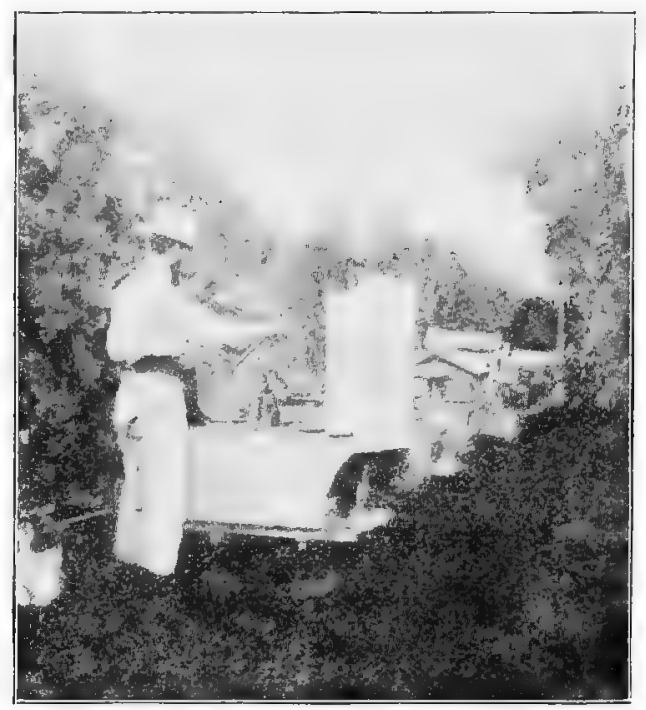

Fig. 89.

OPENING THE HIVE AND EXAMTNING THE COMBS.

Apiary of Mr. Mont-Jovet, Albertville, Savoie.

no more subject it to his control, than he could make a useful beast of burden of a lion or a tiger.

379. One of the peculiarities which constitutes the foundation of the present system of management, and indeed of the possibility of domesticating at all so irascible an insect, has never to our knowledge been clearly stated as a great and controlling principle by any one before Mr. Langstroth. It way be thus expressed: 
A honey-bee when heavily laden with honey never volunteers an attack, but acts solely on the defensive.

This law of the honeyed tribe is so universal, that a stone might as soon be expected to rise into the air, without any propelling power, as a bee well filled with honey to offer to sting, unless crushed or injured by some direet assault. The man who first attempted to hive a swarm (428) of bees, must have been agreeably surprised at the ease with which he was able to accomplish the feat; for it is wisely ordered that bees, when intending to swarm, should fill their honey-bags to their utmost capacity. They are thus so peaceful that they

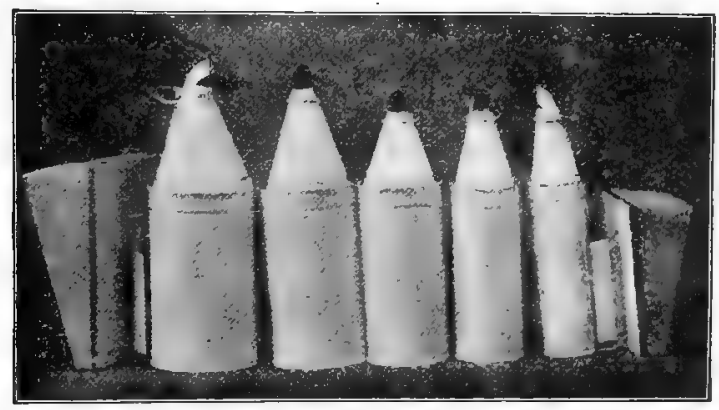

Fig. 90.

BINGHAM SMOKER.

can easily be secured by man, besides having materials for commencing operations immediately in their new habitation, and being in no danger of starving, if several stormy days should follow their emigration.

380. While swarming, bees issue from their hives in the most peaceful mood imaginable; and unless abused allow themselves to be treated with the greatest familiarity. The hiving of them might always be conducted without risk, if there were not, occasionally, some improvident or unfortunate ones, who, coming forth without a sufficient amount of the soothing supply, are filled instead with the bitterest hate against any one 
daring to meddle with them. Such thriftless radicals are always to be dreaded, for they must vent their spleen on something, even though they perish in the act. (84.)

If a whole colony, on sallying forth, possessed such a ferocious spirit, no one could hive them unless clad in a coat of mail, bee-proof; and not even then, until all the windows of his house were closed, his domestic animals bestowed in some place of safety, and sentinels posted at suitable stations,

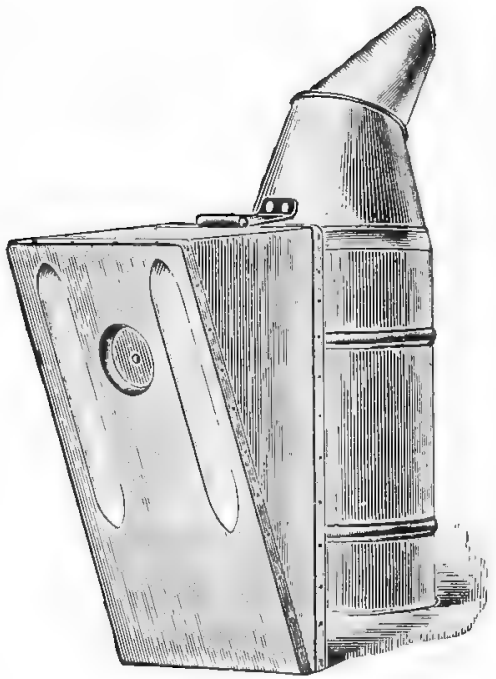

Fig. 91.

CHAMPION SMOKER.

to warn all comers to keep at a safe distance. In short, if the propensity to be exceedingly good-natured after a hearty meal, had not been given to the bee, it could never have been domesticated, and our honey would still be procured from the clefts of rocks or the hollows of trees. Probably the good nature resulting from a hearty meal is not the only cause of the above fact. There is another physiological fact connected with it (85). When her stomach is empty, a bee can curve 
her abdomen easily to sting. If her honey-sack is full, the rings of the abdomen are distended, and she finds more diffculty in taking the proper position for stinging.

381. A second peculiarity, in the nature of bees, gives an almost unlimited control over them, and may be expressed as follows:

Bees, when frightoned, usually begin to fill themselves with honey from their combs.

If the Apiarist only succeeds in frightening his little subjects, he can make them as peaceable as though they were incapable of stinging. By the use of a little smoke, the largest and most fiery colony may be brought into complete subjection. As soon as the smoke is blown among them, they retreat before it, raising a subdued or terrified note; and, seeming to imagine that their honey is to be taken from them, they cram their honey-bags to their utmost capacity. They act either as if aware that only what they can lodge in this inside pocket is safe, or, as if expecting to be driven away from their stores, they are determined to start with a full supply of provisions for the way. The same result may be obtained by shutting them up in their hive and drumming upon it for a short time, but this latter process is only successful with some races of bees easily frightened, like the black bees ( 519$)$.

382. The bellows-smokers, in present use, for smoking bees and controlling them, are as far superior to the old method of blowing smoke on them with the mouth from a piece of punk or rotton wood, or a bunch of rags, as the movable-frame hive is superior to the box hive of old. The writer of this, who kept bees in large numbers in several apiaries before the introduction of the practical bellowssmoker, has many a time felt dizzy from the fatigue of blowing smoke on the bees.

Bellows-smokers were used in Europe long ago, but they were not practical, as they could not be used with one hand.

Quinby, one of the veterans of progressive Apiculture, invented the first bellows-smoker that had the bellows on the 
side of the fire-box, that could stand up and draw like a chimney, and that could practically be held with one hand. Bingham afterwards greatly improved on this smoker. Since then, others bave made different styles, all based on Quinby's or on Bingham's ideas.

The Improved Quinby-Bingham smokers have been imitated all over the world, especially in England and France, and we are sorry to say, some of these imitations have been sold as personal inventions, without any credit being given to the real inventors.

A bee-smoker is indispensable to any Apiarist, and should

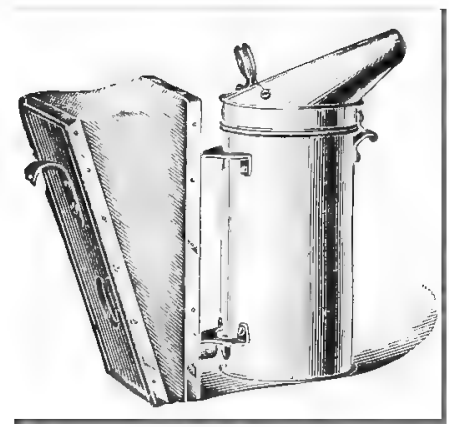

Fig. 92.

CORNEIL SMOKER.

be properly filled, when used, with dry wood, lighted at the bottom by a few hot coals. With a good smoker any kind of wood may be used. Thlen the bees are located in an orchard, dead limbs of apple-trees are handiest and will make good smoke. Shavings, leaves, rags, can also be used, if no wood is at hand. By setting the smoker upright, when not held in the hand, so as to create a good draft, and refilling it from time to time, a good smoke can be kept up from morning till night, if necessary.

In his book, "Forty Years Among the Bees," Dr. C. C. Miller advises the use of what he calls "saltpeter-rags" for lighting the smoker. We quote what he says: 
"Nothing has given me quite so much satisfaction as saltpeter-rags. Like the right kind of rotten wood, the least spark will light a saltpeter-rag so that it will be sure to go, but it is not so slow in its action as the rotten wood and makes a much greater heat, so that chips of sound, hard wood will at once be started into a secure fire. To prepare the saltpeter-rags a crock is kept constantly standing containing a solution of saltpeter. The strength of the solution is not a matter of great nicety. A quarter or a half pound of saltpeter may be used to a gallon of water, and if it evaporates so that the solution becomes stronger, water may be added. A cotton rag dipped in this solution will be ready for use as soon as dried. As a matter of convenience, quite a lot of rags are prepared at a time. They are wrung out of the solution and spread out to dry in the sun."

383. Some Apiarists of England have tried several liquids, for rubbing on the hands, to pacify the bees. Most of these liquids are hydro-carbonous fluids, or volatile oils of plants, such as wintergreen, turpentine, bergamot, cloves, thyme, ete. Mr. Grimshaw, after divers trials, invented a compound of several of these oils, to which he seems to have added ether and chloroform, if our sense of smell does not mislead us. $\mathrm{He}$ calls it Apifuge.

Several apiarists praise this drug, while others say that their bees did not mind it, and sting them as usual; and some complain of blisters on their hands after its use. (British Bee-Journal.)

Mr. Cowan presented us with a vial of Apifuge, but, after trying, we cannot see much advantage to be derived from its use.

384. Mr. Raynor advises the use of a carbolized sheet, to frighten bees :

"Make a solution of $3 \mathrm{oz}$. carbolic acid in a quart of water, and preserve for use. Mix 11/2 oz. of this solution with 11/2 oz. of glycerine; put the mixture in a quart of water, shake well before using; steep in the mixture a piece of calico, or cheese 
cloth, suffeiently large to cover the top of the hive, wring out dry and spread over the hive as soon as the quilt is removed.

"You may use the same to drive the bees out of the sections. Keep the bottles well corked for future use." -(Rev. G. Raynor, in the British Bee-Journal.)

The same liquid may be forced among the bees through an atomizer. As it evaporates it leares no bad smell behind.

385. A neighbor of ours, who is a magnetist, told our

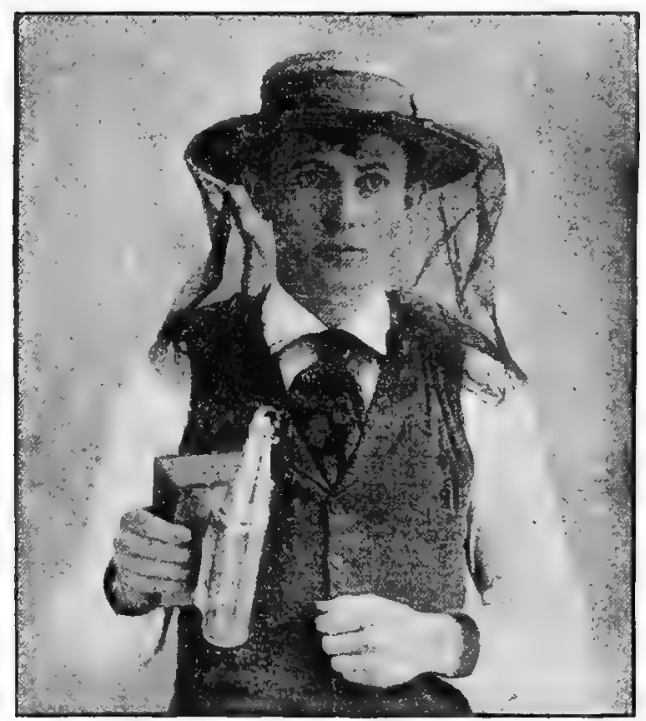

Fig. 93.

VEIL SIWED ON THE HAT.

foreman-Apiarist that bees could be pacified by simply laying one's hands above the combs while the cloth is carefully removed. We have seen bees witlldraw from the frames inside the hive, under this laying on of hands; but we are not sure that such magnetism, if there be magnetism in it, is sufficient to prevent the bees from stinging. 
386. A bee-veil, although objectionable to some beekeepers, who prefer to handle their bees barefaced, is really a necessity in a large apiary. Timid persons feel safer in using it, and even the boldest bee-keepers recognize the necessity of wearing one, when colonies become aroused by accident. The best veils are sewed to the outer edge of the rim of a straw-hat; with a rubber at their lower extremity, to fasten around the neck. The veil can be slipped on and off in a twinkling, if necessity requires; when not in use, it is simply folded into the crown of the hat, where it is always at hand.

We keep a number of these veil hats in our bee-house, for the accommodation of visitors, who wish to look through the wonders of the bee-hive, without fear of stings.

Most veils are made removable, with a rubber at each end; the upper one being slipped over the erown of the hat. This veil can be taken off at will, and carried in the pocket.

In his "Success In Bee-Culture," Mr. Heddon says: "A bee-veil should never be any color but black, as all other shades are more or less difficult to see through clearly," and we fully agree with him. White veils are most especially objectionable. Green is the best color after black.

387. The hands may be protected by india-rubber gloves, such as are now in common use. These gloves, while impenetrable to the sting of a bee, do not materially interfere with the operations of the Apiarist. As soon, however, as he aequires confidence and skill, he will much prefer to use nothing but the bee-hat, even at the expense of an occasional sting on his hands.

An English Apiarist advises persons using gloves to eut the tips of the fingers so as to handle the frames more dexterously, and to wash their fingers with some kind of Apifuge.

Stings on the hands usually cause but little suffering or swelling, while stings on the face are quite painful; and the grotesque appearance which the swelling often gives to the human face, makes it much more desirable to protect the head than the hands. 
If the hands are wet with honey, they will seldom be stung.

388. All woolen clothes are more objectionable to bees than linen or cotton, for wool resembles the hair of animals, being made of it, while linen or cotton resembles the twigs and leaves of plants, being made of vegetable fibre. Butler says:

"They use their stings against such things as have outwardly some offensive excrement, such as hair or feathers, the touch whereof provoketh them to sting. If they alight upon the hair of the head or beard, they will sting if they can reach the skin. When they are angry their aim is most commonly at the face, but the bare hand that is not hairy, they will seldom sting, unless they be much offended."-("Feminine Monarchy," 1609.)

389. In handling bees, it is not always necessary to compel them to fll themselves with honey. With the quiet Italians (551), a few puffs of smoke, at the entrance, when opening the hive, and occasionally on the combs, if they show any disposition to anger, are quite sufficient to keep them down. Some of our best Apiarists often open their hives and handle the bees without smoke. It takes practice, patience and firmness.

While the timid, if unprotected, are almost sure to be stung, there is something in the fearless movements of a skillful operator, that seems to render a colony submissive to his will.

390. Some races, however, like the Cyprian (559), cannot be controlled without a cloud of smoke, but they promptly retreat before the overpowering argument of a good smoker.

391. Bees can be handled at all times; but they are quietest in the middle of the day. At such a time, the old bees, which are the crossest in the colony, are out in the field. In cold, eloudy, or stormy weather, they are most irritable, especially if there is a scareity of honey, as the lurking robbers (664), excite the bees. Old bees that come home loaded, are not cross, while those going out empty, are easily angered. During a plentiful honey flow, when the hives are crowded for room, 
the bees are nearly all full of honey, and the colonies can then be handled without smoke.

By our methods you can superintend a large apiary, performing every operation necessary for pleasure or profit, without as much risk of being stung, as must frequently be incurred in attempting to manage a single hive in the old way.

392. Let all your motions about your hives be gentle and slow; never crush or injure the bees; acquaint yourself fully with the principles of management detailed in this treatise, and you will find that you have little more reason to dread the sting of a bee, than the horns of a favorite cow, or the heels of your faithful horse.

Cotton, quoting from Butler, who, in these remarks, follows mainly Columella, says:

393. "Listen to the words of an old writer:-'If thou wilt have the favor of thy bees, that they sting thee not, thou must avoid such things as offend them: thou must not be unchaste or uncleanly; for impurity and sluttiness (themselves being most chaste and neat) they utterly abhor; thou must not come among them smelling of sweat, or having a stinking breath, caused either through eating of leeks, onions, garlick, and the like, or by any other means, the noisomeness whereof is corrected by a cup of beer; thou must not be given to surfeiting or drunkenness; thou must not come puffing or blowing unto them, neither hastily stir among them, nor resolutely defend thyself when they seem to threaten thee; but softly moving thy hand before thy face, gently put them by; and lastly, thou must be no stranger unto them. In a word, thou must be chaste, cleanly, sweet, sober, quiet, and familiar; so will they love thee, and know thee from all others. When nothing hath angered them, one may safely walk along by them; but if he stand still before them in the heat of the day, it is a marvel but one or other spying him, will have a cast at him."*

* Many persons imagine themselves to be quite safe, if they stand at a considerable distance from the hives; whereas, cross bees delight to attack those whose more distant position makes them a surer mark to their long-sighted vision, than persons who are close to their hives. 
"Above all, never blow $\dagger$ on them; they will try to sting directly, if you do.

"If you want to eatch any of the bees, make a bold sweep at them with your hand; and if you catch them without pressing them, they will not sting. I have so caught three or four at a time. If you want to do anything to a single bee, catch him 'as if you loved him,' between your finger and thumb, where the tail joins on to the body, and he cannot hurt you."

When gorged with honey, they may be taken up by handfuls, and suffered to run over the face, and may even have their glossy backs gently smoothed as they rest on our persons; and all the feats of the celebrated Wildman may be safely imitated by experts, who, by securing the queen, can make the bees hang in large festoons from their chin, without incurring any risk of being taken by the beard.

"Such was the spell, which round a Wildman's arm, Twin'd in dark wreaths the faseinated swarm;

Bright o'er his breast the glittering legions led, Or with a living garland bound his head.

His dextrous hand, with firm yet hurtless hold, Could seize the chief, known by her scales of gold, Prune 'mid the wondering train her filmy wing, Or o'er her folds the silken fetter fling."

394. The ignorance of most bee-keepers of the almost unlimitcd conirol which may be peaceably acquired over bees, has ever been regarded by the author of this treatise as the greatest obstacle to the speedy introduction of modern methods. Such ignorance has led to the invention of costly and complicated hives, all the ingenuity and expense lavished upon which, are known, by the better informed, to be as unnecessary as a costly machine for lifting up bread and butter, and

† While bees resent the warm breath exhaled slowly from the lungs, we have ascertained, that they will run from a blast of cold air blown upon them by the mouth of the operator, almost as quickly as from smoke. Before employing smoke Mr. Langstroth often used a pair of bellows. 
gently pushing it into the mouth and down the throat of an active and healthy child.

We have before us a small pamphlet, published in London in 1851, describing the construetion of the "Bar and Frame Hive" of W. A. Munn, Esq. The object of this invention is to elevate frames, one at a time, into a case with glass sides, so that they may be examined without risk of annoyance from the bees. Great ingenuity is exhibited by the inventor of this very costly and very complicated hive, who seems to imagine that smoke "must be injurious both to the bees and their brood."

395. In opening a hive, little danger may be feared from the bees that are exposed to the light, unless quick motions are made, as they are completely bewildered by their sudden exposure, and removal from the hive.

It is not merely the sudden admission of light, but its introduction from an unexpected quarter, that for the time, disarms the hostility of the bees. They appear, for a few moments, almost as much confounded as a man would be, if, without any warning, the roof and ceiling of his house should suddenly be torn from over his head. Before they recover from their amazement, they are saluted with a puff of smoke, which, by alarming them for the safety of their treasures, induces them to snatch whatever they can. In the working season, the bees near the top are gorged with honey; and those-coming from below are met in their threatening ascent, by a small amount of harmless smoke, which excites their fears, but leaves no unpleasant smell behind. No genuine lover of bees ought ever to use the sickening fumes of tobacco.

396. Heddon says ("Success in Bee-Culture," page 18): "I know of but one instance where the use of smoke can do harm, and that is in smoking the guards of a colony that is in danger of being robbed." (664.) To this important statement, we would add, that too much smoke to a colony already subdued, will drive them from their combs, and often cause them to get in the way of the Apiarist. 
But the greatest care should be taken to repress by smoke, the first manifestations of anger; for, as bees communicate their sensations to each other with almost magic celerity, while a whole colony will quickly catch the pleased or subdued notes uttered by a few, it will often be roused to fury by the angry note of a single bee. When once they are thoroughly exeited, it will be found very difficult to subdue thein, and the unfortunate operator, if inexperienced, will often abandon the attempt in despair.

It cannot be too deeply impressed upon the beginner, that nothing irritates bees more than breathing upon them, or jarring their combs. Every motion should be deliberate, and no attempt whatever made to strike at them. If inclined to be eross, they will often resent even a quick pointing at them with the finger, by darting upon it, and leaving their stings behind.

39y. The first thing to be done, after having opened a hive and removed the cloth (352), is to remove the divisionboard (349) from the inside of the hive-to give room for handling the frames, - with the help of a common wood chisel. Then the frames which have been glued (236) fast to the rabbets by the bees, must be very gently pried loose; this may be done without any serious jar, and without wounding or enraging a single bee. They may be all loosened for removal in less than a single minute.

If there is no division-board (349) in the hive, the Apiarist should gently push the third frame from either end of the hive, a little nearer to the fourth frame; and then the second as near as he can to the third, to get ample room to lift out the end one, without crushing its comb, or injuring any of the bees. To remove it, he should take hold of its two shoulders which rest upon the rabbets, and carefully lift it, so as to crush no bees by letting it touch the sides of the hive, or the next frame. If it is desired to remove any particular frame, room must be gained by moving, in the same way, the adjoining ones on each side. As bees usually build 
their combs slightly waving, it will be found impossible to remove a frame safely, without making roon for it in this way. If the combs are built on foundation $(\mathbf{6 7 4})$, however, they will be much easier to remove, as they are then perfectly straight. In handling heavy frames in hot weather, be careful not to incline them from their perpendicular, or the combs will be liable to break from their own weight, and fall out of the frames.

If more combs are to be examined, after lifting out the outside frame, set it carefully on end, near the hive, when the second one nay be easily moved towards the vacant space,

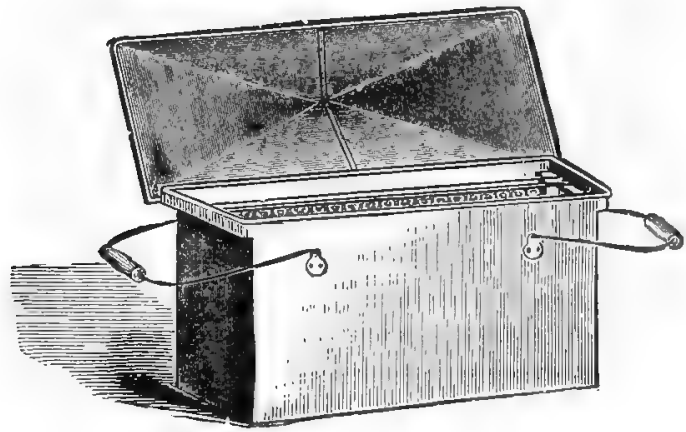

Fig. 94.

COMB-BUCKITT. .

and lifted out. After examination, put it in the place of the one first removed; in the same way, examine the third, and put it in the place of the second, and so proceed until all have been examined. If a division-board is used, it will not be necessary to set any of the frames down outside of the hive, as the removal of this board will leave one vacant space in the hive.

If the frames, as they are removed, are put into an empty hive, or a comb-bucket, they may be protected from the cold, and from robber-bees.

The inexperienced operator, who sees that the bees have 
built small pieces of comb, or bridges (325), between the outside of the frames and the sides of the hive, or slightly fastened together some parts of their combs, may imagine that the frames cannot be removed at all. Such slight attachments, however, offer no practical difficulty to their removal.* The great point to be gained, is to secure a single comb on each frame; and this is effected by the use of the triangular comb-guides, or better, by comb-foundation (68\%).

If . bees were disposed to fly away from their combs, as soon as they are taken out, instead of adhering to them with such remarkable tenacity, it would be far more difficult to manage them; but even if their combs, when removed, are all arranged in a continued line, the bees, and most especially the Italian bees, instead of leaving them, will stoutly defend them against the thieving propensilies of other bees.

398. In returning the frames, care must be taken not to crush the bees between them and the rabbets on which they rest; they should be put in so slowly, that a bee, on feeling the slightest pressure, may have a chance to creep from under them before it is hurt.

The frames should be returned, as far as possible, in the same position, as they were found, with the brood in the forward part of the hive, and the honey in the back, for bees always live and breed in front of their stores, to more easily defend their treasures against intruders.

In shutting up the hive, the surplus story, if any is there, should be carefully lowered, so that any bees which are in

* If sufficient room for storing surplus honey is not given to a strong colony, in its anxiety to amass as much as possible, it will fill the smallest accessible places. If the bees build comb between the tops of the frames and the under side of the upper story, it can be easily cut off, and used for wax. If this shallow chamber were not used, they would fasten the upper story to the frames so tightly, that it would be very diffleult to remove it; and every time it was taken off, they would glue it still faster, so that, at last, it would be well nigh impossible in getting it off, not to start the frames so as to crush the bees between the combs. 
the way may be given a chance to move away, instead of being crushed. A little smoke is always necessary. A beginner will find it to his advantage to practice-using an empty hive-the directions for opening and shutting hives, and lifting out the frames, until confident that he fully understands them. If any bees are where they would be imprisoned by closing the upper cover, it should be propped up a little, until they lave flown to the entrance of the hive, or, they may be brushed away gently.

\section{Mismanagement of Bees.}

399. When a colony of bees is unskillfully dealt with, they will "compass about" their assailant with savage ferocity; and woe be to him, if they can creep up his clothes, or find a single unprotected spot on his person.

Not the slightest attempt should be made to act on the offensive; for, if a single one is struck at, others will avenge the insult; and if resistance is continued, hundreds, and at last, thousands, will join them. The assailed party should quickly retreat to the protection of a building, or, if none is near, should hide in a clump of bushes, and lie perfectly still, with his head covered, until the bees leave him. When no bushes are at hand, they will generally give over the attack, if he lies still on the grass, with his face to the ground. A practical Apiarist, sheltered with a veil and armed with a well lighted smoker, will not retreat much before the most ferocious swarm of bees.

Those who are alarmed if a bee enters the house, or approaches them in the garden or fields, are ignorant of the important fact, that $a$ bee, at a distance from its hive, never volunteers an attack. Even if assaulted, they seek only to escape, and never sting, unless they are hurt.

If they were as easily provoked away from home, as when ealled to defend those sacred precincts, a tithe of the merry gambols, in which our domestic animals indulge, would 
speedily bring about them a swarm of infuriated enemies; we should be no longer safe in our quiet rambles among the green fields; and no jocund mower could whet or swing his peaceful scythe, unless clad in a dress impervious to their stings. The bee, instead of being the friend of man, would, like sarage wild beasts, provoke his utmost efforts for its extermination.

400. Huber has demonstrated that bees have an exceedingly acute sense of smell and that unpleasant odors quickly excite their anger.

Strong perfunies, however pleasant to us, are disagreeable to them; and Aristotle observes, that they will sting those scented with then. Te have known persons ignorant of this fact to be severely treated by bees.

Some persons, howerer cleauly, are assaulted by bees as soon as they approach their hives. It is related of a distinguished Apiarist that after a severe attack of fever, he was never able to be on good terms with his bees. That they can readily perceive the slightest differences in smell, is apparent from the fact that any number of bees, fed from a common ressel, will be gentle towards each other, while they will assail the first strange bee that alights on the feeder.

Putler said, "Their smelling is excellent, whereby, when they $\mathrm{Ay}$ aloft into the air, they will quickly perceive anything. under them that they like, eren though it be covered." They have, therefore, a special dislike to those whose liabits are not neat, and who bear about them a perfume not in the least resembling

\section{"Sabean odlors \\ From the spicy shores of Araby the blest."}

A horse, when assailed by them, is often killed; as instead of running away, like most other animals, it will plunge and kick until it falls overpowered. The apiary should be fenced in, to prevent horses and cattle from molesting the hives. Te have known of a horse, which happening to be 
loose in a bee-yard, was attacked by a few bees. In trying to defend himself against them by kicking and rolling he upset one hive and then another, till tens of thousands of bees assailed him, and the poor animal was stung to death before his owner could come to the rescue. We were informed by an eye-witness that although the carcass remained unburied two days, neither dogs, crows, buzzards nor any of the usual scavengers of decaying flesh, attempted to feed upon it, so great was the amount of poison ( $\mathbf{9 9}$ ) instilled into it by the revengeful bees.

401. The sting of a bee (\%) upon some persons, produces very painful, and even dangerous effects. We have often noticed that, while those whose systems are not sensitive to the venom, are rarely molested by bees, they seem to take a malicious pleasure in stinging those upon whom their poison produces the most virulent effect. Something in the secretions of such persons may both provoke the attack and render its consequences more severe.

The smell of their own poison (87) produces a very irritating effect upon bees. A small portion of it offered to them on a stick, will excite their anger.

"If you are stung," says old Butler, "or any one in the company-yea, though a bee hath stricken but your elothes, especially in hot weather-you were best be packing as fast as you ean, for the other bees, smelling the rank flavor of the poison, will come about you as thick as hail."

\section{REMEDIES FOR THE STING OF A BEE.}

402. If only a few of the host of eures, so zealously advocated, could be made effectual, there would be little reason to dread being stung.

'The first thing to be done after being stung is to pullor rather push-the sting out of the wound as quickly as possible. When torn from the bee, the poison-bag and all the muscles which control the sting accompany it; and it penetrates deeper and deeper into the flesh, injecting continually 
more and more poison into the wound. If extracted at once, it will very rarely produce any serious consequences; but, in extracting it, it should not be taken between the fingers. In so doing, most of the poison will be pressed into the wound. It must be rubbed or scraped off with celerity by a quick motion of the finger-nail so as to prevent any more of the poison of the sack from getting into the flesh. After the sting is removed the utmost care should be taken not to irritate the wound by the slightest rubbing. However intense the smarting, and the disposition to apply friction to the wound, it should never be done for the moment that the blood is put into violent circulation, the poison is quickly diffused over a large part of the system, and severe pain and swelling may ensue. On the same principle, by severe friction, the bite of a mosquito, even after the lapse of several days, may be made to swell again. As most of the popular remedies are rubbed in, they are worse than nothing.

IVhen the operator is perspiring abundantly, the stings are less painful, as some of the poison exudes with the sweat.

If the mouth is applied to the wound, unpleasant consequences may follow; for, while the poison of snakes, affecting only the circulating system, may be swallowed with impunity, the poison of the bee acts with great power on the organs of digestion. Distressing headaches are often produced by it, as any one, who has been stung, or has tasted the poison, very well knows.

403. In our own experience, we have found cold water to be the best remedy for a bee-sting. The poison is quickly dissolved in it; and the coldness of the water has also a powerful tendency to check inflammation.

The leaves of plantain, crushed and applied to the wound, are a very good substitute, when water cannot at once be procured. Bevan recommends the use of spirits of hartshorn, and says that, in eases of severe stinging, its internal use is also beneficial. In very serious cases, the ammonia may be taken, in quantities of from five to twenty drops,-for an 
adult, less for a child,-in hot tea, with beneficial results. It causes an increased perspiration and neutralizes the effects of the poison. ("Commentaires Thérapeutiques," Gubler, Paris, 1874.)

10-1. It may be some comfort to novices to know that the poison will produce less and less effect upon their systen. Old bee-keepers like Mithridates, appear almost to thrive upon poison itself. When we first became interested in bees, a sting was quite a formidable thing, the pain being often very intense: and the wound swelling so as sometimes to obstruct our sight. At present, the pain is usually slight, and, if the stiug is quickly extracted, no unpleasant consequences ensue, even if nó remedies are used. Huish speaks of seeing the bald head of Bonner, a celebrated practical Apiarist, covered with stings, which seemed to produce upon him no unpleasant effects. The Rev. Mr. Kleine advises beginners to allow themselves to be stung frequently, assuring them that, in two seasons, their system will become accustomed to the poison!

An old English Apiarist advises a person who has been stung, to eatch another bee as speedily as possible, and make it sting on the same spot. Eren an enthusiastic disciple of IIuber might hesitate to renture on such a singular homcopathic remedy; but, as this Apiarist had stated, what we had verified in our own experience, that the oftener a person is stung the less he suffers from the venom, the writer determined to make trial of his prescription. Allowing a string to remain until it had discharged all of its poison, he compelled another bee to insert its sting, as nearly as possible, in the same spot. He used no remedies of any kind, and had the satisfaction, in his zeal for new discoveries, of suffering more from the pain and swelling than for years before.

That the bee-keeper becomes inoculated with the poison of the bee, and usually becomes proof against it, is no more to be doubted than the fact that vaccination is a preservative against small-pox. The discoveries of Pasteur, for the cure 
of hydrophobia, are another evidence of the efficiency of inoculation.

The poison of the bee has a beneficial effect as a cure for rheumatism. Numberless cases have been reported where a few stings have caused the disappearance of this affection.

\section{Bees as Meats of Defense.}

405. "A small corsair, equipped with forty or fifty men, and having on board some bees, purposely taken from a neighboring island, and confined in earthen hives ( 275 ), was pursued by a Turkish galley. As the latter boarded her, the sailors threw the hives from the masts down into the galley. The earthen hives broke into fragments and the bees dispersed all over the boat. The Turks who had looked on the small corsair with contempt, as an easy prey, did not expect so singular an attack. Finding themselves defenseless against the stings, they were so frightened, that the men of the corsair, who had provided themselves with masks and gloves, took possession of the galley, almost without resistance."

"Amurat, Emperor of Turkey, luaving besieged Alba, and made a breach in the walls, found the breach defended by bees, whose hives had been brought on the ruins. The Janissaries, the bravest militia of the Ottoman empire, refused to clear the obstacle."'-(Della Rocea, 1790.) 


\section{CHAPTER VI.}

NATURAL SWARMING.

406. In the Spring, as soon as the combs of a hive, well filled, can no longer accommodate its teeming population, the bees prepare for emigration, or in other words, for departing with their queen, by building a number of royal-cells (104). These cells are begun about the time that the drones make their appearance in the open air; and when the young queens arrive at maturity, the males are usually very numerous (186).

The swarming of bees is one of the most beautiful sights in the whole compass of rural economy. Although those who use movable-comb hives prefer the artificial multiplication of colonies, it being more profitable, all Apiarists delight in the pleasing excitement of natural swarming.

"Up mounts the chief, and to the cheated eye Ten thousand shuttles dart along the sky;

As swift through wther rise the rushing swarms,

Gay daneing to the beam their sun-bright forms;

And each thin form, still ling'ring on the sight,

Trails, as it shoots, a line of silver light.

High pois'd on buoyant wing, the thoughtful queen,

In gaze attentive, views the varied scene,

And soon her far-feteh'd ken discerns below

The light laburnum lift her polish'd brow,

Wave her green leafy ringlets o'er the glade,

And seem to beckon to her friendly shade.

Swift as the falcon's sweep, the monarch bands

Her flight abrupt; the following host descends.

Round the fine twig, like eluster'd grapes, they close

In thickening wreaths, and court a short repose."

-Evans.

40\%. Bees sometimes abandon their hives very early in Spring, or even late in Summer or Fall (264). Although 
exhibiting the appearance of natural swarming, they leave, not because the population is so crowded that they wish to form new colonies, but because it is either so small, or the hive so destitute of supplies, that they are driven to desperation. Seeming to have a presentiment that they must perish if they stay, instead of awaiting the sure approach of famine, they sally out to see if they cannot better their condition.

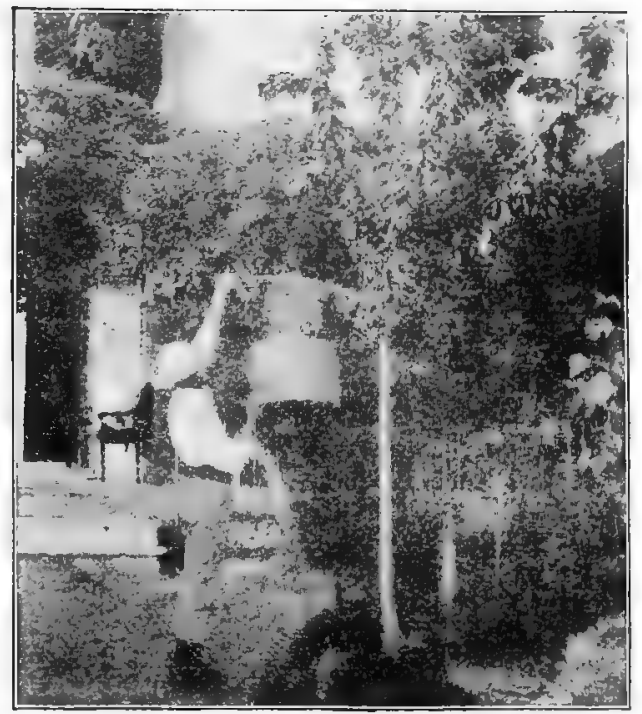

FIG. 95.

GATHERING A SWARM.

From Mont-Jovet, Savoie, France.

Such desertions should not be mistaken for natural swarming 408. The time, when new swarms may be expected, depends, of course, upon the climate, the forwardness of the season, and the strength of the colonies. In our Northern and Middle States, they seldom issue before the latter part of May; and June may there be considered as the great 
swarming month. In Texas, on the lower Rio Grande, bees often swarm quite early in March.

Swarming does not always take place in Spring, although this is the usual time for it. Swarms are likely to issue in any locality, whenever the hive is crowded for room, or nearly so, during a good and prolonged honey-harvest. In warm latitudes, it lasts for several months, owing to a continuous flow of honey. Wherever there are two distinct honey erops (705), there are also two swarming seasons, especially along - the low lands or river bottoms, where Fall pasturage is abundant. Swarms, hived during the forepart of either of these honey seasons, are always the best; having a few weeks of honey crop before them, they have ample time to build comb and fill it with honey and brood; while swarms which are cast during the latter part of either the clover or the Fall harvest, coming as they do, just before a dearth of honey, are unable to build comb and raise brood, and easily perish, if left to themselves. Thus, a swarm harvested in August, in this latitude, at the opening of the Fall crop, stands better chances than one harvested in July, at the close of the clover and basswood crop.

\section{First or Primary Swarm.}

409. The first swarm is almost invariably led off by the old queen, unless she has died from accident or disease, when it is accompanied by one of the young ones reared to supply her loss. There are no signs from which the Apiarist can predict the certain issue of a first swarm. For years, we spent much time in the vain attempt to discover some infallible indications of first swarming; until facts convinced us that there can be no such indications.

410. If the weather is unpleasant, or the blossoms yield an insufficient supply of honey, bees often change their minds, and refuse to swarm at all. If, in the swarming season, but few bees leave a strong hive, on a clear, calm, and warm day, 
when other colonies are busily at work, we may look with great confidence for a swarm, unless the weather prove suddenly unfavorable.

It the weather is rery sultry, a swarm will sometimes issue as early as seven o'elock in the morning; but from ten A. M., to two P. M., is the usual time; and the majority of swarms come off when the sun is within an hour of the meridian. Occasionally, a swarm ventures out as late as five P. M.; but an old queen is seldom guilty of such an indiscretion.

411. We have repeatedly witnessed in our observinghives (374) the whole process of swarming. On the day fixed for departure, the queen is very restless, and instead of depositing her eggs in the cells, roams over the combs, and communicates her agitation to the whole colony. The emigrating bees usually fill themselves with honey, just before their departure; but in one instance, we saw them lay in their supplies more than two hours before they left. A short time before the swarm rises, a few bees may generally be seen sporting in the air, with their heads turned always to the hive; and they occasionally fly in and out, as though impatient for the important event to take place. At length, a violent agitation commences in the hive; the bees appear almost frantic, whirling around in circles continually enlarging, like those made by a stone thrown into still water, until, at last, the whole hive is in a state of the greatest ferment, and the bees, rushing impetuously to the entrance, pour forth in one steady stream. Not a bee looks behind, but each pushes straight ahead, as though flying "for dear life," or urged on by some invisible power, in its headlong career.

41.2. Often, the queen does not come out until many have left; and she is sometimes so heavy, from the number of eggs in her oraries, that she falls to the ground, incapable of rising with her colony into the air $(\mathbf{4 0})$. The bees soon miss her, and a very interesting scene may now be witnessed. Diligent search is at once made for their lost mother; the swarm scattering in all directions, so that the leaves of the adjoining 
trees and bushes are often covered almost as quickly with anxious explorers, as with drops of rain after a copious shower. If she cannot be found, they commonly return to the old hive, in from five to fifteen minutes.

113. The ringing of bells and beating of kettles and frying-pans to cause swarms to settle, is probably not a whit - more efficacious, than the hideous noises of some savage tribes, who, imagining that the sun, in an eclipse, has been swallowed by an enormous dragon, resort to such means to compel his snakeship to disgorge their favorite luminary.

Many who have never practiced "tanging," have never had a swarm leave without settling. Still, as one of the "country sounds," and as a relic of the olden-times, even the most matter-of-fact bee-man can readily excuse the enthusiasm of that pleasant writer in the London Quarterly Review, who discourses as follows:

"Some fine, warm morning in May or June, the whole atmosphere seems alive with thousands of bees, whirling and buzzing, passing and repassing, wheeling about in rapid circles, like a group of maddened bacchanals. Out runs the good housewife, with frying-pan and key-the orthodox instruments for ringing -and never ceases her rough music, till the bees have settled. This custom, as old as the birth of Jupiter, is one of the most pleasing and exciting of the countryman's life; and there is an old colored print of bee-ringing still occasionally met with on the walls of a country-inn, that has charms for us, and makes us think of bright, sunny weather in the dreariest November day. Whether, as Aristotle says, it affects them through pleasure or fear, or whether, indeed, they hear it at all, is still as uncertain as that philosopher left it; but we can wish no better luck to every bee-master that neglects the tradition, than that he may lose every swarm for which he omits to raise this time-honored concert."

414. The queen sometimes alights first, and sometimes joins the eluster after it has begun to form. The bees do not usually settle, unless she is with them; and when they do, and then disperse, it is frequently the case that, after 
first rising with them, she has fallen, from weakness, into some spot where she is unnoticed by the bees.

Perceiving a hive in the act of swarming, the writer on two occasions, contracted the entrance, to secure the queen when she should make her appearance. In each case, at least one-third of the bees came out before she joined them. As soon as the swarm ceased searching for her, and were returning to the parent-hive, he placed her, with her wings clipped, on a limb of a small evergreen tree, when she crawled to the very top of the limb, as if for the express purpose of making herself as conspicuous as possible. The few bees, that frst noticed her, instead of alighting, darted rapidly to their companions; in a few seconds, the whole colony was apprised of her presence, and flying in a dense cloud, began quietly to cluster around her. Bees, when on the wing, intercommunicate with such surprising rapidity, that telegraphic signals are scarcely more instantaneous.

115. That bees send out scouts to seek a suitable abode, admits of no serious question. Swarms have been traced directly to their new home, in an air-line flight, from the place where they clustered after alighting. Now this preeision of flight to an unknown home, would plainly be impossible, if some of their number, by previous explorations, were not competent to act as guides to the rest. The sight of bees for distant objects is so wonderfully acute, that, after rising to a sufficient elevation, they can see, at the distance of several miles, any prominent objects in the vicinity of their intended abode. (13-14.)

Whether bees send out scouts before or after swarming, may admit of more question, but these scouts are usually absent for an hour or more, after the alighting of the swarm.

It is probable that most of the scouts are sent during the alighting; otherwise how could they know where the swarm alighted, so as to come back to it?

The necessity for scouts or explorers seems to be unquestionable, unless we admit that bees have the faculty of flying in an 



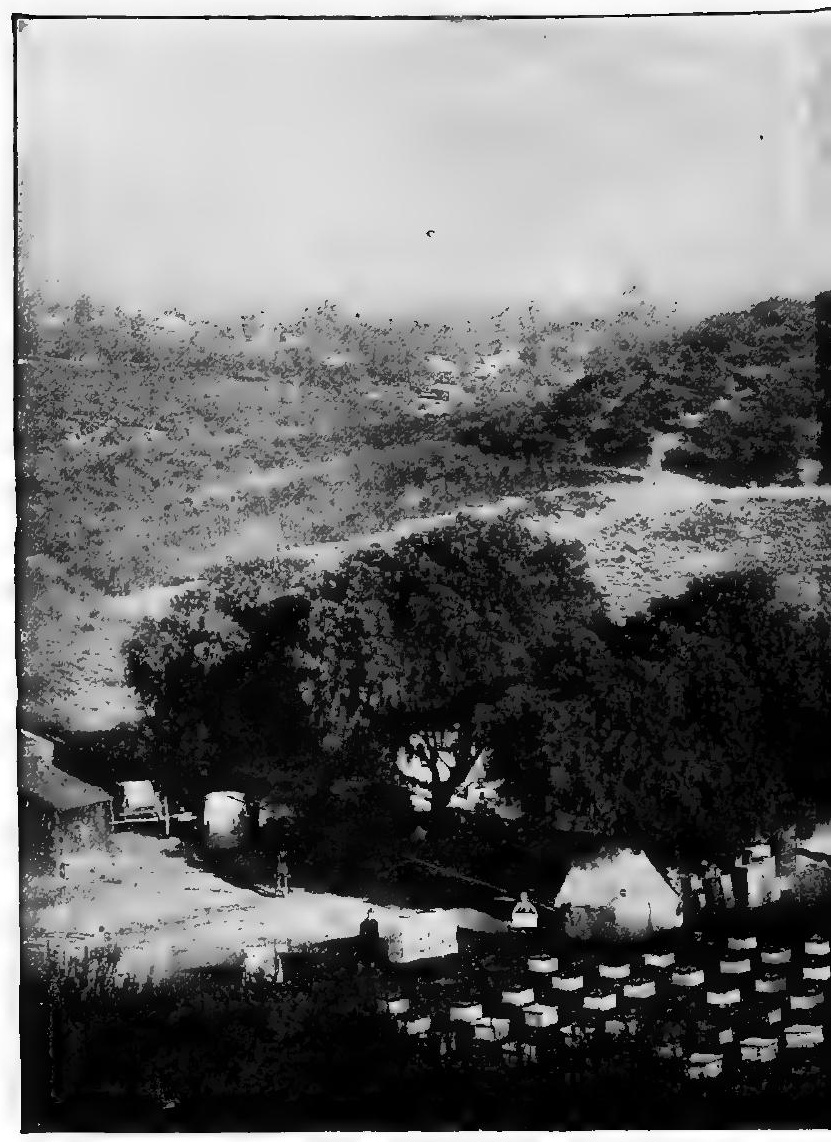

AN APIARY IN

From the "Ameri 
Plate 17.

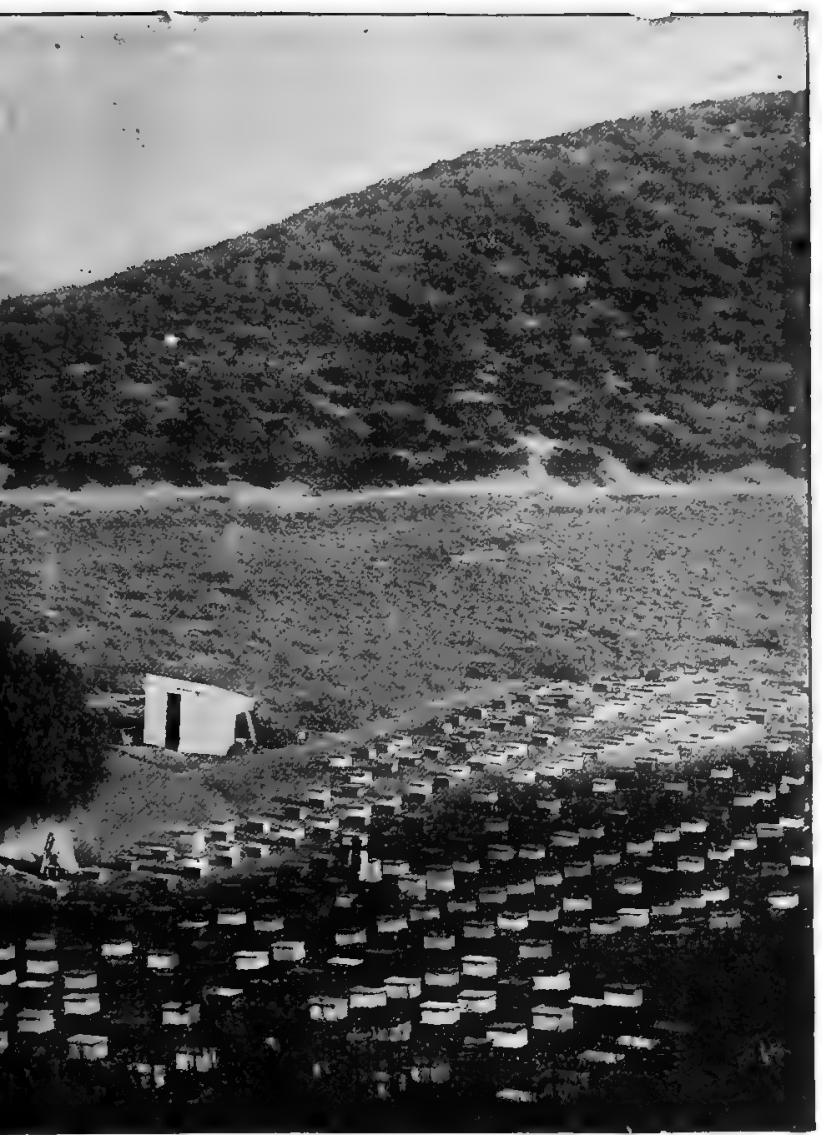

\section{CALIFORNIA.} rean Bee Journal," 

"air line," to a hollow tree, which they have never seen, and which may be the only one among thousands where they can find a suitable abode.

These views are confirmed by the repeated instances in which a few bees have been noticed inquisitively prying into a hole in a hollow tree, or the cornice of a building, and have, before long, been followed by a whole colony.

About fifty yards from our home apiary, there was a large hollow oak tree, which we called "The Squirrel's Oak," because every season it sheltered a family of these pretty animals. One Summer we noticed for several days some bees flying, in and out of a hole, in one of its largest limbs. It seemed to us that they were eleaning the hollow, and we supposed that a swarm had taken possession of it. A change in the weather having taken place; the swarming preparations were discontinued, and we never again noticed any bees around the limb. The tree was cut down the following Winter, and no trace of comb was found in the hollow. It proved conclusively that the bees we had seen were scouts in search of a lodging.

416. The swarm sometimes remains until the next day, where bees have clustered in leaving the hive, and instances are not unfrequent of a more protracted delay.

If the weather is hot when they first eluster, and the sun shines directly upon them, they will often leave before they have found a suitable habitation. Sometimes the queen of emigrating bees, being heary with eggs, unaccustomed to fly, is compelled to alight, before she can reach their intended home. Queens under such circumstances, are occasionally unwilling to take wing again, and the poor bees sometimes attempt to lay the foundations of their colony on fence-rails, hay-stacks, or other unsuitable places.

Mr. Wagner once knew a swarm of bees to lodge under the lowermost limb of an isolated oak-tree, in a corn-field. It was not discovered until the corn was harvested, in September. Those who found it, mistook it for a recent swarm, and in 
brushing it down to hive it, broke off three pieces of comb, each about eight inches square. Mr. Henry M. Zollickoffer, of Philadelphia, informed us that he knew a swarm to settle on a willow-tree in that eity, in a lot owned by the Pennsylvania Hospital; it remained there for some time, and the boys pelted it with stones, to get possession of its comb and honey.

If the apiary is located in the woods, and the bees are allowed to swarm, they may settle on high trees, and the beemaster, unless some special precautions are used, will lose much time in hiving his swarms.

417. Having noticed that swarming bees will almost always alight wherever they see others clustered, we found that they can be determined to some selected spot by an old black hat, or even a mullen-stalk, which, when colored black, can hardly be distinguished, at a distance, from a elustering swarm. A black woolen stocking or piece of eloth, fastened to a shady limb, or to a pole, in plain sight of the hives, and where the bees can be most conveniently hived, would answer as good a purpose. Swarms are not only attracted by the bee-like color of such objects, but are more readily induced to alight upon them, if they furnish something to which they can easily cling, the better to support their grape-like clusters.

Still better than the above, a frame of dry comb, as dark as possible, will often attract the bees and cause them to cluster. None of these devices however are infallible; hence the advisability of locating an apiary among low trees or bushes, or in an orchard, if possible.

When no trees or bushes are to be found, and no settling place has been provided, they will settle wherever the queen may happen to alight, on a grape-vine, on weeds, on the ground, on the corner of a building, ete.

418. It will inspire the inexperienced Apiarist with more confidence, to remember that almost all the bees in a swarm are in a very peaceable mood, having filled themselves with 
honey before leaving the parent-stock (380). Yet there are, in nearly every swarm, a few bees that have either joined from a neighboring hive, or have not filled their honey-sack completely before leaving. These bees are liable to get angry, when the swarm is harvested. So, if the Apiarist is timid, or suffers severely from the sting of a bee, he should, by all means, furnish himself with the protection of a bee-veil (386). The use of a smoker (382), is also advisable, both in preventing the bees from stinging and in helping to drive them into the hive; but it must not be used plentifully, as it might cause the bees to abscond, or to return to the elustering spot.

119. A new swarm should be hived as soon as the bees have quietly clustered around their queen; although there is no necessity for the headlong haste practiced by some, which increases their liability to be stung. Those who show so little self-possession, must not be surprised if they are stung by the bees of other hives; which, instead of being gorged with honey, are on the alert, and very naturally mistake the object of such excited demonstrations. The fact that the bees have clustered, makes it almost certain that, unless the weather is very hot, or they are exposed to the burning heat of the sun, they will not leave for at least one or two hours. All convenient dispatch, however, should be used in hiving a swarm, lest, the scouts have time to return,- which will entice them to go,--or lest other colonies issue, and attempt to add themselves to it.

420. Should you give the scouts time to return, you would first see a few bees flying around the cluster. Slowly their number would increase, till the whole swarm took wing, and it would be almost useless to try to stop it or to follow it. When a swarm thus takes flight, it knows no bounds. Hedges, fences, woods, walls, ditches, rivers, are barriers only to the breathless and disappointed owner. The only thing that we ever have known to stop a departing swarm is throwing water among them. Flashing the sun's rays on them by the use of a 
looking-glass is advised by some. We tried it, but did not succeed in a single instance.

421. As a matter of course, we suppose that the Apiarist has an empty hive in readiness, elean and cool. Bees, when they swarm, being unnaturally heated, often refuse to enter hives that have been standing in the sun, or at best are slow in taking possession of them. The temperature of the parent-stock, at the moment of swarming, rises very suddenly, and many bees are often so drenched with perspiration that they cannot take wing to join the emigrating colony. To attempt to make swarming bees entèr a heated hive in a blazing sun is, therefore, as irrational as it would be to force a panting erowd of human beings into the suffocating atmosphere of a close garret. If the process of hiving cannot be conducted in the shade, the hive should be covered with a sheet or with leafy boughs.

422. In the movable-frame hive, every good piece of worker-eomb, if large enough to be attached to a frame, should be used, both for its intrinsic value and because bees are so pleased when they find such unexpected treasure in a hive, that they will seldom forsake it. A new swarm often takes possession of a deserted hive, well stored with comb; whilst, if dozens of empty ones stand in the Apiary, the bees very seldom enter them of their own accord.

"The bee-keepers of Greece used to attract the swarms into their hives by rubbing the entrance and the inside of their empty hives with bees-wax and propolis. But such practice was often the canse of contests between neighbors, for their bees did not inquire about the ownership of the hive selected.' (Della Rocea, 1790.)

But when a few combs only are given to a swarm, as the queen will not follow the builders (229), too much drone comb (221) will be built. Then, in hiving a swarm, the Apiarist had better dispense with giving any, unless he fills the hive (234).

Drone-combs (221) should never be put up in frames, or 
the bees may follow the pattern, and build comb suitable only for breeding a horde of useless consumers.

423. Frames containing worker combs, from colonies that have died in the previous Winter are very good, if the comb is dry and clean. Combs of honey will do if the swarm is hived on a propitious day, otherwise they will attract robbers (661) and the presence of the latter will prevent the swarm from entering the hive. For this reason, combs containing honey should not be given to the swarm until the following evening.

424. In the absence of combs or comb-foundation starters (684), the triangular comb-guide will greatly help to secure straight combs, in the frames, but it cannot be depended upon, in every case. Comb-foundation in full sheets or in strips is so far superior, and is now in such general use, that the triangular comb-guide $(\mathbf{3 1 9}, \mathbf{3 R \mathbf { R }})$ is discarded by most Apiarists. By the use of comb-foundation, crooked combs,the bane of the apiary-are no longer found, and every comb hangs in its frame, as straight as a board.

425. It is held by some writers that the giving of a hive full of drawn combs to a natural swarm is more injurious than beneficial, because the bees fill these combs at once with honey; the queen having no room to lay, the swarm declinesin strength. Mr. W. Z. Hutchinson in his most excellent book, "Advanced Bee-culture," says: "Occasionally I have hived a swarm upon drawn combs, but the loss has always been so great that it seems folly to repeat it." Such an occurrence happens in a very good season with small hives. During a heavy flow, the bees can fill the entire hive-body with honey in less time than it would take them to build the combs and the queen is thus deprived of room to lay. This same colony, if hived upon empty frames would harvest just enough honey in that length of time to build the combs and keep the brood nourished. The profitable saving thus turns out as a loss, since this extra amount of honey is in the way of the queen. This does not prove the uselessnenss of combs, as some persons 
would infer, but on the contrary it evidences the fact that it costs the bees a great deal of honey to produce the comb, since they can save enough to fill the combs in the same time that it would take them to build those combs. In localities where this condition proves to be common, it is best'to use the built combs only in making artificial (469) increase, or with weak swarms. A rery small quantity of bees with a good queen and built combs will soon make a powerful colony. But in poor honey seasons, when it is difficult for swarms to harvest enough to build their combs, a hive full of combs proves a great boon to them, even if the swarm is large.

426. It is very important that the frames should hang true in the hive, and at the proper distance apart (316). If the hive has to be removed, they should be previously fastened in their places, by the use of small wire nails only partly driven, and removed later. If, however, a frame spacer is used (fig. 76) this will not be necessary. The cloth (35R) and mat (353) should be carefully placed over the frames, or the swarm would build and raise brood in the upper story, intended only for surplus honey.

427. When the hive is thus prepared and placed in a convenient position, the entrance should be opened as wide as possible. If it has a movable-bottom-board, it should be raised from it in front ( $\mathbf{3 H 1})$, and the entrance-blocks inserted under its edges, so as to leave a larger passage for the swarm, that the bees may get in as soon as possible; and a wellstretched sheet, or coarse cloth, should be securely fastened to the alighting-board, to keep them from becoming separated, or soiled by dirt; for, if separated, they are a long time in entering; and a bee covered with dust or dirt is very apt to perish. Bees are much obstructed in their travel, by any corwer, or great inequality of surface; and if the sheet is not smoothly stretched, they are often so confused, that it takes them a long time to find the entrance to the hive.

428. If the bees have alighted on a small limb, which can 
be cut with sharp pruning-shears, without jarring the swarm, or damaging the value of the tree, they may be gently carricd on it to the hiving-sheet, in front of their new home. If they seem at all reluctant to enter it, gently scoop up a few of them with a large spoon, or a leafy twig, or even with the fingers (r2), and shake them close to its entrance. As they go in with fanning wings, they will raise a peculiar note, which. communicates to their companions the joyful news that they have found a home; and in a short time the whole swarm will enter, without injury to a single bee.

When bees are once shaken down on the sheet, they are quite unwilling to take wing again; for, being loaded with honey, they desire, like heavily-armed troops, to march slowly and sedately to their place of encampment.

429. When they alight on a high $\operatorname{limb}$, which cannot be reached, or when the limb is too valuable to be sacrificed, the swarm can be hived by using a light box or swarm-sack, at

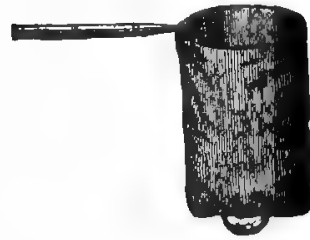

Fig. 96.
SWARM-SACK. the end of a pole of proper length. This swarm-sack (fig. 96) is made of strong muslin, about two feet deep, fastened around a wire hoop, about one foot in diameter, and is similar to a butterfly net. A piece of braid is sewed at the bottom, inside and outside, to help in emptying it. When the sack is placed under the swarm, the bees are suddenly shaken into it by a single tap on the limb. Hold the sack firmly, as the sudden weight will draw it down in a most unexpected manner. To prevent the bees from escaping, hold the handle perpendicularly, as this will close the opening of the bag instantly.

430. In bringing it to the hive, and turning it inside out, by holding the braid with the fingers, some care must be exercised, as this unceremonious imprisoning of the bees is apt to cause some to be angry. A little smoke (382) should be used, 
or a few seconds should be allowed to elapse before they are gently liberated in front of the hive.

431. The sack is preferable to a box or a basket, as the latter do not close readily, and a number of the bees are apt to fly back to the clustering spot, before they are emptied in front of their intended abode.

- If this happens, the process of hiving must be repeated, imless the queen has been secured, when they will quickly form at line of communication with those on the sheet. If the queen has not been secured, the bees will either refuse to enter the hive, or will speedily come out and take wing, to join her again. This happens oftenest with after-swarms, whose young queens, instead of exhibiting the gravity of an old matron, are apt to be frisking in the air.

It is a mistake to suppose that a swarm will not enter a hive unless the queen is with them. If some start for it, the others will speedily follow, all seeming to take it for granted that the queen is somewhere among them. Even after they begin to disperse in search of her, they may often be induced to return, by pouring out a fresh lot of bees, which, by entering the hive with fanning wings, eause the others to believe that the queen is coming at last.

When the swarm is clustered so high that the sack cannot be raised to it on a pole, it may be carried up to the cluster, and the bee-keeper, after shaking the bees into it, may gently lower it, by a string, to an assistant below.

432. When a colony alights on the trunk of a tree, or on anything from which the bees cannot easily be gathered in a basket, or in the sack, fasten a leafy bough, or a comb over them, and with a little smoke, compel them to ascend it. If the place is inaccessible, they will enter a well-shaded basket, inverted, and elevated just above the clustered mass. We once hived a neighbor's swarm, which settled in a thicket, on the inaccessible body of a tree, by throwing water upon the bees, so as to compel them gradually to ascend the tree, and enter an elevated box. If proper alighting places are not furnished, 
the trouble of hiving a swarm will often be greater than its value.

433. If the swarm is noticed, when it begins to issue from the parent hive, the practical bee-keeper often harvests it without trouble, by catching the queen (100). Provided with a queen cage (536) he watches for her exit, and as she comes out, he seizes her and places her in the cage. He then removes the old hive, and places the new one, ready, for the swarm, on its stand, with the caged queen on the platform. The swarm may alight, but as soon as the bees notice their loss, they will return, and will cluster around her; and the hiving of the swarm takes but a few minutes. In a circumstance of this kind, it is well to return the parent colony to its stand, after the swarm is hived, for, if entirely removed, it would lose all the bees that were in the field, when the swarm left, and would be too much weakened.

434. To prevent primary swarms from escaping, some bee-keepers elip one of the wings of their queens previous to the swarming season.

Virgil speaks of clipping the wings of queens, to prevent them from escaping with a swarm. Mr. Langstroth had devised a way of doing this, so as to designate the age of the queens:-With a pair of scissors, let the wings, on one side, of a young queen be carefully cut off; when the hives are examined next year, let one of her two remaining wings be removeu, and the last one the third year.

As an old queen leaves the hive only with a new swarm the loss of her wings in no way interferes with her usefulness or the attachment of the bees. If, in spite of her inability to fly, she is bent on emigrating, though she has a "will," she can find "no way," but helplessly falls to the ground, instead of gaily mounting into the air. If the bees find her, they eluster around her, and may be easily secured by the Apiarist; if she is not found, they return to the parent-stock, to await the maturity of the young queens.

This method will do, provided the apiary ground is bare, 
so that the queen runs no risk of getting lost in the grass. We abandoned it, after having tried it, for several years. But some very good Apiarists hold that clipping the queens' wings is desirable. Doctor C. C. Miller, one of America's most practical and successful Apiarists, in his "Forty Years Among the Bees," already mentioned by us, says:

"Although nowadays the practice of elipping has become quite general, there are a few who doubt its advisability. I would not dispense with elipping if I kept only one apiary and were on hand all the time and with out-apiaries and no one to watch them it seems a necessity. If a colony swarms with a clipped queen, it cannot go off. True, the queen may possibly get lost, but it is better to lose the queen than to lose both bees and queen. If there were no other reason for it, I should want my queens clipped for the sake of keeping a proper record of them. A colony, for example, distinguishes jtself by storing more than any other colony. I want to breed next spring from the queen of that colony. But she may be superseded in the fall after that big harvest, and if she is not clipped there is no way for me to tell in the following season whether she has been superseded or not. Indeed I can hardly see how it is possible to keep proper track of a queen without having her clipped."

435. Where a great many colonies are kept, several swarms may issue at the same time, and unite in a single cluster.

If two swarms cluster together, they may be advantageously kept together, if abundant room for storing surplus honey can be given them. Large quantities of honey are generally obtained from such colonies, if they issue early, and the season is favorable.

"When more than two swarms have clustered together, it is better to divide them. Let us suppose that three have united. After putting three hives near each other, so as to form a triangle, the sack ( 429 ) or box, in which the bees have been captured, is shaken on a eloth just between the three. If most of the bees seem to go into the same hive, this should be re- 
moved a little farther. Great care should be exercised to find the queens, and to direct one towards each hive. But if only one queen is seen, it is better to cage ( 536 ) her till the greater part of the bees have entered. Then, as soon as the bees of one of the hives show signs of uneasiness, and seem ready to join the bees in the others, release the queen, and direct her towards this queenless hive and all will be well."-(Hamet, "Cours d'Apiculture.')

436. If two queens have entered the same hive, they can often be found on its bottom-board, each in a ball (538) of angry bees, strangers to them. Open the ball, and give one of the queens to the queenless hive, if the bees have not already deserted it. When queens have been "balled" by mixed swarms, it is well to keep them caged, in the hive, for a few hours, or till the bees have quieted. The quantity of bees in each hive can be equalized, by shaking a few from the strongest in front of the weakest.

437. Dr. Scudamore, an English physician, who has written a tract on the Formation of Artificial Swarms, says that he once knew as "many as ten swarms go forth at once, and settle and mingle together, forming, literally, a monster meeting." There are instances recorded of a still larger number having clustered together. A venerable clergyman in Western Massachusetts, told uts that in the apiary of one of his parishioners, five swarms once clustered together. As he had no hive which would hold them, they were put into a large box, roughly nailed together. When taken up in the Fall, it was evident that the five swarms had lived together as independent colonies. Four had begun their work, each near a corner of the box, and the fifth in the middle; and there was a distinct interval separating the works of the different colonies. In Cotton's "My Bee Book," is a cut illustrating a similar separation of two colonies in one hive. By hiving, in a large $\bar{b} o x$, swarms which have settled together, and leaving them undisturbed till the following morning, they would sometimes be 
found in separate clusters, and might easily be put into different hives.

If the Apiarist fears that another swarm will issue, to unite with the one he is hiving, he may cover the latter from the sight of other swarms, with a sheet.

438. If, while hiving a swarm, he wishes to secure the queen, the bees should be shaken from the hiving-basket or sack, a foot or more from the hive, when a quick eye will generally see her as she passes over the sheet. If the bees are reluctant to go in, a few must be directed to the entrance, and care be taken to brush them back, when they press forward in such dense masses that the queen is likely to enter unobserved. An experienced eye readily detects her peculiar color and form (100).

It is interesting to witness how speedily a queen passes into the hive, as soon as she recognizes the joyful note (76) amouncing that her colony has found a home. She quickly follows in the direction of the moving mass, and her long legs enable her easily to outstrip, in the race for possession, all who attempt to follow her. Other bees linger around the entrance, or fly into the air, or collect in listless knots on the sheet; but a fertile mother, with an air of eonscious importance, marches straight forward, and looking neither to the right hand nor to the left, glides into the hive with the same dispatchful haste that characterizes a bee returning fully laden from the nectar-bearing fields.

139. Swarms sometimes come off when no suitable hives are in readiness to receive them. In such an emergeney, hive them in any old box, cask, or measure, and place them, with suitable protection against the sun, where their new hive is to stand; when this is ready, they may, by a quick, jerking motion, be easily shaken out before it, on a hiving-sheet.

Persons unaccustomed to bees may think that we speak about "scooping them up," and "shaking them out," almost as coolly as though giving directions to measure so many bushels of wheat; experience will soon convince them that 
the ease with which they may be managed ( $/ 2$ ) is not at all exaggerated.

440. Bees which swarm early in the day will generally begin to range the fields in a few hours after they are hived, or even in a few minutes, if they have empty comb; and the fewest bees will be lost when the hive is removed to its permanent stand, as soon as the bees have entered it. If it is desirable, for any reason, to remove the hive before all the bees have gone in, the sheet, on which the bees are lying, may be so folded that the colony can be easily carried to their new stand, where the bees may enter at their leisure.

While the hive should be set so as to incline slightly from rear to front (327), to shed the rain, there ought not to be the least pitch from side to side, or it will prevent the frames from hanging plumb, and compel the bees to build crooked combs.

441. If several rainy days, or a dearth of honey, should occur immediately after the hiving of bees, it is well to feed (606) them a little to keep them from starving, till there is Loney in the blossoms.

442. The Apiarist has already been informed of the importance of securing straight worker combs for his hives (223). To a stock-hive, such combs are like cash capital to a business man; and so long as they are fit for use, they should never be destroyed.

Mr. S. Wagner had a colony over 21 years old, whose young bees appeared to be as large as any others in his apiary. $\mathrm{Mr}$. J. F. Racine, an old settler of Wallen, Indiana, lost a colony in the Winter of 1884-5 which he had had ever since 1855, without changing the combs. He considered it one of the best in his apiary.

We have ourselves kept colonies of bees without changing any but the very blackest combs, for thirty years or more. As long as a queen will utilize combs by laying eggs in them, they may be considered as good as any.

Those who have plenty of good worker-comb, will unques- 
tionably find it to their advantage to use it in the place of comb-foundation. If a swarm is small, it ought to be confined, by a movable partition (349), to such a space in the hive as it can occupy with comb, as well for its encouragement, as to economize its animal heat. Varro, who flourished before the Christian Era, says (Liber III, Cap. xviii), that bees become cispirited, when placed in hives that are too large.

\section{Primary Swarm with a Young Queen.}

443. We have already stated (15\%) that queens die of old age, when about four years old. If the preparations for queen rearing (189) are begun during the swarming season, from this cause, or by her death through accident, or because she has been removed by the Apiarist, it very often happens that bees prevent the first hatched queen from destroying her rivals (112), and the result is that a swarm leaves the hive with her. These primary swarms with young queens, are cast as unexpectedly, and may be as strong as those that are accompanied by the old queen. They have that in common with secondary swarms, that they behave like them, both in their exit and afterwards.

Secondary or After-Swaris.

411. Having described the method commonly pursued for hiving a new swarm, we return to the parent-colony from which they emigrated.

From the immense number which have abandoned it, we should naturally infer that it must be nearly depopulated. To those who limited the fertility of the queen to four hundred eggs a day, the rapid replenishing of a hive, after swarming, must have been inexplicable; but to those who have seen her lay from one to four thousand eggs a day, it is no mystery at all (40). Enough bees remain to carry on the domestic 
operations of the hive; and as the old queen departs only when there is a teeming population, and when thousands of young are daily hatching, and tens of thousands rapidly maturing, the hive, in a short time, is almost as populous as it was before swarming.

Those who suppose that the new colony consists wholly of young bees, forced to emigrate by the older ones, if they closely examine a new swarm, will find that while some have the ragged wings of age, others are so young as to be barely able to fly.

After the tumult of swarming is over, not a bee that did not participate in it, attempts to join the new colony, and not one that did, seeks to return. What determines some to go, and others to stay, we have no certain means of knowing. How wonderful must be the impression made upon an insect, to cause it in a few minutes so completely to lose its strong affection for the old home, that when established in a hive only a few feet distant, it pays not the slightest attention to is former abode!

445. It has already been stated that, if the weather is favorable, the old queen usually leaves near the time that the young queens are sealed over to be changed into nymphs. In about a week, one of them hatches; and the question must be decided whether or not, any more colonies shall be formed that season. If the hive is well flled with bees, and the season is in all respects promising, it is generally decided in the affirmative; although, under such cireumstances, some very strong colonies refuse to swarm more than once.

If the bees of the parent-colony decide to prevent the first hatched queen from killing the others, a strong guard is kept over their cells, and as often as she approaches them with murderous intent, she is bitten, or given to understand by other most uncourtier-like demonstrations, that even a queen cannot, in all things, do just as she pleases.

416. About a week after first swarming, should the Apiarist place his ear against the hive, in the morning or evening, 
when the bees are still, if the queens are "piping," he will readily recognize their peculiar sounds (115). The young queens are all mature, at the latest, in sixteen days from the departure of the first swarm, even if it left as soon as the royal cells were begun.

The second swarm usually issues on the first or second day after piping is heard; though the bees sometimes delay coming out until the fifth day, in consequence of an unfavorable state of the weather. Occasionally, the weather is so very unfavorable that they permit the oldest queen to kill the others, and refuse to swarm again. This is a rare occurrence, as young queens are not so particular about the weather as oid ones, and sometimes venture out, not merely when it is eloudy, but when rain is falling. On this account, if a very close watch is not kept, they are often lost. As piping ordinarily commences about a week after first-swarming, the second swarm usually issues eight or nine days after the first; although it has been known to issue as early as the third, and as late as the seventeenth; but such cases are very rare.

447. It frequently happens, in the agitation of swarming, that the usual guard over the queen-cells is withdrawn, and several batch at the same time, and accompany the colony; in which case the bees often alight in two or more separate clusters. In our observing-hives, we have repeatedly seen young queens thrust ont their tongues from a hole in their cell, to be fed by the bees. If allowed to issue at will, they are pale and weak, like other young bees, and for some time unable to fly; but if confined the usual time, they come forth fully colored, and ready for all emergencies. We have seen them issue in this state, while the excitement caused by removing the combs from a hive has driven the guard from their cells.

The following remarkable instance came under our observation, in Matamoras, Mexico: A second swarm deserting its abode the second_day after being hived, settled upon a tree. On examining the abandoned hive, five young queers 
were found lying dead on its bottom-board. The swarm was returned, and, the next morning, two more dead queens were found. As the colony afterwards prospered, eight queens, at least, must have left the parent-colony in a single swarm!

Young queens, whose ovaries are not burdened with eggs, are much quicker on the wing than old ones, and frequently fly much farther from the parent-stock before they alight.

The bee-keepers of old, who were not aequainted with the habits of bees, noticing that primary-swarms were more populous than after-swarn!s, used to brimstone (276) the old colony which had swarmed, and its after-swarm, considering the first swarm as the best of the three; but this apparent superiority was often of short duration, for the first swarm is nearly always accompanied by the old queen. We know better now, since we consider the age of the queen as one of the qualities of a colony.

448. After-swarms are much more prone to abscond or leave, after hiving, than primary-swarms. It is probably owing to the fact that the young queen has to go out for her bridal trip (121), and the bees sometimes leave with her. A comb of unsealed brood (166) given them will usually prevent this. An absconding swarm often leaves without settling.

419. After the departure of the second swarm, the oldest remaining queen leaves her cell; and if another swarm is to come forth, piping will still be heard; and so before the issue of each swarm after the first. It will sometimes be heard for a short time after the issue of the second swarm, even when the bees do not intend to swarm again. The third swarm usually leaves the hive on the second or third day after the second swarm, and the others, at intervals of about a day. We once had five swarms from one stock, in less than two weeks. In warm latitudes, more than twice this number of swarms have been known to issue, in one season, from a single colony.

After-swarms seriously reduce the strength of the parentstcek; since by the time they issue, nearly all the brood left by the old queen has hatched, and no more eggs can be laid 
until all swarming is over. If, after swarming, the weather suddenly becomes chilly, and the hive is thin, or the Apiarist continues the ventilation which was needed only for a crowded colony, the remaining bees being unable to maintain the requisite heat, great numbers of the brood may perish.

\section{Prevention of Natural Swarming.}

450. The prevention of natural swarming, in the present state of bee-keeping, is an important item, for several reasons.

1st, Bee-keeping has so spread in the last few years, that many bee-keepers are possessors of as many colonies as they desire to keep. Most Apiarists, especially farmers, keep bees only for the honey, and as it is impossible to produce both an increase of stock, and a large yield of honey in average seasons, they prefer the production of honey to that of swarms.

$2 n d$, Another objection to natural swarming arises from the disheartening fact, that bees are liable to swarm so often, as to destroy the value of both the parent-stock, and its afterswarms. Experienced bee-keepers obviate this difficulty by making one good colony out of two second swarms, and returming to the parent-stock all swarms after the second, and even this if the season is far advanced. Such operations often consume more time than they are worth.

$3 d$, The bees may be located in a town, near a public thoroughfare where people pass constantly, and accidents may take place; or perhaps near the woods where the swarm would cluster on such high limbs that it would be difficult or impos. sible to hive them.

$4 t h$, It is very troublesome to have to watch the bees for weeks, or to have them swarm at unexpected or unwelcome times, when the family is away, or at dinner, or while the owner is engaged with his business, for many bee-keepers are also lawyers, doctors or merchants, occupied in daily labors. 
which require a definite part of their time. The farmer may be interrupted in the business of hay-making, by the ery that his bees are swarming; and by the time he has hived them, perhaps a shower comes up, and his hay is injured more than the swarm is worth. Thus the keeping of a few bees, instead of being a source of profit, may prove an expensive luxury; while in a large apiary, the embarrassments are often seriously inereased. If, after a suceession of days unfavorable for swarming, the weather becomes pleasant, it often happens that several swarms rise at once, and eluster together; and not unfrequently, in the noise and confusion, other swarms fly off, and are lost. We have seen the bee-master, under such circumstances, so perplexed and exhausted as to be almost ready to wish he had never seen a bee.

451. Mr. J. F. Racine, of Wallen, Allen Co., Indiana, had 505 natural swarms from 165 colonies in the summer of 1883. Sixty-one swarms came out on the 3d of July. We will let him tell the story in his own way:

"In the morning, as soon as the watehword had been given for the first swarm, there was no rest. Primary, secondary, and after-swarms, all passed under the same limb of the same tree. The bees were no sooner shaken in a basket, and emptied in-front of a hive, than there was another eluster gathered, in the same spot. Some swarms had no queen, while others had 3, 4 , and even 5 of them. Some were young queens, some were old queens. When we could find a queen, we caged her (536) to preserve her from being balled ( 538 ). The sixty-one swarms were hived in 20 hives, and surplus cases were given them at once. A man, who had come with 5 hives to buy swarms, said that he had never seen the like, neither had I, although I have kept bees for 57 years. And the best of it is, I did not want any swarms at all that season."

452. 5th. It is admitted, by all progressive people, that man can achieve a great deal by artificial selection and cultivation of plants and animals The same selection is advisable in the reproduction of tne honey-bee, and an increase from 
selected colonies or selected races, cannot always be had by natural swarming. In this, artificial swarming is much better, and gives much more satisfactory results whenever an increase is desirable.

453. 6th. The numerous swarms lost every year, is a strong argument against natural swarming.

An eminent $\Lambda$ piarist has estimated that, taking into account all who keep bees, one-fourth of the best swarms are lost every season. While some bee-keepers seldom lose a swarm, the majority suffer serious losses by the flight of their bees to the woods; and it is next to impossible, even for the most careful, to prevent such occurrences, if their bees are allowed to swarm.

Apiarists will then recognize that it is very important to follow a metliod, which will nearly, if not altogether, prevent natural swarming. But in order to prevent it, we must. know the causes of it.

454. Natural swarming is a natural impulse in bees. Yet, it can be prevented, for it is always caused by uneasiness, as we will show in the next paragraph, or by an abnormal condition of the colony. It is caused:

1st. In the majority of instances, by the want of room in the combs. By want of roon, we do not mean want of empty space in the hive, but want of empty comb for the queen to deposit her eggs, or for the workers to deposit their honey. So long as bees have an abundance of empty space below their main hive, they very seldom swarm; but if it is on the sides of their hive, or above them, they often swarm rather than take possession of it.

This happens, not only in the Southern latitudes, where the swarming instinct is so powerful, but even in our Northern or Middle States. This fact is corroborated by Simmins, whose non-swarming system is based on the idea of keeping "open space and unfinished combs at the front, or adjoining the entrance." (Rottingdean, England, 1886.) Persons who are unacquainted with the details of bee-keeping have no idea 
how suddenly the honey harvest comes, and how rapidly the combs can be filled, when it once begins. Strong colonies which were almost destitute, just at the opening of the crop, owing to the large amount of brood they were raising, have been known to harvest twenty pounds, and more, in one day. When bees are thus gathering large quantities of honey, and the combs are becoming crowded, so that the cells, from which the young bees hatch, are filled with honey as fast as they are vacated, they feel the necessity of emigrating, especially as the constant hatching workers add daily to their large population. The building of additional combs, by a part of the bees, is sometimes insufficient to keep them from making preparations for swarming, as it does not give employment to all. The reader must remember that in a good colony, at this season, there are between 50,000 and 100,000 bees, according to the laying capacity of the queen and the size of the breedingroom. There is also an additional inerease over mortality of perhaps 2,000 bees daily. In spite of the admirable order of these wonderful little insects, there cannot help be more or less crowding, unless there is ample room in the combs.

455. If some of the bees decide that they are too crowded, queen-cells are raised (104) and the colony gets what Apiarists call the "swarming fever." It is a very appropriate name, indeed, since the so-called fever is cured only by swarming. In some extraordinary seasons, after this "swarming fever" has taken possession of their little brains; no amount of room given, even by dividing (4\%0) will prevent them from executing their purpose, unless the weather and the honey crop become unfavorable. We have repeatedly, in such seasons, divided a colony into several nuclei (520) without avail, each nucleus swarming in spite of its weakness.

456. $2 d$. The heat of the Summer sun, which alone would not cause them to swarm, hastens their preparations, when the bees are disposed to emigrate.

45\%. 3d. The hatching of a great number of drones due to an excess of drone-comb (224) in the brood chamber, in 
which the queen has deposited eggs, - is also an incitation to the "swarming fever." These big, burly, noisy fellows help to make the already crowded hive quite uncomfortable. This is why a great many bee-keepers of the old school noticed that hives which raise the most drones cast the greatest num. ber of swarms. But they incorrectly concluded that the drones were beneficial.

458. 4th. An improperly ventilated hive (333), or surplus arrangement, strongly induces natural swarming. We have seen ignorant bee-keepers, owners of box-hives, wonder why their bees swarmed and did not work in the surplus honey receptacle. In order to ventilate the honey receptacle, the bees have to form a line $(\mathbf{3 6 3})$ from the outside of the hive through the thickly covered combs, and force in air enough to enable them to breathe and live there.

Under such circumstances, hordes of useless consumers often blacken, for months, the outside of the hives, to the great loss of their disappointed owners.

459. 1st. It results from the above that the principal condition for the prevention of natural swarming is, a sufficient amount of empty comb, and this empty comb must be given in an easily accessible place near and above the brood.

The giving of comb foundation (674) instead of empty combs, will be sufficient if the crop is not flowing too fast. But in a very good season, if the harvesting workers bring the honey faster than the young bees can stretch the foundation into comb, it will not be sufficient.

460. If the breeding story is full and the surplus arrangement is placed above with a wooden division or honey-board (352) between, the bees will often consider the latter as too remote from their breeding room, especially if the holes which connect the two are few, and ventilation cannot be readily given from one apartment to another.

461. The giving of combs in a place of easy access, must be attended to, just before the crop begins, or the bees may make preparations which would render all later enlargements 
of the hive completely useless, as far as prevention of swarming is concerned. The breeding room must be large enough to accommodate the most prolific queen (155).

462. 2d. The hive must be located where the sun will not strike it directly in the hottest hours of the day. It can easily be sheltered artificially with a roof, if there is no shrubbery around it $(\mathbf{3 6 9})$.

463. 3d. The drone-comb must be carefully removed, in Spring, as far as possible, and replaced by worker-comb $(675)$. It is impossible to remove every cell of drone-comb, but a few drones will not hurt. It is the excess, the breeding of thousands of drones which is objectionable, and an incentive to swarming. The removal of drone-comb is highly advisable for other reasons (512).

464. 4th. The hive should be thoroughly ventilated, so that the bees will find themselves comfortable in it.

465. This system, which gives the smallest possible number of swarms, and the largest possible amount of surplushoney, was inaugurated by us, years ago, and has been adopted on both continents. Mr. Cowan, the worthy editor of the British Bee-Journal, says of it, page 148, April, 1886, "Hives managed in this way, will give the maximum of honey with the least amount of labor."

If the above directions are followed, the natural swarms will not exceed three to five per cent. These swarms will be very large-Mr. DeLayens once had a swarm weighing $11 \frac{1}{2}$ lbs. - and after-swarms will be scarce. The few hives that swarm are those which, having old queens, attempt to replace them during the swarming season (499), or those whose queens die while the crop is abundant.

In the first case, one or more young queens being raised in the hive, it often happens that the old queen tries to destroy them; the bees prevent her (114), and swarming is the result. The same reason may cause swarming in a strong colony, in which a queen has been introduced by the Apiarist, during a good yield of honey. Perhaps the bees accept her 
"under protest," and soon begin raising queen-cells to replace her, but the abundant honey harvest causes them to change their preparations, and they swarm with this introduced queen. A hive which has been made queenless during the honey crop, may swarm for the same reasons as soon as the young queens are old enough.

466. The prevention of natural swarming, when combhoney is raised in sections (722), is not so successful, becatuse the Apiarist cannot furnish his bees with empty combs. But very good results can be obtained, by following as nearly as possible all the directions above given.

467. As the queen cannot get through an opening 5-32 of an inch high-which will just pass a loaded worker, if the entrance to the hive be contracted to this dimension, she will not be able to leave with a swarm.

This is done with drone or queen-traps, perforated zine, entrance-blocks, and other fixtures (191).

This method of preventing swarming requires great accuracy of measurement, for a very trifling deviation from the dimensions given will either shut out the loaded workers, or let out the queen. It should be used only to imprison old queens; for young ones, if confined to the hive, cannot be impregnated (120). These fixtures, if firmly fastened, will exclude mice from the hive in the Winter. When used to prevent all swarming, it will be necessary to adjust them a little after sumrise and remove them before sunset, to take out, or allow the bees to carry ont any drones that have died.

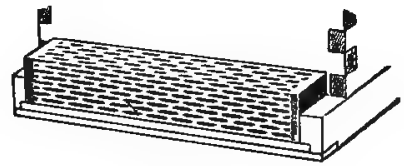

Fig. 97.

ENTRANCE GUARD.

We have seen colonies kill their queen, and raise another, because she ha $\vec{i}$ thus been unable to follow the swarm, hence, 
these appliances will do only in small apiaries, where beekeepers can examine each colony daily; and even there, we would not advise their constant use.

Mr. Langstroth had formerly devised a non-swarmer block, with a metallic slide, to prevent the escape of the queen. This was abandoned, because it annoyed the bees and interfered with ventilation, as all such arrangements do.

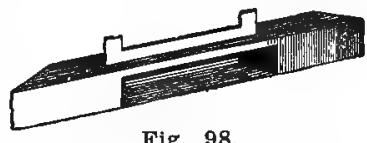

Fig. 98.

NON-SWÁRMER BLOCK.

It is shown attached on the hive in Fig. 61.

It would be a useful implement to reduce the entrance in winter.

Mr. C. C. Miller succeeds in producing large erops, and almost entirely preventing the issue of swarms, but the manipulations to which he resorts are so frequent as to make the practice unadvisable for the average bee-keeper. The specialist who wishes to raise comb honey and avoid swarming had best secure the book "Forty Years Among the Bees" and study it carefully.

468. After-swarms have been prevented from issuing, by a method invented by Jas. Heddon. The Heddon method consists in placing the first swarm side by side with the parent hive, and one week after the issue of the swarm, or just previous to the expected departure of the second swarm, remoring the parent hive to a new location, thus giving all its old bees to the first swarm. This is virtually preventing a natural issue by a forced issue, but making the first swarm strong, at the expense of the mother colony. The sole objection to this method is that it does away only with the annoyance of catching the swarm, and leaves the parent colony much weakened.

468 bis. Some Apiarists who raise comb honey with small hives, such as the eight-frame Langstroth or dovetailed hive, have adopted a method similar to the one just mentioned and much more satisfactory. The new swarm, when hived, is put on the stand of the old colony and this one is removed to a 
new spot. The supers on the old colony are also removed and given to the swarm, with a queen-excluder ( 732 ) between the brood apartment and the upper story. This virtually gives the entire working force and the partly filled honey cases to the swarm, which henceforth becomes the producing colony from which surplus may be expected. The old colony thus depleted of its active bees and stores, barely replenishes itself for the end of the season. Sometimes it happens that there are not even bees enough left in the old hive to take care of the brood, since all the active bees have gone to the old stand. In such a case, the Apiarist may place the old colony on the stand of a third hive which is of insufficient strength either to produce a crop of honey or to swarm. The active bees of this colony are thus given to the colony that swarmed and the third colony is itself removed to another spot.

This method usually does entirely away with secondary swarming. It is recommended by W. Z. Hutchinson, editor of the Bee-Keeper's Review, and author of "Advanced BeeCulture."

The increase of colonies may be kept down within reasonable limits by returning all after-swarms that have issued from the hives to the parent colonies. The swarm is hived in any any kind of box and allowed to remain twenty-four to fortyeight hours. At the end of that time it is shaken in front of the hive from which it has issued. The bees willingly re-enter their former home and rarely issue again. This method of prevention of inerease is sometimes successful even with primary swarms, if the conditions are otherwise favorable to their comfort. It is not a prevention of swarming, but a prevention of increase in spite of natural swarming. 


\section{.}

$\triangle$ 
Plate 18.

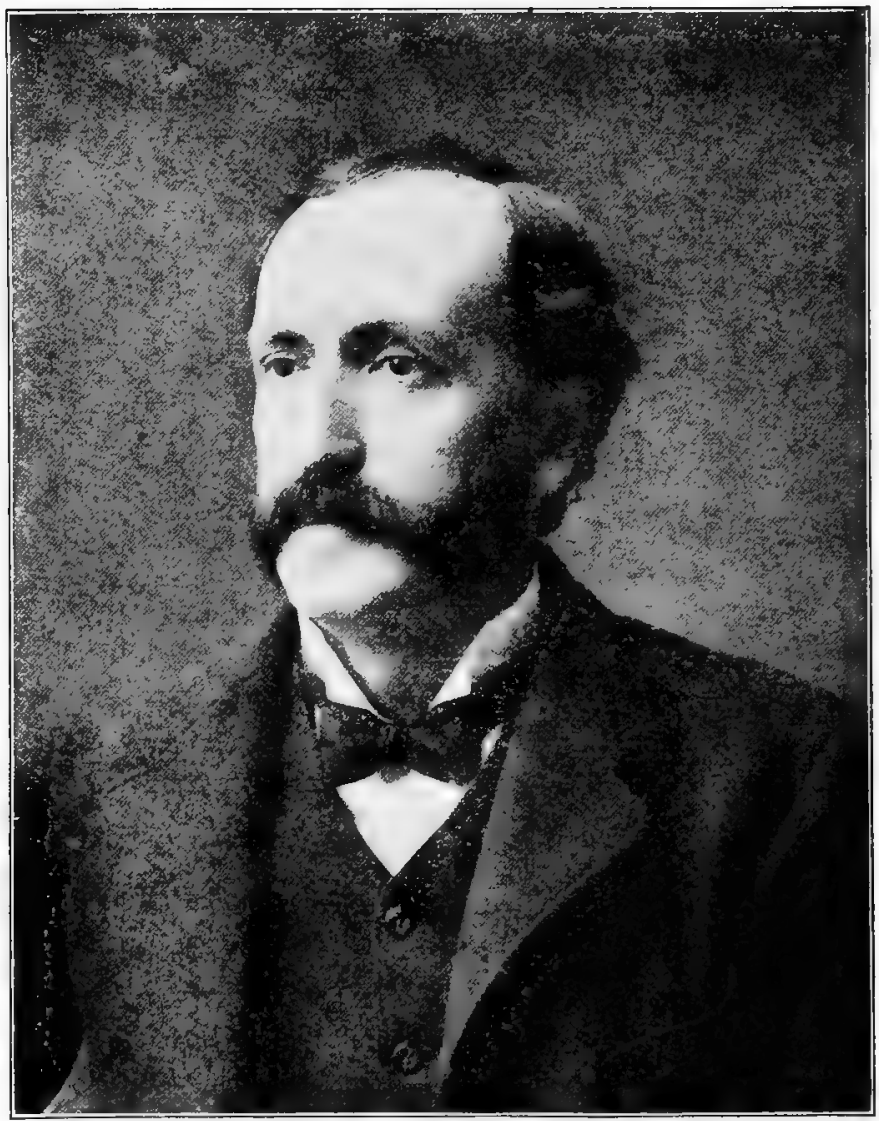

IV Z. HUTCHINSON,

The Ifate Publisher of "The Bee-Keeper's Review," Author of "The Production of Comb-Honey," and of "Advanced Bee-Culture."

This writer is mentioned pages $97,221,242,279,280,281,282,396$, $442,451,511$. 


\section{CHAPTER VII.}

\section{Artificial Swarming.}

469. Every practical bee-keeper is aware of the uncertainty of natural swarming. Under no circumstances can it be confidently relied on. While some colonies swarm repeatedly, others, apparently as strong in numbers, and rich in stores, refuse to swarm, even in seasons in all respects highly propitious. Such colonies, on examination, will often be found to have taken no steps for raising young queens. Besides, it frequently happens that, when all the preparations have been made for swarming, the weather proves so inclement that the young queens approach maturity before the old ones can leave, and are all destroyed. Under such circumstances, swarming, for that season, is almost certain to be prevented. The young queens are also sometimes destroyed, because of some sudden, and perhaps only temporary, suspension of the honey-harvest; for"bees seldom colonize, even if all their preparations are completed, unless the blossoms are yielding an abundant supply of honey.

The numerous perplexities pertaining to natural swarming, have, for ages, directed the attention of eultivators to the importance of devising some more reliable method for increasing the number of their colonies.

Dr. Scudamore quotes Columella as giving directions for making artificial swarms. Although he taught how to furnish a queen to a destitute colony, and how to transfer brood-comb, with maturing bees, from a strong stock to a weak one, he does not appear to have formed entirely new colonies by any artificial process. His treatise on bee-keeping shows not only that he was well acquainted with previous writers on the sub- 
ject, but that he was also a successful practical Apiarist. Its precepts, with but few exceptions, are truly admirahle, and prove that in his time bee-keeping, with the masses, must have been far in advance of what it was fifty years ago.

We have spoken of the bar-hive (282) as at least two hundred years old. From "A Journey into Greece, by George Wheeler, Esq.," made in 1675-6, it appears that it was, at that time, in common use there, and, probably, even then an old invention; he described its uses in forming artificial swarms, and removing spare honey. As the new swarms were made by dividing the combs between two hives, and no mention is made of giving the queenless one a royal cell, those old observers were probably acquainted with the fact that they could rear one from the worker-brood. Huber says:- "Monticelli, a Neapolitan Professor, claims that the plan of artificial swarming was borrowed from Favignana, and that the practice is so ancient that even the Latin names are preserved by the inhabitants in their procedure."

4\%0. Huber, after his splendid discoveries in the physiology of the bee, felt the need of some way of multiplying colonies, more reliable than that of natural swarming. $\mathrm{He}$ recommends forming artificial swarms, by dividing one of the hives, and adding six empty frames to each half.

"Dividing-hives" (278-279) of various kinds have been used in this country. The prineiple seems to have all the elements of success; but it was ascertained that, however modified, such hives are all practically worthless for purposes of artificial increase.

It is one of the laws of the hive, that bees which have no mature queen, seldom build any cells except such as are designed merely for storing honey, and are too large for the rearing of workers (228).

171. Messrs. Langstroth and Dzierzon were the first observers who had noticed the bearing of this remarkable fact on artificial increase. It may, at first, seem unaccountable that bees should build only comb unfit for breeding, when 


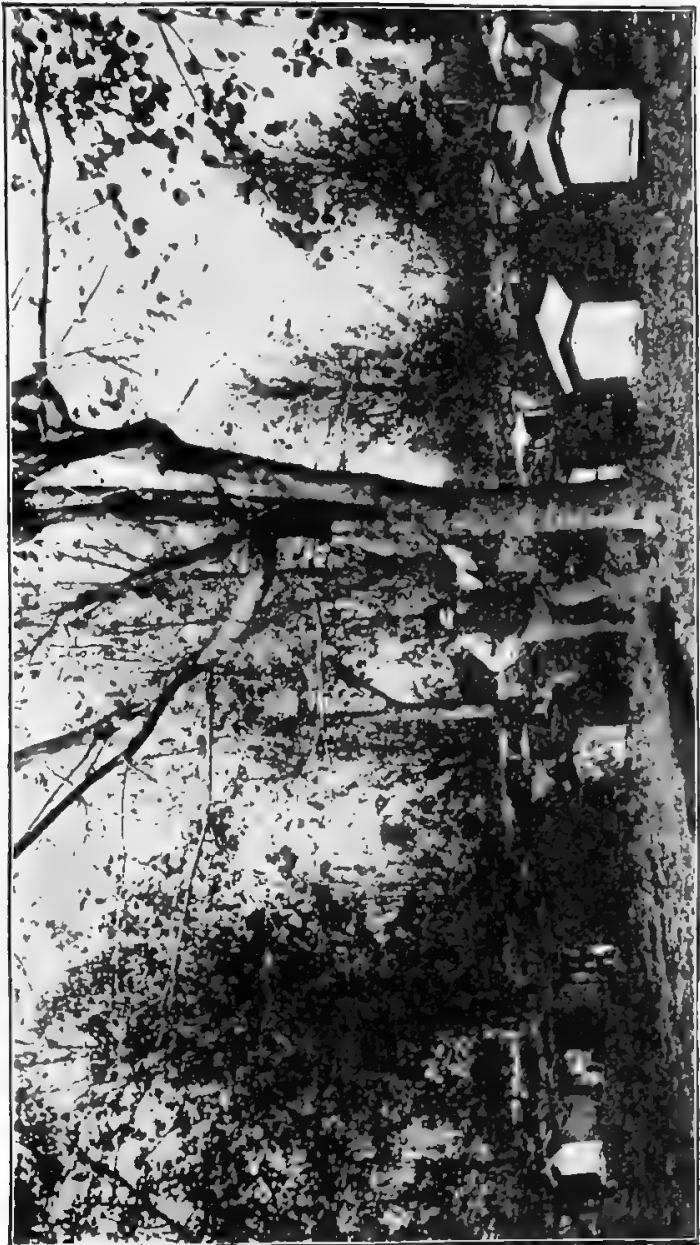

告 
their young queen will so soon require worker-cells for her eggs; but it must be borne in mind that at such times they are in an "abnormal" condition. In a state of nature, they seldom swarm until their hive is full of comb; or if they dn, their numbers are so reduced that they are rarely able to resume comb-building, until the young queen has hatehed.

The determination of bees having no mature queen, to build comb designed only for storing honey, and unfit for rearing workers, shows very clearly the folly of attempting to multiply colonies by dividing-hives, unless the greater part of the bees are given to the queen, and the greater part of the combs to the queenless half, or unless the Apiarist has enough combs already built or sheets of comb foundation, ou hand, to fill up the empty space.

When the queenless part proceeds to supply her loss, if it has bees enough to build new comb, it will build such as is designed only for storing honey. The next year, if this hive is divided, one-half will contain nearly all the brood, while the other, having most of its combs fit only for storing honey, or raising drones, will be a complete failure.

So uniformly do bees with an unhatched queen build coarse, or drone-comb, that often a glance at the combs of a new colony, will show either that it is queenless, or that, having been so, it has just reared a new queen.

472. Some Apiarists have attempted to multiply their colonies, by removing, when thousands of its inmates are ranging the fields, a strong stock to a new stand, and setting in its place an empty hive, with a frame of brood-comb, suitable for raising a queen. This method is still worse than the one just described. One-half of the dividing-hive was filled with breeding comb, while this empty hive having next to none, all that is built before the queen hatches, will be of a size unsuitable for rearing workers. The queenless part of the divided hive might also have contained a young queen almost mature, so that the building of large combs would have quiekly ceased; for it is not always necessary that a queen should have 
commenced laying eggs to induce her colony to build workercells; we have known a strong swarm with a virgin queen, to build beautiful worker-eomb, before a single egg was deposited in the cells.

When a new colony is formed by dividing the old hive, the queenless part has thousands of cells filled with brood and eggs, and young bees will be hatching for at least three weeks; by this time the young queen will ordinarily be laying eggs, so that there will be an interval of not more than three weeks, during which the colony will receive no accessions. But when a new swarm is formed, in the way above described, not an egg will be laid for nearly three weeks, and not a bee hatched for nearly six. During all this time the colony will rapidly decrease.

Every observing bee-keeper has noticed how rapidly even a large swarm diminishes in number, for the first three weeks after it has been hived. So great is the mortality of bees during the height of the working-season, that often, in less than that time, it does not contain one-half its original number.

By the time the progeny of the young queen begins to mature, the new hive will have so few bees that it would seldom be of any value, even if its combs were of the best construction.

4r3. One strong forced swarm, can be obtained in any style of hive, including box-hives, by the driving process (574 to 578) as follows: When it is time to form artificial colonies, we mean a few days before swarming time, or as soon as the hives are about full of bees,--drum a strong stock - which call $A$-so as to secure all its bees.

They may be driven either into a foreing-box, or into the upper story of a rnovable frame hive, and hived like a new swarm, when, if placed on their-old stand, they will work as vigorously as a natural swarm. If they were driven, at first, into a hive which will suit the Apiarist, it may be returned to their old location, without disturbing the bees.

If any bees are abroad when this is done, they will join 
this new colony. Remove to a new stand in the apiary a second stock-which call $B$-and put $A$ in its place.

Thousands of the bees that belong to $B$, as they return from the fields, will enter $A$, which thus secures enough to develop the brood, and rear a new queen. In fact, this colony often becomes so strong, by the help of the field workers of $B$, as well as through its own constantly hatching bees, that there is some danger of its easting off a swarm when the first young queen hatches, unless again divided at that time.

474. It is quite amusing to observe the actions of the bees that return to their old stand, when their homes have been exchanged as above.

If the strange hive is like their own in size and outward appearance, they go in as though all was right, but soon rush out in violent agitation, imagining that by some unaccountable mistake, they have entered the wrong place. Taking wing to correct their blunder, they find, to their increasing surprise, that they had directed their flight to the proper spot; again they enter, and again they tumble out, in bewildered crowds, until at length, if they find a queen or the means of raising one, they make up their minds that if the strange hive is not home, it looks like it, stands where it ought to be, and is, at all events, the only home they are likely to get. No doubt they often feel that a very hard bargain has been imposed upon them, but they are generally wise enough to make the best of it. They will be altogether too much disconcerted to quarrel with any bees that were left in the hive when it was foreed, and these on their part give them a welcome reception, especially if they come in with a heavy load.

This method of artificial swarming will not weaken either of the mother-colonies. If $B$ had been first forced, and then removed, it would have been seriously injured; but as it loses fewer bees than if it had swarmed, and retains its queen, it will soon become almost as powerful as before it was removed. 
The reader will notice that the treatment above recommended for the making of artificial swarms produces exactly the same result as the method mentioned at $\mathbf{4 6 8}$ bis for natural swarms. It secured one swarm from two colonies.

The Apiarist, by treating a natural swarm as he has been directed to treat a forced one, can secure an increase of one colony from two; and of all the methods of conducting natural swarming, in regions where rapid increase is not profitable, this is the best, provided the colonies do not stand too close together, and the hives used in the process are somewhat similar in shape and color.

475. Whenever the bee-keeper learns how to handle the movable-frames safely he must dispense with the forcing-box, and make his swarms by lifting out the frames from the parent-stock, and shaking the bees from them, by a quick jerking motion, upon a sheet, directly in front of the new hive.

If the hive contains much fresh honey, which is usually very thin, the bees must be brushed off, for shaking them off would also shake out a large amount of nectar ( $\mathbf{2 4 9}$ ).

As soon as a comb is deprived of its bees, it should be returned to the parent-stock. If one or two combs containing brood, eggs, and stores, are given to the forced swarm, it will be much encouraged, and will need no feeding (605) if the weather should be unfavorable. In removing the frames, the bee-keeper should look for the queen, and give the comb she is on, to the forced swarm, without shaking off the bees. If he does not see her on the combs, he will seldom after a little practice, fail to notice her, as she is shaken on the sheet, and crawls towards the new hive. The queen is seldom left on a frame after it has been shaken so that most of the bees fall off ( $\mathbf{4 3 9})$.

4\%6. The more combs with brood are taken from $A$, the less chance it will have to send forth a natural swarm with its first hatched queen.

If it is desirable to make a large number of swarms, and the parent colony is strong in hatching bees, only a few of 
the combs need be shaken in front of the new hive containing the queen, and the parent colony, with the adhering young bees, may be set in a new place.

By this method, one swarm is made from each of the hives set apart for inerease, and although the colonies thus divided are not so strong as when one swarm is made from two hives; yet, in ordinary localities and seasons, they become strong enough for all purposes, long before the season is over, especially if young queens are introduced $(\mathbf{5 3 3})$ in the colonies made queenless, and comb-foundation is used in full sheets in the frames $(6 \mathbf{6} 4)$.

This method of making artificial swarms may be varied adinfinitum. It is currently known among practical Apiarists under the name of "shook-swarming."

47\%. If the mother-colony has not been supplied with a fertile queen, it cannot for a long time part with another swarm, without being seriously weakened.

Second-swarming, as is well known, often very much injures the parent-colony, although its queens are rapidly maturing; but the forced mother-colony may have to start them almost from the egg. By giving it a fertile queen, and retaining enough adhering bees to develop the brood, another swarm may be taken away in tell or twelve days in a good season, and the mother-colony left in a far better condition than if it had parted with two natural swarms. In favorable seasons and localities, this process may be repeated two or three times, at intervals of ten days, and if no combs are removed, the mother-colony will still be well supplied with brood and mature bees. Indeed, the judicious removal of bees, at proper intervals, often leaves it, at the close of the Summer, better supplied than non-swarming colonies with maturing brood; the latter having - in the expressive language of an old writer-"waxed over fat."

We have had colonies which; after parting with four swarms in the way above described, have stored their hives with Fall honey, besides yielding a surplus in the supers. 
This method of artificial increase, which resembles natural swarming, in not taking away the combs of the mother-colony, is not only superior to it, in leaving a fertile queen, but obviates almost entirely all risk of after-swarming; for the forced swarm, containing the old queen, seldom attempts to send forth a new colony, and the parent hive, in which the joung queen is placed, is too destitute of field-workers to swarm soon. The young queen herself is equally contentexcept in very warm climates, or in extraordinary seasons-to stay where she is put. Even if the old queen is allowed to remain in the mother-colony, she will seldom leave, if suffcient room is given for storing surplus honey; and it makes no difference-as far as liability of swarming is concernedwhere the young one is put.

478. Artificial increase may be also made, by simply giving several frames of hatching bees to a nueleus (520) containing a fertile queen, and placing the colony thus built up on the stand of a strong hive, removing the latter to a new location.

If, from some cause, the parent-colony could not be moved, the forced swarm might be made to adhere to a new location as follows: Secure their queen, when the bees are shaken out of the hive; and when they show that they miss her, confine them to their hive, until their agitation has reached its height. Then open the hive, and as the bees begin to take wing, present their queen to them. When they have clustered around her, they may be treated like a natural swarm. To do this with every forced swarm would take too much time; but it would answer well when the foreed swarm is to be moved a short distance.

479. If no queens have been raised previously (514), by taking a few forced swarms, from select colonies (513), nine days before the time in which the most are to be made, there will be an abundance of sealed queens, almost mature, so that every parent-colony may have one. If the forced swarms were made a short time before natural swarming 
would have taken place, some of the parent-colonies will contain a number of maturing queens, which may be removed, a few days before hatching, and given to such as have started none. But it is far better to rear the queens first, as they can be bred from choice stock $(\mathbf{5 1 3})$.

However, as queen-rearing, by the Alley or Doolittle methods (528, 530), has now become a special business in the South, Apiarists may find it profitable to buy their queens from some reliable breeder in a southern state, where they can be reared more cheaply, early in the season $(\mathbf{6 0 1})$.

480. A nucleus (520) may be built up after its queen has commenced laying, by helping it with a comb of brood and young bees, from a full colony, adding, at proper intervals, a third, and a fourth, until they are strong enough to take care of themselves. This mode of increase is laborious, and requires skill and judgment; for, the bee-keeper should be very careful never to give a weak colony more brood than its bees can cover, remembering that, should the temperature become colder, the brood might be chilled and perish.

As a number of nuclei are to be simultaneously strengthened the Apiarist cannot complete his artificial processes by a single operation, and must always be on hand, or incur the risk of ending the season with a number of starving colonies. For these and other reasons, we much prefer the other metlods, above given, dispensing with so much opening of hives and handling of combs. If, however, any of the new colonies are weak enough to need it, they must be belped to combs from stronger ones.

481. Whatever method of artificial increase is pursued by the A piarist, he should never reduce the strength of his mothercolonies, so as seriously to cripple the reproductive power of their queens. This principle should be to him as "the law of the Medes and Persians, which altereth not;" for, while a queen, with an abundance of worker-comb and bees, may, in a single season, become the parent of a number of prosperous families, if her colony, at the beginning of the swarm- 
ing season, is divided into three or four parts, not one of them will ordinarily acquire stores enough to survive the Winter.

The practical bee-keeper should remember that no dronecomb is built when the queen is with the builders (2:29), and that the iess increase he takes, from the colonies on which he relies for surplus-honey, the better.

482. With the movable-frame hive, and the improved system, the Apiarist, by raising his queens or queen-celis (514) previously (and this is very important) can take the increase that he wishes to make, from colonies that would have produced little, if any, surplus, and preserve his best colonies for honey production. Let it not be undersiood by this, that we advise taking the increase from weak colonies, in every apiary, there are some colonies, which, though of fair strength, do not become populous in time to harvest more than their supply. Such colonies can furnish good swarms, with but little help, owing to the fact that the greater number of their bees raised during the harvest, instead of before it, are too young to go to the field (162).

If our method is followed, the colonies, which have been kept for honey production, can furnish help, if necessary, towards the end of the season, for those of the artificial swarms that need it.

To the prudent Apiarist, they are as a reserve body of select troops to the skillful general, a timely help, in an emergency.

Remember that populous colonies, that are raising queencells, during the early part of a good honey harvest, are strongly inclined to swarm when the young queens hatch (465).

483. The colonies that are raising young queens, either from worker-brood or from queen-cells given them, must be uell supplied with honey, must have enough young bees to keep the brood warm and to take care of it, and no combbuilding to do.

One artificial swarm made at the opening of the honey 
harvest, when the hive is full of brood, is better than two swarms made at its close.

When new colonies are made by purchasing queens (601) with nuclei (520), shipped from a distance (587), they should be hived on as many combs of brood, taken from other hives, as they can well cover. If full frames of foundation $(\mathbf{6 r 4})$ are added, from time to time, strong colonies may be built out of them, quite readily.

If the colonies are gathering much honey, when artificial swarms are made, but little smoke ( $\mathbf{3 8 2}$ ) will be needed in the operations. The frequent use of smoke makes the queen leave the combs, for greater security. This often causes great delay in the formation of artificial swarms by removing the frames, and in operations where it is desirable to catch the queen, or to examine her upon the comb.

484. Artificial operations of all kinds are most successful when bee-forage is abundant; when it is scarce, they are quite precarious, even if the colonies are well supplied with food.

When bees are not busy in honey-gathering, they have leisure to ascertain the condition of weak colonies, which are almost certain to be robbed, if they are incautiously opened. When forage is searce, the Apiarist who does not guard against robbing $(\mathbf{6 6 4})$ will seriously impair the value of his colonies, and entail upon himself much useless and vexatious labor. Beware of demoralizing bees, by tempting them to rob one another.

485. During a good honey flow, bees from different hives may be mixed without quarreling, owing to their more peaceable disposition, when full of honey, hence all manipulations become much easier. But at other times, great caution is requisite not only in giving a hive a strange queen, but in all attempts to mix bees belonging to different colonies. Bees having a fertile queen will often quarrel with those having an unimpregnated one.

Members of different colonies recognize their hive-companions especially by the sense of smell, and if there should 
be a thousand hives in the apiary, any one will readily detect a strange bee; just as each mother in a large flock of sheep is able, by the same sense, in the darkest night, to distinguish her own lamb from all the others. Colonies might be safely mingled, by sprinkling them with sugar-water, scented with peppermint or any other strong odor, which would make them all smell alike.

Bees also recognize strangers by their actions, even when they have the same scent; for a frightened bee curls herself up with a cowed look, which unmistakably proclaims that she is conscious of being an intruder. If, therefore, the bees of one colony are left on their own stand, and the others are suddenly introduced, in a time of scarcity, the latter, even when boih colonies have the same smell, are often so frightened that they are diseovered to be strangers, and are instantly killed. If, however, both colonies are removed to a new stand, and shaken out together on a sheet, they will peaceably mingle, when seented alike. We find substantially the same thing reeommended, in 1778, by Thomas Wildman (page 230 of the $3 d$ edition of his valuable work on Bees), who says, that bees will "unite while in fear and distress, without fighting, as they would be apt to do, if strange bees were added to a hive in possession of its honey."

486. The foreing of a swarm ought not to be attempted when the weather is cool, nor after dark. Bees are always much more iraseible when their hives are disturbed after it is dark, and as they cannot see where to fly, they will alight on the person of the bee-keeper, who is almost sure to be stung. It is seldom that night work is attempted upon bees, without making the operator repent his folly.

487. We would strongly dissuade any but the most experienced Apiarists, from attempting, at the furthest, to do inore than double their colonies in one year. It would take another book to furnish directions for rapid multiplieation, sufficiently full and explicit for the inexperienced; and even then, most who should undertake it, would be sure, at first, 
to fail. With ten strong colonies of bees, in movable-comb hives, in one propitious season, we could so increase them, in a favorable location, as to have, on the approach of Winter, one hundred good colonies; but we should expect to purchase queens, foundation, and perhaps hundreds of pounds of honey, devoting much of our time to their management, and bringing to the work the experience of many years, and the judgment acquired by numerous lamentable failures.

In one season, being called from home after our colonies Lau been greatly multiplied, the honey harvest was suddenly eut short by a drought, and we found, on our return, that most of our stocks were ruined by starvation.

The time, care, skill, and food required in our uncertain climate for the rapid increase of colonies, are so great, that not one bee-keeper in a hundred* can make it profitable; while most who attempt it, will be almost sure, at the close of the season, to find themselves in possession of colonies which have been managed to death.

A. cellain rather than a rapid multiplication of colonies, is most needed. A single colony, doubling every year, would, in ten years, increase to 1,024 colonies, and in twenty years to over a million! $\dagger$ At this rate, our whole country might, in

* Many a person who reads this will probably imagine that he is the one in a hundred.

+ The following calculation of possible profits from bee-culture, taken Prom "Sydserff's Treatise on Bees," published in England, in 1792, is a perfect gem of its kind :

"Suppose a swarm of bees at the first to cost 10s. 6d, and neither them nor the swarms to be taken, but to do well, and swarm once every year"-bees must be naughty, indeed, if they dare to do otherwise!"what will be the product for fourteen years, and what the proflt, if each hlve is sold at 10 s. $6 \mathrm{~d}$.?

Years. Hives. Profits.

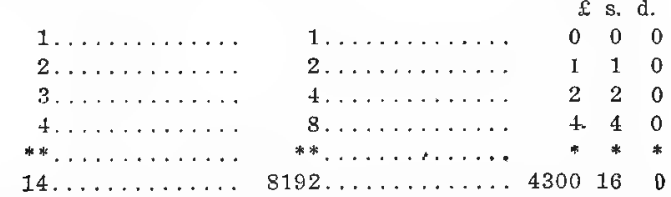

"N. B.-Deduct 10s, 6d, what the first bive cost, and the remalnder 
a few years, be over-stocked with bees; and even an increase of one-third, annually, would soon give us enough.

488. All the methods of increase above given, and several others of less importance, were described by Mr. Langstroth years ago. $\mathrm{He}$ never hesitated to sacrifice several colonies, in order to ascertain a single fact; and it would require a large volume, to detail his various experiments on the single subject of artificial swarming. The practical bee-keeper, however, should never lose sight of the important distinction between an apiary managed principally for purposes of observation and discovery, and one conducted exclusively with reference to pecuniary profit. Any bee-keeper can easily experiment with movable-frame hives; but he should do it, at first, only on a small scale, and if pecuniary profit is his object, should follow our directions, until he is sure that he has discovered others which are better. These cautions are given to prevent serious losses in using hives which, by facilitating all manner of experiments, may tempt the inexperienced into rash and unprofitable courses. Beginners, especially, should follow the directions here given as closely as possible; for, although they may doubtless be modified and improved, it can only be done by those experienced in managing bees.

Let us not be understood as wishing to intimate that perfection has been so nearly attained, that no more important discoveries remain to be made. On the contrary, we believe that apiculture is a growing science. Those who have time and means should experiment on a large scale with the movable-comb hives; and we hope that every intelligent bee-keeper

will be clear profit; supposing the second swarms to pay for hives, labor, etc." The modesty with which this writer, who seems to have had as much faith in his bees as in the doctrine that "figures cannot lie," closes his calculation at the end of fourteen years, is truly refreshing. No bee-keeper, on such a royal road to wealth, could ever find it in his heart to stop under twenty-one years, by which time, probably, he would be willing to close his bee-business, by selling it for over two and three-quarter millions of dollars! The attention of all venders of humbug bee-hives is respectfully invited to this antique specimen of the art of puffing. 
who uses them, will experiment, at least, on a small scale. In this way, we may hope that those points in the natural history of the bee still involved in doubt, will, ere long, be satisfactorily explained.

There is a large class of bee-keepers-not "bee-masters"who desire a hive which will give them, however ignorant or careless, a large yield of honey from their bees. They are easily captivated by the shallowest devices, and spend their money and destroy their bees, to fill the purses of unprincipled men. There never will be a "royal road" to profitable beeÉeping. Like all other branches of rural economy, it demands care and experience; and those who are conscious of a strong disposition to procrastinate and neglect. will do well to let bees alone, unless they hope, by the study of their systematic industry, to reform evil habits which are well nigh ineurable. 


\section{CHAPTER VIII.}

\section{QUEEN REARING.}

489. We have shown (109) that when a colony is deprived of its queen, the bees soon raise another, if they have worker eggs or young larræ.

In geueral, they select, first, some of the oldest among those whose milky "pap" has not yet been changed for coarser food $\left(\mathbf{1 0} \gamma^{\prime}\right)$. Such a selection is wise, for the older the larva is, the sooner the colony will recover a queen.

490. But some Apiarists fear that the bees will secure poorer queens, if they use larvæ, for they suppose that the food given to these during the first three days, may be different from the food given to the queen-larvæ, although it looks the same, and for this reason, they prefer to raise their queens from the egg.

491. A learned bee-keeper, of Switzerland, Mr. De Planta, has made comparative chemical experiments, on the milky food which is first given to the larve of drones, queens, and workers, and has ascertained that this foond is composed of the same substances for all, albumen, fat, sugar, and water, and that the only difference is in the proportions of these substances. Yet he concludes that these variations are but accessory, and not premeditated by the bees.

We think that these conclusions are right, for Mr. De Planta, to get a sufficient quantity of this food, had to take it from different hives, and at different seasons of the year; and as this milky food is apparently the product of glands (64), as is the milk of our cows, the proportions of substances in the "millk" of bees, may vary, as they do in the milk of cows, which contains more or less caseine, fat, sugar, or water, according to the race, the age, and the food eaten. 
192. Other bee-keepers suppose that the newly-hatched larvæ, intended by the bees to be raised as queens, are more plentifully fed from the first, than worker-larvæ. But we have always noticed, that, except during a scarcity, the latter have as much of this pap as they can eat, during the first three days, since they float on the milky food (166). The wise bee-keeper can ward against the rearing of poor queens, by feeding his bees abundantly, if necessary, a few days in advance, and during the queen-breeding.

193. Lastly, some bee-keepers think that bees sometimes nse larvæ more than three days old, and which consequently, have already received coarser food. One of our leaders in bee-culture writes that one of his colonies must have used a larva four and one-half days old, since this colony hatched a queen in eight and one-half days, instead of about ten, as usually (110). (Cook's Guide.) But we cannot admit that the nurses were guilty of such blunder, especially since they would have had the trouble of replacing with better food, the coarse pap already given. Most likely, some already constructed queen-cell had plassed unnoticed. Every one of us, old bee-keepers, has made similar errors, some queen cells being deceptive $(\mathbf{5 1 9})$.

494. The worker-larve are fed with millky food for three days, and with coarse food for the three following days. Not only does this coarse food change their organism, but it retards their growth, since the queens are mature in sixteen days, from the time that the egr is laid (19\%), while the workers do not hatch before twenty-one days, on average. Thus the three days of coarse food have prolonged the growth five days, or in other words, each day of coarse fceding has delayed the maturity forty hours. Therefore, if we suppose that bees could, and would use, larræ four and one-half days old, queens thus produced would hatch two and one-half days later than those raised from larvæ three days old. They would consequently hatch in eleven and one-half days instead of ten as usual. 
495. If some Apiarists have noticed that their best queens were reared during the swarming fever $(\mathbf{4 5 5})$, it is because the colonies are then in the best conditions to produce healthy queens. They have pollen and honey in abundance; as they are numerous, they keep the combs very warm; and, in addition, they have a large number of young bees, or nurses, to take care of the larvæ.

496. The following accidental experiment has proved to us that most of the old workers are unable to act as nurses. Years ago, one of our neighbors moved three colonies of bees about half a mile, in the Summer, without taking proper precautions; we were informed the next day, that quite a number of the oldest bees had returned, and had elustered under an old table. We brought a hive there, with a comb containing eggs and young larvæ. They took possession of it, but neglected to raise a queen, and soon dwindled away.

498. By placing the colonies, intended to raise queens, in the same condition as to food, heat, and nursing, as during the swarming fever, we will raise as good queens as are then raised. If, to these conditions, we add the selection of brood, from our best queens, we will greatly improve the quality of our stock.

For many years, we have used all the precautions described above, and, although our queens have never been reared from the egg, they are very prolifie and long-lived. Using hives with ten or eleven large frames, we are enabled to ascertain, beyond doubt, the prolifieness of our queens. Our preventing swarming ( $\mathbf{4 5 9}$ ) enables us also to reckon their longevity.

498. The interposition of the Apiarist, in queen-rearing, may be necessary:

1st. To supply the loss of a queen in a colony that has not the means of raising another.

2d. To breed a superior race of bees, or improve the present stock.

3d. To provide for the artificial increase of colonies. 
We will study the rearing of queens, in view of these requirements.

\section{Loss OT THE QUeEN.}

199. That the queen-bee is often lost, and that her colony will be ruined unless such a calamity is seasonably remedied, ought to be familiar facts to every bee-keeper.

Queens sometimes die of disease, or old age, when there is no brood to supply their loss. Few, however, perish under such circumstances; for, either the bees build royal cells, aware of their approaching end, or they die so suddenly as to leave young brood behind them. Queens are not only much longer-lived (158) than the workers, but are usually the last to perish in any fatal casualty. As many die of old age, if their death does not occur under favorable circumstances, it would cause, yearly, the loss of a very large number of colonies. As they seldom die when their strength is not severely taxed in breeding, drones are usually on hand to impregnate their successors.

500. Ioung queens are sometimes born with wings so imperfect that they cannot fly; and they may be so injured in their contests with each other, or by the rude treatment they receive when driven from the royal-cells, that they cannot leave the hive for impregnation (123).

501. More queens, whose loss cannot be supplied by the bees, perish when they leave the hive to meet the drones, than in all other ways. After the departure of the first swarm, the mother-colony and all the after-swarms have young queens which must leave the hive for impregnation; their larger size and slower fight make them a more tempting prey to birds, while others are dashed, by sudden gusts of wind, against some hard object, or blown into the water; for, with all their queenly dignity, they are not exempt from mishaps common to the humblest of their race.

502. In spite of their caution to mart the position and appearance of their habitation, the young queens frequently 
make a fatal mistake, and are destroyed, when attempting to enter the wrong hive.

This accounts for the fact that ignorant bee-keepers, with forlorn and rickety hives, no two of which look just alike, are sometimes more successful than those whose hives are of the best construction. The former-unless their hives are excessively crowded-lose but few queens, while the latter lose them in almost exact proportion to the taste and skill which induced them to make their hives of uniform size, shape and color (356).

503. We first learned the full extent of the danger of crowded apiaries, in the Summer of 1854. To protect our hives against extremes of heat and cold, they were ranged, side by side, over a trench, so that, through ventilators in their bottom-boards, they might receive, in Summer, a cooler, and in Winter, a much warmer air, than the external atmosphere. By this arrangement-which failed entirely to answer its design-many of our colonies became queenless, and we soon ascertained under what cireumstances young queens are ordinarily lost.

From the great uniformity of the hives in size, shape, color, and height, it was next to impossible for a young queen to be sure of returning to her hive. The difficulty was increased, from the fact that the ground before the trench was free from bushes or trees, and no hive-except the two end ones, which did not lose their queens-could have its location remembered, from its relative position to some external object. Most of the hives thus placed, which had young queens, became queenless, although supplied with other queens, again and again; and many, even of the workers, were constantly entering hives adjoining their own.

504. If a traveler should be carried, in a dark night, to a hotel in a strange eity, and on rising in the morning, should find the streets filled with buildings precisely like it, he would be able to return to his proper place, only by previously ascertaining its number, or by counting the houses between it and the corner. Such a numbering faculty, however, was not 
given to the queen-bee; for who, in a state of nature, ever saw a dozen or more hollow trees or other places frequented by bees, standing close together, precisely alike in size, shape, and color, with their entrances all facing the same way, and at exactly the same height from the ground?

On describing to a friend our observations on the loss of queens, he told us that in the management of his hens, he had fallen into a somewhat similar mistake. To economize room, and to give easier access to his selting hens, he had partitioned a long box into a dozen or more separate apartments. The hens, in returning to their nests, were deceived by the similarity of the entrances, so that often one box contained two or three unamiable aspirants for the honors of maternity, while others were entirely forsaken. Many eggs were broken, more were addled, and hardly enough hatched to establish one mother as the happy mistress of a flourishing family. Had he left his hens to their own instinets, they would have scattered their nests, and gladdened his eyes with a numerous offspring.

Every bee-keeper, whose hives are so arranged that the young queens are liable to make mistakes, must count upon heavy losses. If he puts a number of hives, under circumstances similar to those described, upon a bench, or the shelves of a bee-house, he can never keep their number good without constant renewal.

505. The bees are sometimes so excessively agitated when their queen leaves for impregnation (120), that they exhibit all the appearance of swarming. They seem to have an instinctive perception of the dangers which await her, and we have known them to gather around her and confine her, as though they could not bear to have her leave. If a queen is lost on her wedding excursion, the bees of an old colony will gradually decline; those of an after-swarm, will either unite with another hive, or dwindle away (18R).

506. It would be interesting, could we learn how bees become informed of the loss of their queen. When she is taken from them under circumstances that excite the whole 
colony, we can easily see how they find it out; for, as a tender mother, in time of danger, is all anxiety for her helpless children, so bees, when alarmed, always seek frst to assure themselves of the safety of their queen. If, however, the queen is very carefully removed, several hours may elapse before they realize their loss. How do they first become aware of it? Perhaps some dutiful bee, anxious to embrace her mother, makes diligent search for her through the hive. The intelligence that she cannot be found being noised abroad, the whole family is speerlily alarmed. At such times, instead of calmily conversing, by touching each other's antennæ, they may be seen violently striking them together, and by the most impassioned demonstrations manifesting their agony and despair.

We once removed the queen of a small colony, the bees of which took wing and filled the air, in search of her. Although she was returned in a few minutes, royal-cells were found two days later. The queen was unhurt, and the cells untenanted. Was this work begun by some that did not believe the others, when assured that she was safe? or from the apprehension that she might be removed again?

507. As soon as the bees begin to fly briskly in the Spring, a colony which does not industriously gather pollen, or accept of flour (26), is almost certain to have no queen, or one that is not fertile-unless it is on the eve of perishing from starvation.

A colony is sure to be queenless, if, after taking its first Spring-flight, the bees, by roaming, in an enquiring manner in and out of the hive show that some great calamity has befallen them. Those that come from the fields, instead of entering the hive with that dispatchful haste so characteristic of a bee returning, well loaded, to a prosperous home, usually linger about the entranee with an idle and dissatisfied appearance, and the colony is restless, late in the day, when others are quiet. Their home, like that of a man who is cursed in his domestic relations, is a melancholy place, and they enter it only with reluctant and slow-nıoving steps. 
508. And here, if permitted to address a word of friendly advice, we would say to every wife-Do all that you can to make your husband's home a place of attraction. When absent from it, let his heart glow at the thought of returning to its dear enjoyments; as he approaches it, let his countenance involuntarily assume a more cheerful expression, while his joy-quickened steps proclaim that he feels that there is no place like the cheerful home where his chosen wife and companion presides as its happy and honored Queen.

"The tenth and last species of women were made out of a bee; and happy is the man who gets such a one for his wife. She is full of virtue and prudence, and is the best wife that Jupiter can bestow." -Spectator, No. 209.

509. The negleet of a colony to expel drones (192), when they are destroyed in other hives, is always a suspicious sign, and generally an indication either that it has no queen, or else a drone-laying one (131), or drone-laying workers (176). A colony, in these circumstances, will not even destroy the drones of other hives, which may come to it, until a healthy queen has been raised in the hive, and is fertilized, and laying worker-eggs.

510. In opening a queenless hive, the plaintive hum of the bees, the listless and intermittent vibrating of their wings, and the total lack of eggs, or young worker brood, tell their condition.

A comb, with hatching bees," should be given to it from a stronger colony, together with another comb, of eggs and larvæ, from the best colony in the apiary; and the number of its combs should be reduced to suit the size of the cluster.

A better way yet to supply the loss, is to give the colony a queen-cell (103) or a young queen raised in the manner to be now described.

\footnotetext{
* That class of bee-keepers who suppose that all such operations are the "new fangled" inventions of modern times, will be surprised to learn that Columella, 1800 years ago, recommended strengthening feeble colonies, by cutting out combs from stronger ones, containing workers "just gnawing out of their cells."
} 


\section{REaring Improved RaCes.}

511. We will show (550) that some races of bees are superior to others. Even in the same apiary, some colonies are better than others, in prolificness, honey-gathering, endurance, gentleness," etc. It is very important to improve the apiary by rearing queens from the best breeds, for the increase of colonies, as well as to replace the inferior ones.

To this end, the bee-keeper should select two or more of the best colonies in his apiary, one for the production of drones, the others for the production of queens. Italian (551) bees are universally preferred; and as they are now almost as easily found as common bees, and are very cheap, we advise the novice to begin with at least two queens of this race.

A slight mixture of Cyprian or Syrian (559) blood is good, provided the issue be gentle and peaceable. Hybrids of common bees and Italians are often inferior, both in quality and disposition, and their characteristies are not fixed.

512. In selecting a colony for drone production, the color and size of the drones should not be considered so much, as the prolifieness of its queen, and the qualities of its workers, unless you wish to breed for beauty, in preference to honey-production.

Place two drone-combs (224) in the center of the broodchamber of this colony, as soon as it has recuperated from its winter losses. If the colony is kept well supplied with honey, enough drones will be raised to impregnate all the queens in the neighborhood; otherwise, they might destroy these early drones after having raised them.

If our directions on the removal of drone-comb (685) are followed, but few drones will be raised outside of those colonies specially intended for drone-breeding. As soon as they begin to hatch, we may make preparations for queenrearing, the best time being at the opening of fruit-blossoms. Some queen-breeders begin earlier, but early breeding gives much trouble and little pay, and our advice to Northern Apiarists, who want early queens, is to buy them from some re- 
liable Southern Apiarist, as they can be raised earlier in the South, much more cheaply than in the North.

513. In an apiary composed of several colonies, there are always some which are not expected to yield much crop, either because their queens are old, or because they are not prolific. Such queens are of very little value, and should be replaced. Select one of these colonies-not the poorest, unless it is populous enough to raise good queens. Kill its queen, and exchange its brood-combs, after having brushed the bees off, for a less number of combs, containing eggs and larvæ, from your best queen. It may be well to feed the colonies containing the select queens beforehand, so as to incite the laying of eggs (15t) and nursing of the brood.

514. If you desire to raise queens from eggs (490), or larvæ just hatching, prepare for it, by giving your select colony some frames of dry comb, or comb foundation, (6r4) a few days ahead, for the queen to lay in. In this ease, only those combs that contain eggs and young larvæ should be given to the queenless colony. It is always better to give but a small number of brood-combs to the colony intended for queen-raising, and to reduce its space with the divisionboard (349); as they can best keep it warm, in this manner, and raise better queens.

We should bear in mind that the nearer we get the colony that raises queens to the condition of a hive preparing to swarm, the better the queens will be. In a word, the hive in which queens are reared must be well supplied with bees, brood and honey, so the young queens may be well fed and kept warm.

515. The largest number of queen-cells can be obtained by cutting holes into the combs under the cells containing: young larvæ or eggs, and feeding the bees plentifully. Some Apiarists hold that, by leaving them without brood of any kind for a few hours, they will raise more cells afterwards.

516. Nine days after the furnishing of the brood to the queenless colony, count the number of queen-cells raised, remembering that one has to be left to the colony that raised 
them. On the same day, make swarms, (475) or nuclei, (52R) or destroy worthless queens (155) which you desire to replace next day.

517. The next day, with a sharp penknife, carefully remove a piece of comb, an inch or more square, that contains a queencell (Fig. 100), and in one of the brood combs of the hive to which this cell is to be given, cut a place just large enough to receive and hold it in a natural position. (Fig. 101.)

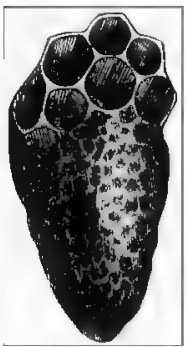

Fig. 100. QUEEN-CELL, REMOVED.

Each queenless stock can thus be supplied with a queer, ready to hatch, from the best breeding mother.

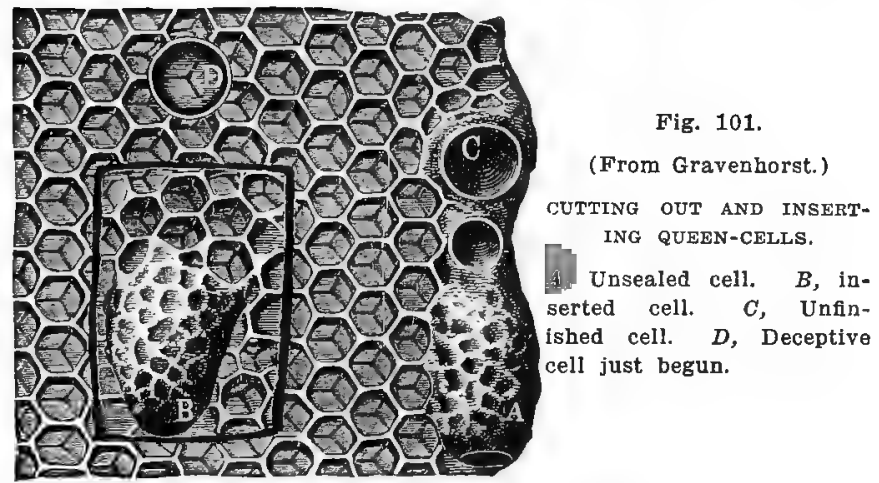

Unless very great care is used in transferring a royal cell, its inmate will be destroyed, as her body, until she is nearly mature, is so exceedingly soft, that a slight compression of her cell-especially near the base, where there is no cocoongenerally proves fatal. For this reason, it is best to defer removing them, until they are within three or four days of hatching. A queen-cell, nearly mature, may be known by its having the wax removed from the lid, by the bees, so as to give it a brown appearance.

518. If the weather is warm, and the hive, to which a 
queen-cell is given, is very populous, the cell may be introduced by simply inserting it in its natural position between two combs of brood. It is very important to have the queencell in or ncar the brood, or the bees might neglect it.

Sometimes, the bees so erowd the royal cells together

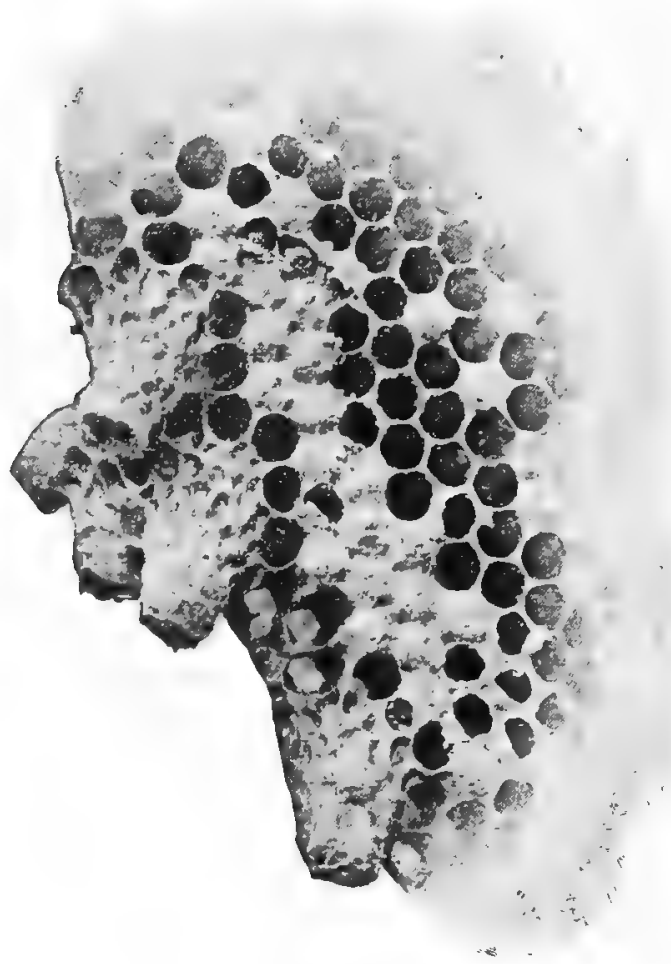

$$
\begin{gathered}
\text { Fig. } 102 . \\
\text { CLUSTER OF CELLs. } \\
\text { (From "Advanced Bee Culture.") }
\end{gathered}
$$

(fig. 102) that it is difficult to remove one without fatally injuring another, as, when a cell is cut into, the destruction and removal of the larva usually follows. Mr. Alley, by 
his method, given further on (528), found a remedy for this. If many queens are to be raised, it is well to have a new supply of cells started every week or even oftener.

519. A day or two after introducing the queen-cells, the Apiarist can ascertain, by examination, whether they have been accepted. If they have not been accepted, the cells will be found torn open, on the side (fig. 103), instead of on the end, and the colonies will have begun queen-cells of their own brood. These queen-cells must be dostroyed and replaced by others from the next supply. In removing them, the greatest care should be taken not to pass the deceptive queen-cells, if any are there (fig. 101), which, although less apparent, would disappoint the end in riew.

520. When queens are raised ahead of time for artificial increase, italianizing, or for sale, it is more profitable to use nuclei instead of full colonies to hatch these queens. The word nuclei (plural of nucleus), from the Latin nucleus a nut, a kernel, was first applied by Mr. Langstroth to diminutive colonies of bees. This term is now universally adopted on both continents.

521. When we were raising

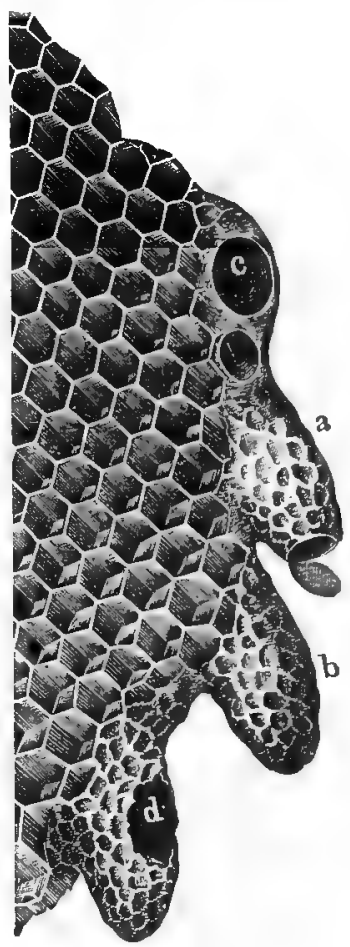

Fig. 103.

QUEEN-CELLS. queens for sale, we had contrived $a$, hatched cell; $b$, sealed cell; a divisible frame (figs. 104-105) to $c$, rudimentary cell; $a$, cell make these nuclei of combs taken torn by the bees.

from full colonies. Uur combs could be thus separated in two, and used in smaller hives, and in the Fall, these same combs 
were returned to the full colonies. Two small frames are more advantageous than one large frame, as they give more compactness to the cluster. Besides, these small colonies can
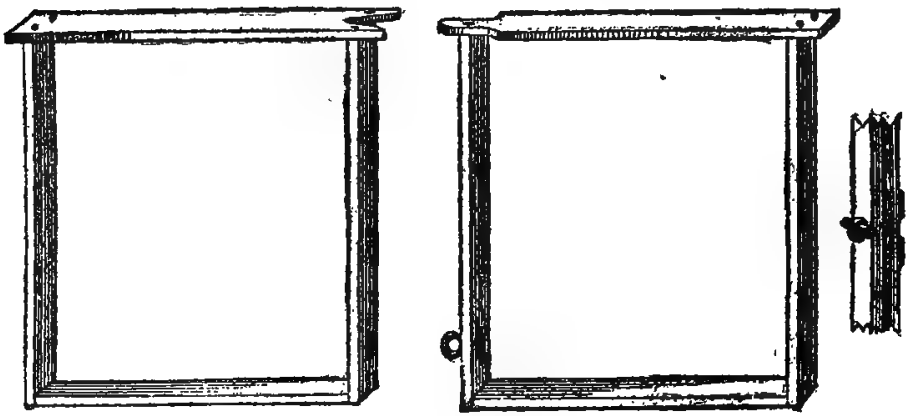

Fig. 104.

DIVISIBLE FRAME, OLD STYLE.

be built up easily afterwards by coupling the frames, and uniting the combs of 3 or 4 nuclei into one large hive.

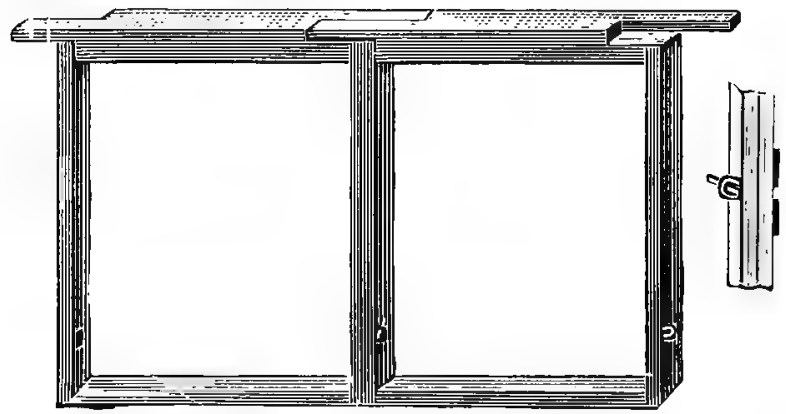

Fig. 105.

INTERCHANGEABLE DIVISIBLE FRAME.

It is not necessary to have many of these frames in an apiary, as a few are sufficient to make a number of nuclei, if they are placed in the centre of full colonies early in Spring. 
Two frames thus made from one standard Langstroth frame measure about $81 / 2$ by $8 \frac{1}{2}$ inches each, a very convenient size for nucleus frames.
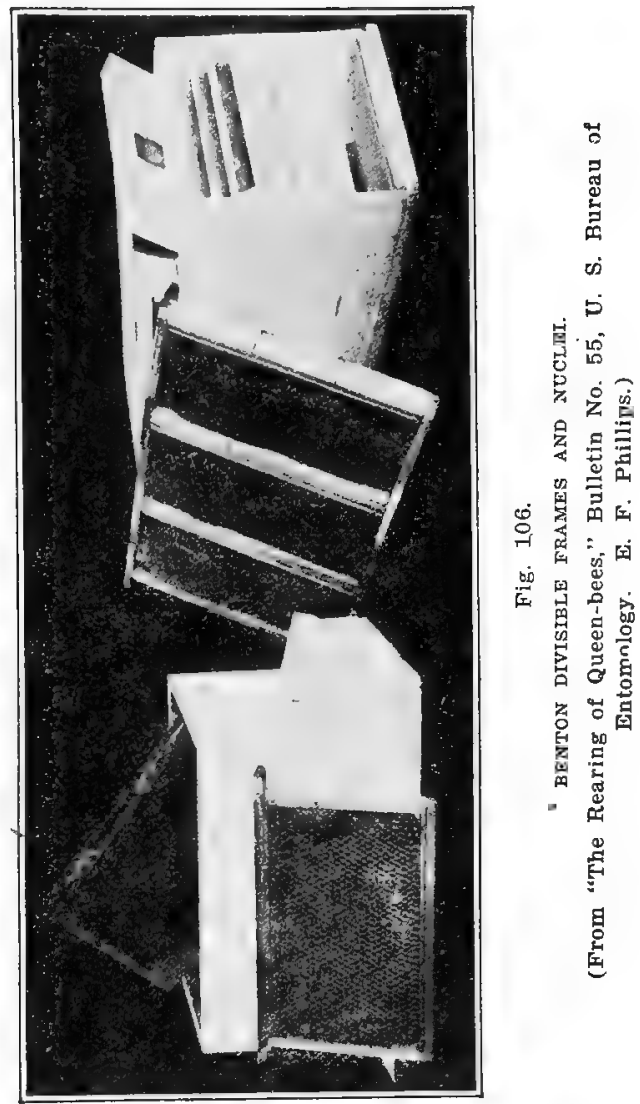

In the Fall, a number of nuclei may be united, in a full sized hive, on their own combs by this method.

522. To make a nucleus, take from a colony, as late in 
the afternoon as there is light enough to do it, a comb containing worker-eggs, and bees just gnawing out of their cells, and put it, with the mature bees that are on it, into an empty hive. If there are not bees enough adhering to it, to prevent the brood from being chilled during the night, more must be shaken into the hive from other combs. If the transfer is made so late in the day that the bees are not disposed to leave the hive, enough may have hatched, by morning, to supply the place of those which will return to the parent stock.

523. In every case, when a swarm has left its hive for another quarter, each bee, as she sallies out, flies with her head turned towards it, that by marking the surrounding objects, she may find her way back. If, however, the bees did not emigrate of their own free will, most of them appearing to forget, or not knowing, that their location has been changed, return to their familiar spot; for it would seem that,

\section{"A 'bee removed' against her will,} Is of the same opinion still.",

Should the Apiarist, ignorant of this fact, place the nucleus on a new stand without providing it with a sufficient, number of young bees, it would lose so many of the bees which ought to be retained in it, that most of its unsealed brood would perish from neglect.

If the comb used in forcing such a nucleus was removed at a time of day when the bees would be likely to return to the parent stock, they should be confined to the hive, until it is too late for them to leave; and if the number of bees, just emerging from their cells, is not large, the entrance to the hive should be closed, until about an hour before sunset of the next day but one. The hive containing this small colony, should be properly ventilated, and shaded-if thinfrom the intense heat of the sun; it should always be well supplied with honey. The space unoccupied in the hive should be separated from the nucleus by a division board (349). 
521. Beginners must remember that it is better to have these small nuclei strong with bees; but, in giving them young bees, care should be taken not to give them the queen. If a nucleus is made at mid-day, nearly all the bees given to it will be young bees, as the old bees are then in the field.*

The best manner to add young bees from strange colonies to weak nuclei, is to shake or brush them, on the apron board in front of the entrance, as is done in swarming (428). $\uparrow$

525. Hives, or nuclei in which queen-cells are to be introduced, should be aware of their queenless condition before a queen-cell is given them. Hence the necessity of preparing them 24 hours previous.

526. A vigilant eye should be kept upon every colony that has not an impregnated queen; and when its queen is about a week old it should be examined, and if she has become fertile, she will usually be found supplying one of the central combs with eggs. If neither queen nor eggs can be found, and there are no certain indications that she is lost, the hive should be examined a few days later, for some queens are longer in becoming impregnated than others, and it is often diffieult to find an unimpregnated one, on account of her adroit way of hiding among the bees.

As soon as the young queen lays, she may be introduced to a queenless colony, or sold, and if queen-cells are kept on hand, another one can be given to the nucleus the next day. Thus, nuclei may be made to raise two queens or more in a month.

527. If the queens are to be multiplied rapidly, the nuclei must never be allowed to become too much reduced in numbers, or to be destitute of brood or honey. With these precautions, the oftener their queen is taken from them, the more intent they will usually become in supplying her loss.

* Some apiarists place nuclei in the cellar for a day or two, to accustom the bees to their new home.

+ If these bees are taken from colonies that have been previously made queenless, they will more readily remain in their new homes, but young bees that have not yet taken flight seldom leave the hive to which they are given. if it has already brood and bees. 
There is one trait in the character of bees which is worthy of profound respect. Such is their indomitable energy and perseverance, that under circumstances apparently hopeless, they labor to the utmost to retrieve their losses, and sustain the sinking State. So long as they have a queen, or any prospect of raising one, they struggle vigorously against impending ruin, and never give up until their condition is absolutely desperate. We once knew a colony of bees not large enough to cover a piece of comb four inches square, to attempt to raise a queen. For two whole weeks, they adhered to their forlorn hope; until at last, when they had dwindled to less than one-half their original number, their new queen emerged, but with wings so imperfect that she could not fly. Crippled as she was, they treated her with almost as much respect as though she were fertile. In the course of a week more, scarce a dozen workers remained in the hive, and a few days later, the queen was gone, and only a few disconsolate wretches were left on the comb.

\section{COMMERCIAL QUEEN REARING.}

THE ALLEY METHOD.

528. Mr. Alley, who raised queens by the thousand, has published his method of queen-rearing. His queens are all raised in very swall nuclei which he ealls miniature hives. From a light-colored worker-comb filled with hatching eggs, le cuts strips with a sharp knife, as in fig. $10 \pi$.

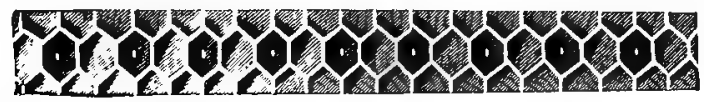

Fig. 107.

LGG IN EVERY OTHER CELL.

(From Alley.)

"After the comb has becn cut up, lay the pieces flat upon a board or table, and cut the cells on one side down to within one-fourth of an inch of the foundation or septum, as seen in 
fig. 108 which represents the comb ready to place in position for cell building. While engaged in this work, keep a lighted lamp near at hand, with which to heat the knife, or the cells will be badly jammed.

The strips of comb being ready, we simply destroy each alter. nate larva or egg, (fig. 107). In order to do this, take the strips carefully in the left hand, and insert the end of a common lucifer match into each alternate cell, pressing it gently on the bottom of the cell, and then twirling it rapidly between the thumb and fingers. This gives plenty of room for large cells to be built without interfering with those adjoining, and permits of their being separated without injury to neighboring cells.' '- 'Bee-keepers' Handy Book,' 1885.

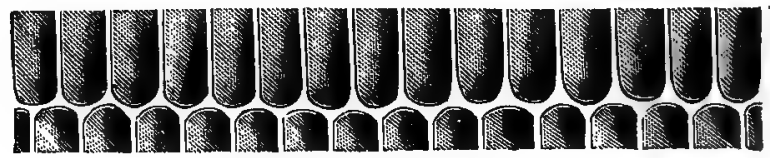

Fig. 108. (From Alley.)

This strip, Mr. Alley fastens under a trimmed comb cut slightly convex, by dipping the cells, which have been left full length, into a mixture of two parts rosin and one of beeswax, taking care not to over-heat this mixture, as the heat might destroy the eggs (fig. 109). The comb thus prepared is given to a prepared colony, which has been queenless and without brood for ten hours, Mr. Alley having noticed that the eggs may be destroyed if given to a colony just made queenless.

529. As it happens very often, that more queen-cells are raised than are needed immediately, and as the bees usually destroy all after the first one has hatched, Apiarists have devised queen-nurseries to preserve the supernumerary cells until needed. It is not safe to leave the queen-cells under the control of the bees after ten days, as a queen may hatch at any time.

The Alley queen-nursery is composed of a number of small 
cages, covered with wire cloth on each side and inserted in a frame. Each cage has two holes at the top, one for a sponge saturated with honey, the other to receive the queen-cell. The frame is inserted in a strong colony, not necessarily queenless,

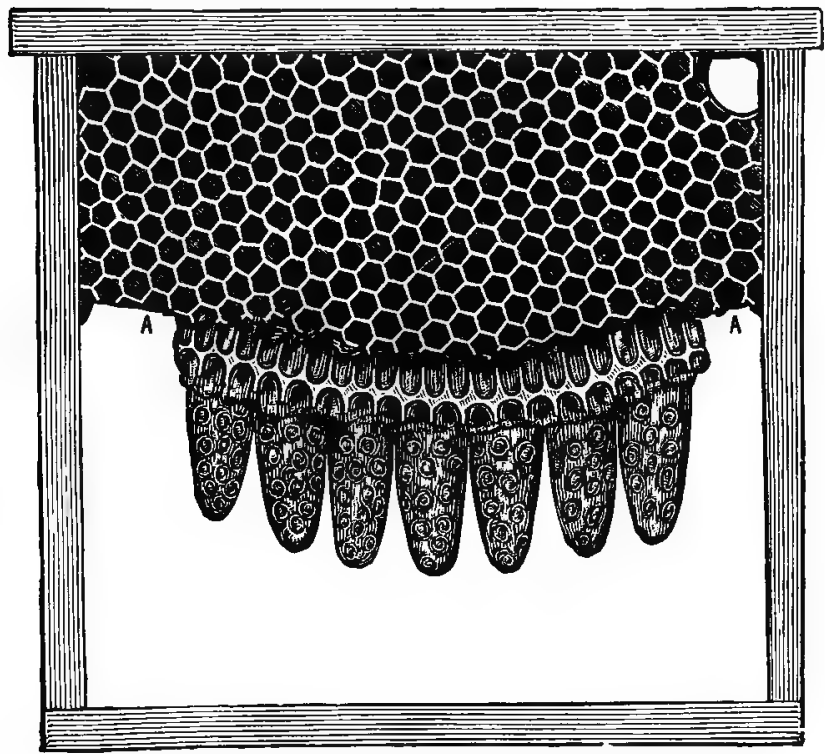

Fig. 109.

ROW OF QUEEN CELLS.

(From Alley.)

since these young queens are caged, and have feed at hand when they hatch.

The latest style of queen nursery is shown on plate 19.

The Doolitile Method.

530. Since the foregoing was written, the breeding of queens for sale has taken a new impetus. Mr. G. M. Doolittle, of New York, devised a method by which it does not become necessary for man to wait for the action of bees in rearing 



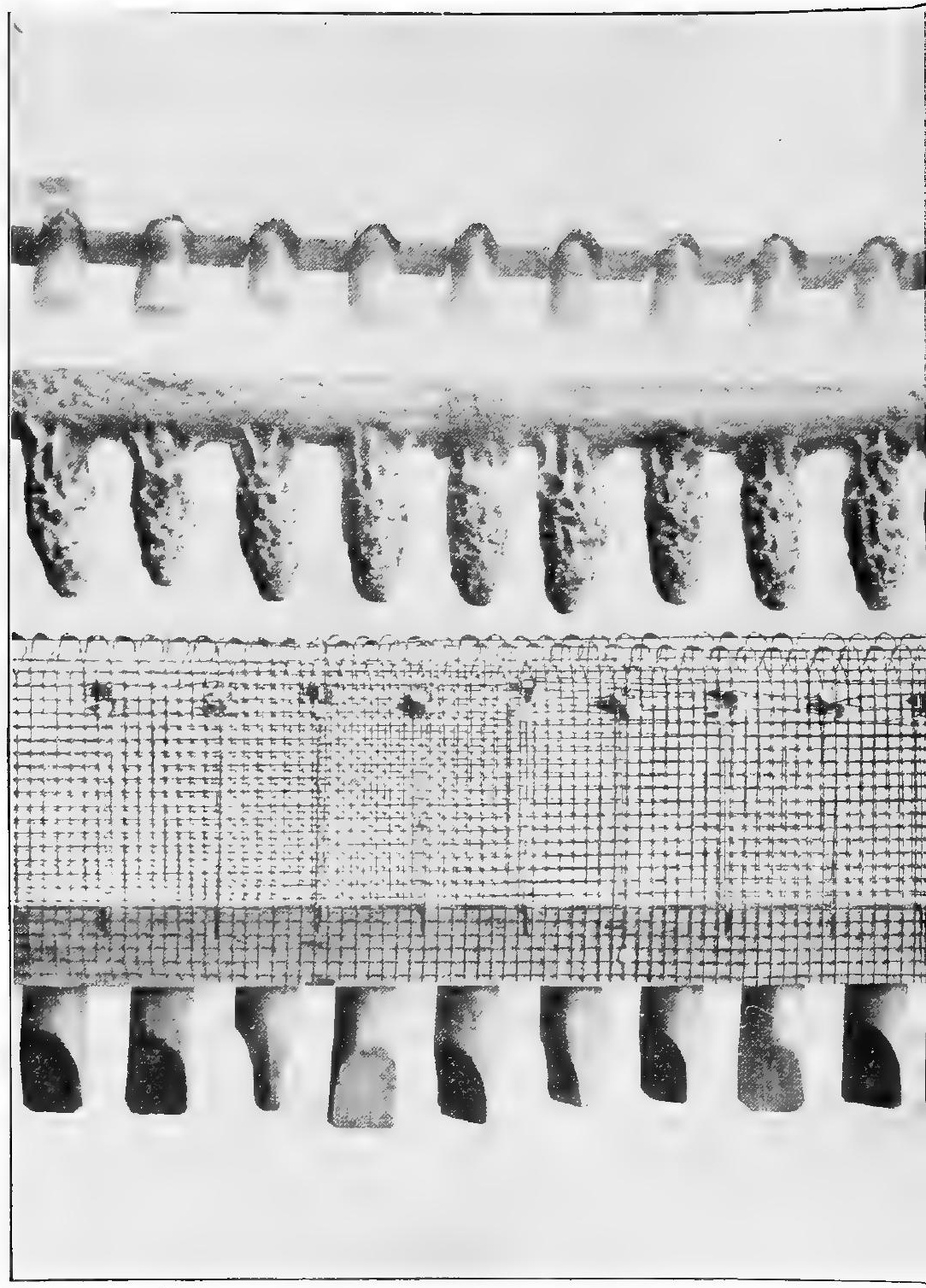

CELL-CUPS, QUEEN-CELL 


\section{Plate 19.}
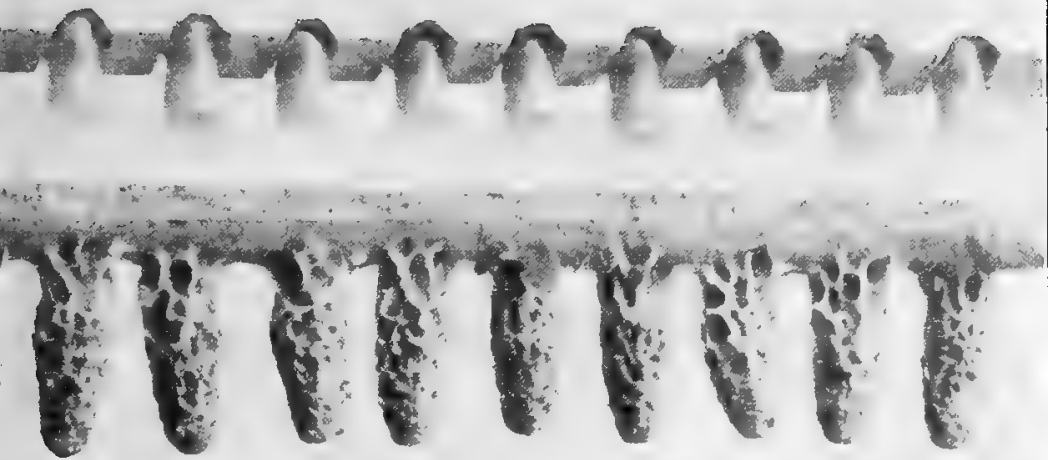

(1)

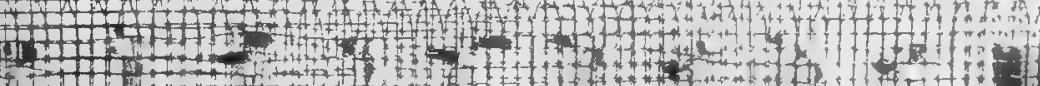
(5)

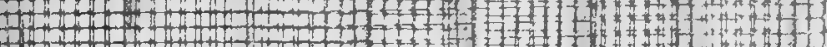
(1)

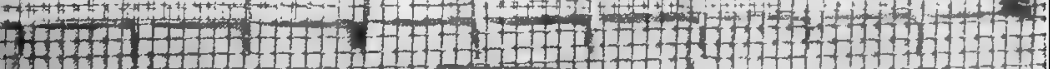

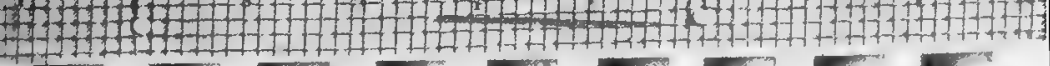
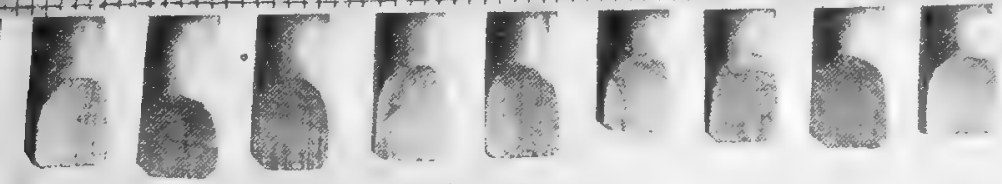

\section{LS, AND QUEEN-CAGES,}




$$
\text { - }
$$

$$
\checkmark
$$


queens. He worked persistently until he succeeded in producing queen-cells artificially, and this method, described by him in his little work, "Scientific queen-rearing," has been much improved upon of late years and is now called "The Doolittle System." It consists in manufacturing queen cell cups artificially out of beeswax and supplying them with young larva or eggs transferred into them from worker cells. A large number of these queen-cells are furnished to a queenless colony, and after the work of perfecting the queen-cells has been done by the queenless bees, they are given into the upper story of a strong colony whose bees will properly take care of these queen-cells on the only condition that this upper story is separated from the main breeding apartment in which the queen is laying, by means of a queen excluder (732). It is astonishing but it is nevertheless a fact that bees on the other side of a queen exeluding partition in a hive containing a good queen, will take care of queen-cells given them and will allow them to hatch. The Messrs. Giraud of Landreau, France, in their little work "Traité Pratique de l'élevage des reines" even advise the using of a colony with queen, for the entire work, separating the combs in which queen cells are reared from the main apartment by a perforated zinc. They succeeded in rearing as many as five hundred queen-cells during one season from one of their best colonies and the entire work was done in the hive occupied by that colony. This colony was kept supplied with a plentiful amount of feed during a scarcity of honey to keep up its breeding and its strength.

In the manner above mentioned, an unlimited number of queens, if properly cared for, may be raised from the best and most fertile queens. But when the queen-cells are about ready to hatch, the queens must be protected, for the first hatched would at once destroy the others. For this purpose, they use something similar to the queen-nursery of Alley. The nursery used by W. H. Pridgen of North Carolina, deseribed and recommended by W. Z. Hutehinson, in his work "Advanced Bee-culture" and of which we give an engraving, Plate 19 , is probably the most practical for the purpose, especially 
as it is kept on the same frame as the cell cups and sealed

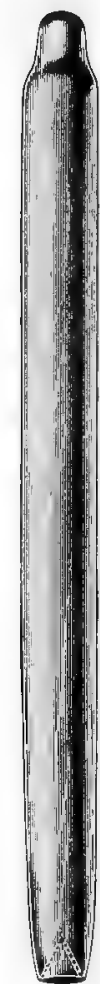
queen-cells.

"For making the artificial cells, there is needed a dipping-stick (fig. 110) which is a round stick 5-16 of an inch in diameter, with a peculiar taper at one end. The tapering part should be about 5-16 of an inch long, reduced rapidly for the first $1 / 8$ of an inch and then graduilly reduced to the end. It would slip into a worker cell $1 / 8$ of an inch before filling the mouth of the cell. These dipping sticks can be made with a lathe, from any kind of hard wood. To dip the cells, beeswax must be kept just above the melting point by placing the dish containing it over a lighted lamp. Keep a little water in the dish, as this will be a guide to the temperature. No bubbling should be allowed. 'The stick after being thoroughty soaked in water is dipped rather less than a lnalf inch into the beeswax, four dips usually completing the cell and attaching it to the wooden bar upon which it is supported while in the hive. Dip three times, then loosen up the cup on the stick, then dip again, and immediately press the base of the cell upon the stick at the point where it is desired to have the eell remain." ("Advanced Bee Culture.")

To transfer the larva, from worker cells into these artificial queen-cells, Mr. Pridgen gives the following directions:

Fig. 110. DIPPING-STICK.

"To make a success of this the comb must be old enough so that the outside of the cocoon is black and glossy. By shaving down the cells with a keen edge knife, slightly heated, until the walls of the cell are only about $1 / 8$ of an inch deep, it is an easy matter to remove the cocoon with the accompanying larva. In fact, by bending the piece of comb back and forth, the cocoons can often be forced to drop out of their own accord. By making a little funnel shaped cavity in the dipping stick. at the opposite end from that used in dipping the cells, the larva and cocoon can be lifted by pressing this cavity down 
over them, much as a gun cap is pressed down over the tube. After placing the end of the stick in one of the cups, a slight pressure and a little twist leaves the cocoon snugly ensconced in the bottom of the cell-cup."

In order to succeed, in breeding queens for sale, it requires good judgment, daily attention to the needs of the queens, and indefatigable perseverance. The queens when hatehed should be at once removed from the queen-nursery, so they may not wear themselves out by repeated attempts at escaping. It may be borne in mind, however, that young queens may be caged quite a while without injury, since in the natural conditions the worker bees often imprison the young queens in their cells until a favorable moment for swarming:

531. In order to economize in the rearing of queens, queen breeders have lately devised what is ealled "baby-nuclei" similar to the diminutive hives of Alley, but still smaller, in which only about two hundred young bees full of honey are introduced. The virgin queen is introduced to one of these and is sure to be welcome, especially if those bees have been taken from a queenless colony. There she remains until mated, which is usually within a very short time. The only advantage that we can see in this method is its cheapness, and the perhaps greater ease with which the queen can be introduced, but for several reasons and especially for the greater comfort and success of the queen, we would prefer to use the larger nuclei (521), where the conditions are more nearly similar to those of full colonies.

Whatever we do in the breeding of queens, let us bear in mind that we must keep our bees as nearly as possible in the conditions in which queens are reared naturally. This is indispensable for the raising of good stock. Apiarists of note have. objected to the Doolittle method, because of its forcing nature, but as good stock is raised, by this method, as in the natural way, and a greater number of good queens may be raised than in any other way. This is very much similar to the methods in which we increase our choice varieties of fruit trees. Graft- 
ing is not one of nature's ways, yet we succeed in raising some of our best fruit by grafting. But in grafting as in queen rearing, much care is needed in order to bring forth the most satisfactory results.

The A piarist who desires to make queen rearing a specialty should carefully read everything of importance concerning the subject. We recommend the special work of Doolittle, "Scientifie Queen Rearing," and the magnificently executed book of Hutchinson "Advanced Bee Culture," of which extracts have been given. Bulletin No. 55 of the Bureau of Entomology at Washington is a paper on the "Rearing of Queen Bees," by E. F. Phillips and contains also some valuable information concerning the different methods.

532. Before we pass to the subject of introducing queens, we cannot refrain from noticing the rapid progress of the business of queen rearing in the last fifty years. The introduction of brighter races has greatly increased the spreading of apiarian science, and many facts which, years ago, were known only to the few, now belong to the public domain.

In breeding the new races, let the novice remember that the qualities be should seek to improve are, first, prolifieness and honey production; second, peaceableness; third, beauty.

Since their introduction into this country, the Italians have been bred too much for color, at the expense of "their other qualities. We have seen queens, that had been so inbred for color, that their mating with a black drone hardly showed the hybridization of their progeny.

This in-and-in breeding, for color, has even produced whiteeyed drones, stone blind, a degeneracy which would tend to the extinction of the race.

\section{Intronucing ImPregnated QueEns.}

533. Great caution is needed in giving to bees a stranger queen. Huber thus described the way in which a new queen is usually received by a colony: 

Plate 20.

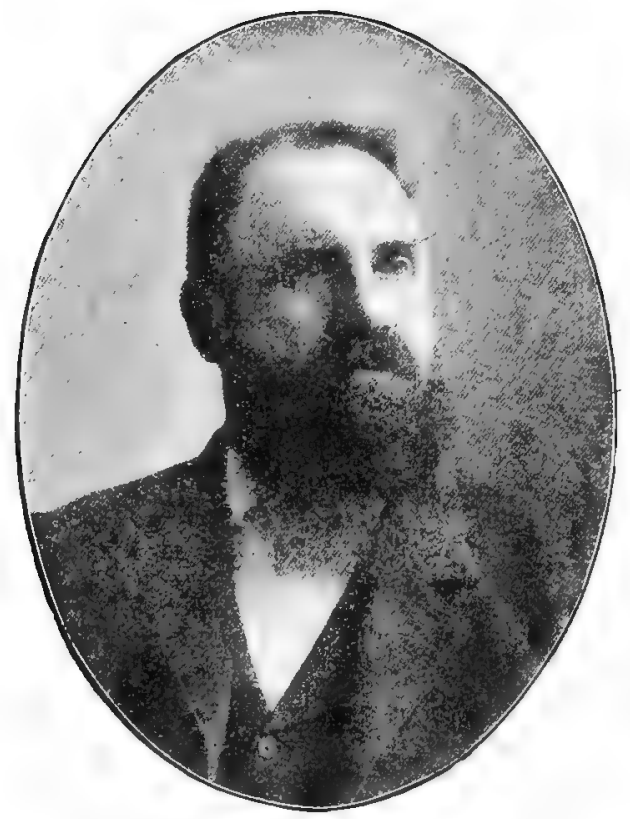

G. M. DOOLITTLE,

Author of "Scientific Qucen-Rerting" and of "Management of Bees."

This writer is mentioned pages $151,175,278,279,333,392,442,443$. 
"If another queen is introduced into the hive within twelve hours after the removal of the reigning one, they surround, seize, and keep her a very long time captive, in an impenetrable cluster, and she commonly dies either from hunger or want of air. If eighteen hours elapse before the substitution of a stranger-queen, she is treated, at first, in the same way, but the bees leave her sooner, nor is the surrounding cluster so close; they gradually disperse, and the queen is at last liberated; she moves languidly, and sometimes expires in a few minutes. Some, however, escape in good health, and afterwards reign in the hive."

The manner in which strange queens are treated by the bees, wher they are queenless, depends mainly on the state of the honey harvest.

534. But in order to meet with uniform sucess, the following conditions must be fulfilled:

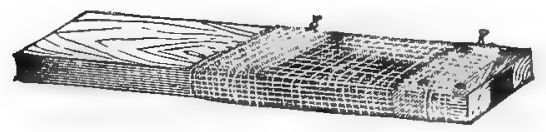

Fig. 111.

MILLER QUEEN CAGE.

(From "The A B C of Bee-Culture.")

The bees must be absolutely queenless. Sometimes a colony contains two (117) queens, and the Apiarist after removing one may imagine that he can introduce a stranger, safely. Many queens are thus killed.

535. Bees recognize one another mainly by scent. The queen, especially when laying, has a peculiar odor,evidently pervading the hive and known to the bees. It is thought that the absence of this odor, when a queen is removed, alarms the bees because they recognize their loss. When a new queen is introduced, if we cause the bees to become accustomed to her odor before we release her, she may be accepted more readily.

536. Our method consists in placing the queen in a small flat cage, made of wire cloth, between two combs, in the most 
populous part of the hive, near the brood and the honey, and keeping her there from 24 to 48 hours. These queen-cages were first used in Germany for introducing queens.

53\%. In catching a queen, she should be gently taken with the fingers, from among the bees, and if none are crushed, there is no risk of being stung. The queen herself will not sting, even if roughly handled.

If she is allowed to fly, she may be lost, by attempting to enter a strange hive.

To introduce her into the cage, she should be allowed to climb up into it. It is a fact well known to queen breeders that a bee or a qucen cannot be easily induced to enter a cage or a box turned dounurd. The meshes of the wire cloth should not be closer than 12 to the inch, that the bees may feed the queen readily through them. This is important, for we have lost two queens successively in a cage with closer meshes.

The bees will cultivate an acquaintance with the imprisoned mother, by thrusting their antennæ through the openings, and will be as quiet as though the queen had her liberty. Such a cage will be very convenient for any temporary confinement of a queen.

538. It is necessary, when the queen is released, that the bees be in good spirits, neither frightened, nor angered, and there should be no robbers about, as they might take her for an intruder, and ball her. (436).

This technical word is used to deseribe the peculiar way in whic's bees surround a queen whom they want to kill. The cluster that encloses her, is in the form of a ball, sometimes as large as one's fist, and so compact that it cannot readily be scattered. She may be rescued by throwing the ball into a basin of water. But the writer never had the patience to delay, for fear of damage to the balled queen, and always succeeded in freeing her with his fingers. We have known bees to ball their own mother in such eircumstances, for queens are of a timid disposition and easily frightened. When 
we release a strange queen, we put a small slice of comb honey, or honey cappings, in place of the stopper of the cage, and close the hive. It takes from 15 to 20 minutes for the bees to eat through, and by that time all is quiet, so the queen walks leisurely out of her cage, and is safe.

539. If the colony, in which a queen is to be introduced, is destitute, the bees should be abundantly fed on the preceding night (605). After she has been released, it is well to leave the colony alone for two or three days.

As a fertile queen can lay several thousand eggs a day, it is not strange that she should quickly become exhausted, if taken from the bees. "Ex nihilo nihil fit"-from nothing, nothing comes-and the arduous duties of maternity compel her to be an enormous eater. After an absence from the bees of only fifteen minutes, she will solicit honey, when returned; and if kept away for an hour or upwards, she must either be fed by the Apiarist, or have bees to supply her wants.

Mr. Simmins has taken advantage of this appetite, and of the propensity of bees to feed the queens, in introducing them directly, after keeping them without bees and food, for about 30 minutes. At dusk he lifts a corner of the cloth (352) of the hive in which he wants to introduce the queen, drives the bees away with a little smoke, and permits the queen to run between the combs. Then he waits 48 hours before visiting the hive. Several bee-keepers report having succeeded with this method. On account of this propensity of bees to feed queens, any number of fertile ones may be kept in a hive already containing a fertile queen, if they are placed in cages between the combs, near the honey and the brood.

In very good honey seasons, queens may be introduced to colonies without previous caging. They evidently accept a queen under such circumstances from the same reason that causes them to accept strange bees (485). But we strongly recommend never to attempt to introduce a valuable queen in this way.

Worker bees should-never be caged with the queen when she 
is introduced, as the other bees, noticing them to be strangers, will allow them to starve, though they will feed the queen.

510. Some Apiarists use chloroform, ether, puff-balls, or other ingredients, to stupefy the bees of mutinous colonies who persist in refusing to accept a strange queen and who show it by angrily surrounding the cage in which she is confined.

The Rev. John Thorley, in his "Female Monarchy," published at London, in 1744, appears to have first introduced the practice of stupefying bees by the nareotic fumes of the "puff ball" (Fungus pulverulentus), dried till it will hold fire like tinder. The bees soon drop motionless from their comb, and recover again after a short exposure to the air. This method was once much practiced in France, (L'Apiculteur, page 17 , Paris, 1856) but is very dangerous, as too large a dose of anæsthetics will cause death instead of sleep.

\section{Introduction of Tirgin QueEns.}

511. The difference in looks between a virgin queen and an impregnated one is striking, and an expert will distinguish them at a glance. The virgin queen is slender, her abdomen is small, her motions quick, she runs about and almost flies over the combs, when trying to hide from the light. In fact, she has nothing of the matronly dignity of a mother.

Bees, in possession of a fertile queen, are quite reluctant to accept an unimpregnated one in her stead; indeed, it requires much experience to be able to give a virgin queen to a colony, and yet be sure of securing for her a good reception.

Mr. Langstroth was the first to ascertain, years ago, that the best time to introduce her, is just after her birtl, as soon as she can crawl readily. If introduced too soon, the bees may drag her out, as they would any imperfect worker. Most queen-breeders liberate them on the comb, or at the entrance of a queenless nucleus. Mr. H. D. Cutting recommends daubing the young queen with honey, as she comes out of her cell, 
and liberating her among the bees, without touching her with the fing'ers.

Nearly all breeders acknowledge that the introduction of virgin queens to full colonies is an uncertain business, and that they can be introduced safely only to small nuclei that have been queenless some time. In this, we fully agree.

Doctor C. C. Miller recommends the introducing of a young queen in a cage while the fertile queen is still in the hive, removing the old queen a little later and leaving the virgin queen caged for two or three days, allowing the bees to liberate " her by eating through honey or candy to reach her (598). But the only way which may be held absolutely safe is to introduce the virgin queen to a colony or nucleus containing only young bees which have been deprived of queen for eight or ten hours. The smaller the number of bees, the greater the safety of the queen; that is why breeders introduce the virgin queens to small nuclei (531).

We would advise novices to abstain from introducing virgin queens, until they become expert in the business of queen rearing; the introduction of unhatehed queen-cells being much more easily performed, and more uniformly successful.

542. In introducing queens or queen-cells to full colonies during the swarming season, it happens very often that the bees also raise queen-cells of their own brood, and swarm with the queen given them (465). In view of this, the Apiarist should watch, for a few days, the colony to which a new queen has been introduced.

543. In hunting for a queen, it is necessary to remember that she is on the brood combs unless frightened away. If the bees are not greatly disturbed, an Italian queen may be found within five minutes after opening the hive.

A queen of common bees, or of hybrids, is more difficult to find, as her bees often rush about the hive as soon as it is opened. If she cannot be found on the combs, and the hive is populous, it is best to shake all the frames on a sheet, in front of an empty box, and secure them in a closed hive, out 
of the reach of robbers, until the search is over, when everything may be returned to its proper place.

544. After a queen is taken from a cage, the bees will run in and out of it for a long time, thus proving that they recognize her peculiar scent. It is this odor which causes them to run inquiringly orer our hands, after we have caught a queen, and over any spot where she alighted when her swarm came forth.

This scent of the queen was probably known in Aristotle's time, who says: "Then the bees swarm, if the king (queen) is lost, we are told that they all search for him, and follow. him with their sagacious smell, until they find him." Wildman says: "The scent of her body is so attractive to them, that the slightest touch of her, along any place, or substance, will attract the bees to it, and induce them to pursue any path she takes."

The intelligent bee-keeper has now realized, not only how queens may be raised or replaced, by the use of the movableframe live, but how any operation, which in other hives is performed with difficulty, if at all, is in this rendered easy and certain. No hive, however, can make the ignorant or negligent very successful, even if they live in a region where the climate is so propitious, and the honey resources so abundant, that the bees will prosper in spite of mismanagement or neglect. 


\section{CHAPTER IX.}

\section{RACES OF BEES.}

545. The honey-bee is not indigenous to America. Thomas Jefferson, in his "Notes on Virginia," says:

"The honey-bee is not a native of our country. Maregrave indeed, mentions a species of honey-bee in Brazil. But this has no sting, and is therefore different from the one we have, which resembles perfectly that of Europe. The Indians concur with us in the tradition that it was brought from Europe; but when and by whom, we know not. The bees have generally extended themselves into the country, a little in advance of the white settlers. The Indians therefore eall them the white man's fly."

"When John Eliot translated the Scriptures into the language of the Aborigines of North America, no words were found expressive of the terms wax and honey." (A. B. J. July, 1866.)

Longfellow, in his "Song of Hiawatha," in describing the advent of the European to the New World, makes his Indian warrior say of the bee and the white clover:-
"Wheresoe'er they move, before them
Swarms the stinging fly, the Ahmo,
Swarms the bee, the honey-maker;
Wheres'ie er they tread, beneath them
Springs a flower unknown among us,
Springs the White Man's Foot in blossom."

546. According to the quotations of the A. B. J., common bees were imported into Florida, by the Spaniards previous to 1763, for they were first noticed in West Florida in that year. They appeared in Kentucky in 1780, in New York in 1793, and West of the Mississippi in 1797. 
547. "It is surprising in what countless swarms the bees have overspread the far West within but a moderate number of years. The Indians consider them the harbingers of the white man, as the buffalo is of the red man, and say that, in proportion as the bee advances, the Indian and the buffalo retire..... They have been the heralds of eivilization, steadily

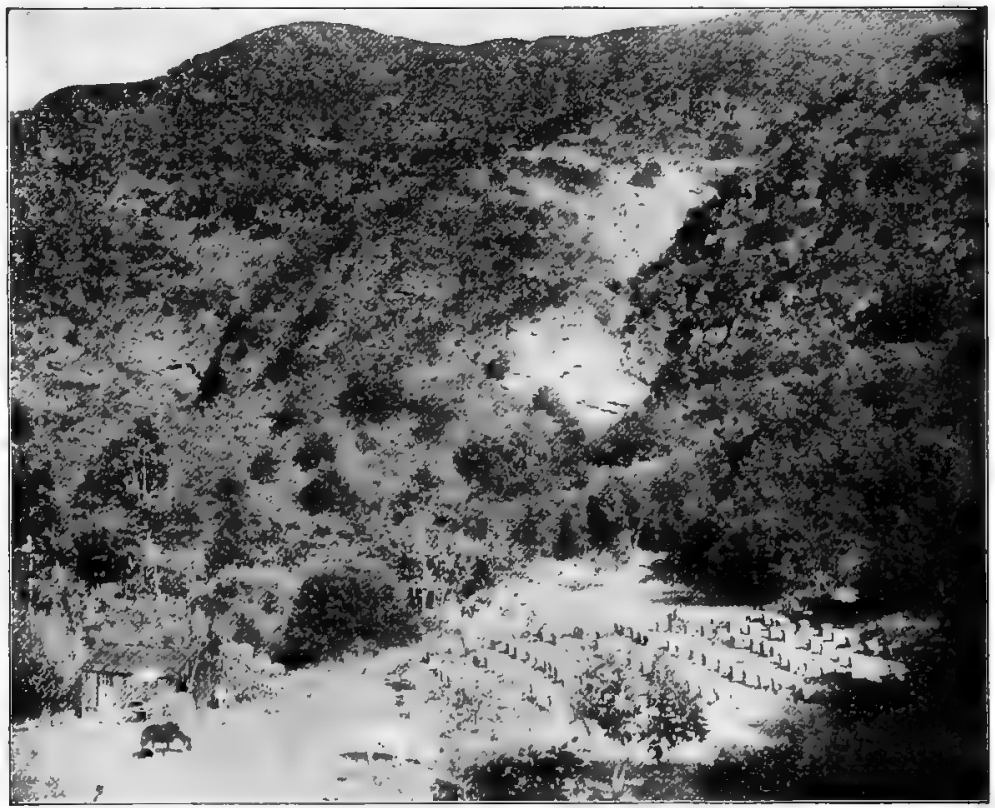

Fig. 112.

AN APIARY IN CALIFORNIA.

(From the "American Bee Journal.")

preceding it as it advances from the Atlantic borders; and some of the ancient settlers of the West pretend to give the very year when the honey-bee first crossed the Mississippi. At present it swarms in myriads in the noble groves and forests that skirt and intersect the prairies, and extend along the alluvial bottoms of the rivers. It spems to me as if these beautiful 
regions answer literally to the description of the land of promse-'a land flowing with milk and honey;' for the rich pasl.urage of the prairies is calculated to sustain herds of cattle as countless as the sands upon the sea-shore, while the flowers with which they are enamelled render them a very paradise for the nectar-seeking bee."-Washington Irving, "Tour on the Prairies," Chap. IX. (1832).

Many Apiarists contend that newly-settled countries are most favorable to the bee; and an old German adage runs thus:-

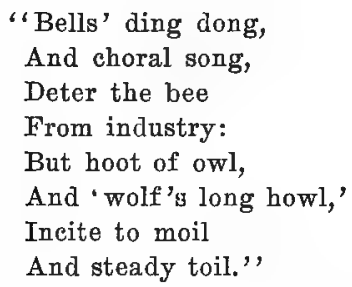

It is evident that the bees spread Westward very rapidly, and to this day, many old bee-men can be found, who positively assert that a swarm never goes Eastward, even after it is proven to them that they usually go to the nearest timber. Our United States are now occupied by the honey-bee, from Maine to Calfornia, from Texas to Montana, wherever man and moisture may be found. The irrigated portions of the arid West, in Arizona, Colorado, Utah, Nevada, have proven an eldorado for them.

At the National Convention of Bee-Keepers held at Los Angeles, California, in August, 1903, Mr. J. S. Harbison, gave an interesting account of his first introduction of bees to the Pacific Coast. He took 116 colonies, in 1857, from Newcastle, Penna., to Sacramento, by way of Panama and the Panama railroad, with the loss of only six colonies and when he reached California with them, he sold readily those that he wished to dispose of, at $\$ 100$ per colony. The reader knows how successful bee-culture has become in California since that early date. 
548. Bees, like all other insects, are divided scientifically into genera, species, and varieties.

Aristotle speaks of three different varieties of the honeybee, as well known in his time. The best variety he describes as small, and round in size and shape, and variegated in color.

Virgil (Georgica, lib. IV., 98) speaks of two kinds as flourishing in his time; the better of the two he thus describes:

"Elucent aliæ, et fulgore coruseant, Ardentes auro, et paribus lita corpora guttis. Hæc potior soboles; hine cœli tempore certo Dulcia mella premes.",

"The others glitter, and their variegated bodies shine like drops of sprinkling gold. This better breed! Thanks to them, if the weather of the sky is certain, you will have honey combs to press."

This better variety, it will be seen, he characterizes as spotted or variegated, and of a beautiful golden color.

549. The first bee introduced into America, was the common bee of Europe, Western Asia, and Western Africa, Apis mellifica, now called Apis mellifera, by many. "Mellifics means "honey waker," while "Mellifera" means "honey bearer." It is usually designated under the name of black, or gray bee. Both names are appropriate, since the race varies in shade, according to localities. In the greater part of Africa, as well as in the European provinces of Turkey, the common bees are dark, nearly black. In other places, their color is grayish. They vary in size, as well. According to some French writers, the bees of Holland are small, and denominated "la petite Hollandaise" (the little Hollander); on the other hand, the Carniolan* bees are quite large. We have never seen queens as large as some Carniolans which we imported some thirty years ago. But, in spite of the prolificness

* Carniola is a province of Austria, near the Adriatic, but on the East slope of the mountains, 
and general good reputation of this race, we did not attempt to propagate it, owing to the difficulty of detecting their mating with the common bees, since they are almost alike in color.

These bees have since been bred largely in the U. S., and are praised for their prolifieness and peaceable disposition.

550. Besides the common bee, there are a great many varieties. The best known are: 1st, the Ligurian, Apis Ligustica, so named by Spinola, because he found it first, in the part of Italy called Liguria. The Rev. E. W. Gilman, of Bangor, Maine, directed the writer's attention to Spinola's "Insectorum Liguriae species novae aut rariores," from which it appears, that Spinola accurately described all the peculiarities of this bee, which he found in Piedmont, in 1805. He fully identified it with the bee described by Aristotle.

2nd. The Apis fasciata (banded bee). This bee, related to the Italian, or Ligurian, which has yellow bands also, is found in Egypt, in Arabia, along both sides of the Red Sea, in Syria, in Cyprus and in Caucasus.

3d. We shall mention also the large Apis dorsata of Southern Asia, and the melipones of Brazil and Mexico.

551. The Italian bee, Apis Ligustica, spoken of by Aristotle and Virgil as the best kind, still exists distinct and pure from the common kind, after the lapse of more than two thousand years.

The great superiority of this race, over any other race known, is now universally acknowledged; for it has victoriously stood the test of practical bee-keepers, side by side with the common bee. The ultimate superseding of the common bee by the Italian in this country is but a matter of time. Already, in many parts of Colorado, no other race is to be found.

552. The following facts are evident:

1st. The Italian bees are less sensitive to cold than the common kind. 2nd. Their queens are more prolific. $3 d$. They defend their hives better against inseets. Moths (802) 
are hardly ever found in their combs, while they are occasionally found in the combs of even the strongest colonies of common bees. Their great vigilance is due to the mildness of the climate of Italy, whose Winters never destroy the moth. Having to defend themselves against a more numerous enemy, they are more watchful than the bees of colder regions. 4th. They are less apt to sting. Not only are they less apt, but scarcely are they inclined to sting, though they will do so if intentionally annoyed, or irritated, or improperly treated.

Spinola speaks of the more peaceable disposition of this bee; and Columella, 1800 years ago, has noticed the same peculiarity, describing it as "mitior moribus," (milder in habits). When once irritated, however, they become very cross.

5th. They are more industrious. Of this fact, all the results go to confirm Dzierzon's statements, and satisfy us of the superiority of this kind in every point of view. 6th. They are more disposed to rob than common bees, and more courageous and active in self-defense. They strive on all hands to force their way into colonies of common bees; but when strange bees attack their hives, they fight with great fierceness, and with an incredible adroitness.

Spinola speaks of these bees as "velociores motu"-quicker in their motions than the common bees.

They however sooner grow tired of hunting, where nothing can be gained; and if all the plunder is put out of their reach, they will give up the attempt at robbing (664) more promptly than common bees.

$7 t h$. Aside from their peaceableness, they are more easily handled than the common bees, as they cling to their combs and do not rush about, or cluster here and there, or fall to the ground, as the common bees do.

It is hardly necessary to add, that this species of the honeybee, so much more productive than the common kind, is of very great value in all sections of our country. Its superior docility makes it worthy of high regard, even if in other 
respects it had no peculiar merits. Its introduction into this country, has helped to constitute the new era in bee-keeping, and has imparted much interest to its .pursuit. It is one of the canses which have enabled America to surpass the world in the production of honey.

553. Their appearance can be described as follows: "The first three abdominal rings (fig. 113) of the worker bee are transparent, and vary from a dark straw or golden color to the deep yellow of ochre. These rings have a narrow dark edge or border, so that the yellow, which is sometimes called leather color, constitutes the ground, and is

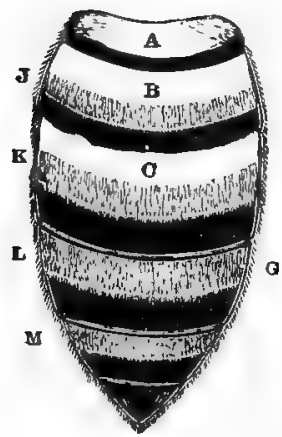

Fig. 113.

ABDOMEN OF THE ITALIAN BEE. seemingly barred over by these black edges. This is most distinctly perceptible when a brood-comb, on which bees are densely crowded, is taken out of a hive, or when a bee is put on a window. When the bee is full of honey these rings extend and slide out of one another, and the yellow bands show to better advantage, especially if the honey eaten is of a light color. On the contrary, during a dearth of honey, the rings are drawn up, or telescoped in one another, and the bee hardly looks like the same insect. This peculiarity has annoyed many bee(From The A B C of keepers, who imagined their beautiful bees Bee Culture.) had suddenly become hybrids.

In doubtful cases, as the purity of Italian bees is very important, it is well to follow the advice of A. I. Root: "If you are undecided in regard to your bees' purity, get some of the bees and feed them all the honey they can take; now put them on a window, and if the band C (fig. 113) is not plainly visible, call them hybrids."

554. Aside from this test, their tenacity and quietness on the comb, while handled, are infallible signs of purity. We have repeatedly carried a frame of brood covered with 
pure Italian bees, from a hive to the house, and passed the comb from hand to hand among visitors, some of whom were ladies, without a single bee dropping off, or attempting to sting.

555. The drones and the queens are very irreglar in markings, some being of a very bright yellow color, others almost as dark as drones or queens of common bees.

"It is a remarkable fact that an Italian queen, impregnated by a common drone, and a common queen impregnated by an Italian drone, do not produce workers of a uniform intermediate cast, or hybrids; but some of the workers bred from the eggs of each queen will be purely of the Italian, and others as purely of the common race, only a few of them, indeed, being apparently hybrids. Berlepsch also had several mismated queens, which at first produced Italian workers exclusively, and afterwards common workers as exelusively. Some such queens produced fully three-fourths Italian workers; others, common workers in the same proportion. Nay, he states that he had one beautiful orange-yellow mismated Italian queen which did not produce a single Italian worker, but only common workers, perhaps a shade lighter in color. The drones, however, produced by a mismated Italian queen are uniformly of the Italian race, and this fact, besides demonstrating the truth of Dzierzon's theory, ( 133 ) renders the preservation and perpetuation of the Italian race, in its purity, entirely feasible in any country where they may be introduced." -S. Wagner.

556. The Italian bees from different parts of Italy are of different shades, but otherwise, preserve about the same characteristics all over the peninsula. But how can they keep pure, since there are common bees in Europe? A glance at the map will answer the question. Italy is surrounded on all sides by water or snow-covered mountains, which offer an insuperable barrier to any insects. This is further evidenced by the fact that the bees of the canton of Tessin (Italian Switzerland) are Italians, being on the South side of the Alps, while those of the canton of Uri (German Switzerland), on 
the other side of the mountains and only a few miles off, are common bees."

55\%. The importation of Italian bees to another country was first attempted by Capt. Baldenstein.

"Being stationed in Italy, during part of the Napoleonic wars, he noticed that the bees, in the Lombardo-Venitian district of Valtelin, and on the borders of Lake Como, differed in color from the common kind, and seemed to be more industrious. At the elose of the war, he retired from the army, and returned to his ancestral castle, on the Rhætian Alps, in Switzerland; and to occupy his leisure, had recourse to bee-culture, which had been his favorite hobby in earlier years. While studying the natural history, habits, and instincts of these insects, he remembered what he had observed in Italy, and resolved to procure a colony from that country. Accordingly, he sent two men thither, who purchased one, carried it over the mountains, to his residence, in September, 1843.

"His observations and inferences impelled Dzierzon-who had previously ascertained that the cells of the Italian and common bees were of the same size-to make an effort to procure the Italian bee; and, by the aid of the Austrian Agricultural Society at Vienna he succeeded in obtaining, late in February, 1853, a colony from Mira, near Venice."'S. Wagner.

Some of the Governments of Europe have long ago taken great interest in disseminating among their people a knowledge of bee culture.

The United States also recognized the importance of our pursuit. An apiarian department has been established and Mr. Frank Benton was sent for a trip around the world, in 1905 , to investigate the value of the bees and honey producing plants of other countries.

558. An attempt was made in 1856 , by $\mathrm{Mr}$. Wagner, to import the Italian bees into America; but, unfortunately, the colonies perished on the voyage. The first living Italian bees

* The idea that select Italian bees raised in America, may be purer than any Italians ever imported, has been gravely discussed by some persons, 
landed on this continent were imported in the Fall of 1859 by $\mathrm{Mr}$. Wagner and Mr. Richard Colvin, of Baltimore, from Dzierzon's apiary. Mr. P. G. Mahan, of Philadelphia, brought over at the same time a few colonies. In the Spring of 1860, Mr. S. B. Parsons, of Flushing, L. I., imported a number of colonies from Italy. Mr. William G. Rose, of New York, in 1861, imported also from Italy. Mr. Colvin made a number of importations from Dzierzon's apiary; and in the Fall of 1863 and $1864 \mathrm{Mr}$. Langstroth also imported queens from the same apiary, but the first large successful importations were made by Adam Grimm of Wisconsin, in 1867, from the apiary of Prof. Mona of Bellinzona, and by us in 1S74, from the apiary of Signor Guiseppe Fiorini of Monselice, Italy. Since then, Mr. A. I. Root, and others, have succeeded well nearly every season.

This valuable variety of the honey-bee is now extensively disseminated in North America.

559. The Egyptian bees (Apis fasciata) are smaller and brighter than the Italian bee. The hairs of their body are more whitish, and their motions are quick and fly-like. Their prolificness is great, but their ill-disposition has caused many who have tried them to abandon them.

The Cyprian bees (a sub-race of Apis fasciata) were imported from Cyprus to Europe in 1872, and they were so much praised that, in 1880, two enterprising American Apiarists, Messrs. D. A. Jones and Frank Benton made a trip to Cyprus and the Holy Land, and brought bees from both countries to America.

The Cyprian bees resemble the Italian bees. The main difference between them, in appearance, is a bright yellow shield on the thorax of the Cyprians not to be seen in the Italians, and the yellow rings of the former are brighter, of a copper color, especially under the abdomen. Their drones are beautiful.

Their behavior is like that of the Egyptians; quick and ready, they promptly assail those who dare handle them. 
Smoke astonishes but does not subdue them. At each puff of the smoker they" emit a sharp, trilling sound, not easily forgotten, resembling that of "meat in the frying pan," and as soon as the smoke disappears, they are again on the watch, ready to pounce on any enemy, whether man or beast, bee or moth. Their courage and great prolifieness would make them a very desirable race, if they could be handled safely.

A slight mixture of this race with the Italian improves the latter wonderfully in color and working qualities.

560. The Holy Land or Syrian bees are almost similar in looks to the Egyptian, these two countries being contiguous. Those who have tried them do not agree as to their behavior; some holding them to be very peaceable, others describing them as very cross. We have never tried them.

Among the different races of Eastern bees, the Caucasian are cited by Vogel, a German, as of such mild disposition, that it is hard to get them to sting. Yet it is said that these bees defend themselves well against robber bees. This is confirmed by Mr. Benton, who has imported them into the U. S. under the auspices of the Department of Agriculture.

According to Vogel, they resemble the Syrian bees, having also the shield of the Cyprians. It would seem that these bees exist in the temperate zone of Asia, from the shores of the Mediterranean to the Himalayas, for Dr. Dubini, in his book, writes that they were found at the foot of these mountains.*

561. According to an article in the "Scientific Review" of England, although bees have been sent from this country and Europe, to Australia, there is an Australian native bee, which builds its nest on the Eucalyptus. These bees gather immense quantities of a kind of honey which, although very sweet, can be used as medicine, to replace the cod-liver oil, used with so much repugnance by consumptives.

* Some apiarists assert that there are two varieties of this bee, which they name Apis caucasia aurea and Apis nigra argentea. So, it would seem from the quotation of a catalog of a Russian apiarist and queen breeder mentioned by Giraud Frères in A, B. J. of February 1st, 1906. 
562. Apis dorsata, the largest bee known, lives in the jungles of India. Mr. Benton attempted to import this bee at great expense and danger, but only succeeded in bringing. one colony to Syria, where it died. Mr. Vogel tried also to bring some of them to Germany without success. At all events further attempts at importing or domesticating these bees would be so expensive, that private enterprise will be balked by the task. Besides Apis dorsata, two other kinds exist in India, Apis florea and Apis Indica. The latter is cultivated by the natives with good results. Both are smaller than our common bee.

563. Another race of bees, ${ }^{*}$ the Melipone, is found in Brazil and Mexico. More than twelve varieties of these have been described, all without stings.

Huber, in the beginning of the nineteenth century, received a nest of them, but the bees died before reaching Geneva. $\mathrm{Mr}$. Drory, while at Bordeaux, France, was more successful. One of his friends sent him a colony of Melipones, and he published in the "Rucher du Sud-Ouest" some very curious facts concerning them. The cells containing the stores of honey and pollen are not placed near those intended for brood, but higher in the hive; they are as large as pigeon eggs, and attached in elusters to the walls of the hive. The brood cells are placed horizontally in rows of several stories. The workers do not nurse the brood, but fill the cells with food, on which the queen lays. The cells are then closed till the young bees emerge from them.

* These bees are scientifically classified as belonging to a different genus of Apidæ. 
- chapter X.

The Apiary.

Location.

564. Any one can keep bees, successfully, if he has a liking for this pursuit and is not too timid to follow the directions given in this treatise. Even ladies ean manage a large apiary suceessfully, with but little help. Miss Emma Wilson, sister-in-law of Dr. C. C. Miller, is an expert apiarist and does a great portion of the work in two large apiaries of several hundred colonies.

Almost any locality will yield a surplus of honey in average seasons. The late Mr. Chas. F. Muth of Cincinnati, with 22 colonies of bees, on the roof of his house, in the heart of this large eity, harvested a surplus honey yield of $198 \mathrm{lbs}$. per colony in one season. Mr. Muth informed us that this surplus was collected from white clover blossoms in 26 days.

565. But an intimate acquaintance with the honey resourees of the country is highly important to those desirous of engaging largely in bee-eulture. While, in some loealities, bees will accumulate large stores, in others, only a mile or two distant, they may yield but a small profit.

"While Huber resided at Cour, and afterwards at Vevey, his bees suffered so much from seanty pasturage, that he could only preserve them by feeding, although stocks that were but two miles from him were, in each case, storing their hives abundantly."-Bevan.

Those desirous of becoming specialists will find the subject of location and yield further treated in the chapter on Pasturage and Overstocking (698).

566. Inexperienced persons will seldom find it profitable to begin bee-keeping on a large seale. By using movable301 


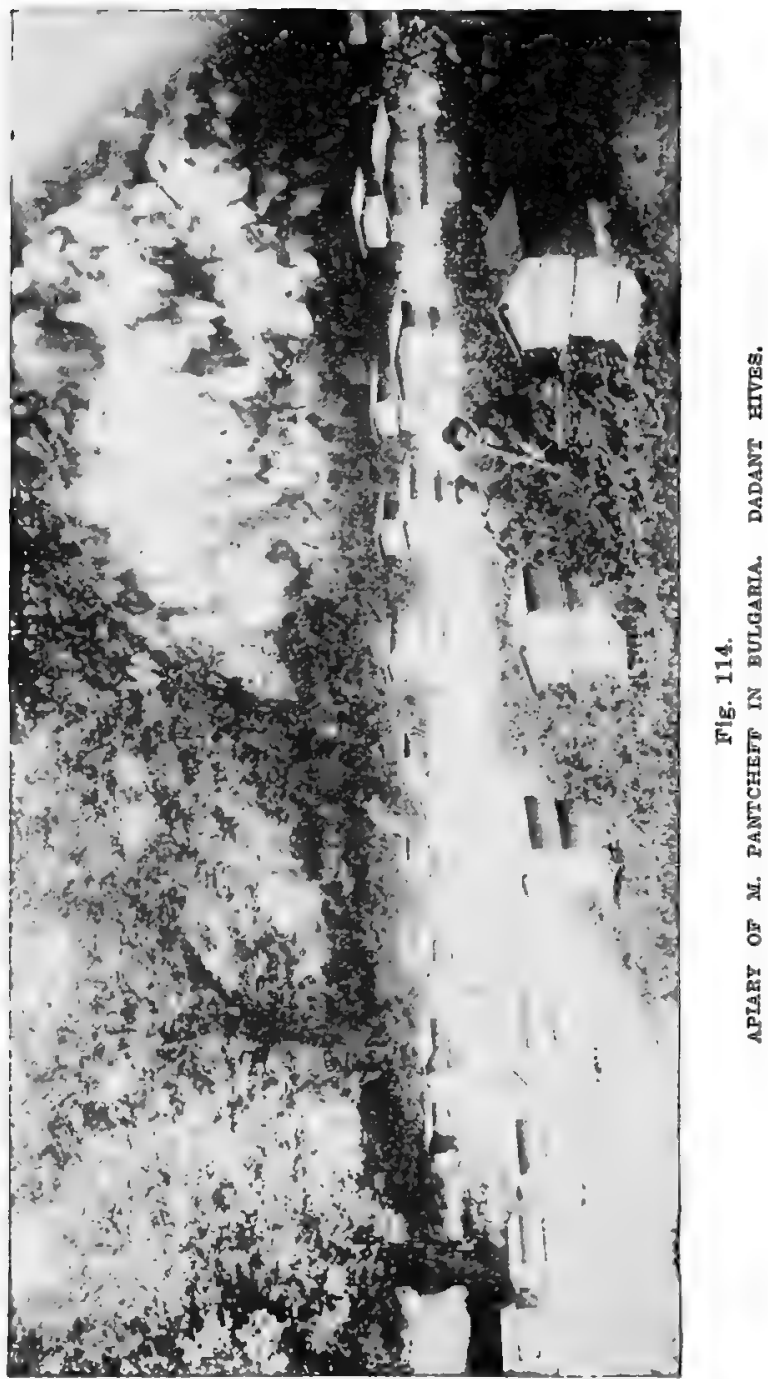


frame (286) hives, they can rapidly increase their stock after they have aequired skill, and have ascertained, not simply that money can be made by keeping bees, but that they ean make it.

While large profits can be realized by eareful and experienced bee-keepers, those who are otherwise will be almost sure to find their outlay result only in vexatious losses. An apiary neglected or mismanaged is worse than a farm overgrown with weeds or exhausted by ignorant tillage; for the land, by prudent management, may again be made fertile, but the bees, when once destroyed, are a total loss. Of all farm pursuits bee-culture requires the greatest skill, and it may well be called a business of details.

567. Wherever the apiary is established, great pains should be taken to protect the bees against high winds. Their hives should be placed where they will not be annoyed by foot passengers or eattle, and should never be very near where horses must stand or pass. If managed on the swarming plan, it is very desirable that they should be in full sight of the rooms most occupied, ôr at least where the sound of their swarming will be easily heard.

In the Northern and Middle States, the hives should have a South-Eastern, Southern, or South-Western exposure, to give the bees the benefit of the sun, when it will be most conducive to their welfare.

568. The plot occupied by the Apiary should be grassy, mowed frequently, and kept free from weeds.

Sand, gravel, saw-dust* or coal cinders, spread in front of the hive, will prevent the growing of gxass in their $(\mathbf{3 4 3})$ immediate vicinity, and be a great help to those overladen bees, that fall to the ground before reaching the entrance.

Hives are too often placed where many bees perish by falling into dirt, or among the tall weeds and grass, where spiders and toads find their choice lurking-places.

* Sawdust is perhaps not very safe, owing to danger of fire from the smokers, in very dry weather. 
A gentle slope southward will help to set the hives as they should be, slanting toward the entrance (326, 327).

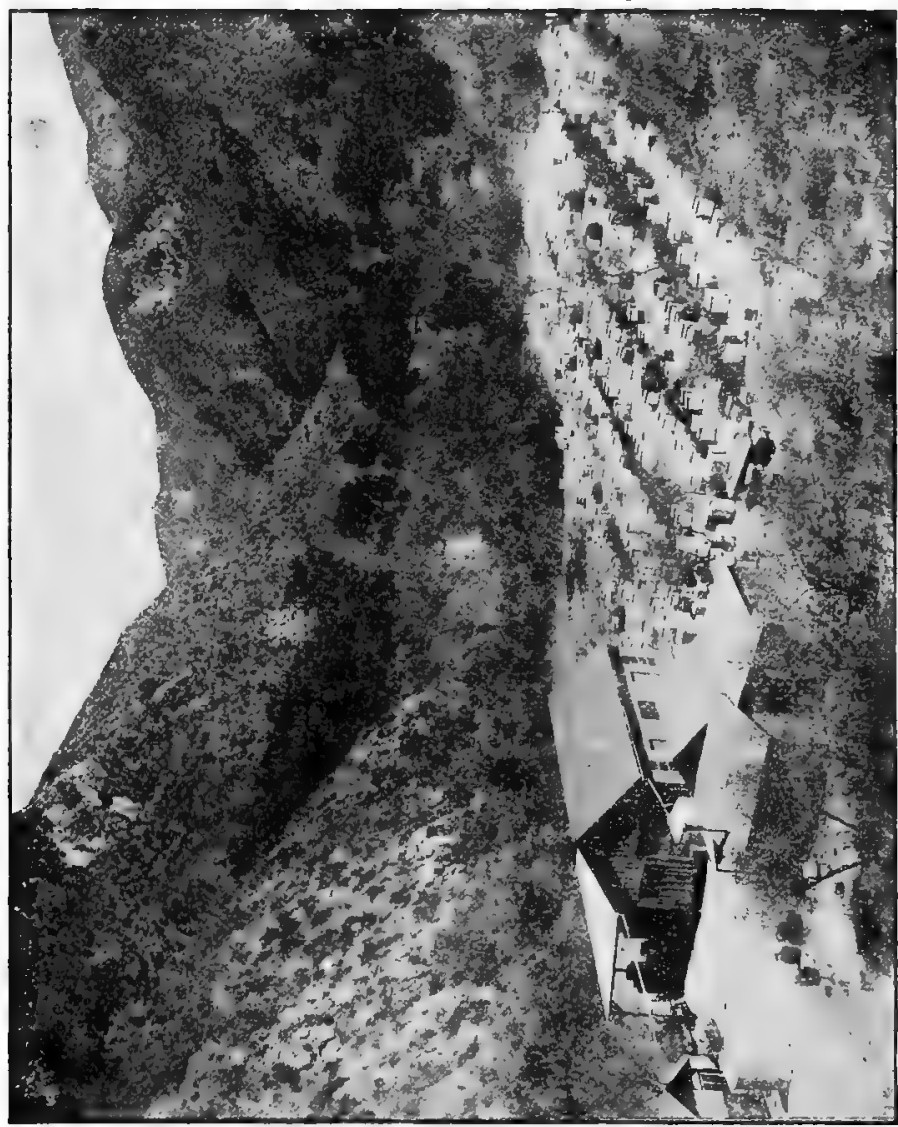

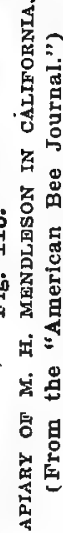

569. They should be placed on separate stands, entirely independent of one another, and, whenever practicable, room should be left for the Apiarist to pass around each hive. Wo 
prefer to place them in rows sixteen feet apart, with the hives about six feet apart in the rows. This isolates each

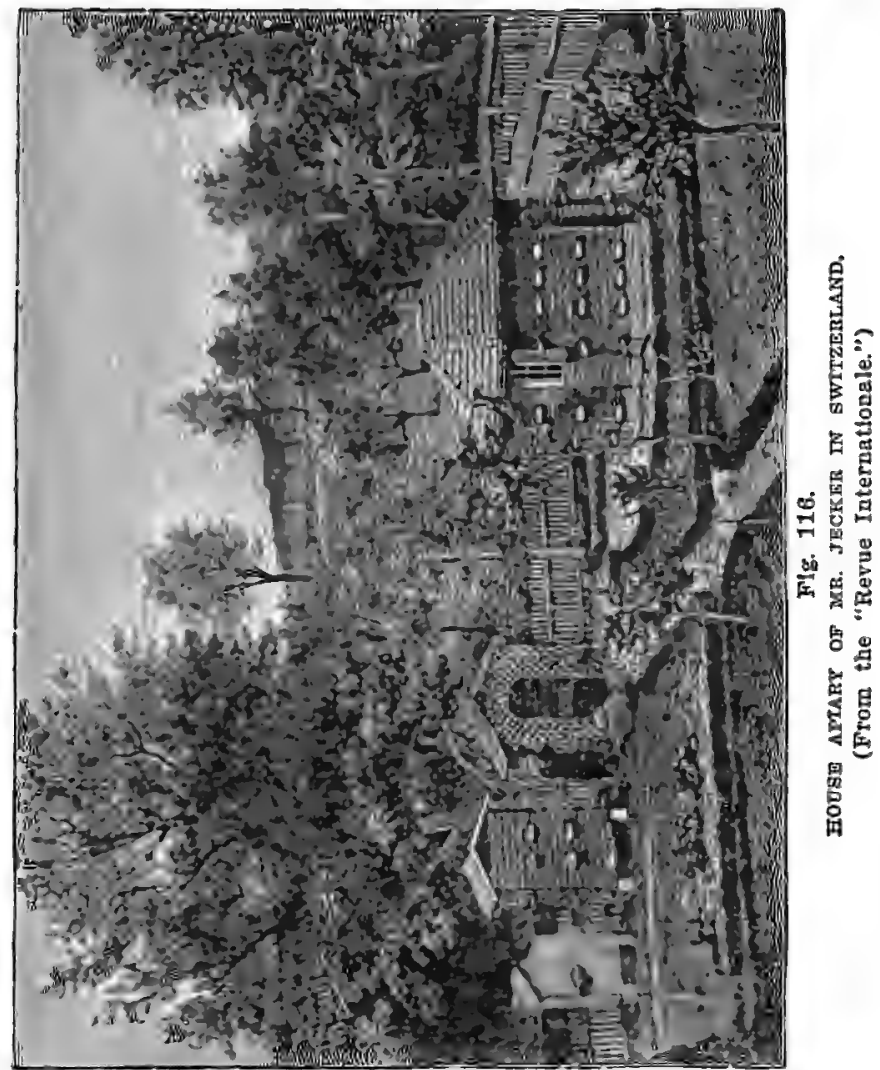

hive completely, and, while handling one colony, the Apiarist is not in danger of being stung by the bees of another. The bees are also less likely to enter the wrong hives (502). 


\section{Covered Apiaries.}

570. Covered apiaries, unless built at great expense, afford little protection against extreme heat or cold, and greatly increase the risk of losing the queens (503) and the young bees. The weak colonies are always the losers, for their young bees, in returning from their first trip (183), are attracted by the noise of other hives closely adjoining, and prove the truth of the French proverb "La pierre va toujours au tas," (the stone always goes to the heap).

When hives must stand close together, they should be of different colors. Even varying the color of the blocks will be of great usefulness.

John Mills, in a work published at London, in 1766, gives (p. 93) the following directions:- "Forget not to paint the mouths of your colonies with different colors, as red, white, blue, yellow, \&e., in form of a half-moon, or square, that the bees may the better know their own homes."

Covered apiaries are common in Germany and Italy; their only quality is that of being thief proof, when shut and locked. But such structures, especially when several stories high, cannot easily shelter top-opening hives.

571. Probably the most convenient covered apiaries are simple sheds, facing South, and open in front during the Summer and warm days of Winter. House apiaries, in which the hives are placed in several stories, facing every direction, are worse than nothing. Their only quality is to be oruamental and costly.

572. In the Summer, no place is so congenial to bees as the shade of trees, if it is not too dense, or the branches so low as to interfere with their flight. As the weather becomes cool, they can, if necessary, be moved to any more desirable Winter location. If colonies are moved in the line of their flight, and a short distance at a time, no loss of bees will be incurred; but, if moved a few yards, all at once, many will 


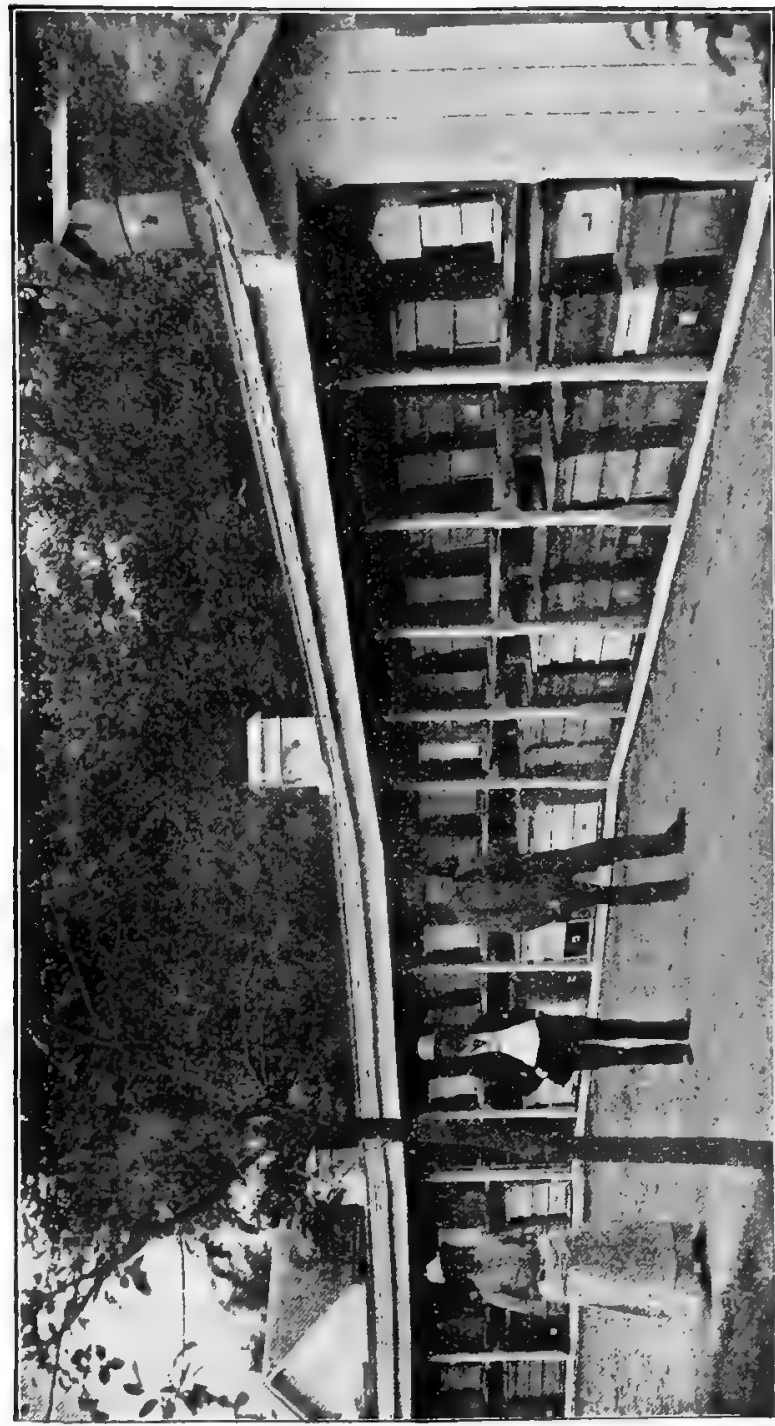

兽总 
be lost. A slanting board placed in front of the hive, so as to prevent the bees from flying in straight line from the entrance to the field, will incite them to mark the change of their position. By a gradual process, the hives in a small apiary may, in the Fall, be brought into a narrow compass, so that they can be easily sheltered from the bleak Winter winds. In the Spring, they may be gradually returned to their old positions.

By removing the strongest colonies in an apiary the first day, and others not so strong the next, and continuing the process until all were removed, we have safely changed the location of an apiary, when compelled to move bees in the working season. On the removal of the last hive, but few bees returned to the old spot. The change, as thus conducted, strengthened the weaker colonies, but we would advise beekeepers to locate their hives in as permanent a position as possible, as this moving is not practical, especially with a large number of colonies. Those who do not winter their bees in the cellar, can easily protect them on their Summer stand. (635.)

If the hives have to be placed in an exposed location without shade, it is well to protect them with roofs. A roof will be found highly economical, as it not only sheds the rain, but wards off the heat of the sun.

573. The beginner will ordinarily find it best to stock his apiary with swarms of the current year, thus avoiding, until he can prepare himself to meet them, the perplexities which often accompany either natural or artificial swarming. If new swarms are purchased, unless they are large and early, they may only prove a bill of expense. If old colonies are purchased, such only should be selected as are healthy and populous. If removed after the working season has begun, they should be brought from a distance of at least two miles (13).

If the bees are not all at home when the hive is to be removed, blow a little smoke into its entrance, to cause those 
within to fill themselves with honey, and to prevent them from leaving for the fields. Repeat this process from time to time, and in half an hour nearly all will have returned. If any are clustered on the outside, they may be driven within by smoke.

The best time to buy full colonies of bees, is Spring. A cool day may be selected, in which to move them, as the bees are not flying, none can be lost. In the present thriving state of bee-keeping, colonies of pure Italian bees (551) in movable-frame hives can usually be bought at very reasonable figures. If the Apiarist's means are very limited, black bees (519) in old style box-hives may prove the cheapest, if they can be found. But they should be promptly transferred into more practical hives, and italianized; these manipulations will help to give to the novice the practice which he lacks. Ttalian bees and movable-frame hives are now a sine qua non of success.

No colony should be purchased, unless it has brood in all stages, showing that it has a healthy queen. For transporting bees, see $(\mathbf{5 8 7}, \mathbf{6 0 3})$.

\section{Transferring Bees from Common to Movable-Frame Hrves.}

574. This process may be easily effected whenever the weather is warm enough for bees to fly.*

It has sometimes been done in Winter, for purposes of experiment, by removing the bees into a warm room, but the best time for it, is when the bees have the least honey, at the beginning of the fruit bloom. If it can be done on a warm

* It may be remarked, by some reader, that the number of box hives in existence in the United States is now so very limited, that a page or two on this subject is a waste, but in a protracted experience we have found that even the most practical Apiarist may occasionally be compelled to hive bees in any kind of box. It is therefore well to know how to transfer them safely to movable-frame hives, without destroying either the worker combs or the brood. 
day, when they are at work, there will be but little danger from robbers $(\mathbf{6 6 4})$.

It is conducted as follows: Have in readiness a boxwhich we shall call the forcing box-whose diameter is about the same with that of the hive from which you intend to drive the swarm. Smoke the hive, lift it from its bottomloard without the slightest jar, turn it over, and carefully carry it off about a rod, as bees, if disturbed, are much more inclined to be peaceable, when removed a short distance from their familiar stand. If the hive is gently placed upside down on the ground, scarcely a bee will fly out, and there will be little danger of being stung. The timid and inexperienced should protect themselves with a bee-veil, and may blow more smoke among them, as soon as the hive is inverted. After placing it on the ground, the forcing-box must be put over it. If smooth inside, it should have slats fastened one-third of the distance from the top, to aid bees in clustering. Some Apiarists place the box slanting on the hive, so as to be able to see the bees climbing. This method, called open driving, is a little slower, but it may give the operator the chance of seeing the queen; when the driving ean be considered as done.

575. As soon as the Apiarist has confined the bees, he should place an empty hive-which we call the decoy-hive -upon their old stand, which those returning from the fields may enter, instead of dispersing to other hives, to meet, perhaps, with a most ungracious reception. As a general rule, however, a bee with a load of honey or bee-bread, after the extent of her resources is ascertained, is pretty sure to be welcomed by any hive to which she may carry her treasure; while a poverty-stricken unfortunate that presumes to claim their hospitality is, usually, at once destroyed. The one meets with as flattering a reception as a wealthy gentleman proposing to take up his abode in a country village, while the other is as much an object of dislike as a poor man, who bids fair to become a public charge.

If there are in the apiary several old colonies standing 
close together, it is desirable, in performing this operation, that the decoy-hive, and the forcing-box, should be of the same shape and even color with that of the parent-stock. If they are very unlike, and the returning bees attempt to enter a neighboring hive, because it resembles their old home, the adjoining hives should have sheets thrown over them, to hide them from the bees, until the operation is completed.

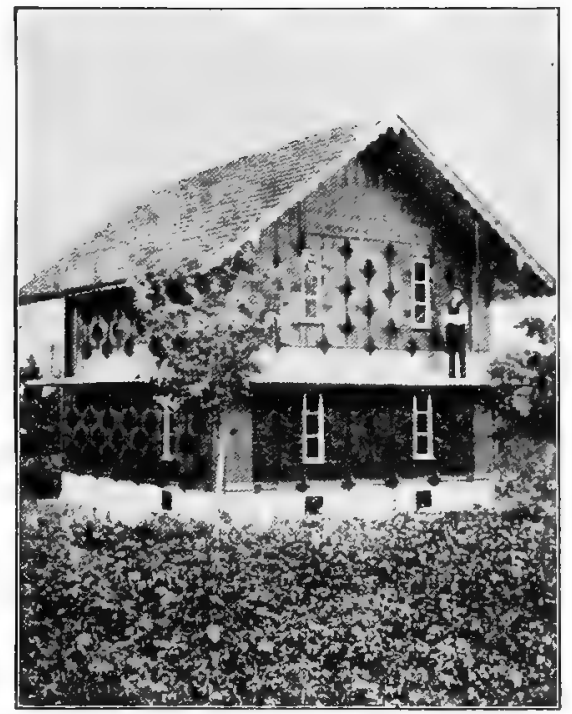

Fig. 118.

HOUSE APIARY OF MR. BLATT IN SWITZERLAND.

576. To return to our imprisoned bees: their hive should be beaten smartly with the palms of the hands, or two small rods, on the sides to which the combs are attached, so as to run no risk of loosening* them. These "rappings," although

* There is little danger of loosening the combs of an old colony, but the greatest caution is necessary when the combs of a hive are new. If, in inverting such a hive, the broad sides of the combs, instead of their edges, are inclined downwards, the heat, and weight of the bees, may loosen the combs, and ruin the colony. 
not of a very "spiritual" character, produce, nevertheless, a decided effect upon the bees. Their first impulse, if no smoke were used, would be to sally out, and wreak their vengeance on those who thus rudely assail their honied dome; but as soon as they inhale its fumes, and feel the terrible concussion of their once stable abode, a sudden fear, that they are to be driven from their treasures, takes possession of them. Determined to prepare for this unceremonious writ of ejection, by carrying off what they can, each bee pegins to lay in a supply, and in about five minutes, all are filled to their utmost capacity. A prodigious humming is now heard, as they begin to mount into the upper box; and in about fifteen minutes from the time the rapping began -if it has been continued with but slight intermissions - the mass of bees, with their queen, will hang clustered in the forcing-box, like any natural swarm, and may, at the proper time, be readily shaken out on a sheet, in front of their intended hive.

Now put the forcing box on their old stand, and carry the parent-hive to some place where you cannot be annoyed by other bees.

57\%. It is important to make sure that the queen is removed, as she might be injured in the transfer of comb. Her presence among the driven bees can be ascertained in a few minutes, by the quietness of their behavior, or by the eggs which she drops on the bottom-board, and which can easily be seen if a black cloth is spread under the forcing box (155).

If the queen is not with the bees, a few will come out and run about, as if anxiously searching for something they have lost. The alarm is rapidly communicated to the whole colony; the explorers are reinforced, the ventilators suspend their operations, and soon the air is filled with bees. If they cannot find the queen, they return to their old stand, and if no hive is there, will soon enter one of the adjoining colonies. If their queen is restored to them soon after they miss her, those running out of the hive will make a half-circle, and 
return; the joyful news is quickly communicated to those on the wing, who forthwith alight and enter the hive; all appearance of agitated running about on the outside of the hive ceases, and ventilation, with its joyful hum, is again resumed. To witness these interesting proceedings, it is only necessary to catch the queen, and keep her until she is missed by her colony. For greater security, she should be confined in a queen cage (536) during the experiment.

If the queen has not left the old hive, it is safer to return the bees and to resume the driving at another time.

578. To transfer the comb, have on hand tools for prying off a side of the hive; a large knife for eutting out the combs; vessels for the honey; a table or board, on which to lay the brood combs; and water for washing off, from time to time, the honey which will stick to your hands.

Have also a number of pieces of wire, No. 16, cut a little longer than the frame, and bent on the ends in this shape $\longrightarrow$ to be driven into the wood of the frame, and to hold the combs in place. Let a certain number of frames be in readiness, with three or four of these wires fastened on one side, and lay them on the table, wire-side down. You must also have your movable-frame hive in readiness near the table, with an extracting pan (780) under it, instead of a bottom-board, to receive what honey may drip. All this must be ready before disturbing the bees.

5\%9. Having selected the worker-combs, carefully cut them rather large, so that they will just crowd into the frames, and retain their places in their natural position (fig. 46), until the bees have time to fasten them.

Now tack as many wires over them as may be necessary to hold them securely, and hang them in the hive. Drone combs should invariably be melted into wax. If drone-brood is found, it can be fed to young chickens, who are very fond of the larvæ. The bottom-board should be put under the hive just before carrying it out.

When the hive is thus prepared, the bees may be put into 


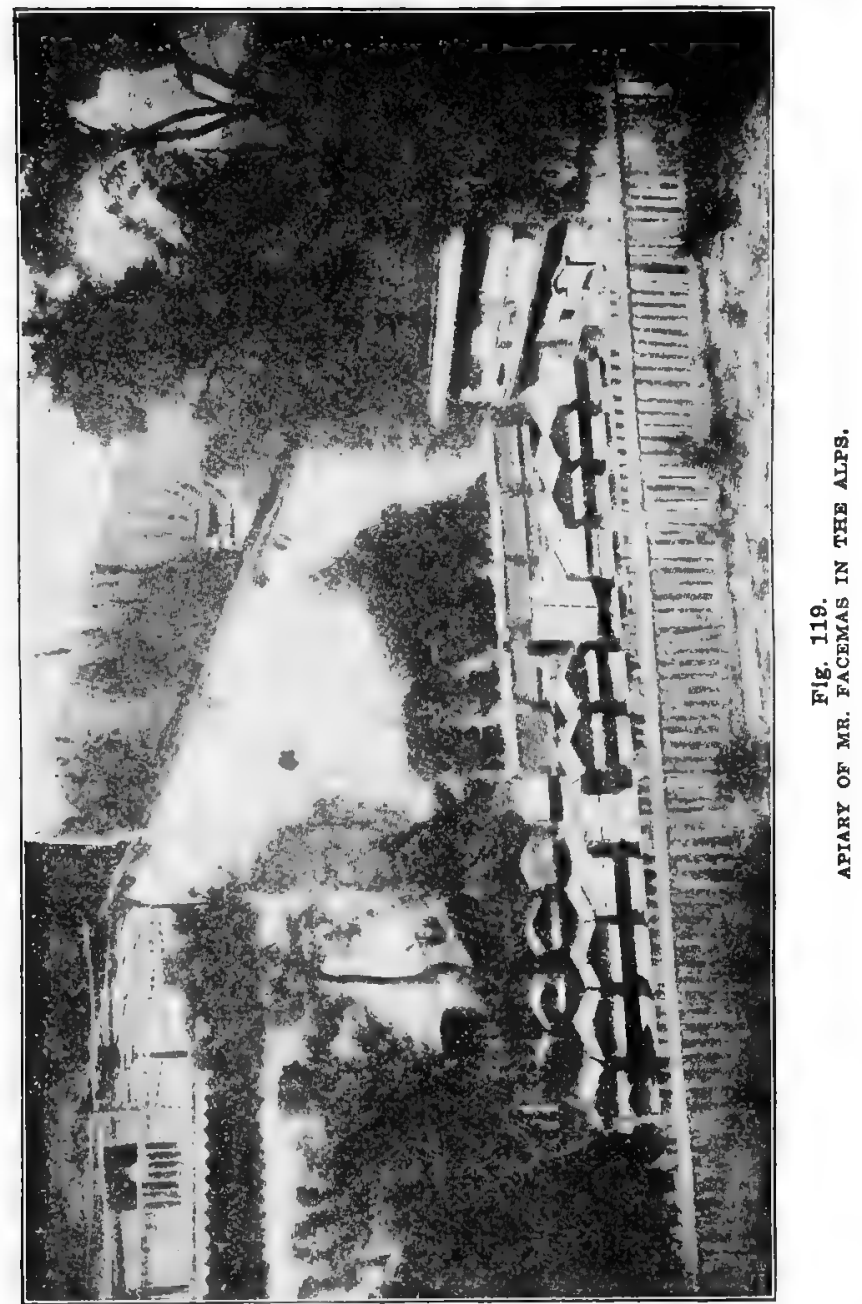

it and confined, water being given to them, until they have time to make all secure against robbers $(\mathbf{6 6 4})$. 
If there is danger of robbers, it is preferable not to put the bees into the hive till late in the afternoon. They should be shaken in front of the new hive on a sheet (427) like a natural swarm.

When the weather is cool, the transfer should be made in a warm room, to prevent the brood from being fatally chilled. An expert Apiarist can complete the whole operation-from the driving of the bees to the returning of them to their new hive-in about an houx, and with the loss of very few bees, old or young.

580. When transferring in early Spring, it should be remembered that the worker-brood $(\mathbf{1 6 8})$ is of great value; and not the least bit of it should be neglected or wasted unnecessarily. After a week, or more, according to the season, the hive may be opened and the fastenings removed.

Let not the novice, however, think that transferring bees is a task that requires but little skill. He who transfers successfully a larger number of colonies may be called an expert in handling bees.

The process, as it has been conducted by careless Apiarists, has resulted in the wanton sacrifice of thousands of colonies.

581. For the benefit of those who are timid in manipulations, we will give Mr. Jas. Heddon's method for transferring, (page 562 of "Gleanings," 1885). About swarming time Mr. Heddon drives the old queen and a majority of the bees into the forcing-box, he then removes the old hive a few feet back, and places the new hive with frames full of foundation on its stand, and "runs in" the forced swarm. It would be well to return a part of the bees to the old hive, as its brood might be chilled if the weather becomes cool.

Twenty-one days after the transfer of the bees, he drives the old hive clean of all its bees, uniting them with the former drive. As the worker-brood of the old hive is all hatched, there is nothing left in it but the combs and the honey, which can be transferred at leisure in cool weather, or, the honey 
may be extracted (749), and the comb melted into wax (858).

\section{Out-Apiaries.}

582. When an Apiarist wishes to make bee-culture his special occupation, he should expect to keep bees in more than one location. If he owns more than 120 colonies, we would advise his establishing an Out-Apiary. It is true that there are many drawbacks to the cultivation of bees four or five miles off, but there are also some advantages. The crop sometimes fails in one locality, and is very good in another a short distance away. One apiary may be in a hilly country, where white clover abounds, and another on low lands, where Fall blossoms never fail. It is well-according to a familiar proverb-not to "put all your eggs in one basket."

In. many years' practice of keeping bees in five or six different apiaries, occupying a range of country about twenty miles in width, we have found out that the crop will vary greatly in a few miles, owing to the different flora of the various localities, and more especially to the greater or less amount of rain-fall at the proper time. We have also learned that an apiary placed near a large body of water (the Mississippi), will produce less honey than one a mile or two from it, owing to the smaller area of pasturage in reach of the bees. ${ }^{*}$

583. In establishing an Out-Apiary on some farmer's land, the following must be taken into consideration: Select a farm on which a grove or an orchard is near the house, some distance from the road. The place ought to be, at least, three miles in a bee-line from your own bee-farm. It is not necessary that it should be more than four miles away. Mr. J. M. Hambaugh, at Spring, Ill., harvested altogether differ-

* Some apiarists, among them Mr. E. W. Alexander, of Delanson, N. Y., keep a very large number of bees in one apiary, the above named apiarist keeping upwards of seven hundred colonies with great success in one spot. This, however, will succeed only in extraordinary locations where almost the entire territory is occupied with honey-producing plants. Such Jocations are rare. 
ent yields both in quality and quantity, from two apiaries only two and a half miles apart. This agrees with our oft repeated experience in apiaries three or four miles apart.

Locate your bees with some careful man. Do net trust a farmer who lets his fences fall, who leaves his mower in the yard over Winter, or puts his cows in his orehard. You will never rest easy, if you think that some of your hives may be upset any day by a vagrant cow.

Do not put your bees on land which is tenanted. Let them be placed at some responsible farmer's own home, for a tenant may leave on short notice, and you cannot remove your bees at all seasons.

584. The terms usually made by us for a bee location are as follows: The farmer furnishes us the apiary ground, one spare room during extracting, and a shed or a corner in some empty room for our hives, combs, and fixtures. $\mathrm{He}$ also furnishes board for the Apiarist and his help while at work. In exchange, he gets one-fifth of the honey, and seventy-five cents for every natural swarm he harvests. His sole duties are, hiving swarms, and seeing that no accidents happen to the apiary. When bees are run for extracted honey, the number of natural swarms is very limited. We can always find more bee locations than we want. In fact, we have never yet met a farmer who refused to take bees on such terms.

We prefer giving the farmer a share of the erop, to giving him a stated sum for ground rent, etc., as some of our leading bee-keepers do, because we thus give him an interest in our success, and he is more likely to pay attention to our bees, and to produce crops that will yield some honey. Association of interests means progress, peace, and harmony.

585. Six apiaries, containing in all 600 colonies, are probably the greatest number that one man ean oversee properly. In good localities, an Apiarist will find more profit from six such apiaries, than an intelligent farmer from half a section of land, and the outlay of money is less. 


\section{Honey-House.}

586. Few pursuits require so small an outlay for tools and implements as practical bee-culture. Outside of the cost of bives, frames, sections, and honey packages, the total outlay need not amount to $\$ 50$. Almost any spare room will do for a honey-room.

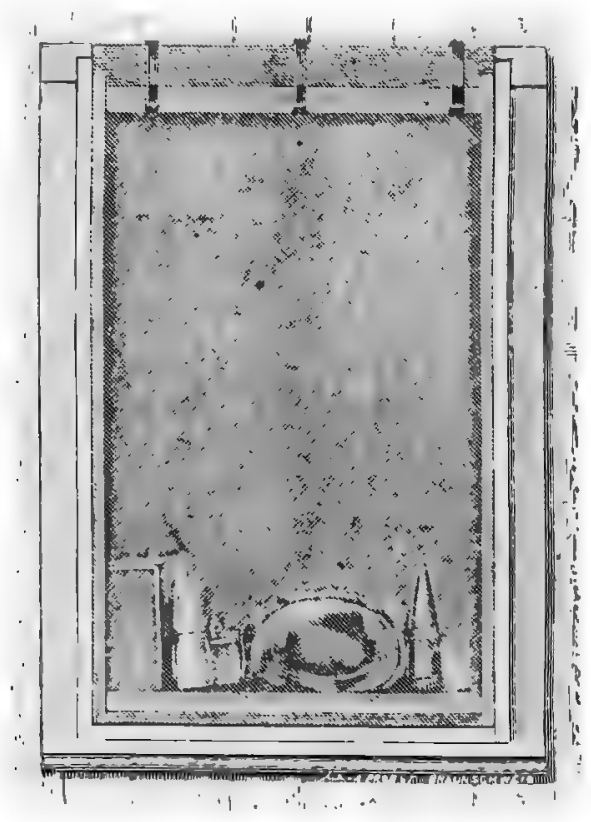

Fig. 120.

WINDOW SCREEN.

Yet when the Apiarist wishes to be at ease, we would advise him to build his honey-house in the middle of his apiary. The windows and doors of this building must all be provided with wire-cloth netting, to exclude bees, flies, etc. We here give an engraving of a simple method of 
placing the wire screen, so as to allow these insects to escape. The netting is nailed on the outside of the window project. ing about six inches above. Three small slats are nailed between the frame and the netting, so as to leave a space of $1 / 4$ of an inch between the wire-cloth and the wall, at the top of the window. The bees and flies that have been brought in with the combs, or that have entered the room, at some time or other, fly against the wire-cloth, and soon find the small fissure above, through which they escape; but, in returning, they smell the honey through the wire-cloth, and forgetting that they have escaped between the wire and the wall, they try in vain to pass through the wire-cloth.

In the engraving, the window sashes have been removed, but their use in no way interferes with the sereen, if the lower one is raised, or the upper one lowered, while there are bees in the room.

The same method might be adopted in grocery stores on windows where flies congregate. In the morning, the flies would climb out of the screen of their own accord. 


\section{CHAPTER XI.}

Shipping and Transporting BeEs.

587. In shipping colonies of bees by rail, it is not necessary to give them much ventilation, if they are sent during the cool weather of Spring. We have successfully shipped hundreds of colonies to all parts of the U. S., in early Spring, with no other ventilation than was afforded by the joints of a rough block nailed over the entrance of the hive. But, if the weather is warm, and the colony populous, plenty of air is needed. We usually replace the bottom-board by a wireeloth-frame protected by slats. The entrance should never be covered with wire-cloth, but should be entirely closed, for the old bees will worry themselves trying to get through it, and it will soon be clogged with dead bees. They should be given as much air as needed with the least possible amount of light.

When the colony is so populous, that draught through the hive cannot injure the brood, we nail a screen over the frames also, and shade it with a board nailed on slats, running across the ends of the hive. The closing of the portico alone, if there is one, with wire-cloth, is not practical, as a part of the swarm crowds into it and kars the ventilation.

588. The frames should, of course, be securely fastened in their places, unless the colonies are in self-spacing frames held in place either by a metal spacer (346) or by projections of the wood $(\mathbf{2 9 8}, \mathbf{2 9 9})$. In addition, some Apiarists fit wooden. slats between the combs to keep them firmly

- in place. This is necessary only when hives are likely to be overturned.

New combs had better not be shipped at all. If there is plenty of fresh honey, we would advise the extracting of all that is unsealed, previous to shipment. When there is brood 
in every comb, and the weather is warm, it is safer to remove a part of the brood, and put frames of dry comb alternately with the frames of brood. The brood removed may be used to strengthen weak colonies.

We have sent bees safely, from Illinois to Utah, by freight.

589. In shipping bees, or colonies, it is important to place conspicuous cautionary eards or labels on the packages: Living Bees, Handle with Care, This Side Up, Keep out of Sun, etc.

The damage done by rough railroad handling, is the greatest item of loss, in the transportation of bees properly packed. If colonies are shipped in carloads, they should be so placed, that the combs will run lengthwise, and not from side to side, as in vehicles drawn by horses. Surplus racks cr stories should be shipped separately.

590. Some Apiarists have practiced shipping bees by water routes to the Southern States in the Fall, for Winter, and returning them in Spring at the beginning of the honey harvest. If proper precautions are taken, this plan may be profitable, where low rates of transportation can be obtained, but much judgment must be exercised as to the time of returning them North. As the colonies become strong very early in the South, if they are brought back North before the warm weather, their brood may become chilled, and a tendency to the development of foul-brood is encouraged.

"Mr. Cotton saw a man in Germany who kept all his numerous stocks rich by changing their places as soon as the honeyseason varied. "Sometimes he sent them to the moors, sometimes to the meadows, sometimes to the forests, and sometimes to the hills.' In France-and the same practice has existed in Egypt from the most ancient times-they often put hundreds of hives in a boat, which floats down the stream by night and stops by day."'-London Quarterly Review.

591. Della Rocea, in his treatise on "Bee-culture in the Island of Syra," speaks of the Egyptian method of keeping bees on boats, which were floated up and down the Nile to 
take advantage of the different crops of honey at different points.

It would even appear that the Greeks in the time of Columella transported their hives to Egypt by sea, "The season of blossoms being later than in Greece; for after the month of September there is no pasture in Achaia for bees, whilst in Egypt flowers are in full bloom even after that time, owing to the receding of the high waters of the Nile." $\mathrm{He}$ relates a laughable story about one of these floating apiaries. One hive having been upset by accident on a boat, the enraged bees attacked the mariners unexpectedly, and forced them to jump into the river and swim to the shore, which likely, was not far distant, nor did they dare return, until they had provided themselves with a supply of smoke-producing ingredients.

592. There is a certain amount of fascinating rowance connected with the idea of a floating apiary, following the blossoms, on the waters of the great Mississippi, or of some of its tributaries. An attempt of this sort was made on a large scale, years ago, by a Chicago firm. It was a total failure, but we are inclined to think that the failure was due to the lack of practical knowledge in bee-keeping, on the part of the managers, rather than to any other cause.

593. Transportation of bees from a location where blossoms are scarce to a good field, and returning them after the crop, is sometimes attended with fair success. Some Apiarists, located in places where the June crop alone can be depended upon, make it a practice to transport their hives to Fall pasturage every Summer. We, ourselves, have taken 120 hives of bees, about eighteen miles, to the Mississippi river bottoms, in August, 1880, when the drouth had destroyed all hopes of a Fall harrest on the hills. The high waters of the Mississippi, which had receded a few weeks before, had left those immense bottom lands covered with a luxuriant vegetation. The result fully answered our anticipations. Those lately starving colonies, yielded a bountiful surplus, 
while their sisters on the hills had to be fed for Winter. But the labor of transportation, the risk incurred, if the colonies are strong and heavy, and the difficulty of transporting old bee-hives, without danger of some bees escaping, make the habitual shipping of bees for pasturage hardly advisable."

\section{ShIPPINg QueEns.}

594. It was in the numerous and partially successful attempts, which we made before 1874, to import bees from Italy, that we became acquainted with the conditions necessary to the shipping of queens.

595. When they are to be confined a long time, the question of food is the most important. Many were the blunders made by the first shippers, who imagined that they required a large amount of food, and literally drowned them in honey. By repeated and costly experiments, we ascertained that the bees that arrived in the best condition were those that were fed on the purest saccharine matter. Those that suffered the most, were those that had the most watery, or the darkest, honey. Water (271), which some Italian shippers persisted in giving them, in spite of what we could say, was noxious; as the consumption of it, with the food, helped to load their abdomen with matter that could not be discharged, eausing what is improperly called dysentery (784). Water is needed only in brood rearing.

596. Old bees, or rather, bees that have begun to work in the field, will stand a longer trip than young bees, as the latter consume more honey, and need to discharge their abdomen oftener.

* Yet, in some locations, it is practiced regularly with success. Mr. R. F. Holtermann, of the Province of Ontario, at the National BeeKeepers' Convention held in Chicago in December, 1905, described the method by which he transported bees to different spots for the different crops during the season, with success. In Northern countries the transporting of bees in summer is attended with less danger than in warmer sections. 
The shipping boxes in which bees are sent from Italy, are about three inches deep, by three inches in width, and four inches in length, with two small frames of comb, one with thick sugar syrup, the other dry. From fifty to seventy-five bees are put with one queen in each box. Air holes are cut into the sides of the boxes, and these are fastened together in a pyramidal shape, with an outer covering of tin, to which is fastened the handle. Queens thus put up, reached us after thirty-six days of confinement with very little loss, and it is in this way that the greatest number of imported queens were received.

598. We might mention in connection with this, an oftrepeated incident, so touching and sweet, as to seem more like a romancer's fable, or a poetic idyl, than a mere fact. On receiving the boxes containing Italian queens, we noticed that frequently all the bees shipped with the queen had died, she being the only one alive in her prison. We afterward found out that the faithful little subjects denied themselves nourishment, and starved to death, sacrificing themselves, that their queen might not be deprived of food.

\section{Mailing Queens.}

598. At the present day queens are forwarded almost exclusively by mail. To Mr. Frank Benton is due the credit of first mailing queens safely across the ocean, but the mailing of them, with more or less success on the American continent, has been practiced for years. Messrs. J. H. Townley and H. Alley, appear to have been the first to succeed, as early as 1868 .

Yet the mails are so roughly handled generally, that we would not advise the sending of valuable queens in this way.

The food given is the Scholz candy (613) made of powdered sugar and honey kneaded together. A sufficient number of bẹes must be put with the queen to keep her warm 
but not enough to crowd the cage-six to ten bees are sufficient, in Summer.

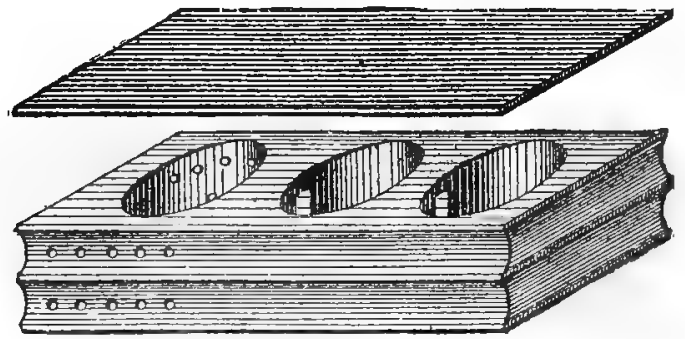

Fig. 121.

THE BENTON CAGE.

599. Some years ago, A. I. Root practiced the shipping of bees by the pound for the stoeking of apiaries, but this

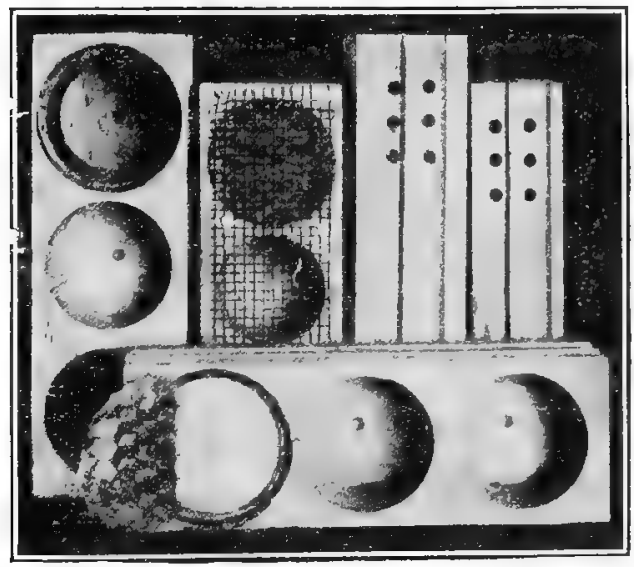

Fig. 122.

BENTON CAGES,

(From "The Rearing of Queen Pses.")

(U. S. Bulletin No. 55, Bureau of Entomology. By E. F. Phillips.)

method has not proven successful and although bees may still be bought by weight, it has been found advisable to ship 
them with some brood and combs. A two-comb nucleus provided with a liberal supply of bees and put into a shipping box of right size and of light weight, may be sent to great distance and will build a very fair colony if purchased at the opening of the elover harvest and properly cared for and supplied with combs already built.

600. How many bees are there in a pound? This question has been propounded to us several times. L'abbe Collin, by careful experiments, found that in a normal condition it takes about 5,100 bees to weigh a pound; while in the swarm, when they are supplied with honey, it takes less than 4,300.

According to Bernard De Gelieu, their weight will vary from 3,640 to 5,460 . He ascertained that, in a good season, a thousand bees carried in about an ounce of honey from the field, at each trip.

The same writer, testing the weight of drones found that about 2,000 weighed a pound. This was verified by the tests of Prof. B. F. Koons, of Connecticut, quoted in the A B C of Bee Culture.

But Collin, who was very accurate in these matters, tested drones, both at their leaving the hive and at their return from the field and found that the outgoing drones number about 1,950 to the pound, while the returning drones number 2,100, which shows a loss of nearly eight per cent in their weight, through the taking of their daily exereise. This is evidently caused by their discharging their excrements and gives a faint idea of the amount of food they must consume while in the hive, for they also discharge their excrements in the hive (190), without much regard to propriety. It also confirms the fact that they harvest nothing but always come home with an appetite.

601. Parties contemplating the breeding of bees and queens for sale, will do well to locate themselves as far South as convenient for easy shipment, as it is by far more lucrative to raise them there than in the North. This is very easy to understand. In the South, the bees usually winter safely, and 
breed early, so that the colonies are strong, while those of the Northern latitudes are still confined in their hives, struggling against the rigors of Winter.

If an Apiarist purchases bees or queens at the proper time -Spring-to recruit his Winter loss, he will most likely buy them from some location South of him, as he can there obtain stronger colonies, and earlier queens, than in his own latitude.

602. On the other hand, as the honey of the Northern States is superior in quality to Southern honey, bee-culture for honey production can be made fully as profitable in the North, in spite of the difficulties of wintering.

\section{Transporming Bees Short Distances.}

Confine the hive, so that it cannot be jolted, in a wagon with springs, and be sure, before starting, that it is impossible for a bee to get out. It will be next to impossible, in warm weather, to move a hive which contains much new comb or much fresh honey.

Indeed, we would strongly urge beginners not to transport bees in warm weather. Just before fruit-blossom is the best time to transport full colonies of bees. Some advise transporting them in Winter, on sleds, but after trial we condemned this method also. The joltings of a sleigh, though few, are hard, and will break combs; and disturbing bees in cold weather should always be discouraged. When hauling bees in warm weather, do not load or unload them while the horses are hitched to the wagon. We have seen serious accidents resulting from a hive dropping from a man's hand to the ground, causing the bees to escape, and to sting both the driver and the horses severely.

If a colony, in hot weather, is to be moved any distance in movable-frame hives, it will be advisable to fasten frames of wire-cloth, both to the top and bottom of the brood apartment, and to transport the bottom-board, cloth, mat, or surplus cap or cover, separately. 
A specially made rack, similar to a hay-rack, is often used, in large apiaries. Hives with movable-frames should be arranged in such a position that the frames run from side to side, and not from front to rear, in the wagon.

603. Upon arrival at the apiary, if the weather is warm, you should at once set the hives in proper position, and release the bees. It is good policy to place a shade board (572) in front of the entrances for a day or two. The object of this is to eause the old bees to notice that something is changed in their location, and to turn around and mark the place, instead of starting out as usual in a bee-line without looking behind.

604. New swarms may be brought home in any box which has ample ventilation. A tea-chest, with wire-cloth on the top, sides, and bottom-board, will be found very convenient.

The bees may be shut up in the box as soon as they are hived. New swarms require even more air than old colonies, being full of honey and closely clustered together. They should be set in a cool place, and, if the weather is very sultry, should not be removed until night. Many swarms are suffocated by the neglect of these precautions. The bees may be easily shaken out from this temporary hive. 


\section{CHAPTER XII.}

\section{Feeding Befs.}

605. FEW things in practical bee-keeping are more important than the feeding of bees; yet none have been more grossly mismanaged or neglected.

In the Spring, the prudent bee-keeper will no more neglect to feed his destitute colonies, than to provide for his own table. At this season, being stimulated by the returning warmth, and being largely engaged in breeding, bees require a liberal supply of food, and many populous colonies perish, which might have been saved with but trifling trouble or expense.

"If e'er dark Autumn, with untimely storm,

The honey'd harvest of the year deform;

Or the chill blast from Eurus' mildew wing, Blight the fair promise of returning Spring;

Full many a hive, but late alert and gay,

Droops in the lap of all-inspiring May.'

-Evans.

"If the Spring is not favorable to bees, they should be fed, because that is the season of their greatest expense in honey, for feeding their young: Having plenty at that time, enables them to yield early and strong swarms." -(Wildman.)

A bee-keeper, whose colonies are allowed to perish after the Spring has opened, is on a level with a farmer whose cattle are allowed to starve in their stalls; while those who withhold from them the needed aid, in seasons when they cannot gather a supply, resemble the merchant who burns up his ships, if they have made an unfavorable voyage.

Columella gives minute instructions for feeding needy colonies, and notes approvingly the directions of Hyginus- 
whose writings are no longer extant-that this matter should be most carefully ("diligentissime") attended to.

\section{Spring Feeding.}

606. When bees first begin to fly in the Spring, it is well to feed them a little, as a small addition to their hoards encourages the production of brood. Great caution, however, should be used to prevent robbing. Feeding should always be attended to in the evening (666), and as soon as forage abounds, the feeding should be discontinued.

Feeding to induce breeding should be done with diluted honey or thin sugar-syrup, warmed before using. This watery and warm food given in small quantities takes the place of fresh honey and, like fresh harvested nectar, saves the bees the necessity of going after water for breeding. It thus serves two purposes, it induces more plentiful breeding and supplies water for the larval food (662, 281). Mr. J. E. Johnson of Williamsfield, Illinois, reported to us great success by this method which is not usually followed, owing to the care required, for one must be careful not to overdo the feeding or feed when the weather is too cold. If a colony is over-fed, the bees will fill their brood-combs, so as to interfere with the production of young, and thus the honey given to them is worse than thrown away.

The over-feeding of bees resembles, in its results, the noxious influences under which too many children of the rich are reared. Pampered and fed to the full, how often does their wealth prove only a legacy of withering curses, as, bankrupt in purse and character, they prematurely sink to dishonored graves.

Colonies, which have abundant stores, may be ineited to breed, by simply bruising the cappings of a part of their honey. This causes them to feed their queen more plentifully, and more eggs are laid.

60\%. Bees may require feeding, even when there are many 
blossoms in the fields, before the beginning of the main harvest, if the weather is unfavorable to the honey flow. Large quantities of brood hatch daily, requiring much food, and a few days without honey sometimes endangers the life of colonies, on the eve of a plentiful harvest.

Few people realize the great risk of starvation just at the opening of the honey crop. A good way to feed destitute colonies in Spring is to give them combs of honey, which have been saved from the previous season for this purpose. If such cannot be had, the food may be put into an empty comb, and placed where it ean be easily reached by the bees.

Honey partially candied, or granulated (830), may be given them, in small quantities, by pouring it over the top of combs in which the bees are elustered. A bee deluged by sweets, when away from home, is a sorry spectacle; but what is thus given them does no harm, and they will lick each other clean, with as much satisfaction as a little child sucks its fingers while feasting on sugar candy.

Hard candied honey is still better and may be heaped or plastered over the top bars back of the eluster.

If a colony has too few bees, its population must be replenished before it is fed. To build up small colonies by feeding, requires more care and judgment than any other process in bee-culture, and will rarely be required by those who have movable-frame hives. It can only succeed when everything is made subservient to the most rapid production of brood.

\section{Fall Feeding.}

608. By the time the honey-harvest closes, all the colonies ought to be strong in numbers; and, in favorable seasons, their aggregate resources should be such that, when an equal division is made, there will be enough food for all. If some have more, and others less than they need, an equitable division may usually be effected in movable=frame hives. Such an agrarian procedure would soon overthrow human society; 
but bees thus helped, will not spend the next season in idleness; nor will those deprived of their surplus limit their gatherings to a bare competency.

Before the first heavy frosts all feeding required for wintering bees should be carefully attended to.

609. Feeders of all descriptions are made and sold. To feed our bees we have used for years a fruit can, (fig. 123) covered with cloth and inverted over the hive. It costs nothing and can be found in every house. We now use IIill's Feeder (fig. 124), FAN FEEDER. in which the cloth is replaced by a perforated cover.

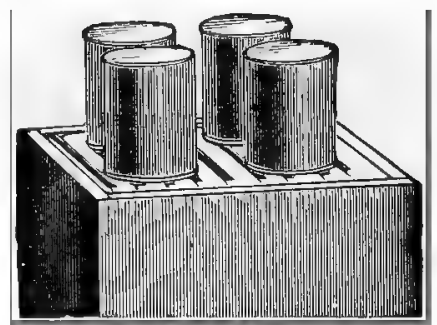

Fig. 124.

HILL'S BEE-FEEDER.

The bees can then get their food, without being chilled even in cold weather, and they promptly store it away in the combs, for later use.

In order that the heat may be better retained, a hole of the size of the feeder may be cut into a piece of enamel cloth used for the purpose in place of the ordinary cloth.

Columella recommended wool, soaked in honey, for feeding bees. When the weather is not too cold, a saucer, bowl, trough, or vessel of any kind, filled with straw, makes a convenient feeder.

It is desirable to get through with Fall feeding as rapidly as possible, as the bees are so excited by it that they con- 
sume more food than they otherwise would. In feeding a large amount for Winter supply, we have given as many as five quart-cans to one colony at one time. Wooden feeders in the shape of troughs, as made by Root, Shuck, and Heddon, have the advantage over the cans of not needing removal to be refilled, but they are not so well in reach of the cluster.

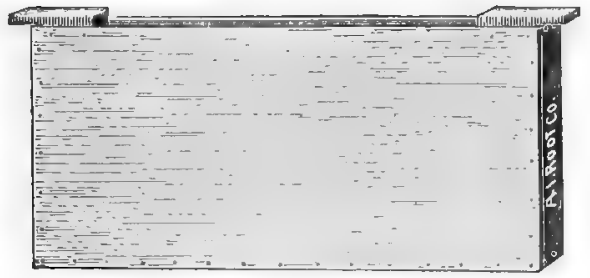

Fig. 125.

DOOLITTLE DIVISION BOARD FEEDER.

The Doolittle division board feeder is made in the shape of a wide frame boarded up on both sides. This feeder will drown the bees unless a slat is put inside of it, to float at the top of the feed given.

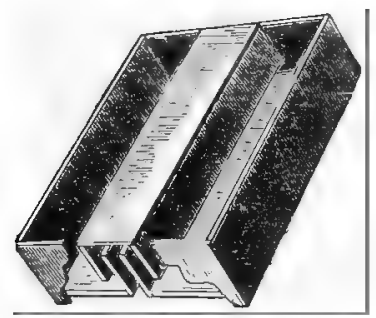

Fig. 126.

THE MILLER FEEDER.

The Miller feeder is placed over the combs in the same manner as a super. It places the feed well in reach of the bees. Numerous other feeders have been devised and all have some good points. 
610. As honey is scarce in the seasons when Fall feeding has to be resorted to, we will give directions for making good syrup for Winter food: Dissolve twenty pounds of granulated sugar (use none but the best) in one gallon of boiling water, with the addition of five or six pounds of honey. Stir till well melted, and feed while lukewarm.*

611. Sugar candy, for feeding bees, was first recommended by Mr. Weigel of Silesia. If the candy is laid on the frames just above the clustered bees, it will be accessible to them in the coldest weather. It may also be put between the combs, in an upright position, among the bees, or poured into combs before it is cold.

To make candy for bee-feed: add water to sugar, and boil slowly until the water is evaporated. Stir constantly so that it will not bum.

To know when it is done, dip your finger first into cold water and then into the syrup. If what adheres is brittle to the teeth, it is boiled enough. Pour it into shallow pans, a little greased, and, when cold, break into pieces of a suitable size.

612. Before attempting to make candy for bee feed, the novice will do well to read the following advice from the witty pen of friend A. I. Root:

"If your candy is burned, no amount of boiling will make it hard, and your best way is to use it for cooking, or feeding the bees in Summer. Burnt sugar is death to them, if fed in cold weather. You can tell when it is burned by the smell, color and taste. If you do not boil it enough, it will be soft and sticky in warm weather, and will be liable to drip, when stored away. Perhaps you had better try a pound or two, at first, while you 'get your hand in.' Our first experiment was with $50 \mathrm{lbs}$. and it all got 'scorched' somehow. . . . Before you commence, make up your mind, you will not get one drop of sugar or syrup on the floor or table. Keep your hands clean, and everything else clean, and let the women folks see that men have common sense; some of them at least. If you should

- Pure sugar syrup without addition of honey often crystallizes in . the combs and becomes as hard as rock candy. 
forget yourself, and let the candy boil over on the stove, it would be very apt to get on the floor, and then you would be very likely to 'get your foot in it,' and before you got through, you might wish you had never heard of bees or candy either; and your wife, if she did not say so, might wish she had never heard of anything that brought a man into the kitehen. I have had a little experience in the line of feet sticking to the floor and snapping at every step you take, and with door knobs sticking to the fingers, but it was in the honey house."

613. The Rev. Mr. Scholz, of Silesia, years ago, recommended the following as a substitute for sugar-candy in feeding bees:

"Take one pint of honey and four pounds of pounded lumpsugar; heat the honey, without adding water, and mix it with the sugar, working it together to a stiff doughy mass. When thus thoroughly incorporated, eut it into slices, or form it into cakes or lumps, and wrap them in a piece of coarse linen and place them in the frames. Thin slices, enclosed in linen, may be pushed down between the combs. The plasticity of the mass enables the Apiarist to apply the food in any manner he may desire. The bees have less difficulty in appropriating this kind of food than where candy is used, and there is no waste."

This preparation has been used of late years with success, as food in mailing and shipping bees, under the name of "Good's candy."

Thick sugar-syrup and candy are undoubtedly the best beefood, especially when the bees are to be confined a long time and no brood is to be raised.

614. An experiment of De Layens has proved that bees can use water to dissolve sugar (273). The same writer relates how a French bee-keeper, Mr. Beuzelin, feeds his bees in Winter:

"He saws into slices a large loaf of lump-sugar, and places these slices upon the frames under a cloth. Another bee-keeper told me several years ago of having saved colonies in straw hives by simply suspending in them, with wires, lumps of sugar weighing several pounds." -(Bulletin de la Suisse Romande.) 
While such methods succeed in a mild and damp climate, like that of France, they are not advisable in the Northern part of the United States, unless the bees are wintered in cellars (646).

615. The prudent Apiarist will regard the feeding of bees-the little given by way of encouragement exceptedas an evil to be submitted to only when it cannot be avoided, and will much prefer that they should obtain their supplies in the manner so beautifully described by him whose inimitable writings furnish us, on almost every subject, with the happiest illustrations:

"So work the honey-bees, Creatures that, by a rule in Nature, teach The art of order to a peopled kingdom. They have a king and officers of sorts, Where some, like magistrates, correct at home, Others, like merchants, venture trade abroad; Others, like soldiers, armed in their stings, Make boot upon the Summer's velvet buds; Which pillage they, with merry march, bring home

- To the tent royal of their emperor, Who, busied in his majesty, surveys

The singing masons building roofs of gold;

The civil citizens kneading up the honey;

The poor mechanic porters crowding in

Their heavy burdens at his narrow gate;

The sad-eyed justice, with his surly hum,

Delivering o'er, to executors pale,

The lazy, yawning drone."

Shakespeare's Henry V, Act 1, Scene 2.

616. All attempts to derive profit from selling cheap honey or syrup, fed to bees, have invariably proved unsuccessful. The notion that they can change all sweets, however poor their quality, into honey, on the same principle that cows secrete milk from any acceptable food, is a complete delusion.

Different kinds of honey or sugar-syrup fed to the bees 
can be as readily distinguished, after they have sealed then up, as before.

The Golden Age of bee-keeping, in which bees are to transmute inferior sweets into such balmy spoils as were gathered on Hybla or Hymettus, is as far from prosaic reality as the visions of the poet, who saw--

"A golden hive, on a golden bank,

Where golden bees, by alchemical prank, Gather gold instead of honey."

Even if cheap sugar could be "made over" by the bees so as to laste like honey, it would cost the producer, taking into account the amount consumed (223) in elaborating wax, as much as the market price of white clover honey.

617. The experienced Apiarist will fully appreciate the necessity of preventing his bees getting a taste of forbidden sweets, and the inexperienced, if incautious, will soon learn a salutary lesson. Bees were intended to gather their supplies from the nectaries of flowers, and, while following their natural instincts, have little disposition to meddle with property that does not belong to them; but, if their incautious owner tempts them with liquid food, at times when they can obtain nothing from the blossoms, they become so infatuated with such easy gatherings as to lose all discretion, and will perish by thousands if the vessels which contain the food are not furnished with floats, on which they can safely stand to help themselves.

As the fly was not intended to banquet on blossoms, but on substances in which it might easily be drowned, it cautiously alights on the edge of any vessel containing liquid food, and warily helps itself; while the poor bee, plunging in headlong, speedily perishes. The sad fate of their unfortunate companions does not in the least deter others who approach the tempting lure, from madly alighting on the bodies of the dying and the dead, to share the same miserable end! No one can understand the extent of their infatuation, 
until he has seen a confectioner's shop assailed by myriads of hungry bees. We have seen thousands strained out from the syrups in which they had perished; thousands more alighting even upon the boiling sweets; the floors covered and windows darkened with bees, some crawling, others flying, and others still, so completely besmeared as to be able neither to crawl nor fly-not one in ten able to carly home its ill-gotten spoils, and yet the air filled with new hosts of thoughtless comers.

We once furnished a candy-shop, in the vicinity of our apjiary, with wire-gauze windows and doors, after the bees had conmenced their depredations. On finding themselves excluded, they alighted on the wire by thousands, fairly squealing with vexation as they vainly tried to force a passage through the meshes." Baffled in every effort, they attempted to descend the chinney, reeking with sweet odors, even although most who entered it fell with scorched wings into the fire, and it became necessary to put wire-gauze over the top of the chimney also.

618. As we have seen thousands of bees destroyed in such places, thousands more hopelessly struggling in the deluding sweets, and yet increasing thousands, all unmindful of their danger, blindly hovering over and alighting on them, how often have they reminded us of the infatuation of those who abandon themselves to the intoxicating cup! Even although such persons see the miserable vietims of this degrading vice falling all around them into prenature graves, they still press madly on, trampling, as it were, over their dead bodies, that they too may sink into the same abyss, and their sun also go down in hopeless gloom.

The avaricious bee that plunges recklessly into the tempting sweets, has ample time to bewail her folly. Even if she

\footnotetext{
* Manufacturers of candies and syrups will find it to their interest to fit such guards to their premises; for, if only one bee in a hundred escapes with its load, considerable loss will be incurred in the course of the season.
} 
does not forfeit her life, she returns home with a woe-begone look, and sorrowful note, in marked contrast with the bright hues and merry sounds with which her industrious fellows come back from their happy rovings amid "budding honeyflowers and sweetly-breathing fields." 


\section{CHAPTER XIIT.}

Wintering and Spring Dwinduing.

Wintering.

619. Bees can be wintered safely in nearly all climates, where the Summer is Iong enough to enable them to store a Winter supply. In the natural state, the vital heat of the live hollow trees in which they dwell, helps to maintain a higher temperature than that of the outside air, and bees Winter so well in such abodes, that travelers, who visit Northern Russia, wonder how so small an insect can live in such inhospitable countries.

620. As soon as frosty weather arrives, bees cluster compactly together in their hives, to keep warm. They do not usually assemble on combs full of honey, but on the empty comb just below the honey. They are never dormant, like wasps and hornets, and a thermometer pushed up among them will show a Summer temperature, even when, in the open air, it is many degrees below zero.

The bees in the cluster are imbricated, like the shingles of a roof, each bee having her head under the abdomen of the one above her, and so on, to the ones who are in reach of the honey. These pass the honey to those below them, which pass it to the next, and so on, to the bottom of the mass.

621. When the cold becomes intense, they keep up an incessant tremulous motion, in order to develop more heat*

* Everybody knows that motion transforms itself into heat, and that heat is but a form of motion. . . whether the motion comes from a large body or from a small one, whether this motion be suddenly or gradually stopped, the result is the same, it is transformed into heat.-(Flammarion, "Le Monde Avant la Création de l'Homme.") 
by active exercise; and, as those on the outside of the eluster become chilled, they are replaced by others. Besides, the fanning of wings, which causes this roar, sends the warm air from the top of the cluster to the bottom of the hive-thus warming the bees placed at the lowest part of the cluster; and these, if not too chilled, take advantage of a warmer day, to elimb above the mass, and get honey in their turn.

When the weather is very cold, their humming can often be heard outside of the hive; and, if the hive be jarred, at any time, there comes a responsive murmur, which is longer or shorter in duration, and lower or higher in tone, according to the strength of the colony.

622. As all muscular exertion requires food to supply the waste of the system, the more quiet bees can be kept, the less they will eat. It is, therefore, highly important to preserve them as far as possible, in Winter, from every degree, either of heat or cold, which will arouse them to great activity.

When all the food which is in their reach is consumed, they will starve, if the temperature is too cold to allow them to move their cluster to the parts of the combs which contain honey; hence, if the central combs of the hive are not well stored with honey, they should be exchanged for such as are, so that, when the cold compels the bees to recede from the outer combs, they may cluster among their stores. In distriets where bees gather but little honey in the Fall, such precautions, in cold climates, will be specially needed, as, often, after breeding is over, their central combs will be almost empty. For this reason Canadian apiarists often feed their colonies until the central combs are entirely filled with honey at the opening of Winter.

623. It is impossible to say how much honey will be needed to carry a colony safely through the Winter. Much will depend on the way in which they are wintered, whether in the open air or in special depositories, where they are protected against the undue excitement caused by sudden 
and severe atmospheric changes; much, also, on the length of the Winters, which vary so much in different latitudes, and the forwardness of the ensuing Spring. In some of our Northern States, bees will often gather nothing for more than six months, while, in the extreme South, they are seldom deprived of all natural supplies for as many weeks. In all our Northern and Middle States, if the colonies are to be wintered out of doors, they should have at least twenty-five pounds of honey.

In movable-frame hives, the amount of stores may be easily ascertained by actual inspection. The weight of hives is not always a safe criterion, as old combs are heavier than new ones, besides being often over-stored with pollen. (263.)

621. Practical bee-keepers usually judge of the amount of stores by sight. The majority of combs in an ordinary Langstroth hive should be at least half full of honey, for outdoor wintering, in this latitude. Remember that food is needed, not only to carry them through the Winter, but also to help them to raise brood largely, during the cold days of early Spring. Bees do not waste their stores, and the wealthy colonies will usually be found stronger, and better prepared for the following harrest.

Enthusiastic beginners, in Apiculture, are apt to overdo extracting, leaving too little honey in the brood-chamber for Winter. If the bees are not actually crowded with honey, we would advise them to leave, to strong colonies, all the honey that the brood-chamber contains. Some may think that nine or ten heary Quinby frames, are too many for a colony, for they may be wintered on six or seven. We will here give a bit of our experience on that point:

625. About the year 1875 , in an apiary away from home, where we were raising comb-honey, we had a number of swarms, which, in the rush of the honey-crop, we did not examine until their combs were built. At that time, the triangular bar (319) was the guide principally used, and the combs of some of these swarms were joined together in a 
way that rendered the frames immovable. In the Fall, we extracted ( $\mathbf{8 4 9}$ ) from the brood-chamber of nearly every colony, as was then our practice, leaving only seven Quinby frames on an average-for Winter. The colonies that had crooked combs were left with all their stores-ten framesbecause we could not disturb them without breaking combs, and causing leakage and robbing, and it was not the proper season to transfer (5/4) them. These colonies did not have to be fed, the following Spring, became very strong, and yielded the largest crop. This untried-for result caused us to make further experiments, which proved that there is a profit in leaving, to strong colonies, a large quantity of honey, so that they will not limit their Spring breeding.

626. The quality of the bee-food is an important matter in wintering bees. Protracted cold weather compels them to eat large quantities of honey, fllling their intestines with fecal matter which they cannot void, for bees never discharge their fæces in the hive, unless they are confined too long, or greatly disturbed.

Unhealthy food in prolonged confinement, sooner or later causes diarrhœa ( $/ 84$ ), not only in wintering out of doors, but in cellar wintering (616), and in shipping bees long distances (587).

Diarrhoa, or as some call it, dysentery, in bees, is not properly a disease, since it is only caused by the retaining in the abdomen, of a large amount of excrements, which in ordinary circumstances would be voided regularly. Whenever bees have been confined for two weeks or more, they discharge in flight excrements which soil everything about the apiary. The housekeeper avoids hanging clothes out to dry on such days. These excrements or fæces, from a reddish yellow to a muddy black in color, according to the quality of the food eaten, have an intolerably offensive smell. In excessive confinement, with a large consumption, from any cause, of more or less healthy food, when bees can no longer retain the excrements in their distended abdomen, they void them upon one 
another, upon the combs, upon the floor, and at the entrance of the hive, "which bees in a healthy state are particularly careful to keep clean."

If bees can void them, in flight $(\boldsymbol{7 3})$, before it is too late, they experience no bad effects, hence it is indispensable that, when wintered out of doors, bees should be enabled to fly, at intervals, during the Winter.

62\%. From numerous experiments made, it is evident that the purcst saccharine matter will feed them with the least production of faeces. Hence watery, unripe, or sour honey, and all honey containing extraneous matter, are more or less injurious to confined bees. Dark honey containing a large proportion of mellose is inferior to clover-honey or sugar-syrup. Honey harvested from flowers which yield much pollen (263), is likely to contain many loating grains of it, and will be more injurious than elear, transparent honey, in cases where bees will be confined to their hives by cold for five or six weeks. Honey-dew (255) seems worse yet. The juices of fruits, apples, grapes, etc. (87\%), are worst of all. After the Winter of $1880-81$, we purchased the remains of some 90 colonies, that had been winter-killed, and in which the only food left was apple-juice, that had been earried in, during the preceding Fall, and had turned to eider. This unwholesome food in Winter confinement, by causing diarrhœa, had killed bees everywhere around us ( $\mathbf{7 8 4})$.

628. Happily these instances, of bees storing apple-juice, are scarce, but the practical bee-keeper will not allow such food to remain in the hive. It may be extracted $(\mathbf{( 4 9 )}$, boiled, and fed back in Spring, for bees do not suffer from this food when not confined to their hives. The same may be said of inferior or unripe honey (261).

Much unsealed honey in the comb is injurious for Winter, even if the honey is ripe. This unsealed honey gathers moisture on account of its hygrometric properties, and becomes thin and watery. In addition to this peculiarity, honey, when cold, condenses the moisture or steam from the bees, in 
the same manner that a pitcher of cold water condenses the moisture of the air in a warm room. In some Winters, we have seen unsealed honey gather so much of the moisture that it overflowed, and ran out of the cells to the bottom-board. Luckily the bees usually consume this honey first, before Winter begins.

629. To avoid the accidents caused by poor honey, some Apiarists have suggested that all the honey might be extracted every Fall, and sugar-syrup fed in its place. At the first glance, this course seems profitable, when the difference between the price of comb-honey and the cost of sugar-syrup is considered, but when we take into account the trouble of -feeding, and the poor results obtained in wintering the bees, we see much labor for a small profit. Having ascertained that bees winter better on Spring or light-colored honey, we no longer extract from the brood-chamber, avoiding the annoyance and the extra labor of feeding. Our experience has convinced us that, unless the Spring erop has failed, or the food is decidedly bad, such as unripe honey (249), or honey-dew (255), or fruit-juice (8\%'), it is cheaper to winter bees on natural stores. When sugar-syrup is needed, none but the best sugar should be used. (616.)

630. All empty combs, whether brood-combs or surpluscombs, should be removed from the hive previous to cold weather, as the bees, which may cluster in them, would starve at the first cold spell without being able to join the cluster. We have seen a whole colony perish, during a cold fortnight in December, because they had occupied an extracting story (which had but little honey in it, and had been left on by neglect), although there was plenty of honey in the hive, a few inches below them. The space left empty by the removal of the combs should be filled with a warm material placed between the side of the hive and the division board.

631. As some bees which cluster on the outside combs are often unable to join the others in cold weather, it would be well to have holes, or Winter passages, through the combs, 
such as will allow them to pass readily, in cold weather, from one to another; but if these holes are made before they fecl the need of them, they will frequently close them. It is suggested that small tubes made of elder, the pith of which has been removed, would make permanent Winter-passages, if inserted in the comb, at any time. On a cold November day, Mr. Largstroth found bees, in a bive without any Winterpassages, separated from the main cluster, and so chilled as not to be able to move; while, with the thermometer many degrees below zero, he repeatedly noticed, in other hives, at one of the holes made in the comb, a cluster, varying in size, ready to rush out at the slightest jar of their hive.

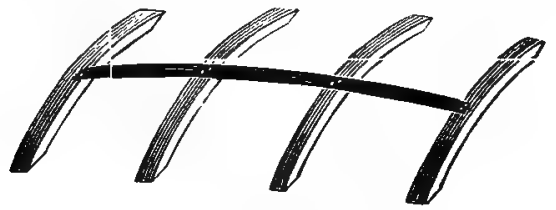

Fig. 127.

HILL DTVICE.

It has been found quite practical to give them a passage above the combs, or between the combs and the straw-mat, or quilt, above them. The Hill device sold by many dealers, is very good for this purpose, although we find that the bees often have bridge-combs in sufficient quantity above the frames to give them the necessary passage.

\section{OUT-DOOR WINTERING.}

632. The usual mode of allowing bees to remain all Winter on their Summer stands, is, in cold elimates, very objectionable. In those parts of the country, however, where the cold is seldom so severe as to prevent them from flying, at frecuent intervals, from their hives, no better way, all things considered, can be devised. In such favored regions, bees are but little removed from their native climate, and their wants may be easily supplied, without those injurious effects 
which commonly result from disturbing them when the weather is so cold as to confine them to their hives.

If the colonies are to be wintered in the open air, they should all be made populous, and rich in stores, even if to do so requires their number to be reduced one-half or more. The bee-keeper who has ten strong colonies in the Spring, will, by judicious management with movable-frame hives, be able to close the season with a larger apiary than one who begins it with thirty, or more, feeble ones.

632 (bis). Small colonies consume, proportionally, much more food than large ones, and then perish from inability to maintain sufficient heat.

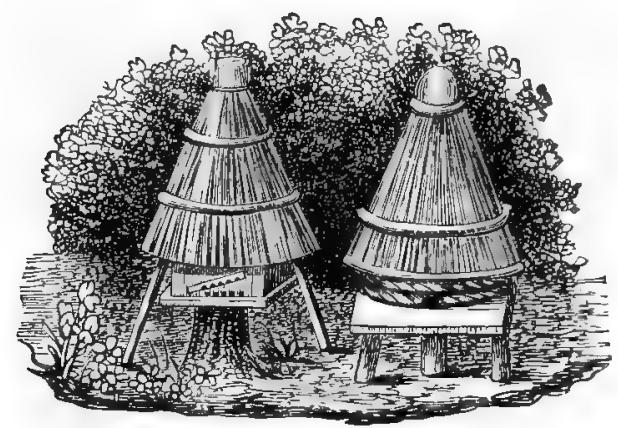

Fig. 128 ,

EUROPEAN COMMON HIVES PROTECTED BY STRAW.

(From Hamet.)

Bees, in small or contracted hives, especially when deprived of all the honey gathered in Spring, as stated before (629), have too scanty a population for a successful wintering, especially out of doors; for, as it is by eating that bees generate warmth, the abdomens of a small number are soon filled with residues, and if the cold continues for weeks the bees get the diarrhou ( $\mathbf{7 4 4}$ ). We have often seen colonies in small hives perishing side by side with large ones whose bees were very healthy. 
Such facts abound, and we have but to open the bee-journals to find the confirmation of our statement.

In the American Bee-Journal for February 8, 1888, page 83, Mr. J. P. Stone of Holly, Mich., asks why a colony, which was hived in 1859 in a large box, is prospering yet, while others have perished. The size given, $16 \times 16 \times 22$, which shows that the box has twice the capacity of an 8-frame Langstroth hive, answers his question.

In the following number of the same journal, page 107, Mr. Heddon mentions a colony which had wintered safely for seven years in a box ten times larger than the Langstroth, while many others died by its side. "The colony, when transferred, contained about double the number of bees usually raised from one queen."

Yet small colonies can be safely wintered out of doors, if their combs and honey are not spread over a large space, and if they are sheltered so as to maintain the proper heat. It is therefore indispensable to reduce the combs of a hive to the amount of room which the bees can best keep warm, by the use of the division or contracting board (349), leaving a sufficient supply of good honey, supply which, sometimes, may be taken from too rich colonies.

\section{UNITING.}

633. A queenless colony, in the Fall, should always be united to some other hive.

If two or more colonies, which are to be united, are not close together, their hives must be gradually drawn nearer, and the bees may then, with proper precautions, be put into the same hive. For this purpose, it is well to kill the poorest queen (if both have queens) and keep the best. This may be dispensed with, but the prudent bee-keeper will never neglect an opportunity to improve his stock. On a cool November day, the combs of the weaker colony that bear the cluster, should be lifted all together, and inserted in the other hive, 
after the bees of the latter have been thoroughly frightened with smoke. (382.)

634. If, when two colonies are put together, the bees in the one on the old stand are not gorged with honey, they will often attack the others, and speedily sting them to death, in spite of all their attempts to purchase immunity, by offering their honey. The late Wm. W. Cary, of Coleraine, Mas" sachusetts, who was an accurate observer of the habits of bees, united colonies very successfully, by alarming those that were on the old stand; as soon as they showed by their notes, that they were subdued, he gave them the new-comers. The alarm which causes them to gorge themselves with honey, puts them, doubtless, upon their good behavior, long enough to give the others a fair chance.

They can also be made to unite peaceably, by sprinkling a little sweet-scented water on them (485). It is well to put a slanting board in front of the entrance (603) to show the moved bees that their location is changed. The empty hive should be removed from its place to prevent the bees from returning to it. The number of combs in the united colony may be reduced as soon as the bees have all clustered together.

In this manner a strong colony with little honey, and a weak one with plenty of stores, may be united to form a good hive of bees.

\section{OdT-Door Sheltering.}

635. The moving of a colony to a warmer or better sheltered place, just before Winter, is not advisable, for many bees, not having noticed their new location, would perish of cold, while searching for their home, and the population would be greatly decreased.

In our Northern, Middle and Western States, the style of hive used has a considerable influence on the safety of outdoor wintering.

With hives that are single-walled all around, great care should be taken to shelter the bees from the piereing winds, 
which in Winter so powerfully exhaust their animal heat; for, like human beings, if sheltered from the wind, they will endure a low temiperature far better than a continuous current of very much warmer air.

In some parts of the West, where bees suffer much from cold winds, their hives are protected, in Winter, by sheaves of straw, fastened so as to defend them from both cold and wet. With a little ingenuity, farmers might easily turn their waste straw to a valuable account in sheitering their bees.

Not only can straw be used for this purpose with much service, but also forest leaves, corn fodder, and rushes. Snow is found to be a very good shelter, provided its successive melting and freezing does not interfere with the necessary ventilation. It must be removed from the entrance on the approach of a warm day.

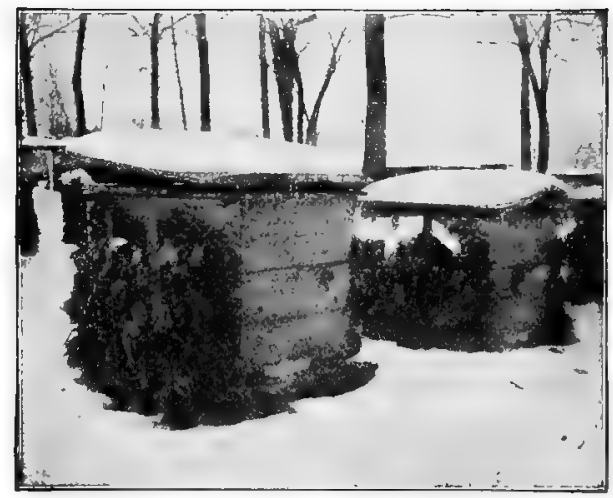

Fig. 128 bis.

WINTER PACKING AROUND THE HIVE.

Mr. Geo. H. Beard, of Winchester, Mo., safely wintered ninety-three colonies out of ninety-six, in the severe Winter of 1884-5, in the lower apartment of two-story Langstroth hives, by removing the oil-cloth and replacing it with coarse 
sack-cloth, filling the upper story with maple leaves, and covering the hives, on all sides, except the front, with what is commonly known as slough-grass. This sucess is worthy of notice, for in that memorable Winter, more than two-thirds of the bees in the Northern States died, some Apiarists losing all they had. Isike that of $1855-6$, it will long be remembered, not only' for the uncommon degree and duration of its cold, but for the tremendous winds, which, often for days together, swept like a Polar blast over the land.

We have, for years, wintered part of our bees on the Summer stand, by sheltering them on all sides but the front, with forest leaves closely packed, and held with a frame-work of lath, or ladder.

636. One of the most important requirements for successful out-door wintering, is the plasing of warm absorbents, immediately over the cluster, to imbibe the excess of moisture that rises from the bees, without allowing the heat to escape.

In March, 1856, we lost some of our best colonies, under the following circumstances: The Winter had been intensely cold, and the hives, having no upward ventilation or moisture absorbents, were filled with frost-in some instances, the ice on their glass sides being nearly a quarter of an inch thick. A few days of mild weather, in which the frost began to thaw, were followeu by a severely cold spell with the thermometer below zero, accompanied by raging winds, and in many of the hives, the bees, which were still wet from the thaw, were frozen together in an almost solid mass.

As long as the vapor remains congealed, it can injure the bees only by keeping them from stores which they need; but, as soon as a thaw sets in, hives which have no upward absorbents are in danger of being ruined.

Mr. E. T. Sturtevant, of East Cleveland, Ohio, once known as an experienced Apiarist, thus gave his experience in wintering bees in the open air:

"No extremity of cold that we ever have in this climate, will injure bees, if their breath is allowed to pass off, so that 
they are dry. I never lost a good colony that was dry, and had plenty of honey."

The absorbents generally used are chaff in cushions, straw, forest leaves (maple leaves preferred), corn cobs, woolen rags, or wool waste, ete. Mr. Cheshire used cork-dust, which he claimed gave fourteen times as much protection as a deadair space. The oil-cloth, which makes an air-tight covering, must be first removed, and if no straw-mat is used, the cushion of absorbents may be placed right over the frames. We use the straw-mat, and fill the upper half-story with dry leaves, these being the cheapest and best absorbent at our command. In the coldest parts of our country, if upward absorbents are neglected, no amount of protection that can be given to hives, in the open air, will prevent them from becoming damp and mouldy, even if frost is excluded, unless a large amount of lower ventilation is given. Then they need as much aix as in Summer. Often, the more they are protected, the greater the risk from dampness. A very thin hive unpainted, so that it may readily absorb the heat of the sun, will dry inside much sooner than one painted white, and in every way most thoroughly protected against the cold. The first, like a garret, will suffer from dampness for a short time only; while the other, like a cellar, may be so long in drying, as to injure, if not destroy, the bees.

Some apiarists have objected to this paragrapl, because they have never had the experience mentioned in the two Winters above named. Such Winters are rare, but we must be prepared for a recurrence of similar conditions, as we too often have Winters similar to those of Siberia.

637. If the colonies are wintered in the open air, the entrance to their hives must be large enough to allow the bees to fly at will. Many, it is true, will be lost, but a large part of these are diseased; and, even if they were not, it is better to lose some healtly bees than to incur the risk of losing, or greatly injuring, a whole colony by the excitement created by 
confining them when the weather is warm enough to entice them abroad.

If the sun is warm and the ground covered with new-fallen snow, the light may so blind the bees, that they will fall into this fleecy snow, and quickly perish. Even at such times, it is hardly advisable to confine them to their hives. A neighbor of ours killed four colonies, all he had, by "closing the entrances with wire-cloth for Winter. We had advised him to remove it, but he did not do so because some one had told him that his bees would get lost in the snow.

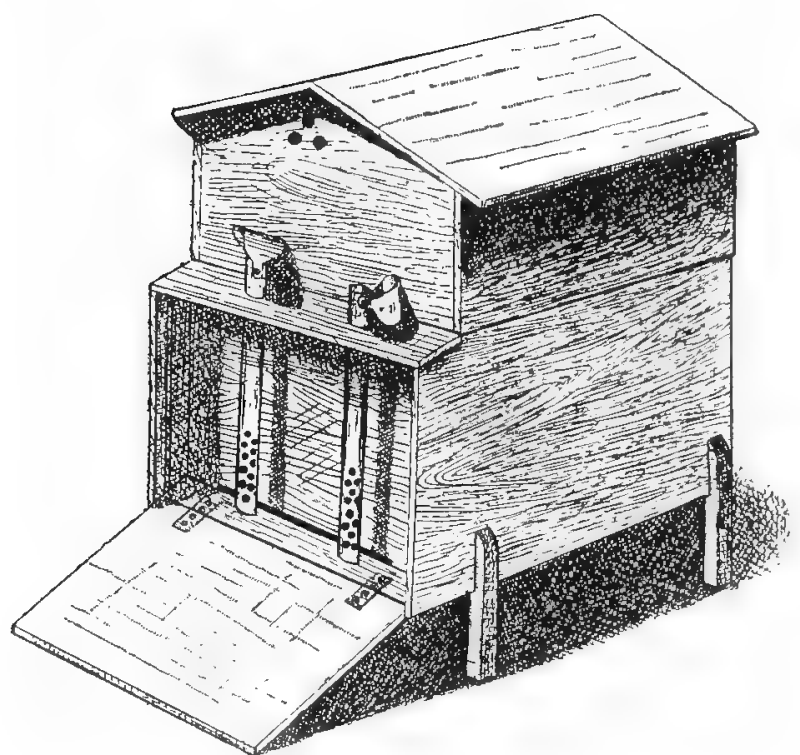

Fig. 129.

THE CLOISTER HIVE.

638. In some countries, as in parts of France, or England, the weather is often for weeks just chilly enough to make it necessary for the bees to remain in the hive, as those who take advantage of an occasional ray of sun light become 
chilled before they can go far, and yet there are no very cold days. In such countries the confining of them to the hive is not objectionable, because they have not consumed large quantities of honey at any time and do not become rest'ess. For this reason Mr. Gouttefangeas, of Noirétuble, France, has devised what he calls a "cloister." The hive is made with a portico. the alighting board is hinged on the bottom and raised

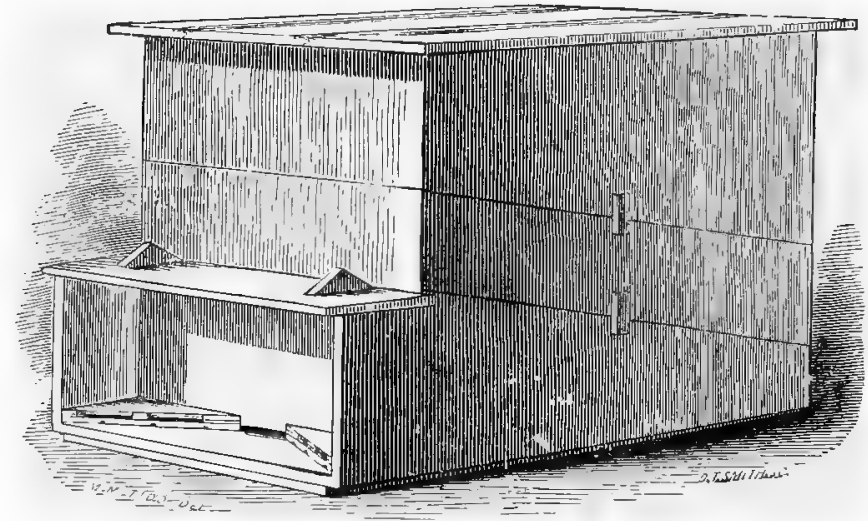

Fig. 130.

TWO-STORY DOUBLE-WALLED LANGSTROTH HIVE, OLD STYLE.

up so as to close the hive when there is any necessity of confining the bees to the hive. Two tubes pierced with holes at their lower end serve for air, and light is excluded. With the use of this "cloister" the bees are confined in a way that keeps them quiet, for they see no light and the rays of the sun do not attract them to the field. But this inplement must be used sparingly, for should a warm day come, the bees would becomie restless in spite of the darkness and the confinement would be more injurious to them than freedom. $\mathrm{Mr}$. Gouttefangens claims for this inrention a number of advantages, as it permits him to confine the bees without danger whenever there is chance of their being lost by sallying forth 
in bad weather. In the hot and cold climate of the Mississippi Valley, the cioister could be used but little.

Great injury is often done by disturbing a colony of bees when the weather is so cold that they cannot fly. Many that

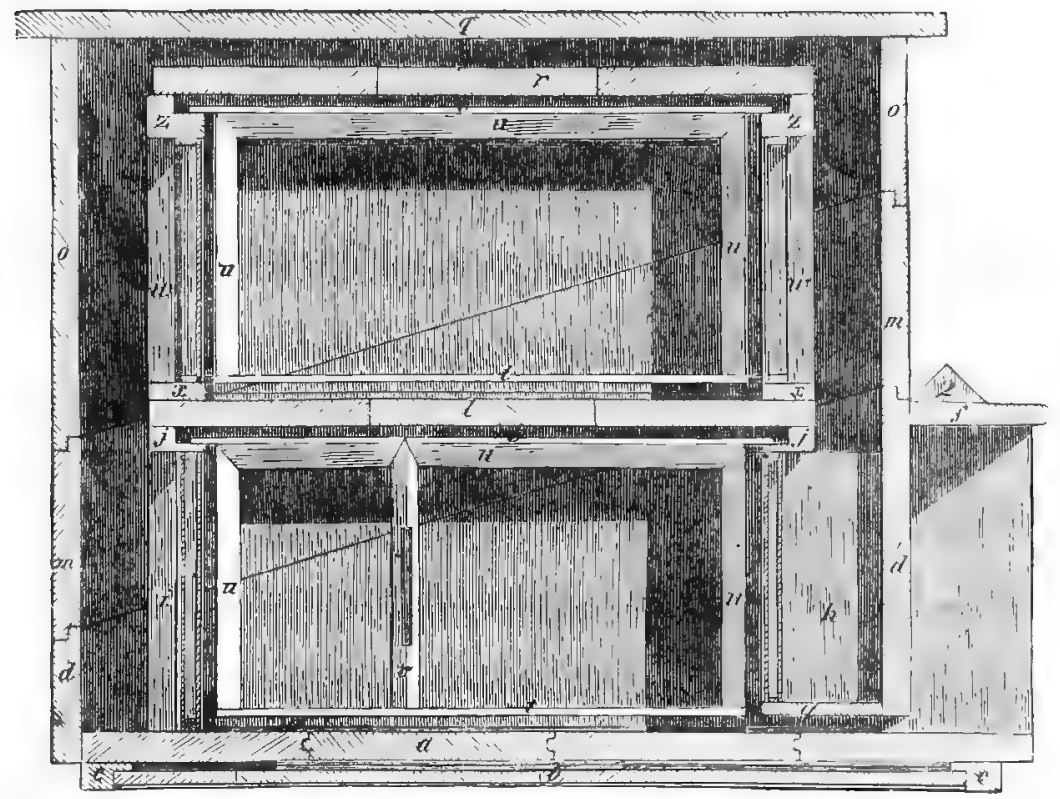

Fig. 131.

INSIDE VIEW OF TWO-STORY DOUBLE-WALL LANGSTROTH HIVE. Old style.

$u, b, c$, double bottom-board. $a$, stationary outer-case. $f$, portico. $g$, entrance through double wall. $h$, $i$, front and back of lower hive. $j, \boldsymbol{z}$, rabbetted pieces. $l$, lower honey-board, $m$, lower part of cover. $o, q$, cover. $r$, upper honey-board. $u, u, t$, frames. $w$, front and rear of upper story.

are tempted to leave the cluster, perish before they can regain it, and every disturbance, by rousing them to needless activity, causes an increased consumption of food. On the other hand, 
it is of the ntmost importance that they be allowed to fly and void their excrements ( $\mathbf{8 3})$ whenever the weather is warm enough. At such times it will be advisable to elean the bottomboards of hives, of dead bees, and other refuse.

639. To show the advantages derived by the bees from a Winter flight, we will give our experience during one of the coldest Winters, that of 1872-3. From the beginning of December to the middle of January, the weather was cold and the bees were unable to leave the hive. The 16 th

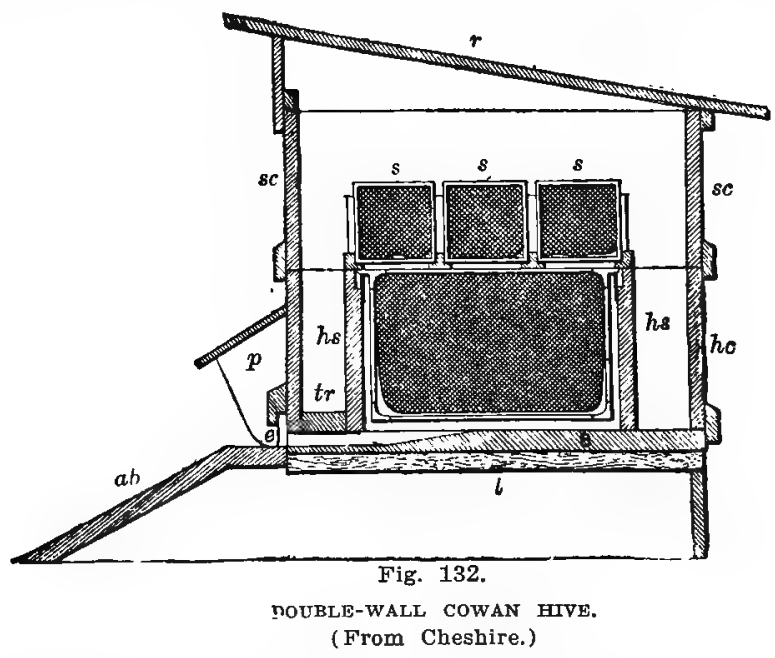

$a b$, apron-board. c, entrance. p, portico. $h s$, hollow space. $t r$, tunnel-roof or cover to entrance. $h c$, hive case. $s c$, surplus case. $r$, root.

of January was a rather pleasant day. We took occasion of this to examine our weak colonies, being anxious in regard to their condition. To our astonishment, they were found alive, and our disturbing them caused them to fly and discharge their excrements. Being convinced that all our bees were safe, we did not disturb the strong colonies, and a few 
Plate 21.

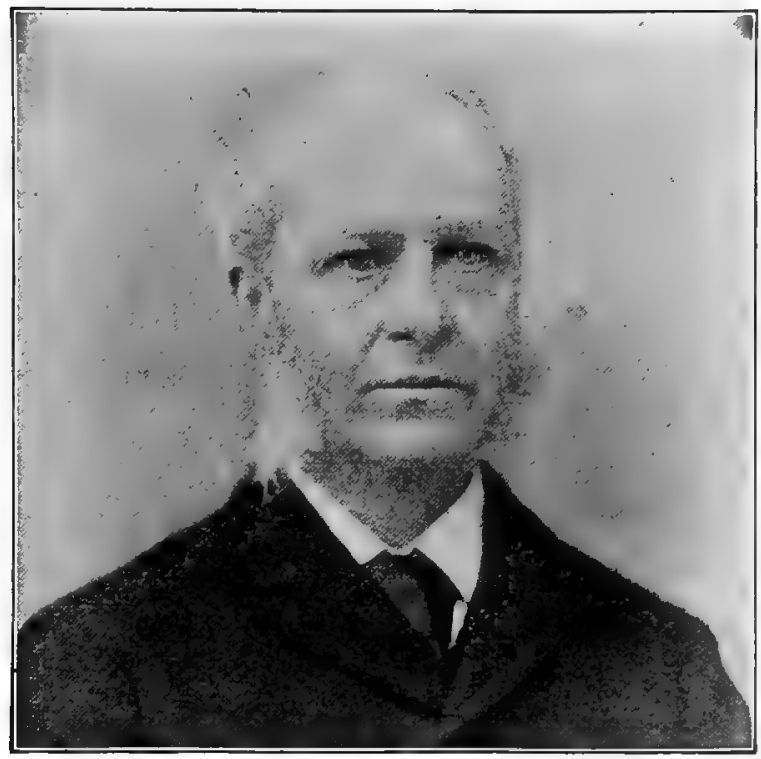

T. W. COWAN, F. G. S., F. R. M. S.

Editor of the "British Bee Journal."

Author of "The British Bee-Keeper's Guide Book" and of "The Honey-Bee."

This' writer is mentioned pages $12,146,195,239,356,469,479,480$, $481,487$. 
of the latter remained quiet. The next day, the cold weather returned, and lasted three weeks longer. Then we discovered that the weak colonies, that had had a cleansing flight, were alive and well, while the strong ones which had remained confined, were either dead or in bad condition.

610. In order to shelter bees more efficiently, in outdoor wintering, against elimatic influences, Apiarists have devised hives, with double walls, filled at the sides, as well as on top, with some light material non-conductor of heat. Some are made on the same principle as the old two-story donble-wall L. hive (fig. 131) without packing.

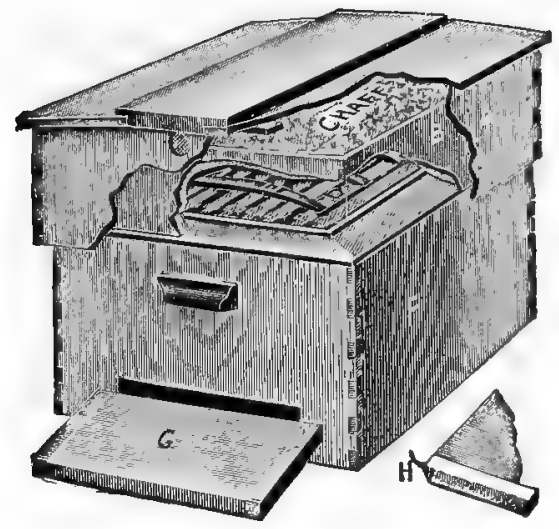

Fig. 133.

ROOT CHAFF HIVE.

( $\mathrm{A}$ B $\mathrm{C}$ of Bee-Culture.)

The most wide-spread style, is the chaff-hive, of A. I. Root. This hive is far superior to single-wall hives for outdoor wintering. It was formerly made in two stories, all in one piece, which rendered it very inconvenient. They now make it as we made ours for years. The cap may be filled with chaff, dry leaves, or a cushion of any warm material. Some Apiarists also use one-story chaff-hives with loose bottom- 
boards that can be taken off to remove the dead bees in Spring.

641. After having used some eighty chaff-hives during twenty-five years or more, we find two disadvantages in them: 1st. They are heavy and inconvenient to handle, especially when made to accommodate ten large Dadant frames. $2 d$. As

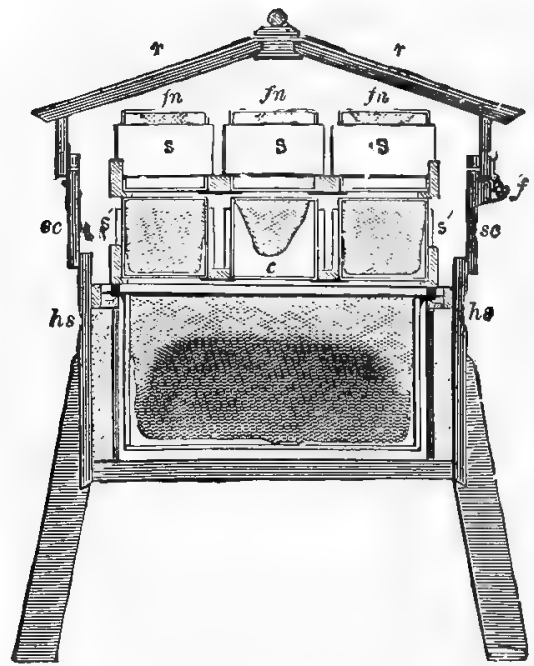

Fig. 134.

INSIDE OF THE CHESHIRE HTVE.

$h s$, hives sides with cork-dust for packing. $s c$, section case. 's, section. $\checkmark$ separators. $f n$, foundation.

they do not allow the heat or cold to pass in and out readily, the bees in these hives may remain in-doors, in occasional warm Winter days, while those of thin-front hives will have a cleansing flight. Thus, in hard Winters, these bees suffer as much from diarrhœa (626-884) as others, unless the Apiarist takes pains to disturb them and make them fly, occasionally, in suitable weather. 
642. But we highly recommend the use of these hives, to the bee-keepers who do not wish to go to the trouble of sheltering their bees every Winter. With the chaff-hive, it is a matter of only a few minutes to put into Winter-quarters a colony that has sufficient stores and bees, As to the advantage, claimed for these hives, of keeping weak colonies warm, in the Spring, we found it counterbalanced by the loss

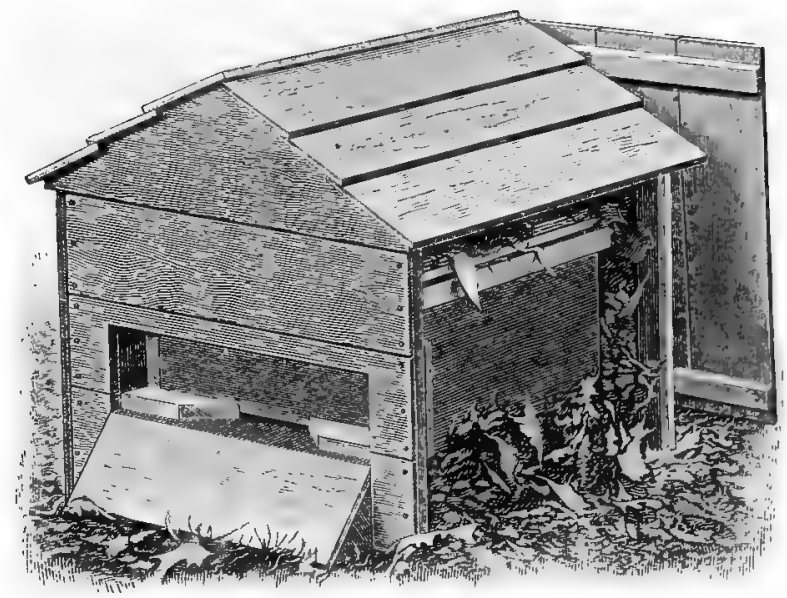

Fig. 135.

OTJTER COVERING.

As used by J. G. Norton and others. One side is removed to show the hive within.

of the sun's heat during the first warm days, and we found that bees bred as fast, in our ordinary hives (double only on the windward sides) owing to the quick absorption of the sun's rays by the boards.

643. To obtain the advantages of the chaff-hive without any of.its disadvantages and at the same time retain in use the single-wall Langstroth or dovetailed hives, some beekeepers have devised outer-boxes to be placed over the colonies during Winter, and removed in Spring. These can be filled 
with absorbents, and make the best and safest out-door shelters (Fig. 135). They are only hooked together by nails partly driven, and are taken off in pieces, in the Spring and put away, under shelter. The roofs may be used over the hives all Summer, if desirable. The only disadvantage of outer-boxes is that they may harbor mice or insects. Some use them, without any packing, and we know by experience, that even in this way, very small colonies may be wintered safely. If the hive has a portico, the front of the box is made to fit around it. In any case, the portico itself can be closed, during the coldest weather, by a door fitting over it, but it must be opened on warm days. In the extraordinary Winter of 1884-5, several bee-keepers of McDonough County, Illinois, among whom, we will eite Mr. J. G. Norton, of Macomb, safely wintered their Simplicity hives with this method, while their neighbors lost all, or nearly all, their bees.

614. If the colonies are strong in numbers and stores, have upper moisture absorbents, easy communication from comb to comb, good ripe honcy, shelter from piercing winds, and can have a cleansing flight once a month, they have all the conditions essential to wintering successfully in the open air.

IN-DOOR WINTERING.

645. In some parts of Europe, it is customary to winter all the bees of a village in a common vault or cellar. Dzierzon says :

"A dry cellar is very well adapted for wintering bees, even though it is not wholly secure from frost; the temperature will be much milder, and more uniform than in the open air; the bees will be more secure from disturbance, and will be protected from the piereing cold winds, which cause more injury than the greatest degree of cold when the air is calm.

"Universal experience teaches that the more effectually bees are protected from disturbance and from the variations of temperature, the better will they pass the Winter, the less will 
they consume of their stores, and the more vigorous and num. crous will they be in the Spring. I have, therefore, constructed a special Winter repository for my bees, near my apiary. It is weather-boarded both outside and within, and the intervening space is filled with hay or tan, ete.; the ground and plat enclosed is dug out to the depth of three or four feet, so as to secure a more moderate and equitable temperature. When my hives are placed in this depository, and the door locked, the darkness, uniform temperature, and entire repose the bees enjoy, enable them to pass the Winter securely. I usually place here my weaker colonies, and those whose hives are not made of the warmest materials, and they always do well. If such a structure is to be partly underground, a very dry site must be selected for it."

In Russia, bee-keepers dig a well from twenty to twentyfive feet deep, and six or eight feet wide. The hives, which there, are hollow trees, are then piled horizontally upon one another, like cord-wood, with one end open. The well is filled to within six feet of the top, and a shed, made of straw, is built above. The bees are left there during the five or six months of Winter. But Russia is fast adopting the methods of advanced countries and they are beginning to use our hives and winter bees much on our plan.

In some other countries, they are kept in caves, abandoned mines, or any under-ground place near at hand.

646. In the North of the United States, and in Canada, they are generally wintered in cellars, and remain there in quiet from November till March or April, sometimes till May.

In all localities, where the bees cannot fly at least once a month, in the Winter, it is best to follow this method of wintering.

As Dzierzon says, a dry cellar is the best, although bees can be wintered in a damp cellar, but with more danger of loss, especially if the food is not of the best.

647. In the first place, the bees should be moved to the cellar, just after they have had a day's flight, at the opening of cold weather, It is better to put them in a litțle early than 
run the risk of putting them away after they have been exposed to a long cold spell.

Dr. C. C. Miller, who is one of the best authorities, because he is much experienced and a very good observer, says this on the proper time to take them in:

"It is a thing impossible to know beforehand just what is the best time to take bees into the cellar. At best it can only be a guess. Living in a region where winters are severe, there are some years in which there will be no chance for bees to have a flight after the middle of November and I think there was one year without a flight after the first of November (Northern Illinois). One feels badly to put his bees into the cellar the first week in November and then two or three weeks later have a beautiful day. But he feels a good deal worse after a good flight-day the first week in November to wait for a later flight, then have it turn very cold, and after waiting through two or three weeks of such weather, to give up hope of any later flight and put his bees in after two or three weeks' endurance of severe freezing. So it is better to err on the side of getting bees in too early.' - (Forty Years Among the Bees, page 292.)

We lake only the brood-apartment leaving the cap, and sometimes the bottom-board, on the Summer stand, beins careful to mark the number of each hive inside of its cap* so as to return it to the same location in Spring (32-33). Not all bee-keepers do this but we know that it helps. In the cellar, the hives are piled one upon another. An empty hive or a box is put at the bottom of each pile, so that the bees will be as high up from the damp ground as possible. If the botiom-board is brought in with the hive, the entrance should be left open. It is well to raise the lower tier of hives from their bottoms with entrance-blocks, unless .they have good lower ventilation without this. Some upper ventilation had better be given also, for the escape of moisture. If the

* In a well-regulated apiary, each hive bears a number painted on the body, or a number tag fastened in some way. 
cellar is damp, the combs will mould more or less; if it is dry, they will keep in perfect order.

648. After the bees are put in, they should be left in darkness, at the temperature that will keep them the quietest. We find that from $42^{\circ}$ to $45^{\circ}$ is the best. Every Apiarist slould have a thermometer, and use it. The cost is insignificant, and it will pay for itself many times.

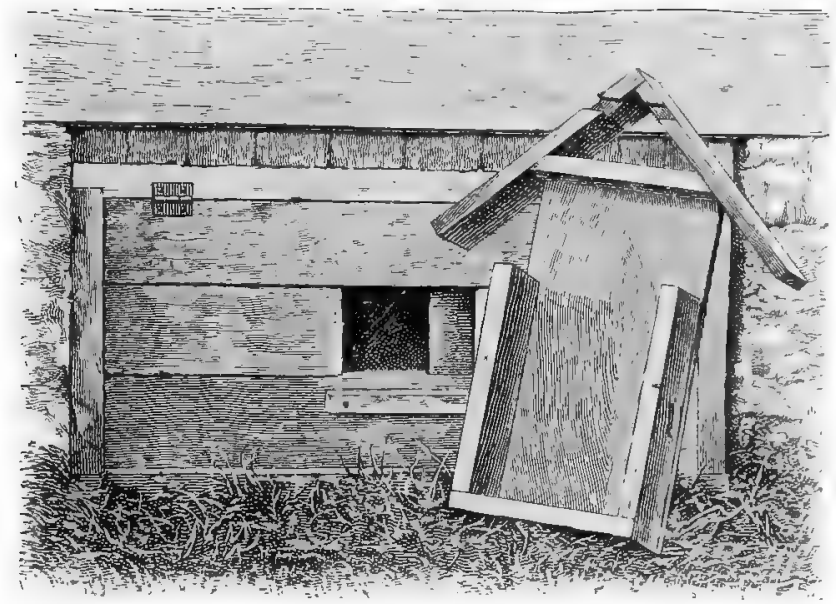

Fig. 136.

CELLAR BLIND, TO GIVE ARR WITHOUT LIGHT.

But thermometers vary, especially the cheap ones. Try to find at what temperature, with your thermometer in your cellar, they are the quietest, and then aim to keep it at that.

The fact that bees, in Russia (645), are confined in deep wells, for six months, shows that a total deprivation of light cannot be injurious. It prevents them from flying out of their hives, to which they would be unable to return, after flying to the windows, allured by the light, when the temperature of the cellar rises oceasionally and unexpectedly to 50 or 60 degrees. 
As bees, wintered on their Summer stands, begin to fly out when the temperature in the shade reaches about 50 degrees, and are in full flight at about 55, one can imagine how restless they become when the temperature of the cellar rises to 55 or 60 degrees. They wait impatiently for the dawn of the day which will afford them the opportunity for flying ont. But as the days pass and larkness continues they are uneasy and tired.

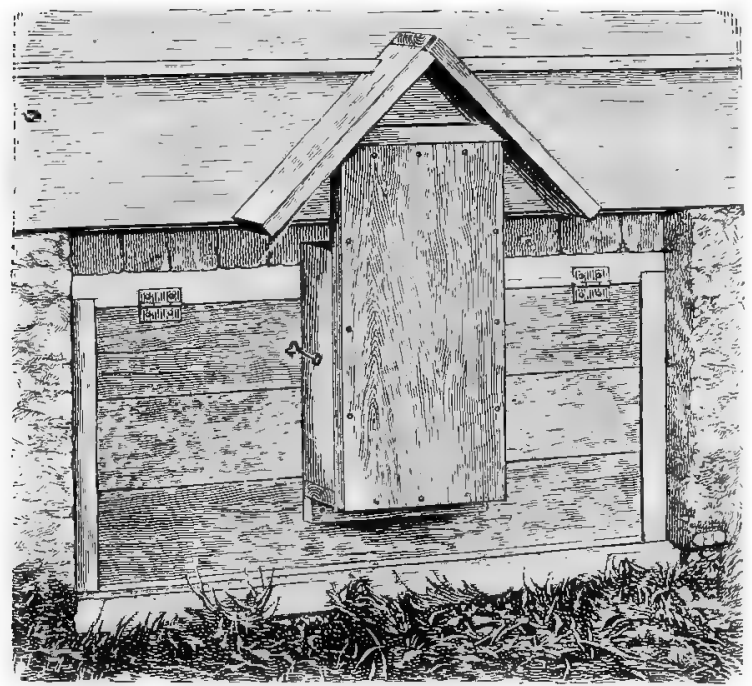

Fig. 137.

CELLAR BLIND IN PLACE.

The warmth incites them also to breed, and as they need water for their brood (271), some leave the hive in quest of it and are lost. This happens more or less every Winter. To cool the air of the cellar, ice may be brought in and allowed to melt slowly over a tub.

The Apiarist must guard against cold, also, but in wintering a large number of colonies, the heat which they generate 
will usually keep the cellar quite warm in the coldest weather. In our experience, we have had to keep the cellar windows open, often, in cold weather.

649. To allow cold air to enter without giving light, we have devised cellar blinds (figs. 136-137). When the window, inside, is raised, a wire-cloth frame is put in its place to keep mice out, and there is a slide on the inside of the shutter which can be used to give more or less air as the case requires. Besides, the windows of our bee-cellar are made with double panes, to exclude cold or heat more efficiently, when they are shut. A slight quantity of pure air is needed at all times.

As we have said above, when the warmer days of Spring come, with alternates of cold, the bees will breed a little, and if this is not begun too early, it will be a help to them rather than an injury, for they will become strong, all the sooner, after being taken out.

650. A small number of colonies can be wintered in any ordinary cellar, quite safely, when their food is of good quality, and the temperature does not vary too much, but they must be quiet and in the dark.

651. If the temperature of the cellar is too low, or too high, or if the food is unhealthy, the bees will have a large amount of fecal accumulation in their intestines, and will show their anxiety by coming out of the hive in clusters, during the latter part of their confinement. If, in addition to this, the cellar is damp, the comb will mould; and when taken out, some colonies may desert $(\mathbf{4 0 7}, \mathbf{6 6 3})$ their hives.

652. Great loss may be incurred in replacing, upon their Summer stands, the colonies which have been kept in special depositories. Unless the day when they are put out is very favorable, many will be lost when they fly to discharge their fæces. In movable-frame hives, this risk can be greatly diminished, by removing the cover from the frames, and allowing the sun to shine directly upon the bees; this will warm them up so quickly, that they will all discharge their fæces in a very short time. 
The following is an extract from Mr. Langstroth's journal:

"Jan. 31st, 1857.-Removed the upper cover, exposing the bees to the full heat of the sun, the thermometer being $30 \mathrm{de}-$ grees in the shade, and the atmosphere calm. The hive standing on the sunny side of the house, the bees quickly took wing and discharged their fæces. Very few were lost on the snow, and nearly all that alighted on it took wing without being chilled. More bees were lost from other hives which were not opened, as few which left were able to return; while, in the one with the cover removed, the returning bees were able to alight at once among their warm companions."

653. If more than one hundred colonies are wintered in the cellar, and it is desired to remove them all the same day, enough help shorld be secured to put them all on their stands before the warm part of the day is over. It is far better to keep them in the cellar even one week longer, than to take them out when the weather is so cold that they cannot cleanse themselves immediately; to our mind, $45^{\circ}$ in the shade, is the lowest temperature in which it is best to put bees out.

654. As bees remember their location, it is important to return each colony to its own place. If this is not done, the confusion may cause some colonies to abandon their hives. Dzierzon also advises placing them on their former stands, as many bees still remember the old spot.

This, however, is less important in locations where the confinement lasts a very long time, as it does in very cold countries. If it is desirable to remove some hives to a new location, a slanting board ( $\mathbf{6 0 3}$ bis) should be placed in front of the hive. All the bottom boards should be cleaned of dead bees or rubbish, without delay.

655. If the hives of an apiary are all removed from the cellar on the same day, there will be but little danger of robbing, for they are somewhat bewildered when first brought out; but if some are taken out later than others, the last removed will be in danger, unless some precautions are taken.

656. If the bees that are wintering in the cellar, are 
found to be restless, it may be good policy to give them some water (281), or to take them out on a warm day when the temperature is at least $45^{\circ}$ in the shade, to let them have a

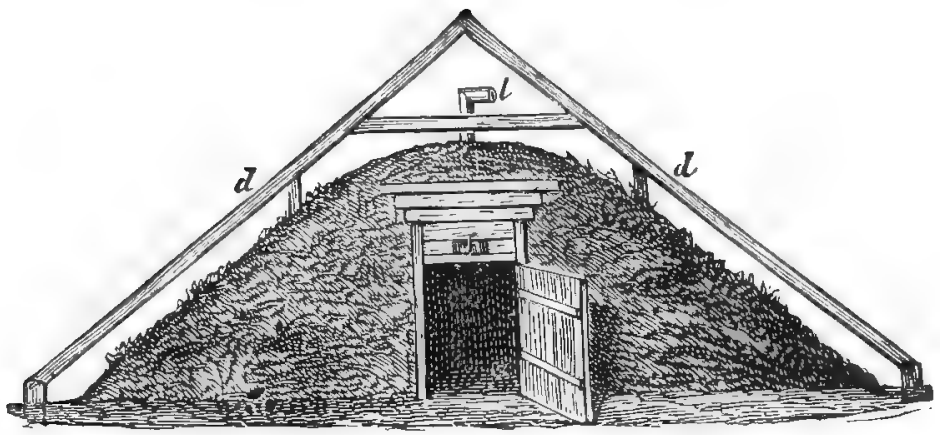

Fig. 138. (From L'Apicoltore, of Milan.)

BEE CLAMP FOR WINTERING.

$l$, air draft. $d$, roof.

flight, and return them to the cellar afterward. We do not advise it as a practice however. On the contrary, if they are

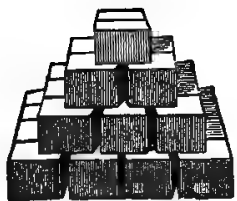

Fig. 139.

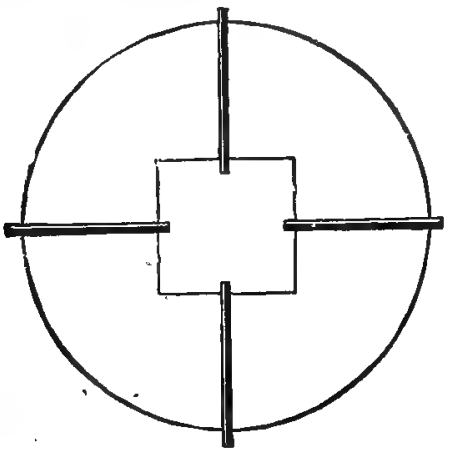

Fig. 140 .

GROUND PLAN OF A BEE CLAMP.

HOW TO PILE THE HIVES.

quiet, it is better to keep them indoors, till the early Spring days have fairly come, to avoid what is called Spring-dwindling (659). 
657. Those, who have no cellar, can successfully winter their bees in clamps or silos as advised by the Rev. Mr. Scholz, of Lower Silesia, already mentioned in several instances. These clamps are made similar to those in which farmers place apples, potatoes, turnips, etc., to preserve them during cold weather. The only objection to this mode, is the dampness of the ground in wet and warm Winters. The hives are put, on a bed of straw, in a pyramidal form (fig. 139), and covered, first with old boards, then with a thick layer of straw, and another, of earth. Wooden pipes are placed at the bottom (fig. 140), and one in the shape of a chimney, at the top, for an air-draft. The requisites are the same as in cellar wintering, an equal temperature, sufficient ventilation, a fairly dry atmosphere, and quiet.

658. We must warn novices against the wintering of bees in any repository in which the temperature descends below the freezing point. In such places the bees consume a great deal of honey, and they soon become restless, for want of a flight. Their Summer stand, even without shelter, is far safer than any such place, because they can at least take advantage of any warm Winter day to void their excrements. These facts are demonstrated beyond a doubt.

\section{Spring DwindLing.}

659. When the conditions necessary to the successful wintering of bees are not complied with, and they have suffered from diarrhca ( $/ 84)$, many colonies may be lost by Spring dwindling, especially if the Spring is cold and backward. Even colonies, which appeared to have gone through the Winter strong in numbers, may slowly lose bee after bee till the queen alone remains in the hive. This is sometimes mistaken for desertion (10\%), as will be seen in the following paragraph, which we quote from The London Quarterly Review, and in which the author attributes to lack of loyalty in the bees, that which evidently must have been due only to Spring dwindling: 
"Bees, like men, have their different dispositions, so that even their loyalty will sometimes fail them. An instance not long ago came to our knowledge, which probably few beekeepers will credit. It is that of a hive which, having early exhausted its store, was found, on being examined one morning, to be utterly deserted. The comb was empty, and the only symptom of life was the poor queen herself, 'unfriended, melancholy, slow," crawling over the honeyless cells, a sad spectacle of the fall of bee-greatness. Marius among the ruins of Carthage-Napoleon at Fontainebleau-was nothing to this."

Several such instances, caused by Spring dwindling, with subsequent robbing of the honey, were observed by us. Colonies are thus destroyed as late as April and May.

660. In some instances, the enlarged abdomen of the bees will show that they are suffering from constipation-( 785 ) or inability to discharge their fæees, even though they may have voided their abdomen since their long confinement. Probably their intestines are in an unhealthy condition. In the worst cases of Spring dwindling, sometimes, even the queens show signs of failing, and eventually disappear. This may oceur also with colonies that were wintered in the cellar, if they have suffered from diarrhœa, or have been removed too early.

There is another sort of Spring dwindling caused by the loss of working bees in cold Springs, while in search of water (271), or pollen (263), for the brood.

661. To avoid losses or to check them as far as possible, after a hard Winter, it is indispensable that the following be observed:

1st. The hives should be located in a warm, sunny, wellsheltered place. All Apiaries that are placed in exposed windy situations, or facing North, suffer most from Spring dwindling.

2d. The number of combs in the hive should be reduced in early Spring, with the division-board or contractor, to suit the size of the cluster (349). This helps the bees to keep 
warm and raise brood. The space must again be enlarged gradually, when the colony begins to recruit.

We consider this contraction of the hive as altogether indispensable when using large hives. Let us suppose that, in early Spring, we have a colony whose population is so much reduced that it cannot warm, to the degree needed for breeding, more than 500 cubic inches of space. If we leave the brood-chamber without contraction, as its surface, in a 10frame Langstroth hive, will be about 270 square inches, the cubic space heated will have about two inches in thickness at the top, since heat always rises. If, on the contrary, we have reduced the number of frames to three, the depth of the space warmed at the top will amount to more than three times as much, or to more than six inches. Thus, the bees will not only be more healthy, but the laying of the queen, not being delayed by the cold, and the number of the bees increasing faster, they will be able to repay the bee-keeper for the care bestowed, instead of dwindling, or remaining worthless for the Spring crop.

3d. The heat should be concentrated in the brood apartment, by all means, and not allowed to escape above. The entrance also must remain reduced.

In instances of this kind, the cloister (638) or some other method of confining the bees without light, might prove useful, provided the colonies were supplied with pollen and water so that they might breed without having to seek for the necessaries.

662. Apiarists in general, do not attach enough importance to the necessity of furnishing water (271) to bees in cold Springs, in order that they may stay at home in quiet. Although Berlepseh laid too much stress on the question of water, the lack of which he even said was the cause of dysentery, yet he was right in calling our attention to the need of it for breeding:

"The Creator has given the bee an instinct to store up honey and pollen, which are not always to be procured, but not water, 
which is always accessible in her native regions. In Northern latitudes, when confined to the hive, often for months together, they can obtain the water they need only from the watery particles contained in the honey, the perspiration which condenses on the colder parts of the hive, or the humidity of the air which enters their hives.

"In March and April, the rapidly-increasing amount of brood causes an increased demand for water; and when the thermometer is as low as 45 degrees, bees may be seen carrying it in at noon, even on windy days, although many are sure to perish from cold. In these months, in 1856, during a protracted period of unfavorable weather we gave all our bees water, and they remained at home in quiet, whilst those of other apiaries were flying briskly in search of water. At the beginning of May, our hives were crowded with bees; whilst the colonies of our neighbors were mostly weak.

"The consumption of water in March and April, in a populous colony, is very great, and in 1856, one hundred colonies required eleven Berlin quarts per week, to keep on breeding uninterruptedly. In Springs where the bees can fly safely almost every day, the want of water will not be felt.

"The loss of bees by water-dearth, is the result of climate, and no form of hive, or mode of wintering, can furnish an absolutely efficient security against it." -(Translated from the German, by S. Wagner.)

That bees cannot raise much brood without water, unless they have fresh-gathered honey, has been known from the times of Aristotle. Buera of Athens (Cotton, p. 104), aged 80 years, said in 1797 :

"Bees daily supply the worms with water; should the state of the weather be such as to prevent the bees from fetching water for a few days, the worms would perish. These dead bees are removed out of the hive by the working-bees if they are healthy and strong; otherwise, the stock perishes from their putrid exhalations."

In any movable-frame hives, water can be given to the bees by pouring it into the empty cells of a comb. 
A better method still is to supply the bees from time to time with small quantities of thin sugar syrup or watery honey (606) warmed up for this purpose. This takes the place of fresh nectar and saves the bees many a trip for cold water to the neighboring pond. But thin, watery syrup should never be fed at the opening of cold weather, in the Fall.

\section{Deserting.}

663. We have shown (40\%) that bees sometimes desert their hives, when the colony is too weak, or short of stores, or suffering from dampness, mouldy combs, ete., etc. This desertion, which differs from natural swarming in this, that it may take place in any season, and that the deserting bees do not raise any queen-cells previously, is more frequent in cold backward Springs than at any other time.

At different times we have seen bees deserting their hives and forsaking their brood for lack of pollen (264). A comb containing pollen having been put in their hive and the bees returned they remained happy. But.the worst of these desertions is when the bees have suffered while wintered indoors (651.) These colonies abandon their hives very soon after being replaced on their Summer stands. When such desertion is feared, it is better not to put out more than one dozen colonies at one time, and to prepare a few dry combs, in elean hives, to hive the swarm as soon as possible; for, too often some other colonies following the example, mix with the first, the queens are balled (538), causing great annoyance and loss to the bee-keeper. Such swarms should be hived on clean dry comb, and furnished with honey and pollen. ' $i$ 'he capacity of the hive in which they are put should be reduced to suit the size of the swarm, and increased very cautiously, from time to time, when the bees seem to be crowded; for warmth is indispensable to bees in Spring. The condition of such colonies must be regularly ascertained and their wants supplied. 
We would refer those who think that "it is too much trouble" to examine their hives in the Spring, to the practice of the ancient bee-keepers, as set forth by Columella: "The hives should be opened in the Spring, that all the filth which was gathered in them during the Winter may be removed. Spiders, which spoil their combs, and the worms from which the moths proceed, must be killed. When the hive has been thus eleaned, the bees will apply themselves to work

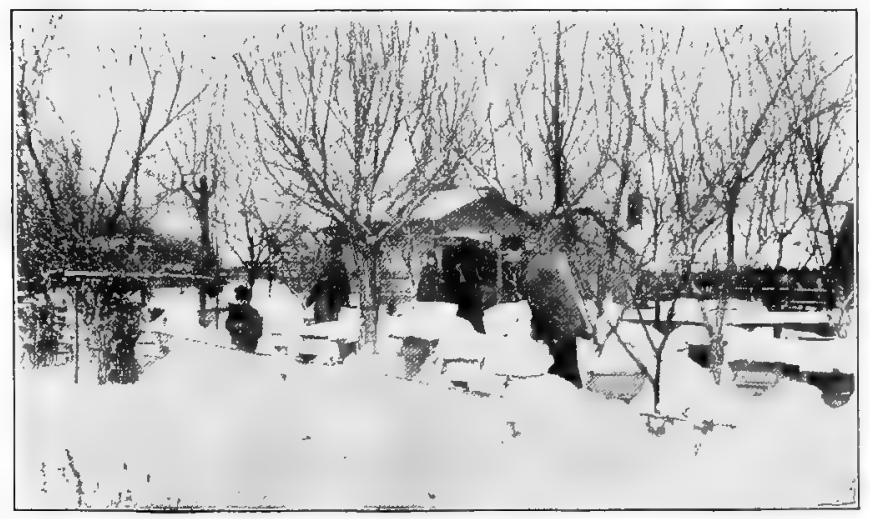

Fig. 141.

IN THE SNOW.

Apiary of L. W. Elmore, of Fairfield, Towa.

with the greater diligence and resolution." The sooner those abandon bee-keeping, who consider the proper care of their bees as "too much trouble," the better for themselves and their - unfortunate bees.

In making this thorough cleansing, the Apiarist will learn which colonies require aid, and which can lend a helping hand to others; and any hive needing repairs, may be put in order before being used again. Such hives, if occasionally repainted, will last for generations, and prove cheaper, in the long run, than any other kind. 


\section{CHAPTER XIV.}

Robbing, and How Prevented.

"An ounce of prevention is worth a ton of cure."

664. BeEs are so prone to rob each other, in time of scarcity, that, unless great precautions are used, the Apiarist will often lose some of his most promising colonies. Idleness is, with them, as with men, a fruitful mother of mischief. They are, however, far more excusable than the lazy rogues of the human family; for they seldom attempt to live on stolen sweets, when they can procure a sufficiency by honest industry.

As scon as they ean leave their hives in the Spring, they may begin to assail the weaker colonies. In this matter, the morals of our little friends seem to be sadly at fault; for, those colonies which have the largest surplus are-like some rich oppressors - the most anxious to prey upon the meagre possessions of others.

If the marauders, who are prowling about in seareh of plunder, attack a strong and healthy colony, they are usually glad to escape with their lives from its resolute defenders. The bee-keeper, therefore, who neglects to watch his needy colonies, and to assist such as are weak or queenless, must count upon suffering heavy losses from robber-bees.

665. It is sometimes difficult, for the novice, to discriminate between the honest inhabitants of a hive, and the robbers which often mingle with them. There is, however, an air of roguery about a thieving bee which, to the expert, is as characteristie as are the motions of a pickpoeket to a skillful policeman. Its sneaking look, and nervous, guilty agitation, once seen, can never be mistaken. It does not, like the 
laborer carrying home the fruits of honest toil, alight boldly upon the entrance-board, or face the guards, knowing well that, if caught by these trusty guardians, its life would hardly be worth insuring. If it can glide by without touching any of the sentinels, those within-taking it for granted that all is right-may permit it to help itself.

Bees which lose their way, and alight upon a strange hive, can readily be distinguished from these thieving scamps. The rogue, when eaught, strives to pull away from his executioners, while the bewildered unfortunate shrinks into the smallest compass, submitting to any fate his captors may award.

These dishonest bees are the "Jerry Sneaks" of their profession. Constantly ereeping through small holes, and daubing themselves with honey, their plumes assume a smooth and almost black appearance, just as the hat and garments of a thievish loafer, acquire a "seedy" aspect.

Dzierzon thinks that these black bees, which Huber has described as so bitterly persecuted by the rest, are nothing more than thieves. Aristotle speaks of "a black bee which is called a thief."

666. The writer has known the value of an apiary to be so seriously impaired by the bees beginning early in the season to rob each other, that the owner was often tempted to wish that he had never seen a bee. Yet, we should hardly blame them for their robbing propensities. With them, as with men, much depends on the education which they are allowed to receive. Their nature teaches them to hunt for sweets industriously, wherever they can find them, and any sweet, which they ean reach, by the most strenuous efforts, is considered by them, at once, as their private property. Were it not for this disposition of the bee, to hunt for sweets everywhere, and take them home, the honey of those colonies that dwell in the woods, and frequently perish during the Winter, would be wasted. The propensity to rob is acquired only during a dearth of honey in the flowers; for bees have a much greater relish for fresh honey, as produced in the 
blossorns, than for any other sweet on earth. In a day of abundant harvest, honey may be left exposed where bees can reach it, without being touched, or even approached, by a single bee, for hours; while, if placed in the very same spot during a dearth of honey, it will be covered with bees in very few minutes.

If the bee-keeper would not have his bees so demoralized that their value will be seriously diminished, he will be $e x$ ceedingly careful in time of scareity to prevent them from robbing each other. If the bees of a strong colony once get a taste of forbidden sweets, they will seldom stop until they have tested the strength of every hive. Even if all the colonies are able to defend themselves, many bees will be lost in these encounters, and much time wasted.

66\%. An experienced bee-keeper readily perceives when any robbing is going on in his apiary. Bees are flying vagrantly about, hunting in nooks and comers, and at all the hive-crevices. Extensive robbing causes a general uproar, and the bees of all the hives are much more disposed to sting. The robbers sally out with the first peep of light, and often continue there depredations until it is so late that they cannot find the entrance to their hive. Some even pass the night in the plundered colony.

The cloud of robbers arriving and departing need never be mistaken for honest laborers (173-174) carrying, with unwieldy flight, their heavy burdens to the hive. These bold plunderers, as they enter a hive, are almost as hungry-looking as Pharaoh's lean kine, while, on coming out, they show by their burly looks that, like aldermen who have dined at the expense of the city, they are stuffed to their utmost capacity.

668. When robbing-bees have fairly overcome a colony, the attempt to stop them-by shutting up the hive, or by moving it to a new stand-if improperly conducted, is often far more disastrous than allowing them to finish their work. The air will be quickly filled with greedy bees, who, unable to bear their disappointment, will assail, with almost frantic 
desperation, some of the adjoining hives. In this way, the strongest colonies are sometimes overpowered, or thousands of bees slain in the desperate contest.

\section{How to Stop Robiing.}

When an Apiarist perceives that a colony is being robbed, he should contract the entrance, and, if the assailants persist in forcing their way in, he must close it entirely. In a few minutes the hive will be black with the greedy cormorants, who will not abandon it till they have attempted to squeeze themselves through the smallest openings. Before they assail a neighboring colony, they should be thoroughly sprinkled with cold water, which will somewhat cool their ardor.

Unless the bees, that were shut up, can have an abundance of air, they should be carried to a cool, dark place, after the Apiarist has allowed the robbers to escape out of it. Early the next morning they must be examined, and, if necessary, united to another hive.

"In Germany, when colonies in common hjves are being robbed, they are often removed to a distant location, or put in a dark cellar. A hive, similar in appearance, is placed on their stand, and leaves of wormwood and the expressed juice of the plant are put on the bottom-board. Bees have such an antipathy to the odor of this plant, that the robbers speedily forsake the place, and the assailed colony may then be brought back.

"The Rev. Mr. Kleine says, that robbers may be repelled by imparting to the hive some intensely powerful and unaccustomed odor. He effects this the most readily by placing in it, in the evening, a small portion of musk, and on the following morning the bees, if they have a healthy queen, will boldly meet their assailants. These are nonplussed by the unwonted odor, and, if any of them enter the hive and carry off some of the coveted booty, on their return home, having a strange smell, they will be killed by their own household. The robbing is thus soon brought to a close."'-S. Wagner. 
It will often be found that a hive which is overpowered by robbers has no queen, or one that is diseased.

669. One of the best methods which we have found to stop the robbing of one hive by another, when the robbed colony is worth saving, is to exchange them; $i$. e., to place the robbed colony on the stand of the robbing colony, and vice versa. The robbing colony can usually be found by sprinkling the returning bees with flour, as they come out of the robbed hive, and watching the direction which they take. It can also often be detected by the activity of its bees, if the neighboring hives are idle, especially after sunset.

This method, however, cannot be practiced when the robbing and the robbed colonies do not belong to the same person; or when the robbing is carried on by many hives at one time, although, in the latter case, the exchange of stands between the strongest of the robbing hives and the weak robbed colony, in the evening, and the reducing of the entrances of both, usually has a good result. The old robber bees, bewildered by this exchange, make their home in the robbed colony, since they find it on the stand where they are accustomed to bring their honey; and they defend it with as much energy as they used in attacking it before. See Quinby's "Mysteries of Bee-Keeping," N. Y., 1866.

670. We read in the British Bee-Journal that a carbolized sheet (381) can be used to stop robbing, if spread in front of the robbed hive. This same sheet, spread on the hive while extracting ( $/ 19)$, and on the surplus box where the combs are placed ( $\mathbf{7 6 8}$ ), displeases the robbers and protects the comb, but strong smelling drugs must be used sparingly over a super full of honey, for fear of damaging the flavor of the honey.

671. There is a kind of pillage which is carried on so secretly as often to escape all notice. The bees engaged in it do not enter in large numbers, no fighting is visible, and the labors of the hive appear to be progressing with their usual quietness. All the while, however, strange bees are carrying 
off the honey as fast as it is gathered. After watching such a colony for some days, it occurred to us one evening, as it had an unhatehed queen, to give it a fertile one. On the next morning, rising before the rogues were up, we had the pleasure of seeing them meet with such a warm reception, that they were glad to make a speedy retreat.

This is another proof that discouragement caused by queenlessness often leads to the loss of a colony.

\section{Prevention.}

672. If the Apiarist would guard his bees against dishonest courses, he must be exceedingly careful, in his various operations, not to leave any combs or any honey where bees can find them, for, after once getting a taste of stolen honey, they will hover around him as soon as they see him operating on a hive, all ready to pounce upon it and snatch what they can of its exposed treasures.

In times of scarcity, food should never be given to the bees in the day time, but only in the evening, always inside of the hive and above the combs. The feeding of bees $(\mathbf{6 0 5})$ in the day time causes robbing in two ways. It excites the bees which are fed, and induces them to go out to hunt for more, and the smell of the food given attracts the bees of the other hives. Hence follows fighting and tronble. But, above all things, the Apiarist must try. to keep his colonies strong. When there is a scarcity of blossoms, or of neetar in the flowers, the entrance of the hive should be lessened, to suit the needs of the colony, by moving the entrance blocks (339). If the hive contains more combs than the bees can well defend, the number of the combs should be reduced by the use of the division board (349).

673. It is especially with weak colonies that care should be taken, in Spring or Fall. The strong hives being better able to keep warm, their bees fly out earlier in the day and will readily discover the weaker ones, which, unless their honey is protected, they will soon overpower. 
When the above instructions are carried out, if thieves try to slip into a feeble colony they are almost sure to be overbauled and put to death; and if robbers are bold enough to attempt to force an entrance, as the bottom-board slants forward (326) it gives the occupants of the hive a decided advantage. Should any succeed in entering, they will find hundreds standing in battle-array, and fare as badly as a forlorn hope that has stormed the walls of a beleaguered fortress, only to perish among thousands of enraged enemies.

Cracks and openings in disjointed hives, should be securely closed with wet clay, until the bees can be transferred into better abodes.

When the hives are opened, the work must be performed speedily and carefully; and, if any great number of robbers show themselves during the operation, it is well, after closing the hive, and reducing the entrance, to place a bunch of grass (fine grass or fine weeds preferred) over it, for an hour, or till the temporary excitement has subsided. The guardian bees station themselves in this grass and chase out robbers much more easily than they could otherwise. The robbers themselves recognize that their chances of "dodging in" are slim, and give up the undertaking. We have never had any trouble with robbers after closing a hive in this way.

When the robbed colony is weak, the robbing may be abated by preventing any bees from entering it till evening, when other colonies have stopped flying; allowing, at the same time, any bee that wishes to depart from it, and closing the entrance till late in the moming. By this course most of the robbers will be tired of their useless attempts, while the remaining workers of the robbed hive will be ready to repel the attacks.

When none of these methods succed, a small comb of hatching Italian bees (551) may be given, with the necessary precautions (480), to the weak colony, and the hive placed in the cellar for a few days. The hatched Italians will receive the intruders warmly when the hive is brought back. 
The Italian bees defend their hives much better than the black (519) against the intrusion of robbers, and the Cyprians and Syrians (559) surpass even the Italians.

When a comb of honey breaks down in a hive from any cause, it should be removed promptly, and the bottom-boaril should be exchanged for a clean one at once. If any drops of honey fall about the apiary, it is best to cover them up with earth promptly. In short, no honey should be left exposed, where bees can plunder it.

Of late years some Apiarists have practiced outdoor feeding of thin watery honey on a large seale, to prevent robbing. Their aim is to produce the same conditions as are made by a erop of honey, supply all the bees with all they want, for the time. The robbers are thus kept busy and do not think about bothering the weak hires. We can see nothing acceptable in this method and we find that advanced Apiarists agree with us. Doetor C. C. Miller, on this subject, says:

"I have fed barrels of sugar syrup in the open air, and it is possible that circumstances may arise to induce me to do it again, but I doubt it. There are serious objections to this outcloor feeding. You are not sure what portion of it your own bees will get, if other bees are in flying distance. Considerable experience has proved to me that by this method, the strong colonies get the lion's share, and the weak colonies very little."-(Forty Years Among the Bees.)

We are glad to see that so high an authority agrees with us on this matter, for we have been considered as little short of old-fogy, because we did not countenance outdoor feeding. 


\section{CHAPTER XV.}

\section{Comb Foundation.}

674. The invention and introduction of comb foundation, wilh the use of movable frames, marked an important step in the progress of practical bee-culture. The main drawback to the perfeet success of movable-frame hives was the difficulty of always obiaining straight combs in the frames (318). Although the bevelled top bar (319) often secured this object, yet, in many instances, the bees deviated from this guide and fastened their combs from one frame to another; and if the matter was not promptly attended to, the combs of the hive became as immovable as those of box hives. One frame slightly out of place was a sufficient incentive for the bees to fasten two frames together. In the management of four large apiaries, previous to the introduction of comb foundation, we found that, in spite of our efforts, a certain number of colonies would so build their combs, that only a part of the frames were movable without the use of a knife. Even the combs that were built in the right place were made somewhat waving, or bulged in spots, and were thus rendered unfit for such interchanges as are daily required in ordinary manipulations.

675. Another drawback to success was the building of drone-comb (225). We have had colonies in which nearly one-fourth of the combs were drone-comb. In such hives the number of drones that might be raised would be sufficient to consume the surplus honey. To be sure, with movable-frame hives, such combs can be removed, but the difficulty consists in procuring straight and neat worker-combs to replace them; for if we simply remove the drone-combs, the bees often replace them with the same kind ( 233$)$. 
676. Good straight worker-comb, not too old, is the most valuable capital of the Apiarist (442). For years, before the introduction of comb-foundation, we had been in the habit of buying all the worker-comb from dead colonies that we could find, but we never had enough.

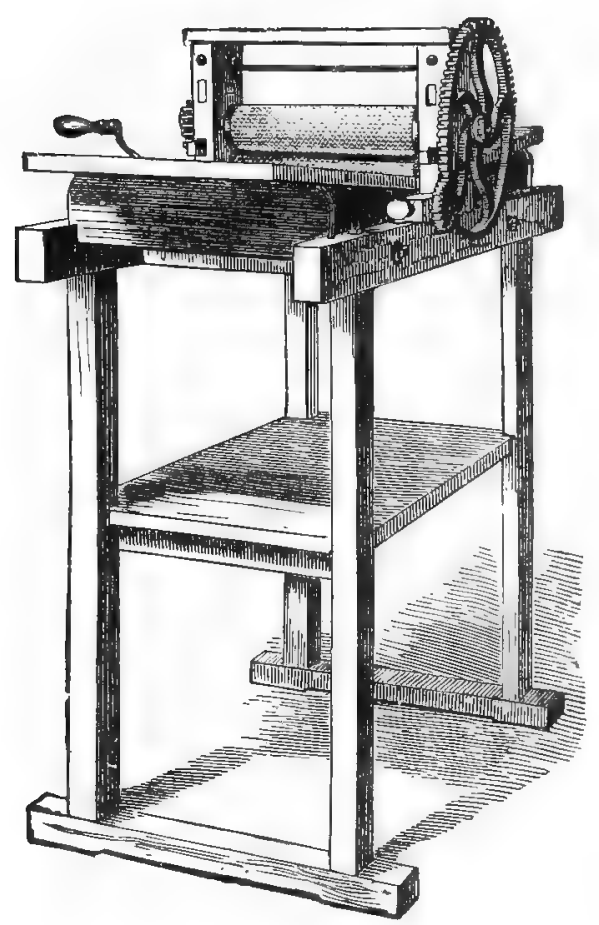

Fig. 142.

THE ORIGINAL "ROOT" MILL.

(From Root's "A B C of Bee-Culture.")

The consideration of the above important points, atd of the great cost of comb to the bees (223), had long ago drawn the attention of German Apiarists to the possibility of manufacturing the base, or foundation, of the comb. 
67\%. In 1857, Johannes Mehring invented a press to make wax wafers, on which the rudiments of the cells were printed. Those only, who experienced the obstacles which this industry presents, can form an idea of the energy and perseverance that were required to succeed as he did.

The foundation made by him then, was far from being equal to what is now made. The projections of the cell-walls were too rudimentary, sometimes not printed, and the bees often built drone-cells instead of worker-cells; but these imperfect efforts were the beginning of an industry which has proved of immense advantage to bee-keepers, and has spread like wild-fixe wherever bees are kept.

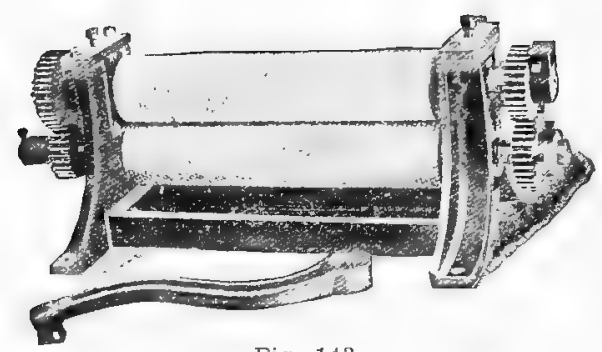

Fig. 143 .

THE LATEST FOUNDATION MILL.

(A B C of Bee-Culture.)

678. Another Apiarist, Peter Jacob, of Switzerland, improved on the Melnring press, and in 1865, some of his foundation was imported to America, by Mr. H. Steele, of Jersey City ( $4 \mathrm{~m}$. Bee-Joumal, Vol. 2, page 221), and tried by Mr. J. L. Hubbard, who reported favorably upon it. In 1861, Mir. Wagner had secured a patent in the United States, for the manufacture of artificial honey comb-foundation by whatever process made. His patent was never put to use, and rather retarded the progress of this industry in America.

6r9. The first comb-foundation made in America, was manufactured in 1875, by a German, Mr. F. Weiss, very 


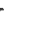


Plate 22.

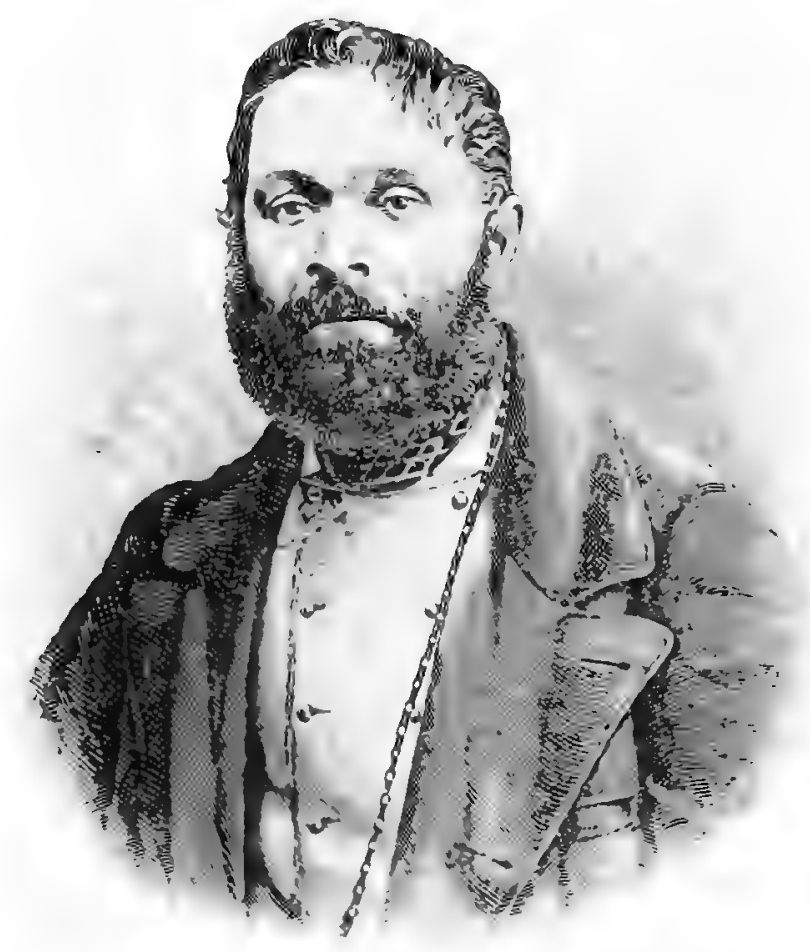

JOHANNES MEHRING,

Inventor of Comb-Foundation.

This Aplarist to mentioned pages 157 and 384. 
probably on an imported machine. Mr. A. I. Root, to whom the credit is due of popularizing the invention the world over, manufactured a large roller-mill, in February, 1876, with the help of a skilled mechanic, A. Washburne. He sold hundreds of these mills afterwards.

680. In the practical use of comb-foundation, the most sanguine expectations were realized:

1. Every comb that is built on foundation is as straight as a board, and can be moved from one place to another, in any hive, without trouble.

2. The combs built on worker-foundation are exclusively worker-combs, with the exception of occasional patches, when the foundation sags slightly, owing to being overloaded by the bees before the cells are fully built out.

3. All the wax produced by the bees, and gathered by the Apiarist from scraps, old combs, or cappings, is returned to the bees in this shape, instead of being sold at the commercial value of beeswax, which is several times less than its actual cost (223). The cost of foundation for broodcombs is not very great, especially if we consider that this capital is not consumed, but only employed; as the wax contained in the combs represents at least one-half of the primary value of the foundation, and can be rendered again, after years of use, none the worse for wear. It has been asserted that beeswax decays with time when exposed to dampness. We have never seen this and believe it to be an error.

681. Comb foundation has been made largely, especially in Europe, on plaster casts. There is also a press, the Rietsche, which makes cast sheets of wax to which it gives the rudiments of cells. These sheets are made very much like waffles and for that reason the sheets of comb foundation are called in the French language "gaufres de cire." They have the advantage of being easily made by almost any person, but are very rudimentary and very brittle. Similar sheets were made in this country formerly by the Given press but they have gone into disuse, as our bee-keepers are 
not satisfied with imperfect work. The only reason we can ascribe to the Rietsehe press being popular in Europe is that the bee-keepers find it difficult to purchase foundation made of pure beeswax there. So they prefer to make an imperfect article out of their own product, rather than buy an imitation which breaks down in the hive and which the bees often reject $(\mathbf{6 5 6})$.

682. Comb foundation is now made by several firms in endless sheets, which are cut to proper length as fast as they

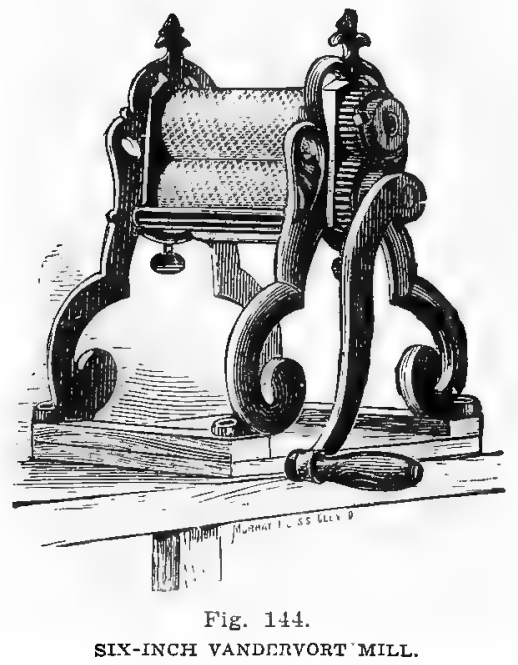

are printed. The Treed process produces sheets most clear and malleable and makes a superior article of foundation. But for the bee-keeper who wishes to make his own wax into sheets, the dipping process may still be used. We give a short description of it (689).

683. The wax used for thin surplus-foundation is a selected grade. Wax from eappings (7/2) and Southern wax are the best for this purpose, owing to their light color. 
In every case, whether the foundation is to be used for surplus, or for brood-combs, the wax should be thoroughly cleaned by heating it to a high temperature and allowing it to cool slowly in flaring vessels, from which the cold wax can be easily removed. Wax, that is allowed to retain impurities, has less consistency, and will sag more readily. The method used by wax-bleachers of purifying with acids should not be resorted to, as the bees have a dislike for any disagreeable smell or taste.

681. Nothing but pure wax should be used in any grade of foundation. Paraffine, ceresine, etc., have been tried with disastrous results. Aside from the fact that these compounds melt at a lower degree than beeswax and break down in the -hive, the bees readily discover the imposition and show a decided preference for pure foundation.

685. The most common adulteration of crude beeswax is made with tallow. Luckily, this is easily recognized by the soft, dull appearance of the cakes. The smell of tallow is also noticeable in freshly broken fragments.

686. Paraffine and other mineral waxes are detected in beeswax, by the following methods:

Specific gravity. Beeswax is a little heavier than some of the other waxes. By putting a piece of beeswax into water and pouring in alcohol until the wax goes to the bottom, one bas a solution which will test lighter materials. As comb foundation has been laminated and is uneven in surface it is well to chew the wax and the foundation, before making comparative tests, so as to put both in the same condition. Paraffine will readily show considerably lighter specific weight, and will float.

Melting points. Tie a piece of the material you wish to test on the bulb of a round thermometer and hang this into a vial over a slow fire. Good beeswax melts between $144^{\circ}$ and $150^{\circ}$, while the common grades of paraffine melt between $120^{\circ}$ and $140^{\circ}$.

Saponification Test. Hot liquid lye will entirely change the 
nature of beeswax, making it into a soapy substance, while it will leave paraffine and other mineral wax unchanged.

68\%. The machines used for thin foundation are not the same as those used for brood foundation. The latter, made on a light wall machine, would be too weak to stand the weight of the bees, in a full-sized brood frame, and would not contain wax enough for the bees to build their comb; for it is a remarkable fact that the bees "thin out" the foundation to a certain extent and make it considerably deeper out of
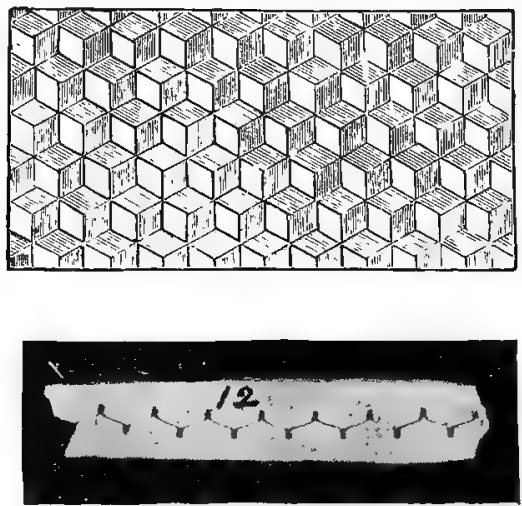

Fig. 145.

THIN BASE FOUNDATION.

(A B C of Bee-Culture.)

the same material. When it has been made, with a thin base and a heavy wall, the bees draw it out more readily into comb.

On the other hand, foundation for surplus (731) must be made as light as the finest machine can make it, to avoid what is called the "fish-bone," a central rib found in the honey-comb that has been built on too heavy foundation. There is no "fish-bone," if the proper grade has been used, and even an expert in comb-honey hesitates in deciding whether the base is natural or artificial. 
688. At the present day, nearly every section (721) of comb-honey that is sold, has been built on such foundation. The daintiest and most fastidious ladies can have no objection to it, and on visiting a well-managed foundation shop, they declare that the tender sheets are "nice enough to eat."

689. To prepare the wax sheets, use soft wood boards $3 / 8$ of an inch thick, bathed in tepid water. They are wiped with a sponge, and dipped in melted wax, two or three times. The lower part of the board is then dipped in cold water, when it is turned bottom side up, and the other end is treated in the same manner. After the board has been put in water

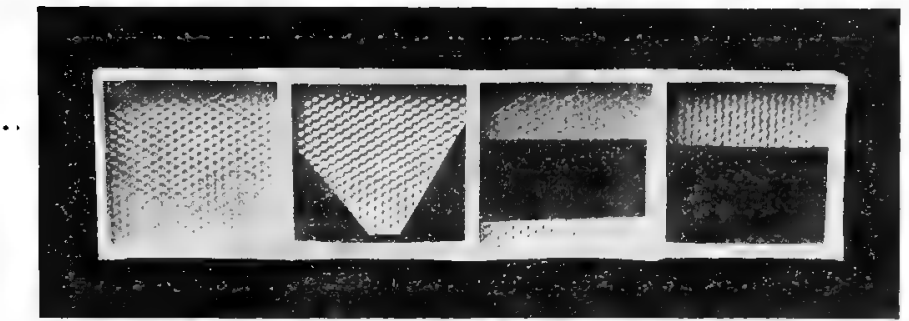

Fig. 146.

FOUNDATION IN SECTIONS.

to cool for a little while, it is taken out; its edges are trimmed with a sharp knife, and the two sheets of wax are peeled off. If the sheets are intended for heavy foundation, twice as many dips are necessary. The wax should be liquid but not hot. If it is too hot, the sheets will crack. To secure rapid work, you must have a room arranged purposely for the dippers, with a zine or tin floor to eatch the drips of water and wax.

690. The sheet wax, after a few days cooling in a dry cellar, is tempered, in the moulding tank with warm water, and run through the rollers. The latter are lubricated with starch, or soapsuds. When soapsuds are used, it is very important that the sheets be pressed so tightly in the rollers, as 
to come out dry. This also makes a better print. The foundation, as fast as it comes from the rollers, is laid upon a hard wood block-a dozen sheets or more, at a time. A wooden pattern is laid over them, and they are trimmed to the proper size, by a knife made for the purpose, whose blade bas been wet with soapsuds. The projecting edges are trimmed off, and the damaged sheets are meited over for future use.

For the thin grades of foundation, the narrower the sheets are, the thinner the foundation can be made. A wide sheet spreads the rollers by springing the shafts to a certain extent, and is heavier.

691. The manufacture of foundation; which at first seemed likely to be undertaken by every Apiarist, has become an industry of itself, owing to the greater skill and speed acquired by those who make it daily. It might be compared to cigar making. Any Apiarist can make wax into sheets and run it through rollers and any farmer can raise tobacco and roll its leaves into cigars, but, to the uninitiated, a neat sheet of foundation is as difficult to malze as an elegant cigar. Inproved and expensive machinery is used in most factories for quick and perfect work.

692. Well-made foundation will keep for years, in a dry place. It should never be handled when cold; and when too much softened by heat, should be cooled in a cellar, a few hours before it is handled.

When it is cold, it becomes so brittle, after a few days of exposure, that the least handling will crack it. We have seen hundreds of pounds which had been handled roughly in cold weather, fall to pieces when taken out of the box. The jarring of the boxes had cracked the foundation imperceptibly, so that the sheets appeared perfect, but as soon as they were touched, they fell into numerous pieces. Too much heat has a contrary effect. It makes the foundation too malleable. The temperature of the blood is the proper degree at which the bees can best manipulate it and that is also the best tem- 


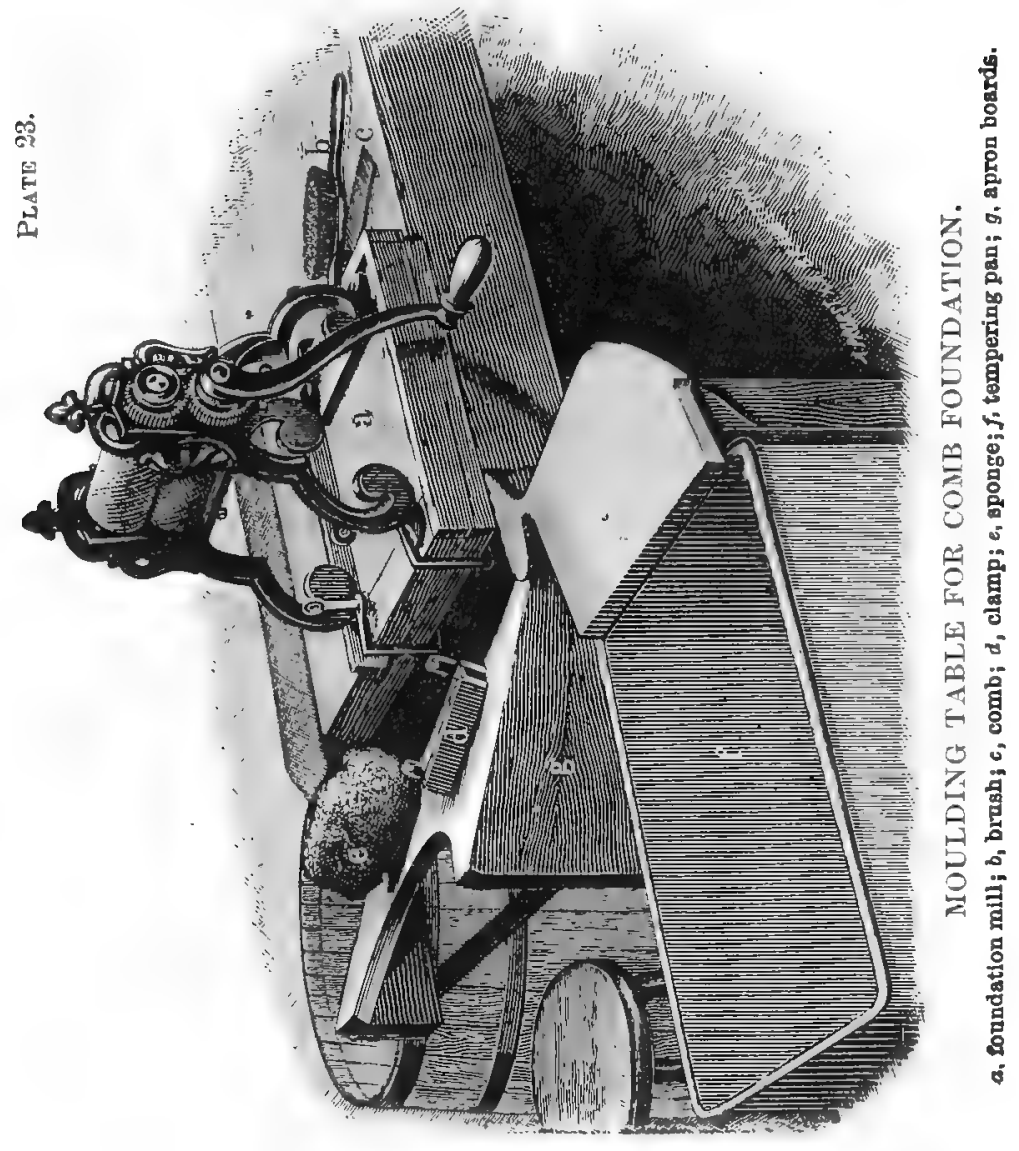


$-$ 
perature to handle it when fastening it in the frames, though some degrees lower will not be injurious.

The best grade of foundation for brood or extract-

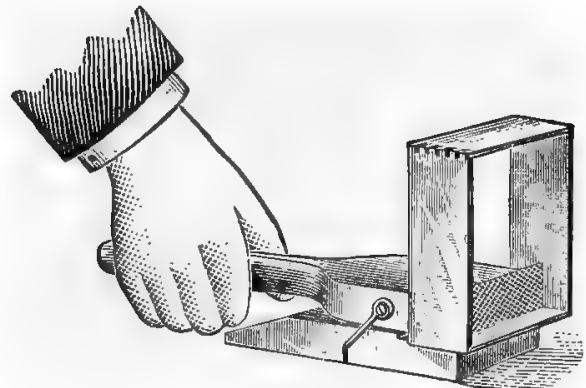

Fig. 147.

THE PARKER FASTENER.

ing combs is that which measures about six square feet to the pound; that for sections, ten to twelve feet. On this

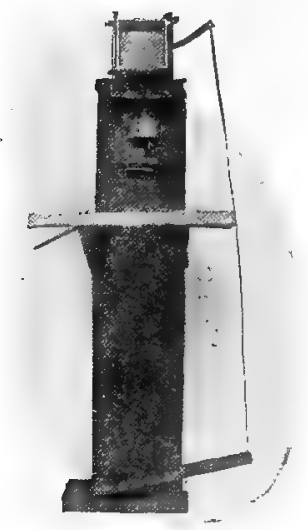

Fig. 148.

THE RAUCHFUSS.

Section folder and foundation fastener.

latter grade, the comb is not so readily built, for the bees have to add their own wax to it. 
693. The foundation is fastened in the sections by different machines, the most simple of which is the Parker Fastener, soid by all dealers in bee-implements.

In his "Management of Bees" Mr. Doolittle describes his method as follows:

"Turn your section top side down, hold a hot iron close to the box, and after holding the starter immediately above and touching the iron, draw the iron out quickly and press the starter gently on to the wood, when it is a fixture.

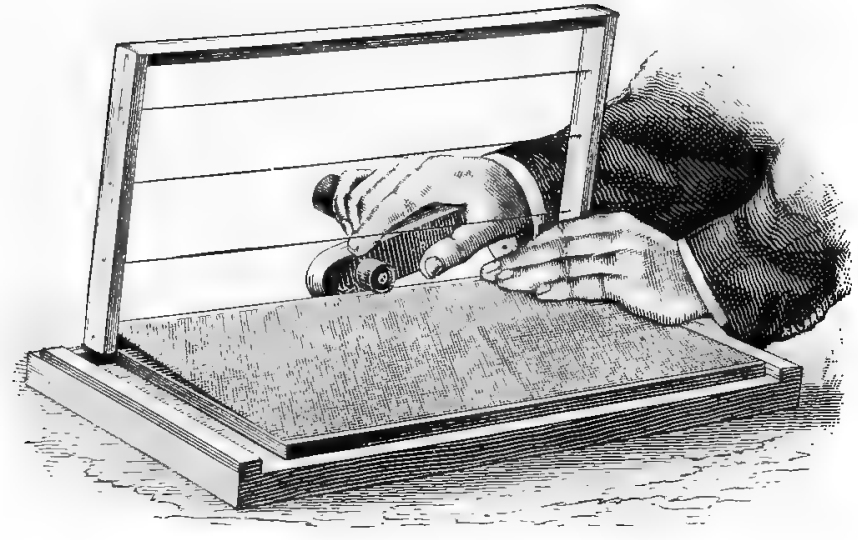

Fig. 149.

HAMBAUGH ROLLER.

The daintiest implement we have seen anywhere for fastening foundation in sections, while at the same time folding the one piece section, is the small press invented by Frank Rauchfuss, the energetic manager of the Colorado Honey Producers' Association, at Denver. Thousands of sections are prepared daily, by practical apiarists, with this instrument. It is the most complete thing of its kind yet devised.

To fasten the foundation on a flat top-bar, some use the roller (fig. 149) invented by the late Mr. Hambaugh. How- 
ever, at the present day, the frames are usually made with grooves and wedge under the top bar. This makes the insertion of foundation a very simple matter (fig. 69).

694. In brood-frames, it may be fastened with or without wires. The wire used is malleable timned wire, No. 30. A shallow frame needs no wires at all, but in brood-combs, - to insure safety and prevent warping-it is as well to use two or three horizontal wires as in fig. 150. This method

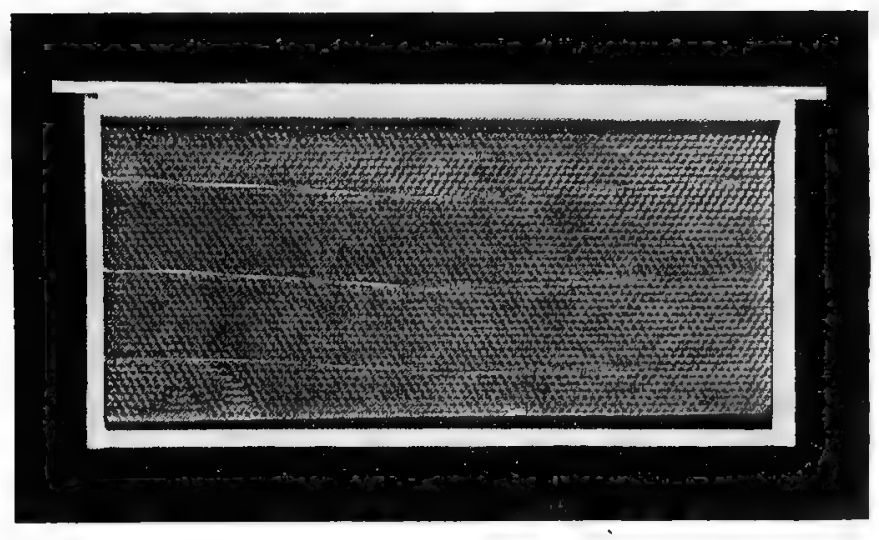

Fig. 150.

FOUNDATION WIRED IN THE BROOD-FRAME.

of horizontal-wiring was first given us by Mr. Vandervort, to whom the world is also indebted for the spur for imbedding the wire in the foundation (fig. 151). The excessive wiring resorted to by some is worse than useless.

Dr. C. C. Miller uses light wooden splints perpendicularly in the frame, instead of wires to support the foundation. The bottom bar of his frame is made in two equal pieces so as to pinch or hold the foundation between them. The splints are dipped into a shallow tin pan containing hot beeswax 
until they are saturated with wax and while hot they are pressed upon the surface of the sheet of foundation so that they may be perpendicular when the frame is hung in the hive. These splints about 1-16 of an inch square do not

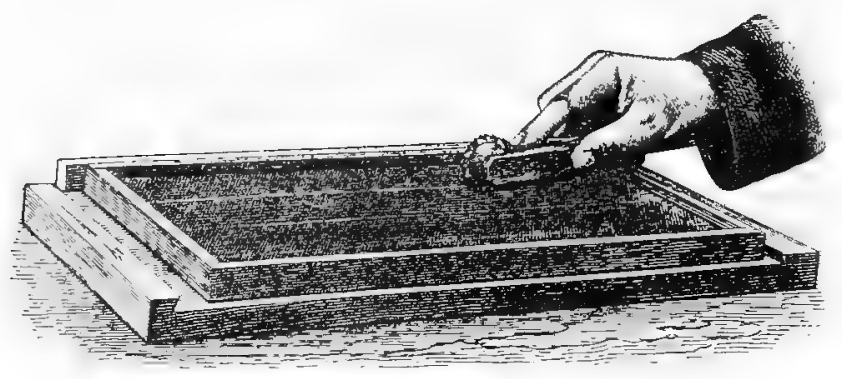

Fig. 151.

VANDERYORT IMBEDDING SPUR.

seem to be at all in the way when the combs are built upon them and they make an absolutely solid support for the foundation.

695. As comb-foundation is generally bought in long strips, it may be well to give directions to cut it into pieces of the right size for sections. This may be done with almost any sharp knife. Have a pattern of the size of the pieces wanted, made of hard wood. Take six or eight sheets at one time, arranged in an even pile. Lay your pattern on them, holding it down firmly; dip your knife in strong soapsuds, and if the wax is at the proper temperature, you will cut the eight pieces at one stroke of the knife. If the sheets have a tendency to slip from under the pattern, you may nail cleats on three sides of it, to encase the pile as in a box.

696. Are there a right and a wrong way, to suspend foundation in the frames? Or, in other words, should two of the six sides of the cell be perpendicula: nr horizontai? Huber, and Cheshire after him, call our attention to the fact, that the bees always build their combs, with two sides 
of the cells perpendicular. Mr. Cheshire explains, at length, the adaptation and advantages of this natural fact, and its bearing on the strength of the comb. From his explana-

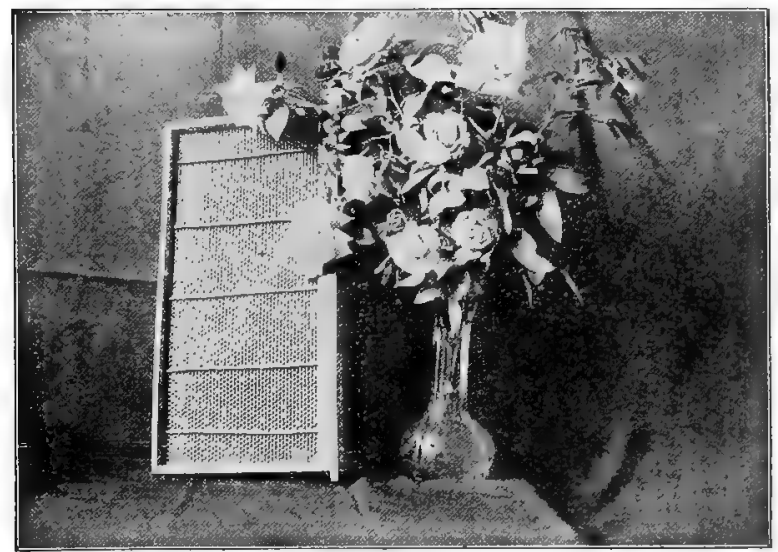

Fig. 152.

THE MILLER SPLINTS TO FASTEN FOUNDATION.

(Forty Years Among the Bees.)

tions, it results that foundation suspended thus: i. e., with two perpendieular sides, would be properly fastened, while if suspended thus: two horizontal sides, it would be

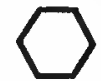
i. e., with

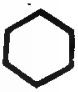
tened.

Most of the machines that are made turn out foundationsheets, which are to be hung horizontally, when the cells are in the proper position. But in the cutting of section foundation, the sheets are often made so that they must hang the other way. Yet there seems to be no bad result when this is done and the bees accept the foundation, no matter how the cells are turned. It is not always best however to give comb foundation in full sheets to natural swarms, for two reasons. The first is that 
advanced by W. Z. Hutchinson, in his book "Advanced BeeCulture" and which has been mentioned in "Natural Swarming" (425). The other is that when a heavy swarm is hived on full sheets of comb foundation, the great weight of the bees, connected with the unusual heat of the temperature at that time, sometimes causes the sheets to sag, and drone combs may be the result, wherever the sheets are slightly stretched. If the foundation is given to artificial divisions or to weak colonies to be drawn, such results are not to be feared. If a natural swarm for some reason is likely to be unable to promptly fill its hive with combs, the apiarist will be astonished to see how much of a help full sheets of comb foundation will be. Secondary swarms will always profit by its use, as they are not powerful enough to cause either of the inconveniences above mentioned.

It is well, however, to place foundation in the correct position, whenever practicable, especially with the light grades for sections, which are more in danger of stretching under ordinary circunstances.

69\%. It is astonishing, as well as pleasing, to see how quickly a swarm will build its combs, when foundation is used. The enthusiasm, with which it is used by bee-keepers, is only exceeded by that of the bees, "in being hived on it." This invention certainly deserves to rank next to those of the movable-frames (282) and of the honey-extractor ( $\mathbf{8 4 9}$ ). 


\section{CHAPTER XVI.}

Pasturage and Ovenstocking.

Pasturage.

698. The quantity of nectar yielded by different flowers varies considerably; some give so little, that a bee has to visit hundreds to fill her sack, while the corolla of others overflows with it.

In the vicinity of the Cape of Good Hope, there is a blossom, the Protea mellifera, which probably surpasses all others in the abundance of its nectar. Indeed, so abundant is it, that it is said, the natives gather it by dipping it from the flowers, with spoons. Mr. De Planta, in a lengthy and scientific article published in the Revue Internationale $d^{\prime}$ Apiculture, gives an account of his analysis of some samples of this honey, which he had received through the "Moravian United Brothers." He reports it to have the scent and the taste of ripe bananas, and considers it very sweet and good.

699. The same plants yield nectar in different quantities in different countries. The Caucasian Comfrey, from which the bees reap a rich harvest in some parts of Europe, is of little aecount here.

700. Every bee-keeper should carefully acquaint himself with the honey-resources of his own neighborhood. We will mention particularly some of the most important plants from which bees draw their supplies. Since Dzierzon's discovery of the use which may be made of flour (267), early blossoms producing pollen only, are not so important. All the varieties of willow abound in both pollen and honey, and their early blossoming gives them a special value.

"First the gray willow's glossy pearls they steal, Or rob the hazel of its golden meal, 
While the gay crocus and the violet blue, Yield to their flexible trunks ambrosial dew."

-Evans.

The sugar-maple (Acer saccharinus) yields a large supply of delicious honey, and its blossoms, hanging in gracefu? fringes, will be alive with bees.

In some sections, the wild gooseberry is a valuable help to the bees, as it blossoms very early, and they work eagerly on it.

Of the fruit trees, the apricot, peach, plum, cherry and pear, are great favorites; but none furnishes so much honey as the apple.

The dandelion, whose blossoms furnish pollen and boney, when the yield from the fruit trees is nearly over, is worthy of rank among honey-producing plants.

The tulip tree (Liriodendron) is one of the greatest honey-producing trees in the world. As its blossoms expand in succession, new swarms will sometimes fill their hives from this source alone. The honey, though dark, is of a good flavor. This tree often attains a height of over one hundrer feet, and its rich foliage, with its large blossoms of mingled green and yellow, make it a most beautiful sight.

The common locust (Fig. 153), is a very desirable tree for the vicinity of an apiary, yielding much honey when it is peculjarly needed by the bees.

The wild cherry blooms about the same time.

701. Of all the sources from which bees derive their supplies, white clover (Fig. 154), is usually the most important. It yields large quantities of very pure white honey, and wherever it abounds, the bee will find a rich harvest. In most parts of this country it seems to be the chief reliance of the apiary. Blossoming at a season of the year when the weather is usually both dry and hot, and the bees gathering its honey after the sun has dried off the dew, it is ready to be sealed over almost at once.

It is at the blossoming of this important plant that the 
main crop of honey usually begins, and that the bees propagate in the greatest number.

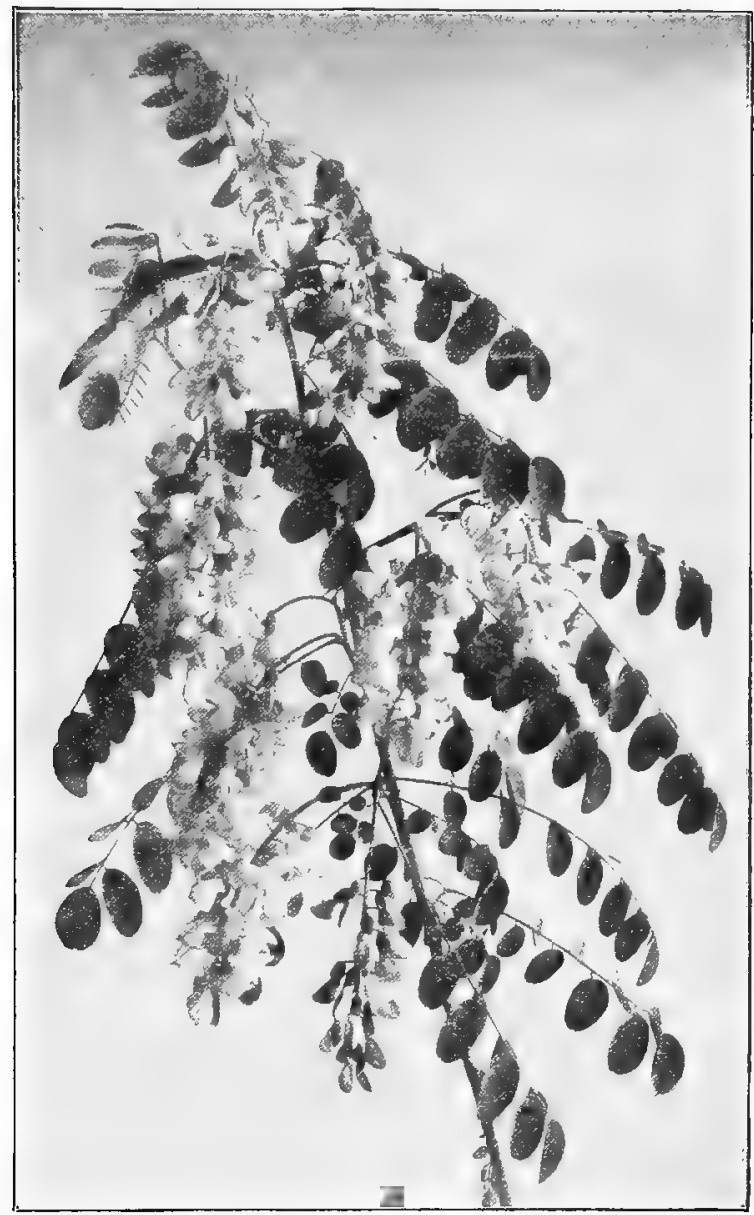

Fig. 153.

LOCUST BLOSSOMS.

(From the American Bee Journal.) 
The flowers of red clover (fig. 157) also produce a large quantity of nectar; unfortunately its corollas are usually too deep for the tongue of our bees. Yet sometimes, in Sum-

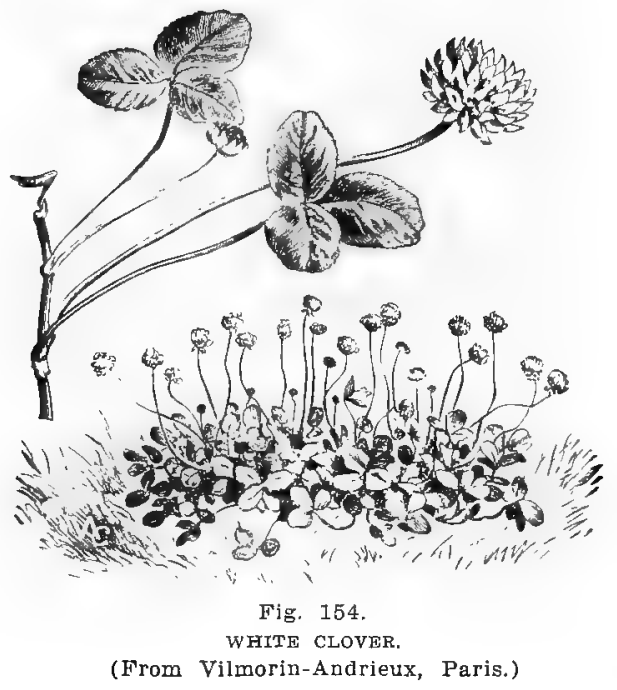

mer, they can reach the nectar, either because its corollas are shorter on account of dryness, or because they are more copiously filled.

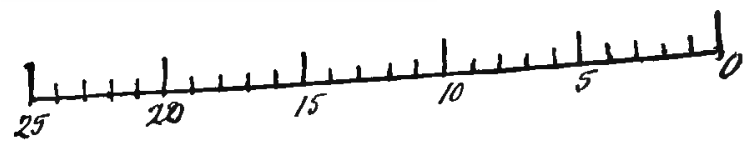

Fig. 155.

IMPLEMENT FOR ASCERTAINING THE LENGTH OF TONGLE OF BEES. (From the American Bee Journal.)

Attempts have been made to select, for breeding, bees with longer tongues, in order to secure the honey of the red clover 



\section{Plate 24.}

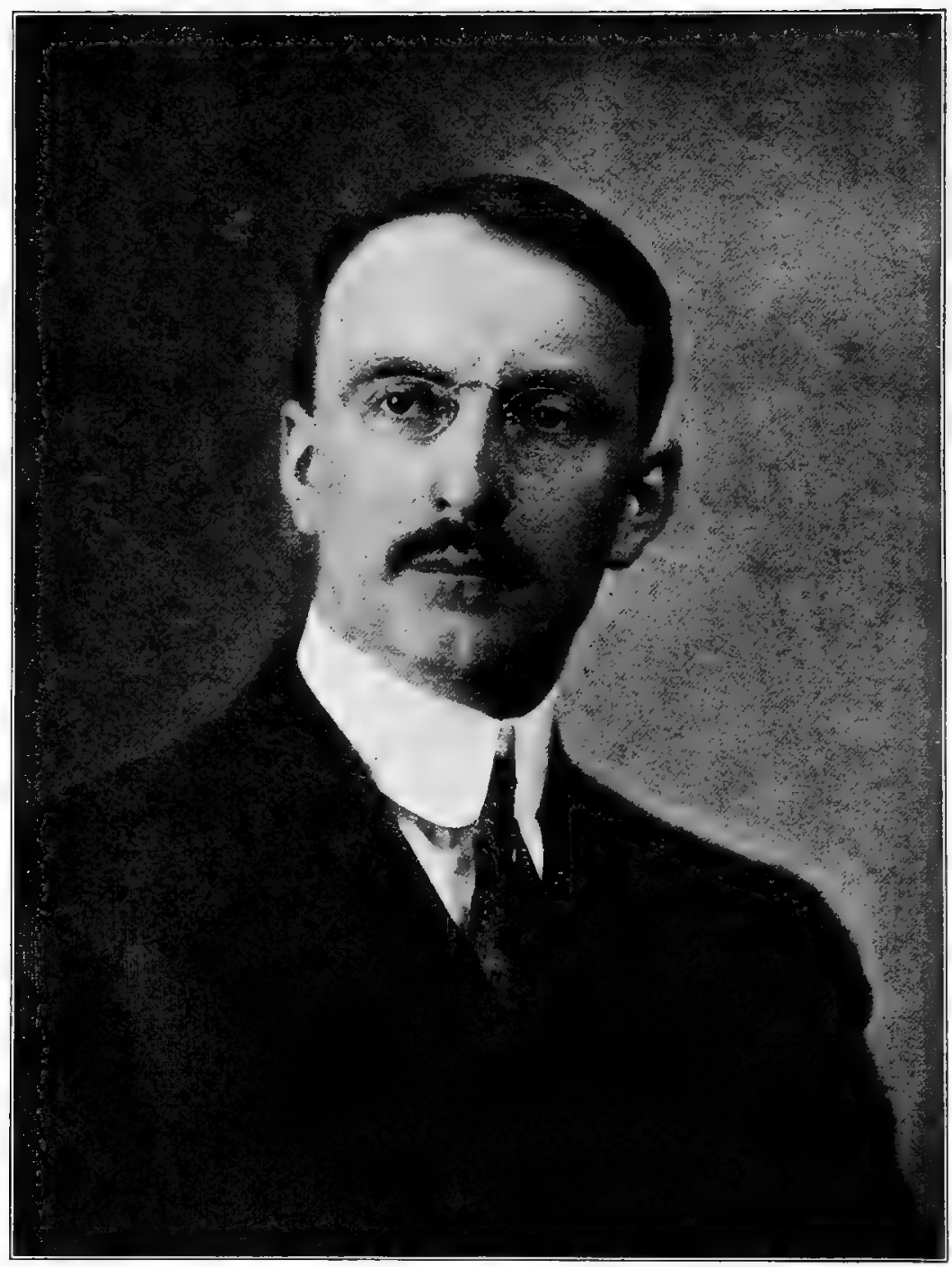

DR. E. F. PHILLIPS,

Of the Bureau of Entomology at Washington, Author of "Bee-Keeping," and several United States Bulletins on Bees.

This writer is mentioned pages $474,482,483,487,489$. 
blossom at all times. The Italian bee seems to be in advance of other races, in this respect, and so-ealled "red-elover queens" have been bred and offered for sale. The attempt is praiseworthy, but we must not lose sight of the fact that traits of this kind are very slow to become fixed and we

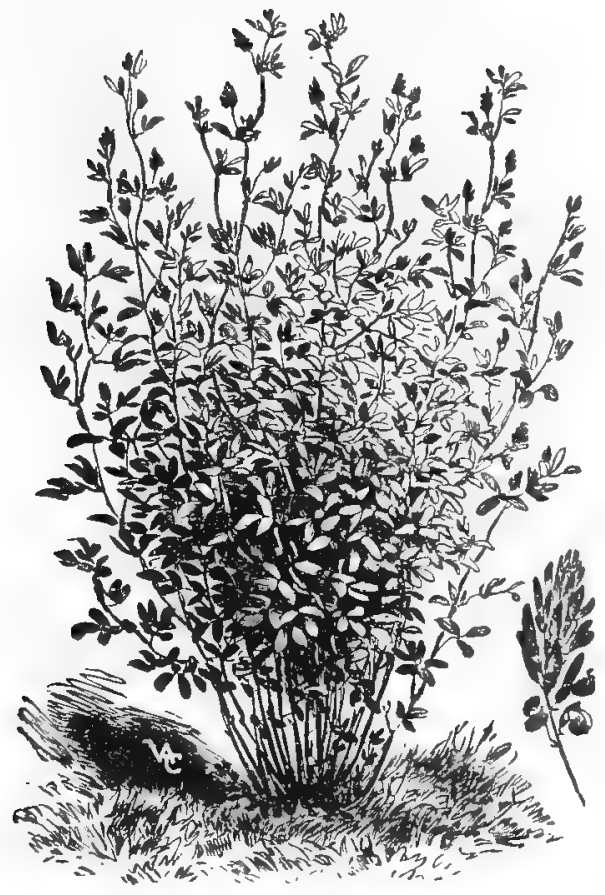

Fig. 156.

ALFALFA OR LUCERNE.

(From Vilmorin-Andrieux, Paris.)

should beware of too much enthusiasm. Very fugitive progress will probably be made for a long time, before anything fixed is secured.

Bee-keepers may ascertain for themselves the comparative length of tongue of their bees, by the help of a very simple 
device (Fig. 155). A smooth glass surface moistened with thin honey is covered with a screen placed in a slanting position and graduated. The bees which reach the farthest on the glass may be selected for breeding, provided they are equally proficient in other respects.

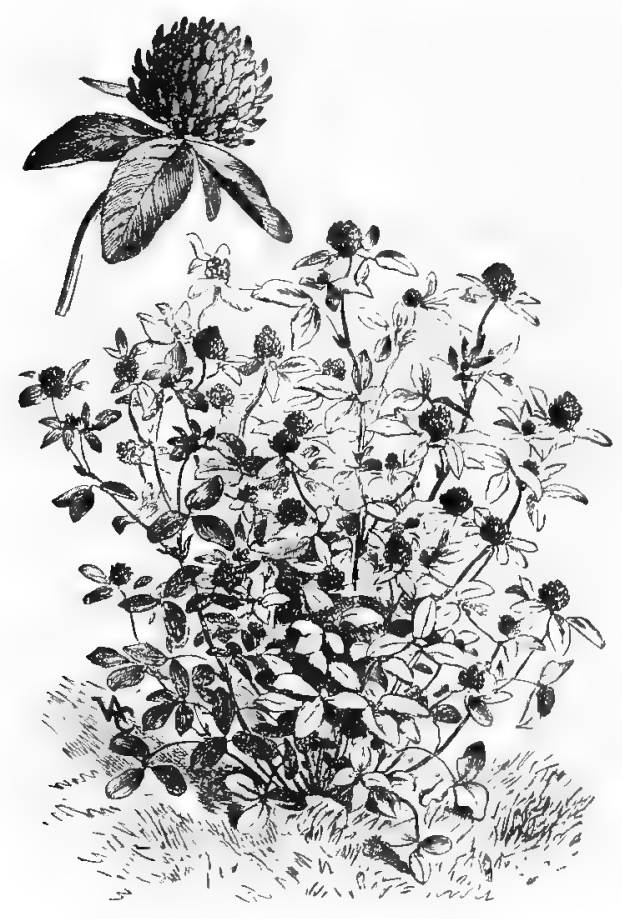

Fig. 157.

RED CLOVER.

(From Vilmorin-Andrieux, Paris.)

Another desirable attainment is red clover with a shorter corolla. This will probably be secured only by hybridization.

y02. The linden, or bass-wood (Tilia Americana, fig. 158), 
yields white honey of a strong flavor, and, as it blossoms when both the swarms and parent-colonies are usually populous, the weather settled, and other bee-forage searce, its value to the bee-keeper is great.

"Here their delicious task, the fervent bees

In swarming millions tend: around, athwart,

Through the soft air the busy nations fly,

Cling to the bud, and with inserted tube,

Suck its pure essence, its ethereal soul.",

-Thomson.

This majestic tree, adorned with beautiful clusters of fragrant blossoms, is well worth attention as an ornamental shade-tree. By adorning our villages and country residences with a fair allowance of tulip, linden, and such other trees as are not only beautiful to the eye, but attractive to bees, the honeyresources of the country might, in process of time, be greatly increased. In many districts, locust and basswood plantations would be valuable for their timber alone.

703. We have also a variety of clover imported from Sweden, which grows as tall as the red clover, bears many blossoms on a stalk, in size resembling the white, and, while it answers admirably for bees, is preferred

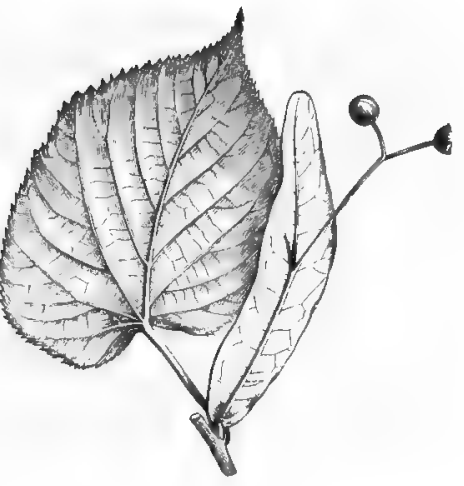

Fig. 158. LINDEN OR BASSWOOD. (From Vilmorin-Andrieux, Paris.) by cattle to almost any other kind of grass. It is known by the name of Alsike or Swedish clover (Fig. 159).

The objection made to this elover is that its stem is so light that it falls to the ground. This is remedied by sowing 
it with timothy. The latter helps it to stand. It is as good for honey as white clover.

y0t. The raspberry furnishes a most delicious honey. In flavor it is superior to that from the white clover. The sides of the roads, the borders of the fields, and the pastures of much of the "hill-country" of New England, and of

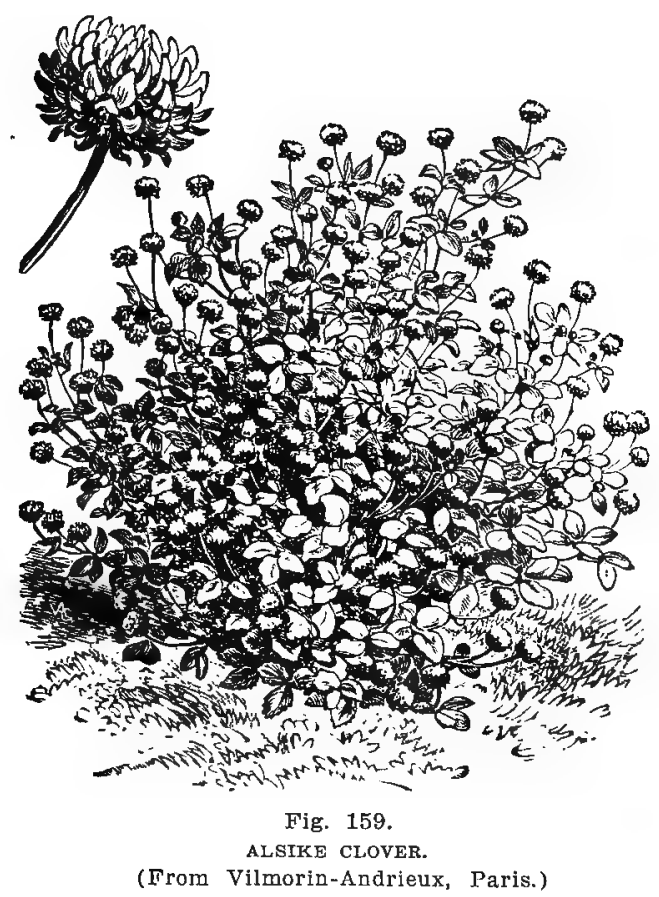

the great Northwest, from Wisconsin to Alaska, abound with the wild red raspberry. When it is in blossom, bees hold even the white clover in light esteem. Its drooping blossoms protect the honey from moisture, and they can work upon it when the weather is so wet that they can obtain nothing 
from the upright blossoms of the clover. In spite of the barrenness of the soil, the precipitous and rocky lands, where it most abounds, might be made almost as valuable as some of the vine-clad terraces of the mountain districts of Europe.

The Borage (Borago officinalis), (Fig. 160), blossoms continually from June until severe frost, and, like the raspberry, is frequented by bees even in moist weather. The honey from it is of a superior quality.

The Canada thistle, the Viper bugloss yield good honey after

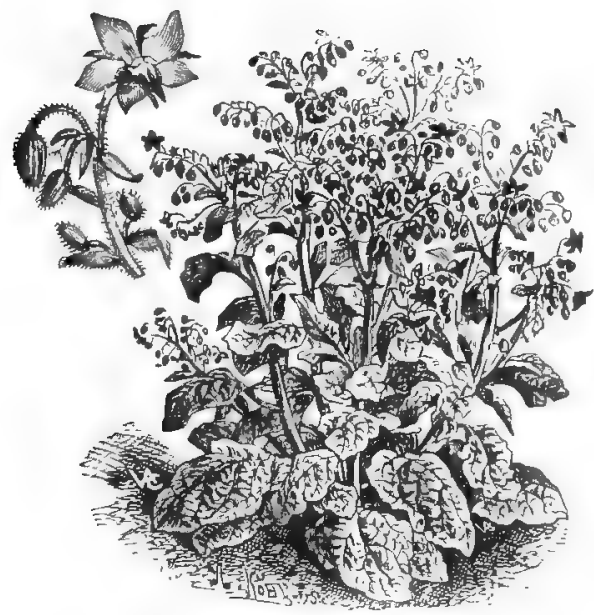

Fig. 160.

BORAGE.

(From Vilmorin-Andrieux, Paris.)

white elover has begun to fail. But these plants are troublesome, for they cannot easily be gotten rid of.

705. Melilot, or sweet clover (fig. 161), which grows on any barren or rocky soil without eultivation, is one of the most valuable honey-plants. It will not always thrive, however, where cattle can graze on it, as they often destroy it. 
If cut early to be used as forage, it blooms later than white clover and till frost. It is a biennial.

According to the Department of Agriculture of the United States there are two kinds of yellow melilot, "Melilotus officinatis" (Fig. 162) a biennial, and "melilotus indira," smaller and annual.

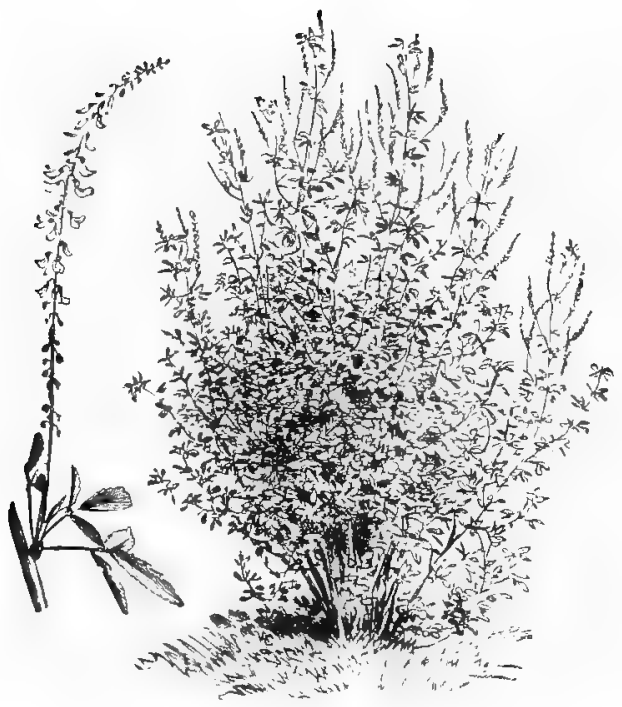

Fig. 161.

SWEET CLOVER.

Melilotus Alba.

(From Vilmorin-Andrieux, Paris.)

The different varieties of smart-weeds (Persicaria), goldenrod, buckwheat, asters, iron-weed, Spanish-needles in low lands and marshy places, give a very abundant honey-erop in the latter part of the Summer. They form the bulk of what is called the "Fall crop" in this latitude. 
In California the Sage, in Texas the Horse-mint, in Florida the Mangrove, form the main honey-harvests of those countries.

In the irrigated portions of the arid West, the Alfalfa (Fig.

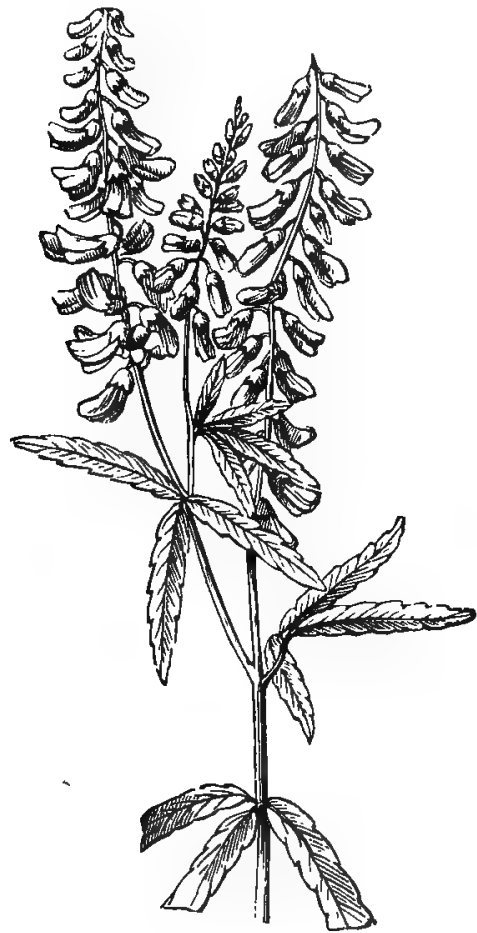

Fig. 162.

YELLOW OR OFFICINAL MELILOT.

(From L'Apicoltore.)

156) is grown profusely, usually giving three crops of hay and at each blooming an abundance of the most delicious white honey. Alfalfa honey is a staple on the market. 
706. We here present a list of the flowers known as being visited by the bees for their nectar or for their pollen. We have grouped them in Families, and we give engravings of some of their most prominent types, in order to help the Apiarist in his investigation. But our list is far from being complete.

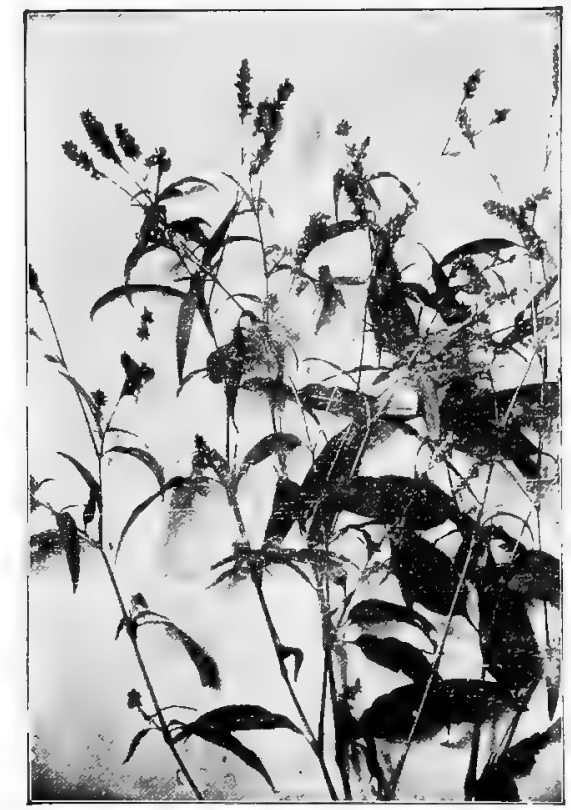

Fig. 163.

PERSICARLA, COMMONLY CALLED "HEARTSEASE."

(From Forty Years Among the Bees.)

Compositae:-Dandelion, Thistle, Chamomile, Sunflower, Ox-eye Daisy, Goldenrod (Fig. 164), Coreopsis, Lettuce, Chicory, Boneset, Iron-weed, Indian Plantain, Fire-weed, Aster (figures 165, 166), Burr-Marigold, Spanish Needles, 
Coneflower, Star Thistle, Thoroughwort, Butterweed, Sneezewort, Blue Bottle, Ragweed, several varieties of Echinops, one of which, the Spherocephalus, was introduced here by

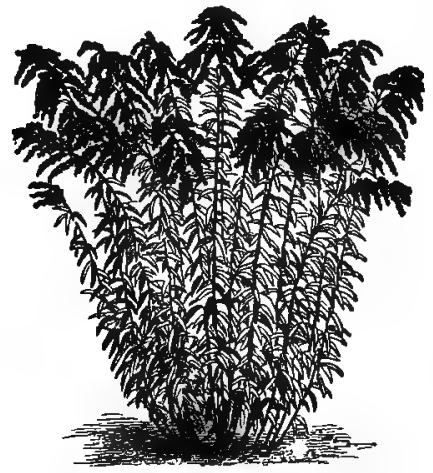

Fig. 164.

GOLDEN ROD OR SOLIDAGO.

(From. Vilmorin-Andrieux, Paris.)

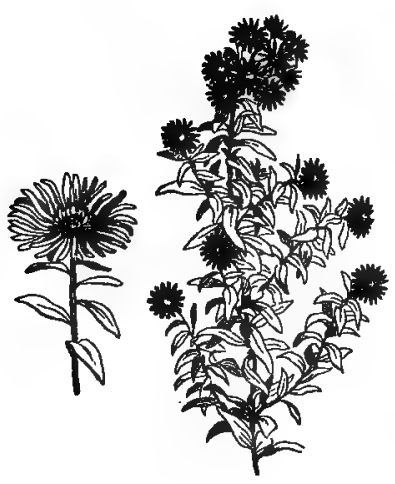

Fig. 165.

ASTER ROSEUS.

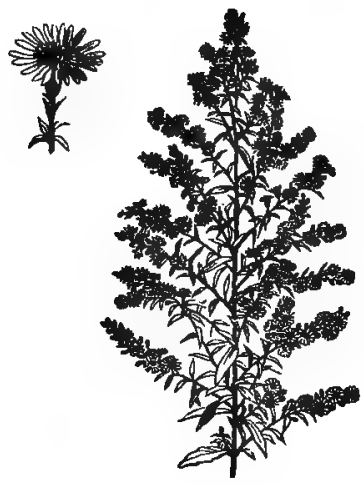

Fig. 166.

Aster tradescanti.

Mr. Chapman. The Echinops ritro (smaller in size) (Fig. 167), is cultivated in Europe on aceount of its beautiful blue heads. 


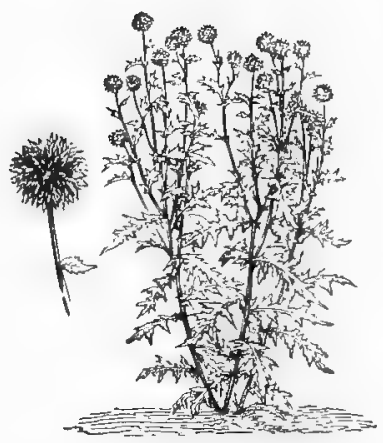

Fig. 167.

ECHINOPS RITRO.

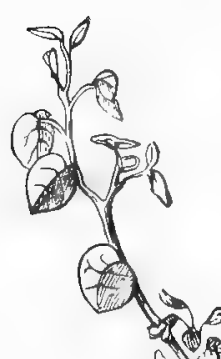

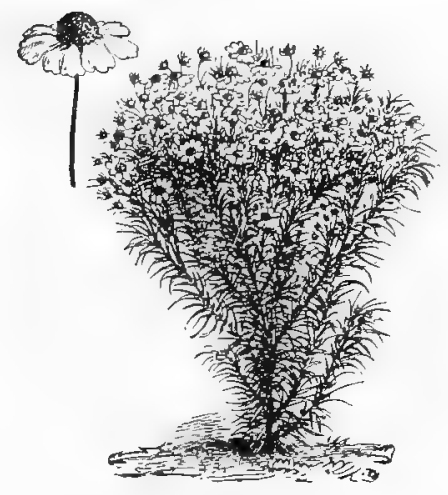

Fig. 168.

HELENIUM TENULFOLIUM.

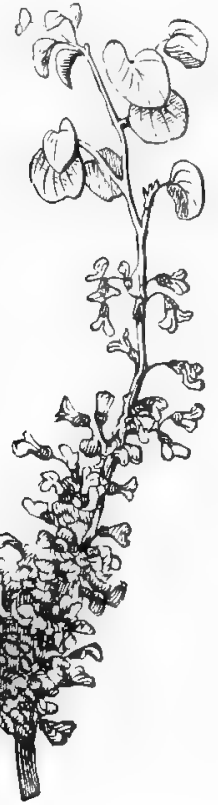

Fig. 169.

JUDAS TREE.

(From L'Apicoltore.) 
This family includes also the Helenium tenuifolium (Fig. 168), which is the southern "sneeze weed." . H. BRown.)

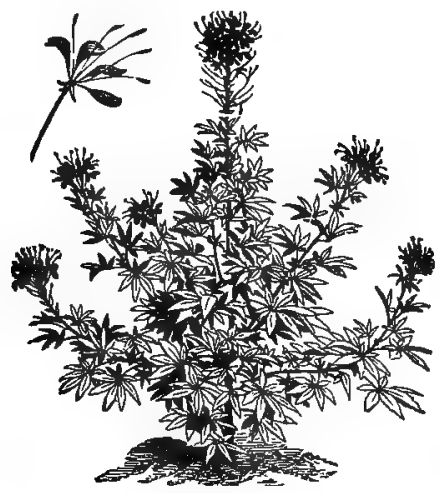

Fig. 170.

CLEOME PUNGENS.

Leguminosae:-Judas tree (Fig. 169), which blooms very early, Locust tree, Honey Locust, Wistaria, white, red and

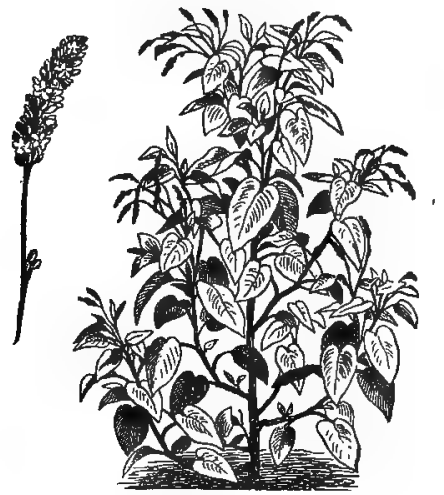

Fig. 171.

KNOT-WEED.

(Polygonum orientale.)

alsike Clover, Melilot (Fig. 161), Lucerne or Alfalfa, Peas, Beans, Vetches, Lentils, False-Indigo, Partridge pea, Wił̦ 
Senna, Milk vetch, Yellow-Wood, Mesquit-tree of Texas, Cleome integrifolia and pungens (Fig. 170).

Labiatae:-(from Labium, a lip). Ground Ivy, Sage, Mint, Horehound, Catnip, Motherwort, Horse-Mint, Basil, Hyssop,

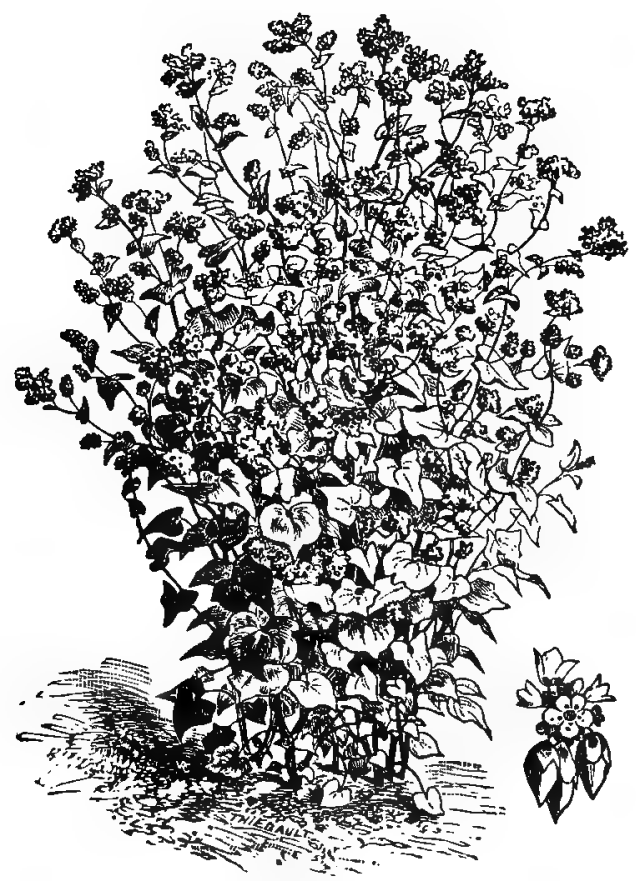

Fig. 172.

BUCKWHEAT,

(From Vilmorin-Andrieux, Paris.)

Bergamot, Marjoram, Thyme, Melissa, Dead Nettle, Brunella, Pennyroyal.

Rosaceae:-Wild Rose, Cherry, Plum, Peach, Apricot, 
Apple, Pear, Quince, Hawthorne, Blackberry, Raspberry, Strawberry, Juneberry, Cinquefoil, Bowmansroot, Queen of the Prairie, Meadow Sweet, Pyracantha.

Polygonacae:- Buckwheat, Lady Thumb, Rhubarb, Sorrel, and a variety of Knot-weeds or Persicarias (Fig. 171).

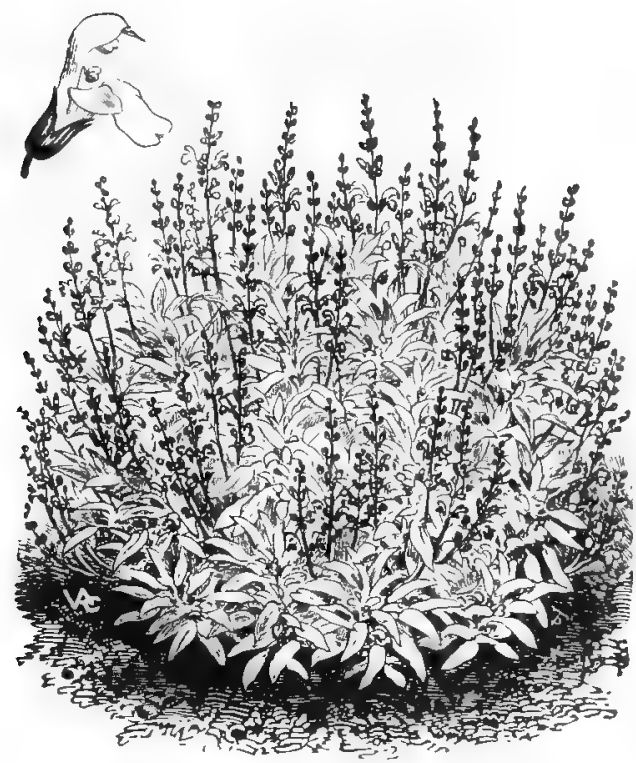

Fig. 173.

SAGE.

(From Vilmorin-Andrieux, Paris.)

Borraginaceae:-Borage (Fig. 143). Viper-bugloss, Comfrey, Phacelia, Virginia Lungwort, Hound's tongue, Gromwell, False Gromwell.

Scrophulariaceae:-Scrophularia nodosa (Simpson's honey- 


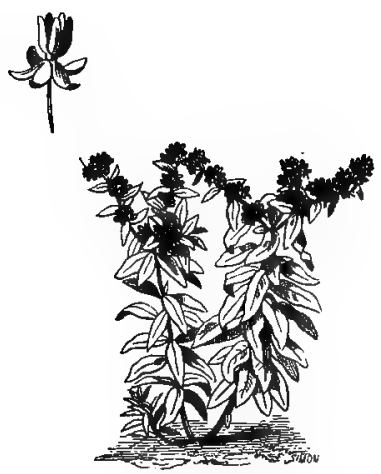

Fig. 174 .

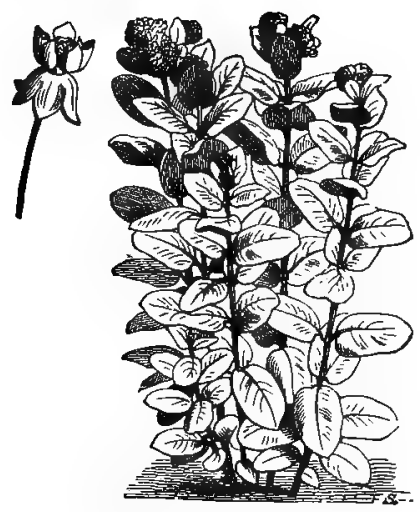

Fig. 175.

ascleptas tuberosa. Pleurisy Root.

plant), Veronicas, Yellow Jessamine of the South, whose honey is poisonous. - (Dr. J. P. H. Brown.)

Asclepiadaceae:-The common Milkweed (Fig. 175), or Silkweed, Asclepias cornuti, is much frequented by bees, but these visits are often fatal to them. All the grains of pollen of the Silkweed, in each anther, are collected in a compact mass, inclosed in a. sack; these sacks are united in pairs (a. Fig. 176) by a kind of thread, terminated by a

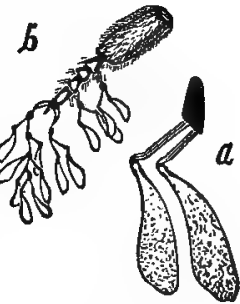

Fig. 176. small, viscous gland. These threads POLLEN OF MILEWEED. tic sacs of pollen in stick to the feet. (b. Fig. 176) and often pairs ; $b$, the same atto the labial palpi (4.6) of the bees, who (From "A A B C of Beecannot easily get rid of them, and perish.

Culture.")

In some parts of Ohio and Western Illinois, a variety of the common kind, the Asclepias Sullivantii, does not present to bees these difficulties to the same degree. We have seen bees gathering honey freely on four or five different varieties which grow in our neighborhood, and especially on the Tube- 
rosa or Pleurisy root (Fig. 174), fitly recommended by James Heddon. This kind is noticeable by its orange flowers.

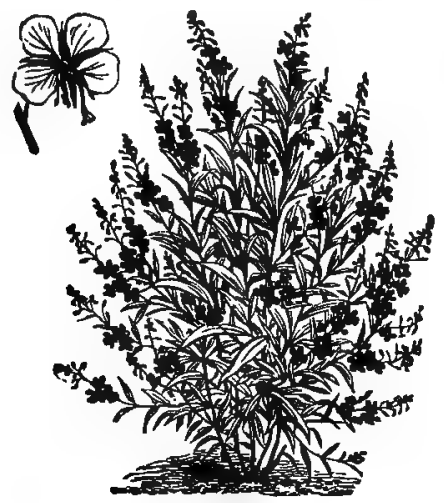

Fig. 177.

EPILOBIUM SPICATUM.

(From Vilmorin-Andrieux.)
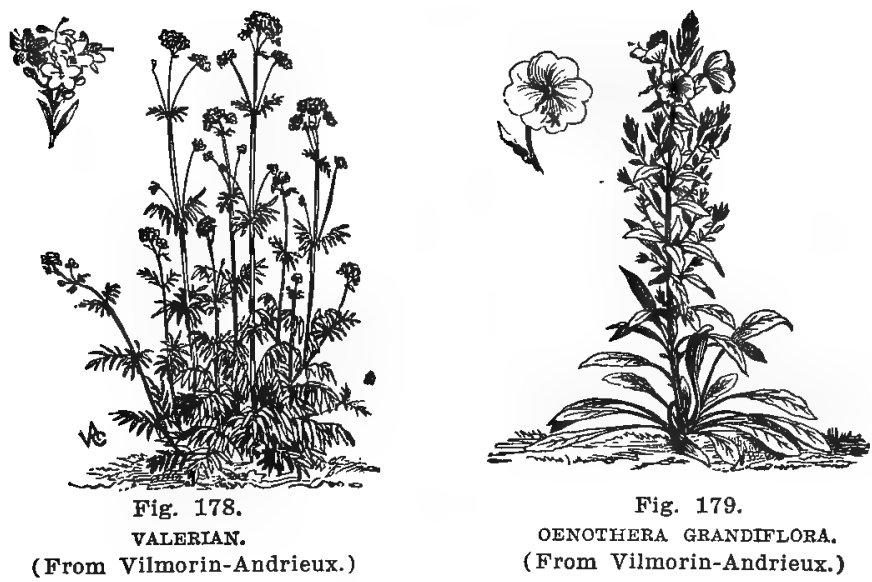

Fig. 179.

OENOTHERA GRANDIFLORA. (From Vilmorin-Andrieux.)

Cruciferae:-Rape, Mustard, Cabbage, Radish, Candytuft, stock, Wallflower, Moonwort, Sweet Alyssum, Cress. 
Ericaceae:-This family, on the old Continent, includes the numerous varieties of Heath, on which bees reap a large

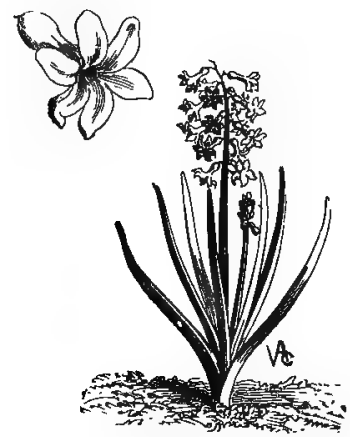

Fig. 180.

HYACINTH.

(From Vilmorin-Andrieux.)

harvest of inferior honey, so thick that it is impossible to extract it. Blueberry, Sour Wood, Laurel, Clethra alnifolia,

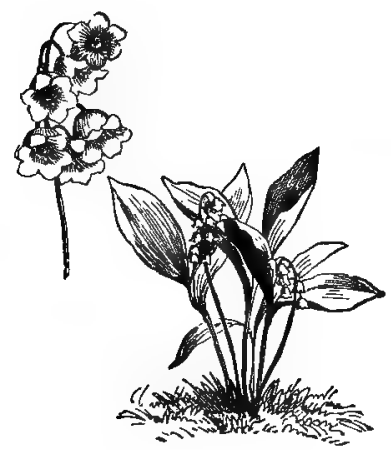

Fig. 181.

LILY OF THE VALLFY.

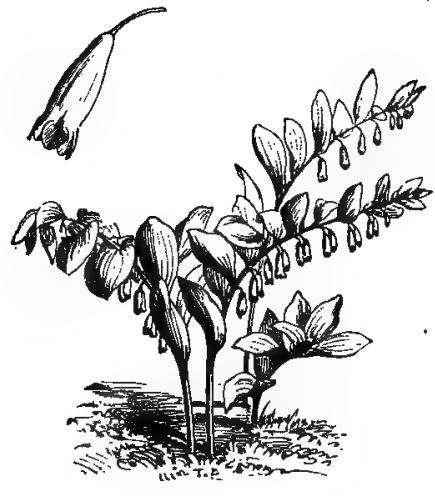

Fig. 182.

SOLOMON'S SEAL.

Cowberry, Huckleberry, Whortleberry, Gaultheria procumbens, or Creeping wintergreen,-- which is indicated, by some 
English bee-keepers, as preventing bees from stinging the hands when they are rubbed with its leaves,-belong to this family.

Valerianaceae:--Valerian (Fig. 178), Corn Salad or Lamb lettuce, belong to this family.

Onagraceae:-(Evening Primrose family) Gaura, Fuschia, Oenothera (Fig. 179) Epilobium (Willow Herb, Fig 177).

Liliaceae:-Lilies, Asparagus, Wild Hyacinth (Fig. 180), Star of Bethlehem, Lily of the Valley (Fig. 181), Solomon's

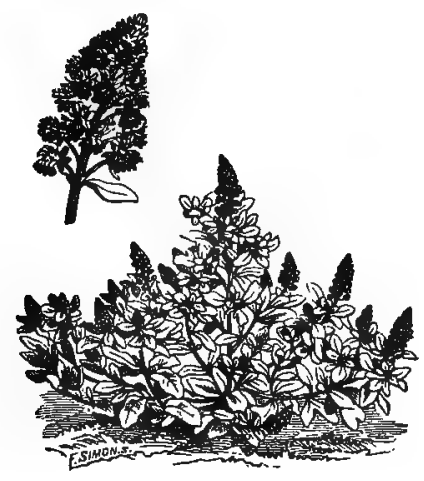

Fig. 183.

MIGNONETTE.

Seal (Fig. 182), Dog's tooth Violet, three-headed Night-shade, Garlic, Onion, Crocus.

Malvaceae:-Common Mallows, and others, Hollyhock, Cotton, Abutilon.

Caprifotiaceae:-Honeysuckle, Snow and Coral berries, Arrow-wood.

Cucurbitaceae:-Cucumber, Melon, Squash, Gourd.

Umbelliferae:-Parsley, Angelica, Lovage, Fennel, Parsnip, Coriander, Cow-parsnip.

Caryophyllaceae:-Pink, Lychnis, Chickweed, Saponaria.

We can name also: Rib-Grass, or Plantain, Goosefoot, Blue-eyed grass, Corn-flag, Buckthorn, Barberry, Sumac, 
Grape-vine, Polanisia, Button weed, Mignonette, or Reseda (Fig. 183), Teasel, Skunk cabbage, Waterleaf, Hemp, Touchme-not, Amaranth, Crowfoot, St. Johnswort, and among the trees: Willow, Poplar, which have their sexual organs on different trees; Oak, Walnut, Hickory, Beech, Bireh, Alder,

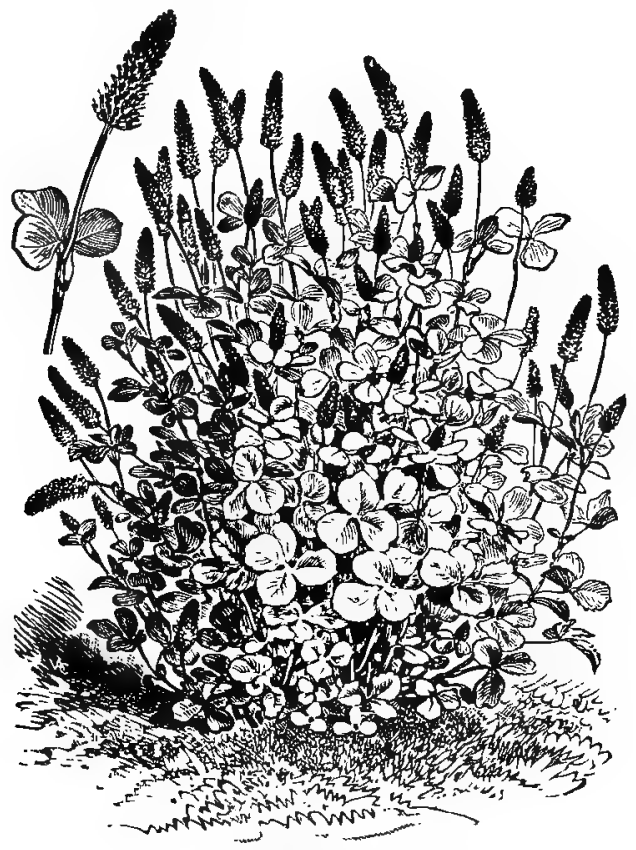

Fig. 184.

CRIMSON CLOVER.

(From Vilmorin-Andrieux.)

Elm, Hazelnut, Maple, whose organs of reproduction are separated, although on the same tree.

Horse chestnut, Persimmon, Gum-tree, Dogwood, Buttonbush, Cypress, Liquidambar, Linden.

We shotrld mention also, Ailanthus glandulosus (Varnish tree of China), a large, ornamental tree, which gives an 
abundance of honey so bad in taste, as to compel the beekeepers who have some in their neighborhood to extract it as soon as it is gathered, that it may not injure the quality of their erop.

Bees also visit some of the plants of the grass family, such

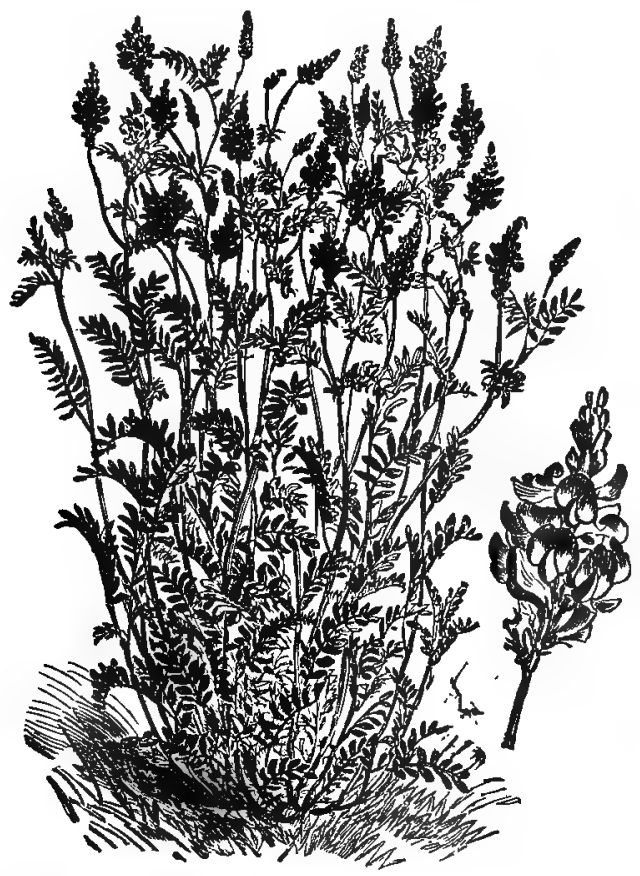

Fig. 185.

SAINFOIN OR ESPARCET.

(From Vilmorin-Andrieux.)

as corn and sorghum. A plant of this family, the Setaria, or bristly foxtail grass, is known in France under the name of accroche-abeilles, (bee-catcher). Its curved hairs grasp the bees' legs, and the poor insects, unable to free themselves, are soon exhausted, and die. 
Strange to say, the principal crop of honey in a country may be harvested from a flower which yields nothing in other countries. The white clover, so well known in the Mississippi valley as the very best melliferous plant, yields nothing in Switzerland. The alfalfa, mentioned as the principal crop of Colorado, Utah, Nevada, is not a honey producer in Illinois. Some plants also attract the bees continuously, by their fragrance, which yield little or no nectar.

The Eryngium giganteum is one of these. Mr. Bertrand tested its yield by marking with flour bees that were working upon it. The same bee was seen to work about the same bunch of these flowers, for five consecutive hours, without any apparent result. He nicknamed this plant "the honey-bee's bar-room" because the more they sip, the drier they are.

As a rule it is not advisable to plant for honey anything that has not value otherwise either as forage, ornament or shade. For this very reason, however, there are foreign forage plants which would be desirable everywhere. We will name among these the Crimson Clover and the Sainfoin or esparcet, of which we give engravings, figs. 184 and 185. The Sainfoin (healthy hay) is a very desirable forage plant.

\section{OVERSTOCKING.}

OUR COUNTRY NOT IN DANGER OF BEING OVERSTOCKED WITH BEES.

\%07. If the opinions, entertained by some, as to the danger of overstocking were correct, bee-keeping in this country would always have been an insignificant pursuit.

It is difficult to repress a smile when the owner of a few hives, in a district where hundreds might be made to prosper, gravely imputes his ill-success to the fact, that too many bees are kept in his vicinity. If, in the Spring, a colony of bees is prosperous and healthy, it will gather abundant stores, in a favorable season, even if many equally strong are in its immediate vicinity; while, if it is feeble, it will be of little 
or no value, even if it is in "a land flowing with milk and honey," and there is not another colony within a dozen miles of it.

As the great Napoleon gained many of his victories by having an overwhelming force at the right place, in the right time, so the bee-keeper must have strong colonies, when numbers can be turned to the best account. If they become strong only when they can do nothing but consume what little honey has been previously gathered, he is like a farmer who suffers his erops to rot on the ground, and then hires a set of idlers to eat him out of house and home.

708. Although bees can fly, in search of food, over three miles, still, if it is not within a circle of about two miles in every direction from the apiary, they will be able to store but little surplus honey.* If pasturage abounds within a quarter of a mile from their hives, so much the better; there is no great advantage, however, in haring it close to them, unless there is a great supply, as bees, when they leave the hive, seldom alight upon the neighboring flowers. The instinet to fly some distance seems to have been given them to prevent them from wasting their time in prying into flowers already despoiled of their sweets by previous gatherers.

Bees will go farthest in a direction where no obstacles exist, such as hills, woods or large areas of unproductive land. If the blossoms from which they gather honey extend out in a continuous stretch in one direction, they may travel five miles away or perhaps farther when the wind brings to them the smell of flowers. But the fact that apiaries only four miles apart give different yields under the same management shows that the opportunities differ even at that short distance.

"Mr. Kaden, of Mayence, thinks that the range of the bee's flight does not usually extend more than three miles in all directions. Several years ago, a vessel, laden with sugar,

* "Judging from the sweep that bees take from the side of a rallroad train in motion, wer should estimate their pace at about thirty miles an hour. This would give them four minutes to reach the extremity of their common range."-London Quarterly Review. 
anchored off Mayence, and was soon visited by the bees of the neighborhood, which continued to pass to and from the vessel from dawn to dark. One morning, when the bees were in full flight, the vessel sailed up the river. For a short time, the bees continued to fly as numerously as before; but gradually the number diminished, and, in the course of half an hour, all had ceased to follow the vessel, which had, meanwhile, sailed more than four miles."'-Bienenzeitung, 1854, p. 83.

Our own experience corroborates the statements of Kaden. We have known strong colonies of bees to starve upon the hills in a year of drouth, while the Mississippi bottoms, less than four miles distant, which had been overflowed during the Spring, were yielding a large erop. It is evident that districts, where honey blossoms are scarce, can be much more readily overstocked than those rich lands which are covered with blossoms, the greater part of the Summer. A great amount of land in cultivation, is not always a hindrance to honey production, for eultivated lands often grow weeds, which yield an abundance of honey. Heartsease and Spanish needle grow plentifully in cornfields and wheat stubble in wet seasons. Pasture lands abound with white clover.

709. It is impossible to give the exact number of colonies that a country can support profitably. In poor locations, a few hives will probably harvest all the honey to be found, while some districts can support perhaps a hundred or more to the square mile. The bee-keeper must be his own judge, as to the honey capacity of his district.

"When a large flock of sheep," says Oettl, "is grazing on a limited area, there may soon be a deficiency of pasturage. But this cannot be asserted of bees, as a good honey-district cannot readily be overstocked with them. To-day, when the air is moist and warm, the plants may yield a superabundance of nectar; while to-morrow being cold and wet, there may be a total want of it. When there is sufficient heat and moisture, the saccharine juices of plants will readily fill the nectaries, and will be quickly replenished when carried off by the bees. Every cold night cheeks the flow of honey, and every clear, warm day 
reopens the fountains. The flowers expanded today must be visited while open; for, if left to wither, their stores are lost. The same remarks will apply substantially in the ease of honey-dews. Hence, bees cannot, as many suppose, collect tomorrow what is left ungathered to-day, as sheep may graze hereafter on the pasturage they do not need now. Strong colonies and large apiaries are in a position to collect ample stores when forage suddenly abounds, while, by patient, persevering industry, they may still gather a sufficiency, and even a surplus, when the supply is small, but more regular and protracted."

Although we believe that a district can be overstocked, so as to make bee-culture unprofitable, yet the above extract gives a correct view of the honey harvest, which depends much on the weather, and must be gathered when produced.

The same able Apiarist, whose golden rule in bee-keeping was, to keep none but strong colonies, says that in the lapse of twenty years since he established his apiary, there has not occurred a season in which the bees did not procure adequate supplies for themselves, and a surplus besides. Sometimes, indeed, he came near despairing, when April, May, and June were continually cold, wet, and unproductive; but in July, his strong colonies speedily filled their garners, and stored up some treasure for him; while, in such seasons, small colonies could not even gather enough to keep them from starvation.

In countries where the entire area of the farming land is devoted to honey-producing plants, - as in the irrigated plains of Colorado, where the only crop is alfalfa and thousands of acres of this plant are to be seen in a body,-the overstocking of land with bees is almost an impossibility. Examples of this kind are to be found in California, with a natural honey plant, the sage, which covers the uncultivated hillsides. In New York State, buckwheat is raised in such large areas that as many as seven hundred colonies are kept in one apiary. We will name that of Mr. E. W. Alexander of Delanson, N. Y., the description of whose methods attracted much attention in "Gleanings in Bee Culture" at the 
end of the year 1905. Mr. Alexander reported a crop of about 70,000 lbs. of honey in one-season. But in years of scarcity of honey, it is quite probable that many colonies will starve in a very large apiary, while a small apiary might gather enough for Winter.

710. According to Oettl (p. 389), Bohemia contained 160,000 colonies in 1853, from a careful estimate, and he thought the country could readily support four times that number. This province contains 19,822 square English miles.

We say square English miles, and we insist on the word English, for we have read of reports from Germany, showing incredible figures as to the number of bees, and the amount of beeswax and honey gathered on areas of a few square miles; and yet, some of these reports may have been true, for there are different sized miles, in Germany. The German geographical mile is equal to 4. 611-1000 English miles; the German short mile, to 3. 897-1000; and the German long mile to $5.753-1000$, \&c., the shortest German square mile being as about 15 of the English, and the long being about equal to 33 of our square miles. This we glean from "Chambers Encyelopedia."

According to an official report, there were in Denmark, in 1838, eighty-six thousand and thirty-six colonies of bees. The annual product of honey appears to have been about 1,841,$800 \mathrm{lbs}$. In 1855, the export of wax from that country was 118,379 lbs.

In 1856, according to official returns, there were 58,964 colonies of bees in the kingdom of Wurtemberg.

In 1557, the yield of honey and wax in the empire of Austria was estimated to be worth over seven millions of dollars.

Doubtless, in these districts, where honey is so largely produced, great attention is paid to the cultivation of crops which, while in themselves profitable, afford abundant pasturage for bees.

711. California, which seems to be the Eldorado of bee- 
culture, ean probably support the greatest number of bees to the square mile, and yet in some seasons the bees starve there in great numbers owing to the drouth.

We have no official statisties of the honey crops of the United States, but the following extract from the American Bee-Jounal (1886), will give an idea of the immensity of our honey resources, considering the comparatively small areas of this country now occupied by Apiarists.

"The California Grocer says that the erop of 1885 was about 1,250,000 pounds. The foreign export from San Francisco during the year was approximately 8,800 cases. The shipments East by rail were 360,000 pounds from San Franciseo, and 910,000 pounds from Los Angeles, including both comb and extracted. We notice that another California paper estimates the crop of 1885 at $2,000,000$ pounds, and the crop of the United States for 1885 was put down at $26,000,000$ pounds. We do not think these figures are quite large enough, though it was an exceedingly poor erop."

But former years have given still better results. Through the eourtesy of Mr. N. W. MeLain, of the U. S. Apicultural Station, we have received the following statisties from "The Resources of California, 1881":

The honey shipped from Ventura County, California, during 1880 amounted to $1,050,000$ lbs. The Pasific Coast Steamship Company of San Diego shipped 1,191,800 pounds of honey from that county in the same year.

The crop of the five lower counties in California that year, was estimated by several parties at over three million pounds.

According to a report of S. D. Stone, Clerk of the Merchants' Exchange of San Francisco, the actual amount of honey shipped to that city from different parts of California in the sixteen months ending May 1, 1881, was 4,340,400 pounds, equal to two hundred and seventeen carloads.

One hundred tons of honey, in one lot, were shipped during the same year, from Los Angeles to Europe on the French 
bark Papillon. This had all been purchased from Los Angeles Apiarists.

112. In the excellent season of 1883 , the honey erop of Hancock County, Illinois, was estimated at about 200,000 pounds, which made an average of less than half a pound per acre. 36,000 pounds of this was our own crop, and the county did not contain one-tenth of the bees that could have been kept profitably on it. Yet, at this low rate, the crop of Illinois alone, with the same percentage of bees, would have been $15,000,000$ pounds. We cannot form an adequate idea of the enormous amount of honey which is wasted from the lack of bees to harvest it.

713. In our own experience in the Mississippi valley, we have found eighty to one hundred colonies to be the number from which the most honey could be expected in one apiary. Dr. C. C. Miller in his interesting work " $\mathrm{A}$ Year Among the Bees," says also that one hundred colonies is the best number in one location. Mr. Heddon strongly urges bee-keepers not to locate within any area already occupied by an apiary of one hundred colonies or more. The extensive experience of both these Apiarists confirms ours, but we must remember that locations differ greatly.

\%14. In all arrangements, aim to save every step for the bees that you possibly can. With the alighting-board properly arranged, the grass kept down, or better still, coal-ashes or sand spread in front of the apron-board, bees will be able to store more boney, even if they have to go a considerable distance for it, than they otherwise could from pasturage nearer at hand. Many bee-keepers utterly neglect all suitable precautions to facilitate the labors of their bees, as though they imagined them to be miniature locomotives, always fired up, and capable of an indefinite amount of exertion. $\mathbf{A}$ bee cannot put forth more than a certain amount of physical effort, and a large portion of this ought not to be spent in contending against difficulties from which it might easily be guarded. They may often be seen panting after their return 
from labor, and so exhausted as to need rest before they enter the hive.

715. With proper management, at least fifty pounds of surplus honey may be obtained from each colony that is wintered in good condition. This is not a "guess" estimate, it is the average of our crops during a period of over twenty years in different localities.

Such an average may appear small to experienced beekeepers, but we think it large enough when we consider that we are in a district where wheat, corn, oats, and timothy are the staple crops, none of these being honey producing plants. A careful man, who, with Langstroth hives, will begin beekeeping on a prudent scale, enlarging his operations as his skill and experience increase, will succeed in any region. But, in favorable localities, a much larger profit may be realized.

Bee-keepers cannot be too cautious in entering largely upon new systems of management, until they have ascertained, not only that they are good, but that they can make a good use of them. There is, however, a golden mean between the stupid conservatism that tries nothing new, and that rash experimenting, on an extravagant scale, which is so characteristic of our people. 


\section{CHAPTER XVII.}

\section{Honey Production.}

716. History does not mention the first discovery of honey, by human beings. Whether it became known to primitive wan by accident, from the splitting of a bee-tree by lightning, or by his observation of the fondness of some animals for it,certain it is that when he first tasted the thick and transparent liquid, the fear of stings was overcome, and the bee-hunter was born. Since that time, the manner of securing honey has undergone a great many changes, improving and retrograding, as we can judge from writings now extant.

Killing bees for their honey was, unquestionably, an invention of the dark ages, when the human family had lostin apiarian pursuits, as well as in other things-the skill of former ages. In the times of Aristotle, Varro, Columeila, and Pliny, such a barbarous practice did not exist. The old cultivators took only what their bees could spare, killing no colonies, except such as were feeble or diseased.

The Modern methods have again done away with these customs among enlightened men, and the time has come when the following epitaph, taken from a German work, might properly be placed over every pit of brimstcned bees:

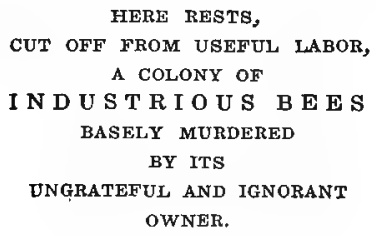


To the epitaph should be appended Thomson's verses:

"Ah, see, where robbed and murdered in that pit, Lies the still heaving hivel at evening snatched, Beneath the cloud of gilt-concealing night, And fixed o'er sulphur! while, not dreaming ill, The happy people, in their waxen cells,

Sat tending public cares.

Sudden, the dark, oppressive steam ascends. And, used to milder scents, the tender race, By thousands, tumble from their honied dome Into a gulf of blue sulphureous flame!"

718. The present methods are as far ahead of the old ways, as the steel rail is ahead of the miry road; as the palace car is ahead of the stage coach.

It is to the production of surplus honey that all the efforts of the bee-keeper tend, and the problem of apiculture is, how to raise the most honey from what colonies we have, with the greatest profit.

718. In raising honey, whether comb or extracted, the Apiarist should remember the following:

1st. His colonies should be strongest in bees at the time of the expected honey harvest $(\mathbf{5 6 5})$.

2d. Each honey harvest usually lasts but a few weeks.

If a colony is weak in Spring, the harvest may come and pass away, and the bees be able to obtain very little from it. During this time of meagre accumulations, the orchards and pastures may present

\footnotetext{
"One boundless blush, one white empurpled shower of mingled blossoms;"'
}

and tens of thousands of bees from stronger colonies may be engaged all day in sipping the fragrant sweets, so that every gale which "fans its odoriferous wings" about their dwellings, dispenses 
"Native perfumes, and whispers whence they stole Those balmy spoils." **

By the time the feeble colony becomes strong-if at allthe honey harvest is over, and, instead of gathering enough for its own use, it may starve, unless fed. Bee-keeping, with colonies which are feeble, except in extraordinary seasons and locations, is emphatically nothing but "vexation of spirit."

3rd. Colonies that swarm cannot be expected to furnish much surplus, in average localities and seasons.

4th. A hive containing or raising many drones (189) cannot save as much surplus as one that has but few, owing to the cost of production of these drones, who do not work and are raised in place of workers. We have insisted on this point already, but it is of such importance, that we cannot refrain from recalling it. The hives should be overhauled every Spring, and the drone comb cut out and replaced by neat pieces of worker comb, or of comb foundation (6ry). Every square foot of drone comb, replaced with worker comb, represents an annual saving, in our estimation, of at least one dollar to the colony.

\section{COMB Honey.}

719. Although more extracted honey can be produced than comb honey, from the same number of colonies, yet a newly made and well sealed comb of honey is unquestionably most attractive, and, when nicely put up, will find a place of honor, even on the tables of the wealthy. Thite comb honey will always be a fancy article, and will sell at paying prices.

Dark honey in the comb does not usually find ready sale. Hence, the bee-keepers, in districts where white honey is har-

* The scent of the hives, during the height of the gathering season, usually indicates from what sources the bees have gathered their supplies. 
vested, are mostly producers of comb honey; while those in the districts producing dark honey, in the South mainly, rely more on extracted honey.

720. We have not the space to describe the different evolutions, through which the production of comb honey has passed since box-hive times; production in large frames in glass boxes, in tumblers, ete.

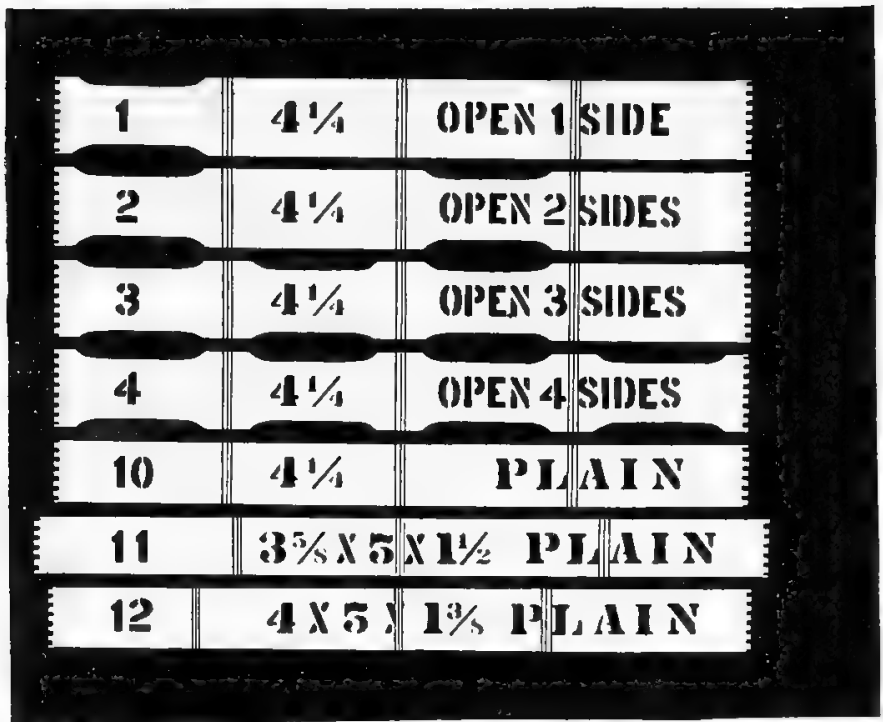

Fig. 186.

ONE-PIECT SECTIONS.

Honey in large frames does not sell well, and cannot be safely transported. Were it not for this, its production in this way would be advisable. The experienced bee-keeper well knows that bees will make more honey in a large box, than in several small ones whose united capacity is the same. In small boxes, they cannot so well maintain their animal heat 
in cool weather and cannot ventilate so readily in hot weather. In the exceedingly hot season of 1878 , the colonies that were provided with glass boxes yielded on an average, less than one-fourth of the average yielded by others.

The bees have another important and natural objection to the small receptacles, mentioned by a noted Apiarist, as will be seen farther ( 111$)$. Practically, there is more labor for the bees in small receptacles, as the joints and corners of the combs require more time and more wax.

721. But to produce salable comb honey, we have no

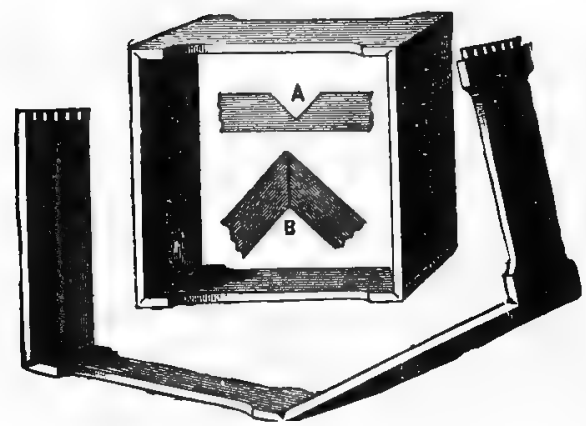

Fig. 187.

FOLDED SECTIONS.

choice. We must produce it in a small receptacle. The Adair section boxes, which we used as early as 1868, marked the first progressive step, so far as we know.

These sections forming a case by the overlapping of their top and bottom bars, and furnished with glass at each end, were much admired, and we sold several tons of honey, in this shape, in St. Louis, at the now fabulous prices of from 25 to 28 cents per pound.

722. But the one pound sections, as now made, have been universally adopted of late years. 
These sections are made of two kinds, dovetailed in four pieces, or in one piece and folded. The first can be made of any kind of white wood, while the latter are made of basswood only.

723. Sections are usually made $1 / 8$ inch thick and $1 \frac{1}{2}$ to 2 inches wide. The standard section for Langstroth hives is $41 / 4 \times 41 / 4$ inches, with openings at the bottom and top.

724. 'They are given to the bees in the upper story. Stor-

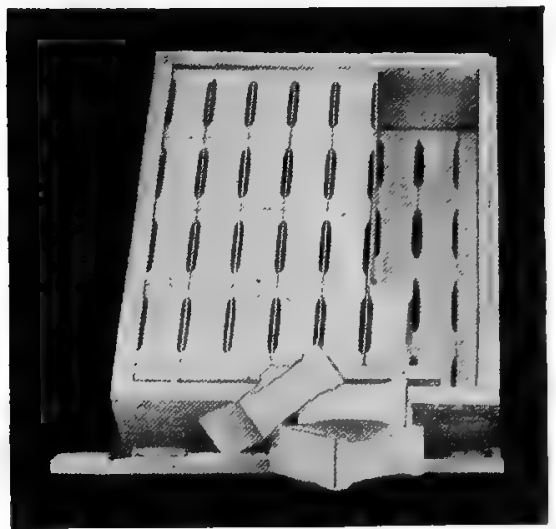

Fig. 188.

SUPER WITH PATTERN SLATS.

age room, on the sides of the brood chamber, has been periodically advised by inventors of new hives, but bees never fill and seal seetions placed at the side as fast as if put above the brood chamber.

Sections are placed on the hive in supers with pattern slats on which the sections rest as in fig. 188, in $T$ supers with metal rests, fig. 201, or in wide frames, figs 189 and 199.

With either of these methods, some principles must be adbered to. 
725. These principles are based on the difficulties, that have to be overeome in comb-honey production, as follows:

1st. Inducing the bees to work in small receptacles;

2d. Forcing them to build the combs straight and even, without bulge, so that the sections can be interchanged without being bruised against one another, when taken off and crated for market;

$3 d$. Keeping the queen in the brood apartment, and preventing her from breeding in the sections;

4th. Preventing swarming as much as possible;

5th. Arranging the sections so as to have as little propolis put on them as possible ( $23 \mathbf{y})$;

6th. Getting the greatest number of sections thoronghly sealed, as unsealed honey is unsalable.

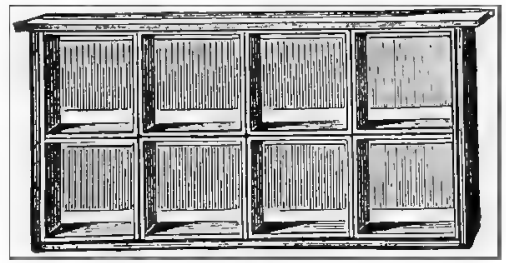

Fig. 189.

FULL DEPTH SECTION FRAME.

(From "Bees and Honey.")

726. 1st. INDUCING BeES TO WORK IN SMALL RECEPTACLES. Rather than work in small, empty receptacles, the bees sometimes crowd their honey in the brood chamber, till the queen can find no room to lay in, and swarming, or a smaller crop of honey, is the consequence. To renedy this evil, some of our leading bee-keepers have resorted to an old, discarded, French practice, "reversing." Reversing cunsists in turning the brood chamber upside down and placing hives containing empty combs, whose bees died the preceding Winter, or empty 
supers, over it. The honey contained in the brood chamber, which is always placed above and behind the brood, safe from pilfering intruders, is now at the bottom, near the entrance. The cells are wrong side up (fig. 190), and the most watery honey is in danger of leaking out. Hence an uproar in the hive, and the immediate result is, that the bees promptly occupy the upper story, and store in it all this ill-situated honey. The result is so radical, that "reversing bee-keepers" admit that their bees have to be fed in the Fall, as too little honey is left in the brood chamber for the hives to winter on. In the box-hive times, the following was already the almost unanimous report of bee-keepers on the results of "reversing." The reeruiting and feeding for Winter of

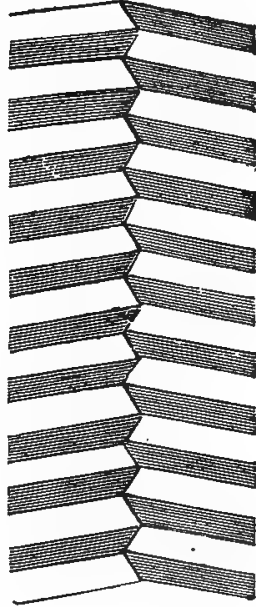

Fig. 190.

SLOPE OF THE CELLS WHEN INVERTED. reversed colonies being considered too costly and risky, the apiaries were supplied every year with new colonies bought from bee-keepers whose business was to raise swarms to sell.

"If you want the greatest quantity of honey, reverse your colonies; but if reversing was practiced everywhere, we would diminish the number of our colonies, and would finally even destroy the race of bees, for as far as bee reproduction is con. cerned the 'reversing Apiarist' reaches the same result as the 'brimstoning Apiarist.', -French Apiarian Congress, Paris, 1861. L'Apiculteur, Volume, 6, page 175.

In the present state of progress in bee culture, "reversing" is less damaging, but its disadvantages to the bees cannot overbalance its advantages, unless it is practiced very cautiously and sparingly.

727. Yet this practice is sufficiently enticing-as it forces the bees to occupy the supers so quickly-to have caused the 
invention of a number of reversible hives or frames. The reversing method caused quite a craze about 1888 , but it was a "fad" which soon wore itself out.

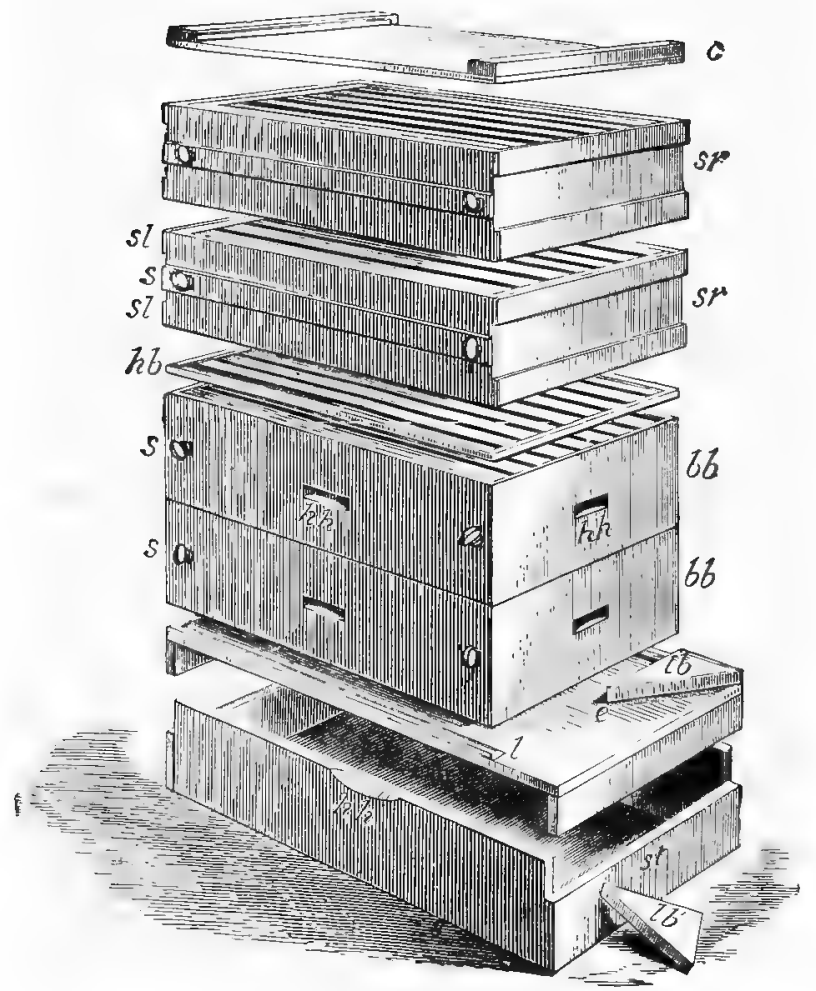

Fig. 191.

HEDDON'S REVERSIBLE HIVE.

(Fróm Cheshire.)

$s t$, stand; $b b$, body; $h b$, honey board; $s r$, section racks; $c$, cover; $h h$, hand holds; $l b$, entrance blocks; $\epsilon$, entrance; $l$, cleat to give bee space; s, screws to hold frames.

F2S. Reversing during the harvest does not cause the bees to gather any more honey; nay, they harvest even a little 
less, owing to the time occupied in transporting the honey, but it is all placed in the surplus apartment at the mercy of their owner.

A much safer method to induce the bees to work in the supers, is to place in them, nearest the brood, a few unfinished sections from the previous season. This is what Dr. C. C. Miller calls a "bait." These unfinished sections have been emptied of their honey by the extractor, and cleaned by the bees the previous Fall. The supers should be located as near the brood apartment as possible, with as much direct communication as can be conveniently given.

729. But, with the greatest skill, it is impossible to attract the bees into the supers, as long as there are empty combs in the brood-chamber.

If the queen is unable to occupy all the combs with brood, the empty ones should be removed at the beginning of the honey harvest, and either given to swarms or divided colonies, or placed outside of the division board (319). This is called "contraction." We would warn our readers against excessive contraction, for, after the honey season is over, a hive which has been contracted to, say, two-thirds, of its capacity, has become dwarfed in honey, brood, and bees, and will run some risks through the Winter. Besides, that part of the super, which is above the empty space, is but reluctantly occupied by bees.

"If the reader has ever constructed a hive, whose surplus department was wider than the brood chamber, jutting out over the same, he has noticed the partial negleet paid by the bees, to the surplus boxes which rested over wood instead of combs.

"Now this same difference made by the bees, between wood and comb, they will also make between combs of honey and eombs of brood, and with our 8-frame Langstroth hive, we notice far less neglect of the side surplus combs than we noticed when using the 10-frame hives. This is one objection to the method of contracting by replacing the side combs of brood chambers with fillers or dummies."-J. Heddon "Suceess in Bee-Culture." 
730. A method which avoids contraction, and makes the best honey-producing colonies still better, consists in taking brood combs from colonies that are not likely to yield any surplus, and exchanging them, for empty combs from the best colonies, just before the honey harvest. This method requires too many manipulations to be very advantageous, and prevents the poorest colonies from becoming stronger.

The most potent argument that has been adranced against the Dadant large hive is that, in the raising of comb honey, it becounes necessary to remove all the combs that may not lave becu filled with brood, by queens of inferior prolificness. This contraction is necessary if we want all our honey in the sections. But many bee-keepers like to produce both comb and extracted honey and with this hive they secure both. The eight-frame Langstroth hive, on account of its diminutive size has been preferred by many, because just as soon as there is a surplus the bees are compelled to put it into the sections, so that the Apiarist gets more honey, in a poor season, from small hives than from large ones, but if he were to weigh the anount of honey actually harvested, whether in the body or the supers, he would soon ascertain that the large hives averaged a great deal more crop, owing to the greater population in hives containing rery prolifie queens. We mention this because the ten-frame Langstroth hives are usually preferred for the production of comb honey.

We have already stated (312), how Doctor C. C. Miller, with eight-frame hives, manages to secure the greatest amount of brood before the opening of the honey crop, by adding another story for brood to his strongest colonies, then reducing them at the opening of the crop, to one story full of brood, using the extra brood combs for weaker colonies. To this method Dr. Miller ascribes his constant success. It is only another method of achieving the same end, securing the greatest amount of brood and contracting the brood nest for the honey crop. By our method it is done with only one brood apartment. The bee-keeper who uses small hives must either 


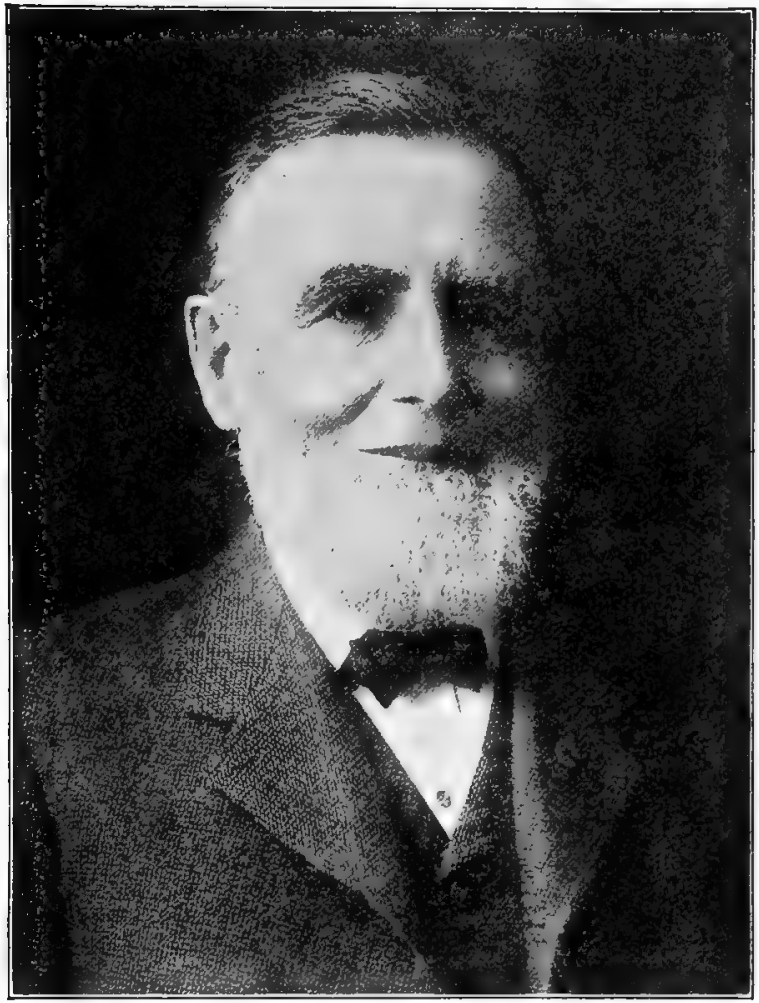

DR. C. C. MILLER,

Author of "A Year Among the Bees," "Forty Years Among tha Bees," and "Fifty Years Among the Bees."

This writer is mentioned pages $46,156,167,175,194,195,226,241$, $283,287,333,362,381,393,426,437,442,443,444$, $445,446,449,463,464,546$. 

take one of these methods or expect less crop than he would otherwise get from the most prolific queens.

731. 2d. Securing Straight, eVen combs, in SeCtions. With thin comb foundation (683), in strips filling $1 / 2$ to $3 / 4$ of the section, the combs are always straight, but their surface, when sealed, is not always even. Some cells are built longer than others, and, in packing the honey, these bulged combs might come in contact with one another and get bruised. To prevent this occurrence, many Apiarists use "separators," made of tin, wood, or coarse wire cloth, placed between the rows of sections, as in figs. 189 and 192. This invention, claimed by

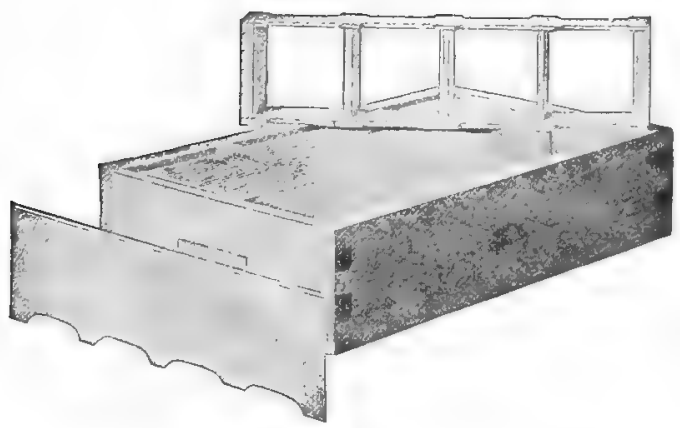

Fig. 192.

SECTION SUPER WITH WOOD SEPARATORS.

Mr. Betsinger, of New York, was first tried in the brood chamber, by $\mathrm{Mr}$. Langstroth in 1858. It was suggested by $\mathrm{Mr}$. Colvin. (See former edition, page 374.)

Another method has been devised. Plain sections, without insets for the passage of the bees, are made, and a "fence" is used between the sections. This fence is made of slats, fig. 193, with upright strips which rest perpendicularly against the edge of the sections. The bee space is thus made by the help of the fence, the entire length of the sections at top and bottom. Either method succeeds in securing straight combs, 
though the results differ somewhat, as will be seen farther (736).

But many bee-keepers succeed in securing straight combs without separators simply by the use of full sheets of comb foundation in the sections.

732. 3d. KEEPING THE QUEEN IN THE BROOD APARTMENT. If the supers have been put on just previous to the opening of the honey erop, with sufficient bait to attract the bees in them, there will be but litle danger of the queen's moving up

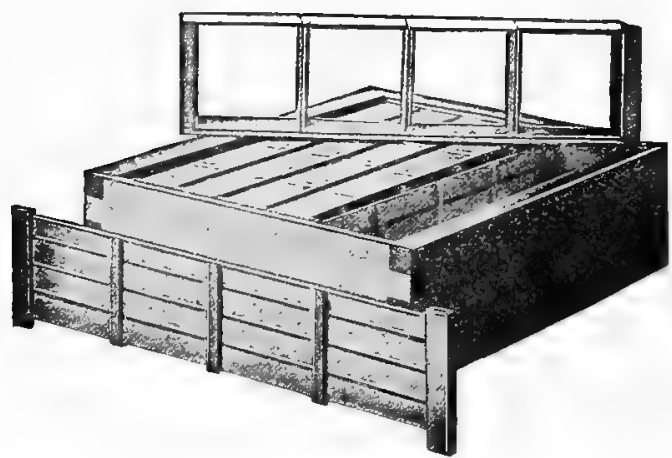

Fig. 193.

SECTION SUPER WITH FENCES.

into them, unless her breeding room is too much cramped by honey, or by the exiguity of the brood nest.

The condition of the honey erop has something to do with her propensity to move out of the brood apartment. When the honey erop is heavy, and of short duration, there is no danger on this score, as the honey combs are filled as fast as they are built, and the queen, should she move to the super, would soon leave it, owing to her inability to lay there. In localities where the crop is lasting and intermittent, much advantage has been derived from the use of the Collin perforated zine between the brood chamber and the supers. The 
only obstacle to its use, is that it hinders ventilation and free access for the bees.

The slatted honey board with zine strips between the slats is probably the best queen excluder made. The full zine sheet

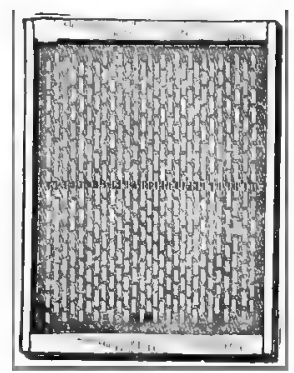

Fìg. 194.

WOOD-BOUND ZINC.

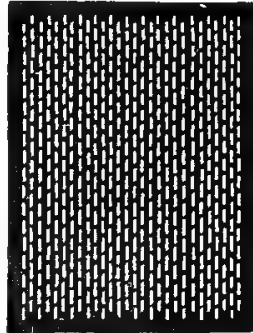

Fig. 195.

UNBOUND ZINC.

is more apt to get out of shape by being glued up by the bees when propolis is plentiful.

The greater or less necessity of queen excluders to prevent

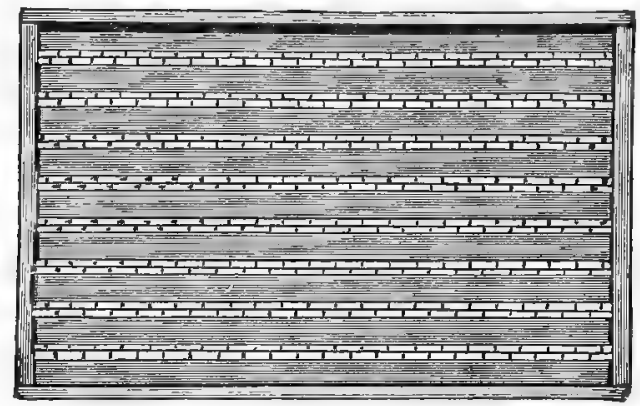

Fig. 196.

SLATTED WOOD-ZINC HONEY BOARD.

the queen from ascending into the seetions and filling them with brood, seems to depend much on location. We have never found that queen excluders were sufficiently needed to 
make them desirable, but many other bee-keepers have often asserted that they cannot get along without thein. However, such an authority as Dr. C. C. Miller says: "The queen so seldom goes into a super that not one section in a hundred, some times not more than one in a thousand, will be found troubled with brood." Other writers are equally emphatic in favor of the excluder. So each bee-keeper will have to decide this point for himself.

According to Doctor Miller, the queen rarely goes into the supers except to seek drone cells in which to lay, when she becomes tired of worker cells. At such times, the bees seem to understand her wishes so well that they leave drone cells unoccupied in order to give her an opportunity to lay in them. If at such times she finds drone comb in the sections she will be likely to fill it with eggs. Otherwise her laying in sections will be very rare.

733. 4th. SWARMING WITH COMB-HONEY PRODUC'TION. As the directions given by us elsewhere (161) do not altogether prevent swarming, when comb-honey is raised, and as the swarming of a colony usually ends its surplus production for the season, it has been found advisable to give the surplus cases to the swarm, instead of leaving them on the old hive. (168 bis.) To further strengthen the swarm, which is thus depended upon for surplus, it is placed on the stand of the old hive, and the latter is removed to a new location. This is a very practical method. It is due to Messrs. Heddon and Hutchinson-at least they have popularized it. But the prudent Apiarist, who follows this course, will keep a vigilant eye on the old colony, thus deprived of all its working force, and will help it, if needed.

731. 5th. Preventing the Bees from propolizing.

"Propolis on sections is a nuisance, be the same little or much, and a plan which will allow of the filling of the section with nice comb honey without changing the clean appearance which they present when placed upon the hive, will be heralded with delight by all, and give great honor to him who 
works out the plan."-G. M. Doolittle, "Gleanings," page 171. 1886.

We have shown (238) that bees propolize every crack, and daub with this yellowish or brownish glue every thing inside of their hive. This is very hard to clean, and it can never be removed sufficiently to restore to the sections their original whiteness.

"All four sides of the sections are scraped clean of propolis, and the edges as well. It is not a difficult job for a careful hand, but a very disagreeable one. The fine dust of the beeglue is very unpleasant to breathe. A scraper should be a careful person, or in ten minutes' time he will do more damage than his day's work is worth. Even a careful person seems to need to spoil at least one section, before taking the care necessary to avoid injuring others. But when the knife makes au ugly gash in the face of a beautiful white section of honey, that settles it that care will be taken afterward.'-Dr. C. C. Miller: "A Year Among the Bees."

To prevent propolizing, the sections should be fitted tightly together, and as little of their outside as possible exposed to the bees. The honey should be removed promptly, when sealed, before the bees have time to do much gluing.

Not only is it necessary that the sections should be removed early after they are filled, on account of the propolis brought by the bees, but it is also useful to remove the other contrivances employed, such as excluding honey-boards, separators or fences, so they may not be so daubed with the sticky substance as to become useless. Besides, in the present condition of progressive bee-culture and close competition, it is necessary to have honey which does not show any travel stains from the bees and the whitest honey is often soiled in appearance by the travel of the bees over it. An experienced eye will easily detect combs which have been left on the hive too long and have become travel-stained.

735. 6th. Securing Sealed comb Honey. For this purpose no more cases should be given than the bees are likely 
to fill. The second case should not be added until the first is half filled. The outside sections, being the last filled, may not be sealed at all, unless the bees are somewhat crowded for room. To remedy this, many bee-keepers are in the habit of "tiering out," instead of "tiering up;" that is, they put the empty or unfinished sections in the middle of the super, removing all that are filled, or placing them on the outside. This is an increase of labor, but some hold that it pays.

There is quite a difference in localities and seasons, as to the time of adding supers. Much depends on the yield of honey. Each Apiarist must judge of the probabilities, not only of ordinary seasons, but of extraordinary seasons as well and this knowledge can be gained only by practice. To show what may be expected in a good location, we will quote a passage from Dr. Miller's "Forty Years Among the Bees":

"On the whole, there is a mixture of judgment and guesswork as to putting on supers after the first. Perhaps the nearest to a general rule in the matter is to give a second super when the first is half filled. If, however, honey seems to be coming in slowly, or if the colony is not strong, and the bees seem to have plenty of room in the super, no second super is given, although the one already there may be filled with honey. On the other hand, if honey seems to be coming with a rush, and the bees seem crowded for room, a second super may be given, although there is very little honey in the first. These same conditions continued, a third super may be given when the second is only fairly started and the first not half full, and before the first super is ready to take off there may be four or five supers on the hive. In the year 1897-a remarkably prosperous year-there were at one time in the Wilson apiary an average of four supers to each colony, some colonies with less than four and some with more, and not a finisled super in the lot. The supers were all well filled with bees, and although I took some chances as to unfinished work, $I$ feel pretty sure that if I had allowed less room it would have been at a loss. But that was a very exceptional case."

Instead of removing the filled sections from the center of 
the super as by the method above mentioned, Dr. Miller removes the entire super when nearly filled, without waiting for the outside sections to be sealed, and the unfinished sections of several supers are put together and given back to some strong eolony to be finished by them. This avoids mueh handling of sections on the hive.

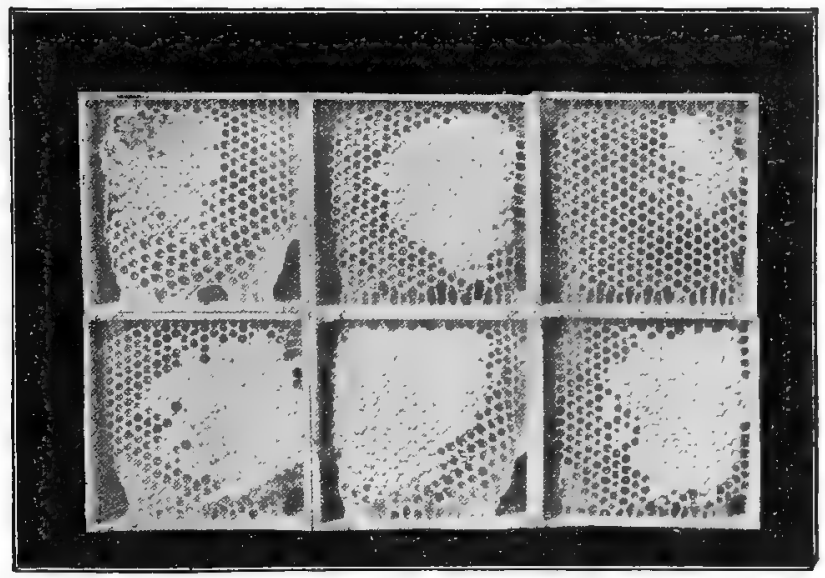

Fig. 197.

UNFINISHED SECTIONS THAT ARE NOT MARKETARLE.

(Forty Years Among the Bees.)

736. It often happens that the bees fasten the comb only at the top of the section. For safe transportation it is very important that it should be fastened to the section wall, all around. To secure this, not only do Apiarists use comb foundation, but some have devised "reversible" section cases. When the sections are turned over, the empty space now at the top, seems unnatural to the bees, and they hasten to fill it, making a solid comb in the section. But this is not the only method.

"Years ago my seetions were always filled so full by the bees, that they carried very securely in transportation. Afterwards I 
began to have trouble from combs breaking down. It was due, perhaps, mainly to the bees having too much surplus room. Some sections would be filled with a nice comb of honey, not very strongly attached at the top, very little at the side, and not at all at the bottom. Aside from depending upon crowding the bees to make them fill the sections, I wanted a plan whereby I could be sure of having the sections fastened at the bottom as well as at the top. I tried to take partly filled sections out of the supers and reversing them, and went so far as to invent a reversible super. I abandoned this, however, and adopted the plan of putting a starter in the bottom as well as at the top of the section." ("A Year Among the Bees.")

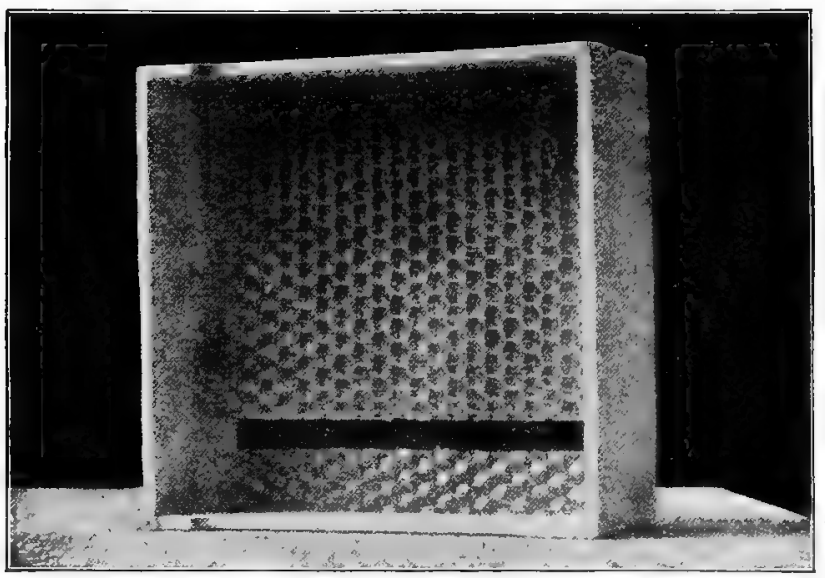

Fig. 198.

TOP AND BOTTOM STARTERS.

(Forty Years Among the Bees.)

Between the publication of "A Year Among the Bees," and that of "Forty Years Aniong the Bees," both by the same author, Doctor C. C. Miller had seventeen years of practice of comb honey production, on a very large scale and with extraordinary results. The reader will readily agree with us that his opinion has great value. He insists that top and 
bottom starters as per Fig. 198 give the best results, the bottom starter being five-eighths of an inch wide, with a space of only a quarter inch between the two. This allows of the slight stretching usual in comb foundation.

737. It is held by some Apiarists that the fence with plain sections, fig. 193, secures better filled combs than the ordinary section with insets and separators, fig. 188. But when the bees are supplied with foundation in full or nearly full sheets, the advantage seems to be on the side of the separator. The

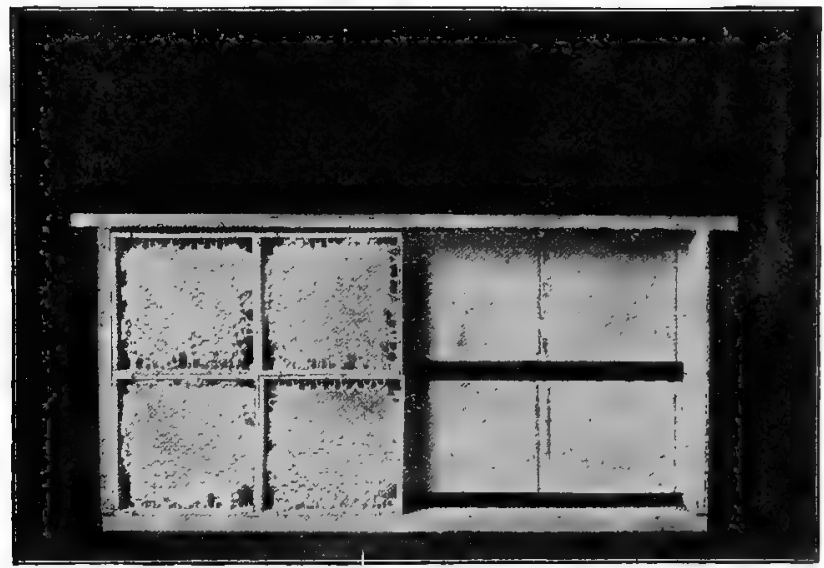

Fig. 199.

WIDF FRAME, HALF FIZLED.

(Forty Years Among the Bees,)

fullest sections that the writer has seen were secured by splitting the sections exactly through the center and placing the sheet of foundation so that it was eaught between the two halves of the section and fastened all around. This is the English method.

Miss Emma Wilson, Doctor Miller's able sister-in-law, who has for many years managed a large number of colonies for comb honey says: 
"I can pick just as well filled sections among those that have insets as among the plain fence sections, and $I$ can find as many ill-filled sections among the latter as among the former. But I much prefer the sections with inset to the plain, because when handling them, I am more likely to damage the cappings of the honey in the plain sections, and the sections are also more likely to topple over while being fixed for market."

Mr. Frank Rauchfuss, the Secretary of the Colorado Honey Producers, handling ten to twenty carloads of honey annually for his stockholders, said: "In selling honey to our Eastern

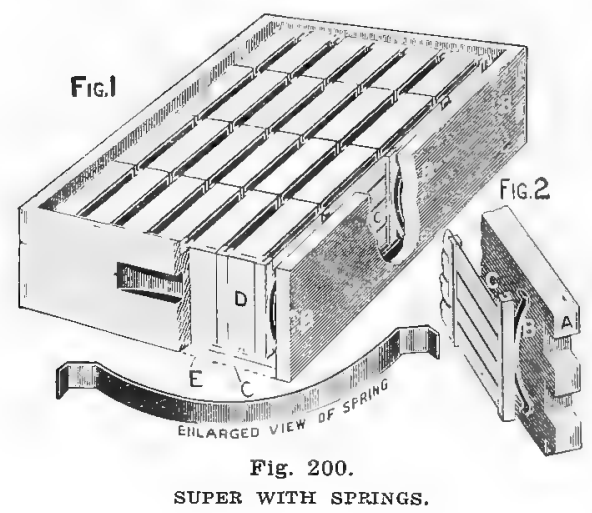

trade we found that they were not so willing to handle honey in plain sections as in the standard sections."

We will now consider a few of the rarious cases used in the production of comb honey.

838. The deep wide frames (fig. 199), have the decided advantage of allowing the Apiarist to use sections in a full size upper story. In linited comb honey production, they can probably be used with satisfaction, especially with the eight or ten frame Langstroth hive.

739. The half-story comb honey supers, figs. 200 and 201 , are preferable to the full story wide frames. A full story is 
often too large for surplus and two half stories will always be found more easily handled and more evenly filled, especially if given only when needed. Many styles are made, but the leading ones are with bottom and side slats enclosing the sections and with springs crowding them together, an improvement on the Oliver Foster method described in a previous edition of this work, fig. 200.

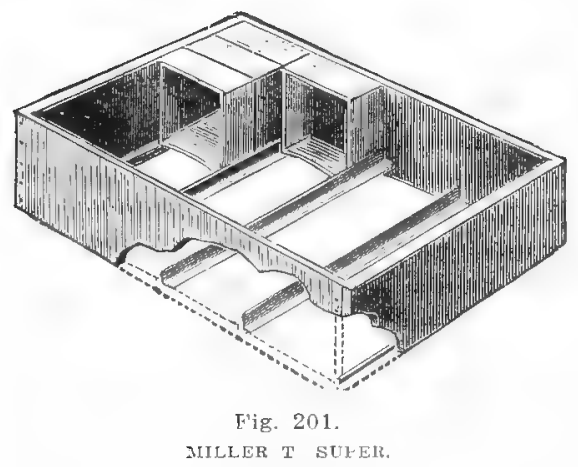

\%40. Mr. C. C. Miller places his sections in super's without top or bottom, three-eighths of an inch deeper than the sections. To support the sections in these boxes he nails, under both ends, a strip of tin, which projects one-fourth inch inside. Strips of tin, bent in the form of a $\perp$ are supported across the box, by six small pieces of sheet iron nailed at regular intervals, under the sides of the box. The sections rest on these $\mathbf{T}$ 's, and on the end strips. These supers holding 28 or 32 sections, can be piled upon one another, leaving a bee space between them. The only objection that we have ever heard offered to the $\mathrm{T}$ super, as the Miller super is called, is the danger of the bees propolizing the exposed parts of the section. In the supers which furnish slats for the support of the sections, there is nothing exposed but the edges of a part of each section. Otherwise the Miller plan seems to bring the sections in closer proximity to each other. But the above men- 
tioned plans are all good and the Apiarist is to decide for himself which suits his taste best.

741. There are a few considerations worthy of notice, in the raising of comb honey, which were advanced years ago, by Oliver Foster. We quote from his pamphlet, now out of print:

"There should be free communication between the sections in every direction. They should have deep slots on all 8 edges as shown in Fig. 202 so that bees can pass freely over the combs from end to end of the case, as well as from side to side, and from top to bottom."

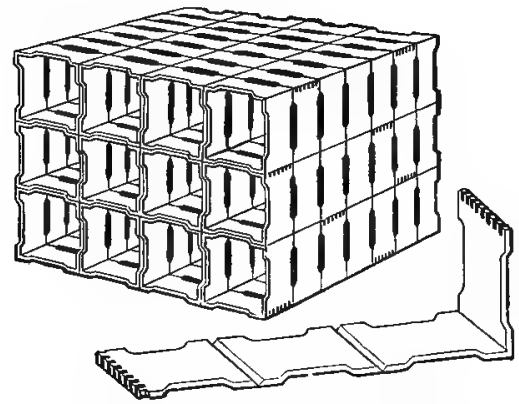

Fig. 202.

OPEN SECTIONS.

(From "How to Raise Comb Honey.")

"You may not appreciate the importanee of this until you have tried them.

"When we take into consideration that the object on the part of the bees, in storing up honey in Summer, is to have it accessible for Winter consumption, and that in Winter, the bees collect in a round ball, as nearly as possible, in a semi-torpid state with but little if any motion, except that gradual moving of bees from the center to the surface and from the surface to the eenter of this ball, we may imagine how unwelcome it is to them to be obliged to divide their stores between four separate apartments, each of which is four inches square and twelve inches long, with no communication between these apartments." 
742. Although Mr. Foster's methods and implements have been improved upon in the past twenty years, the ideas expressed above are original and correct and it is necessary that we should consider them. The improvements which go towards a more comfortable situation for the bees while working in the supers are sure to be in the line of progress. Separators are needed to secure straight combs but the less we will have of them, the better for our success. The fence, the faults of which we have shown, is very certainly praised and used because it gives a more thorough passage from one story to another, since it gives an opening along the entire length of the section.

743. For the same reason of comfort to the bees and also for ease of manipulation, it is advisable to abstain from using the queen excluder, if the A piarist finds that he can get along without it. These implements are in the way for the travel of the bees over the combs, for the ventilation, and they are also much in the way of the Apiarist.

744. So in accepting new improvements, we should at all times remember that simplicity in the implements makes for greater success, not only because it is an economy of money, but because our bees will feel better, fare better and swarm less if not hampered with obstructions.

745. All improvements that are made must be based on a full consideration of the instinets of the bees. Like Mr. Hutehinson ("Production of Comb-Honey" p. 18), we "have seen bees sulk for days during a good honey flow, simply because the present condition of things was not to their liking." You should make your bees feel as natural and as much "at home" as possible.

\section{Extracted Honey.}

846. To separate the honey from the wax, the bee-keepers of old used to melt or break the comb and drain the lioney out. Beeswax, as a sweet-scented luminiferous substance, far 
superior to oils or the crude grease of animals, was greatly appreciated by the priests, and placed among the best offerings required to please the gods. The custom of offering wax, or wax candles, continued to this day by some churches, especially by the Greek and Roman Catholic churches, caused for centuries the levy of heavy taxes, payable in beeswax, in countries where the inhabitants kept bees. Some countries, in Europe, had to pay to the church, every year, several hundred thousand pounds of beeswax. Such taxes compelled the beekeepers to separate the honey from the wax with as little waste as possible.

Different grades of honey were harvested by the careful Apiarists. The light-colored combs produced a light-colored and pure honey; the combs which had contained brood produced turbid honey of inferior quality.

$\boldsymbol{\gamma 1 \%}$. These primitive methods were afterwards greatly ameliorated, as for instance, in the French province of Gatinais, where the bee-keepers used the heat of the sun to melt the combs, and separate the honey from the melted wax. The choice honey obtained in Gatinais, from the sainfoin, cannot be excelled by our best extracted clover honey, as to color and taste, and it is sold in Paris altogether.

Owing to these causes, strained honey, of different grades, was a staple in Europe. But the demand being ahead of the supply, especially when the season was unfavorable for bees, Europe imported strained honey from Chili, and Cuba, and lately, extracted honey from California.

7 18. These causes did not exist in this country. Bees were scarce here at first. The American settlers had too much work on hand to eare much for bees. The few who owned a limited number of colonies, brimstoned one of them occasionally, and consumed the honey at home. The more extensive bee owners could sell some broken combs to their neighbors, or a few pounds of strained honey to the druggist, who was not very hard to please, being accustomed to buy Cuba honey, harvested with the most slovenly carelessness. By 
and by, however, owing to very favorable conditions, the wild woods swarmed with bees in the "hollow trees," and the beehunter made his appearance. Thousands of trees fell under his ax, to yield the sweets that they contained. Bee-hunting became an occupation in some of our forests. The method followed to find the colonies established in hollow trees, was to place a bait of honey in some open spot, attracting the bees by burning a little of the comb. When the bees had formed a bee-line from the honey to their abode, a new baiting place was

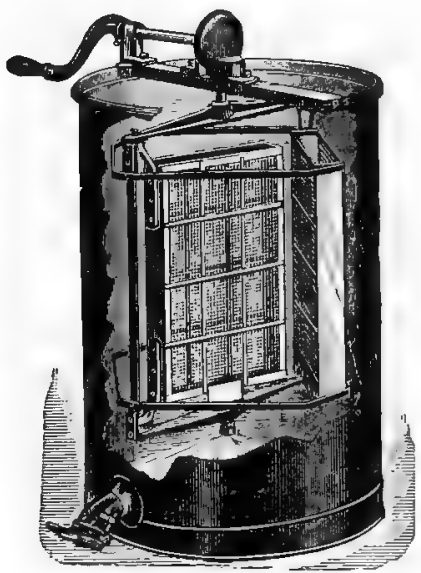

Fig. 203.

COWAN HONEY EXTRACTOR.

started in a diagonal position to the first. The meeting place of both lines was of course the spot occupied by the swarm.

This rough-and-ready bee-keeping, or rather bee-killing, produced comparatively large quantities of honey; but, as this honey was nearly always badly broken up and mixed with pollen, dead bees, and rotten wood, it became customary to boil the honey, so as to force the impurities and the wax to rise on top with the seum. Hence the cheap, liquid, dirty and 
opaque strained honey, dark in color and strong in taste. $\overline{\mathrm{B} y}$ the side of this unwholesome article, a little fancy comb honey was sold, that led to a national preference for comb honey.

But in view of the cost of comb to the bees (223), in honey, time and labor, it was earnestly desired by progressive beekeepers. especially after the invention of the movable frames, that some process be devised to empty the honey out of the combs without damaging the latter, so that they conld be roturned to the bees to be filled again and again.

719. In 1865 the late Major de Hruschka, of Dolo, near Venice, Italy, invented "Il Smelatore," THE HONEY EXTRACTOR.

It happened in this wise: He had given to his son, a small piece of comb honey, on a plate. The boy put the plate in his basket, and swung the basket around him, like a sling. Hruschka noticed that some honey had been drained out by the motion, and conciuded that combs could be emptied by centrifugal force.

This invention was hailed, in the whole bee-keeping world, as equal to, and the complement of, the invention of movable frames; and it fully deserved this honor.

750. As soon as we heard of the discovery, we had a machine made. It was not so elegant as those which are now offered by our manufacturers. It was a bulky and cumbersome affair; four feet in diameter and three feet high; yet it worked to our satisfaction, and we became convinced, by actual trial, of the great gain which could be obtained,-by returning the empty combs to the bees.

751. Let us say here, that the profit was greater than we had anticipated; but we, together with a great many others,. first committed the fault of extracting, before the honey was altogether ripened by evaporation. Like "Novice" who thought of emptying his eistern to put the overflow of his extracted honey, we had to go to town again and again, for jars and barrels, to lodge our crop. But experience taught us that we cannot get a good merchantable article, unless the honey is ripe. 
Plate 26.

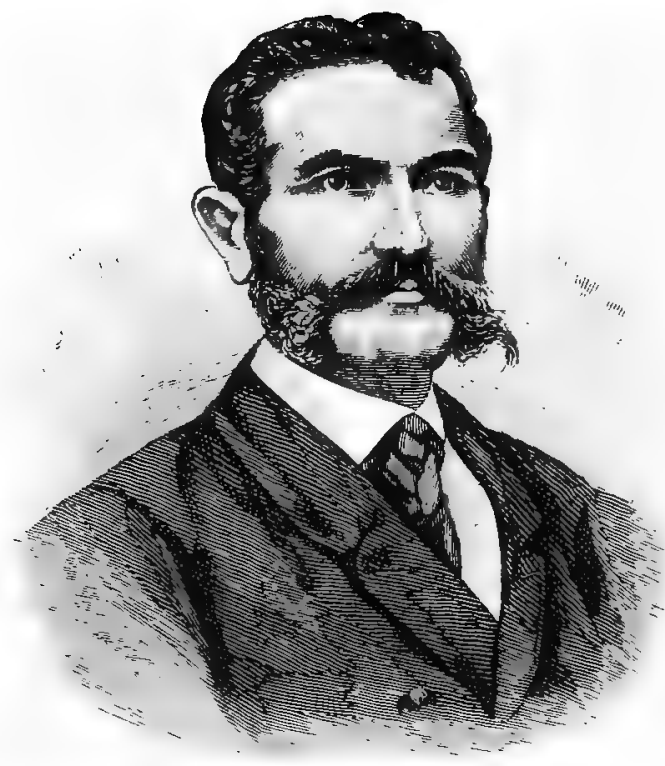

FRANCESCO DI HRUSCHKA,

Inventor of the Honey Extractor.

This Apiarist is mentioned page 454. 
752. If we give to bees empty combs, to store their honey, we will find, by comparing the products of colonies who have to build their combs, with those of colonies who always have empty combs to fill, that these last produce at least twice as much as the others.

A little consideration will readily show, to the intelligent bee-keeper, the great advantages given to the bees by furnishing them with a full supply of empty combs. To illustrate all these advantages, let us compare two colonies of bees, of equal strength, at the beginning of the honey season; one with empty boxes, the other with empty comb in the boxes.

The two colonies have been breeding plentifully, and harvesting a large quantity of pollen, and a little honey, for several weeks past. The brood chamber is full from top to bottom. After perhaps one rainy day, the honey crop begins. The bees that have been given empty combs can go right up in them, and begin storing, as fast as they bring their honeyfrom the fields. Not a minute is lost; and as they have plenty of storing room, there is no need of crowding the queen out of her breeding cells.

In the other hive, there is indeed plenty of empty space in the upper story; but before it can be put to any use, it has to be first partly filled with combs. Before a half day is over, the greater part of the bees have harvested, and brought, to their newly-hatched companions, all the honey that the latter can possibly hold in their sacks. What shall they do with the surplus? They have to go into that upper story, and hang there (205) for hours, waiting for the honey to be transformed into beeswax, by the wonderful action of these admirable little stomachs, whose work man cannot imitate, despite his science. But, while this slow transformation is going on, while the small scales of wax are emerging from under the rings of the abdomen (201) of each industrious little worker; while their sisters are slowly but busily carrying, moulding and arranging the warm little pieces of wax in their respective places, in order to build the frail comb (206); 
during all this time, the honey is flowing in the blossoms, and the other colony is fast increasing its supply of sweets. Meanwhile, the few bees, which have found a place for their load, go back after more, and, finding no room, they watch for the appearance of each hatching bee, from its cell, and at once fill that cell with honey; thus depriving the queen of her breedingroom, and forcing her to remain idle, at a time when she should be laying most busily.

The loss is therefore treble. First, this colony loses the present work of all the bees which have to remain inside to lelp make wax. Secondly, it loses the honey of which this wax is made. Thirdly, it loses the production of thousands of workers, by depriving the queen of her breeding-room, in the brood-chamber. All this, for what purpose? To enable the owner to eat his honey with the wax; when, as every one well knows, wax is tasteless and indigestible.

One word more in regard to the loss of production, by the crowding of the queen. This loss is two-fold in itself. When the bees find that the queen is crowded out of her breedingroom, they become more readily induced to make preparations for swarming (406).

It is then that a large number of young bees would be necessary to make up for the loss which the colony will sustain, in the departure of the swarm; and yet the diminished number of eggs laid produces exactly the reverse of the desired result.

There is perhaps a fourth item of loss, in failing to furnish empty combs to this colony, and that when the season is not very favorable. Many practical bee-keepers have noticed that, in rather unfarorable seasons, it is diffeult to induce bees to work in an empty surplus box, in which they would work readily if it were furnished with combs. It is a question which may remain doubtful, whether the bees do not sometimes, in such cases, remain idle for a day or two, rather than begin building comb in a box which they do not expect to be able to fill (\% $\mathbf{1 5})$. 
753. In view of the above facts, and after an experience of many years with the honey extractor, we urge beginners to produce extracted honey in preference to comb-honey, whenever they can sell it readily for half to two-thirds as much as comb honey. We have shown the advantages of its production to the bees; let us now show the advantages to the A piarist.

751. 1st. $\mathrm{He}$ can control, and take care of, a much greater number of colonies. The manipulations of an apiary, run for extracted honey, occupy less than one half of the time required for the production of comb-honey. Our largest combhoney producers acknowledge that one man cannot handle more than two hundred colonies successfully, when run for comb-honey, while as many as five hundred colonies, located

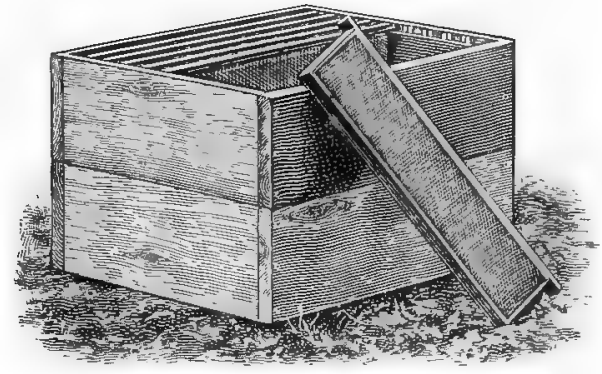

Fig. 204.

TWO HALF-STORY SUPERS FOR EXTRACTING.

in different apiaries (582), are managed successfully by one Apiarist, when run for extracted honey. During extracting time, of course, additional help is required, but this needs not be skilled labor, which is always hard to find.

755. 2d. By the production of extracted honey, the surplus combs are saved, and given to the bees at the opening of the following harvest. This virtually does away with natural swarming, and enables the bee-keeper to control the increase of his colonies to suit his desires. One of the most successful 
comb-honey producers, Mr. Manum, of Vermont, who sold some 15 tons of comb-honey in 1885, acknowledged to us, that with his management in the production of comb-honey, it was nearly impossible to control swarming.

856. The farmer, or merchant, who keeps only a few hives, to produce honey for his own use, will find it much preferable to produce extracted honey. With three colonies of bees and an extractor, in a very ordinary location, from 150 to 300 lbs. of honey can be produced on an average, every season.

757. For the production of extracted honey, we use half stories or cases (fig. 204) with frames 6 inches deep, and of the same length as the frames of the lower story. We have also used full-story supers, but only on standard Langstroth hives, and we decidedly prefer the half-story supers, for several reasons, after having used both kinds on a large scale for years.

758. The frames of the half-story supers are more easily handled when full, and the combs are less apt to break down from heat or handling. The half-story super is better suited for the use of an average colony, and in cool weather is more easily kept warm by the bees, than a full-story. Very strong colonies, in extraordinary seasons, can be readily accommodated with two and even three of these cases successively.

With the full-story supers, the queen and the bees are more apt to desert the lower story altogether, in poor honey seasons, and establish their brood-nest in the upper story, especially when the combs of the lower or brood chamber are old, and those above are new. The sole advantage of the full-story super is that the frames in it are exactly of the same size as those below, and can be interchanged with them if necessary; but with large hives it will nerer be required to use upper story combs for feeding, and even if the queen should breed in these shallow cases, at times, she is soon crowded out of them by the surplus honey.

759. The upper story frames are filled with comb founda- 
tion (6y4), or even with old worker combs, and can be used indefinitely, since the honey is extracted from them, and they are returned unbroken to the bees. We have now several thousands of these combs, some of which have already passed thirty or forty times through the extractor and are now as good as at first, nay, even better; for some, which were very dark, are lighter in color now, on account of the dark cells having been shavel by the honey knife and mended, by the bees, with new wax. Thiese supers are given to the bees, a few days previous to the opening of the honey crop.

The mat (353), and cloth (352), are removed and the upper story is placed immediately over the frames (fig. 72 ).

760. One great advantage of this style of supers, lies in the facility, with which the bees can reach the upper story from any comb, or from any part of a comb, either to deposit their honey or for ventilation, during lot weather. Bees show their preference for these large receptacles very decidedly. For comparison, let two or three wide frames (721)-filled with sections which are of more difficult ventilation and access -be placed in the center of one of these supers with some extracting frames on each side, all equally filled with strips of foundation, and the small sections (722) will be filled last almost in every instance, even although placed nearest to the center of the brood-nest.

Mr. Langstroth was the first to call the attention of Apiarists to the loss incurred by compelling bees to store the surplus honey in small receptacles. The bee-keeper cannot afford to sell honey stored in small sections, except at a considerable advance over its value in large frames. It is for this reason that some Apiarists have practiced producing comb honey in large frames, which has been sold in "ehunks." They find it pays, in some markets, although sold at a less price than honey in sections.

For extracting, a super as shallow as that used for onepound sections is not satisfactory. It requires too much handling, for the quantity of honey that may be stored in a 
frame only $4 \frac{1}{4}$ inches deep is inadequate when the extractor is used. The smallest super that we woud use on Langstroth hives is that with a $5 \frac{3}{8}$ inch side bar to the frame. The frames of our supers have a 6 -inch side bar.

761. Colonies, which do not have the breeding apartment nearly full of brood, honey and pollen, need not be supplied with supers till they show a marked progress. After the opening of the honey erop, which is very easily noticed by the greater activity of the bees and the whitening of the upper cells of their combs, a regular inspection of their progress is necessary. The season is short, but the daily yield is sometimes enormous.

762. Mr. A. Braun stated, in the Bienenzeitung, September, 1854, that he had a mammoth hive furnished with combs containing at least 184,230 cells, and placed on a platform scale, that its weight might readily be ascertained at stated periods. On the eighteenth of May it gained eighteen pounds and a half. On the eighteenth of June, a swarm weighing seven pounds issued from it, and the following day it gained over six pounds in weight. Ten days of abundant pasturage would enable such a colony to gather a large surplus, while five times the number of equally favorable opportunities would be of small avail to a feeble one.

Weights of colonies taken regularly by Swiss Apiarists show that twenty pounds a day of harvest is frequently gathered by strong colonies. A part of this amount is evaporated during the following night, according to the greater or less density of the nectar harvested $(\mathbf{2 4 9}, \mathbf{2 6 1})$.

The largest yield of extracted honey, ever harvested by the colonies of one apiary under our control, was 13,000 pounds in about fifty days, the most protracted honey crop we evel knew. This was harvested by eighty-seven colonies, making a daily average of three pounds a day per colony of evaporated honey. Such seasons are scarce.

As some colonies harvest much more than others, they need more attention. 
763. To secure the greatest possible amount of extracted honey, the colony should never be left without some empty comb.

As soon as the combs of one of these supers are about threefourths full, we put another super under the first, and sometimes a third under the second. All this without waiting for the honey to be sealed; but we never remove the honey, to extract it, until the crop is at an end, for we want to get our honey entirely ripened.

Honey is evaporated, or ripened, by the forced eirculation of air, eaused by the fanning of the bees through the hive, in connection with the great heat generated by them. As honey evaporates, it diminishes in volume, and as long as the bees continue their harvest, they constantly bring in unripened, or watery honey, which they store in the partly filled cells that eontain honey already evaporated. It is for this reason that unsealed honey, after the erop is over, is as ripe as honey sealed during the crop, and sometimes riper. If the crop is abundant, they often seal their combs too soon, and the honsy thus sealed may afterwards ferment in the cell and burst the capping.

\section{Extracted Honey.}

764. Some Apiarists extract the honey as fast as it is harvested by the bees, and afterwards ripen it artificially by exposing it to heat in open vessels. We do not like this method, and prefer to extract the whole crop at once. It is much more economical, for, with our system, one skilled man attends to as many as five or six apiaries during the honey crop, and extracts at leisure afterwards, with almost any kind of cheap help. Since honey now has to compete in price with the eheapest sweets, the question of economical production is not to be disregarded.

"He who produces at maximum cost will fail. He who produces at minimum cost will succeed."-(Jas. Heddon.) 
What proportion of water does fresh-gathered nectar contain? A number of observers have attempted to answer this question and have made experiments upon it. Great have been the differences and in some cases, persons who had made but one or two experiments attempted to make a positive assertion of a stated proportion. But no rule can be given. At times, the nectar is so very thin that it drops out of the cells like water if the combs are inverted or slightly inclined, when handled. At other times, the nectar has great consistency when

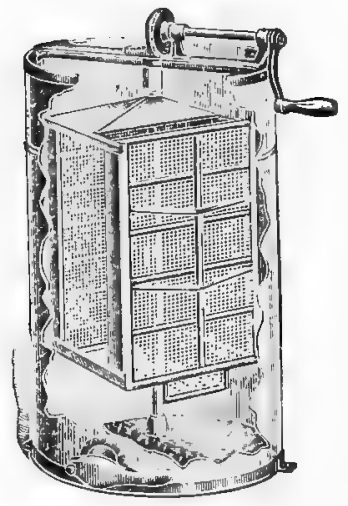

Fig. 205.

NOVICE HONEY EXTRACTCR.

first gathered. Some European Apiarists hold that heather honey can never be extracted, because of its density almost immediately after it is harvested. The greater or less density of honey at the time it is brought in from the field depends on the kind of blossom from which it is taken, on the condition of the soil at that time, whether dry or wet, and on atmospheric conditions. The most watery honey is perhaps harvested from such source as the basswood, after rainy weather and when the atmosphere is heavily laden with electricity and moisture; while plants which grow in dry sandy soils, like 
some varieties of heather or the mountain sage, will furnish, in dry weather, honey that is ripe almost as soon as gathered.

765. As some colonies do not begin work in the supers until very late, and do not fill all the space given them, the surplus of other colonies can be given them in such a manner that all will be equally filled. This can be done without brushing the bees off (185).

The equalizing of empty.combs in the surplus stories of different colonies, towards the end of the crop, will save time in extracting, as the supers will be found more evenly full. The giving of a few combs of honey to a colony that has not yet begun work in the supers also acts as an inducement, and gives the bees new energy.

HARVESTING.

766. The extracting, to be done swiftly, requires the work of four persons: three men and a boy. This work is done at a time when the bees have ceased to harvest honey, and the greatest care has to be exercised not to leave any honey within the reach of robber bees. The work of opening the hives, removing the combs and brushing off the bees, must be done quietly, but swiftly and carefully. The receptacles for combs should each have a cover, and the hive should be closed and its entrance reduced, as promptly as possible. In this way, there is not the least danger of robbing; but if robbing is once begun, by some carelessness or forgetfulness of the operator, the work has to be stopped until it has subsided.

r67. The utensils needed for neat extracting on a large scale are: In the apiary-a good smoker (382), one or two brushes made of asparagus tops, or some other light fibrous material, a wood chisel to loosen the cases, two tin pans, deseribed farther on (F/0), one comb bucket, and two strong "robber cloths."

768. The "robber cloths," so named by Dr. C. C. Miller, 
are used to cover the cases to keep away robbers. They ar made of very coarse cloth or gunny, about a yard square.

"Take two pieces of lath, each about as long as the hive, and lay one upon the other, with one edge of the cloth between them. The cloth is longer than the lath, allowing 6 inches or more of the cloth to project at each end of the lath. Now nail the laths together with $1 \frac{1 / 2}{2}$ inch wire nails, elinching them. Scrve the opposite end the same way, and the robber cloth

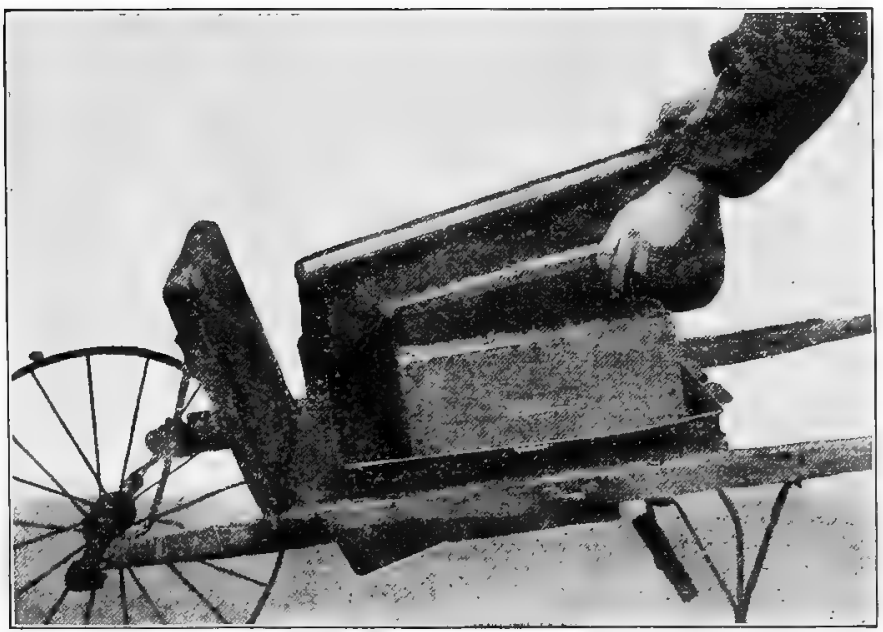

Fig. 206.

SUPER WITH ROBBER CLOTH AND PAN.

is complete. You can take hold of the lath with one hand, lift the cloth from a hive or super, and with a quick throw, in. stantly cover up again your hive or super perfectly bee tight." ("A Year Among the Bees," 1886.)

The operator opens a hive, removes the super, places it in a tin pan, and covers it with a robber cloth. He then examines the brood chamber, from which one or two combs may be removed if advisable. We nsually leave all the honey in 
the lower story, unless the bees are crowded out of breeding room, which will not happen, if they had plenty of room above.

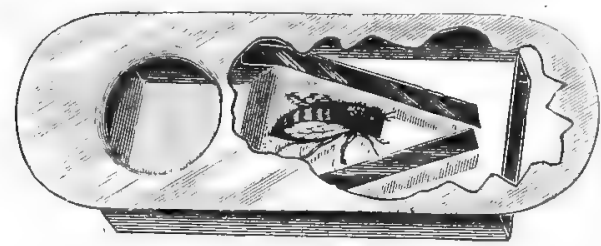

Fig. 207.

PORTER'S BEE-ESCAPE.

r69. The reninval of the bees from the supers, inay be simplified by the bee-escape (ig. 207). This implement is placed in a board $1 / 2$ inch in thickness, and of the size of the top of the brood-chamber: and so cleated that, when placed between the brood chamber and the super, there will be a full bee-space both above and below it. The hole for the escape should be made near the center of the board by boring two $1 \frac{1 / 8}{8}$ inch holes, $2 \frac{1}{2}$ inches from center to center and cutting the wood between them. One escape to the board is sufficient. If there is no brood, or queen, in the super, and the escape is put on the day before, the bees will practically be all out the next mornin:, and sometimes within six hours after it has been placed on the hive.

The only objection to the bee escapes is that they must be placed on the hives the day previous, and this necessitates an extra trip, when the bees are located in an out-apiary. Otherwise they are very useful, if not left on the hive through the heat of the day, when the exclusion of bees from the super might cause collapse of the combs, by lack of ventilation, in very hot weather.

770. In the honey house, there should be an extractor, a capping can (fig. 208), a honey knife, a funnel with sieve, a pail, a barrel, and two tin pans like those used in the apiary. Each person may be provided with a good enamel-cloth apron, and all the windows furnished with wire cloth netting, to allow the bees to escape (586). The tin pans above mentioned are shallow, in the shape of bread pans, large enough to receive one of the supers freely, to keep the leaking honey 
from daubing anything, or from attracting robbers (666). They are supplied with strong handles.

781. We have said that we do not usually take honey from the brood chamber, but in an emergency we sometimes extract even from combs containing brood. Sealed brood is not injured by the rotation but one should abstain from taking combs containing unsealed larve.

ry?. In the extracting room; a man uncaps the combs,

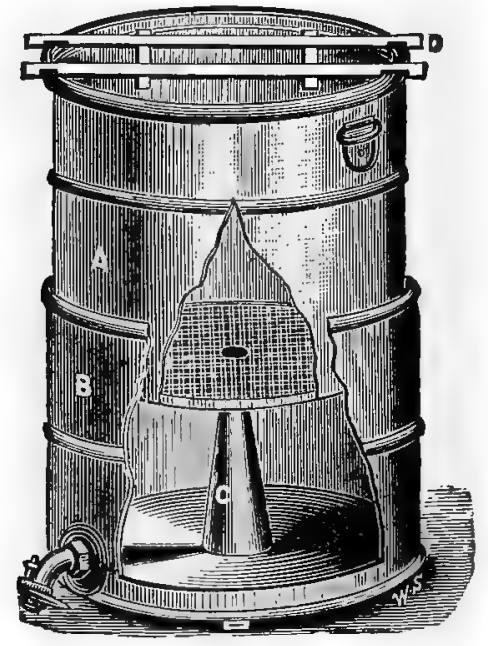

Fig. 208.

THE DADANT CAPPING-CAN.

as fast as they are brought. He stands before the cappingcan (fig. 208). The capping can is formed of a lower can B, 24 inches wide and 14 inches high with a slanting bottom, a faucet and a central pirot $C$. On this lower ean is placed another can A, 23 inches wide and 22 inches high, with a coarse wire cloth bottom resting at the center on the pivot $\mathrm{C}$. The upper can acts as a large sieve. On the top of it is placed a wooden frame D, notched, so as to fit on the edges of the 
ean. It is on this frame that the combs are uneapped, and the cappings fall in the sieve, where the honey drains out of them, into the lower ean. Our capping can is meant to hold the cappings of two days' extracting.

Manufacturers generally eall this implement "uncapping

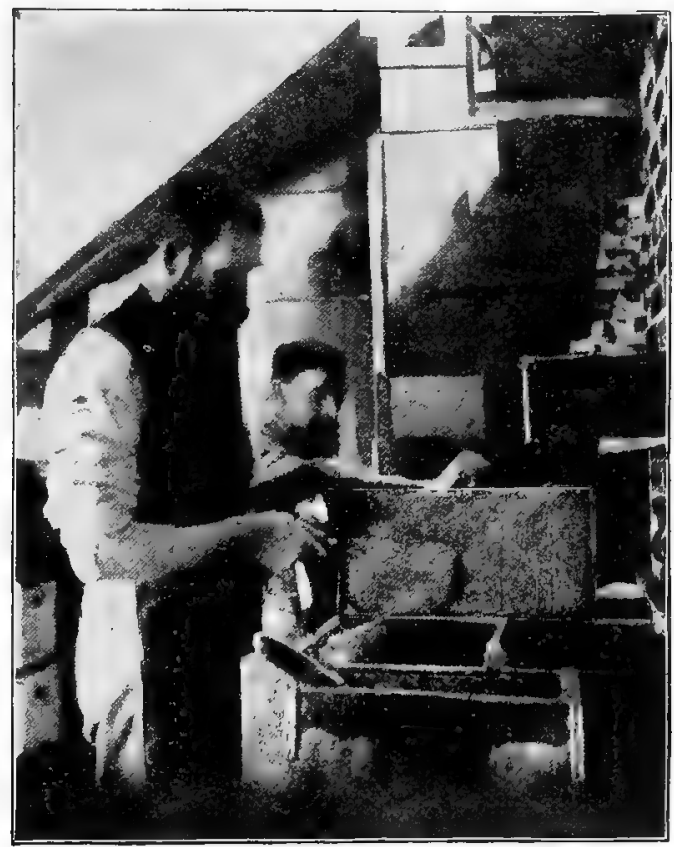

Fig. 209.

UNCAPPING AND EXTRACTING.

(From The American Bee Journal.)

ean," because it is used when uncapping. We prefer to calt it "capping can," because it receives the cappings.

7\%3. 'The all-metal extractors, of different makes, are the only ones now in use. Two-frame extractors are the most 
common, but we use four-frame extractors altogether, one in each apiary. These extractors accommodate eight half-story frames.

774. In regard to the honey or uncapping knife, justice compels us to say that, so far, to our knowledge, there is but one which is really practical, the Bingham honey knife. This knife does away with the annoyance of having the eappings stick to the comb again, after having been shaved off, because it is made with a bevel, which causes the shaver to hold it in a slanting position, so that the cappings cannot stick to the comb again, unless purposely allowed to do so.

A machine has been devisea to perforate the cells instead of uncapping them. There are numerous objections to such an instrument. It does not always open the cells sufficiently to allow the honey to drain out, it wastes the eappings which

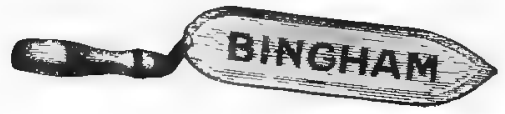

Fig. 210.

THE BINGHAM KNNTE.

would otherwise furnish beeswax enough to pay for the entire cost of extracting and it causes the little bits of wax to float in the honey, increasing the amount of scum that may rise to the top. We warn our readers against any such contrivance. We discarded them years ago, after trial.

As fast as the combs are uncapped on both sides, they are put into the extractor, which may be turned by a boy. Care should be taken that the combs, that are placed opposite one another, be of nearly equal weight, as the unequal weight causes the extractor to swing right and left, fatiguing the boy and injuring the machine.

ry5. A quiet, regular motion is all that is necessary tc throw the honey out, and, in warm weather, it fairly rains against the sides of the can with a noise similar to that of a shower on a tin roof. 
7r6. Now is the time to invite the neighbors and their children to come to see the fun, and taste the golden nectar. Aside from the pleasure of making everybody happy, the present of a few pounds of honey proves an inducement to its use, and an advertisement for the producer. Extractingday should always be understood to mean "free honey to all visitors." Let them visit the honey-room, and if the ladies get their dresses a little daubed while peeping in the extractor, they will soon find out that honey does not stain like grease, but will wash off in warm water.

ry. After the combs are extracted on one side, they are turned over and extracted on the other. Mr. Stanley, of

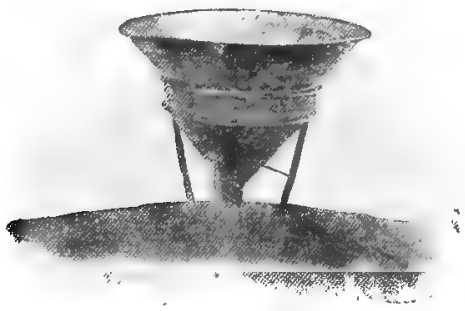

Fig. 211.

LARGE FUNNEL AND SIEVE.

New York, invented an extractor in which the combs are turned over by simply reversing the motion of the gear. Similar extractors were introduced into England, by $\mathrm{Mr}$. Cowan, several years ago.

The Cowan extractors, fig. 203, have been improved upon again and again, until now most of the machines are made so that the combs may be reversed without slacking perceptibly or reversing the motion. The only fault of the reversing extractors is their large size, which renders them rather cumbersome.

yry. The extractor is fastened on a high platform, so that the honey pail can be put under the faucet. A barrel is in readiness, with the large funnel and sieve over it. This 
sieve should be large enough to take a pailful of honey, so as to cause no delay.

A mark is made on the barrel, with a crayon, or chalk, as each pailful is poured in. In this way we know when the barrel is full, without having to gauge it, and we avoid having the honey run over and waste.

The latest method is to have a large tank instead of a barrel to receive the honey. The tank is intended to ripen the honey and is usually made of galvanized iron. The writer has seen tanks of this kind out in the open air, in California, where it never rains during the summer season. Honey that is allowed to remain in an open tank with only a light eloth cver it, in a hot room, will often ripen considerably by evaporation. It is a good method. But as we have a number of out-apiaries, we find it more convenient to barrel our honey, especially as we always wait till the bees have ripened the honey before extracting it. Not only have we barreled our honey for years, but very extensive apiarists around us have done the same, among whom we will eite E. J. Baxter of Nauvoo, Illinois, who produces a number of tons of extracted honey every season. The honey must be very ripe when hatvested and the barrels, if used in preference to tanks, must be of the proper kind and quality. (829.)

779. We would advise beginners, who extract for the first time, to go slowly and carefully. A little care, besides saving time, will save the waste of several pounds of honey, and make things more comfortable; for a pound of honey wasted goes a great way towards making everything sticky and dirty. If a splendid crop and neat work are pleasurable, a daubed honey-room and cross bees in the apiary irritate both the Apiarist and his assistants, who soon become sick of the work. When things are rightly managed, the work is so delightful that more help can be found than is needed.

780. Of all manipulations, extracting is that which requires the greatest precautions against robbing (664). Carefully avoid all unnecessary exposure of comb or honey. Rob- 
- bers not only annoy the Apiarist, but cause the bees to get angry, and to sting:

y81. All the cases, when extracted, are piled up on an oil-cloth carpet, till the day's work is done. The combs are not put back into the hive before evening, at sundown; to prevent too much excitement in the apiary. In half an hour, every hand helping, the whole number is distributed on the hives; though we may have extracted as much as three thousand pounds in a day.

There are seasons, in which a continuation of the honey crop, permits returning the combs, as fast as they are extracted. In such seasons it causes no excitement, and is much more convenient.

782. Within two or three days after extracting, the bees have sleaned the combs, and repaired them. But, to prevent the moths from injuring them, we keep them on the hives during the whole summer; the bees take care of them, and in the Winter, we pile up the cases, carefully closed, in cold rooms where the cold of Winter destroys the eggs of the moth (802).

In localities, where there are two or more distinct crops of honey, each crop should be harvested separately. Thus, we always extract the June crop in July, and the Fall crop in September.

Honcy production, with the above methods, is so successful that the problem for practical Apiarists is no longer, how to produce large erops of honey, but how to sell it $(\mathbf{8 3 9})$. Extracted honey can certainly be produced, at very low cost, and it can be truly said, that in the last fifty years, there has been more progress in bee-culture, than in any other branch of rural economy.

\%83. As the wax of the cappings amounts to a little more than one per cent. of the weight of the honey extracted, and as these cappings even after they are well drained, contain a large amount of honey fit to be converted into vinegar when separated from the cappings by washing, the expense of extracting is more than compensated: 


\section{CHAP'TER IVIII.}

\section{Diseases of Bees.}

784. Bees are subject to but few diseases that deserve special notice. We have said (626) that we consider diarrhoa as the result of an accumulation of fœces only, but Mr. Cheshire has examined some of the foces of diarrhœa, and found in some of them living organisms, which indicate that, sometimes, the distension of the abdomen is not caused by the vverloading of the intestines alone. These organisms, when better known, will probably explain some of the losses of bees, after Winter, and the Spring dwindling (659), which reduces so many colonies.

785. There is, however, a disease of bees which seems akin to diarrhoea and at times becomes epidemic. The bees do not discharge any excrements but their abdomens are distended with a fetid matter, they lose their hairs and assume a smooth black appearance. They are first noticed erawling at the top of the combs as if cold and numb, looking as if paralyzed in some of their limbs. This disease, which is rare, has yet been noticed in many countries and has been rariously named "bee-paralysis" in this country, "vertigo-dizziness" in Europe, "Mal de Mai" in France, "Mal de Maggio" in Italy, "Maikrankheit" in Germany. Cheshire has deseribed it under the name of Bacillus Gaytoni because he obtained the first simples of the disease from a Miss Gayton. Other English scientists have called it Bacillus depilis, which is much more appropriate, since the diseased bees generally lose their hairs during the progress of the malady. This disease was first considered by us as a sort of constipation which degenerated into a contagious infection, as it usually begins after a hard winter, but the fact that it exists in warm countries such as Florida, California, Italy, \&c., would indicate that cold 
weather is not the originating cause. The disease is not commonly dangerous, and does not seem to propagate itself from one colony to another, but in some seasons, during the month of May, it has caused great ravages in some apiaries. In the province of Ancone, Italy, during the years 1901-05, entire apiaries were depopulated just at the opening of the honey harvest by this strange malady. This is a disease of the adult bees and not of the brood.

Mr. O. O. Poppleton of Florida recommends the sprinkling of the bees and combs in the diseased hives, with powdered sulphur. But as this seems to stop the disease mainly ly destroying all the sick bees, and as it also destroys the unsealed brood unless this be removed, we do not recommend it. An Italian, Mr. A. Belluei of the province of Ancone, succeeded in entirely preventing the disease in his apiary, while his neighbors' bees were suffering heavily, by feeding them a preparation made by boiling lavender, garden ginger, rosemary, savory and other aromatic plants and flowers in wine mixed with honey. Since the wine was evidently added as a tonie but lost all its alcohol by boiling, we judge that it did but little good, unless it be from the tonic properties of the grape. He also added a very small quantity of salicylic acid, about cone per thousand, which would be ample. Until more positive experiments are made, we would recommend the use of a similar preparation, for the cure or prevention of this disease, which is not usually injurious.

\section{Fotr-Brooid.}

786. There are other unimportant diseases, which have not yet been studied, but all are nothing, when compared to the dreadful contagious malady, already known thousands of years ago* and commonly called foul-brood, because it shows

* As Aristotle (History of Animals, Book IX., Chap. 40) speaks of a disease which is accompanied by a disgusting smell of the hive, there is reason to believe that foul-brood was common more than two thousand years ago. 
its effects mainly by the dying of the brood, the contagion being transmitted through the food of the larvae.

787. Dr. G. F. White, of the Bureau of Animal Industry at Washington, has lately deseribed two kinds of foul brood, which he denominates "bacillus pluton," until lately popularly and commonly called "black brood," and "bacillus larvae," the more malignant kind, which is not so easily produced in cultures by bacteriologists, since Mr. White was unable to produce it in the common cultures, a bouillon made of beelarvae being necessary. The first he denominates "European foul-brood" because it was first described in Europe, the second "American foul-brood" because it was first described by himself in America, but both kinds evidently exist in either hemissphere. The name "bacillus" $\dagger$ means "a stick" and is applied to both diseases because the germs of the disease are imperceptible sticks which break suceessively into several parts, every one of which forms a colony of spores, that pass through divers shapes before developing into new bacilli. We can judge of the promptness of their reproduction, and of their minuteness, when we read in Cheshire, that a dead larva frequently contains as many as one billion of these spores.

788. Bacillus pluton, perhaps the "bacillus alvei" of Cheshire being the lesser of the two diseases will be described first. It has been quite fully mentioned by Dr. Phillips, in Circular No. 79 of the Bureau of Entomology, to which we refer the student. This disease has been quite prevalent in the United States since 1900 .

\section{DESCRIPTION OF BACILLUS PLUTON.}

The brood dies a little earlier than in the American foulbrood, a comparatively small pereentage of it being ever capped, the diseased larvae which are covered having sunken or perforated cappings. A small yellow spot near the head of the larva is the first sign, at death it turns yellow, then black. Some of the dead and dried larvae are removed by 
the bees, which is never the case with the other disease because of the sticky adherence of the dead matter to the cell wall. Decaying larvae that have died of this disease have no ropiness usually and cannot be stretched out in a string as with the other disease. There is very little odor from the dead larvae and when there is any, it does not resemble that of a "glue pot" which is characteristic of the more dangerous foul-brood. The odor more resembles that of soured brood.

The methods of treatment of the two diseases differ greatly and will be mentioned farther. For a more complete description of bacillus pluton, see "Bacteria of the Apiary," U. S. Bureau of Entomology, Technical Series No. 14, by G. F. White, Ph. D.

789. Bacillus larvae or foul-brood proper is a more malignant disease. It may be very clearly described.

DESCRIPTION OF MALIGNANT OR AMERICAN FOUL-BROOD.

"In most cases the larva is attacked when nearly ready to seal up. It turns slightly yellow, or grayish spots appear on it. It then seems to soften, settles down in the bottom of the cell, in a shapeless mass, at first white, yellow, or grayish in color, soon ehanging to brown. At this stage it becomes glutinous and ropy; then, after a varying length of time, owing to the weather, it dries up into a dark coffee-colored mass. Usually the bees make no attempt to clean out the infected cells, and they will sometimes fill them with honey, covering up this dried foul-brood matter at the bottom.

"Sometimes the larvae do not die until sealed over. We have been told that such may be easily detected by a sunken capping perforated by a 'pin-hole.' This is by no means invariably the case. Such larvae will often dry up entirely, without the cap being perforated or perceptibly sunken, although it usually becomes darker in color than those covering healthy larvae.

"The most fatal misapprehension has been in regard to the smell of the disease. In its first stages there is no perceptible smell, and it is not until the disease has made a considerable progress that any unusual smell would be noticed by most persons. In the last stages, when sometimes half or more of the 
cells in the hive are filled with rotten brood, the odor becomes sufficiently pronounced, but the nose is not to be relied on to decide whether a colony has foul brood or not. Long before it can be detected by the sense of smell, the colony is in a condition to communicate the disease to others.

The eye alone can be depended on, and it must bea sharp and

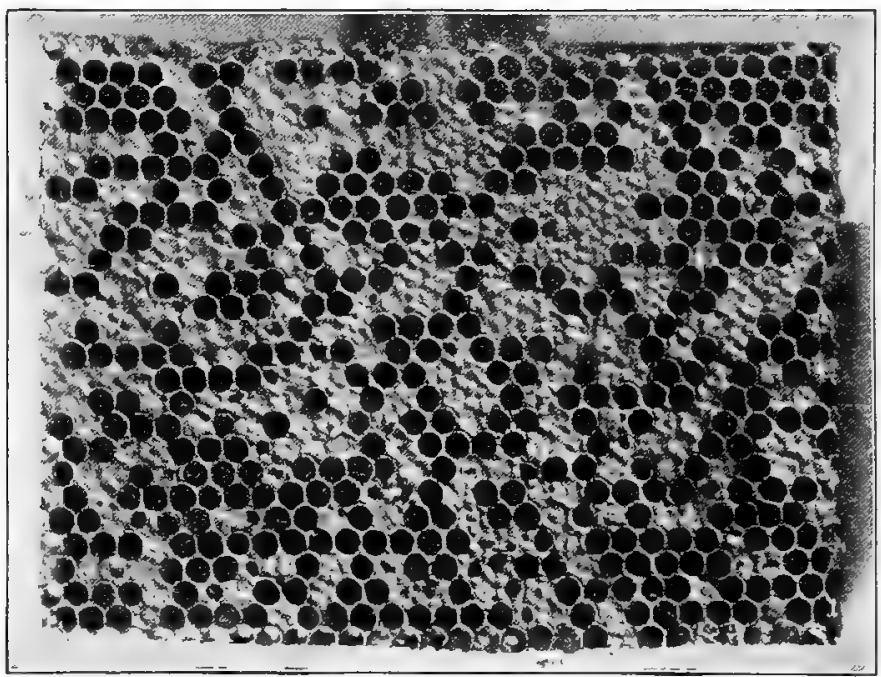

Fig. 212.

APPEARANCE OF FOULRBROOD.

(Courtesy of N. E. France.)

trained eye, too, if any headway is to be made in curing the disease." (J. A. Green, in "Gleanings," January, 1887.)

790. "Foul-brood can be detected in the Spring, either through an unusual spreading of the brood, resulting from an unnoticed previous infection, of an indefinite number of cells, which contain sick or dead larvae, or, if the disease is just beginning, by the presence among the brood, of sick or rotten larvae. The larvae die and rot either before or after sealing. It is only when the disease has lasted for some time, that the 
eappings are punctured, and that the brood has an offensive odor.' -(Bertrand, Revue Internationale d'Apiculture.)

Two things are important in the detection of the disease and on these we will insist, the ropiness and the glue-pot smell. The ropiness gave the idea of the French name of the disease "la loque" which means "rag, tatter." Evidently the Frenchman who gave it a name noticed that the dead larva, if you attempt to draw it out, comes in tatters, in rags, just as so much liquid India rubber. The glue-pot smell is also plain. These matters are important for there is a disease called "sac brood" which is far from being as dangerous as foulbrood and has most of the symptoms of foul-brood except the ropiness and smell (801).

791. CURE. For bacillus larvae, or American, ropy foulbrood, several methods of cure by antiseptics were more or less successful, in the hands of Hilbert, Chas. F. Muth and the noted Swiss apiarist, Bertrand. The latter quite successfully coped with the disease by the use of fumes of salicylic acid through a method given in our former editions. He and Cheshire also used, in the food of the diseased colonies, carbolic acid in the proportion of an ounce to 40 pounds of syrup. But the use of drugs, either in the food of the bees or in fumes requires too careful and persistent treatment to be safe in a general way. As an evidence of this, we will quote Mr. E. R. Root in the $A B C$ of Bee Culture some years ago:

"We did not get very satisfactory results by the use of drugs, when foul-brood visited our apiary some years ago. We did find, however, that they invariably held the disease in check; but as soon as their use was discontinued, the disease broke out again. While I do not advise one to place his sole dependence on drugs, as an auxiliary to the regular treatment, they might and probably would prove very efficacious. They would also be very useful in preventing the breaking out of the disease if all syrups fed to the bees were medicated." 
Some apiarists insist that the only way to get rid of ropy foul-brood is to entirely destroy the colonies suffering from it, hives, bees and combs, by fire. This is wanton waste and quite unnecessary.

In spite of Cheshire's assertion that no spores are to be found in the honey of diseased colonies, practice has sufficiently proven that Cheshire's assertions on that score were erroneous. The honey, in this disease, is the main source of transmission. Schirach, the man who discovered that a queen may be reared from any egg that would produce a worker (109), in his "Histoire Naturelle de la Reine Abeille" (The Hague, 1771), recommends the removal of all the combs, starving the bees for two days, then giving them fresh combs with a remedy composed of diluted honey with nutmeg and saffron.

792. Following this advice, D. A. Jones of Canada, and later, Wm. MeEvoy, then inspector of apiaries for the Province of Ontario, succeeded fully in the method which we here give and which is now recommended by all authorities, with slight variations. Mr. N. E. France, for a long time inspector of apiaries for Wisconsin and former General Manager of the National Beekeepers' Association, who has had a most extensive experience in the matter of foul-brood, gave the method in the following words:

MeEvoy treatment: "In the honey season, when the bees are gathering honey freely, remove the combs in the evening and shake the bees into their own hives; give them frames with comb-foundation starters and let them build comb for four days. The bees will make the starters into comb during the four days and store the diseased honey in them, which they took with them from the old comb. Then in the evening of the fourth day take out the new comb and give them comb foundation (full sheets) to work out, and then the cure will be complete. By this method of treatment all the tainted honey is removed from the bees before the full sheets of foundation are worked out. All the old foul-brood combs must be burned or carefully made into wax after they are removed from the hives, and all the new combs made out of the starters during the four days must be burned or made into wax on account of the 
Plate 27.

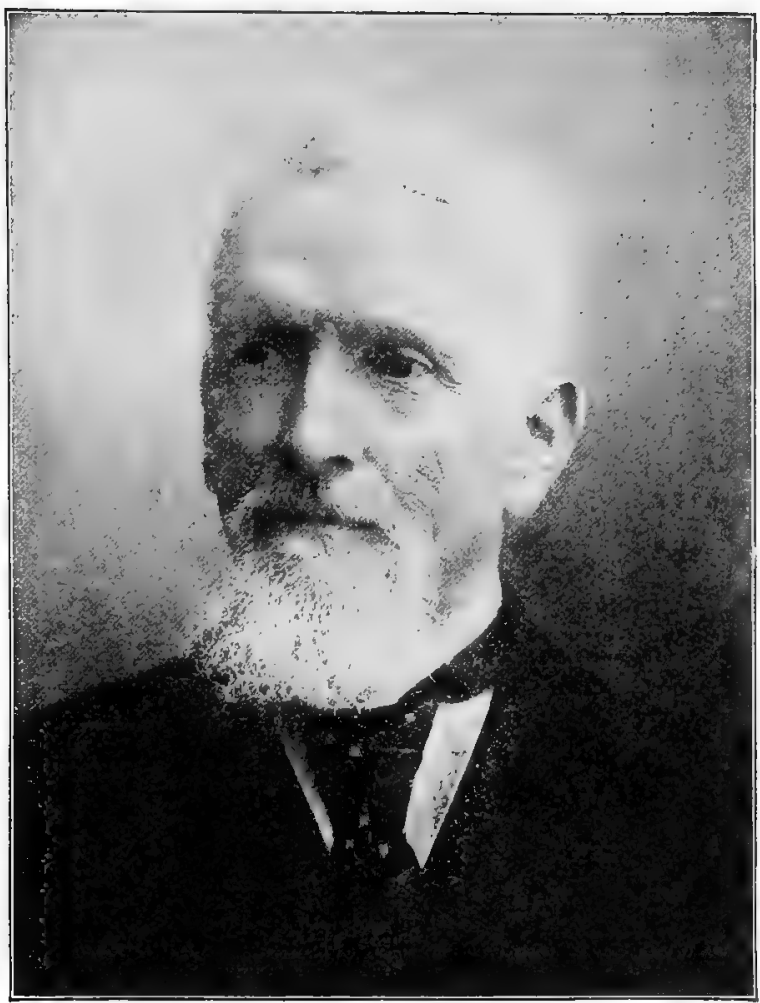

\section{EDOUARD BERTRAND,}

Author of "Conduite du Rucher."

Former publisher of the "Revue Internationale D'Apiculture." This writer is mentioned pages $114,146,420,474,476,477,478,479$, $485,486,487,530$, 

diseased honey that may be stored in them. All the curing or treating of the colonies should be done in the evening, so as not to have any robbing, or cause any of the bees from the diseased colonies to mix and go with healthy colonies. By doing all the work in the evening it gives the bees a chance to settle down nicely before morning and then there is no confusion or trouble.

"All the difference from the McEvoy treatment that I practice, I dig a pit on the level ground near the diseased apiary, and after getting a fire in the pit, such diseased combs, frames, etc., as are to be burned are burned in this pit in the evening and then the fresh earth from the pit returned to cover all from sight. . . . . I also cage the queens while the bees are on the strips of foundation."-(N. E. France, in Bulletin No. 2, Wisconsin Bee-Keeping.)

The above method is called the starvation method. That is to say, the bees are transferred and forced to build comb until they have used up all of the honey they had in their stomachs from the diseased hive.

This method is based on the theory, quite well proven, that honey is the main transmitter of the disease, in spite of Cheshires conclusions. Although the spores of the bacillus may not be very numerous in the honey, they are there in the very best position to spread the disease, since out of the honey and pollen is made the food which goes to the larva and it is the larva which suffers from the disease, in most cases. However, according to the bacteriologists who have made a study of the matter, the bacillus may also be found in the organs of the bees and of the queen, and some even assert that bees and queens (796) have been killed by the disease. MeEvoy asserts that it is not necessary to disinfect the hives that have contained the diseased colonies. In this he is sustained by many others, but in very virulent eases we believe it is advisable to do it. Although the BertrandCowan method has been used successfully we believe that the destruction of the combs of the diseased colonies will prove most effective. Such combs as contain brood should be burnt up, but those that contain no brood may as well be made into wax (858-862). Care should be taken 
when either honey or beeswax is heated to kill the germs of foul-brood-to keep the liquid at the boiling point for a period of about 15 minutes. Tests made by Dr. G. F. White, the bacteriologist whose studies have eaused such advance in the knowledge concerning bee diseases, show that from 10 to 15 minutes of boiling is required to destroy the germs. (Bulletin of the United States Bureau of Entomology, No. 92.)

793. TREATMENT OF BACILLUS PLUTON OR EUROPEAN FOUI-BROOD. This was customarily treated like American foul-brood, by removing all the combs containing honey or brood. But in 1905, E. W. Alexander of New York State, who had much trouble with this disease, found out that removing the queen for a certain length of time, returning her or preferably giving the bees another of Italian stock at the end of 10 to 22 days, or sometimes allowing them to rear another from her brood, usually conquered the disease. This indicates that the contagion is not so serious as that of bacillus larvae. Indeed, the most apparent point in the ease with which the cure may be performed lies in the fact that the dead larva does not become liquefied, but remains usually whole and may be carried out by the bees, who even suck the juices of the very young larvae when they die, as noted by Dr. C. C. Miller, who also fought this trouble in his apiary. So the bees clean up the cells and burnish them, if the disease is not too far advanced. Whenever all the diseased brood has disappeared the hive is judged safe for a new queen. Italian bees have the reputation of being much more immune to European foulbrood than the common blacks and it is always recommended to introduce a queen of this race.

794. It must be noted that, although this disease appears much less difficult to cure and less contagious than American foul-brood or bacillus larvae, yet it is much more persistent, coming back again and again when the disease is thought to have entirely disappeared. In numerous instances, entire apiaries have been depopulated by it. It should be closely watched. The number of days during which the colonies 
should be kept queenless depends upon its virulence. In mild cases, a period of ten days of queenlessness has proven sufficient, while in very bad cases, it has been necessary to keep a colony queenless until every cell of brood was hatched.

795. In the treatment of either American or European foulbrood, it is useless to treat weak colonies, or colonies that have become thoroughly infected. In extreme cases several of the diseased colonies may be united together before or during treatment. Weak colonies not only neglect their brood, but run the risk of being robbed, which would doubtless give the disease to the robbing colonies.

796. That queens may transmit the disease as stated (792) has been proven by Maurice Dadant who, in the treatment of European foul-brood, tried the experiment of giving queens from diseased colonies to entirely healthy hives, with the result of transmitting the disease in each case. But this may not be an invariable occurrence, as several apiarists reported having used the queens of diseased colonies without transmitting the contagion. Cheshire stated having found bacilli within the ovaries of queens of diseased colonies. Possibly the condition of the colony and its strength have much to do with the result. In unfavorable conditions, queens may transmit the disease.

797. Many inspectors and experienced apiarists assert that it is not necessary to disinfect the hives in either disease; that the removal of the combs containing honey and depriving of the bees of food is entirely sufficient in the treatment of American foul-brood. We believe this correct in European foul-brood. But in American foul-brood the disease is much more positively eradicated if we thoroughly disinfect every part of the hive. It is not a tedious job. Some advise the painting of coal oil upon the inside of the hives, piling them up one upon another and touching a match to the pile, extinguishing the fire as soon as the walls have been singed. Our method is better, as we have had experience with this disease and have completely eradicated it, since the previous edition of this work was published. Here it is: 
798. Transfer the bees of a diseased colony to a new hive body as mentioned in paragraph 792, being careful that none of their bees go to a neighboring colony. If necessary the colonies on each side may be covered with a cloth during the operation. Then, with a painter's or tinner's blow-toreh, singe every part of that empty brood chamber and transfer the next diseased colony into it.

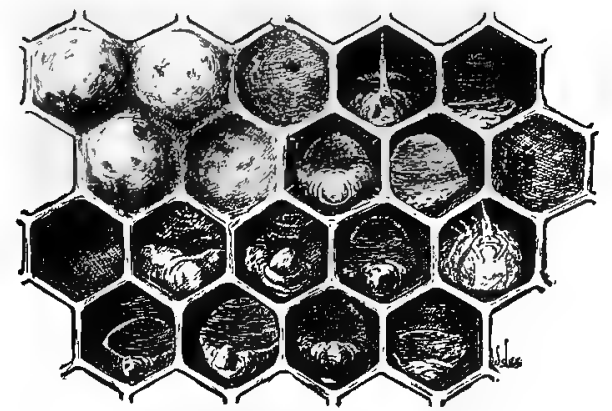

AMERICAN FOUL-BROOD

From Farmers' Bulletin, Department of Agriculture, No. 442.

By Dr. E. F. Phillips.

In this way hives are not left exposed where robbers might get at a possible drop of honey and earry the infection. But they are treated as fast as emptied and there is no need of a large number of new brood chambers to transfer the bees, if we find it necessary to transfer a large number of colonies. Each hive is used for the next operation.

799. It is no longer considered necessary to remove the combs containing honey from colonies suffering with European foul-brood. We are strongly of the opinion that it is more injurious than beneficial, as the removal of the comb disturbs the colonies greatly and weakens them. We have treated entire apiaries, for this disease, without a recurrence of the trouble. 
Of course, the origin of these diseases is still unknown. What brings them may again bring them after we have cured the bees. The disease may exist among other bees, wild bees, or bumble-bees, and be again transmitted from bee-trees in the woods. But the writer wishes to assert, that he kept bees for over forty years without seeing a single instance of either of these brood diseases. He has since had thorough experience with them, has cured them and harvested as large crops of honey as ever before. So there is no need to be discouraged, if we find them in our apiaries. But, since they are contagious diseases, we must use the greatest precautions in keeping our hands clean when going from one hive to another after treating a diseased colony. We should carefully prevent all chances of robbing (667) and leave nothing exposed that has belonged to a diseased colony, for if but a few spores escape and find good breeding room, they will soon spread the contagion.

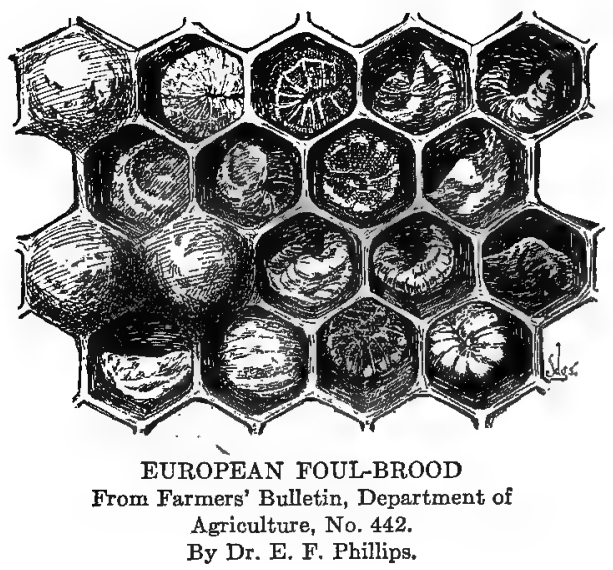


Those who have lived through the trying days of 1918, when the World War came to an end and an unexpected contagion called "Spanish influenza" spread upon all civilized countries, taking a toll, in spite of doctors, and destroying five or six per cent of the population of some uncivilized spots, can have a faint idea of the danger of any contagion.

Laws have been passed concerning foul-brood, in many countries and in the greater number of the states of the Union, but these laws are of diffeult enforeement. Inspectors of apiaries have difficulty in reaching every infected spot. When they do find them, it is another difficulty to secure action on the part of every bee-keeper. One man who neglects to treat his bees when they are diseased causes the continuance of the trouble. So it behooves every lover of apiculture to help spread the information which will enable every one to eradicate the disease.

The writer once visited apiaries in the mountains of the West, where disease was known to exist, in order to become acquainted with its appearance and methods of cure. $\mathrm{He}$ called upon two bee-keepers only three miles apart, the one with a thriving apiary, the other with neglected colonies. The first was constantly watching for disease and treating it as soon as it showed itself. The other did the treating in a half-hearted manner and indolently stated that "when a bee-keeper has found foul-brood among his bees he must never expect to get rid of it." So this man soon went out of business, while the other succeeded.

An incident mentioned by a country physician, in Europe, is to the point, in the necessity for thoroughly treating an apiary where disease is found. A laborer had come to the old doctor for an ointment to cure the "itch." He had caught this -now uncommon and ever disgraceful-contagious skin disease while working as a harvest hand in the country. Directions were given him for using the ointment, and he was told that his wife should anoint with this also, as a preventive. But 
the woman, who did not have the disease, refused to use it. In two weeks afterwards, the man came back for more ointment. He was cured but his wife had the itch in her turn. The doctor gave him some and told him that he should use it too, or he might catch the disease again; but he did not mind the warning, and two weeks later he had to call for more. "Well," said the old doctor, "I hope that these two experiments will convince you of the necessity of a thorough treatment for both, with a disease that is transmitted so readily, by contact."

The case is exactly the same with the bacillus. While we are treating one colony, a few spores may be transmitted to a neighboring hive, by the contact of a single bee, and the disease is spread, unknown to us, while we are congratulating ourselves, in the firm belief that we have eradicated it.

The difference in the treatment between the two diseases is, first, because in the one case the honey has proven to transmit the germs of disease. Secondly, in the European foul-brood the assumption is that the bees are able to clean out all the dead brood. Should they fail to do so, or be unable to clean it, the treatment would fail.

All disinfectants and antiseptics are good, as preventives and perhaps also as cure, but it must be borne in mind that they cannot very readily reach to the bottom of cells containing putrid or dried-up larvae. The irregularities in the reports of cure, some failing where others succeeded, may be ascribed to differences in the intensity of the disease. On this matter Mr. Bertrand, in his work, "La loque et son traitement," says:

"In countries that are rich in melliferous resourees, where bees have been kept for years, and where, in consequence, foulbrood must have been in existence for a long time and exists in an endemic state, the race has acquired a relative immunity, a force of resistance which diminishes considerably the effects of the disease and permits of its being more easily overcome. 
Perhaps, also, in those regions, the virus of foul-brood may have become weakened, in time, as has been observed in the virus of certain diseases affecting the human race. In such countries, the simple transferring of a colony of foul-brood bees into a healthy hive, seems sufficient to cure them."

800. Foul-brood is transmitted from one hive to anotherlike Asiatic cholera among men-by different means. Robbing (664) is probably one of the main helps to contamination, as the robber bees may take the bacillus home, among their hair, unawares. Working bees may even gather the scourge from some sweet-scented blossom contaminated by previous visitors. The transportation, or shipping, of bees, from one part of the country to another, is of ten a means of spreading the disease, and some of our State legislatures have made very stringent laws on the subject. No contaminated combs should be shipped from one part of the country to another.

Contagious diseases were once the scourge of the land. Who has not heard of the plague, the dread disease of the dark ages? According to Chambers' Encyclopedia, the plague of 1665 destroyed seventy thousand people, in London alone. Earlier still, in 1348, according to Sismondi, the plague destroyed three-fifths of the entire population of Europe, extending even up into Iceland. It was during that terrible scourge that the city of Florence lost over one hundred thousand people. If those dreaded diseases are now but little feared, we owe it to scientific discoveries. The microscope has shown that nearly all contagious diseases, which men or animals are subject to, are caused by living organisms, and medical science now teaches how they may be avoided by inoculation, or other means. More discoveries are daily made, and we can hope that the day is not far, when the advancement of science will have put an end to all these ills, and the bacillus alvei will be a thing of the past.

W. R. Howard of Texas, F. C. Harrison of Ontario, T. W. 

Plate $2 \overline{8}$.

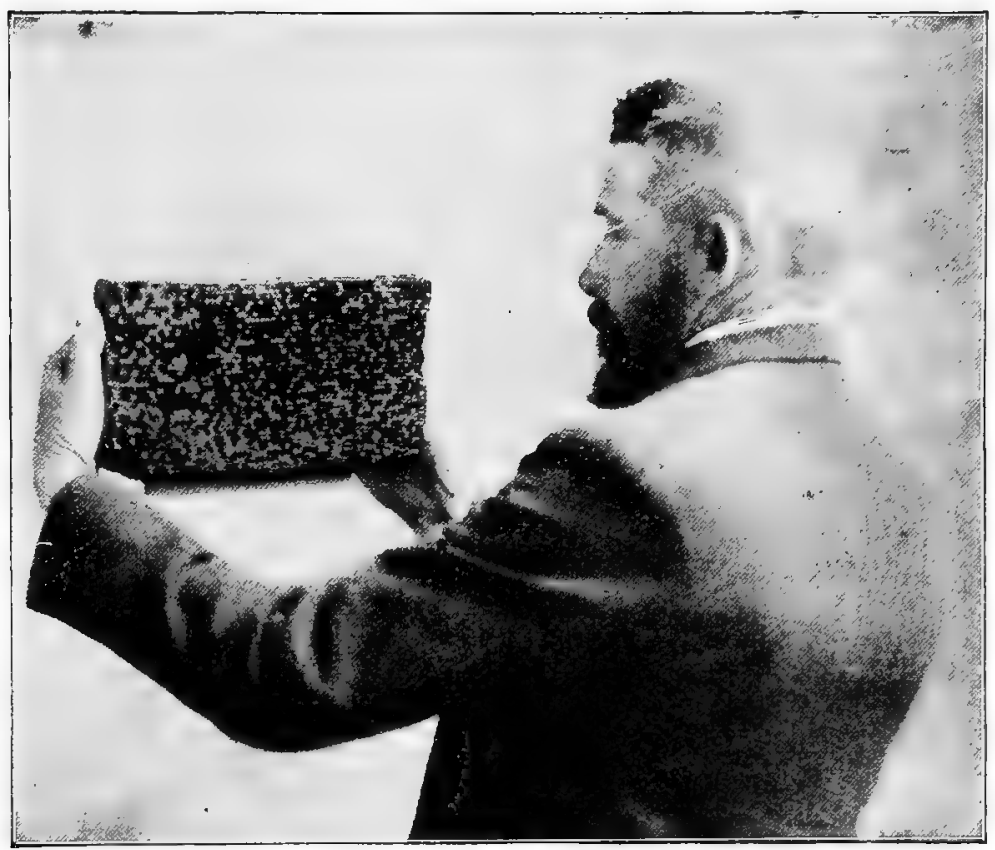

\section{N. E. FRANCE,}

Expert on Foul-brood, holding a diseased comb. The line drawn shows the direction of the eye to detect the dried-up larvae.

This writer is mentioned pages $476,478,479$. 
Cowan of England, N. E. France of Wisconsin, Ed. Bertrand of Switzerland, and many others, have carefully described the disease in short pamphlets, but the most important and useful publications on the subject are the Bulletins of the Department of Agriculture at Washington, "The Control of European Foul-Brood," Bulletin 975 by Dr. E. F. Phillips; "The Bacteria of the Apiary," by Dr. G. F. White, Technical Series No. 14; "The Brood Diseases of Bees," Circular No: 79, by Dr. E. F. Phillips, "The Cause of American Foul-Brood," Circular No. 94, by Dr. G. F. White, etc. These works should be read by the student.

801. Aside from foul-brood, accidents may cause the brood to die, and even to rotin the cells, without special damage to the bees. Sudden and cold weather, in a promising Spring, when the bees have been spreading their brood, and are compelled to leave a part of it uncovered; the neglect of the apiarist, or his mismanagement, in placing back the brood-after an inspection-out of the reach of the cluster; or even the suffocation of a colony by heat (367), or by close confinement (368), may cause the death of the brood.

These accidents have none of the malignance of foul-brood, and nothing need be done in such oecurrences besides removing the dead brood, and burying it carefully.

It is usially easy to recognize when brood has been chilled, for it dies evenly all at one time, while deaths from disease are always scattering at first, here and there, in the cells.

A disease, much resembling foul-brood, which has done considerable damage among bees, but not a contagious malady, first designated under the name of "Pickled brood" because of the sour smell of the dead brood was diagnosed by Dr. White under the name of "Sac-brood," United States Bureau of Entomology No. 431."

This name was given because the dead larva when it dies remains within its skin as within a sack, and often dries so as to become loose in the cell and fall out when the comb is inverted This never happens in either of the other diseases. 
Since we have a department of bee-keeping in the Bureau of Entomology in Washington, we urge every beekeeper who finds disease in the brood to send an enquiry, mentioning the fact, to this Bureau, and explicit instructions and directions will be sent him.

Honey from diseased colonies is absolutely harmless to human beings. If it is heated to the boiling point of water for a few minutes, it will be safe also to feed the bees. The beeswax rendered from diseased comb is also safe.

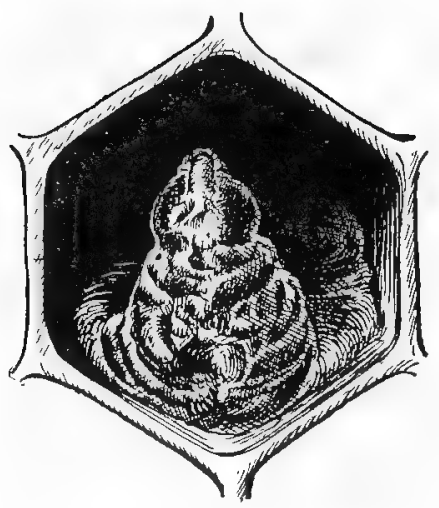

SACBROOD

From U. S. Bulletin, No. 431.

By Dr, G. F. White. 


\section{CHAPTER XIX.}

\section{Enemies of BeEs.}

802. THE Bee-Moth (Tinea mellonella) is mentioned by Aristotle, Virgil, Columella and other ancient authors, as one of the most formidable enemies of the honey-bee. Even in the first part of this century, the bee-writers, almost without exception, regarded it as the plague of their apiaries.

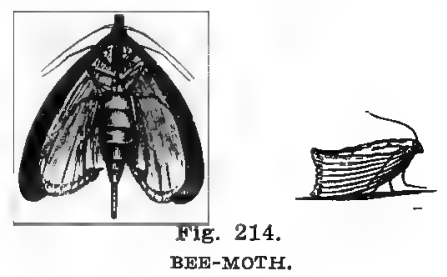

Swammerdam speaks of two species of the bee-moth (called in his time the "bee-wolf"), one much larger than the other. Linnæus and Réaumur also deseribe two kinds -Tined cereana and Tinea mellonella.

Seientists do not agree exactly as to these species, nor their names, calling them, galleria cereana, galleria alvearia, tinea cerella, etc.

The smailer moth, now denominated "Achroia Grisella," is mentioned in the A B C of Bee-eulture. Mr. E. F. Phillips speaks of it in Gleanings, of October 1, 1905.

Most writers supposed the former to be the male, and the latter the female of the same species. The following description is abridged from Dr. Harris' Report on the Insects of Massachusette :

803. "Very few of the Tinga exceed or even equal it in size. 489 
In its adult state it is a winged moth, or miller, measuring, from the head to the tip of the closed wings, from five-eighths to three-quarters of an inch in length, and its wings expand from one inch and one-tenth to one inch and four tenths. The fore-wings shut together flatly on the top of the back, slope steeply downwards at the sides, and are turned up at the end somewhat like the tail of a fowl. The female is much larger than the male, and much darker-colored. There are two broods of these insects in the course of the year.* Some winged moths of the first brood begin to appear towards the end of April or early in May-earlier or later, according to climate and season. Those of the second brood are more abundant in August; but some may be found between these periods, and even much later."

No writer with whom we are aequainted has given such an exact description of the differences between the sexes, that they can always be readily distinguished. The wood-cuts of the moths, larvæ, and cocoons, which we present to our readers, were drawn from nature, by Mr. M. M. Tidd, of Boston, Mass, and engraved by Mr. D. T. Smith, of the

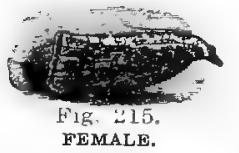

While some same city. Mr. Tidd seems first to have noticed that the snout or palpus of the female, projects so as to resemble a beak, while that of the male is very short.

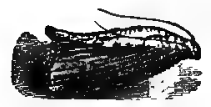

Fig. 215. MALE.

guished at a glance.

801. These insects are seldom seen on the wing, unless started from their lurking places about the hives, until towards dark. On cloudy days, however, the female may be

* Prof. Cook is of opinion (Guide, page 315) that there may be three broods in a year and we believe he is correct. We have seen them most numerous in hot October weather. 
noticed endeavoring, before sunset, to gain entrance into the hives.

"If disturbed in the daytime," says Dr. Harris, "they open their wings a little, and spring or glide swiftly away, so that it is very difficult to seize or hold them."

They are surprisingly agile, both on foot and on the wing, the motion of a bee being very slow, in comparison. "They are," says Réaumur, "the most nimble-footed creatures that I know."

In the evening, they take wing, when the bees are at rest, and hover around the hive till, having found the door, they go in and lay their eggs.

"It is curious," says Huber, "to observe how artfully th" moth knows how to profit by the disadvantage of the bees which require much light for seeing objects, and the precau tions taken by the latter in reconnoitering and expelling si dangerous an enemy.

"Those that are prevented from getting within the hive, lay their eggs in the cracks on the outside; and the little worm-like caterpillars hatched therefrom, easily creep into the hive through the cracks, or gnaw a passage for themselves under the edges of it." - Dr. Harris.

One afternoon, about twenty-five years ago, our Senior saw a female bee-moth on the front of an eke hive (278), and noticed that she was laying in the crack, between two ekes, through which the propolis could be seen; the ekes being rabbeted to received the comb-bars, their thickness there was reduced to about three-eighths of an inch.

The moth laid about ten eggs, then walked about, seeming satisfied with her work, and came back to lay about the same number, repeating the manœuver several times.

This shows that moths may lay eggs in the hive from the outside, and that propolis is a food for their just-hatched larvæ. One of our objects, in preserving the strip around 
the hive to support the cap (fig. 72), and in incasing the bottom (34:), was to hinder the moth.

805. "As soon as hatched, the worm encloses itself in a case of white silk, which it spins around its body; at first it is like a mere thread, but gradually increases in size, and, during its growth, feeds upon the cells around it, for which purpose it has only to put forth its head, and find its wants supplied. It de-

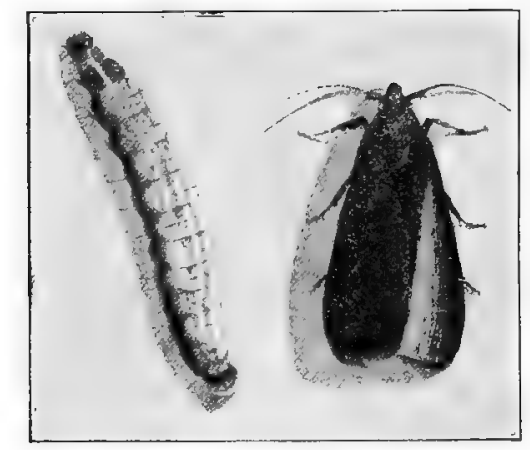

Fig. 216.

LARVA AND MOTH AFTER BARBO. MAGNIFIED.

vours its food with great avidity, and, consequently, increases so much in bulk, that its gallery soon becomes too short and narrow, and the creature is obliged to thrust itself forward and lengthen the gallery, as well to obtain more room as to procure an additional supply of food. Its augmented size exposing it to attacks from surrounding foes, the wary insect fortifies its new abode with additional strength and thickness, by blending with the filaments of its silken covering a mixture of wax and its own exerement, for the external barrier of a new gallery,* the interior and partitions of which are lined with a smooth surface of white silk, which admits the occasional movements of the insects, without injury to its delicate texture.

- This representation of the web, or gallery of the worm, was copied from Swammerdam. 
"In performing these operations, the insect might be expected to meet with opposition from the bees, and to be gradually rendered more assailable as it advanced in age. It never, however, exposes any part but its head and neck, both of which are covered with stout helmets, or scales, impenetrable to the sting of a bee, as is the composition of the galleries that surround it."'-Bevan.

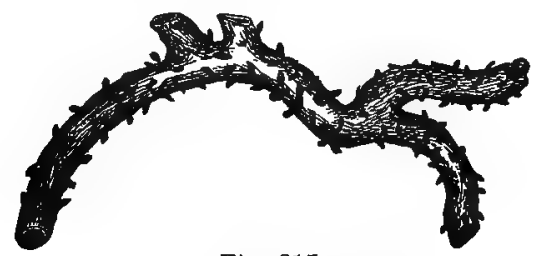

Fig. 217.

GALLERY OF MOTH WORM.

80i:. The worm is here given of full size, and with all its peculiarities. The scaly head is shown in one of the worms; while the three pairs of claw-like fore legs, and the five pairs of hind ones, are delineated. The tail is also furnished with two of these legs. The breathing holes are seen on the back.

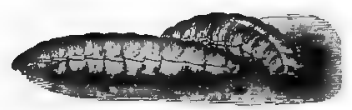

Fig. 218.

THIS WORMS.

807. Wax is the chief food of these worms, but as Dr. Dönhoff says: "Larvæ fed exclusively on pure wax will die, wax being a non-nitrogenous (221) substance, and not furnishing the aliment required for their perfect development"; and his statement agrees with the fact that their larvæ prefer the brood-combs, which are lined with the skins cast away by the bee-larvæ (167), and which, in consequence, are more liable to be devoured than the new ones. In fact, they eat pollen and propolis, and while making their 
cocoons, they even seem to relish woody fibre, for they often eat into the wood of the frames or of the hives in which they are allowed to propagate, while comb-foundation remains almost untouched by them.

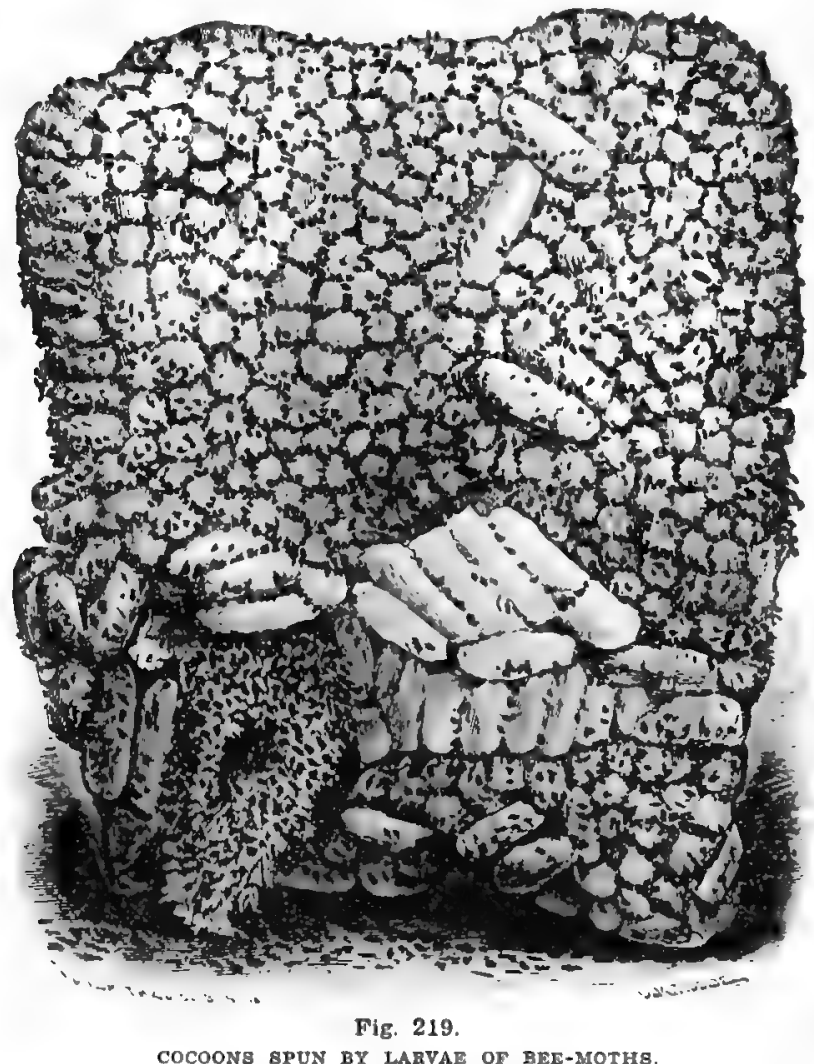

808. When obliged to steal their living among a strong colony of bees, they seldom fare well enough to reach the size which they attain when rioting at pleasure among the 
full combs of a discouraged population. In about three weeks, the larvæ stop eating, and seek a suitable place for encasing themselves in their silky shroud. In hives where they reign unmolested, almost any place will answer their purpose, and they often pile their cocoons upon one another, or join them together in long rows. They sometimes occupy the empty combs, so that their cocoons resemble the capping of the honey-cells. In Fig. 219, Mr. Tidd has given a drawing, accurate in size and form, of a curious instance of this kind. The black spots, resembling grains of gunpowder, are the excrements of the worms.

If the colony is strong, the worm runs a dangerous gauntlet, as.it passes, in search of some crevice, through the ranks of its enranged foes. 'Its motions, however, are exceedingly quick, and it is full of cunning devices, being able to crawl backwards, to twist round on itself, to curl up almost into a knot, and to flatten itself out like a pancake. If obliged to leave the hive, it gets under some board or concealed crack, spins its cocoon, and patiently awaits its transformation.

809. The time required for the larvæ to break forth into winged insects, varies with the temperature to which they are exposed, and the season of the year when they spin their cocoons. We have known them to spin and hatch in ten or eleven days; and they often spin so late in the Fall, as not to emerge until the ensuing Spring.

810. In Northern latitudes where the thermometer ranges for days and weeks below 10 degrees the bee-moth-worm can winter only in the hive near the bee-cluster. It is a fact worthy of notice that apiaries that are wintered in the cellar are more annoyed by the moth during the following Summer than those that are wintered out of doors, because none of the larvæ of the moth perish.

Dr. Dönhoff says that the larvæ become motionless at a temperature of 38 to 40 degrees, and entirely torpid at a lower temperature. A number, which be left all Winter in his summer-house, revived in the Spring, and passed through 
their natural changes. This was in Germany, where the Winters are milder than in our Northern and Middle States.

"If, when the thermometer stood at 10 degrees, I dissected a chrysalis, it was not frozen, but congealed immediately afterwards. This shows that, at so low a temperature, the vital force is sufficient to resist frost. In the hive, the chrysalids and larvæ, in various stages of development, pass the Winter in a state of torpor, in corners and crevices, and among the waste on the bottom-boards. In March or April, they revive, and the bees of strong colonies commence operations for dislodging thern." -Dönhoff.

Some larva which Mr. Langstroth exposed to a temperature of 6 degrees below zero, froze solid, and never revived. Others, after remaining for eight hours in a temperature of about 12 degrees, seemed, after reviving, to remain for weeks in a crippled condition.

"The eggs of the bee-moth are perfectly round, and very small, being only about one-eighth of a line in diameter. In the ducts of the ovarium, they are ranged together in the form of a rosary. They are not developed consecutively, like those of the queen bee, but are found in the ducts, fully and perfectly formed, a few days after the female moth emerges from the cocoon. She deposits them, usually, in little clusters on the combs. If we wish to witness the discharge of the eggs, it is only necessary to seize a female moth, two or three days old, with finger and thumb, by the head-she will instantly protrude her ovipositor, and the eggs may then be distinctly seen passing along through the semi-transparent duct.

"Last Summer I reared a bee-moth larva in a small box. It spun a cocoon, from which issued a female moth. Holding her by the head, I allowed her to deposit eggs on a piece of honeycomb. Three weeks afterwards, I examined the comb, and found on it some web and two larvæ. The eggs were all shriveled and dried up, except a few which were perforated, and from which, I suppose, the larvæ emerged. This appears to be a case of true parthenogenesis in the bee-moth." - Translated from Dr. Dönhoff by $\mathrm{S}$. Wagner. 
811. In Fig. 220, Mr. Tidd has faithfully delineated, and Mr. Smith skillfully engraved, the black mass of tangled webs, cocoons, excrements, and perforated combs, which may

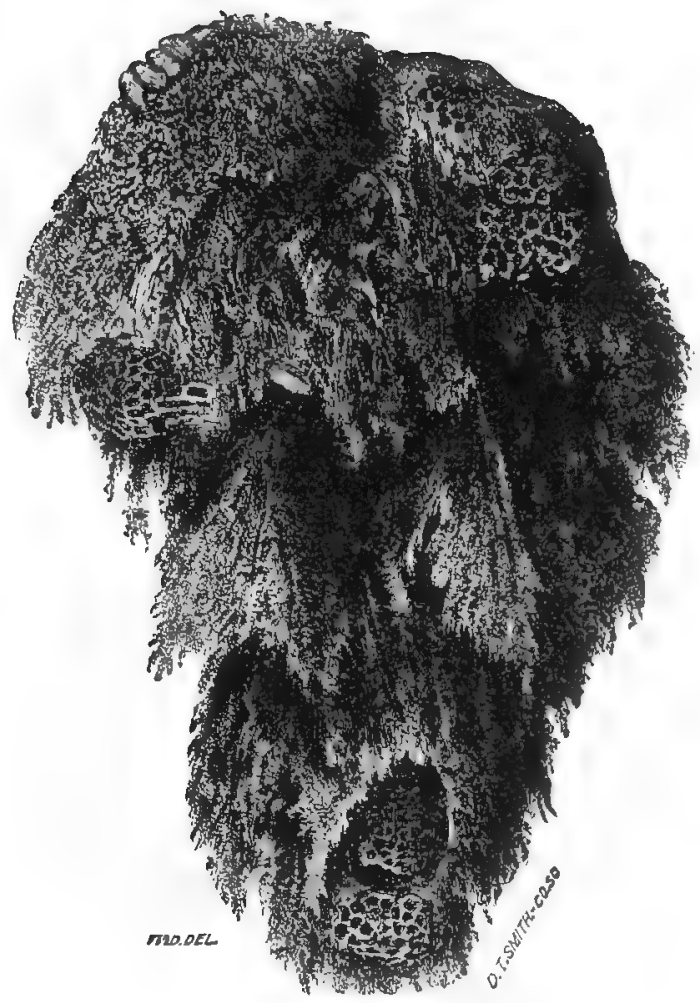

Fig. 220.

WEBS AND REMNANTS OF COMES DESTROYED BY MOTHS.

be found in a hive where the worms have completed their work of destruction.

The entrance of a moth into a hive and the ravages com. mitted by her progeny, forcibly illustrate the havoe which 
vice often makes when admitted to prey unchecked on the precious treasures of the human heart. Only some tiny eggs are deposited by the insidious moth, which give birth to very innocent-looking worms; but let them once get the control, and the fragrance* of the honied dome is soon corrupted, the hum of happy industry stilled, and everything useful and beautiful ruthlessly destroyed.

As a feeble colony is often unable to cover all its combs, the outside ones may become filled with the eggs of the moth. The discouraged aspect of the bees soon indicates that there is trouble of some kind within, and the bottom-board will be covered with pieces of bee-bread mixed with the excrement of the worms.

If a feeble colony cannot be strengthened so as to protect its empty combs, the careful bee-keeper will take them away until the bees are numerous enough to need them.

812. Combs having no brood, from dead colonies, or surplus combs, with or without honey, should be smoked with the fumes of burning sulphur, to kill the eggs or worms of the moth, when kept from the bees in the months of June, July, August, and September. The box, hive, or room in which they are kept should be tightly elosed to prevent the gas from escaping till it has done its work. In smoking combhoney in a room, the sulphur may be placed on hot coals in a dish, and care should be taken not to use too much of it, as the gas has the effect of turning the propolis to a greenish color, quite damaging to the looks of the beautiful sections. Enough smoke to kill the fies, in a room, will be found sufficient. Dry combs kept over Winter in a well-closed room without a fire, are not in danger of the moth the following Summer, unless they are in some manner exposed. Combs, in which there have been moths, should be examined occasionally, to be smoked again if any worms are found.

Bee-keepers also use bi-sulphide of carbon, poured on a rag or in a saucer and enclosed within the hive or box, but

\footnotetext{
* The odor of the moth and larva is very offensive.
} 
sulphur fumes is a less expensive remedy, though a little more troublesome. Bi-sulphide of carbon is an evaporating explosive substance, which must be handled with care, but its evaporation within a closed box is sufficient to destroy all living insects; a tablespoonful is enough for the combs of a hive. Sulphur or brimstone may be used by first making it into wicks; it is melted over a slow fire and strips or rags dipped into the liquid. These strips, when coated with brimstone, may be used by cutting them into pieces of the required size for each operation.

A bee-keeper of Switzerland, Mr. Castellaz, keeps his combs in a closed box, in which he places some lumps of eamphor. He says that bees accept these combs, even when impregnated with the odor of camphor.

813. Italian bees, unless exceedingly weak and queenless, will defend a large number of combs against moths. One of our neighbors, who had, occasionally, helped us in the apiary, after witnessing our success in bee culture, bought a colony of Italian bees and divided it into three swarms, without regard to the scantiness of the crop. His swarms having dwindled to naught, he returned their combs to the impoverished colony, whose population was unable to cover more than two or three combs. But the returned combs had not been protected against moths, which hatched so numerous that our neighbor, surprised to see about as many moths as bees going out of the hive, came to us for advice. On opening the hive, we found three combs of brood crowded with bees, and seven others that were a perfect mass of webs, spotted with excrements. The bees were all on their combs and the moths on theirs; not one worm could be found on either of the three combs, protected by the Italians. Both populations, the one of bees, the other of moths, seemed to dwell harmoniously near each other.

814. The most fruitful cause of the ravages of the moth still remains to be described. If a colony becomes hopelessly queenless (499), it must, unless otherwise destroyed, in- 
evitably fall a prey to the bee-moth. By watching, in glass hives, the proceedings of colonies purposely made queenless, we have ascertained that they make little or no resistance to her entrance, and allow her to lay her eggs where she pleases. The worms, after hatching, appear to have their own way, and are even more at home than the dispirited bees.

How worthless, then, to a hopelessly queenless colony, aro all the traps and other devices which, formerly, have been so much relied upon. Any passage which admits a bee is large crough for the moth, and if a single female enters such a hive, she may lay eggs enough to destroy it, however strong. Under a low estimate, she would lay, at least, two hundred eggs in the hive, and the second generation will count by thousands, while those of the third will exceed a million.

In the Ohio Cultivator for 1849, page 185, Micajah T. Johnson says:- "One thing is certain-if bees, from any cause, should lose their queen, and not have the means in their power of raising another, the miller and the worms soon take possession. I believe no hive is destroyed by worms while an efficient queen remains in it."

This seems to be the earliest published notice of this important fact by any American observer.

It is certain that a queenless hive seldom maintains a guard at the entrance after night, and does not fill the air with the pleasant voice of happy industry. Even to our dull ears, the difference between the hum of a prosperous hive and the unhappy note of a despairing one is often sufficiently obvious; may it not be even more so to the acute senses of the provident mother-moth?

$\mathrm{Her}$ inerring sagacity resembles the instinct by which birds that prey upon carrion, single out from the herd a diseased animal, hovering over its head with their dismal croakings, or sitting in ill-omened flocks on the surrounding trees, watching it as its life ebbs away, and snapping their blood-thirsty beaks, impatient to tear out its eyes, just glazing in death, and banquet on its flesh, still warm with the blood of life, 
Let any fatal accident befall an animal, and how soon will you see them,-

\section{"First a speck and then a Vulture,"}

speeding, from all quarters of the heavens, on their eager flight to their destined prey, when only a short time before not one could be perceived.

When a colony becomes hopelessly queenless, even should the bees retain their wonted zeal in gathering stores and defending themselves against the moth, they must as certainly perish as a carcass must decay, even if it is not assailed by filthy 1 lies and ravenous worms. Occasionally, after the death of the bees, large stores of honey are found in their hives. Such instances, however, are rare, for a motherless hive is almost always assaulted by stronger colonies, which, seeming to have an instinetive knowledge of its orphanage, hasten to take possession of its spoils; or, if it escape the Scylla of these pitiless plunderers, it is dashed upon a more merciless Charybdis, when the miscreant moths find out its destitution.

815. The introduction of movable-frame hives and Italian bees, with the new system of management, has done away with the fear of the moth. It is no longer common to hear bee-keepers speak of having "good luck" or "bad luck" with their bees; as bees are now managed, success or failure never depends on what is called "luck."

To one acquainted with the habits of the moth, the beekeeper who is constantly lamenting its ravages, seems almost as much deluded as a farmer would be, who, after searching diligently for his cow, and finding her nearly devoured by carrion worms, should denounce these worthy scavengers as the primary cause of her untimely end.

The bee-moth has, for thousands of years, supported itself on the labors of the bee, and there is no reason to suppose that it will ever become exterminated. In a state of nature, a queenless hive, or one whose inmates have died, being of no 
further account, the mission of the moth is to gather up its fragments, that nothing may be lost.

From these remarks, the bee-keeper will see the means on which he must rely, to protect his hives from the moth. Knowing that strong colonies which have a fertile queen, can take eare of themselves in almost any kind of hive, he should do all he can to keep them in this condition. They will thus do more to defend themselves than if he devoted the whole of his time to fighting the moth. Inexperienced bee-keeper's, who imagine that a colcny is nearly ruined when they find a few worms, should remember that almost every colony (especially black bees) however strong or healthy, has some of these enemies lurking about its premises.

It is hardly necessary, after the preceding remarks, to say much upon the various contrivances to which some resorted as a safeguard against the bee-moth. The idea that gauzewire doors, to be shut at dusk and opened again at morning, can exclude the moth, will not weigh much with those who have seen them on the wing, in dull weather, long before the bees have ceased their work. Even if they could be excluded by such a contrivance, it would require, on the part of those using it, a regularity almost akin to that of the heavenly bodies.

An ingenious device was invented for dispensing with such elose supervision, by governing the entrances of all the hives by a long lever-like hen-roost, so that they might be regularly closed by the crowing and eackling tribe when they go to rest at night, and opened again when they fly from their perch to greet the merry morn. Alas! that so much skill should have been all in vain! Some chickens are sleepy, and wish to retire before the bees have completed their work, while others, from ill-health or laziness, have no taste for early rising, and sit moping on their roost, long after the cheerful sun has purpled the glowing East. Even if this device conld entirely exclude the math, it could not save a colony which has lost its queen. The truth is, that such contrivances are 
equivalent to the lock put upon the stable door after the horse has been stolen; or, to attempts to banish the chill of death by warm covering, or artificial heat.

The prudent bee-keeper, remembering that "prevention is better than cure," will take pains to destroy the larvæ of the moth as early in the season as he can, while swarming his bees. The destruction of a single female worm may thus be more effectual than the slaughter of hundreds at a later period.

816. MICE. It seems almost incredible that such puny animals as mice should venture to invade a hive of bees; and they often slip in when cold compels the bees to retreat from the entrance. Having once gained admission, they build a warm nest in their comfortable abode, eat up the honey and such bees as are too much chilled to offer resistance," and fill the premises with such a stench, that the bees, on the arrival of warm weather, often abandon their polluted home. The entrance should never be made deep enough to allow mice to pass (318).

817. BIRDs. Very few birds are fond of bees. Tha King-bird (Tyrannus Carolinensis) which devours them by scores, is said-when he can have his choice - to eat only the drones; but as he catches bees on the blossoms-which are never frequented by these fat and lazy gentlemen-the industrious workers must often fall a prey to his fatal snap. There is good reason to suspect that this gourmand can distinguish between an empty bee in search of food, and one which, returning laden to its fragrant home, is in excellent condition to glide-already sweetened-down his voracious maw.

818. The bee-keepers of England complain of the sparrows, which they accuse of eating bees. If these birds add this mischief to so many others of which they are guilty, the bee-keepers should find some means of getting rid of them.

* In eating bees, the mice eat the head and corselet, but not the abdomen, probably because of the smell of the poison. sack. 
In the Vosges (France) most of the farmers suspend earthen pots to the walls of their barns in which the sparrows make their nests. These jug-shape pots are examined every week and the young birds are killed as soon as they are ready to fly out, and are put into the frying-pan. We have seen as many as five or six dozen pots on the same wall, nearly all filled with nests, for sparrows raise many broods every year.

If-as in the olden time of fables-birds could be moved by human language, it would be worth while to post up, in the vicinity of our apiaries, the old Greek poet's address to the swallow:

"Attic maiden, honey fed,

Chirping warbler, bears't away

Thou the busy buzzing bee,

To thy callow brood a prey?

Warbler, thou a warbler seize?

Winged, one with lovely wings?

Guest thyself by Summer brought,

Yellow guests whom Summer brings?

Wilt not quickly let it drop?

'Tis not fair; indeed, 'tis wrong,

That the ceaseless warbler should

Die by mouth of ceaseless song."

819. No Apiarist ought ever to encourage the destruction of any birds, except the too-plentiful sparrows, because of their fondness for bees. Unless we can check the custom of destroying, on any pretense, our insectivorous birds, we shall soon, not only be deprived of their ærial melody among the leafy branches, but shall lament, more and more, the increase of insects from whose ravages nothing but these birds can protect us. Let those who can enjoy no music made by these winged choristers of the skies, except that of their agonizing screams as they fall before their well-aimed weapons, and flutter out their innocent lives before their heartless gaze, drive away, as far as they please from their cruel premises, all the little birds that they cannot destroy, and they will, 
eventually, reap the fruits of their folly, when the caterpillars weave their destroying webs over their leafless trees, and insects of all kinds riot in glee on their blasted harvests.

820. Tame chickens eat drones, but not workers. Once we noticed a rooster seemingly eating bees at the entrance of a hive. The bees were then killing their drones (192). On approaching the hive, we saw him carefully pick out a drone from among the bees, shake off a worker-bee which had clung to him, and swallow the drone. Young drones ean be fed to chickens, who soon learn to eat them greedily, but if a worker-bee is found among them they will shake their heads at her, with a knowing look of disgust. Young ducks, if insufficiently fed, will eat bees, and are often killed by being stung while swallowing them.

821. Other enemies. The toad is a well-known devourer of bees. Sitting, towards evening, under a hive, he will sweep into his mouth, with his swiftly-darting tongue, many a late-returning bee, as it falls, heavily laden, to the ground; but as he is also a diligent consumer of various injurious insects, he can plead equal immunity with the insectivorous birds.

It may seem amazing that birds and toads can swallow bees without being stung to death. They seldom, however, meddle with any, except those returning fully laden to their hives, or such as, being away from home, are indisposed to resent an injury. As they are usually swallowed without being crushed, they do not instinctively thrust out their stings, and before they can recover from their surprise, they are safely entombed.

822. Bears are exceedingly fond of honey; and in countries where they abound, great precautions are needed to prevent them from destroying the hives.

In that quaint but admirably common-sense work, entitled, "The Feminine Monarchie, written out of Experience, by Charles Butler; printed in the year 1609," we have an amusing adventure, related by a Muscovite ambassador to Rome: 
"A neighbor of mine," saith he, "in searching in the woods for honey, slipped down into a great hollow tree, and there sunk into a lake of honey up to the breast; where-when he had stuck fast two days calling and crying out in vain for help, because nobody in the meanwhile came nigh that solitary place-at length, when he was out of all hope of life, he was strangely delivered by the means of a great bear, which, coming hither about the same business that he did, and smelling the honey, stirred with his striving, elambered up to the top of the tree, and then began to lower himself down, backwards, into it. The man bethinking himself, and knowing that the worst was but death, which in that place he was sure of, beclipt the bear fast with both hands about the loins, and, withal, made an outery as long as he could. The bear being thus suddenly affrighted, what with the handling and what with the noise, made up again with all speed possible. The man held, and the bear pulled, until, with main force, he had drawn him out of the mire; and then, being let go, away he trots, more afraid than hurt, leaving the smeared swain in a joyful fear."

823. The braula cnea, improperly called bee-louse, exists in Italy, Southern France and other mild climates. Dr. Dubini has seen queens so completely covered with them, that only their legs could be seen. These lice, whose second name, coca, means lind, have beew often found by us on imported queens on their arrival. They are so large that they can easily be taken off the queen and killed. It appears that they can only propagate in warm countries, for they exist in the South of Europe and are unknown either in Russia, or in North America.

821. Small ants often make their nests about hives, to have the benefit of their warmth. They are annoying to the Apiarist, but neither molest the bees nor are molested by them.

A sheet of tarred paper in the hive cover or cap where they ustally congregate will drive them away, as the smell is unpleasant to them. Salt, ashes, or powdered sulphur will also keep them away.

Our limits forbid us to speak of wasps, hornets, milli- 
pedes (or wood-lice), spiders, libellulas and other enemies of bees. These lesser enemies are detailed at length and in a scientific manner, with engravings, in the work of Prof. Cook, "The Bee-Keeper's Guide," to which we refer the lovers of entomological study. If the Apiarist keeps his colonies strong, they will usually be their own best protectors, for, unless they are guarded by thousands ready to die in their defense, they are ever liable to fall a prey to some of their many enemies, who are all agreed on this one point, at least-that stolen honey is much sweeter than the slow aceumulations of patient industry. 


\section{LHAPTER XX.}

\section{Honey Handling.}

\section{Marheting Honey.}

825. The quality of honey "depends very little, if at all, upon the secretions of the bees; and hence, apple blossom, white clnver, buckwheat, and other varieties of honey, hars each their peculiar flavor, and color. The difference between the honey of one blossom, and that of another, is so great, that persons unacquainted with this diversity, when tasting honey different from that to which they are accustomed, imagine that either the one or the other is adulterated.

The most-prized and best-flavored honey produced in this country, is that from white clover blossoms (701). Basswood honey, if unmixed with any other grade, is too strong in taste, but a slight quantity of it in clover honey makes a delicious dish. Both these grades, being very white, sell more readily than any other, in the comb, excepting perhaps alfalfa honey and the white honey of the California sage.**

Smart-weed, or heartsease, honey,-which should properly be called knot-weed or Persicaria honey,-is of a pale yellow color and very fine in flavor. Asters produce honey nearly as white as clover. Different grades of fall-honey, from Spanish needles, solden-rod, iron-weed, etc., are of a yellow color, and strong in taste. Buckwheat honey is dark; boneset honey and honey dew are the ugliest and poorest in quality, looking almost like molasses.

- The honey of Hymettus, which has been so celebrated from the most ancient times, is of a fair golden color. The lightest-colored honey is by no means always the best. 
Some kinds of honey are bitter, and others very unwholesome, being gathered from poisonous flowers. The noxious properties of honey gathered from poisonous flowers would seem to be mostly evaporated before it is sealed over by the bees. Heating, however, expels them still more effectually, for some persons eannot eat even the best, when raw, with inpunity. Well ripened honey is more wholesome than that freshly gathered by the bees. W'hen it is taken from the bees, it should be put where it will be safe from all intruders. The little red and the large black ant are extravagantly fond of it, and wili not only carry off large quantities if within their reach, but many of them will drown in it, spoil its appearance, and render it unfit for use.

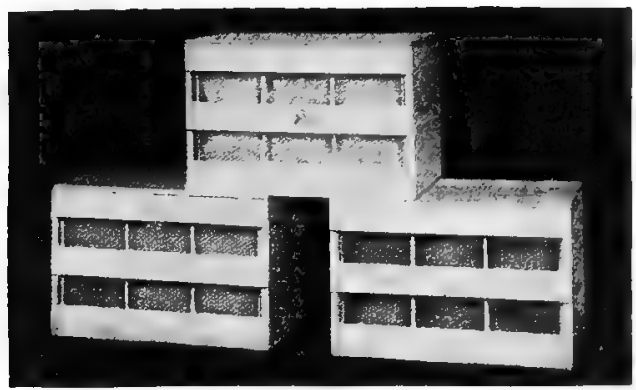

Fig. 221.

COLORADO SHIPPING CASES.

From the Colorado Honey Producers' Association.)

826. Comb honey, in sections put up in cases of 12,16 , 24 , or 40 sections, with glass on the side, sells most readily; and were it not for the greater eost of production, and the difficulty of safe transportation, this kind would be raised exclusively. One objection to it, by large producers, is that it cannot always be kept in good shape, from one year to another, owing to its tendency to "sweat." 
Sweating takes place in comb-honey which has been sealed by the bees before it was fully ripened or evaporated ( $/ 44)$, during a plentiful honey harvest. The changes of temperature in Spring and Summer cause a certain amount of fermentation in it, exactly as in the housekeepers' sealed preserves, when not sufficiently heated or sweetened. The result is a bursting of the cappings, by the pressure of the expanding honey, which runs out and over the comb and renders it unsalable. The same expansion sometimes takes place in

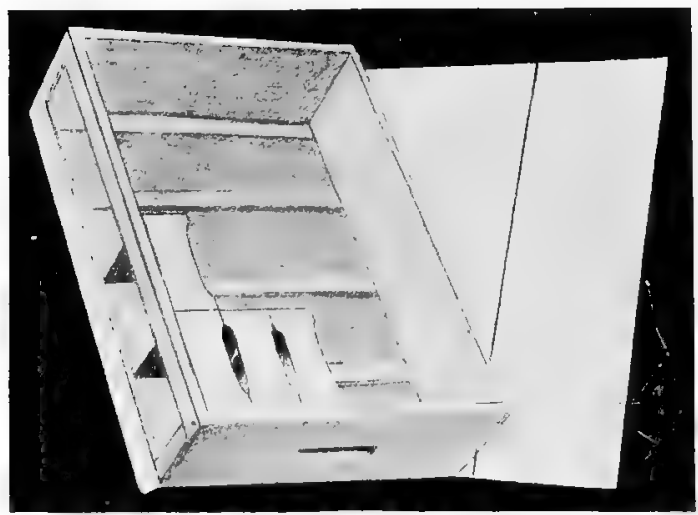

Fig. 222.

NON-DRIP FOSTER CASE.

granulated extracted honey, accompanied by a slight fermentation.

827. It is also held, by some leading Apiarists, that the cells, although sealed, are not moisture-proof, and that combhoney gathers water from the air, till it overfills the cell and escapes through its pores. For this reason they keep their comb-honey in a warm dry room. This is a good thing to do in every case. Honey is hygrometric, and whenever exposed, gathers moisture rapidly, so that when kept in a damp place, 
a few unsealed or damaged cells very readily overflow, with watery honey, that daubs everything. "Therefore, whether we believe that the sealed cells are air-tight or not (262), we should keep our honey in a dry place at all times.

To prevent the leaking honey in sections from running out of a case and daubing other boxes, a sheet of strong manila paper should be placed at the bottom of each case, with the edges folded up slightly, say half an inch.

"The cases for shipping and retailing honey should be light, and glazed on one or both sides. Those holding but one tier are best. The sections should rest on narrow strips of wood $1 / 4$-intch thick, tacked to the bottom of the case over a sheet of manila paper. This is to preserve the boxes from being daubed, in case the honey drips.

"These cases should be in readiness before the honey is ready to be taken off." -(Oliver Foster.)

This style of shipping case has been lately sold by manufacturers under a new name, "the non-drip shipping case." They should be named the "Foster shipping case."

828. "Glazed sections"-one glass on each side of each section-have been largely sold in the East; but this mode of putting up honey, being very expensive, will only do for fancy trade. The producer can best tell what his trade requires.

Cartons containing one pound section and nicely labeled sell well and are less expensive.

When shipping comb-honey to the large cities, Mr. Hutchinson, who was a large producer, wrapped each case separately in paper, to protect it against dirt, dust, or coal-smoke, along the way. By this method his cases arrived on the market, as fresh and neat-looking on the outside, as when first put up.

As the careful handling of comb-honey during shipment is very important, it is best to mark each case with a large label or a stencil, bearing the words: 


\section{HONEY IN GLASS. Handle with CaRe.}

Very small lots ought never to be sent by rail, at least until we get better railroad regulations, concerning the handling of goods in transit, than we have at present.

Comb-honey in large lots should be shipped in large crates, with handles at each end, each crate containing about one hundred pounds of honey, or about eight cases, of twenty-four sections each.

829. The barrels that we use for extracted honey are oak barrels, which have contained alcohol. They are gummed inside, with some composition, to prevent the alcohol from soaking through the wood, and this gum, or glue, prevents the leakage of honey. Whisky barrels are often unfit to contain honey, for they are usually charred on the inside, and motes of charcoal fall into the honey and spoil its appearance. We keep our empty barrels in a dry place. As soon as filled, they are bunged and rolled into a cool and dry cellar, where they remain until the honey selling season, which begins in September, or October. Any dry room will do, when a dry cellar is not at hand, but a cellar has a more even temperature when cold weather comes.

If the barrels are damp, when the honey is put in, and are removed to a dry place afterwards, they will soon leak; for honey does not keep the wood from drying and shrinking. Honey barrels, then, should not be treated in the same way as wine or eider barrels; and swelling them, with steam, or hot water, rrevious to filling them with honey, will not be of any benefit, unless they are kept damp afterwards. This is not to be thought of, for honey must be kept dry, on account of its hygrometric properties. It will absorb the moisture out of the staves of the barrel that contains it and will become thin and watery, and at the same time, the staves, in giving up their moisture, will shrink and the honey will leak out. Thus it is easy to see that none but the best dry barrels will do. 

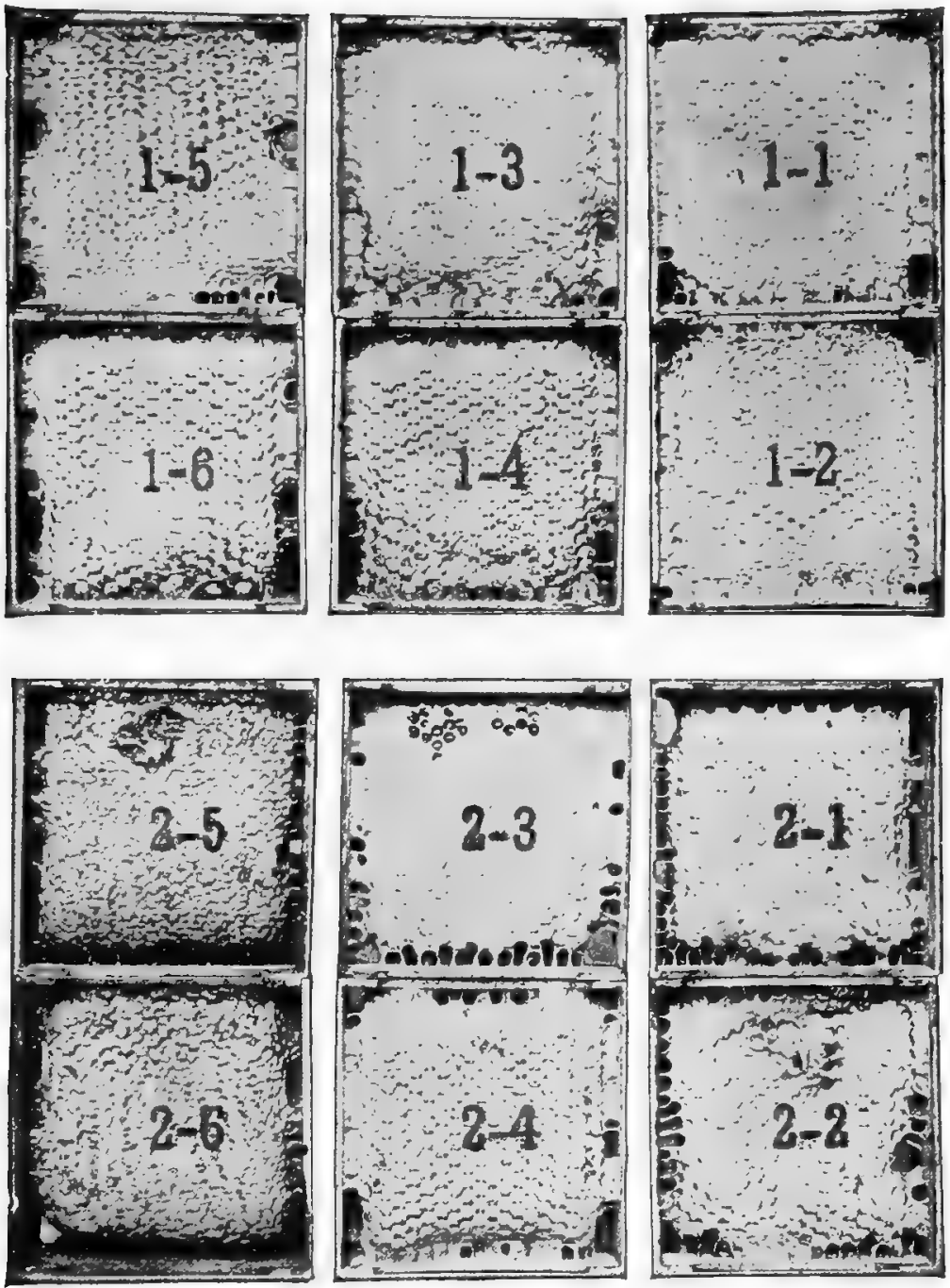

Fig. 223.

GRADING HONEY.

The Colorado grading, No. 1 and No. 2. 
In this connection the reader will permit us to illustrate to him the hygrometric qualities of honey by narrating a little incident. We had received an order for a barrel of honey, to be in the liquid state. As this was midwinter, all our honey being granulated, a barrel was opened, the head taken out and the honey melted au bain-marie (834). It was immediately replaced in the barrel, while hot, and prepared for shipmert. But it happened that this barrel had been kept, for some time after granulation of the honey, in a damp place, and the wood was somewhat damp. This hot honey absorbed the moisture from the staves during the night to such an extent that the next morning, the barrel was leaking from every joint. We have since that time allowed honey to cool off when treated in this way, before returning it to the barrel. But usually when honey is melted, it is at once put up into retail packages.

Cheap barrels cannot be opened to remove the honey by taking out the head without damaging them, while good ironbound oak barrels will last for years, and will never leak, if managed properly. To take the head out, it should be marked, with a chisel, so as to replace it afterwards exactly in the same position. A strong gimlet is screwed into the middle of it, for a handle. After the hoops have been chased off, the head can be pulled out readily, and it is replaced in the same manner, when the barrel is empty.

If care and judgment were used in these matters there would be but little complaint on the part of dealers, about leaking honey shipped from the apiarist.

One of the most popular packages for putting up extracted honey and disposing of it in a wholesale manner is the sixtypound can, either round or square. The square cans are boxed, one or two in a case and are easily piled in wagons or cars, but the round can with a wooden jacket has been much recommended of late by a man of great experience in the production of extracted honey, Mr. N. E. France. The smaller packages for retail trade are discussed further (841). 
The honey, when put into large tanks to ripen, had better be - changed to the retail package at the next handling. But the apiarist who extracts, as we do, at the out-apiaries, will find good barrels the handiest package to bring a crop of well ripened honey home immediately.

830. In October, the honey of the July crop is all granulated, and that of the September crop is beginning to granu-

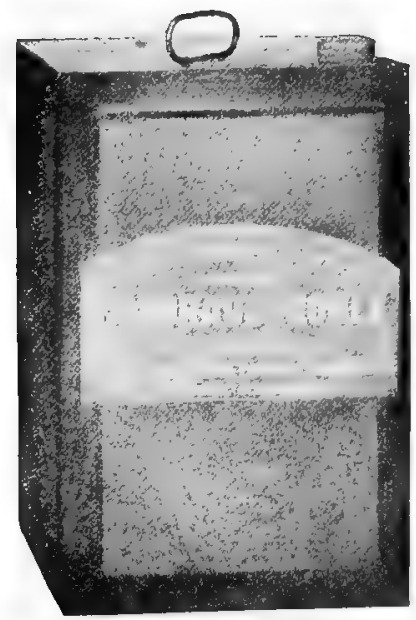

Fig. 224.

THE SIXTY-POUND HONEY CAN.

late. There are many different opinions in regard to the causes of granulation. Some think that it is effected by the action of light, but this is certainly a mistake, for our honey only sees the light when extracted, and is then kept in the dark until sold. We are more inclined to think that it is the action of cold air which eauses granulation; for sealed combhoney generally remains liquid. The extracted honey, which we harvest, always granulates. We have handled liquid honey, however, several times, but we have always found it to be un- 
ripe; and have laid it down as a rule for ourselves, that good honey should be granulated after November. We speak of honey harvested in the Mississippi valley; such as clover, basswood, knot-weed, golden rod, buckwheat, Spanish-needle, etc.

831. Of California honey, we can say nothing, having never handled it. But we have handled Louisiana honey, which, we were told, would not granulate before a year, and we had searcely had it three weeks in our cold climate, before it began to granulate. The only ripe honey which did not gramulate, was a lot of Spanish-needle honey, which had been extracted late in November. It remained liquid until sold, a month or two later, and we ascribed its not granulating to the late harvesting of it.

We have, however, seen a few instances of slowly ripened honey that did not granulate, although very thick and rich. These are exceptions. If honey is melted when granulated and allowed to evaporate a little, it will be very slow to granulate again.

832. Every bee-keeper has noticed that, at times, honey hardens in very coarse and irregular granules, that look like lumps of sugar, and have no adherence with one another, with a small amount of liquid honey interposed between them; and that at other times, the candying is compact, and can be compared to the hardening of lard.

The first kind of granulation is always produced in honey harvested, like clover or basswood, during the warm months of the year; while the soft candying is prevalent in the honey extracted in the Fall. In France, coarsely granulated honey is held as less valuable than the fine grained honey, and there is a good reason for this preference, for the coarsely granulated honey cannot be kept as well as the fine grained. It is evidently less evenly ripened.

In this country also, coarsely granulated honey sells with less facility-especially because many ignorant persons imagine that it las been adulterated with sugar, and that the coarse grains arc lumps of sugar. 
In such honey, the liquid parts come to the surface, and absorbing moisture from the air, are very apt to become acid by fermenting. But, even after granulation, it can easily be brought to a fine grain by melting it and exposing it to the cold of our Northern Winters. Basswood honey would even be benefited by this, as it would lose a little of its too strong flavor.

Basswood and clover honey are more apt to ferment than any other class of honey, even when thoroughly granulated, if they remain exposed to the heat of the following Summer, and it is advisable to keep these two kinds in a cool, dry place during the hot weather. A damp cellar would be objectionable, since honey readily absorbs moisture from the air.

833. Those bee-keepers who will follow our methods, of extracting ( $\mathbf{7 6 3}$ ) after the honey crop, will have but little trouble with honey fermenting, even if they have to keep it through the following Summer. If any honey should ferment, however, let them not think that it is spoiled, unless it was really unripe and has turned sour. A slight amount of alcoholic ferment can be evaporated readily by melting the honey over water, when the ferment escapes in the shape of foam. As this fermentation is caused by the presence of unripe honey, some of our friends succeed in entirely preventing it by melting all their honey immediately after granulation. The melting evaporates all excess of moisture contained in it.

Mr. C. F. Muth, whose large experience in handling honey made him a high authority, ripened all his honey by keeping it in open vessels in a dry and ventilated room, for a month or two after extracting. Many noted Apiarists are now following that method.

834. Melting Honey. Honey should never be placed directly over a fire to melt it. The least over-heating will evaporate its essential oils, and give it the burnt taste of dark molasses instead. It should be put in a tin or copper vessel, and this in another large vessel containing water. This heating au bain-marie, as the French call it, is resorted to by 
cooks, confectioners and others, whenever there is any danger of scorching the substance heated.

In the case of honey, the water should not even be allowed to boil.

835. The increase of honey production has been so great, in a few years, that the consumption has barely kept pace with it. But it will soon take its rank among necessities, like butter or syrups; and change from a luxury to a staple.

836. Our first crops of extracted honey, were sold readily at wholesale, and at good prices; for it was then that the wholesale dealers and manufacturers were making the largest profits, by mixing the honey, which they bought from beekeepers, with cheap substances, like giucose, which kept the honey from granulating, and by putting it up in tumblers, with a sniall piece of comb honey in the center. This honey, or rather mixture of honey, was sold by them usually at lower prices than they had paid for the pure honey. But ready sales in this way did not last long; for, after a year or two, the markets were crowded with this drug.

Should our readers ever come across suspicious-looking honey, they will find the following a cheap recipe to recognize adulteration :

"Put in a small vial about one ounce of the honey to be tested, fill the vial with pure cistern water, shake thoroughly to dissolve the honey; then add to the mixture about a thimbleful of pure alcohol. If the honey is pure the solution will remain unchanged, but if adulterated with glucose, it will be turbid and whitish.

"This is the means used by the honey dealers of Paris, to detect adulterated honey." -(Annales de la Societe d'Apiculture de l'Aube.)

837. We have now United States laws concerning the adulteration of food and it is to be hoped that no honey will ever again be sold that contains a proportion of corn syrup or commercial glucose. This cheap syrup should be sold under its own name. It is oi very inferior value when compared 
to honey as it contains only about twenty-five to thirty per cent of saccharine matter.

False assertions have been made at different times concerning the possibility of manufacturing comb honey, filling it and sealing it over by machinery. It is hardly necessary to say that this is entirely impossible and if it ever became possible, it would be readily detected, as human hands could never make the variety of shapes that are achieved by the bees. No two combs are alike, when built by the bees, even if they have been built on comb foundation.

"So widespread was this falsehood, that in our journal of November 1, 1885, page 738, I offered $\$ 1,000$ to anybody who would tell me where such spurious comb-honey was made. No one has ever given the information, neither has one ounce of manufactured comb-honey ever been forthcoming. It is a mechanical impossibility, and will, in my opinion, always remain so. * * I hardly need add, that the above slanderous report in regard to bogus comb-honey was very damaging to the bee-keeping industry. It probably obtained wider eredence because one Prof. Wiley, some years ago, started it by what he termed a 'scientific pleasantry.' "-A. I. Root.

838. The granulation of honey was objected to by many consumers, at first, from the prejudiced idea that granulated honey had been mixed with sugar. It has ceased to be an objection, for, in our neighborhood, nearly all honey consumers now know that good ripe honey generally granulates in cold weather. But, now and then, a person is found who wants liquid honey, or comb honey, thinking that no other is pure.

We were told that the judges at an agricultural exposition refused to give a premium to a bee-keeper for his honey, because it was spoiled by granulating. These competent judges probably think that water is spoiled by freezing, for granulated honey if carefully melted (834), is as good as before hardening.

839. We have always found an easy sale for extracted 
honey among foreigners-especially German or French; as they have been used to granulated strained honey, which has been produced for centuries in almost all parts of Europe. Some of them are so well acquainted with it, that they prefer it to the finest comb-honey, saying that comb is not made to be eaten.

Once, having received a favor from a French farmer, living a short distance from us, we selected a beautiful large comb of nicely sealed clover honey, while extracting, and sent it to this family after having carefully laid it on a dish. Much to our astonishment, we learnt, a few days after, that the good. French housewife had put our nice comb in a clean towel, carefully pressed the honey out, and melted the wax; and besides, that she was very much astonished at our having sent eomb honey to her, when we had such nice extracted honey on hand. The reader may readily imagine that henceforth we never sent to them anything but extracted honey, much to their satisfaction and ours.

Every bee-keeper who understands his business, should try to sell his honey when granulated, explaining to his customers that adulterated honey does not granulate, and that granulation is the best proof of purity. We have these words printed on all our labels.

840. To improve the present prices of honey, which are in some cases lower than the prices of second elass sweets, it is necessary that the masses should be induced to buy it. Thus far it is an article which few persons will buy regularly. Consumers will go to the grocery for tea, coffee, sugar, flour, meal, butter, etc., but very few make it a custom to buy honey -not that they dislike it, for "what is sweeter than honey?" but because they are not used to it.

All children, even in the heart of our manufacturing centers, have heard of "honey," but how many have never tasted it! Why? Fifty years ago honey was thirty cents per pound. Thirty years ago the very cheapest grades retailed higher than the best sugars. To-day, in many places, honey is still re- 
tailed at from fifteen to twenty cents, while sixteen pounds of the best sugar are sold for a dollar. Yet the Apiarists crowd it to the markets at prices ranging as low as three cents. What is lacking? Proper distribution. Instead of shipping our honey to the cities, whence it will be partly shipped back to our village retailers after having passed through the hands of commission men, and wholesale merchants, we must cultivate home consumption. We must show our neighbors, our farmers, our mechanies, at home, that our progressive methods enable us to furnish to them the sweetest of all sweets, at nearly as low a price as syrups. The occasional depression of the honey market is but temporary and its termination is on! $y$ a question of time.

841. It is important, in offering honey, whether to grocers or to consumers, to have it put up in neat and attractive shape. Comb-honey in sections weighing only a pound sells best, because it is, and always will be, a fancy article.

But in putting up extracted honey, a one-pound package is now too small. We must encourage a consumption in which the expense of packing will not materially advance the cost, and we find that, owing to this advance of cost, the one or one and-aquarter-pound package is less in demand than it was a few years ago.

842. Tin is the cheapest package for honey, in small quantities. Our favorite sizes are two and-ahalf-pound, five-pound, and tenpound pails. The two and-a-half-

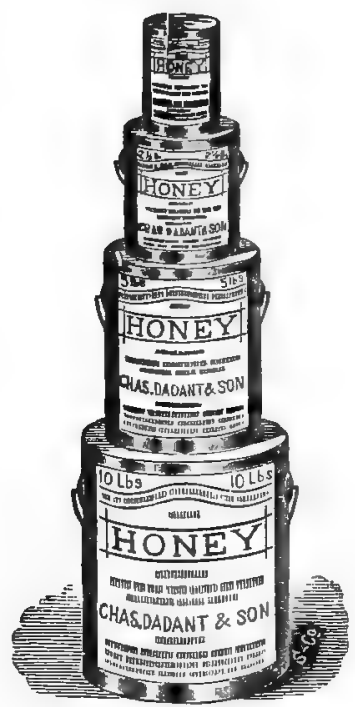

Fig. 225 . DADANT HONEY PAILS. pound pail is in great demand, and in the Winter of 1886-7, 
the bulk of our crop of that year, about 24,000 lbs., was sold in this package, at twenty-three cents per pail, or about nine cents per pound.

Some of our readers will ask why we do not put up our honey in these pails from the first, instead of putting it up in barrels. We never do so, because we do not know what proportion of each size will be required by the trade; because honey in small cans occupies too much room, and is not so

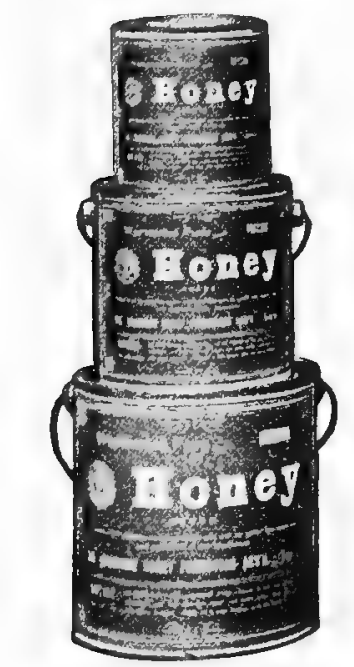

Fig. 226.

THE FRICTION-TOP HONEY PAIL.

easily moved out of the way; and especially because we keep honey from the best seasons for the years of poorer crop, and it keeps best in barrels. We have kept honey in pails for two years or more, but the pail often rusts on the outside, and becomes unsalable. The objections above given are very weighty, in extensive production, when tens of thousands of pounds have to be cared for, but the small producer 
may, if he chooses, put up his honey, at once, in retail packag'es.

843. To stop the accidental leakage of honey in pailsfor, owing to its weight, it will leak through seams that are water-tight-we simply rub over the leaky spot a little tallowwax, prepared by melting beeswax with tallow or lard, in varied quantities.

A friction-top pail is now manufactured by the Tin Trust which is sufficiently honey-tight to fulfill every purpose. These pails are in many instances taking the place of the pail originated by us and which is for that reason called the "Dadant pail." All kinds of packages are sold by dealers, and papers or paper sacks are recommended for granulated honey. There is no doubt that these paper sacks are the véry cheapest package for retailing honey to the masses, but the amount put up in these must be limited to the actual winter consumption, owing to their probable leakage when warm wealher comes. The sacks are generally coated with paraffine.

A great deal of honey is sold in glass jars, but our objection to them is that granulated honey does not look well in them, and they are more costly than tin. Honey, in tinn, ean be put up gross weight and although no one objects to the weight of the pail, this weight helps to pay for its cost. Those who use glass as a honey package, melt the honey before bottling it.

For shipping honey in small packages, Mr. Aug. Christie, a large producer of Iowa, puts it up in soldered cans. But the honey must be very ripe, or else must be previously heated, for the least fermentation would burst the can.

844. In every case when honey is sold, it should be neatly labeled with the name and address of the producer, which is, in itself, a guarantee of its quality.

When you go into a strange grocery, where you are unknown, the immediate answer of the grocer, to your mention of honey is: "I don't want any honey; I have no sale for it, and I don't like to handle it." Should you then take your leave and go, there would be but little hope of increasing your 
sales. You have to study, and learn to imitate the eunning and perseverance of the traveling agent, and quietly talk it out. You first have to assure the grocer that you only wish to show him your goods and your prices at his leisure, and that he can then refuse to buy, if he chooses. You must show him why he has no sale for honey. You tell him that pure honey is one of the best sweets in the world, to which he readily agrees. You then explain that honey, not being a staple, his customers never come on purpose to buy it, but that when they see it, they are tempted to buy; that, for this reason, it should be put up with large and showy labels, and placed in a conspicuous position, so that it will readily eatch the eyc.

815. White honey in nice sections will generally sell at sight, unless the grocer has had some leaky packages, which dripped honey on the counter, left a sticky reminiscence of their presence, and attracted flies and bees. But if your honey is put up carefully, according to directions given, the first sale alone will be difficult. In selling extracted honey it may be necessary for you to explain the facility with which granulated honey may be liquefied.

With grocers that were unacquainted with us, we usually began by supplying them with yellow honey, such as buckwheat, or heartsease, or golden rod. This honey, strong in flavor, sells better to the inexperienced, who are afraid of getting sugar, or glucose. It is only after one or two years that we venture to offer to such grocers our whitest clover and bass-wood, which, though of superior flavor, are objected to, on account of their very beauty and quality. In every case wo try to furnish some good reference to the grocer, and we give him a full guarantee of satisfaction, with an agreement to take the honey back, if it does not prove altogether as we represent it. When a dealer is well satisfied that the merchandise which he sells is pure, his customers are quite likely to have confidence in it themselves; but, on the other hand, if he is in doubt as to the quality and purity of 
it, he will have but little chance of selling it, unless he does not care for the satisfaction of his patrons.

846. We must therefore spare no pains to fully convince . our grocers of the quality of our goods.

After the first sales have been made, the demand always becomes larger and easier. Of course, occasional objections are made, by persons who are unacquainted with the properties and qualities of good honey; but these are easily overcome, when you have once gained the confidence of the dealers.

Extracted honey is usually sold at between half and twothirds of the price of comb-honey. It ships better, leaks less, and keeps more easily than comb-honey; and its lower eost of produetion will sooner or later make it the honey for the masses.

\section{USES OF HONEY.}

847. The traditions of the remotest antiquity show that honey lias always been considered a pleasant and healthy food. For several thousand years, it was the only sweet known.

Now that the sap of the cane, or the beet, converted into sugar, or the eheaper corn syrup, made by boiling corn starch with sulphuric acid, have become a necessity in every family, let,us see what place honey may occupy in our diet, not only as a condiment like sugar, but as food, drink, and medicine.

\section{As Food.}

Honey as food is very healthy. It is admitted that those who use honey freely at meal time, find in it health and long life.

"It is Nature's offering to man-ready for use, distilled drop by drop in myriads of flowers, by a more delieate process than any human laboratory even produced." - (T. G. Newman, "Honey as Food and Medicine.")

The following extract from the work of Sir J. More, Lon- 
don, 1707, will show the estimate which the old writers set upon bee-products:

"Natural wax is altered by distillation into an oyl of marvellous vertue; it is rather a Divine medicine than humane, because, in wounds or inward diseases, it worketh miracles. The bee helpeth to eure all your diseases, and is the best little friend a man has in the world.... Honey is of subtil parts, and therefore doth pierce as oyl, and easily passeth the parts of the body; it openeth obstructions, and eleareth the heart and lights of those humors which fall from the head; it purgeth the foulness of the body, cureth phlegmatick matter, and sharpeneth the stomach; it purgeth those things which hurt the clearness of the eyes, breedeth good blood, stirreth up natural heat, and prolongeth life; it keepeth all things uncorrupt which are put into it, and is a sovereign medicament, both for outward and inward maladies; it helpeth the grief of the jaws, the kernels growing within the mouth, and the squinancy; it is drank against the biting of a serpent or a mad dog; it is good for such as have eaten mushrooms, for the falling sickness, and against the surfeit. Being boiled, it is lighter of digestion, and more nourishing."

848. When Augustus-Julius-Cæsar, dining with PollioRumilius on his hundredth birthday, inquired of him how he had preserved both vigor of body and mind, Pollio replied: "Interius melle, exterius oleo."-Internally by honey, externally by oil.

Honey is in daily use on our table, and we find that children prefer it to sugar. The only cause of its not being in general use in place of "vile syrups" is the high price at which it was formerly sold.

Mr. Newman in his little pamphlet above quoted, says:-

"It is a common expression that honey is a luxury, having nothing to do with the life-giving principle. This is an errorhoney is food in one of its most concentrated forms. True, it does not add so much to the growth of the muscles as does beefsteak, but it does impart other properties no less necessary to health ard vigorous physical and intellectual action! It gives 
warmth to the system, arouses nervous energy, and gives vigor to all the vital functions. To the laborer it gives strengthto the business man, mental force. Its effects are not like ordinary stimulants, such as spirits, \&c., but it produces a healthy action, the results of which are pleasing and permanent-a sweet disposition and a bright intellect."

849. As a condiment it can be used in many ways. In candies it may finally replace the unhealthful glucose of com- . merce. The confectioners who now use it, increase their trade every ycar.

In France, "pain-d'epice," "ginger bread," is sold in immense quantities at the fairs. The best makes are sold at the most important fairs through the country. It keeps an indefinite length of time, and farmers' wives are wont to buy enough to last for months. The following is the recipe:

850. "Dissolve 4 ounces of soda, in a glass of warm skimmed milk. Take 4 pounds of flour and pour in the milk and enough warm honey to make a thick dough, flavor with anise and coriander seeds, eloves, and cinnamon, all powdered fine. Knead carefully, as you would bread. Let it rise two hours in a warm place, spread in pans and bake in a moderately warm oven. Ten or twelve minutes will do, if the cakes are thin. As soon as the cake resists to the touch of the finger it is done. Before baking, it may be decorated with almonds, preserved lemon peel, etc. Wheat flour makes good 'pain-d 'epice,' but some prefer rye flour. Fall honey is preferable for it, on account of its stronger taste." -L'Apiculteur.

The spices may be varied according to taste. Some add powdered ginger, or grated lemon or orange peel.

851. Crisp ginger bread can be made by mixing in it a quantity of broken almonds, blanched by dipping in boiling water, hazel-nuts, English walnuts, ete. The same dough, in skilled hands, with different seasonings, will make a variety of dainties, all with honey.

Instead of lard or butter, artistic cooks use olive oil to grease the pans; in America, cotton seed oil takes its place, and is good. The Italians sometimes use beeswax. 
852. Alsatian Ginger Bread: "Take, yellow honey 1 pound, flour 1 pound, baking soda $1 / 2$ ounce. Dissolve the soda in a tablespoonful of brandy, heat the honey and put in the flour and the soda. Knead the whole carefully, and eut in lumps before putting in the oven.

"This mixture can be kept in the cellar for months and can be used to make the

"Leckerli: Add to the dough, chopped almonds $1 / 2 \mathrm{lb}$., preserved orange peel 2 drams, ditto lemon 1 dram, cinnamon 1/2 dram, and 20 cloves, all finely powdered. Mix well and bake.' (Dennler, "Honey and Its Uses.")

853. Honey Cake: Warm half a glass of milk with $1 / 4$ pound of sugar in a stew pan. Put in $3 / 4$ of a pound of honey and boil slowly. Then add 1 pound of flour, $1 / 2$ dram of soda, and knead, spread on a pan and bake for an hour."

854. Italian "Croccante Di Mandorle": "Blanch two pounds of almonids, by dipping in boiling water. Slice them with a knife. Add the yellow peel of a lemon cut fine, some powdered vanilla, and a few lumps of sugar flavored by rubbing them on orange peel. Boil 2 pounds of good honey with an ounce of olive oil or good unsalted butter, till it is reduced to thick syrup. Then add the almonds, lemon, etc., a little at a time, mix well, pour in a buttered tin pan and press the mixture against the sides with a lemon peel. It should not be more than half an inch thick. When cool take the crisp cake out of the vessel by warming it a little." (Sartori \& Rauschenfels, L'Apicoltura in Italia.)

855. Muth's Honey Cake: 4 quarts of hot honey and 10 pounds of flour, with ground anise seed, eloves and cinnamon to suit the taste. This is made into a dough and left to rest for a week or two, when it is rolled out in cakes and baked. The longer the rest, the better the cakes.

Fruit jellies with honey: Take the juice of eurrants or other fruits, and after adding a like quantity of honey, boil to a jelly. Put in small tumblers, well sealed, in a dry room.

856. Honey-vinegar is superior in quality to all other kinds, wine vinegar included.

It takes from one to one and a half pounds of honcy to make one gallon of vinegar. Two good authorities on honey 
vinegar, Messrs. Muth and Bingham, advise the use of only one pound of honey with enough water to make each gallon of vinegar. We prefer to use a little more honey, as it makes stronger vinegar, but the weaker grade is more quickly made. If the honey water was too sweet, the fermentation would be much slower, and with difficulty change from the alcoholie, which is the first stage, into the acetic. This ehange of fermentation may be hurried by the addition of a little vinegar, or of what is commonly called vinegar mother.

If honey water, from cappings, is used, a good test of its strength is to put an egg in it. The egg should float, coming up to the surface at once. If it does not rise easily, there is too little honey. As vinegar is made by the combined action of air and warmth, the barrel in which it is contained must be only partly filled, and should be kept as warm as convenient. It is best to make a hole in each head of the barrel, about four or five inches below the upper stave, to secure a current of air above the liquid. These, as well as the bung hole, should be covered with very fine wire screen, or with cloth, to stop insects.

A very prompt method consists in allowing the liquid to drip slowly from one barrel into another, as often as pos. sible during warm weather.

As we make vinegar not only for our own use, but also to sell to our neighbors, we keep two barrels, one of vinegar already made, the other fermenting. When we draw a gallon of vinegar, we replace it with a gallon from the other barrel. This keeps up the supply.

Vinegar should not be kept in the same cellar with wines, as its ferment would spoil the wines sooner or later.

\section{Honey as Medicine.}

857. In Denmark and Hanover, the treatment of Chlorosis, by honey, is popular. The pale girls of the eities are sent to the country, to take exereise and eat honey. The good 
results of this treatment have suggested to Lehman the theory that the insufficieney of hepathic sugar is the cause of Chlorosis, which thus explains the euring effect of honey. (JACCoud, as quoted by the Revue Internationale $\&$ Apiculture.)

Honey, mixed with flour, is used to cover boils, bruises, burns, ete. ; it keeps them from contact with the air, and helps the healing. Beverages, sweetened with honey, will cure sore throat, coughs, and will stop the development of diphtheria, especially if taken on an empty stomach, at bed time. A glass of wine or cider, strongly sweetened with honey, is advised in $L$ 'A piculteur, as a cure for colds. (1886.)

Suckling babies are cured of constipation, by a mixture of bread and honey given them, tied in a "sugar teat."

A constant use of honey, at meal time, cures some of the worst cases of piles.

"According to Mr. Woiblet, washing the hands with sweetened water will kill warts. Having heard of the healing he put honey plasters on the hands of a child who had a large wart in the palm of the hand, and after a few days of treatment the wart disappeared." -Bertrand, (Revue Internationale d'Apiculture.) 


\section{CHAP'TER XXI.}

Befswax, and its Uses.

\section{Melling Wax.}

858. We will now deseribe the different processes used by bee-keeper's to render the combs into wax. To melt every comb, or piece of comb, as it is taken from the hive, would increase the work, and, as it is preferable to choose our time for this operation, we have to preserve them from the ravages of the moths (802) by some of the methods that we have given (\$12).

859. The eappings ( 72 ) after extracting, are allowed to drain in a warm place for several weeks; very nice honey being obtained from them. They are then washed in hot water, and the sweet water obtained can be used for eider, or wine, or vinegar (856). These eappings, as well as the broken pieces of white comb in which brood was never raised, should be melted apart from the darker combs, for, not only are they easier to melt, but the wax obtained being very bright in color, is unsurpassed for making comb-foundation (674) for șurplus boxes.

860. When the combs are blackened by the dejections of the worker bees $(\mathbf{7 8 4})$, or of the drones $(\mathbf{4 0})$, and by the skins and cocoons of the larvæ (167), it is so difficult to render the wax, that many bee-keepers think it is not worth the trouble. We advise washing these combs and keeping them under water for about twenty-four hours. Then the cocoons and other refuse being thoroughly wet and partly dissolved, will not adhere to the wax. This will be lighter colored, if the combs are melted with clear water and not with the water already darkened by the washing. 
But as this method always leares some wax in the residues, for some of it goes into the cells during the melting, and it is impossible to dislodge it, a better result is obtained by crushing the combs before washing them. But this pulverizing can be done only in Winter, when the wax is brittle.

861. The combs should be melted with soft or rain water,

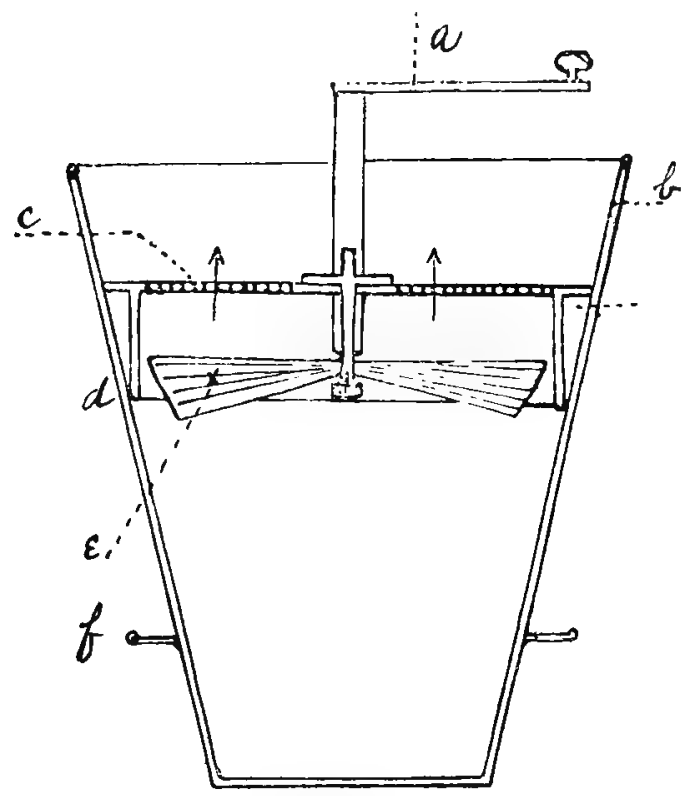

Fig. 227 .

KLHAN WAX KETTLE.

a-Removable crank. b-Level of the water, c-Screen for straining the liquid wax. d-Level of the combs. e-Wings of the wheel. f-Shoulders for supporting kettle on stove.

the boiler kept about two-thirds full, and heated slowly, to prevent boiling over. If the floor, around the stove, is kept wet; any wax that may drop will be easily peeled off.

During the melting carefully stir till all is well dissolved. 
Then lower into the boiler a sieve made of a piece of wire cloth, bent in the shape of a box, from which the wax can be dipped as it strains into it. If the whole is thoroughly stirred for some time, very little wax will be left in the residues. This is the cheapest and best method of rendering wax, without the help of a specially made wax-extractor.

862. To obtain as much wax as possible from the eombs,

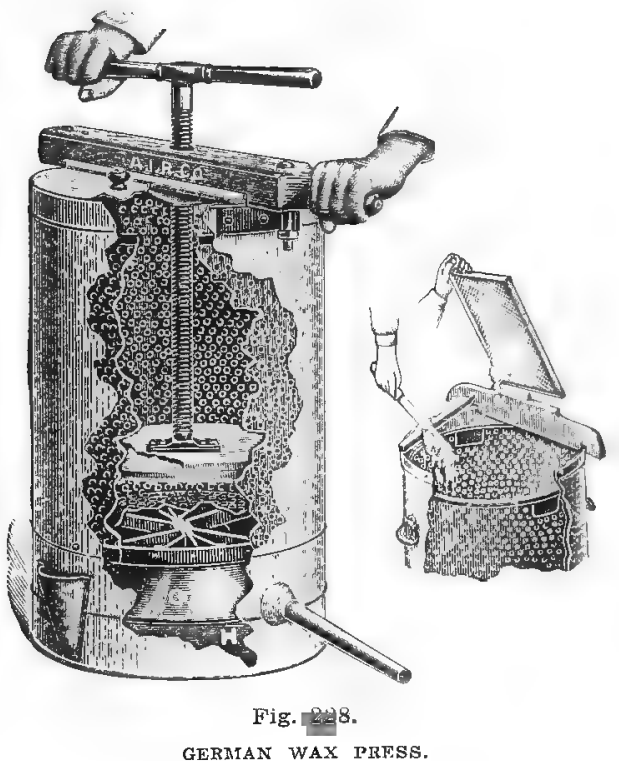

(From the A B C of Bee Culture.)

the large wax manufacturers of Europe empty the coutents of the boiler into a bag, made of horse-hair or strong twine, and place the bag under a press while boiling hot. All the implements used, as well as the bag, are previously wetted, to prevent their sticking.

Several implements have lately been devised for rendering 
beeswax. A French wax-bleacher devised a kettle, Fig. 227, described in the American Bee Journal, which permits of stirring the combs while they are held under water. In this way the wax is permitted to escape. To make it still more easy for the wax to come to the surface they use salt water, which is heavier than ordinary rain water and its greater density causes the wax to float more readily.

But the ultimate method for getting all the wax out of the "slum-gum" or residues is the use of a press. The German

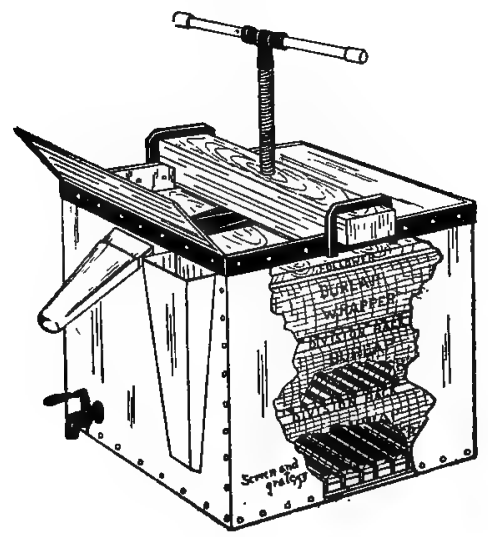

Fig. 229.

HERSHISER WAX PRESS

press, Fig. 228, does good work, if not too great a quantity of residue is rendered at one time. Mr. Hershiser of Buffalo has devised a press, Fig. 229, in which he uses screens between several layers of comb wrapped in burlap. These screens allow the wax to escape from the center of the mass, much on the same plan as the large cider presses of Illinois, in which the apple cheese is separated by cloth in a dozen different layers. The different presses must be used over steam or water, so as to keep the mass hot all the time. 
863. Cappings from the extracting and small pieces gathered from time to time, may be rendered during the summer, by the use of a sun-extractor, wherever the sun is sufficiently powerful. At this latitude, the $42^{\circ}$, sun-extractors can be efficiently used during the months of May, June, July, and August. The sun-extractor requires no labor from the Apiarist, other than filling it with combs and removing the melted wax.

861. The dealers in France buy, from the bee-keepers, for little or nothing, the residues of their melted combs. They dissolve them in turpentine, press the pulp dry, and distill the liquid, to separate the turpentine. As the wax is not volatile, it remains in the still. It is said that, when wax was dearer than it is now, large profits were realized by this operation.

865. To cleanse beeswax from its impurities, we melt it (arefully with cistern water and pour it into flaring cans (wider at the top than at the bottom) containing a little boiling water. This wax is kept in the liquid state, at a high temperature, for twenty-four hours. During this time, the impurities drop to the bottom and can be scraped from the cake when cold. Some wax can be obtained from this refuse, but some of it is always left in the dregs, as is proven by the impossibility of dissolving them by exposure. Nothing can destroy beeswax, except fire, or the ravages of the beemoth. Exposure to the weather does not affect it, but only bleaches it.

To prevent the cakes of wax from eracking, it should be poured into the molds or cans when only $165^{\circ}$ Fahr. and should be kept in a warm place to cool slowly.

Sulphuric acid is used by bleachers and foundation manufacturers in rendering beeswax out of the dark residues. Some writers have recommended this method to the bee-keeper. We wish to warn them against it. No acid is necessary in separating the wax from the impurities of the combs and if it is used, the beeswax loses its fine honey and bee flavor and 
smell. There would be but little harm, if the acid (oil of vitriol) was used sparingly, but beginners often use enough in rendering a hundred pounds, to serve for a thousand pounds or more. The only utility of it is in rendering residues of the worst quality in large establishments.

866. The utmost care is necessary not to spoil wax in melting it. If heated too fast, the steam may disaggregate it. Then its color is lighter, but very dim; the wax having lost its trainsparency, resembles a cake of corn meal. When it is in this condition, water will run out of it if a small lump is pressed between the fingers. The best way to restore it is to melt it slowly in a solar wax extractor (fig. 229). We have succeeded also by melting it with water, and keeping the water boiling slowly till all the water contained between the particles of wax had evaporated. But this work is tedious and cannot be accomplished without the greatest care and a skillful hand. Whatever the means used, you may rely on more or less waste.*

Wax-bleachers draw wax into small ribbons which are exposed to the rays of the sun for sereral weeks, or melted with chemical acids; but wax-bleaching is beyond the purpose of this book.

Uses of Wax.

86\%. Before the invention of parchment, prepared as a material for writing, from the skins of goats, sheep, calves, cte., tablets covered with a light coat of wax were used. A style-an instrument sharp at one end to engrave characters in the wax, and broad and smooth at the other end to erase them-was used in place of a pen. The Latin poet Horatius, born sixty-five years before Christ, probably used these tablets, for, in his admonition to poets, he writes: "Saepe stylum

* Whenever beeswax is melted in water, cven with the utmost care, some small portions of it are water-damaged and settle to the bottom of the cake with the dregs. This water-damaged beeswax has ofton been mistaken for pollen residucs, 
vertas." - "turn often your style;" thereby meaning: "Carefully correct your writings."

Several nations of old, having noticed that beeswax does not rot, used it to embalm their dead. Alexander the Great was embalmed with wax and honey.

868. Beeswax is largely used by the Catholic ehurches, for lights, during the eeremonies, for it is preseribed to priests to use exclusively wax produced by bees.

869. In several countries of Europe the floors and stairs, instead of being covered with carpets, are rubbed with wax and carefully scrubbed with a dry brush every day till they shine. In Paris, floor scrubbing is a business which supports many working families.

Beeswax is used also by the sculptors and painters to varnish their work, to model wax figures; by dentists to take imprints of jaw-bones. It is retailed in small lumps and used to give smoothness and stiffness to thread for sewing.

The casting of bronze statues and works of art a cire perdue, has been largely practiced in France since the Renaissance. This process is mentioned in Harpers' Monthly for September, 1886.

870. Beeswax forms part of a great many medicines, and pomades for the toilet. Here are a few recipes selected among: hundreds of others:

1. Salve or Cerate for Inflamed Wounds.

Beeswax ................... part

Sweet almond oil.............4 parts

Dissolve the wax in the oil and stir well till cold. Sweet almond oil can be replaced by olive, or cotton seed, or linseed oil, or even by fresh unsalted butter.

This cerate, may be used as a vehicle by the endermic method-we mean by frictions on the thin parts of the skin - to introduce into the blood several substances, such as quinine, against fever; surphur, for itches; camphor, henbane, opium, as sedatives; iodine, as depurative; and so on, the only care being to have the drugs earefully mixed. 
2d. Turpentine Balm for Atonic Wounds, (without inflammation) :

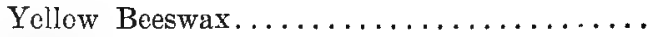

Turpentine.

Essence of Turpentine.

Equal parts.

Melt the wax, add the turpentine, then the essence.

3d. Salve for the Lips:

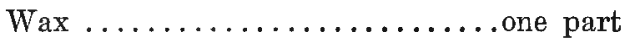

Sweet Almond Oil............two parts

Add a small quantity of Carmine to color it, strain and add, when melted again and half cold, some volatile Oil of Rose.

Sth. Adhesive Plaster for Cuts (sweet-scented):

Colophony .............40 parts

Wax .................... "

Elemi rosin $\ldots \ldots \ldots \ldots \ldots \ldots 25$ "

Melt and add:

Oil of Bergamot...........5 parts

Oil of Cloves...............

Oil of Lemon..............

5th. Green $\Pi^{\top}$ ax for Corns:

Yellow wax $\ldots \ldots \ldots \ldots \ldots \ldots \ldots 4$ parts

White pitch $\ldots \ldots \ldots \ldots \ldots \ldots \ldots 2$ "

Venice Turpentine ........... 1 "

Sub-acetate Copper (finely powd.) 1 "

Melt the wax and the white pitch, add the acetate of copper well mixed with the turpentine, and stir till cold. If too hard to be spread or small pieces of cloth, add a little olive, or cotton seed, oil. 
6th. Balm of Lausanne, for Ulcerated Chilblains and Chaps of the Mammae or Teats:

Olive or Cotton seed oil...........500

Rosin of Swiss Turpentine.........100

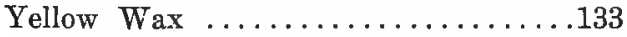

Powdered Root of Alkanet.......... 25

Keep it melted au bain-marie (834) for half an hour and add :

Balsamum Peruvianum........... 10

Gun Camphor................ 1

7th. Mixture to Remove the Cracks in Horses' Hoofs:

Melt equal parts of wax and honey on a slow fire, and mix thoroughly.

Clean carefully the hoof with tepid water and rub the mixture in it with a brush. The cracks will disappear after several applications and the hoof will be softened.

8th. To Keep the Luster of Polished Steel Toois:

Oil of Turpentine.............. 8

Wax ....................... 1

Boiled Linseed Oil............. 1/2 


\section{CHAPTER XXII.}

\section{Bees and Fruits and Flowers.}

8\%1. We have shown, in the chapter on Physiology (43), that bees cannot injure sound fruits, and in the chapter on Food (268), that they help the feeundation of flowers; but this accusation of bees injuring fruits has become of so much importance in the past years, especially in the best fruit and bee country of the world, California, that we deem it necessary to give it a whole chapter.

While the honey-bee is regarded by the best informed horticulturists as a friend, a strong prejudice has been excited against it by many fruit-growers; and in some communities, a man who keeps bees, is considered as bad a neighbor, as one who allows his poultry to despoil the gardens of others. Even some warm friends of the "busy bee," may be heard lamenting its propensity to banquet on their beantiful peaches and pears, and choicest grapes and plums.

That bees do gather the sweet juice of fruits when nothing else is to be found, is certain; but it is also evident that their jaws being adapted chiefly to the manipulation of wax, are too feeble to enable them to puncture the skin of the most delicate grapes.

87. Te made experiments in our apiary on bees and grapes, during the season of 1879-one of the worst seasons we ever knew for bees. The Summer having been exceedingly dry, the grape crop was large and the honey crop small. In every vineyard a number of ripe grapes were eaten by bees, and the grape-growers in our vicinity were so positively certain that the bees were guilty, that they held a meeting, to petition the State Legislature, for a law preventing any one from owning more than ten hives of bees. 
This serious charge called our attention to the matter, and we decided to make a thorough investigation, in our own vineyard. But although many bees were seen banqueting on grapes, not one was doing any misehief to the sound fruit. Grapes which were bruised on the vines, or lying on the ground, and the moist stems, from which grapes had recently been plucked, were covered with bees; while other bees were observed to alight upon bunches, which, when found by careful inspection to be sound, they left with evident disappointment.

Wasps and hornets, which secrete no wax, being furnished with strong, saw-like jaws, for cutting the woody fibre with which they build their combs, can easily penetrate the skin of the tonghest fruits. While the bees, therefore, appeared to be comparatively innocent, multitudes of these depredators were seen helping themselves to the best of the grapes. Occasionally, a bee would presume to alight on a bunch where one of these pests was operating for his own benefit, when the latter would turn and "show fight," much after the fashion of a snarling dog, molested by another of his species, while daintily discussing his own private bone.

During grape picking, the barrels in which our.grapes were hauled to the wine cellar, were covered with a cloud of bees feeding on the damaged elusters, and they followed the wagon to the cellar. After removing the barrels to a place of safety, we left one bunch of sound grapes, on the wagon, puncturing one of the grapes with a pin. This bunch, being the only one remaining exposed, was at once covered with such a swarm of bees that it was entirely hidden from sight. It was three o'clock in the afternoon. At sunset the bees were all gone, except three, who were too exhausted to fly off. The bunch had lost its bloom, the grapes were shiny, but entirely sound. The one punctured grape had a slight depression at the pin hole, showing that the bees had sucked all the juice they could reach, but they had not even enlarged the hole.

We also placed bunches of sound grapes inside of some four 
or five hives of bees, directly over the frames, and three weeks after we found that the bees had glued them fast to the combs as they glue up anything they cannot get rid of, but the grapes were perfectly intact. This test may be made by every Apiarist.

Mr. McLain, at one time U. S. Apiarian expert, was instructed to test this matter thoroughly by shutting up bees with sound fruit, and the results were the same as in our case. (See the Agricultural Reports for 1885.)

873. The main damage to grapes is done by birds. Hence, the borders of a large vineyard are first to suffer, especially when in proximity to hedges, orchards or timber.

Even in small cities, the number of birds that feed on fruit is extraordinary, and one can have no idea of their depredations until he has watched for them at daybreak, which is the time best suited to their pilfering.

After the mischief has been begun by them or by insects, or whenever a crack, or a spot of decay is seen, the honey-bee hastens to help itself, on the principle of "gathering up the fragments, that nothing may. be lost." In this way, they undoubtedly do some mischief, but they are, on the whole, far more useful than injurious.

875. Among thousands of testimonials, we translate the following from L'A picoltore, of Milan, Italy, May, 1874, page 181:

"Being a lover of good wine, I manufacture mine from wilted grapes; my crop amounts annually to from thirty to forty hectolitres* of wine, worth on average, one frane, seventy-five centimes per litre. $\dagger$ When my grapes are gathered, I spread them on mats of reed or straw in a sunny place in front of my apiary, where they remain about two weeks. For the first two or three days the mats are covered with bees, but I pay no attention to this, for I have ascertained that they gather only the juice of the berries that are damaged. As soon as the

* One hectolitre is twenty-five gallons.

$\dagger$ This is about one dollar and forty cents per gallon, a high price for Italy. 
injured berries are sucked dry, the bees cease visiting the mats, for they cannot open sound berries. Instead of doing me any damage, they help me greatly, as they take away from my grapes the otherwise souring juices, which would give a bad taste to my wine.-Gaetano Taxini, Coriano, Italy, February, 1874.

876. Those who handle grapes, apples, etc., in times of honey-ciearth, should avoid attracting the bees, by unnecessarily exposing the erushed fruit, in warm weather, as the presence of bees in press-houses and sheds, where fruit is either made into wine, or otherwise prepared for use, is the greatest annoyance that they can cause the horticulturist.

With a little care, a wine-grower may escape all trouble, even if his press-house is in reach of a large apiary. But let him not imitate the grocer who had an open box of comb-honey at his door "for show," and tried to "shoo" the bees off, when they, in turn, deputized a few of their number to "shoo" him off, with great success.

877. In these depredations, the wine-growers who do not own bees are often very much incensed, because they believe that the Apiarist is making a profit out of their loss. But such is not the case. The Apiarist loses more than the winegrower, for many of the bees are destroyed, and the juice which the others bring home is worse than useless, as it is bad Winter food (628).

It is therefore, to the interest of the Apiarist, as well as of the fruit-grower, to prevent the bees, in all possible ways, from getting a taste of the forbidden juices, in seasonsluckily scarce-when there is a dearth of honey during winemaking time.

878. Some ignorant people have also contended that the numerons visits of bees to flowers, injure the latter and cause them to abort. This is the greatest of all delusions. Whiteclover, knot-weed, and Spanish-needles, which are among the plants most visited by bees, are also the most abundant, and if they were damaged, by being deprived of the honey which 
they 'yield, they would sooner or later disappear. All the observations that have been made, whether scientific or practical, show that the contrary is the truth. 


\section{CHAPTER XXIII.}

\section{Bee-Keeper's CaLendar.}

This ehapter gives to the inexperienced bee-keeper brief direetions for each month in the year,* and, by means of the full alphabetical index, all that is said on any topic can easily be referred to.

879. JaNUARY. - In cold elimates, bees are now usually in a state of repose. If the colonies have had proper attention in the Fall, nothing will ordinarily need to be done that will exeite them to an injurious activity.

In January there are occasionally, even in very cold latitudes, days so pleasant that bees can fly out to discharge their fæces; do not confine them, even if some are lost in the snow.

It is advisable to arouse them early so as to cause them to fly $(639)$, if the day is sufficiently warm. Otherwise, disturb them as little as possible. In very cold climates, where cellar wintering (646) is resorted to, all that is required is to keep the temperature as even and as near $42^{\circ}$ to $45^{\circ}$ as possible (648), with quietude and darkness (650). The Winter months are those, in which the bee-keeper should prepare his hives, sections, foundation, \&c., for the coming busy season.

880. February. - This month is sometimes colder than January, and then the directions given for the previous month must be followed. In mild seasons, however, and in warm regions, bees begin to fly quite lively in February, and in some locations they gather pollen (263). The bottom-board should be cleaned of the dead bees and other rubbish $(\mathbf{6 6 3})$ that sometimes obstruet the entrance, and prevent the bees from

* Palladius, who wrote on bees nearly 2,000 years ago, arranges his remarks in the form of a monthly calendar. 
flying out; as their worry in finding themselves imprisoned does them much harm. If any hives are suspiciously light, food (607) should be given them; this only in mild climates.

Strong colonies will now begin to breed slightly, but nothing should be done to excite them to premature activity.

881. MaRCH.-In our Northern States, the inhospitable reign of. Winter still continues, and the directions given for the two previous months are applicable to this. If there should be a pleasant day, when the bees are able to fly briskly, seize the opportunity to remove the covers (636); carefully clean out the hives $(\mathbf{6 6 3})$, and learn the exact condition of every colony. See that your bees have water (271), and are well supplied with rye-flour (265). In this month, weak colonies commonly begin to breed, while strong ones increase quite rapidly.

If the Winter has been very severe, this month is the most destructive to unhealthy bees. The hives of dead colonies should be thoroughly cleaned, and closed tightly to keep robbers (664) out, or they would carry off what honey may remain in them. Spring dwindling (659) should be guarded against by shutting off all upward ventilation (352), and reducing the space in the brood-chamber $(\mathbf{3 1 9})$ to the number of combs actually occupied by the bees. The entrance of the hives, especially of the weak colonies, should also be narrowed $(\mathbf{3 4 8})$.

If the weather is favorable, colonies which have been kept in a special Winter depository, may now be put upon their proper stands.

The time of removal from cellars (646) must depend altogether on the locality. Dr. C. C. Miller removes his bees when the first maple tree blooms. In Canada, they are sometimes left in the cellar till May. As a rule, bees are not, and should not be, wintered in cellars, south of the 39 th degree of latitude.

882. AprIL.-Bees will ordinarily begin to gather murh pollen ( $\mathbf{2 6 3})$, in this month, and sometimes considerable 
honey. As brood is now very rapidly maturing, there is a largely increased demand for honey, and great care should be taken to prevent the bees from suffering for want of food (607). If the supplies are at all deficient, breeding will be checked, even if much of the brood does not perish, or the whole colony die of starvation. If the weather is propitious, and the bees do not have a liberal supply of stores on hand, feeding to promote a more rapid increase of young may now be commenced $(\mathbf{6 0 6})$. Feeble colonies must now be reinforced (180), and should the weather continue cold for several days at a time, the bees ought to be supplied with water (271) in their hives.

This point is much neglected, by ourselves, as well as by others, in practice, but we are convinced that much of our April loss is due to the bees going in search of water in inclement weather $(\mathbf{6 6 2})$. At this time, if not before, the larvæ of the bee-moth will begin to make their appearance, and should be carefully destroyed, not that they are very damaging to bees in a carefully-conducted apiary, but only that they give annoyance by their presence on the combs or comb-honey, removed from the bees, in the latter part of the season (81:). "One stitch in time saves nine." One moth killed in April, prevents several thousand in October.

It is at this time, that the hives should be inspected, to remove all drone comb that can be found, as well as crooked combs and broken pieces,- to be replaced by straight worker comb (676), or strips of foundation (674). At this time, also, the hives that are intended for drone raising (511), should be supplied with sufficient drone comb for the purpose. Queenless colonies should be given young queens, purchased from queen-breeders in the South. This may be deferred until May, if the weather is cool. Weak queenless colonies should be united to others, as a rule, it does not pay to give brood to a queenless colony for raising young queens, unless it is quite strong, in bees.

883. MaY.-As the weather becomes more genial, the in- 
crease of bees in the colonies is exceedingly rapid, and drones, if they have not previously made their appearance, begin to issue from the hives that have been allowed to retain a notable amount of drone comb, and this is the time to raise queens for increase, or for inprovement ( $\mathbf{1 8 9}$ ).

The breeding space of weak colonies, which has been previously reduced, should again be enlarged as their needs may demand (349). If their combs are judiciously increased, with a proper anount of stimulative food $(\mathbf{6 0 6})$, and a little help from the stronger colonies (180), they may become as strong as any for the June harvest. In some localities, the strongest colonies may already gather mueh honey, and it will often be advisable to give them the supers (\%21); but in some seasons and localities, either from long and cold storms, or a deficiency of forage, hives not well supplied with honey will exhaust their stores, and perish, unless they are fed. In favorable seasons, swarms (406) may be expected in this month, even in the Northern States. These May swarms often issue near the close of the blossoming of fruit-trees, and just before the later supplies of forage, and if the weather becomes suddenly unfavorable, may starve, unless they are fed, even when there is an abundant supply of blossoms in the field.

881. JUNE. - This is the great swarming month in all our Northern and Middle States. As bees keep up a high temperature in their hives, they are by no means so dependent upon the weather for forwardness, as plants, and as most other insects necessarily are. We have had as early swarms in Northern Massachusetts, as in the vicinity of Philadelphia.

If the surplus cases (721) have been put on before the honey crop, there will be a less number of swarms, especially if the boxes have been furnished with combs, as baits, and the entrance enlarged to help rentilation $(\mathbf{3 4 4})$.

If the apiary is not carefully watched the bee-keeper, after a short absence, should examine the neighboring bushes and trees, on some of which he will often find a swarm 
clustered, preparatory to their departure for a new home (410).

"As it may often be important to know from which hive the swarm has issued, after it has been hived and removed to its new stand, let a eup-full of bees be taken from it and thrown into the air, near the apiary, after having sprinkled them with flour; they will soon return to the parent colony, and may easily be recognized, by standing at the entrance, fanning, like ventilating bees."-Dzierzon.

This is the quickest method to discover the home of a swarm.

As fast as the surplus honey receptacles are filled, more room should be given $(\mathbf{7 3 5}, \mathbf{7 6 3})$. Careless bee-keepers often lose much, by neglecting to do this in season, thereby condemning their colonies to a very unwilling idleness. The Apiarist will bear in mind, that all after-swarms which come off late in this month, should be either aided, doubled, or returned to the mother-colony. The issue of such swarms may be prevented, by removing, in season, the supernumerary queen-cells. During all the swarming season, and, indeed, at all other times when young queens are being bred, the bee-keeper must ascertain seasonably, that the hives which contain them, succed in securing a fertile mother (152).

885. JuLY. - In some seasons and districts, this is the great swarming month; while in others, bees issuing so late, are of small account. In Northern Massachusetts, we have known swarms coming after the Fourth of July, to fill their hives, and make large quantities of surplus honey besides. In this month, or as soon as the first crop is over, all the spare honey should be removed from the hives, before the delicate whiteness of the combs becomes soiled by the travel of the bees, or the quality of the honey is impaired by an inferior article gathered later in the season ( $\mathbf{8} 8 \mathbf{2})$. For the same reason, the honey extracted after this crop should not be mixed with that harvested later. In all the localities where 
a second erop is expected, the bees should again be incited to breed (606) to be ready for this second crop.

The bees should have a liberal allowance of air during all extremely hot weather, especially if they are in unpainted hives, or stand in the sun (311).

The larger the amount of honey they contain, the greater the danger of combs breaking down from the intense heat (369). The end of the honey crop can be told by the presence of a few robbers who immediately begin lurking about the hives $(\mathbf{6 6 4})$.

896. August. - In most regions, there is but little forage for bees during the latter part of July, and the first of August, and they being, on this account, tempted to rob each other, the greatest precautions should be used in opening hives (666). In districts where buckwheat is extensively cultivated, on flat prairies, or in the low land surroundin? $0.2 \mathrm{r}$ rivers, in which Fall-blossoms grow, the main harvert is sonetimes gathered during this month and the next, and swarming (106) may be resumed. In 1856, we had a buckwheat swarm as late as the 16th of September!

The bee-keeper who has queenless hives (199) on hanil as late as August, must expect, as the result of his ignorance or neglect, either to have them robbed $(\mathbf{6 6 1})$ by other colonies, or destroyed by the moth (\$02).

887. September. - This is often a very busy month with bees. The Fall flowers are in full blossom, and in some seasons, colonies which have hitherto amassed but little honey, become heavy, and even yield a surplus to their owner. Bees are quite reluctant to build comb so late in the season, even if supplies are rery abundant; but if empty combs are provided, they will fill them with astonishing celerity ( $\mathbf{r 6 3})$.

As suon as the first frost takes place, or whenever the crop is at end, the entire surplus must be removed, whether it be comb or extracted honey. If our method of extracting (881) is resorted to, the supers that have been returned to the bees, for cleaning, after the honey is extracted, may be 
left on the hives till Oetober, as they are safer from the moths, when in care of the bees.

If no Fall supplies abound, and any colonies are too light to winter with safety, then, in the Northern States, the latter part of this month is the proper time for feeding (608) them. We have already stated, that it is impossible to tell how much food a colony will require (623), to carry it safely through the Winter; it will be found, however, very unsafe to trust to a bare supply, for, even if there is food enough, it may not always be readily accessible (631) to the becs. Great caution will still be necessary to guard against robbing; but if there are no feeble, queenless or impoverished colonies, the bees, unless tempted by improper management, will not rob each other $(\mathbf{6 6 4})$.

888. ОстовеR.-Forage is now almost entirely exhausted in most localities, and colonies which are too light should either be fed, or have surplus honey from other hives given to them, early this month.

The extracting cases (781) should be removed previous to cold weather, as some bees may eluster in them and starve. These cases must be piled up carefully in the coldest room (810) of the honey house, safe from mice (816). The exact condition of every hive should be known now, at the latest, and, if any are queenless, they should be broken up. Small colonies ought to be promptly united.

The honey-selling season is now at hand, and from this time till the end of the holidays, the producer must look for a honey market. He should not only rely on sale in large eities, for they are always crowded, but a home market must be cultivated $(\mathbf{8 4 0})$.

889. NoveMber. - The hives should now be put in Winter quarters, the quilt removed, and absorbents placed in the upper story (636).

All possible shelter should be given $(\mathbf{6 3 5})$. For cellarwintering (646), the time of removing the bees should be at the opening of cold weather. The later in the season that 
the bees are able to fly out and discharge their fæces, the better. The bee-keeper must regulate the time of housing his bees by the season and climate, being careful neither to take them in until cold weather appears to be fairly established, nor to leave them out too late. A cold day, immediately after a warm spell is the best time (618).

890. Decenter. - In regions where it is advisable to house bees, the dreary reign of Winter is now fairly established, and the directions given for January are for the most part equally applicable to this month. It nay be well, in hives out of doors, to remove the dead bees and other refuse from the bottom boards if the weather is warm enough for them to $\mathrm{fly}$; but, neither in this month nor at any other time should this be attempted with those removed to a dark and protected place. Such colonies must not, except under the pressure of some urgent necessity, be disturbed in the very least.

We recommend to the inexperienced bee-keeper to read this synopsis of monthly management, again and again, and to be sure that he fully understands, and punctually discharges, the appropriate duties of each month, neglecting nothing, and procrastinating nothing to a more convenient season; for, while bees do not require a large amount of attention, in proportion to the profits yielded by them, they must have it at the proper time and in the right way. Those who complain of their unprofitableness, are often as much to blame as a farmer who neglects to take care of his stock, or to gather his crops, and then denounces his employment as yielding only a scanty return on a large investment of capital and labor.

\section{IN SHORT.}

891. Sprina.-Keep hives warm, give plenty of fcod, help weak colonies, look out for robbers, remove drone-comb, prepare for queen-breeding, and for the honey erop.

892. Summer. - Watch for swarms; and make divisions, 
if increase is wanted. Give sufficient storage-room. Give additional ventilation if needed. Whenever the erop is over, remove the surplus.

893. FALL. - Look out for robbers, and for moths on unoceupied combs. See that all hives have suffcient stores for Winter, and unite worthless colonies to others.

89.1. IrINTER.-For out of doors, pack absorbents in upper story, removing air-tight quilts. Shelter as much as possible from winds. Leave the bees quiet in cold weather, and see that they have a flight in warm weather. Do not be confident of safe wintering till March is over. Then proportionate the room to the strength of the colony. For cellar wintering, take the bees in, after a warm day, leave them quiet, in the dark, with an even temperature; take them out on a warm day, and decrease the brood-chamber to suit the strength of the colonies.

\section{Mistakes that Beginners Are Liable to Make.}

895. 1.- They are apt to think themselves posted after they have read the theory, and before they get the practice.

2.-Hence they are apt to invent or adopt new hives, that are lacking in the most important features (358).

3.- They are apt to think that bees are harvesting honey, at times when they are starving. They should remember that each honey crop lasts only a few days, - a few weeks at most.

4.-They are apt to mistake young bees on their first trip for robbers and vice versa. Young bees fly out in the afternoon only, and do not hunt around corners. Robbers are gorged with honey when coming out of the plundered hive, and a number of them are slick, hairless and shiny. Bees that have been fed in the hive or whose combs have been damaged, or extracted, and returned to the hive, act like robbers, and incite robbing (664).

5.-They are apt to overdo artificial swarming (481). 
6.-They are apt to extract too much honey from the broodcombs $(\mathbf{7 r 1})$.

r.-They underestimate the value of good worker comb (6\%6).

8.-They do not pay sufficient attention to the remoral of the excess of drone-comb $(\mathbf{6 r 5})$.

9.-They become easily discouraged by Winter losses and Spring dwindling. Some of our most successful Apiarists periodically lose a large portion of their colonies, and promptly recruit again, by the help of their empty workercombs $(\mathbf{6 r 6})$.

10.-When they find bee-keeping successful, they are liable to rush into it on too large a scale before being sufficieintly acquainted with it. "If there is any business in this world that demands industry, skill and tact, to insure success, it is this of ours."-(HEDDON.)

11.-They are apt to try two or three different styles of hives, before they find out that it is important to have all the hives, frames, caps, crates, ete., in an apiary, alike, and interchangeable, except for purposes of experiment.

12.-They are liable to attempt to winter their bees in a cold room, or in some repository in which the temperature goes below the freezing point (618). Many a colony has been thus innocently murdered, by misguided solicitude.

13.-They are prone to establish rules of action from experiments made on one or two colonies and thus make a rule ont of an exception. Experiments have little value if they have not been conducted on a large scale.

\section{Bet-Keepers' Axioms.}

896. There are a few first principles in bee-keeping which ought to be as familiar to the Apiarist as the 'etters of his alphabet:

1st. Bees gorged with honey never volunteer an attack. 
Thus, bees that come back loaded from the field, or bees that have gorged themselves for swarming, are not dangerous.

2d. The bees that are to be feared are those that have joined a swarm without fully gorging themselves. In the hive, the guardians, and the old bees that are ready to depart for the field, are the most dangerous.

3d. During a good honey harvest, the bees are nearly all filled with honey and there is but little danger from stinging.

4th. Those races of bees that cannot be compelled, by smoke, to fill themselves with honey, are the most dangerous, to handle.

5th. Bees dislike any quick movements about their hives, especially any motion that jars their combs.

6 th. The bee-keeper will ordinarily derive all his profits from colonies, strong and healthy in early Spring.

rth. In distriets where forage is abundant only for a short period, the largest yield of honey will be secured by a very moderate increase of colonies.

8th. A moderate increase of colonies in any one season, will, in the long run, prove to be the easiest, safest, and cheapest mode of managing bees.

9th. Queenless colonies, unless supplied with a queen, will inevitably dwindle away, or be destroyed by the bee-moth, or by robber-bees.

10th. It must be obvious, to every intelligent bee-keeper, that the perfect control of the combs of the hive is the soul of a system of practical management, which may be modified to suit the wants of all who cultivate bees.

11th. A man, who knows "all about bees," and does not believe that anything more can be gained by reading BeeJournals, new bee-books, ete, will soon be far behind the age. Yet, as what is written in the journals and books, ours included, is not always perfeetly correet, every bee-keeper should try to sift the grain from the chaff.

12th. The formation of new colonies should ordinarily be confined to the season when bees are accumulating honey; 
and if this, or any other operation must be performed wher forage is scarce, the greatest precautions should be used to prevent robbing.

The essence of all profitable bee-keeping is contained in Oettl's Golden Rule: KKEEP yOUR COLONIES STRONG. If you cannot succeed in doing this, the more money you invest in bees, the heavier will be your losses; while, if your colonies are strong you will show that you are a bee-master, as well as a bee-keeper, and may safely calculate on generous returns from your industrious subjects. 


\section{INDEX OF ENGRAVINGS.}

\begin{tabular}{|c|c|}
\hline 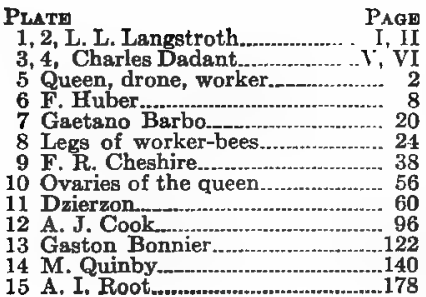 & 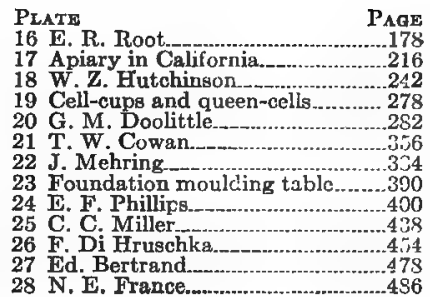 \\
\hline
\end{tabular}




\section{'TEXT ILLUSTRATIONS.}

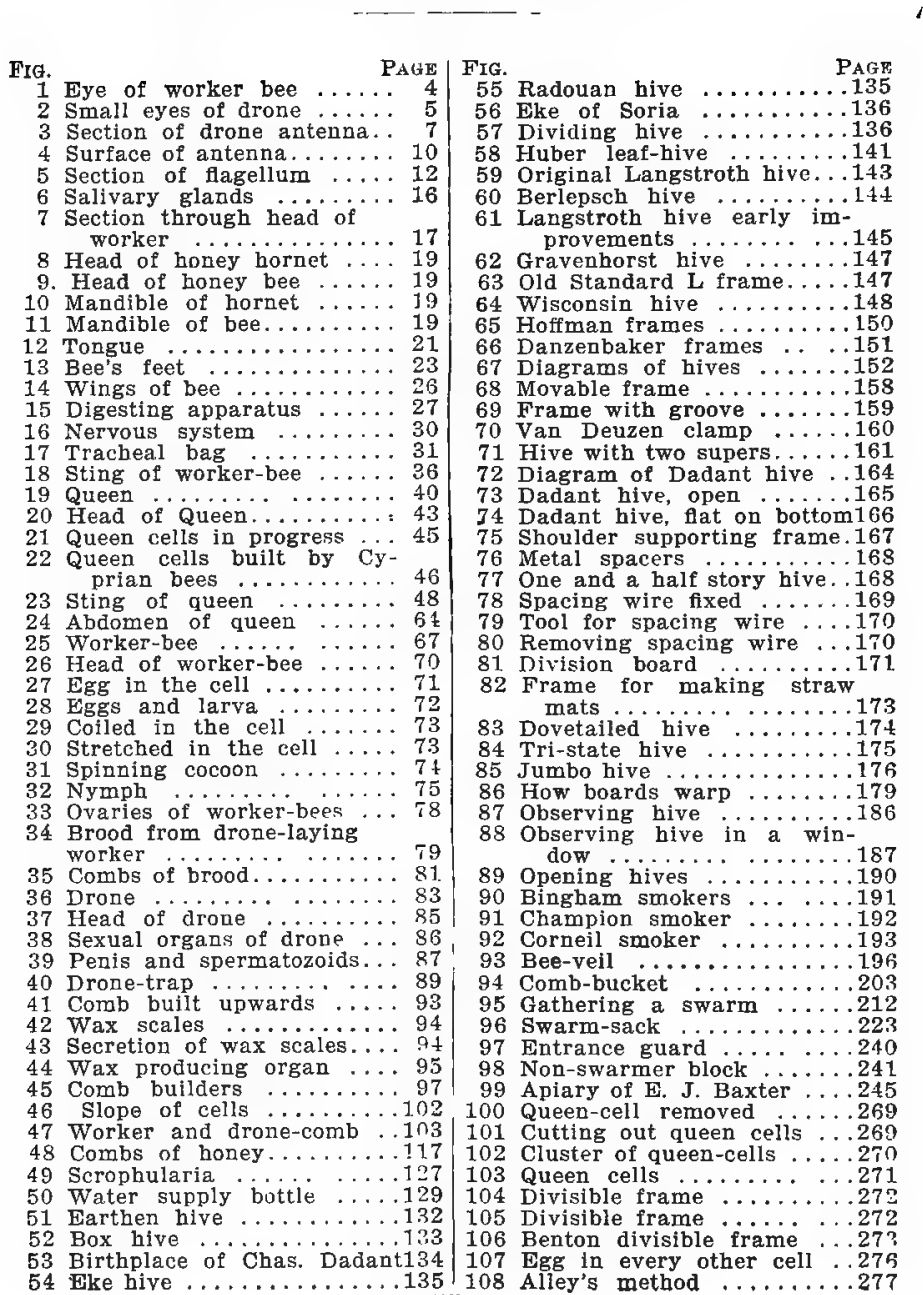


FIG.

109 Row of queen-cells. . . . . .278

110 Dipping-stick ...........280

111 Miller queen cage.......283

112 Apiary in Callfornia.....290

113 Abdomen of Italian bee. . . 295

114 Apiary in Bulgaria......302

115 Apiary of Mendleson......304

116 House apiary of Jecker.....305

117 Shed apiary ............307

118 House apiary of Blatt.... 311

119 Apiary in the Alps....... 314

120 Window screen .............318

121 Benton cage .............325

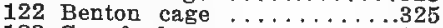

123 Can feeder ..............332

124 Hill feeder ...............332

125 Doolittle feeder ............333

126 Miller feeder . . . . . . . . .333

127 Hill device .............346

128 Hives sheltered with straw.347

128bis Winter packing ......350

129 Cloister hive ............

130 Double-wall hive ..........354

131 Double-wall hive, inside view ..................

132 Double-wall Cowan hive. . .356

133 Chaff hive ...................

134 Cheshire hive ..........358

135 Outer covering .........359

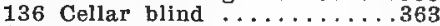

137 Cellar blind.............364

138 Bee-clamp ................367

139 How to pile the hives.....367

140 Ground plan of clamp.....367

141 In the snow...........373

142 Original foundation mili. . .383

143 Latest foundation mill....384

144 Vandervort mill ........386

145 Thin base foundation.....388

146 Foundation in sections. . . . . 389

147 Parker fastener..........391

148 Rauchfuss section folder . . . 391

149 Hambaugh roller.........392

150 Foundation wired in frame.393

151 Vandervort spur ......394

152 Mîller splints .......... . 395

153 Locust blossoms. .............. 399

154 White elover..........400

155 Implement for ascertaining

length of tongue.........400

156 Alfalfa ............. 401

157 Red clover...........402

158 Linden ..............403

159 Alsike elover..........404

160 Borage ...............405

161 Sweet clover .........406

162 Yellow melilot..........407

163 Persicaria ..........408

164 Golden rod..............409

165 Aster roseus ............409

166 Aster tradescanti........409

167 Echinops ritro ........410

168 Helenium tenuifolium ...410

169 Judas tree............410

170 Cleome pungens ........411

171 Knot-weed ..........411
FIG.

172 Buckwheat . . . . . . . .412

173 Sage .................413

174 Asclepias tuberosa ... . . . 414

175 Asclepias syriaca........4414

176 Pollen of milkweed. . . . . . .414

177 Epilobium spicatum.......415

178 Valerian .............415

179 Enothera grandiflora.....445

180 Hyacinth ............4 416

181 Lily of the valley .......4 416

182 Solomon's seal..........416

183 Mignonette ...........4417

184 Crimson clover...........418

185 Sainfoin .............. 419

186 One piece sections........431

187 Folded sections.........432

188 Super with pattern slats. . .433

189 Full depth section frame...434 190 Slope of cells when in-

verted .............435

191 Heddon reversible hive... .436

192 Section super with wood separators .......439

193 Section super with fences. 440

194 Wood-bound zinc .......441

195 Unbound zinc ..........441

196 Slatted wood-zinc honeyboard ............441

197 Unfluished sections ......445

198 Top and bottom starters. . 446

199 Wide frame, half flled... . 447

200 Super with springs........448

201 Miller T super...........449

202 Open sections .........450

203 Cowan honey extractor...453

204 Half-story supers ......457

205 Novice honey extractor. . . .462

206 Super with robber cloths. 464

207 Porter bee-escape ......4465

208 Dadant capping-can .....4466

209 Uncapping and extracting. . 467

210 Bingham honey-knife .... 468

211 Large funnel and sieve. . . 469

212 Appearance of foul-brood . .476

213 Bertrand fumigator ....479

214 Bee-moth ...........489

215 Moth ................ . 490

216 Larva and moth........4492

217 Gallery of moth....... 493

218 The worms ............493

219 Cocoons spun by larva of

220 Webs and ${ }^{\text {moth }}$............ 494 combs destroyed by moths .............497

221 Colorado shipping cases. . . . 509

222 Non-drip Foster case.....510

223 Grading honey .........513

224 The sixty-pound honey can.515

225 Dadant honey-pails .....521.

226 Friction-top honey-pail ...522

227 Kuhn wax-kettle .......532

228 Gerınan wax-press .......533

229 Doolittle solar extractor...534 


\section{N D E X.}

Abbott metal spacer..... Page.

Absconding swarms .........233

Adobe for hives............. I77

Adulteration, of beeswax.....387 of honey.......518

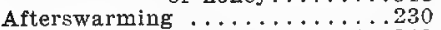

Afterswarms, prevention of. $2 \pm 1,242$ superiority of ...233 " objections to....233

Age of the queen when fecundated ..................... 53

Age sign of old, in bees.... 80-82

Air, see Ventilation.........179

Alexander, on overstocking....423

Alley, drone trap........... 89

" mailing queens .......32.

" method of queen-rearing

“ on impregnation ..... 54

Alighting-board, see Apron..... . 160

Alsike clover .............4n3

American frames ...........153

Ammonia for stings............208

Anger of bees.......... 189, 205

Antennæ ................ 7

" bees cannot live without 14

“ cutting of the.......14-15,

“ as organs of hearing.... 10

“ as organs for smelling.. 11

“ experiments of Huber on the.

Ants about the hive........506

" fondness for honey.......509

" their fecundity ......... 41

Aphides, Parthenogenesis of the 61 causes of honey dew

119,120

Apiaries, covered ............306

" out of doors..........303

“ sheds for ............306

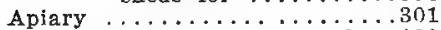

"s slow motions around the. 199

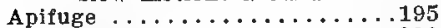

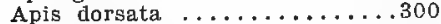

Apis fasciata ............298

Apis ligustica ............. 293

Apis mellifica ............292

Apron, or alighting-board.....166
Aristotle, on drones. ......... Page. 88

on eggs ...........6 60

on foul-brood ......473

on fruit ........... 19

on Italian bees.......292

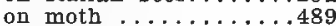

on pollen ..........125

on robber-bees .......375

on scent of the queen. .288

on strong odors.......206

on water .....................

Artificial swarming ........243

" advices on. 253

caution about 255,256

“ by dividing. 211

* by driving

bees. 217

“ by removing

the hive. 246

" improved ..249

" nucleus

method . 251

with queens

already reared.250, 252

w i t h queen-

increasing cells. 251

too fast. 256

Association of bee-keepers.... 543

Australian bees ...........299

Austria, yield of honey.........421

Automatic extractor .......4469

Axioms, bee-keepers' ........553

Bacillus alvei, see Foul-brood

Bait, in sections..........437

Baldenstein, on Italian bees. . . . 297

Balled queens .........227, 284

Bar-hives . . . . 135, 136, 140, 244

Barbo ................... IX

Barrels for honey............

.........469,470,512, 514

Basswood, see Linden

Bears and bees...........505

Beaunier on the production of wax ................ 99 
Bee-bread, see Pollen

Bee-dress ...............197

Bee escape ..............465

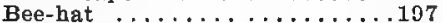

Bee-keepers' calendar ......555

Bee-louse ..............506

Bee-moth . . . . . . . . . . .489

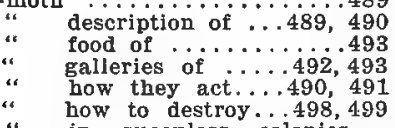

، in queenless colonies 498,499

“ Italian bees and. . . . .499

“ killed by cold ...495, 496

“ lays eggs in propolis. . 111

“ not to be feared.....501

“ preserving comb, against . 498 temperature required for their growth. 495

"s worm of the....492, 493

. their disgusting work.4.97

Bees, and flowers....127, 128, 543 and fruits ..........19, 540 angered ..............202

$$
\text { ". by bad odors....206 }
$$$$
\text { " by the odor of their }
$$

poison. 207

* " by the jarring of

the hive.202

“ bewildered by light........201

“ building combs .......... 93

* building few store cells... . I07

" building third store cells. . 109

“ building store cells here and there. 109

“ Carniolan ...........292

“ Caucasian .............2299

" climbing on polished sur-

clustering in winter..... 340

“ clustering outside ... 162, 182

“ Cyprian..............298

" deprived of their antenna. 15

. deserting .....211, 365, 372

. discharge in fight...... 33

“ do not make honey..116, 336

" dwindling in spring......368

. eating to keep warm... . . 341

" eyes of ............. 4

“ feeding the queen.......

* filled with honey.........191

* first introduced in this

country 292

4 first noticed in Florida...289

"for honey production in the North.327

going Westward ........29

" handling ............189

. hatching ............ 75

" hearing organs of....... 10

"Holy Land and Syriai... . 299
Bees how far they fly........421 how many in a pound....326 in California ...423, 424, 425 in Germany ...........424 injured by fruit juice . 344, 542 Italian, see Italian

" killing their drones......99

" memory of .......... 14

“ mouth of ............. 19

" noticing their new location 308,328

“ not indigenous to America. 289

“ on boats........ 321, 322

* peaceable when filled with honey.191

" peaceable when swarming.191

* preparing to swarm ...211 procuring ..............309 propolizing small holes...111 quiet at mid-day........198

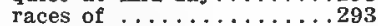
rebullaing store cells..... 108 removing from the cellar 365,366 return to their Iocation $274,328,366$

"s sending scouts ........216

“ smelling organs of ...... 11

“ smelling honey ........ 13

“ starving in Spring........317

" suffocated ...........181

“ swarming ...............

" swarming with introduced

queen. 287

“ transferring ..........309

“ unable to take wing...... 32

. understand each other.... 80

“ varieties ...........292

“ ventilating ........... 179

Bee-smokers, see S'mokers.

Beeswax (see also Wax) . . . . 531 aduIteration of .......387 for comb-foundation ...387 melting ............531 pressing .........533, 534 residues $\ldots \ldots \ldots \ldots .534,535$ spoiled ...........536 uses of .......... 536

Bee-veil ............. 196, 197

Beginners' mistakes .......... . . . . . . Beginning on a small scale....301.

Benton, apis dorsata........300

" Caucasian bees ........299

“ divisible frame .......273

" mailing queens ........324

“ trip to Cyprus.........298

“ trip around the world...297

Berlepsch, on comb building....105 on drone-laying

". on Italian bees.... 296

" on refrigerating

queens. 64 on water in Winter $129,370,371$ 
Berlepsch, hive $\ldots \ldots \ldots \ldots \ldots 144$ Bernard, on the brain of birds. 15 Bertrand, description of foulbiood. $476,477,485$ “ on Hilbert's cure...479 “ " honey as cure

for warts.530

“ " " honey plants ..420 “ " Langstroth hive bacillus alvei. 474

Bevan, cure for bee stings.....208 " on bee-moths $\ldots .492,493$ “ “ larvæ .....71, 73, 74 “ “ propolis .......110, 112 “ “ salt ............131 "4 quotations of Huber....291

Bickford, first use of the oilcloth ................. 172

Bingham, knife ..........468 on honey vinegar. . . 529 smoker .......191, 194

Birds and bees.............503 ". should not be killed....5504 injuring fruit ........541

Bi-sulphide of carbon.......4498

Bledsoe, on the sting......... 38

Blocks for the entrance........166

Blood of bees............ 29

Boerhaave on Swammerdam.... 40

Bohemia honey production.....424

Boiling honey against foul brood $479,480,484$ “ $\quad$ ax $\ldots \ldots \ldots \ldots \ldots .532,533$

Boissier, on honey-dew....... 118

Bonnier, on Darwin......... 6

“ “ honey-dew ........ 121

“ nectaries .... 118, " 121

Bottom-boards ....... 160-164-167

Bottom-boards, encased ......165

Box-hives .............133, 134

Brace-combs, see Bridges.

Brain of bees............. 15

Braula coca ..............506

Breathing upon bees.........200

Breeding in and in..........91

Bridges ..........159, 203, 204

Bridal trip .............. 54

Brimstoning bees ......... boney comb to keep out the moth. 498

Brood accidentally killed.....487

"casting the skin........73

“ chamber in two stories objectionable.152

“ duration of development.. 92

“ bow fed.............71

“ pure air for............. 181

" sealed by bees.......... 73

" transformation of the ...: 7.4

Buckwheat honey ...406, 423,508 Buera, on water for brood

rearing .371
Burmeister, names the stomach-

mouth. 28 covers difierent sounds in the humming of bees 34

Burnens as an observer...... 77 helped Huber .......8, 9

Butler anecdote from........ . . 505 on drones ........... 89 on drone traps........ 89 on handling bees..198, 199 on the bee-sting......207 on sectional hives..... 135 on sense of smell......206 saw the queen deposit eggs ...........4 40

Cages, introducing ........283

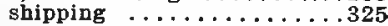

Cakes $\ldots \ldots \ldots \ldots \ldots \ldots \ldots \ldots . . . . . . .528$

California, crop of ......... 425

Candied honey bees .........291

"* how bees dissolve. 129

“ melting .......517

Candy, for feeding...... 334,335

" for shfpping .........324

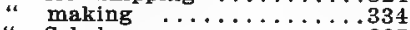

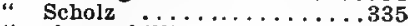

" shops, killing bees........ 338

Cans, for honey...........521

Cap of the hive..............

Capping can ............... 466

Cappings $\ldots \ldots \ldots \ldots \ldots \ldots \ldots+67,531$

Capplngs of honey cells, air-

tight? ................... 122

Carbolic acid for foul-brood... 481

Carbolized sheet .......195, 378

Carniolan bees .............292

Cary, on uniting colonies........ $3 \div 9$ witnessed the mating of a queen .......... 55

Castellaz, on preserving combs

from the moth..........499

Catalogue of bee plants....... 408

Catching the queen of a swarm.225 queens for shipment or introduction .......281

Causes of swarming......211, 236

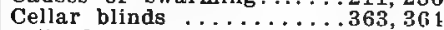

" damp . . . . . . . . . 362, 365

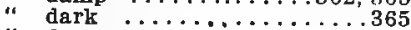

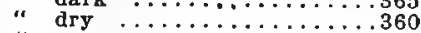

" removing bees from...... . . 366

“ temperature .............. 369

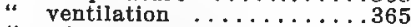

“ wintering bees in..........360

Cells, accommodation ....103, 104

" bottom of ...........100

" diameter of.................

“drone .............. 103, 107

" natural explanation of the shape of ...............

“ not horizontal ..........102

" opposed preference of queen

and worker .......107 
Cells, queen

$45,46,268-271$.

sine $\ldots \ldots \ldots \ldots \ldots .278-281$

solution of a problem.......100

thickness of .........104

worker . . . . . . . . 103

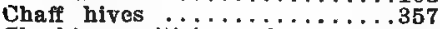

Cheshire, criticlsm of ........ 12 his criticism of an engraving .........104

hive ............358 winter packing of. . .352

mistake of ........145

on air-tight cappings..122

on breathing ....... 32

on cure of foul-brood... $\ldots \ldots \ldots \ldots .481,483$

on diarrhea .......472

on foul-brood.......474

on how to suspend foundation in frames...395

on the antennæ....7,8,10,

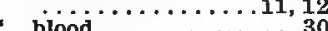

" eyes $\ldots \ldots \ldots \ldots \ldots \ldots$,

, feet ..........23

“ glands $\ldots \ldots \ldots \ldots$ 16-17

“ heart .......... 30

“ larvæ ........... 73

“ legs $\ldots \ldots \ldots, 23,24,25$

“ name of worker-eggs 61

“ pollen baskets...24-25

“ skeleton of the bee. 2

“ survival of the fittest ..........8 84

" tongue $\ldots \ldots \ldots \ldots 20-21$

on $\operatorname{wax} \ldots \ldots \ldots \ldots .94$

Chickens close hives in the even-

ing .............502

“ eat drones ..........

Chin of the bee............ 18

Chitine $\ldots \ldots \ldots \ldots \ldots \ldots \ldots \ldots 2$

Chloroform ............286

Chyle $\ldots \ldots \ldots \ldots \ldots \ldots \ldots \ldots 28$

Clamps for wintering........368

Claws and pulvilli..........23

cleaning propolis from the

hands .........112

propolis from the sec-

sections ........443

Cleansing beeswax …........531

Clipping the wings of queens...

Cloister h............225, 226

Cloth, oil or enameled........

Clover, alsike ...........403

Clover, melilot or sweet. . . . . 405

" red $\ldots \ldots .22,121,128,400$

“ white ....................

Clover honey .............508

Clypeus $\ldots \ldots \ldots \ldots \ldots \ldots \ldots, 19$

Cocoons of bees............. 74 of bee-moth .......497

Cold climate for wintering....340

"water for stings.......208
Collin, can bees hear?....... 10

invention of perforated zinc 89 on duration of cransforma-

tions ............75.

on how many bees in a

pound.............326

Colonies, artificial increase of..243

" killed by heat........181

“ natural increase of ....211 number of, in an apiary . queenless......316,423,426.

$42,262,265,379,499$

“ removing .........327

“ shipping ............

* strong, best for honey..429

“transferring

$309,313,314,315$

“ weak, easily robbed....379

، yield from ............427

Colorado, Italian bees in. . . . 293

Colors as guide for bees. $6,7,306$

Columella, his writings........177 mentions the bee-moth.. 489 on artificial swarming..243 on feeding bees... .329, 332.

on handling bees.....199

on Italian bees.......294

on spring examination of

colonies .........373.

. on transporting bees....322 Colvin, importation of Italian

bees. . 298

invention of separators...439

on bees transferring eggs. 47

Combat of queens.......... 52

Comb bucket ..........203 bullding $\ldots \ldots \ldots \ldots \ldots .93,107$

built upwards .......93.

foundation, advantages of.382

" a success ........396

“ dipping .........389

“ fastener ..........392

" for brood-combs, 388,393

“ for comb honey....388

“ for swarms....395, 396

" how to cut.......394

“ how to fasten.392, 393

" results of .......385.

“ first manufacturer. ............ 384, 390

“ in sections....388, 389

“ inventor of........384

“ mills, Root . .384, 385

“ " Vandervort . .386

" moulding .........389

“ plaster moulds for. 385

* press ...........385

“ right position.....395

" strips for guides...158

" wax for .........387

“ Weed process.......386

" weight of different

grades. . 391 
Comb guides for frames.157,158,22. Comb honey, best selling.......130

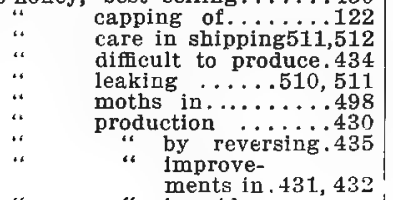
" " in wide

16

4

$a$

6

4

64

46

ac

a

12

is

16

“

$$
\text { “ in large }
$$$$
\text { “ in lower }
$$

frames. . 431

story . . 433

“ in sections...431 in shallow upper stories. .433

“ in supers.448,449 on, . .450, 451

“ with fences... 439

“. with separa.

" tors. .439

" with swarm-

sealed ..... ing. 4444 sweating $\ldots \ldots \ldots 510$ unsalable .......4t5 without propolis 42,443$$
\text { frames . . } 448
$$

“ remarks

Combs ...............99

" age of $\ldots \ldots \ldots \ldots \ldots .74,229$

“ breaking down ........1s2

" brimstoning to keep out

moths ...........4.498

. built upwards...........93

- care in returning after in-

spection .........204

“ care of in winter.......471

" economy of bees in build-

ing $\ldots \ldots \ldots \ldots \ldots \ldots 4$

“ empty, furnishing to bees. 461

“ " given to prevent

swarming .....2.238

“ extracting from.........463

“ guides for straight

“ made of wax $157,158,382$,

$\ldots . . .93$

“ melting ...........532

“ moths in .............497

“ pruning ................

" returned to the bees after extracting ........471

“ straight ....... . $157,383,385$

" surface occupied by brood. 155

" transferring ............313

“ washing dark............531

Comparative table of transfor-

mations $\ldots \ldots \ldots \ldots \ldots \ldots 92$

Comparison of the eyes of

queens, drones, and workers 4

Confectioners annoyed by bees. . 338

Confining bees unsafe........181

Confining colonies .......320, 353

Confining queens $\ldots \ldots \ldots \ldots \ldots 323$

Confinement, fertilization in... 55
Confinement, in cellar ......360

out of doors.....353

Constipation ......... 369

Consumption of honey ......520 by bees in

Winter. .341, 342

" of pollen.......125

Contagious diseases..... 472-487

Contraction of brood chamber . . . . . . 369, 370, 437

Cook, his praise of the Langs-

troth hive...142

Lubbock's experiment..... 6 on enemies of bees......507 on Neighbour's opinion....54 on the broods of the moth, 490 on the ears of bees....... 11 on production of wax scales in old bees. . 96 quotation of Doolittle...260

Cowan, apifuge............. automatic extractors . . . 469 hive ..............25i in Italy .............. 176 microscopical studies .... 12 on foul-brood ........479 on the prevention of swarming. . 239

" on the treatment of foulbrood. .479, 487 Cracks, closed with propolis by bees...111 " how to close when bees rob380 Crates, see Section-crates

Cutting, H. D., on the introduction of virgin queens...2286 Cyprian bees ......293,298,299 " "difficult to subdue. 198 “ " rearing queen-cells. 46

Debeauvoys ..............142

Decoy hives $\ldots \ldots \ldots \ldots \ldots \ldots 310$ Deep frames $\ldots \ldots \ldots \ldots \ldots \ldots \ldots 153$ De Gelieu hive.............. on weight of bees. ...326

De Layens counted the eggs

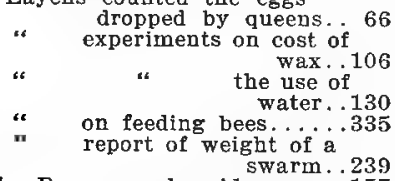

Della Rocca comb-guide......157

“ on age of colonies...8 81

“ on attracting-swarms. 220

" on bees as means of

as defense..210

. on floating apiaries..321

De Planta, experiments on food

$$
\text { " of larvæ. } 259
$$

on honey. . 397

Desertion .......211, 369,372

Diarrhca $\ldots \ldots \ldots \ldots \ldots \ldots . \ldots \ldots \ldots \ldots, 472$

Digesting apparatus.........26

Digestion, process of $\ldots \ldots \ldots 28,29$ 
Diseases

at
at
a
a
4
4

.........472

bacillus alvei......474 Gaytonf 472,473

black-brood.....474, 485

diarrhœa ........472

foul-brood .......473

mal de Maggio..472,473

paralysis .....472,473

pickled-brood .....487

vertigo ..........472

Disturbing bees in cold weather. 355

Dividing $\ldots \ldots \ldots \ldots \ldots \ldots 244$ "c

hive .........136

unreliable ........246

Divisible frame ..........272

Division boards .............171

removing ....202

space under....172

Dönhoff, description of moths..496 " experiments on young

bees. . $68-69$

“ on development of moths496

" on food of moths.....493

“ on thickness of honey

Doolittle, feeder.............333

" method of fastening....

“ foundation ..........392

“ method of queen-rear-

ing. .278

". on propolis ........442

" "tin roops ......175

Dovetailed hives....175, 176, 178

Driving bees . . . . . . 247, 311

Drone brood in worker cells. .64, 91

Drone cells. See Cells.

Drone comb, bees building....107

$$
\text { “s } \quad \begin{aligned}
& \text { rebuilt } \ldots \ldots \ldots \ldots \\
& \text { removed } \ldots \ldots \ldots
\end{aligned}
$$

foundation ....382

"s scattered .........109

“ larva, bees trying to raise queen from $\ldots \ldots \ldots 59,80$

“ laying queens $. .57,58,59,61$

“ -laying workers . . . . . . 77

“ traps ..........89,240

"description and office... 83

Drones, difficulty to raise early, 64

" expelled by bees...... 90 expelled by the bee-

keeper .......... 90

“ kept in queenless hives.266

" mating in the air..... 83

number in a hive...... 85

number in a pound....326

perish in mating..... 84 raised in worker cells 63,91 selection of ........267 time of appearance of. . 83 why mating outside... 91

why so many....... 85

Drory experiment on laying....6 63

Drumming bees ...........311

Dubini on cleansing the antennæ

Dubint on commercial uses of

propolis ..........114

on food of larva..... 72

on the braula coeca.....506

on the Caucasian bee..299

on the scales of wax... 94

Dummies $\ldots \ldots \ldots \ldots \ldots 171,172$

Dzierzon, discovery of partheno-

genesis $\ldots \ldots \ldots 58,60$

hive $\ldots \ldots \ldots \ldots \ldots 140$

on cellar wintering 360,366

‘s on development of lar-

væ $\ldots \ldots \ldots \ldots .75$

“ on drones ....... 84

" on fertility of queens. 66

* on issue of swarms..549

on pollen and substi-

tute $\ldots \ldots 124,125,397$

“ on refrigerating queens 64

“ on robbers .........375

on the italian bee.

$$
\begin{array}{lll} 
& \text { sex of eggs... } & 62 \\
\text { “ } & \text { spermatheca } \ldots & 56 \\
& \text { wedding flight. } & 54
\end{array}
$$

Earthen hives ...........132

Eggs, are they laid in queen

cells? $\ldots \ldots \ldots \ldots \ldots 47$

drone and worker in dif-

ferent cells .....662

from laying workers.... 77

how fecundated ..... 56

impregnation of........ 60

not better than larva to

rear queens.......259

of the bee-moth.......491

number of, laid by queens. 4.1

shallow frames hindering

the laying of..151, 152, 153

shape of ......... 71

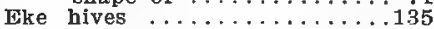

Eliot, John .............289

Empty combs to prevent swarm-

removed for Winter.345

" cloth ...........172

Enemies of bees........... 489

Entrance ...............171

“ contracted against

robbing .....377, 379

“ enlarged to hive

"swarms ........222

" enlarged in Summer 162

“ guard ..........240

“ left open in Winter. 352

“ open in the cellar...362

Ether ................286

Evans, quotations from 81,82 ,

$83,100,111,112,120,211$,

$329, \ldots \ldots \ldots \ldots \ldots \ldots \ldots . . \ldots \ldots 7$

Excessive swarming ..........234 
Excluders

Fxcrements, see Foces.

Extracted honey

barrels for . . 469,512 granulation of ...515 sale of $518,519,523$

Extracting ..............463 advantages of $\ldots .454,455$ conclusions on.....471 from brood combs...466 half stories for. . . . 458 how to proceed......463 implements for . .463, 465 lessens the work....457 prevents swarming...457

Extractor $\ldots \ldots \ldots \ldots 453,454,469$ reversible ......449

Eyes of bees................. 4 comparison of .... 4 Facets of the eye.......... 4

Famine, desertion by . . . . 212,372

Fear of stings.............200

Fecundation delayed, its results ...........60,61 of flowers by bees 126,127

of the queen..... 53

Feeble colonies, feeding.........330 uniting .........348 unprofitable 429,430

Fecundity of the queen.......41

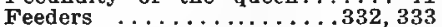

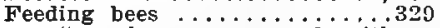
larva compared with mammal feeding....28 in the Fall...........331 in Spring .................. loaf sugar ............335 not to be encouraged. 336 Scholz candy.............335 stimulative .........330 sugar candy $\ldots \ldots . .334$ syrup $\ldots \ldots \ldots \ldots . .335$

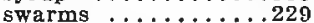

Fences .................439

Fermentation of honey........517 Fertility of the queen, see Fecundity . ..... 41

Fertilization, see Impregnation.

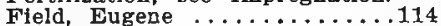

Fighting of queens........... 52

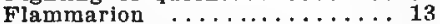

Flight during Winter...... 356,366

Flight of bees, range of......421 speed of ....... 26

Floating aplaries ..................

Flour given to bees.........126

Flowers, bees not injurious to

$\because \ldots \ldots$ 127-128, 543

iist of honey......4.48

Foces of bees, discharge of the. 29 "discharged in the hive...343 . unhealthy ............472

" of the queen............ 18

st of young bees............ 71
Food, bees' ...............116

" for wintering.........343, 344

" how much for winter...342

" its effect on queen larvæ.. 47

" on worker larva.......77

“ best to ship queens.....323

Forcing box ...............310

Foster ....................

" open side sections... 450,451

" shipping directions... 510,511

Foul-brood ..............473

" care and perseverance needed ........484

. detected in Spring...476

“ description of......475

* Dupont experiments..475

“ from infected queens. 485

* fumigating .......479

“ method of Alexander. 485

. method of Bertrand..479

" " of Cheshire...481

" $"$ of McEvoy.... 482

Foundation, see of Comb foundation.

Frame of the bodies of insects. 3 Frames.142, 147, 150,151, 158, 164 " comparison of divers sizes

$\ldots \ldots \ldots \ldots \ldots 150,151,153$

"distance between ..... 157

“ Danzenbaker ...........151

. divisible ..........272, 273

“. first attempts at movable, 142

“ groove for foundation....159

“ Hoffman ..........149, 151

“ Langstroth ... . . . . . . . . . 149

“ number per hive... . . . . 154

“ perpendicular to the en-

trance .........160

“Quinby ........... 15i, 158

"Q ". dimensions of $\ldots 164$

“ regularity of the ontside

measure of $\ldots \ldots \ldots 158,159$

" removing from the hives. 202

“ space around ..........142

“ spacing wire for.........170

" success with every kind of

155,156

“ top and bottom bars of...159

“ triangular edge .........157

“ wide ...............448

“ width of the top bar..... 159 France, N. E., on foul-brood

482,483

on legal rights.544

Fruits and bees.........19, 510

"f blooms benefited by bees

126, 127

“ damaged by birds. . . . . . 542

" juices of, injurious to bees

344,543

Fumigations against foul-brood. 479 “ 1 to tame bees.193, 194

Gelieu vertical, divisible hive. .136 German hive, inferiority of.... 
Gingerbread

Girard on honey..............116 on the breathing organs. 33 “ " " glands....... 16 "، “ “ “ smell organs ... 13 " “ sounds produced

" "4 sting by bees.33-34

Giraud, queen-rearing $\ldots \ldots \ldots \ldots 279$

Glands of bees.........15, 16,18

Gloves ...............197

Goldsmith, quotation from...... 188

Gouttefangeas, on confinement. .354

Grading honey ...........513

Granulation of honey.515, 518,519

Grapes and bees...........540

Gravenhorst hive ..........147

Green on foul-brood. . ....475, 476

Grimshaw's apifuge .........195

Gubler on cure for bee-stings. 209

Gundelach on the necessity of

pollen ..............121

Hairless bees $\ldots \ldots \ldots \ldots \ldots 375,472$ Hairs of bees............. 3 as organs of touch 8 their uses on the legs. . 23, 24

Hambaugh on out-apiaries...3.3.6 roller ..........392

Hamet, his description of the movable frame hive. .136

on several swarms clustered together. .226, 227

Handling bees ............189 with the hands...3 32

Harbison, first bees in Cal....291

Harris on moths. . . . . .489, 491

Harvesting honey ..........463

Hearing of bees..........10, 11 organs, where located.. 11

Heart of bees............ 29

Heartsease, (persicaria) .....406

Heat breaking the combs......182

Heddon hive .............435 “ method of transferring.315

“ comb honey ......437 “ economical pro-

- "prevention of after-

swarms. . 241

the use of smoke..201

Hilbert on foul-brood....478, 479

Hill device $\ldots \ldots \ldots \ldots \ldots \ldots . . \ldots 346$

Hill feeder ................332

Hives, African $\ldots \ldots \ldots \ldots \ldots \ldots 132$

“ American $\ldots \ldots \ldots \ldots \ldots \ldots 153$

“ Berlepsch ...........144

" bodies ..............168

“ box ...............133

it bottom-board of $\ldots 165, .167$

“ cap of ............174
Hives, chaff .........357, 358

Cheshire .............358

Cowan ...........356

diagram of our........164

division-board of......, 171

double-back ..........168

double wall ........357

dovetailed $\ldots \ldots 175,176,178$

Dzierzon. . . . . . . . 140

earthen ............132

eke ............135

enamel cloth for.......172

entrance of ........171

Gelieu .............136

Gallup ........152, 155

German ...............145

Gravenhorst ......147, 149

hanging trame .......149

Huber .............141

Jumbo .............175

Langstroth ......143, 145

large may be reduced ...156 to improve the

races. . 155

manufacture of ........178

material for .........177

metal spacer .........170

movable comb .........140

frame ......142

numbering . . . . . . . 17

observing ............184

outer covering of......359

painting .......175, 176

patent $\ldots \ldots \ldots \ldots \ldots \ldots 177$

preferred by us........163

protection for ........350

Quinby closed end frame.141 suspended frame. 151

rabbet for frames.....170

Radouan ...........135

ready for swarms......220

requísites of a complete.137

roof of ...........239

slanting forward ......160 small, cause excessive

swarming. . 156

“ limit the laying...155

Soria .............136

spacing wire of.....169-170

straw $\ldots \ldots \ldots \ldots \ldots \ldots 135$

straw mat for.........173

strip on, to widen the

projection . 172

upper story of ........174

ventilation of $\ldots .162,179$

Winter cover of......359

“ packing of.351, 352

“ shelter of ....349

Wisconsin ..........148

Hiving swarms ........218, 219

Hoffman trames ..........150

Holtermann, on moving bees. . 323

Holy Land bees...........299

Honey, adulteration of .......518

“ as tood ............ 525

“ as " food bees $\cdots$...

" as medicine ...........529

" board discarded $\ldots . . . . .160$ 
Honey cakes...............528 cells, are they air tight?.122 comb, see Combs.

crop in California.....425 Germany ......424

" our this country ...4426

dew $\ldots \ldots 118,119,120,121$

" as seen by Knight...120

" from aphides.119, 120, 121

“ its looks ..........120

" origin of ..........119

different grades of ......508

evaporating $\ldots \ldots \ldots \ldots 122$

extracted ..............451

extractor ..........434

fermenting .......510,517

from clover .......398-400

" divers flowers ....398

" hollow trees .....453

“ linden ...........402

granulating ........ 515

handling ............508

harvesting ........463

house .............. 318

" implements ...463,465

in sections $\ldots \ldots \ldots \ldots \ldots 432$

marketing .........508

melting ............517

poisonous ..........509

production ........4.428

sack .........26, 27

shipping cases ........509

storing and evaporating..122

strained ............452

“ uses of $\ldots \ldots \ldots \ldots \ldots \ldots 525$

“ vinegar .........528, 529

Hornets damaging fruit... 19, 128

Horse killed by bees. . . . . . 206

Hour of the fecundation of

queens. . 54

“ of swarming ........214

House apiary ...............

Hruschka ...............454

Huber, apiary ...........301

experiments on comb

building. . 104, 105

" $\quad$ ". pollen $\ldots . .123,124$

“ “ the antennæ $8,10,14$

" " the memory" of bees.. 14

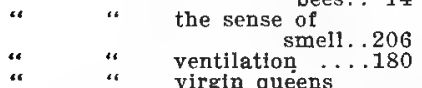

50,51

“ hlve .............141

“ imported Melipones........300

" on artifleial swarming....244

" bees transporting eggs. 47

" drone reared in queen cell.. 59

“ fertile workers ..... 77

" how bees bufld their

" location combs 394
Huber, oa the impregnation of queens. .55, 57,84 the introduction of

queens . . 282

the talents of Burnens

74,77

" tribute to .........8, 9

". was blind ........... 8

wite of $\ldots \ldots \ldots \ldots \ldots \ldots . \ldots . \ldots$

Humming $\ldots \ldots \ldots \ldots \ldots \ldots \ldots \ldots \ldots \ldots$

Hutchinson, on comb building. 97

comb honey pro-

duction . 442,451

packing comb

prevention of honey . . 511

after-swarms . . 242 queen rearing $279,280,282$

shipping honey.511

use of comb...221 use of foundation. . 396

Hymenoptera

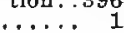

Implements, see Tools.

Importing bees. .297, 298, 323, 324 Impregnation of the queen.....53 in confinement....55 in the open air... 53

Increasing too fast........ 487

Inhabitants of a hive....... 2

Insects and bees...........506

Introducing queens . . . . . . 282

Trving, quotation from....259,290

Italian bees .........59, 293 $\begin{array}{ll}“ & \text { color } \ldots \ldots \ldots \ldots \ldots 295 \\ \text { description of } \ldots . .295 \\ \text { destroy moths ...2499 }\end{array}$ ftrst importa-

. tion in America. .297

Italian cakes vary even in Italy.295

Jarring combs, anger bees. . . .202

Jaws of bees............ 19

Jefferson, quotation of.......289

Jelly fed to larva..........71

Jobnson, J. E., on feeding bees.330

Jones, cure of foul brood.....449

" importer of bees.......298

" on number of queen cells. 46

Kirby and Spence..........119

Knives for uncapping....465, 468

Labial palpi and maxillæ..... 20

Labrum .................. 19

Landois on the humming....26, 34

Language of bees........... 34 
Larvæ casting the skin.......73 duration of development.. 74 fed from the glands of

workers.....2 28

" how fed ........... 71

“ of queens copiously fed.47, 48

raying of eggs...........65 hindered by shallow frames......152

" of two queens in the same

“ -workers ........... 77

1. "Workers ".... how to get rid of. 80

Leakage of honey...5510,512, 523

Legs of bees............. 22 covered with hairs...23

" notches of the first pair.. 24

“ pollen baskets of the posterior. . 24

“ " second pair $\ldots \ldots \ldots \ldots .24$ Leidy, dissections of queens. . 56,59 Levi on mating.........54, 55 Life of colonies, length of.... 81

Life of queens, length of.....67 67

Life of worker, length of . . . . . 80

Light in the cellar..........363 on bees ............201

Linden ..............403

Longfellow, quotation from. . . . 289

Loosening the frames........202

Loss of bees by heat........182

" the queen .........262

“" sting .............. 37

Love of the workers for the

Lungs of bees ........... 31

MacCord on hive covers......175 McEvoy, treatment of foul-

brood . 482, 483, 487

MeLain statistics from.......425

Magnetizing bees ..........196

Mahan, experiments on drones.. S8 refrigerating

queens.... 64

“ imported Italian bees..298

Mailing queens ............324

Malpighian tubes .........29

Mandibles of bees.......... 19

Manum on the control of

swarming. . . . 458

Marketing, see Honey marketing.

Mats ................173

Material for hives..........177

Mating of the queen........54

Maxille ..............20

Mehring, inventor of comb

foundation. ....384

“ stamp for securing

straight combs. .157

Melipones ............293, 300

Melting honey .........514, 517

" $\operatorname{wax} \ldots \ldots \ldots \ldots \ldots \ldots \ldots . . \ldots \ldots 32$

Memory of bees.........14, 366

Mentum .............. 20

Metatarsus of bees........ 24

Mice in bee hives..........503
Miller, C. C., adding supers. . .444

baits in sections. . . . 437

bottom boards ......167

cellar wintering ....362

clipping queens' wings.226

excluders $\ldots \ldots \ldots .442$

fastening foundation. 393

feeder ..........333

feeding out doors....381

foundation starters...

445,446

introduction of queens. 287

number of colonies in

one location. 426

prevention of swarm-

ing. . 241

queen cage $\ldots \ldots \ldots .283$

queen cells ........ 46

removing comb honey. 445

robber cloths ......443

scraping propolis from

sections. . 443

section supers .....449

smoking bees . . . 194, 195

success with small

hives. 156

. $\quad$ super ..........449

“ time of removal of

bees from cellar. .546

“ uses tin tops.......175

Mills on painting hives different

colors . .306

Mismanagement of bees.....205

Mistakes of beginners........553

Mixing bees from different hives

254,463

More on honey............525

Moth, see Bee-Moth.

Mouth of bees...........15-19

Movable comb hives..........140

frame hives, see Hives.

frame, see Frames.

Moving bees ........306,320,327

Munn hive ...............142

Muth honey eake.............

" honey vinegar ........529

" location ................301

" foul-brood method...477, 478

. on ripening honey.......517

Natural swarming ........211

uncertainty of...213

Nectar, best condition to pro-

duce. 118

id changed to honey......116 contains more or less

water. . 116

exists in different parts of the plant..118

extrafloral ..........18

in deep corollas.121,122,400

reabsorbed by plants..118

storing and evaporating.122

yields of, vary greatly.

$117,397,420$

Nervous system in bees...... 29 
Newman on uses of honey..525, 526 Norton on outdoor wintering...360 Notch of the first pair of legs.. 24 Nucleus ........ .....269, 271 “ for artificial swarming..251 “ how made ......271, 273 “ prepared in advance...275 “ small .............281 “ strong ............275

Numbering the hives........176 Nursing glands of workers... 15, t 6 Nurses ..............68, 69

Observing hives ..........184 for pleasure and instruction. 185 in apartments...187

Ocelli of bees............. 5 Odor of bees..........254,255 " of drones .......... 53 “ of foul-brood $\ldots \ldots \ldots 476,477$ " of the moth...........498 " of the poison of bees..... 38 " of the queen.......283, 288 Oettl, golden rule...........556 " on honey yield....422,423 " on the language of bees. . 34 “ on statisties ........4.t “ straw hive ............136

Oil cloth .............172 Old age, signs of, in bees. . . . 82 old and young queens living together

old bee-keepers venom-proof. 209 olfactory organs ...........11 Girard experilead bees to flowers.. 13

Opening hives ..........202 Orphan bees raising queens... 47 Otis saw impregnation...... 55 Out-apiaries, why ........316

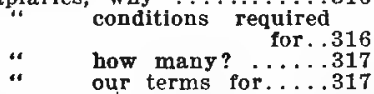

Outer-boxes for wintering......359 Out of doors wintering.......346 Ovaries of a drone-laying queen 59 “ of the queen.........57 “ of workers ........... 77 Overbeck, discovery of origin of

Overstocking $\ldots \ldots \ldots \ldots \ldots .420$ opinions on $\ldots \ldots 426$

Packard on the breathing organs 32 instinct of bees 39

Pain d'épices ............527 Painting hives ...........176

" " different colors..306

Paley on the sting......... 36

Palteau hive ................
Palpi and maxillæ........ 20

Paraffine, melting point of...387

Parsons importation .......298

Parthenogenesis .........58,59 proven by Italian bees. . 59

Pasteur on breeding bacilli...475 on inoculation ......209

Pasturage for bees.............397 Patents .................177 Perforated zinc ......89,240,441 Phillips, on the bee-inoth..... 489 on queen-rearing . ...282

Physiology ............. 1

Piping of the queen......51, 232 Poison of the sting.......38, 207 “ sack ............ 35 Pollen ................ 123

" baskets ...........24,25

“ fresh preferred ..........124

“ gathering, useful to plants

126,127

" indispensable to bees.....123

“ substitutes ......... 125, 126

" used when bees make

combs. . 105

Portico .........163, 353, 360

Pound, how many bees in one. .326

Press, $\operatorname{wax} \ldots \ldots \ldots \ldots \ldots \ldots 534$

Prevention of afterswarms....241 " moths in combs.

498,502

" robbing .......377

Pridgen, queen-rearing..$\ldots 234$

Production of honey..........428

Propolis ................ 110

" hard in winter........111 how to clean from the

hands. .112

“ from other things......112

“ on sections .........443

" solls the comb...........

“ uses for bees......i1i, 112

" " in commerce......114

Pulvilli $\ldots \ldots \ldots \ldots \ldots \ldots \ldots 22,23$

Queen, age at fecundation..... 54

"balled ..........227, 28

“ beginning to lay.......65

" best conditions to raise....

261,281

“ cages . . . . . . 283, 284, 325

“ clipping wings of . ..225, 226

“ contents of spermatheca of 56

“ dejections, licked by work-

ers. . 18

“ description of $\ldots \ldots \ldots 42,48$

" destitute of nursing glands 16

“ difference in prolificness of 66

“ does not govern........4 41

" duration of development of

48,50

transformations of. . 92 
Queen entering the wrong hive.

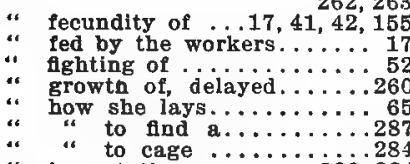

" importation $\ldots \ldots \ldots \ldots \mathbf{3 2 3}, 324$

“ impregnation of eggs...55, 60

" " " the queen 53

“ impregnation of the queen

delayed..60,61

* impregnation of the queen

for life.. 53

" impregnation of the queen

in confinement.. 55

“ introduction of impreg-

“
“ knowing the sex of ber

“ knowing the sex of her 62

* last to die........... 324

* laying drones in workercells. .58, 62, 64

* in queen-cells .........47

a worker eggs in drone-cells 63

“ lays more in Spring...... 42

* longevity of ........67

* loss of the ........43,262

* lost in her wedding trip..262

* love of bees for the..... 42

" malling ............324

* mating $\ldots \ldots \ldots \ldots \ldots \ldots \ldots 53$

* missing $\ldots \ldots \ldots \ldots \ldots 214,264$

* odor of the..........288

" old ..............67

« ovaries of $\ldots \ldots \ldots \ldots \ldots \ldots 50$

*. a drone-laying..57, 58

a parthenogenesis of the...58

“ preference for worker cells

* prisoner in the hive 63,108

a reared from egrs ...4728

4

4

4

4

4

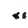

4

4

4

4

$$
4
$$

$$
\text { : }
$$

“ virgin to fy........... 50

" why not impregnated in the

“ young, confined by Huber 57 Queen-cell cups ...........280 Queen-cell cups artificial $\ldots \ldots .279,280$ . destroyed .....50,51 - for artiflcial swarm-

ing. . 251
Queen-cells, how reared ...... 45

" "to transfer ...268

“ inserting .......269

- large number of. 46,268

. preparing for .....268

Queenless colonies destroyed by

moths 499

their drones. 266

" $"$ how detected..265

Queens, several in a swarm...232

"t two in a hive.......... 52

“ " in a swarm....226, 227

Quinby closed end hive.......141

" frames, size of. ........

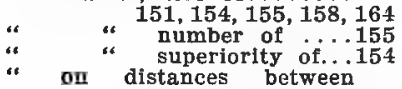

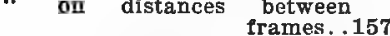

* " robbing .........378

" "shape of frames.15i, 153

"* smoker ............193

Rabbet . . . . . . . . . . . 167, 170

" enlargement of top edge.172

Races of bees............289

Racine on old combs.........229

" swarming .......235

Radouan hive ............... 136

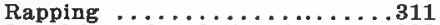

Rauchfuss, foundation fastener. 392

selling honey ....448

Rauschenfels, .......... IX, 96

Rearing queens ......44, 45,259

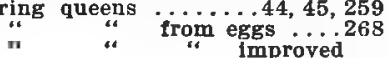

races. 267

in moderate colonies. . 268

Réaumur on impregnation.....53

Reid on the shape of the cells.111

Remedies for foul-brood......477

for stings .......207

Removing trames ...........202

Reversible hives ..........4436

Reversing ..................... 435

Ringing bells to stop swarms..215

Ripening honey artifcially.461, 517

Robber bees ..........374, 375 acting like young bees. . 79

Robber cloth ............464

Robbing, danger of, after cellar wintering. 366

“ difflcult to detect.....374

« how to detect..........376

“ to stop .........377, 378

“ prevention of .......379

“ promoted by the bee-

keeper . . 376

“ secret ...............378 stopped by a carbolized

sheet. . 378

. by exchanging hives....378 
Roof apiary ...............301 Root, A. I. (Novice) chaff-hive. . 357

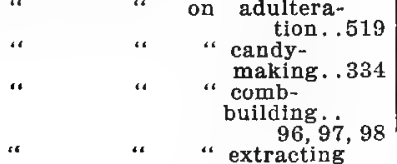
$\begin{array}{lll}\text { “ } & \text { “ extracting } \\ \text { “ } & \text { “ } & \text { " feeding } \\ & & \text { bees. .334 } \\ \text { “ } & \text { “ } & \text { " foundation }\end{array}$

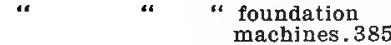
* 4 ". hivemaking.178, 179 " "Italian “ “ " bees.295, 298 "long and short frames. 153 on drone production 63 . " on shipping bees by the pound.....325

Root, E. R., on foul-brood. . 481,482 on frames ........150 on Danzenbaker

frames. . 15t

" on weight of bees....326

Root, L. C., author of Quinby's New Bee-keeping. .141 uses closed-end frames

Royal jelly

$17,47,259$

Russia, wintering in ....340, 361

Sack for hiving swarms. . . . . .223

Salivary glands $\ldots \ldots \ldots \ldots 15,16,21$

Salt for bees..........130, 131

Saltpeter-rags ............194 Sartori \& Rauschenfels, honeycake. .528 on combbuilding. . 96

Sashes for windows..........318 Saunier experiment on brood.. 75 Savage observing hive.......186 Scales of wâx............ 91 Schiemenz describes the stomach mouth. . 28 Schirach discovery of the origin of the queen... 49 Scholz candy ..........324, 335 " material for hives....177

Schonfeld on the chyle....... 28 Scouts ................216 “ returning ............219

Screen ..................... Scudamore on swarm.....227, 243 Sealed honey for extracting. ...461 " " in sections. .443, 444 Sealed queen cells........45, 269 Sealing of comb.........122
Sectional hives.............135 Sections .............431,432 " brood frames for. .433, 448 “ case ............433. “ " Milier ......... “ propolizing $\ldots \ldots \ldots \ldots \ldots 442$ “ removing ..........444 “ securing straight combs

Selection in bees. $235,236,261,267$

Selling honey $\ldots \ldots \ldots \ldots \ldots \ldots 518$ bees ..................327

Separators ..................439

Shade ..............239

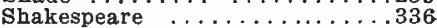

Shaking the bees like seeds.32, 228

Sheds .................306

Shipping bees .............320

" to better pasture.322

" honey........511, 512

" queens .............323

" " $"$ by mail .......

“ " $"$ food for $\ldots \ldots ., 328$

" " from Italy ..., 324

Shook-swarming ...........250

Siebold, his opinion of the "Berlepsch" hive. 144

" on parthenogenesis...56,60

Sieve ...............469. Simmins' method of introducing

queens. . 285

" non-swarming system.236 Size of frames.......149,153,15t " of our hive ............ 16t Skeleton of insect.......... Slanting apron-board .....166,167 Smelling organs $\ldots \ldots \ldots \ldots \ldots 11$ $\begin{array}{ccc}\text { " } & \text { direct bees to } \\ \text { flowers. 13, } 14 \\ \text { " } & \text { Girard experi- } \\ \text { ments on. } 13 \\ \text { very acute }\end{array}$ Smoke for handling bees. $13,206,288$ " helping robbers ......201 Smokers ..........191, 192 “ fuel for . . . . . . . 194 Smoking bees ............. 193 not always necessary.198 Snails propolized ...........112 Snow .............350,353 Soria space hive...........136 Sounds produced in flight..... 34 Sour honey ............517 Space around the frames..142, 164 " under division board.....172 Spaces between brood stories...152 spacing wire ..............170 Sparrows and bees.........503 spermatheca ............ 56 Spine of the second pair of legs 24 Spinola on the Italian bees. 293, 294 Spiracles of the lungs of bees. . 32 Spring dwindling .............368 " feeding ..............330 Sproule on foul-brood.........481 Square frames ...........153 
Stahala on the language of bees 34 Stanley extractor .........469 Standard Langstroth frame....147 Starvation ............329, 331 Statistics .............424,425 sting ..................... 37 " bees living without........ 37 “ can wound after removal. 38 " effects of the....38, 207, 208 “ fear of the............200 “ left in the wound...... 37 “ of queen ............49 49 " not easily withdrawn by the bee.. 37 " remedies for the wounds of the. .207 Stomach ........... 28 Stone on safe wintering..........348 Store cells ................107 bees building few. 107,108

Stories, defects of full upper. 448,458

" half, for extracting... 458 surplus equalizing in upper. .463 Stralght combs....157, 221,229, 385 Strained honey .........453,454 Straw hives ...........132, 177 " for protection .....350, 352 " mat ..........173, 352 .. "frame for making..... 173

Stupefying bees ............286

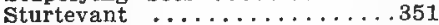
Suffocation ............. 181, 182

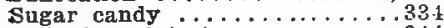

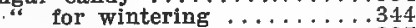

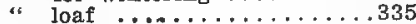

“ syrup ......................

Sulphur for moths. . . . . . 498, 499

Supers ................174

" for comb honey... . 448, 449

* for extracted honey . . 458

Superstition ..............113 Swammerdam ..........40,185 swammerdam on the moth... “ $\quad 489,492$ $\because \quad$ “ $\quad$ tribute to $\ldots$. . . 15 Swarming, artificial, see Artificial.

" fever $\ldots \ldots \ldots \ldots \ldots \ldots .237$
natural
"
$240,241,442$
Swarming, with a virgin queen.

230,232

without a queen....214

with several queens. 232

Swarms absconding .........233 catching the queen of .225 comb guides for......221 easily handled ........191 feeding ...........229

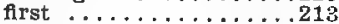
hived on worker comb. 220,221 " on comb-foundation 221 hiving ........... . 219

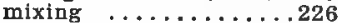
on a trunk..........224

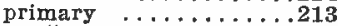
"with a young queen . .230

sack for ........... 223

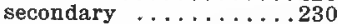
selecting an alighting place. . 218 several hived together. 226,227

third ..................

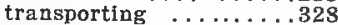
waiting for scouts....216 weight of ............. 239 with several queens....232 two queens.......227

Syrian bees ........46, 293,299 Syrup ............, 334, 336

T Super ................ . 449

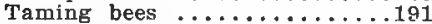

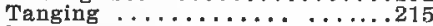

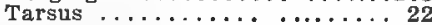

Telling the bees..........114, 115

Thickness of cells............ 104

Thomson, quotations from. .403, 429

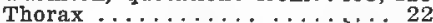

Thorley on stupefying bees...286

Tidd on the moth....440,495, 497

Tin cans for feeding...............

Tin vessels for honey.........521

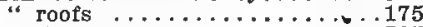

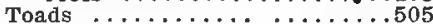

Tongue ...............20, 21

length of ........22,400

Tools to extract honey...463, 465

" to handle bees. . . $193,197,202,203,318$

"s to transfer bees.......313

Top and bottom bars of frames.. 159

Townley on mailing queens....324

Trachea ..............31,32

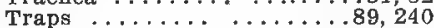

" for moths ......... 502

Transferring colonies ........309

Heddon method of. . 315 queen cells ......269

Transporting bees ......306, 327

Triangular guide .........157 
Tulip trees $\ldots \ldots \ldots \ldots \ldots \ldots$, 398

Uncapping $\ldots \ldots \ldots \ldots \ldots \ldots \ldots .467$ knives $\ldots \ldots \ldots \ldots 468$ Unlting colonies $\ldots .254,255,348$ Upper stories, see Supers.

Vandervort mill .........386 spur .......393,394

Van Deusen clamp..........160

Veil ...............196, 197

Ventilation $\ldots \ldots \ldots \ldots \ldots 162,179$

" in cellar .........365

" in winter......181, 350

، to prevent swarming.239

. when shipping .....320

Viallon experiments on comb-

building . . 106

" on laying workers...... 77

Virgil description of the Italian bee. .292, 293

. mentions the bee-moth...489

" on clipping wings of

“. queens....225

.. on material for hives....177

Virgin queens ........... 50

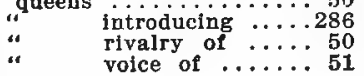

Wagner incident of swarming..217 on age of comb.....229

on egg laying.....47,62

on robbing ..........377

on success $\ldots \ldots \ldots \ldots \ldots 140$

on the Italian bee.296, 297

patent on comb-founda-

tion. . 384

. on sex of eggs.......662

“ on translation of “ ‘ "Berlepsch. .371

Warm absorbents for Winter..351

Warping boards ...........179

Water for bees.........129, 370

“ as a remedy for stings. .203

“ needed in Spring.......370

“ injurious in shipping bees. . . 130

Wax $\ldots \ldots \ldots \ldots \ldots \ldots \ldots . . \ldots 3$

aduiteration of ..........

“ bleaching ............536

“ candles ...........537

" chemical composition of...105

“ cleaning ............. 535

“ extractors .........533-534

“ from cappings ..471, 531, 535

" how produced .........94

“" many pounds of honey

to produce....106

“ made by young bees...... 94 94

“ melting point of ..........387

“ not made of pollen.......104

“ old bees can make......95, 96

" pollen necessary to make
Wax produced by eating . . . .94, 95 resiaues of .......... “ scales $\ldots \ldots \ldots \ldots \ldots \ldots \ldots 94$ " " who discovered the... 99 “ " on the bottom-board... 99 " uses of ............. 536 Weigel recommends candy. ...334 Weight of bees............326 " "drones ........... 326 “ swarms ........239 Weiss, first manufacturer of

foundation in America. . 384

Wide frames for sections.....448. Wide top bars for brood frames.159 Wildman on comb-building... 99

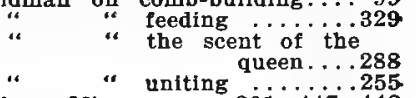
Wilson, Miss ......301, 447,448 . Window screens ..........318. Winds protection from........350 Wings $\ldots \ldots \ldots \ldots \ldots \ldots 25,26$. " used in ventilation......180 “ of queens. ef queens, clipping.225, 226

Winter flight ......355, 356, 367 passages $\ldots \ldots \ldots \ldots 345,346$

. protection $\ldots \ldots \ldots \ldots \ldots .349$

wintering bees ................. 340 " best conditions for. 360 “ cellar for .......361 “ chaff hives for. . .357 “ clamps for ....368 ، cold repositories

for. . . 368

“ experiment on ...342

“ food for ........344

“ in-doors ........360

“ mistakes in . . . 342

“ narrowing the

space for. . . 345

“ on full combs....341

“ outer boxes for

359,360

Workers ............67 agitated when the queen is removed. . 265

“ balling queens ......284

. building $\ldots . \ldots \ldots .94,96$

“ cells, see Cells.

“ crippled ..........82

" discharges of $\ldots \ldots \ldots 29$

“ Dönhoff experiment on. 68

“ duration of transforma-

tion of. 92

“ duties of $\ldots \ldots \ldots \ldots 663$

" eat eggs ........6.

“ eggs in drone cells....63

" to raise queens.47, 259

“ leeding the young...... 15

" " $"$ queen ..... 18

" fertile ........... 77

" " how discovered...79

" " use of .......77

“ first flight of .....68, 76

functions of $\ldots \ldots \ldots \ldots 67$ 
Workers, larvæ

" life

of $\ldots \ldots \ldots \ldots \ldots 71$

Workers trying to raise queens

losing their queen $42,43,262$

“ love of for thelr queen

$42,265,324$ ?

¿ newly hatched .......7 76

.. old, work in the flelds.. 68

* sexual organs not de-

veloped.. 77

Yield, large ........... .460

“ with drone eggs. .59, 80

“ ventilating ..........179

“ young, build combs.69, 94

" " feed the brood.. 67

Worms, see Moth.

signs of old age.....8 82 Zoubareff, uses of propolis.114, 115 


\section{Books On Beekeeping For Sale by the American Bee Journal}

\section{PRODUCTIVE BEE- KEEPING}

\author{
BY FRANK C. PELLETT
}

$\mathrm{O}$ $\mathrm{NE}$ of the latest text books on beekeeping, by the former State Apiarist of lowa and Staff correspondent of The American Bee Journal, as its name indicates, is a book for the practical man. Easily understood by the beginner, it coverg the field of practical honey production very fully and is a valuable book of reference for the extensive honey producer. The author enjoys a wide acquaintance among leading beekeepers of the United States and Canada and has described the systems of management which are successfully employed under a wide range of conditions. The best methods have been studied, sifted and excellently arranged. A Lippincott Farm Manual, 134 illustrations, 320 pages.

\section{CONTENTS-}

1. Beekeeping a Fascinating Pursuit.

2. The Business of Beekeeping.

3. Making a Start With Bees.

4. Arrangement of the Apiary.

5. Sources of Nectar.

6. The Occupants of the Hive.

7. Increase.

8. Feeding.

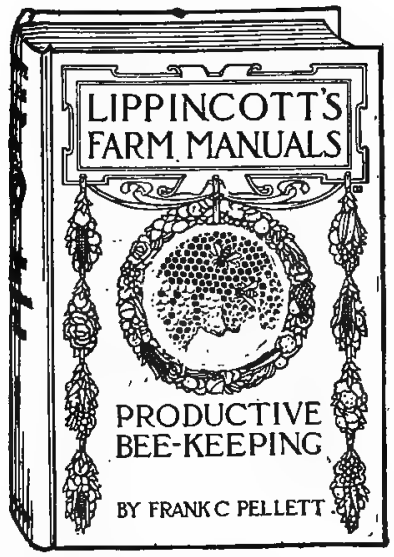

9. Production of Comb Honey.

10. Production of Extracted Honey.

11. Wax, A By-Product.

12. Diseases and Enemies of Bees.

13. Wintering.

14. Marketing the Honey Crop.

15. Laws That Concern the Beekeeper.

Durable cloth binding. Price, \$1.75, postpaid.

With American Bee Journal, 1 year, \$2.50.

\section{FIRST LESSONS IN BEEKEEPING}

BY C. P. DADANT.

GOR many years a book under the above title has been in the market. It 1 was originally written by Thos. G. Newman, and later revised by $C$. $P$. Dadant.

While the present book bears the same title, it is entirely new and has been rewritten from beginning to end. Even though you have the old book, you will want the new one also, for it is a far better book than the old one ever was, and it is right up to date.

The senior editor of The American Bee Journal, who is the author of the New First Lessons, has spent nearly all his life in a beekeeping atmosphere. His father, the late Charles Dadant, was an investigator who became well known on both sides of the Atlantic, and whose writings have been translated into several languages. As a young man the author of First Lessons was associated with his father in honey production and assisted him in the many experiments which he conducted in his efforts to make beekeeping a practical business.

Of late Mr. Dadant has traveled extensively, both in Europe and America, and is familiar with the best methods of honey production and with the leading beekeepers of many countries. With a lifetime of practical experience and such unusual opportunities for observation, C. P. Dadant is especially fitted to prepare a book for the beginning beekeeper.

Just the things you want to know, in a style easily understood, and with many pictures to explain the text.

You may bafely recommend First Lessons in Beekeeping to your friends.

200 pages, cloth, fully illustrated. Price, postpaid, $\$ 1.00$. With the American Bee Journal, 1 year $\$ 1.75$. Canadian postage 15 cents extra. 


\section{Books On Beekeeping For Sale by the American Bee Journal}

\section{LANGSTROTH ON THE HONEY BEE}

\section{REVISED BY DADANT.}

\section{$\mathrm{T}$} IS book originally written by Rev. L. L. Langstroth, the inventor of the movable frame hive, has been revised and kept up to date by the editor of the American Bee Journal. It is the one book that no beekeeper can afford to be without. It containg careful and accurate accounts of the life and habits of the honey bee and the mysteries of the hive. Full and reliable information concerning the detection and treatment of disease, the sources of nectar and pollen, and the care of the apiary throughout the year are included. The best methods of producing and marketing large crops of honey are made clear. This book is nicely bound in attractive cloth cover and contains 575 pages. The price is very low for a book of the size and quality. Sent postpaid for $\$ 1.50$, or with the American Bee Iousnal one year both for only $\$ 2,50$. Canada postage, 15 cents extra. It is published in 3 foreign languages, French. Spanish and Russian, at a slightly advanced price.

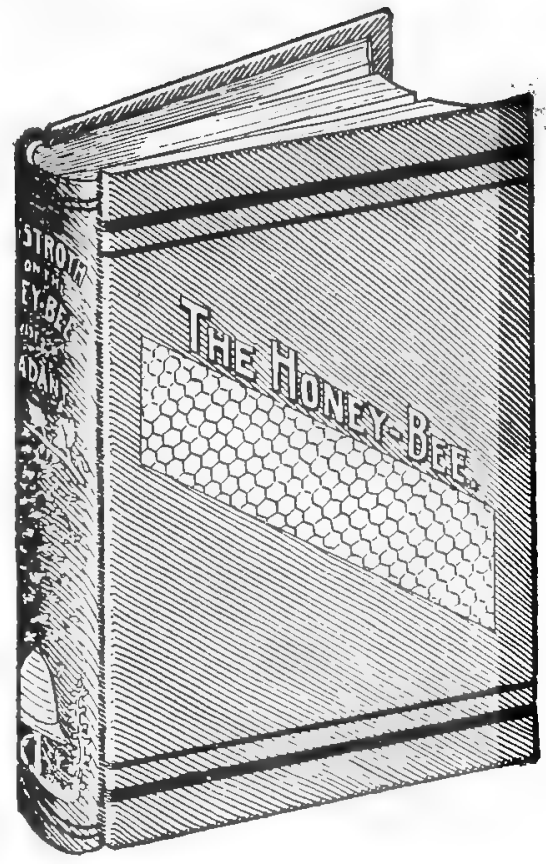

\section{1,000 QUESTIONS ABOUT BEES}

ANSWERED BY DR. C. C. MILLER.

TOR many years Doctor Miller has conducted the question and answer department 4 in The American Bee Journal. During that time he has answered questions relating to every phase of beekeeping. These questions have been sifted and arranged by $M$. G. Dadant and are now offered in book form.

No matter what your problem is, you will find the answer in this book, for beekeepers of all ages and all stages of experience have brought their queries to Doctor Miller. This book is intended to supplement the regular text books on beekeeping. and will be an invaluable aid to every beekeeper, whether he be a novice or an expert.

The texts tell a connected story of bee life and the principles of honey production, while this takes up singly the many questions that confront the beekeeper in his everyday practice in the apiary. Dozens of subjects not mentioned in the ordinary text and special angles of many other subjects which have been overlooked elsewhere are taken up and made clear by the most popular writer on beekeeping.

Should be included in every liat of bee books.

-

Attractive cloth cover; 200 pages; $\$ 1.25$.

As a premium with The American Bee Journal. Price with one year's gubsaription, \$2.00. Canadian postage 15 cents extra. 


\title{
The American Bee Journal First and Best in Its Field
}

The American Bee Journal, oldest bee journal in the English language is a 36 page monthly magazine profusely illustrated with photographs, showing beekeeping in many lands, the principal honey plants, new inventions, etc.

Indispensable to every live beekeeper.

One dollar a year, worth five.

Canadian postage, 15 cents extra, foreign, 25 cents extra.

\section{Practical Queen Rearing}

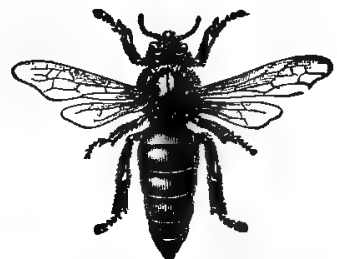

\author{
By FRANK C. PELLETT \\ Associate Editor American Bee Journal
}

MR. PELLETT has travelled extensively throughout the United States, spending much of his time in the largest queenrearing yards. He gives in his book many different methods of queen rearing as used by the older breeders, such as Doolittle, Pratt, Dines, Alley and others, with the variations as practiced by the present large queen breeders. The text is written elearly, making it easy for any beekeeper to raise his own queens from his best colonies.

Price, postpaid, $\$ 1.00$, or with the American Bee Journal one year, $\$ 1.75$. 



